
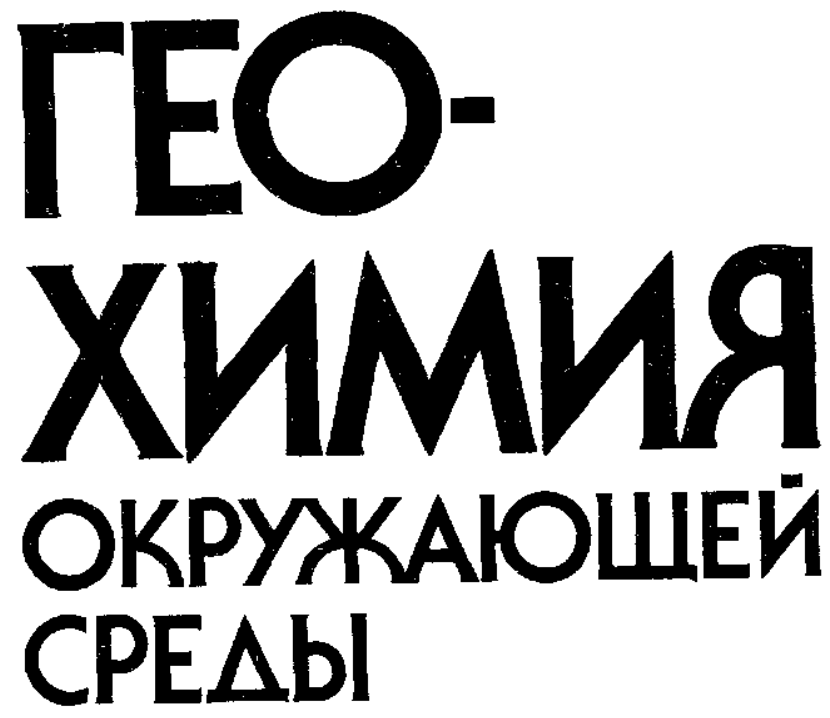

\title{
758406
}


MOСКВА "НЕДРA" 1990 • 


\section{УДК 550.4}

Геохимия окружающей среды/Ю. Е. Сает, Б. А. Ревич, Е. П. Янин и др.- М.: Недра, 1990.-335 с.: нл.-

ISBN 5-247-01127-9

Обоснованы возможности и показана эффективность методов прикладной геохимии при изучении и оценке состояния окружающей среды. Приведен эколого-геохимический анализ антропогенной миграции химических элементов. Описаны источники загрязнения окружающей среды (выбросы, стоки, твердые отходы, средства химизации), миграционные цепи распространения элементов в природных системах (воздушной, водной, биогенной). Рассмотрены принципы, методы и результаты биогеохимической и геогигиенической оценки отрицательных последствий загрязнения окружающей среды для здоровья человека.

Для научных работников, занимающихся охраной окружающей среды - геологов, географов, медиков, биологов, агрохимиков, архитекторов, инженеров по очистным сооружениям.

Табл. 100, ил. 94, список лит.- 50 назв.

А в т оры:

Ю. Е. Сает, Б. А. Ревич, Е. П. Янин, Р. С. Смирнова,

И. Л. Башаркевич, Т. Л. Ониценко, Л. Н. Павлова,

Н. Я. Трефилова, А. И. Ачкасов, С. НІ. Саркисян

Р е ц е н з е н т

д-р геол.-минер. наук А. И. Перельман

$1804020100-244$

$043(01)-90$

Коллектив авторов, 1990

ISB N 5-247-01127-9 


\section{ПРЕДИСЛОВИЕ}

Геохимическое преобразование природы человеческой деятельностью, постоянно усиливающееся в ходе научно-технической революции, привело к появлению центральной проблемы современной экологической ситуации - проблемы загрязнения окружающей среды.

Накопление химических элементов и их поступление в объекты окружающей среды являются результатом производственной и сельскохозяйственной деятельности человека. Дальнейшее распределение химических элементов осуществляется природными факторами миграции, образующими антропогенные ореолы и потоки рассеяния. Характеристики ореолов и потоков рассеяния состав, степень концентрации, формы нахождения элементов, интенсивность биологического поглощения - определяют качестзо окружающей среды.

В настоящее время большая часть многочисленных обобщений по проблеме загрязнения окружающей среды химическими элементами носит теоретический характер. В то же время важнейшей задачей изучения загрязнения природной среды токсичными элементами является выявление пространственной структуры распределения очагов загрязнения, установление источников вредных воздействий, размеров зон их влияния на население и оценка этого влияния. Решение этих задач прежде всего необходимо для разработки природоохранных мероприятий, а также для экологического обоснования схем развития и размещения производительных сил, генеральных планов городов и территориально-производственных комплексов.

В предлагаемой работе впервые сделана попытка обобщения материалов по особенностям образования, состава и морфологии техногенных и агрогенных геохимических ореолов и потоков рассеяния в окружающей среде, а также по методам их выявления и оценки для разработки практических мероприятий, направленных на ликвидацию, уменьшение и предотвращение негативных воздействий.

Основой для написания книги послужили многолетние при- 
кладные геохимические исследования окружающей среды в различных антропогенных ландшафтах, проводимые большим коллективом геологов, географов, гигиенистов, химиков Института минералогии, геохимии, кристаллохимии редких элементов Министерства геологии СССР и его экспедиций под научным руководством доктора геолого-минералогических наук Ю. Е. Саета. Авторы выражают искреннюю признательность своим товарищам и коллегам по работе - Л. Н. Алексинской, А. В. Глебову, М. Г. Журавлевой, Л. И. Кашиной, Л. Н. Павловой, Е. П. Сорокиной, Г. А. Тимошкину, И. В. Токареву - за ценные советы и замечания, а также за возможность использования в книге их научных разработок, позволивших сделать ее более информативной. Особую благодарность авторы приносят О. Г. Кулачковой, А. В. Литвинову, Э. А. Дрозд, Е. С. Киселевой, И. И. Григорьеву, Н. И. Субчеву за помощь при оформлении данного труда.

Развитие и применение методов прикладной геохимии при исследовании окружающей среды началось лишь в самые последние годы и, естественно, сколько-нибудь значительного опыта пока не накоплено. Любые дополнения, отзывы и замечания помогут улучшить работу и будут приняты с благодарностью. 
Загрязнение окружающей среды происходит при распространении в ней неутилизируемых отходов человеческой деятельности - стоков, твердых отходов, выбросов в атмосферу, а также при рассеянии средств химизации, применяемых в сельском · и лесном хозяйстве.

В. И. Вернадский первый раскрыл геохимический смысл преобразования природы деятельностью человека и его глобальный характер. Тем самым им был заложен методологический принцип изучения окружающей среды. Характеризуя необходимость развития прикладных геохимических исследований, В. И. Вернадский писал: «Подходя к научному изучению природы, мы никогда не должны и не можем забывать, что оно всегда неизбежно связано с практическим значением его в жизни человечества... Особенно это должно чувствоваться, когда мы касаемся вопросов геохимии, где культурная жизнь человечества является могучей силой, меняющей химические явления нашей планеты. Очевидно, что изучение хода развития роста геохимического значения человечества должно повести за собой и большее проникновение человека в понимание прикладного характера научной работы» [9]. В. И. Вернадский подчеркивает возможность неожиданных и непредвиденных последствий воздействия человека на природные среды и называет наименее устойчивые компоненты: атмосферу и воды. «Лик планеты - биосфера - химически резко меняется человеком сознательно, и, главным образом, бессознательно. Меняется человеком физически и химически воздушная оболочка суши, все ее природные воды» [10]. Он показал, что проблема антропогенного воздействия является проблемой геохимической и биогеохимической. В качестве нового для биосферы вида геохимической миграции В. И. Вернадский выделил биогенную миграцию атомов 3-го ряда, вызываемую человеческим разумом и трудом. Огромная интенсивность этой миграции позволила ему сформулировать положение о сопоставимости деятельности человечества с геологическими процессами.

Советские ученые под руководством Н. П. Моисеева создали глобальную биогеоценотическую модель, которая показала, что совокупное действие загрязнения окружающей среды и уменьшения белковой компоненты рациона питания приведут около 2100 г. к падению плотности населения в четыре раза. Только сочетание жесткой борьбы против загрязнения с интенсивным развитием сельского хозяйства дает более благоприятный прогHO3.

Л. М. Гвишиани, анализируя данные по глобальным процес- 
сам антропогенного преобразования окружающей среды, показывает, что они наносят удар по некомпетентному оптимизму в отношении процессов развития. В то же время, признавая сложность существующей ситуации, автор отмечает, что, в отличие от пессимистической концепции экологов Римского клуба о «пределах роста», применение к анализу ситуации метода исторического материализма - общесоциологической теории марксизма - позволяет создать концептуальную модель развития, реализуемую в рамках социалистической общественной формации. Диалектически противоречивое единство человека и среды его обитания обеспечивается прежде всего материальным производством. «Труд,- отмечал К. Маркс,-- есть прежде всего процесс, совершающийся между человеком и природой, процесс, в котором человек своей собственной деятельностью опосредствует, регулирует и контролирует обмен веществ между собой и природой» (К. Маркс и Ф. Энгельс, Соч. т. 23, с. 188). Именно благодаря контролю и регулированию этого обмена веществ и может быть достигнуто разумное равновесие между человеческой деятельностью и состоянием окружающей среды.

Л. М. Гвишиани приходит к выводу, что научно-техническая революция определяет две основные взаимосвязанные задачи, необходимые для решения кризисной экологической ситуации: 1) мониторинг окружающей среды и анализ потоков вещества и энергии на разных уровнях; 2) разработка принципов оптимизации взаимодействия общества и окружающей среды.

Совершенно очевидно, что обе эти задачи в значительной степени являются геохимическими и в полной мере соответствуют выводам, следующим из учения В. И. Вернадского о ноосфере особом состоянии эволюции биосферы (состоянии наших дней).

A. Е. Ферсман, назвавший техногенезом геохимическое воздействие промышленности, на примере распределения годовой добычи металлов показал, что их концентрирование - лишь временный промежуточный этап процесса, конечным итогом которого является «безвозвратное распыление», рассеяние вещества. А. Е. Ферсман отмечал также, что геохимическая миграция, обусловленная технической деятельностью человека, превышает по скорости природные процессы.

В. А. Ковда, сравнивая массы транспортируемого в природе вещества (сток рек и атмосферная взвесь) с массами антропогенного происхождения, показал их соизмеримость. Так, при общем природном транспорте вещества водами в $19 \cdot 10^{9}$ т/год, антропогенный вклад составляет $2 \cdot 10^{9}$ т/год (около $10 \%$ ). Параметры антропогенного стока вредных веществ ныне таковы, что не дают возможности рассматривать даже моря и океаны как неисчерпаемый резервуар. Для атмосферы антропогенный вклад по пыли составляет $5 \cdot 10^{8}-1 \cdot 10^{9}$ т/год $(5-10 \%$ общего запаса). 
Проблема загрязнения окружающей среды выявилась не как теоретическое обобщение, а как практическая задача, вызванная многочисленными отрицательными реакциями в различных областях человеческой жизни и производства. В числе таких реакций могут быть названы: 1) изменение показателей состояния здоровья населения, рост заболеваемости, инвалидности, доказательно обусловленные загрязнением окружающей среды; 2) достоверное установление эпизодических случаев гибели людей изза загрязнения окружающей среды; 3) массовые случаи гибели гидробионтов в загрязненных водах; 4) непригодность по химическому составу большого числа водоисточников для питьевого и технического водоснабжения, рыбохозяйственных и рекреационных целей; 5) невозможность во многих случаях проведения тонких технологических операций из-за загрязнения атмосферного воздуха.

До недавнего времени в качестве важнейших загрязняющих веществ рассматривались, главным образом, пыль, угарный и углекислый газы, оксиды серы и азота, углеводороды, соединения азота, калия и фосфора, ядохимикаты, синтетические органические вещества, радиоактивные изотопы. Химические элементы и их соединения (тяжелые металлы, микроэлементы) рассматривались обычно в меньшей степени. В последнее десятилетие, однако, интерес к оценке химических элементов как загрязняющих в ществ резко повысился. Это, прежде всего, связано с фактами проявления острых токсичных эффектов, вызванных промышленным загрязнением ртутью, кадмием, селеном, свинцом.

Экспериментальные и эпидемиологические исследования, проведенные и проводимые ныне различными специалистами, выявили широчайшую гамму отрицательных воздействий химических элементов на живые организмы всех основных групп на различных уровнях их организации. Очень важно подчеркнуть, что для многих химических элементов, помимо прямого токсического воздействия, характерны и так называемые отдаленные эффекты, которые затрагивают основополагающие функции живых организмов: воспроизводство и биопродуктивность. Степень их вредности в конечном счете значительно больше, нежели в случае токсических эффектов, так как угроза создается не для отдельных организмов, а для целых популяций и поколений. В этом плане они могут считаться экологически токсичными (экотоксичными).

В отличие от многих загрязняющих веществ, химические элементы не включаются в процессы самоочищения: в ходе миграции они меняют лишь уровень содержания или формы нахождения. Включаясь во все типы миграций и биологический круговорот, они неизбежно приводят к загрязнению важнейших жизнеобеспечивающих природных сред: воды, воздуха, пищи. 
Способность химических элементов к аккумуляции в живых организмах с токсическим воздействием на многие их системы приводит как к появлению специфической заболеваемости (микроэлементов, по А. П. Авцыну), так и к ослаблению иммунных систем и росту общей неспецифической заболеваемости, особенно аллергического характера.

В качестве прогнозного показателя интенсивности участия химических элементов в загрязнении окружающей среды А. И. Перельман предложил использовать понятие «технофнльность химических элементов» (отношение ежегодной добычи элемента в тоннах к его среднему содержанию в земной коре). Bce наиболее известные как загрязнители окружающей среды химические элементы обладают высокой (более 10) технофильностью $(\mathrm{C}, \mathrm{Pb}, 5, \mathrm{P}, \mathrm{Hg}, \mathrm{Cd})$. Вместе с тем, имеющиеся данные свидетельствуют о крайне низком уровне знаний о химических элементах как загрязняющих веществах. Даже для некоторых элементов с очень высокой технофильностью (Bi, 5п, Вr. 5b, W, $\mathrm{Ag}$, Se) с этих позиций практически нет систематизированных данных. Для многих других элементов (Си, 2п, $\mathrm{Cr}, \mathrm{As}, \mathrm{Cd})$ отсутствует общая картина их распределения в окружающей среде.

Важнейшая современная задача - разработка принципов и методов оптимизации взаимоотношений между человеком и окружающей средой. В практическом плане это выражается в необходимости регулирования воздействия общества на окружающую среду и управления ее состоянием. С этой целью прежде всего необходима разработка таких приемов контроля состояния окружающей среды, которые максимально точно локализовали бы неблагоприятные ситуации («горячие точки») и дали возможность оптимизировать природоохранные затраты.

В этой связи материалы контроля за состоянием окружающей среды должны давать возможности: 1) получения объективной информации, позволяющей выявить источники загрязнения и дифференцировать их по типам потоков загрязняющих веществ, их качественному составу и объемам, т. е. сформировать приоритетный ряд источников вредных воздействий; получаемая информация должна дать пространственную картину распределения вредных воздействий, т. е. выявить конкретные территории, а, следовательно, и численные параметры различных групп живых организмов и природных систем, требующих охраны; 2) интерпретации информационных данных, определения степени влияния вредных воздействий и выявления изменений, выходящих за допустимые пределы; 3) обоснования таких организационных, технологических, территориально-планировочных, здравоохранительных мероприятий, которые бы привели к ликвидации или необходимому сокращению вредных воздействий, либо локализовали их на участках, откуда они не могут распространяться. В настоящее время проводится большая работа по инвентари- 
зации источников загрязнения, определению предельно допустимых выбросов, по контролю в различных природных компонентах приоритетных загрязняющих веществ. Однако, имеющаяся информация о содержании химических элементов не позволяет точно зафиксировать источники их поступления и локализовать на местности зоны их воздействия, дифференцированные по степени экологической опасности. Существующая система контроля не показывает взаимосвязи между природными средами и не отражает в едином по месту и времени исследований уровня воздействия на биогеоценозы и население, а также их отклик на это воздействие.

Отмеченные сложности - неизбежное следствие многоведомственности служб контроля за окружающей средой. Они также обусловлены традиционной системой организации контроля, основанной на динамическом изучении загрязняющих веществ на сравнительно редкой сети стационарных постов и створов с последующим математическим моделированием распространения токсикантов. Такая организационная служба контроля наследует концепции гидрометеорологии, хорошо себя зарекомендовавшие при прогнозе глобальных и региональных ситуаций. В то же время, перенос схемы на значительно более локальные по масштабу явления со сложной мозаичной структурой распределения источников вредных воздействий и зон их влияния требует принципиально иного согласования временных и пространственных характеристик проявления загрязнения с масштабом контроля. Проведение таких исследований возможно при помощи методов прикладной геохимии. Это связано с тем, что химические элементы неизбежно являются составной частью всех видов загрязнения окружающей среды. Современными химико-аналитическими методами они достаточно экспрессивно и количественно определяются в любых природных средах. Bсе это позволяет использовать химические элементы в качестве индикаторов потоков загрязняющих веществ, дающих возможность выявить источники загрязнения и зоны их влияния, проследить взаимодействие между природными средами и оценить интенсивность воздействия на живые организмы.

Опираясь на представления В. И. Вернадского и А. Е. Ферсмана и развивая идеи и подходы к исследованию техногенной миграции, намеченные ведущими геохимиками и специалистами в области охраны природы (А. А. Беус, Дж. Вуд, М. А. Глазовская, Е. Голдберг, В. В. Добровольский, Ю̆. А. Израэль, В. В. Ковальский, В. А. Ковда, В. К. Лукашев, К. И. Лукашев, А. И. Перельман, И. Фёрстнер и др.), авторы совместно с коллегами с 1976 г. начали планомерные комплексные геохимические исследования распространения загрязняющих веществ, связанных с отходами, выбросами и стоками различных производств и коммунально-бытовой деятельности, а также со 
средствами химизации сельского хозяйства. Было установлено, что в ходе распространения загрязняющих веществ, осуществляемого, главным образом, природными миграционными механизмами, образуются ореолы и потоки рассеяния, сходные с ореолами и потоками рассеяния месторождений полезных ископаемых. Это позволило предположить возможность использования для эколого-геохимической оценки состояния среды обитания человека (окружающей среды) приемов и методов, применяемых при геохимических поисках.

С геохимических позиций выявилась следующая логика исследования загрязнения окружающей среды:

1) изучение ассоциаций, концентраций и форм нахождения химических элементов в твердых отходах, выбросах, стоках, средствах химизации, выявление участков и путей их поступления в окружающую среду;

2) прослеживание путей и способов миграции химических элементов в окружающей среде, установление природных компонентов, взаимодействующих с миграционным потоком; исследование интенсивности и результатов этого взаимодействия техногенных геохимических аномалий;

3) оценка площади распространения техногенных ореолов и потоков рассеяния, выявление их морфоструктурных особенностей, установление зональности распределения химических элементов и центров наиболее интенсивного воздействия, характеризующихся максимальными нагрузками экотоксичных элементов и определяющих контингенты живых организмов с повышенным риском проявления отрицательных реакций;

4) биогеохимическая оценка воздействия выявленной ассоциации химических элементов на живые организмы, прослеживание их распределения по трофическим цепям, оценка степени метаболизма; изучение биокруговоротов.

Авторы детально разработали принципы и технологии применения геохимических методов для обоснования рекомендаций по ликвидации или уменьшению вредных последствий загрязнения окружающей среды для решения широкого круга научных и практических задач ее охраны [26-30].

Геохимические проблемы окружающей среды исследуются главным образом для решения практических задач. Эти задачи и способы их решения сильно различаются для функциональных типов территорий, наиболее сильно испытывающих последствия загрязнения окружающей среды (города и их обрамления, сельскохозяйственные и горно-промышленные территории).

Именно для этих типов территорий авторы и систематизировали геохимические данные по источникам загрязнения, зонам их воздействия, биогеохимическим и биологическим реакциям живых организмов, геогигиеническим оценкам последствий, прежде всего для человека. 
Гл а в а 1

\section{ПОНЯТИЙНЫЙ АППАРАТ И НАУЧНО-МЕТОДИЧЕСКИЕ ОСНОВЫ ГЕОХИМИЧЕСКОГО ИЗУЧЕНИЯ ОКРУЖАЮЩЕЙ СРЕДЫ}

Общий анализ человеческой деятельности как геологического, геохимического и, в конечном счете, биогеохимического явления создал методологическую основу для организации геохимических исследований преобразования природной среды - формирующегося научного направления. В своей основе это направление является прикладным, так как имеет главной целью выявление геохимических закономерностей изменения химического состава природных систем, т. е., в сущности, их загрязнения при антропогенных воздействиях.

В геохимии окружающей среды, как и во всяком новом направлении в науке, одновременно разрабатываются научнометодические принципы исследований и их понятийная база. Используемая геохимией окружающей среды система терминов и понятий органически связывает общенаучную геохимическую базу с географической, биологической и гигиенической основами природоохранной деятельности.

При определении терминов и их смысловой нагрузки авторы опирались на практический опыт изучения окружающей среды в Институте минералогии, геохимии и кристаллохимии редких элементов и других геохимических организациях Министерства геологии СССР и АН СССР, а также на представления В. И. Вернадского, А. Е. Ферсмана и их последователей - создателей теоретической основы геохимии окружающей среды: А. А. Беуса, М. А. Глазовской, В. А. Ковды, В. В. Ковальского, К. И. Лукашева, А. И. Перельмана; кроме того использованы материалы, изложенные в новейших словарях и справочниках $[4,6,13,15$, $17,24,36,39,49]$.

\section{1. ОКРУЖАЮЩАЯ СРЕДА И ЕЕ КОМПОНЕНТЫ}

Предметом прикладных геохимических исследований является окружающая среда *, т. е. совокупность природных и природноантропогенных тел, явлений и факторов, прямо или косвенно влияющих на условия жизни человека и связанных с ним вещественным и энергетическим обменом.

* Выделены основные понятия, сущность которых раскрывается, в скобках приводятся близкие понятия сопредельных наук. 
Понятие «окружающая среда» удобно применять не как глобальное и общенаучное, а как утилитарное для определения экологических условий жизни человека или какой-либо интересующей человека группы живых организмов в условиях антропогенного воздействия.

Термин экология большинство исследователей толкуют не в первоначальном классическом биологическом понимании, а расширительно, как комплекс факторов, обеспечивающих условия жизни, или как всесторонне рассматриваемый комплекс взаимодействия живых организмов с природными телами и системами. В то же время экология человека включает и социальные аспекты взаимоотношения человека с биосферой.

Окружающая среда представляет собой систему ландшафтов или территориальных образований, в которых формируется сочетание специфического, характерного для данной географической зоны, взаимодействия природных и антропогенных элементов. В зависимости от характера и соотношения этих элементов ландшафты с известной условностью подразделяются на природные ландшафты, агроландшафты и урболандшафты.

Природные ландшафты - территории, геолого-географические и биологические особенности которых определяются естественными биосферными процессами, и антропогенные изменения существующими методами исследования достоверно не фиксируются. Ценность природных ландшафтов определяется их значением как экологического ресурса (совокупность средообразующих компонентов, обеспечивающих типичное для данной территории экологическое равновесие в биосфере), и, что особенно важно, как генетического фонда. С целью сохранения этих ресурсов среди природных ландшафтов выделяются заповедники, заказники, резерваты и другие особо охраняемые территории. Кроме того, природные ландшафты - единственный резерв развития курортно-рекреационной деятельности (отдых, восстановление здоровья и трудоспособности).

Природные ландшафты могут быть антропогенно-преобразованными - загрязненными или механически поврежденными, но сохраняющими основные типоморфные геоморфологические и почвенно-ботанические особенности. Степень деградации антропогенно-преобразованных природных ландшафтов может варьировать очень широко. Она фиксируется прежде всего характером смены растительного покрова (антропогенной сукцессией). В зонах максимального преобразования (полное сведение растительности или ее угнетение вплоть до вымирания) формируется так называемая техногенная пустыня, то есть неосвоенная территория, лишенная естественной растительности, но сохраняющая первичную, геоморфологию, общий тип и вертикальную ненарушенную структуру почвенного покрова, обычно сильно химически загрязненного. 
Агроландшафты - антропогенные ландшафты, у которых естественная растительность заменена каким-либо биотическим сообществом или отдельным видом сельскохозяйственного или лесохозяйственного значения. Агроландшафты дифференцируются в зависимости от типа применяемого севооборота (полевые, овощные, садовые и др.), от водохозяйственных условий (поливные, богарные) и т. д.

Урболандшафты (урбосистемы) по наиболее общему определению - территория, основные особенности строения и свойства которой определяются наличием в ее пределах человеческих поселений, прежде всего городов. Урболандшафт включает в себя как собственно город, жители которого связаны с несельскохозяйственной деятельностью, так и его обрамление. Это обрамление испытывает наиболее сильное воздействие города, прежде всего в результате рекреационной деятельности горожан, загрязнения окружающей среды, сгущения сети транспортных магистралей близ городов, появления отходов и других воздействий.

Окружающая среда состоит из компонентов - структурных единиц, включающих основные материально-энергетические природные и природно-антропогенные системы абиогенного (косного), биогенного или смешанного (биокосного) происхождения и состава, необходимые для неопределенно долгого, в пределе бесконечного поддержания жизнеобеспечения.

Основными природными компонентами окружающей среды являются: геологический фундамент, почва, поверхностные водные системы, подземные воды, атмосферный воздух и живые организмы.

Структурными элементами урболандшафтов являются промышленные предприятия, промзоны (агломерация предприятий, объединяемых единой территорией), транспортные магистрали (улицы с транзитными транспортными потоками), селитебные зоны (жилые территории и участки внутридворового озеленения), рекреационные зоны (зоны отдыха - бульвары, парки, сады, водоемы, лесопарки).

Промышленные предприятия могут быть отдельно стоящими и иметь примыкающий к ним рабочий поселок (типовая ситуация для крупных предприятий и комбинатов старой,- - до 80-х годов - застройки). Они могут входить в структуру города и мозаично распределяться среди селитебных и рекреационных территорий - типовая ситуация для подавляющего большинства крупных городов, когда промзоны могут находиться в самых различных пространственных соотношениях с другими функциональными типами городских территорнй). Лишь в самое последнее время (да и то не всегда) промышленные предприятия (промзоны), селитебные и рекреационные территории пространственно разделяются. 
Рекреационные зоны могут находиться как внутри города, так и в примыкающем к городу зеленом поясе (зеленой зоне, лесопарковом защитном поясе), обычно специально формируеMOM.

\section{2. ИЗУЧЕНИЕ ЗАГРЯЗНЕНИЯ ОКРУЖАЮЩЕЙ СРЕДЫ}

Геохимическое изучение загрязнения окружающей среды комплекс взаимосвязанных, синхронизированных и территориально совмещенных исследований, включающих выявление и количественную оценку источников загрязнения; прослеживание распространения загрязняющих веществ в компонентах окружающей среды с оценкой их состояния и пространственной дифференциации; установление степени биогеохимического концентрирования загрязняющих веществ живыми организмами и определение экологических последствий такого концентрирования.

\section{Источники загрязнения}

Всякое преобразование окружающей среды в результате деятельности человека может быть названо антропогенным. Антропогенное воздействие, приводящее к изменению химического состава одного или нескольких природных компонентов окружающей среды, является геохимическим, поскольку неизбежно с той или иной скоростью и интенсивностью включает это изменение во взаимодействующие друг с другом природные системы. Таким образом, сформулированное А. Е. Ферсманом понятие «техногенез» включает любое антропогенное геохимическое воздействие и не ограничивается каким-либо определенным видом человеческой деятельности (в частности, промышленным производством), а в равной мере относится и ко всем остальным (сельское и лесное хозяйство, строительство, рекреация и т. Д.).

С классических геохимических позиций изменение химических свойств окружающей среды, не связанное с естественными природными процессами, является загрязнением. В то же время, при использовании этого термина чаще всего в него вкладывается медико-биологический смысл. В этих случаях под загрязнением подразумевают появление или количественное изменение в окружающей среде тех или иных свойств - физических (например, шума, радиации, электромагнитных полей, вибрации) или химических (загрязняющих вешеств), - уровень проявления которых может оказать неблагоприятное влияние на условия жизни. При таком понимании, загрязнение - явление количественное. Оно может возникнуть не только антропогенным способом, но и в связи с естественными природными причинами (пыльными бурями, паводками и т.д.).'Таким образом появились нело- 
гичные на первый взгляд, термины, как, например, природное или естественное загрязнение, которые, однако, уже вошли в практику и достаточно удобны для прикладных целей. Особенно характерно природное химическое загрязнение для участков месторождений полезных ископаемых, особенно рудных месторождений, и в районах вулканической деятельности.

Загрязняющие вещества (поллютанты) - материальные носители загрязнения - связаны с наличием источников загрязнения. Этот термин имеет очень широкое и не очень определенное применение. Под источником загрязнения может подразумеваться как вид человеческой деятельности (например, радиотехническое производство, поливное овощеводство, водная рекреация), так и конкретные объекты деятельности (завод, свалка, хранилище отходов, автомобильный транспорт и т. д.) или материальные носители загрязняющих веществ (отходы производства, средства химизации).

Средства химизации - вещества, преднамеренно вносимые в окружающую среду с целью увеличения эффективности того или иного вида производственной деятельности. Загрязнение окружающей среды чаще всего есть побочный непредвиденный результат этой деятельности.

Отходы - неутилизируемая в данный момент и возвращаемая в окружающую среду часть используемых и перерабатываемых человеком материалов. Загрязнение окружающей среды неизбежное следствие появления отходов.

Отходы могут быть промышленными, коммунальными, бытовыми, сельскохозяйственными.

Различают складируемые отходы, а также выбросы и стоки.

Складируемые отходы (жидкие и твердые) представляют собой ту часть отходов человеческой деятельности, которая собирается с целью захоронения на свалках или депонирования на полигонах - накопителях для последующей утилизации. Довольно часто общее понятие «отходы» относят именно к складируемым отходам.

Стоки - часть жидких отходов, которые рассеиваются в окружающей среде. Стоки обычно состоят из дисперсионной среды (жидкой фазы раствора) и дисперсной фазы (взвешенных частиц, водной взвеси, взвешенного вещества). Очень часто наиболее значительное загрязнение связано именно с дисперсной фа$30 и ̆$.

Выбросы - часть отходов, рассеиваемая в атмосфере. Как и стоки, выбросы обычно двухфазны и состоят из воздушно-газовой смеси и твердых частиц - воздушной взвеси, пыли, аэрозолей.

Стоки и выбросы могут быть организованными, т. е. осуществляемыми через те или иные технические устройства, на которых происходит количественный учет загрязняющих веществ, и 
неорганизованными, возникающими стихийно (пыление конвейеров, оконная вентиляция и т. д.) .

По характеру поступления загрязняющих веществ в окружающую среду источники загрязнения разделяются на локальные, точечные, площадные и линейные (неточечные). Bce промышленные источники выбросов и стоков точечные. Неточечные источники связаны с сельским хозяйством, химизацией, поверхностным стоком с загрязненных территорий и т. д.

Загрязняющие вещества могут быть органические, органоминеральные и минеральные. При изучении загрязнения минеральными веществами обычно исследуют отдельные химические элементы, а не соединения. При этом очень широко используется термин «тяжелые металлы». Первоначально к ним относились металлы с плотностью более $5 \mathrm{r} / \mathrm{cm}^{3}$. В последнее время термин иногда используется для обозначения большой группы токсnнных химических элементов и, прежде всего, цветных и редких металлов.

Все виды источников загрязнения содержат широкую группу загрязненных веществ полиэлементного состава (табл. 1). Сочетание химических элементов характеризует специфические индивидуальные особенности источников загрязнения. Во всех случаях антропогенное геохимическое воздействие является мощным, комплексным по составу источником загрязнения окружающей среды.

\section{Распространение загрязняющих веществ}

\section{Образование и характеристика геохимических аномалий}

Загрязнение окружающей среды происходит в результате миграции загрязняющих веществ, генерируемых источниками загрязнения.

Геохимическая миграция - неразрывный комплекс процессов, приводящих к перераспределению химических элементов в природных телах. Этот комплекс включает перевод химических элементов в структурное состояние, форму нахождения, обеспечивающих их подвижность в данных внешних условиях, транспортировку элементов в физических и химических градиентных полях природных тел; осаждение, концентрирование элементов в результате его взаимодействия с веществом транспортирующего потока или вмещающей его природной системы и перевод их в неподвижное структурное состояние, равновесное с новыми внешними условиями.

Основной геохимической мерой качества окружающей среды является содержание химических элементов: массовая доля химического элемента (мкг/г, мг/кг, г/т или \%) либо объемная концентрация - масса химического элемента в единице объема

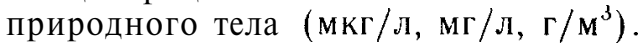


Та блица 1. Ассоциации химических элементов в различных видах отходов. По [29, 34]

\begin{tabular}{|c|c|c|c|c|c|}
\hline \multirow{2}{*}{$\begin{array}{l}\text { Загряз- } \\
\text { няющие } \\
\text { вещества }\end{array}$} & \multirow{2}{*}{$\begin{array}{l}\text { Источ- } \\
\text { ники } \\
\text { загряз- } \\
\text { нения }\end{array}$} & \multicolumn{4}{|c|}{ Коэффициенты канцентрации относнтельно кларка } \\
\hline & & $n \cdot 1000$ & $n \cdot 100$ & $n \cdot 10$ & $n \cdot 1$ \\
\hline \multirow[t]{2}{*}{$\begin{array}{l}\text { Рaccen- } \\
\text { ваемые } \\
\text { пыли }\end{array}$} & $\begin{array}{l}\text { Промышленtые } \\
\text { предприятия } \\
\text { (объединенная } \\
\text { выборка) }\end{array}$ & $\mathrm{Hg}_{50}-\mathrm{W}_{10}-\mathrm{Sb}_{5}-\mathrm{Cd}_{12}$ & $\begin{array}{c}\mathrm{Mo}_{8}-\mathrm{Ag}_{7,3}-\mathrm{Cu}_{7,3}-\mathrm{In}_{67} \\
\mathrm{Bi}_{4}-\mathrm{Pb}_{3,8}-\mathrm{Zn}_{3,8}\end{array}$ & $\begin{array}{c}\mathrm{Sn}_{9,6}-\mathrm{Co}_{5,6}-\mathrm{Cr}_{5,4}-\mathrm{V}_{3,1}- \\
-\mathrm{Ni}_{2,4}-\mathrm{Hf}_{\mathrm{i}, 7}\end{array}$ & $\begin{array}{l}\mathrm{Mn}_{\mathbf{9}, 2}-\mathrm{Zr}_{7}-\mathrm{Tl}_{5}-\mathrm{B}_{3,9}- \\
\quad-\mathrm{Sc}_{3,6}-\mathrm{Zr}_{3,1}-\mathrm{Be}_{2}\end{array}$ \\
\hline & $\begin{array}{l}\text { Электростан- } \\
\text { ции }\end{array}$ & - & - & - & $\begin{array}{c}\mathrm{Yb}_{9-}-\mathrm{Hg}_{6}-\mathrm{B}_{6}-\mathrm{Sc}_{6}- \\
-\mathrm{Mo}_{6}-\mathrm{As}_{5}-\mathrm{Ag}_{3}-\mathrm{Sb}_{3}- \\
-\mathrm{Cu}_{3}-\mathrm{Pb}_{2,7}-\mathrm{Zn}_{2,5}\end{array}$ \\
\hline \multirow[t]{3}{*}{$\begin{array}{l}\text { Твердые } \\
\text { отходы } \\
\text { (золы и } \\
\text { Шлаки) }\end{array}$} & \begin{tabular}{|l|} 
Промышленные \\
предприятия \\
(обьединенная \\
выборка)
\end{tabular} & $\mathrm{Bi}_{25}-\mathrm{Cd}_{8}-\mathrm{Ag}_{2,5}$ & $\begin{array}{c}\mathrm{Sn}_{8}-\mathrm{Sb}_{48}-\mathrm{Zn}_{36}- \\
-\mathrm{Cu}_{2,1}-\mathrm{Cr}_{1,2}\end{array}$ & $\mathrm{Ni}_{5}-\mathrm{V}_{4}-\mathrm{W}_{3,7}-\mathrm{Pb}_{3,2}$ & $\mathrm{~B}_{8}-\mathrm{Zr}_{2}$ \\
\hline & Бытовой мусор & $\mathbf{B i}_{18}$ & $\begin{array}{c}\mathrm{Ag}_{6,8}-\mathrm{Pb}_{2}-\mathrm{Sn}_{1,8--} \\
\sim \mathrm{Cd}_{1,7-}-\mathrm{Zn}_{1,4}\end{array}$ & $\begin{array}{l}\mathrm{Cu}_{8,6}-\mathrm{Sb}_{4,6}-\mathrm{W}_{16}- \\
-\mathrm{Cr}_{1,5}-\mathrm{Hg}_{1,5}-\mathrm{Mo}_{1,3}\end{array}$ & $\mathrm{Ni}_{3}$ \\
\hline & $\begin{array}{l}\text { Электростан- } \\
\text { ции }\end{array}$ & - & - & - & $\begin{array}{c}\mathrm{Hg}_{6}-\mathrm{Yb}_{3}-\mathrm{Mo}_{3}-\mathrm{Cu}_{3}- \\
-\mathrm{Zn}_{2}-\mathrm{Pb}_{2}\end{array}$ \\
\hline \multirow[t]{2}{*}{ Стоки } & $\left|\begin{array}{l}\text { Промышленные } \\
\text { предприятия }\end{array}\right|$ & $\begin{array}{c}\mathrm{Hg}_{100}-\mathrm{Cr}_{12 \mathrm{~s}}-\mathrm{Cd}_{10}- \\
\sim \mathrm{Cu}_{6.5}\end{array}$ & $\mathrm{~Pb}_{1}-\mathrm{Zn}_{47}$ & $\mathrm{~F}_{7, b}-\mathrm{As} \mathrm{s}_{1}-\mathrm{Sr}_{1}$ & $-\cdot$ \\
\hline & $\begin{array}{l}\text { Электростан- } \\
\text { цни }\end{array}$ & 一 & - & $\mathrm{Al}_{6,4}-\mathrm{As}_{5}-\mathrm{Cu}_{1,1}$ & $\mathrm{Cr}_{3}-\mathrm{F}_{2,5}$ \\
\hline
\end{tabular}

Примечание. Индекс элемента - величина $n$. 
В некоторых случаях изучается распределение так называемых показателей техногенной нагрузки или модулей техногенного давления - массовой доли или объемной концентрации загрязняющих веществ, поступающих в окружающую среду на единицу площади (длины) за единицу времени (например, г/м² в сутки).

Каждая миграционная природная система является одновременно транспортирующей и вмещающей средой. В результате геохимической миграции может происходить как рассеяние химических элементов, так и их концентрирование. Процесс рассеяния химических элементов обусловливается их разбавлением нли осаждением из транспортирующих потоков. Процесс концент'’.нии происходит в случаях, когда в силу тех или иных физических или химических причин скорость транспортирующего потока в целом, или скорость перемещения каких-либо составных частиц потока резко уменьшается. Такие участки являются геохимическими барьерами. Вся система от источника поставки элементов до геохимического барьера может быть названа миграционным потоком или цепью распространения загрязняющего вещества.

Природные среды, накапливающие загрязняющие вещества (почвы, растительный покров, снеговой покров, донные отложения) являются депонирующими. Перемещение происходит в транспортирующих средах в водно-миграционных и воздушномиграционных потоках, а также путем биологического поглощения элементов (транслокация) растительностью и далее по цепям питания живых организмов (трофическая цепь распространения). Транспортирующие среды для живых организмов являются главными жизнеобеспечивающими природными средами.

Распространение химических элементов в антропогенезе может происходить и техническими средствами (автомобильные и железнодорожные перевозки, авиатранспорт и т. д.).

В процессе миграции происходит распределение химических элементов между природными телами.

Интенсивность миграции определяется скоростью обмена, перераспределения химических элементов между компонентами природной среды. Она зависит от физических, физико-химических и биологических свойств природных систем, обусловливающих то или иное соотношение между скоростями перехода элементов в мобильное состояние и скоростями их транспорта и осаждения. В конечном счете интенсивность миграции зависит от ландшафтно-геохимических условий, т. е. от специфики сочетания гидрометеорологических, литолого-геохимических и почвенно-ботанических характеристик конкретной территории. Численно интенсивность миграции может быть выражена в виде какого-либо индекса или коэффициента, т. е. относительного показателя, сопоставляющего содержание химических элементов или их объем18 
ную концентрацию в фиксированном наблюдении, месте, или моменте времени по отношению к такому же состоянию природного объекта, принимаемого за базовый.

В прикладной геохимии разработана подробная система коэффициентов $[1,5,36]$.

В основе большинства коэффициентов лежит общепринятый в научных исследованиях коэффициент распределения, т. е. величина отношения средних содержаний в каких-либо сравниваемых между собой взаимосвязанных объектах или частях одного объекта. За базовую величину в данном случае принимается либо исходное (до начала геохимического преобразования) состояние объекта, или какая-либо часть преобразуемого объекта, либо аналогичный объект, не затронутый исследуемым геохимическим процессом. Применительно к прикладным геохимическим исследованиям этот показатель для случаев роста содержания элемента в изучаемом природном теле в ходе распределения или миграции трансформируется в коэффициент концентрации (накопления), а для случаев уменьшения содержаний в этих процессах - в коэффициент рассеяния (выноса или разубоживания в зависимости от механизма явления). В качестве базового здесь чаще всего принимается фоновое содержание, понятие, которое является основополагающим в прикладной геохимии. Фоновое содержание - среднее содержание химических элементов в природных телах по данным изучения их естественной вариации (статистических параметров распределения) в пределах однородного в геологическ и или (и) ландшафтно-геохимическом отношении участка. Геохимический фон - понятие местное, локальное. Коэффициенты концентрации, подсчитанные по отношению к геохимическому фону, называются коэффициентами аномальности (контрастности). Коэффициенты концентрации, подсчитанные по отношению к среднему содержанию химического элемента в литосфере (кларку), в какой-либо геохимической системе (почве, горной породе, растительности и т. д.) или ее таксономической части (тип почвы, тип горной породы и т. д.) называются кларками концентрации.

В результате миграции химических элементов по природным транспортным каналам в окружающей среде образуются геохимические аномалии.

Прежде всего следует отметить высокую динамичность воздушных и водных потоков.

Концентрации элементов в атмосферном воздухе зависят от многих несинхронно изменяющихся технологических параметров выбросов и метеорологических характеристик, условий рассеяния. Теоретические и экспериментальные исследования специалистов по физике атмосферы показывают связь распределения приземных концентраций загрязняющих веществ от тур- 


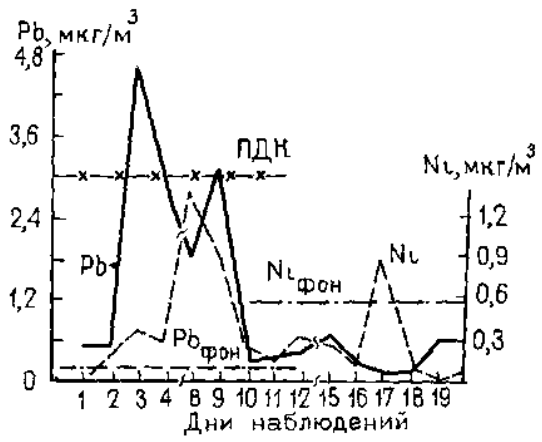

Рис. 1. Распределение свинца (сплошная линия) и никеля (пунктир) в атмосфере.

Направление факела выброса: дни 3 -16 -- на точку наблюдения, дни 2, $17,18,19-$ под углом к точке наблюдения, день 1 - от точки наблюдения

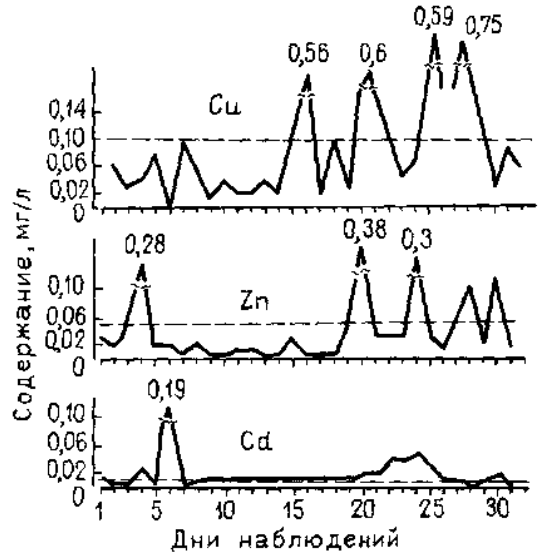

Рис. 2. Распределение меди, цинка и кадмия в водотоке, дренирующем промышленную зону (пунктирная линия - ПдК)

булентности воздушных течений (сочетание солнечного притока тепла и его излучения от земной поверхности и технических источников); от условий температурной стратификации атмосферы (при температурных инверсиях ухудшаются условия рассеяния); от влажности воздуха (прямая зависимость); от рельефа местности, расстояния от источника выброса; высоты выбpoca и его тепловых и физико-химических характеристик; от скорости и направления ветра $[8,17]$.

В урбанизированных зонах приземная концентрация определяется воздействием множества источников выбросов, что приводит к высокой динамичности содержаний и соотношения химических элементов в воздухе.

На рис. 1 представлены графики синхронных наблюдений за динамикой распределения в воздухе свинца и никеля вблизи группы приборостроительных предприятий. Несмотря на сравнительно устойчивый по направлению и силе ветер, химические элементы появлялись в воздухе несинхронно, регистрировались в разное время и далеко не весь период наблюдений.

Интенсивная динамика распределения химических элементов отличает и техногенные водные потоки рассеяния. На приводимом примере (рис, 2) мы видим, что пики концентрации химических элементов в воде для различных химических элементов не совпадают по времени, частоте появления и длительности существования.

Высокая вариабельность распределения загрязняющих веществ в природных средах, транспортирующих техногенные геохимические потоки имеет три важных следствия. 
Во-первых, для получения представительной оценки уровня поступления в организм загрязняющих веществ с водой и воздухом необходимо осреднение значительного количества измерений (до 200, по гигиеническим расчетам $M$. А. Пинигина и H Cosemas) [11]. Во-вторых, получение такой информации возможно только в условиях стационарной сети наблюдений, что, собственно, и обосновывает санитарно-гигиенический и гидрометеорологический подходы к системе контроля за состоянием окружающей среды. В третьих, по данным прямых наблюдений за воздухом и водой достоверную картину пространственной структуры загрязнения окружающей среды с множеством источников получать трудно; в этом отношении перспективен геохимический анализ структуры выпадений загрязняющих веществ из техногенных потоков.

Механизмы выведения химических элементов из транспортирующих потоков в депонирующие природные среды, хорошо понятные в общем виде, фактически почти не наблюдались и очень мало описаны. Они обусловлены прежде всего формами нахождения химических элементов в потоках.

Химические элементы в воздухе и воде мигрируют в виде двух основных групп форм: 1) растворенной, входящей в состав главных фаз этих природных компонентов,- их дисперсионной среды; 2) взвешенной, представляющей собой непостоянную механически перемещаемую дисперсную фазу, не стабильную по составу и объемам. Пространственно-временные особенности поведения химических элементов в этих двух фазах обусловлены разными причинами и имеют свою специфику. Для дисперсионной среды концентрация загрязняющих веществ регулируется прежде всего процессами разбавления, а также сорбционного химического взаимодействия.

Для дисперсной фазы (взвесей) концентрация связанных c ней загрязняющих веществ обусловлена содержанием этих веществ в самой фазе, количеством фазы и скоростью ее. седиментации, связанной с размерностью частиц и скоростью потока.

Таким образом, концентрация загрязняющих веществ в потоках и интенсивность выпадения из них зависят от соотношения «раствор (газовая смесь) - взвесь». Интересно отметить, что в практике контроля за окружающей средой при оценке состояния воздуха почти всегда анализируется пыль или аэрозоль, накопившаяся на фильтре. Для воды же либо форма нахождения не фиксируется, либо (что чаще), анализируется фильтрат.

В этой связи данных по реальным формам нахождения химических элементов в потоках очень мало.

В водных потоках многие химические элементы мигрируют преимущественно во взвешенной форме [27, 30]. Поэтому при оценке загрязнения водных систем большое значение приобретает мутность воды. Загрязнение водных потоков по принятым 
сейчас критериям оценки определяется как масса загрязняющего вещества в единице объема. При этом, в случае увеличения мутности воды даже при фоновых содержаниях элементов в составе взвеси происходит рост объемных концентраций, создающий «видимый уровень загрязнения».

Вместе с тем, появление небольшого количества техногенной взвеси с очень высокими массовыми содержаниями химических элементов также приводит к значительному загрязнению («реальный уровень загрязнения»). Но в этих случаях в периоды увеличения мутности (например, половодье) может регистрироваться уменьшение загрязнения.

Общая концентрация химических элементов в растворенной форме, складывающаяся из суммы неорганических и органических компонентов, в условиях загрязнения определяется прежде всего степенью разбавления речной водой поступающих стоков, а также взаимодействием в системе «вода - биота твердое вещество».

Химические элементы, связанные со взвешенным веществом, могут быть закреплены в разнообразных химических формах. Они могут присутствовать в виде геохимически подвижных форм (m. е. могут относительно легко трансформироваться при изменении условий среды): сорбированных; связанных с органическим веществом; гидроксидами железа и марганца; карбонатами; и в виде неподвижных форм - сульфидов, силикатов, входить в состав решеток неразложившихся обломочных и глинистых минералов (кристаллическая форма). Все эти формы выявляются фазовым химическим анализом [41].

В воздушных потоках рассеяния проблема форм нахождения элементов долгое время стояла, главным образом, как проблема дисперсного состава аэрозолей. Сравнительный анализ размеров частиц для различных химических элементов позволил разработать количественные модели их рассеяния и рассчитать скорости оседания. В последнее время выяснилось, что большое значение имеет изучение распределения элементов между аэрозольной фазой (взвешенной в воздухе, дисперсной) и парогазовой фазой (дисперсионной средой).

На биосферных заповедниках, т. е. в эталонных фоновых условиях, большинство тяжелых металлов (Cd, Co, Cr, Си, 2п, $\mathrm{Pb}$ и $\mathrm{Hg}$ ), а также 5e, As, $\mathrm{Br}$, 5b находятся в атмосфере, главным образом в паро-газовой форме. Лишь для литофнльных элементов (HI, 5c, TR) преобладающая доля концентрации связана с взвешенными частицами $[18,28\}$.

В атмосферном воздухе жилых территорий крупного промышленного города роль взвесей в составе атмосферы (по А. 3. Миклишанскому) для большинства элементов возрастает до 70 (2п, Со) - 90\% (Си, Сг). Однако, для ряда элементов паро-газовая фаза или, вернее, не улавливаемая фильтром субмикронная 


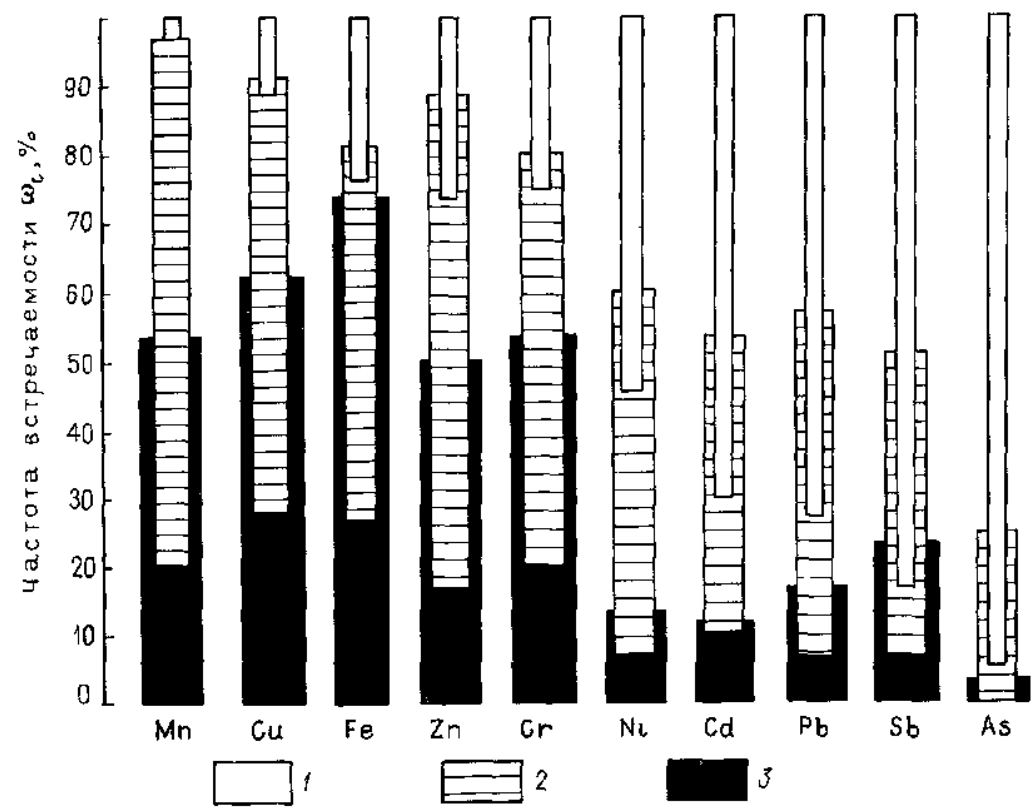

Рис. 3. Распределение химических элементов по размерам несущих частиц: 1 - субмикронная фракция (менее 0,05 мкм), 2 - мелкодисперсный аэрозоль (0,05-2 мкм), 3 -- крупнодисперсный -аэрозоль (более 2 мкм)

фракция составляет значительную часть содержания (As $66 \%, \mathrm{Sb}-67 \%, \mathrm{Hg}-60 \%)$.

В районе промышленных источников выбросов изучение соотношения «взвесь - газ» едва начато. По первым результатам (работы А. В. Волоха) это соотношение сильно меняется. Удельный вес субмикронной фракции повсеместно велик: $\mathrm{Cd} 40-50 \%$, $\mathrm{Pb} 22-28 \%, \mathrm{Zn}$ до 24\%. Полученные данные исключительно важны, так как ставят под сомнение достоверность существующих методов контроля и учета поступления загрязняющих веществ в организм (рис. 3).

При анализе особенностей образования техногенной анома лин за счет выпадений из атмосферы также очень важны представления о формах нахождения химических элементов и прежде всего о соотношении растворенных и взвешенных форм. Как показывают многочисленные материалы, это соотношение связано со степенью загрязненности выпадений. Так, авторами изучен характер изменения данного соотношения в снеговом покрове по мере приближения к крупному промышленному городу. Практически для всех исследованных химических элементов на относительно удаленных и сравнительно чистых территориях в выпадениях из атмосферы преобладают раствори- 
Т аблиц 2 Соотношение растворенных и взвешенных форм нахождения химических элементов в атмосферных выпадениях

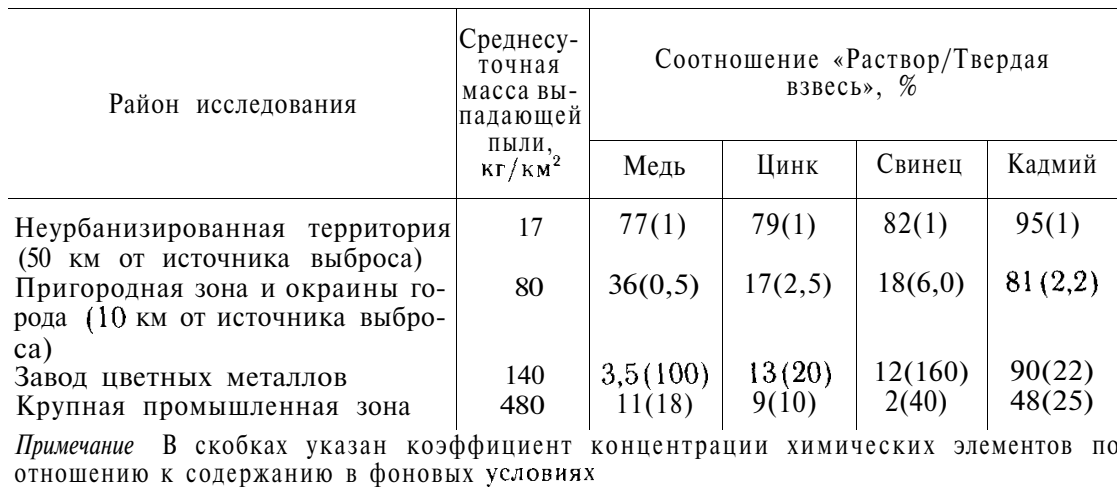

мые формы (табл. 2). Близ источников выбросов одновременно с увеличением общей массы выпадающей пыли и степени концентрации в ней элементов резко уменьшается доля растворимых форм (кроме $\mathrm{Cd}$ ).

Таким образом, формирование техногенных потоков и ореолов рассеяния во многом связано с характером распределения твердых взвешенных частиц. Этот вывод касается прежде всего территорий, обрамляющих источники выбросов и стоков так называемой «ближней» зоны выпадений, наиболее опасной с экологических позиций. Различие характера выпадений в ближней и дальней зонах описывается многими исследователями. Однако, почти нет надежных данных по балансам распределения материала выбросов в этих зонах. Авторы провели на нескольких объектах синхронные наблюдения за массой организованных выбросов $\mathrm{Pb}, \mathrm{Zn}, \mathrm{Cи}, 5 п, \mathrm{Cd}$ и массой выпадений этих элементов, уловленных снеговым покровом и установленных путем картирования зоны распространения из аномальных концентраций. Выяснилось, что выпадениями фиксируется всего лишь 20-30\% массы выбросов. Остальная часть выброса рассеивается, поступая в региональные и глобальные миграционные циклы, создавая «фоновое» загрязнение.

Влияние процессов глобального переноса антропогенных загрязняющих веществ привело к тому, что сейчас в сущности не удается собрать надежные данные о природном фоновом состоянии воздуха и выпадений, определяемом космогенным, вулканогенным и литогенным поступлением химических элементов.

В этой связи многие ученые обратились к изучению воздуха арктических и антарктических районов, а также океанов, используя как прямое определение химических элементов в атмосфере, так и данные по химическому составу выпадений на ледниковые покровы. 
Сравнение данных по составу пылей в датированных разрезах слоев арктического и антарктического снега и льда показало, что в расположенной относительно близко к промышленным районам Гренландии, начиная с 1940 г., концентрации $\mathrm{Pb}, 2$ 2п и $\mathrm{SO}_{4}^{2-}$ увеличились в 2-3 раза, тогда как в Антарктиде содержания тяжелых металлов существенно не менялись $[8,28]$.

Обобщение данных по прямому определению металлов в воздухе, также показывает наиболее низкий уровень содержаний в Антарктиде и их повышение в районах, более близких к континентам (океан северного полушария), и, особенно, к промышленным районам (Альпы).

Можно предположить, что воздух и выпадения Антарктиды могут быть приняты лишь за условный эталон. В то же время совершенно ясно, что истинным фоном он служить не может, так как в условиях континентов состав атмосферы в значительно большей степени определяется природной литогенной составляющей рассеяния.

В качестве условного фона многие исследователи применяют данные по концентрациям металлов в воздухе и в выпадениях сельских территорий, где, однако, в настоящее время долю антропогенного вклада выделить очень трудно.

Как отмечает А. П. Лисицын, фоновая поставка вещества из атмосферы сильно варьирует в зависимости от особенностей циркуляции воздуха. Последняя обусловлена наличием струйных течений (каналов миграционных потоков) и зон конвергенции, определяющих в совокупности три типа переноса взвешенного материала: локальный, тропосферный и стратосферный. Среднесуточная поставка аэрозольного материала варьирует: $100 \mathrm{kг} / \mathrm{km}^{2}$ (плато Колорадо) - около $5 \mathrm{kr} / \mathrm{KM}^{2}$ (Новая Зеландия) $1 \mathrm{kr} / \mathrm{kм}^{2}$ (Антарктида) - 0,006-0,06 кг $/ \mathrm{kм}^{2}$ (Арктика).

Авторы на основе большого статистического материала (около 2000 наблюдений) для нечерноземной зоны европейской части СССР получили оценку фона около 10 кг $/ \mathrm{kм}^{2}$ в сутки (при флуктуации от 6 до $20 \mathrm{kг} / \mathrm{KM}^{2}$ в сутки).

При оценке интенсивности концентрации химических элементов в пылевых выпадениях из атмосферы следует иметь в виду, что соотношение природной и техногенной составляющей в них довольно динамично. В частности, увеличение в составе выпадений доли почвенного материала, характерного для летнего периода, увеличивает общую массу взвеси, оседающей на дневную поверхность, но снижает в ней массовую концентрацию «техногенных» химических элементов. Коэффициент летнего разбавления пылевых выпадений варьирует в зависимости от типа источников химических элементов и расстояния до него (табл. 3). Так, он во всех случаях довольно стабилен для Си и 2п, но снижается в городе для РЬ (поступление свинца из почв, загрязненных автомобильными выбросами) и очень резко 
Т а бли ц 3 Коэффициенты летнего разбавления химических элементов в выпадениях из атмосферы

\begin{tabular}{|c|c|c|c|c|}
\hline $\begin{array}{c}\text { Участок } \\
\text { наблюдения }\end{array}$ & Медь & Свинец & Цинк & Никель \\
\hline $\begin{array}{l}\text { Региональный фон выпаде- } \\
\text { ний } \\
\text { Окраины крупной промыш- } \\
\text { ленной зоны } \\
\text { Центр крупной промышлен- } \\
\text { ной зоны }\end{array}$ & $\begin{array}{c}1,7 \\
(100 / 60) \\
1,9 \\
(300 / 160) \\
1,7 \\
(450 / 270)\end{array}$ & $\begin{array}{c}2,2 \\
(90 / 40) \\
1,5 \\
(150 / 100) \\
1,3 \\
(300 / 220)\end{array}$ & $\begin{array}{c}2,0 \\
(1100 / 550) \\
1,8 \\
(900 / 530) \\
1,8 \\
(1100 / 630)\end{array}$ & $\begin{array}{c}5,0 \\
(50 / 10) \\
2,0 \\
(155 / 80) \\
2,0 \\
(100 / 50)\end{array}$ \\
\hline
\end{tabular}

Примечание В скобках указана концентрация элементов в пыли (в мг/кг) числитель в зимних выпадениях, знаменатель - в летних выпадениях

у $\mathrm{Ni}$ (следствие влияния отопительного сезона с выбросами мазутных ТЭЦ).

В связи с вариацией состава пыли в выбросах предприятий следует учитывать возможность появления двух принципиально различных типов нагрузки химических элементов на земную поверхность от загрязненной атмосферы: 1) высокая нагрузка, формируемая в результате выпадения больших количеств пыли с фоновыми или близкими к ним содержаниями химических элементов; 2) высокая нагрузка, образуемая выпадением пыли с высокими содержаниями химических элементов.

Первый тип нагрузки является, в сущности, условно-аномальным. Для участков проявления этого типа нагрузки может быть характерно несколько повышенное потребление химических элементов при дыхании (за счет большой массы пыли), но воздействие на почвы, воды, растения практически отсутствует.

Второй тип нагрузки (собственно-аномальный) воздействует отрицательно на все компоненты окружающей среды, повышая в них концентрацию химических элементов.

Например, на одном из цементных заводов с большой общей массой выброса поступление в окружающую среду цинка с выпадениями составило 456 т в год, в том числе за счет увеличения содержания элемента по сравнению с фоновой почвенной пылью в той же массе всего 14 тонн. На соседнем заводе цветных металлов масса цинка в выпадениях была почти в 2 раза меньше 244 тонны, но за счет техногенного увеличения содержаний в пылевом выбросе масса аномального цинка здесь была 127 тонн (в 9 раз больше). В результате около цементного завода аномалии цинка в почве не наблюдались, а около завода цветных металлов она была весьма контрастна. На рис. 4 приведены типичные примеры пространственного распределения выпадений двух химических элементов в окрестностях промзоны с мощным источником выброса свинца и менее мощным олова.

Обобщение материалов такого рода позволило по средним данным выбросов, рассчитанным для наиболее характерных точек пространственного распределения, построить графики рас- 




Рис. 4. Соотношение среднесуточных аномальных нагрузок химических элементов: 1 - собственно аномальная нагрузка, 2 - условно аномальная нагрузка

Рис. 5. Характер изменения суммарных показателей загрязнения снегового покрова:

О - геометрический центр промышленной зоны, $\mathrm{K}_{\mathrm{pn}}-$ коэффициент концентрации пыли, уловленной снегом, по сравнению с фоном, $Z_{c}$ - суммарный показатель степени загрязнения пыли химическими элементами, $\quad Z_{p}-$ суммарный показатель нагрузки химических элементов на окружающую среду На оси ординат отложены величины $Z_{c_{1}} / Z_{c_{o}}, K_{p_{1}} / K_{p_{0}}, Z_{p_{1}} / Z_{p_{0}}$

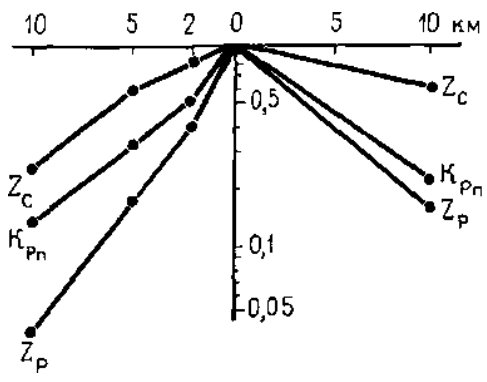




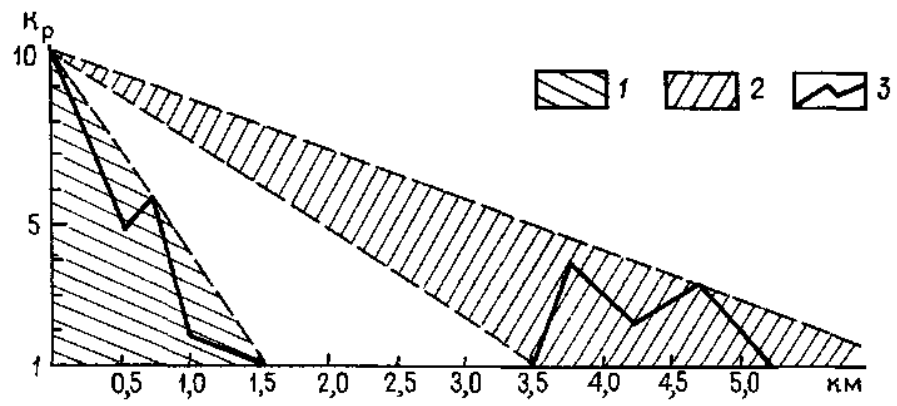

Рис. 6. Распространение ртути выбросов углеперерабатывающего предприятия: 1 - предполагаемая трасса распространения грубой твердой взвеси, 2 - предполагаемая трасса распространения тонкой взвеси и газовой фазы, 3 - уровень выпадения ртути в аномалиях по отношению к фоновому уровню $\mathrm{K}_{\mathrm{p}}$

пределения важнейших показателей загрязнения материала выпадений (рис. 5). Количество выпадающей пыли, суммарный показатель загрязнения пыли химическими элементами и суммарная нагрузка, создаваемая выпадениями, представлены в виде коэффициента распределения, т. е. пронормированы по отношению к их значению в источнике аномалии - промышленной зоне.

На графиках, построенных в полулогарифмическом масштабе, суммарный показатель степени загрязнения пыли химическими элементами, общее количество пыли и производный от них суммарный показатель нагрузки химических элементов на окружающую среду уменьшаются с удалением от группового источника загрязнения по закону, близкому к экспоненциальному (линии графика близки к прямым).

Скорость уменьшения концентрации химических элементов в пыли в 1,5-2,0 раза ниже скорости уменьшения выпадения самой пыли. Это обусловливает относительное обогащение пыли химическими элементами с удалением от источников загрязнения.

Близкий пример наблюдался Е. П. Сорокиной и одним из авторов при прослеживании воздушного потока ртути от углеперерабатывающего предприятия. Других источников ртути на территории нет, в то же время наблюдаются две зоны выпадений этого элемента: близ предприятия и на значительном удалении (рис. 6). Можно предположить, что зоны фиксируют трассы распространения различных форм нахождения ртути.

Центр наиболее высоких выпадений приурочен к источнику выброса. Размеры центра (для очень крупных источников выброса - километры) хорошо коррелируются с мощностью источника. Это хорошо подтверждается данными рис. 7, где приведены примеры для предприятия с чисто пылевым выбросом и для «химического» выброса плавильных металлоперерабатывающих производств. 


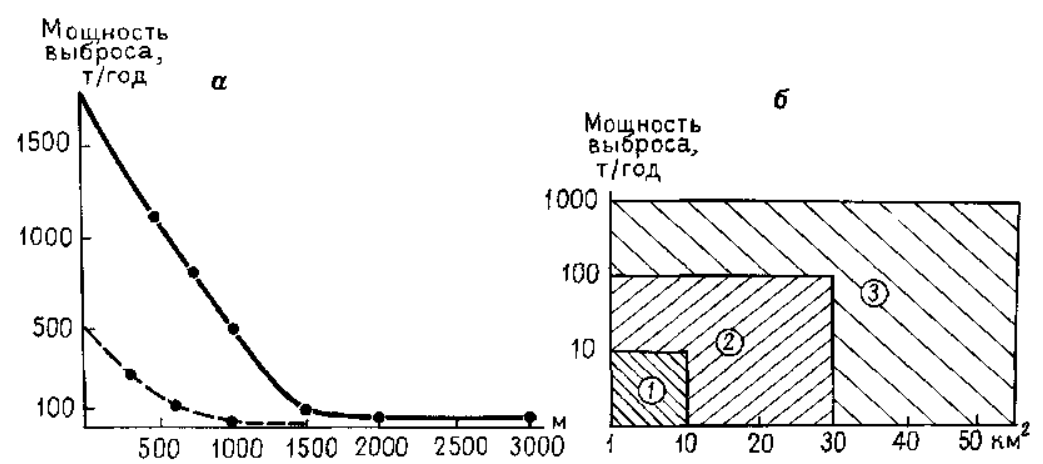

Рис. 7. Соотношение массы выброса и дальности распространения материала выпадений из атмосферы:

$a$-распространение пыли заводов строительных магериалов (цементный завод - сплошная линия, известковый завод - пунктир), б-- распространение цинка в выбросах предприятий разного размера $(1-$ мелкое, $2-$ среднее, 3 крупное)

Другая важная закономерность - намечающееся различие в изменении характеристик загрязнения территорий с наветренным и подветренным направлением распространения техногенных потоков. При редких и обычно тихих ветрах скорость уменьшения параметров загрязнения меньше, чем в направлении более частых и сильных ветров. Эти закономерности хорошо понятны. В условиях относительно слабого влияния горизонтальной составляющей воздушного рассеяния, что характерно для подветренной стороны и зоны, прилегающей к источнику в периоды штилей, лучше проявлено гравиметрическое распределение частиц выбросов с дифференциацией обогащенных химическими элементами тонких аэрозолей и бедных или грубодисперсных взвешенных частиц. Именно эти процессы •и обусловливают приуроченность центра высоких выпадений к территории промзоны и слабую зависимость его морфологии от розы ветров. В то же время общая пространственная структура распределения выпадений, представленная обычно полем невысоких концентраций загрязняющих веществ, хорошо корреспондирует с метеорологическими параметрами.

Морфология потоков рассеяния в урбанизированных зонах и особенности распределения химических элементов и их ассоциаций определяется прежде всего закономерностями пространственного распределения выпадений из атмосферы на земную поверхность.

Имеется ряд физико-математических моделей, описывающих процессы выпадения загрязняющих веществ $[17,28]$

Основными параметрами моделей распространения примесей являются мощность и высота источника, высота слоя вымыва- 



Рис. 8. Зональность выпадения химических элементов в техногенном воздушном потоке рассеяния. По $Е$. П. Со рокиной и Ю. Е Саету

Рис. 9. Зависимость между содержаниями свинца в атмосферном воздухе $\left(x\right.$, мкг $\left./ \mathrm{m}^{3}\right)$ и содержаниями свинца в почве $\left(y_{1}, \mathrm{mr} / \mathrm{kг}\right)$ и снежном покрове $\left(y_{2}, \mathbf{м г / \mathbf { ~ }}\right)$

ния, скорость и направление воздушных потоков, гравитационные характеристики примесей, интенсивность осадков. Все эти параметры наиболее стабильны для высоты выброса более 100 м, высоты слоя вымывания порядка 1000-3000 м. Для этих условий и одиночных источников загрязнения удалось рассчитать хорошее совпадение изолиний потоков выпадений с розой ветров, соотношение потоков грубо- и тонкодисперсных примесей, соотношение гравитационного и мокрого удаления и ряд других зависимостей. В конечном счете, по данным Б. И. Стыро и К. К. Шопаускаса, время вымывания химических элементов из атмосферы сравнительно невелико: 1,1-1,6 суток для $\mathrm{Mn}$, $\mathrm{Ni}, \mathrm{Pe}, \mathrm{A1}$, Си; 3,6 суток - для $\mathrm{Pb}$.

Следует заметить, что граничные условия существующих моделей далеко не полностью осуществляются в реальных промышленных зонах, для которых характерна множественность источников загрязнения с относительно низкими выбросами (менее 100 м), и где распространение примесей происходит в наименее устойчивых условиях.

Различие скоростей выпадения химических элементов, а также различия форм их нахождения в потоках рассеяния определяют возможность формирования в них геохимической зональности (рис. 8). Естественно, что для территорий с множеством источников она может быть непроявлена.

Важнейшим итогом проведенных в последние годы исследований по условиям образования и распространения техногенных геохимических потоков рассеяния является формирование представлений о корреляционных связях в окружающей среде в цепи «источник загрязнения - техногенный поток - геохимическая аномалия, создаваемая при выпадении загрязняющих веществ». Во многих случаях связи подтверждаются статистически достоверной корреляцией распределений содержаний химических 
элементов в сосуществующих природных средах, испытывающих влияние одних и тех же источников загрязнения. И, наконец, они подчеркиваются пространственным совпадением источников загрязнения центров и общей структуры ореолов и потоков рассеяния (рис. 9).

Данных, оценивающих корреляционные связи между составом и количеством химических элементов в промышленных выбросах, их концентрацией в воздухе, в выпадениях на земную поверхность и степенью загрязнения почв пока еще очень мало. Имеющиеся материалы демонстрируют лишь отдельные фрагменты этой сложной цепи.

Геохимическое изучение зависимости распределения химических элементов в выбросах промышленных предприятий и в выпадениях из воздушных потоков может быть проведено только на уровне приближенных оценок. Это вызвано прежде всего недостатком, а чаще всего, отсутствием точных данных по объемам организованных выбросов и невозможностью учета неорганизованного выброса. Кроме того, обычно известны только те химические элементы, которые по принятым технологиям должны участвовать в производственном процессе, элементы-примеси в сырье не учитываются. Ярким примером является производство серной кислоты. В случае использования для этого пиритных огарков в выбросах обнаруживаются As, Pb, Cd, 2п, Си и другие элементы в относительных концентрациях, не меньших, чем 5 .

Спектры химических элементов в выбросах и пылях, осажденных на снег, хорошо совпадают (см. рис. 9, $a$ ).

На основании результатов сопряженных исследований металлов в атмосферном воздухе и почве в ряде крупных промышленных городов выявлены количественные связи между концентрациями некоторых металлов в этих сопредельных средах.

Наблюдаемые корреляции статистически достоверны и выражаются следующими уравнениями регрессии (см. рис. 9):

зависимость между концентрацией свинца в атмосферном воздухе $x$ и в выпадениях из атмосферы на снеговой покров $y$ :

$$
y=5317 x+130
$$

зависимость между концентрацией свинца в атмосферном воздухе $x$ и почве $y$ :

$$
y=840 x+165
$$

зависимость между концентрацией меди в атмосферном воздухе $x$ и почве $y$ :

$$
y=526 x+457
$$

зависимость между концентрацией ртути в атмосферном воздухе $x$ и почве $y$ :

$$
y=130 x+1
$$




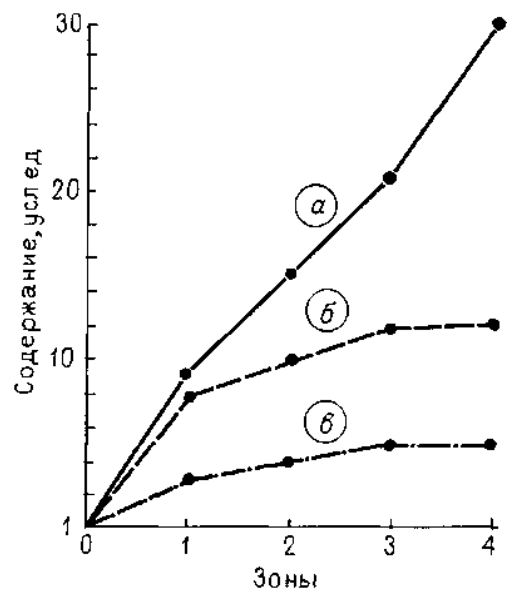

Рис. 10. Распределение пыли (a), соединений азота (б) и сульфатов (в) в снеговом покрове различных функциональных типов городских территорий:

0 -4-зоны 0 - фоновая, 1 парковая, 2 - селитебная, 3 - селитебно транспортная, 4 - промышленная

Установленные соотношения позволяют для перечисленных элементов определить уровни их содержания в депонирующих средах, оконтуривающие территории, где с большой степенью вероятности могут быть обнаружены превышения предельно-допустимых концентраций металлов в атмосферном воздухе. Выявление корреляционных связей в системе «атмосферный аэрозоль - выпадение» позволяет считать, что при изучении структуры загрязнения депонирующих сред городов эффективно изучение распределения возможно более широкой ассоциации металлов, отражающей весь комплекс химических элементов, загрязняющих атмосферный воздух.

Важно отметить, что аномалии выпадений пыли и химических элементов, как правило, совпадают с участками проявления в атмосферном воздухе аномалий оксидов серы, азота, хлоридов, антропогенных органических соединений - т. е загрязняющих веществ, приоритетных для воздушного бассейна [8]. Интересно отметить, что в ряде случаев (рис 10) загрязненные пылью и химическими элементами выпадения проявлены контрастнее, чем для приоритетных газообразных загрязняющих веществ. Таким образом, геохимические аномалии, важные сами по себе, имеют большое индикационное значение.

Наличие геохимических корреляционных связей в окружающей среде позволяет решать прикладные задачи: по аномалиям в природных средах, которых депонируют выпадения загрязняющих веществ, оценивать состояние жизнеобеспечивающих природных сред Таким образом, возникает принципиальная возможность использования геохимического картографирования для пространственной дифференциации структуры загрязнения окружающей среды. В основе картографирования лежит выявление и оконтуривание на местности геохимических аномалий.

Геохимическая аномалия - участок территории, в пределах которого хотя бы в одном из слагающих его природных тел статистические параметры распределения химических элементов достоверно отличаются от геохимического фона. 
Геохимический фон - средняя величина природной вариации содержаний химических элементов Он устанавливается на территории, где с большой надежностью можно предположить отсутствие природных или антропогенных источников поступления химических элементов.

Появление геохимических аномалий всегда связано с теми или иными природными и неприродными источниками воздействия, не являющимися обязательным компонентом данного типа геологической структуры или ландшафта. В случае антропогенных источников воздействия образуются антропогенные геохимические аномалии.

При этом различают геохимические ореолы и геохимические потоки рассеяния.

Геохимический поток рассеяния - термин, уже широко нами использовавшийся,- - применяется при описании аномалий в природных средах, транспортирующих загрязняющие вещества (в водах и воздухе). Их главными особенностями являются динамичность, неустойчивость состава и концентраций химических элементов во времени.

Геохимический ореол рассеяния - термин, используемый для описания аномалий в природных средах, накапливающих загрязняющие вещества при их выпадении из потоков рассеяния. $\mathrm{K}$ депонирующим средам относятся почвы, донные отложения, растительный и снеговой покровы. Слово «ореол» подчеркивает наличие надежно фиксируемой пространственной связи между аномальным полем и источником его образования. Геохимические ореолы по сравнению с потоками рассеяния значительно менее динамичны и, соответственно, лучше воспроизводимы при повторных наблюдениях. Геохимические ореолы рассеяния поле аномальных концентраций загрязняющих веществ и их ассоциации, отражающие воздействие на данную конкретную территорию источника загрязнения или группы источников за весь период их существования. Это своеобразная геохимическая фотография зоны воздействия источников загрязнения.

Техногенные геохимические аномалии и зоны загрязнения понятия, широко используемые в природоохранной литературе, не являются полными синонимами. Под зоной загрязнения обычно подразумевается часть геохимической аномалии, в пределах которой загрязняющие вещества достигают концентрации, оказывающей неблагоприятное влияние на живые организмы.

Техногенные ореолы и потоки классифицируются по типам вмещающих природных сред, по направленности изменения содержаний химических элементов в результаге геохимического преобразования и генезису.

По типам геохимических потоков, формирующих аномалии, и их источникам они могут быть аэрогенными (связанными с выпадением из воздушных потоков), гидрогенными (связан- 
ными с выпадением из водных потоков), биогенными (обусловленными концентрированием живыми организмами), вейстогенными (связанными с распространением отходов, внесением отходов в качестве удобрений, засыпкой отходами при строительстве) и агрогенными (связанными с особенностями ведения сельского и лесного хозяйства - внесение удобрений, ядохимикатов, агротехническая обработка почв). Отметим, что существуют природные геохимические аномалии рудогенные и вулканогенные, которые в случае использования территорий их распространения под расселение или сельское хозяйство могут рассматриваться как зоны загрязнения.

По природным средам, вмещающим аномалии, ореолы и потоки могут быть литохимическими (в почвах, горных породах, донных отложениях), сноухимическими (в снеговом покрове), гидрохимическими (в водах), атмохнмическими (в воздухе), биогеохимическими (в живых организмах).

По направленности изменений химического состояния объектов окружающей среды различаются аномалии концентрации и аномалии выноса химических элементов. При техногенной миграции могут возникать также аномалии разубоживания участки, где в результате искусственного механического перемещения вещества, связанного со строительством и планировкой местности, происходит разбавление природных концентраций материалом с низкими содержаниями.

Для биогеохимических аномалий в случаях, когда уровни концентрации элементов определяют состояния организмов и биокосных систем (почв), различают аномалии избытка и аномалии дефицита химических элементов.

Для всех видов техногенных ореолов характерна высокая неоднородность распределения химических элементов. Для аэрогенных аномалий показано [28], что как для приближенной к источнику загрязнения зоны наиболее интенсивных аномалий, так и для сравнительно удаленных периферических участков с аномалиями ослабленной интенсивности распределение характеризуется очень высокими дисперсиями и соответственно коэффициентами вариации (табл. 4).

С удалением от источника выбросов в пределах зоны воздействия в периферических частях аномалий дисперсия распределения возрастает. Таким образом, аэрогенные аномалии в почвах образуются за счет крайне неравномерно распределенных очень богатых химическими элементами техногенных частичек, разбавленных почвенной массой с фоновыми содержаниями. Естественно, что всякая геохимическая проба усредняет картину. Тем не менее, ситуация очень хорошо видна при анализе частот встречаемости аномальных содержаний, резко уменьшающихся с удалением от источника выброса (рис. 11).

Для гидрогенных ореолов в донных отложениях также харак- 

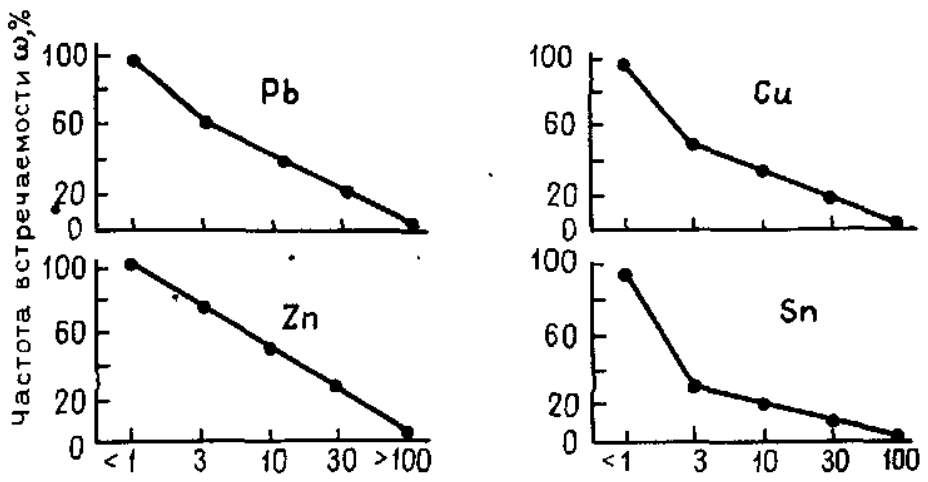

Расстояние, кM

Рис. 11. Частота встречаемости аномальных концентраций в аэрогенных ореолах на различном удалении от источника загрязнения

терны резко варьирующие распределения содержаний. Вблизи источника стоков содержания химических элементов всегда остаются в аномальной области, при удалении от него по руслу может наблюдаться вариация от контрастно аномальных до фоновых концентраций.

При загрязнении сельскохозяйственных территорий неравномерность распределения химических элементов особенно ярко наблюдается для аномалий смешанного агрогенно-вейстогенного происхождения, т. е. в случае использования в качестве удобрений бытовых или промышленных отходов.

Аэрогенные ореолы рассеяния наиболее четко проявлены в снеговом покрове и почвах. Мы уже отмечали хорошие корреляционные связи между распределением химических элементов

Т абли ц 4. Характеристика распределения химических элементов в загрязненных промышленными выбросами почвах

\begin{tabular}{|c|c|c|c|c|c|c|c|c|c|c|}
\hline \multirow{3}{*}{$\begin{array}{l}\text { Химический } \\
\text { элемент }\end{array}$} & \multicolumn{4}{|c|}{ Центр аномалии } & \multicolumn{6}{|c|}{ Периферия аномалии } \\
\hline & \multicolumn{2}{|c|}{ дворы } & \multicolumn{2}{|c|}{ улица } & \multicolumn{2}{|c|}{ дворы } & \multicolumn{2}{|c|}{ улица } & \multicolumn{2}{|c|}{ парк } \\
\hline & $\mathrm{C}$ & $\mathrm{a}$ & $\mathrm{C}$ & $\mathrm{a}$ & $\mathrm{C}$ & $\mathrm{a}$ & $\mathrm{C}$ & $a$ & $\mathrm{C}$ & $\mathrm{a}$ \\
\hline Свинец & 326 & 165 & 263 & 238 & 51 & 59 & 55 & 86 & 44 & 12 \\
\hline Цинк & 380 & 120 & 250 & ПО & 250 & 200 & ПО & 40 & ПО & 20 \\
\hline Медь & 84 & 60 & 92 & 75 & 34 & 43 & 34 & 14 & 19 & 7 \\
\hline Олово & 19 & 19 & 30 & 24 & 16 & 4,5 & 7 & 3 & 14 & 3 \\
\hline Ртуть & 0,015 & 0,029 & 0,044 & 0,144 & 0,07 & 0,24 & 0,07 & 0,24 & 0,01 & 0,01 \\
\hline Вольфрам & 4 & 3 & 6 & 5 & 2 & - & 0,3 & - & 1 & - \\
\hline Никель & 33 & 7 & 23 & 11 & 36 & 8 & 22 & 13 & 37 & 5 \\
\hline Хром & 53 & 21 & 34 & 17 & 50 & 18 & 32 & 14 & 75 & 24 \\
\hline
\end{tabular}

Примечание. Изучены площадки размером $10 \mathrm{X} 10$ м с отбором проб через 1 м (C среднее содержание в выборке, мг/кг; $a$ - стандартное отклонение) 
Габлица 5 Средневзвешенные содержания химических элементов в золах

\begin{tabular}{l|c|l|l|l|}
\hline \multicolumn{1}{c|}{ Источники загрязнения } & \multicolumn{1}{c|}{$\mathrm{Sr}$} & \multicolumn{1}{c|}{$\mathrm{T}^{\prime}$} & $\mathrm{V}$ & \multicolumn{1}{c|}{$\mathrm{N}$} \\
\hline Завод цветных металлов & $717(0,7)$ & $650(1)$ & $10(0,6)$ & $393(6)$ \\
Завод черной металлургии & $618(0,6)$ & $453(0,7)$ & $30(2)$ & $128(2)$ \\
Завод изделии из цветных & $342(0,4)$ & $647(1)$ & $67(4)$ & $101(1,5)$ \\
металлов & & & & \\
Завод приборостроения & $825(0,8)$ & $700(1)$ & $16(1)$ & $80(1)$ \\
Угольная ТЭЦ & $770(0,8)$ & $570(0,8)$ & $42(3)$ & $72(1)$ \\
Нефтеперерабатывающий за- & $922(0,9)$ & $488(0,7)$ & $31(2)$ & $61(1)$ \\
вод & & & & \\
\hline Фон & 994 & 670 & 16 & 65
\end{tabular}

Примечание Опробовдлись листья с мелкими ветвями, взвешивание средних пронзво концеитрации элемента огносительно фона

в выбросах, воздушных потоках, выпадениях из атмосферы и почвах. Менее изучены пока связи между воздушными потоками и растительным покровом. Влияние выбросов на растительность изучается давно и очень детально. Имеются интересные работы по принципам индикации загрязнения воздушного бассейна по геоботаническим особенностям растительности (главным образом, по лишайникам и мхам). Однако количественные корреляционные связи между распределением химических элементов в воздушных потоках и в биогеохимических ореолах изучены хуже.

При исследовании влияния промышленных выбросов на растительность трудно отделить химические элементы, поглощенные растительным организмом в процессе жизнедеятельности, от элементов, механически загрязняющих поверхность растения. Эта методическая задача пока не решена, и поэтому большая часть данных по концентрации химических элементов в растениях в зонах выбросов позволяет дать лишь приближенную оценку реального воздействия. Действительно, исследования по накоплению свинца близ автодорог показывают, что от 30 до 60\% металла удаляется при смыве листьев [28]. В. С. Аржанова установила, что пылевое накопление металлов на листьях в зоне влияния металлургического комбината настолько интенсивно, что может использоваться для изучения пространственных закономерностей распространения выбросов.

Связь между составом химических элементов в выпадениях и растительности (табл. 5) позволяет рассчитывать на принципиальную возможность картографирования загрязнения воздуха по составу растений (особенно листьев). Вместе с тем наличие значительной пылевой составляющей, нестабильно закрепляемой на листьях, требует более детальной методической проработки условий использования биогеохимических ореолов для картографирования атмосферных потоков. 
древесных растенин в зоне влияния различных источников загрязнения

\begin{tabular}{l|l|l|l|l|l}
\hline \multicolumn{1}{c|}{ Си } & \multicolumn{1}{c|}{$\mathrm{Ag}$} & \multicolumn{1}{c|}{$\mathrm{Z}_{\text {лl }}$} & \multicolumn{1}{c|}{$\mathrm{Pb}$} & \multicolumn{1}{c}{$\mathrm{Sn}$} & \multicolumn{1}{c}{ Мо } \\
\hline $2683(15)$ & $4,1(14)$ & $1583(1,6)$ & $492(6)$ & $24(3)$ & $53(4)$ \\
$264(1,5)$ & $0,5(1,7)$ & $747(0,8)$ & $170(2)$ & $68(8)$ & $128(10)$ \\
$506(3)$ & $0,4(1)$ & $821(0,8)$ & $222(3)$ & $77(10)$ & $101(8)$ \\
$875(3)$ & $0,3(1)$ & $2275(2)$ & $6525(74)$ & $4(0,5)$ & $14(1)$ \\
$225(1)$ & $0,3(1)$ & $1810(2)$ & $94(1)$ & $14(2)$ & $42(4)$ \\
$142(1)$ & $0,1(0,5)$ & $756(0,8)$ & $47(0,5)$ & $5(0,7)$ & $5(0,4)$ \\
& & & & & \\
\hline 180 & 0,3 & 990 & 88 & 8 & 12
\end{tabular}

дилось на число шроб каждого вида растения в выборке в скобках - коэффициент

Техногенные ореолы, связанные с выпадением химических элементов из атмосферы, концентрируются в самой верхней части почв (рис. 12). В этом их главное отличие от вейстогенных и рудогенных ореолов рассеяния, для которых характерно увеличение концентрации химических элементов вниз по разрезу (рудогенные аномалии) или незакономерное, сильно варьирующее распределение (вейстогенные аномалии на свалках). В то же время для аэрогенных ореолов в ненарушенных почвах наблюдается связь глубины проникновения в почву с мощностью выпадений (см. рис. 12). Однако даже для выпадений в эпицентре аномалий одного из крупнейших заводов цветной металлургии глубина проникновения элементов в ненарушенных почвах за более чем 100-летнюю историю не превышает $35-40$ см.

В техногенных геохимических аномалиях, как правило, не может быть изучен весь возможный спектр загрязняющих ве-


Рис. 12. Распределения свинца и олова в разрезах загрязненных и фоновых почв (a) и глубнна проникновения аномальных (Kc более 3 ) концентраций свинца при удалении от источника (6):

$1-3$ - почвы $(1$ - дерново подзолистые фонового уцастка, 2 - дерново-подзолистые в зоне воздействия завода цветных металлов, 3 - антропогенные нарушенные в центре крупной промышленной агломерацин) 
ществ, который часто далеко не ясен. Поэтому обычно исследуются главные или приоритетные (и часто наиболее распространенные) ингредиенты - загрязняющие вещества, оказывающие наиболее неблагоприятное воздействие на окружающую среду.

В то же время для фиксации зоны неблагоприятного воздействия источников загрязнения обычно достаточно изучить типоморфные ингредиенты (типоморфные химические элементы, элементы-индикаторы), т. е. те химические элементы или показатели воздействия, которые позволяют судить о состоянии изучаемой системы в целом.

Например, с выбросами автотранспорта, работающего на этилированном бензине, связано загрязнение окружающей среды нефтепродуктами, угарным газом, полицикличными ароматическими углеводородами (ПАУ), бромом, свинцом, цинком, кадмием и многими другими веществами. Приоритетными (по концентрированию и опасности воздействия) здесь являются угарный газ, ПАУ и свинец. Типоморфным можно считать один свинец - элемент, корреляционно связанный со всеми другими ингредиентами, исследование которого позволяет описать всю систему воздействия автотранспорта.

При геохимических исследованиях окружающей среды наряду с отдельными химическими элементами проводится анализ распределения ассоциаций химических элементов. Ассоциация химических элементов - группа элементов, обнаруживаемая в изучаемом объекте в количестве, отличном от критериального уровня. Таким уровнем может быть либо геохимический фон, либо норматив, задаваемый условиями задачи.

Количественной мерой ассоциации является суммарный показатель загрязнения, представляющий собой аддитивную сумму превышений коэффициентов концентрации (рассеяния) над единичным (фоновым) уровнем.

$$
Z_{c}=\sum_{1}^{1} \frac{\mathrm{C}_{1}-C_{\phi}}{\mathrm{C}_{\Phi}}+1=\sum_{1}^{n} \mathrm{~K}_{\mathrm{c}}-(n-1),
$$

где $K_{c}-$ коэффициент концентрации (отношение содержания химического элемента в оцениваемом объекте к его фоновому содержанию, $n$ - число химических элементов, входящих в изучаемую ассоциацию, C, - аномальное содержание; $\mathrm{C}_{\phi}-$ фоновое содержание.

Количественными показателями, используемыми при описании и типизации ассоциаций химических элементов, являются также индексы соотношений между отдельными химическими элементами или какими-либо их группами. Выбор видов таких индексов зависит как от особенностей выбранного эталона сравнения, задающего первичный масштаб уровня соотношений между элементами и их группами, так и от специфики изучае- 
мого объекта. Система таких индексов (показателей) часто является константой и позволяет разработать чувствительные способы геохимической интерпретации аномалий (например, разделение аномалий по источникам их образования).

Наиболее известным в техногенной геохимии примером такого" индекса является отношение $\mathrm{Pb} / \mathrm{Br}$, позволяющее отделить аномалии свинца, связанные с автомобильными выбросами, имеющими высокие конценграции брома, от выбросов иных источников, как правило, не содержащих брома.

В случаях, когда появление химических элементов в ассоциации связано с единым источником поставки или миграционным процессом, ассоциации являются парагенетическими. В случаях, когда воздействие разных источников механически сводит химические элементы на одной территории и в одном объекте, появляются ассоциации сонахождения.

Ассоциации могут быть полными, включающими все химические элементы, обнаруживаемые в исследуемом объекте в аномальных количествах, и частными, включающими химические элементы, отражающие какую-либо сторону геохимического явления. Примерами частных ассоциаций являются ассоциации токсичных элементов, ассоциации элементов, типоморфных для какого-либо вида производства или процесса, ассоциации редких металлов и т. д.

Анализ ассс циаций элементов - основа картографирования техногенных геохимических аномалий [28]. Геохимическая структура ассоциаций - важнейшая характеристика техногенной аномалии, демонстрирующая еe специфичность и позволяющая идентифицировать источники загрязнения. Ниже приведено много примеров ассоциаций химических элементов для аномалий, связанных с различными видами антропогенных воздействий и природными аномалиями. Как и для источников загрязнения (отходов, выбросов, стоков), в техногенных аномалиях четко проявляется преимущественное концентрирование элементовпримесей. Яркий пример этой закономерности наблюдался в серии аномалий, связанных с циклом переработки богатых свинцово-цинковых руд: добыча (механические процессы) обогащение (водно-механические процессы) - металлургия (термические процессы). Мы видим (рис. 13), что главные элементы технологии ( $\mathrm{Pb}$ и 2п) во всех типах аномалий накапливаются примерно одинаково, тогда как примеси ( $\mathrm{Ag}, \mathrm{Cd}, \mathrm{Cu}$, особенно Мо и $\mathrm{Bi}$ ) резко повышают свой ранг в ореолах при увеличении разрушения первичного сырья.

Качественные и количественные признаки подбора элементов, включаемых в ассоциации, определяются задачами исследования. Можно назвать важнейшие типы задач, где требуется изучение геохимических ассоциаций.

Во-первых, эта задача картографирования загрязнения тер- 


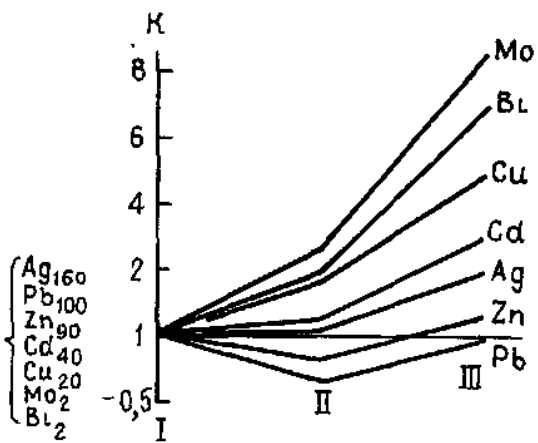

Рис. 13. Изменение состава ассоциаций химических элементов в почвах центров техногенных аномалий, связанных с добычей и переработкой свинцово-цинковой руды:

I - III - ореолы рассеяния элементов (I - на участке добычи руды, II - на участке обогащения руды, III - на участке металлургического передела) K - коэффициент обогащения ореолов относительно участка добычи В индексе элемента указан его коэффициент концентрации в почве на участке I

риторий, требующая выделения геохимических аномалий, однородных по качественным и количественным признакам, выявления связи аномалий с источниками загрязнения, выделения и разделения в пространстве зон воздействия отдельных источников.

Во-вторых, это характеристика динамики и кинетики поведения загрязняющих веществ.

Естественно, что на одной территории могут сочетагься (и чаще всего сочетаются) техногенные геохимические аномалии, имеющие разное происхождение и проявленные в различных природных телах. Иными словами, чаще всего загрязнение окружающей среды полигенно и полиформно. Характер сочетаний различных типов геохимических аномалий позволяет судить об общей направленности динамики процессов загрязнения, что имеет огромное значение для интерпретации зон загрязнения и разработки природоохранной политики.

Техногенные аномалии, проявленные только в долговременно депонирующих загрязнение природных средах (почвах, донных отложениях) и отсутствующие в транспортирующих средах (воздухе, воде) и в средах кратковременно депонирующих загрязняющие вещества (снег, поверхность растений), являются регрессивными. Они фиксируют былые источники загрязнения, ныне не функционирующие.

Техногенные аномалии, проявленные только в природных средах, транспортирующих и кратковременно депонирующих загрязнение, являются неотрансгрессивными. Они связаны с недавно созданными источниками загрязнения и вновь формируемыми зонами загрязнения.

При развитии техногенных аномалий одновременно в депонирующих и транспортирующих средах аномалии являются трансгрессивными и фиксируют устойчиво существующие источники со стабильными зонами загрязнения.

На рис. 14 приведен схематизированный геохимический профиль через крупную урбанизированную зону, где наблюдались все названные выше типы аномалий. 


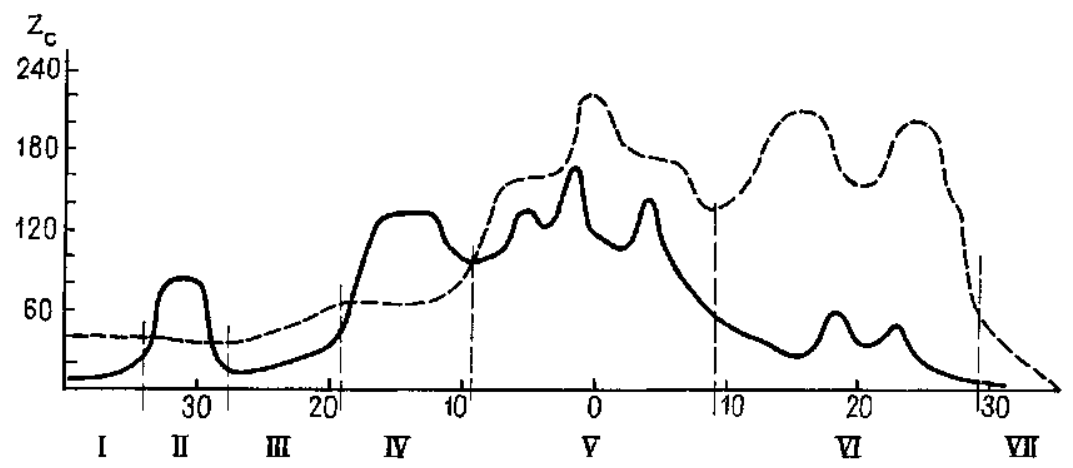

Рис. 14. Характерный геохимический профиль через крупную урбанизированную территорию с различными типами техногенных аномалий:

I, III, VII - фоновые зоны, II - регрессивная аномалия на освоенной свалке, IV - регрессивная аномалия промышленного района, V - трансгрессивная аномалия давно сложившегося промышленного района, VI - неотрансгрессивная аномалия нового промышленного района $Z_{\ell}-$ суммарный показатель загрязнения, сплошная линия - распределение загрязняющих веществ в выпадениях из атмосферы, пунктир распределение загрязняющих веществ в почвах

Яркий пример наблюдался в районе недавно созданной промзоны приборостроительного профиля. Здесь нами зафиксированы наиболее высокие из отмечавшихся где-либо выпадения $\mathrm{Cd}$ (до 23,5 r/ $\mathrm{km}^{2}$ в сутки, что более чем в 10000 раз выше фонового), $\mathrm{Hg}$ (до $1,1 \mathrm{r} / \mathrm{Km}^{2}$ в сутки, что в 1000 раз выше фонового), $\mathrm{Pb}$ $\left(81,7\right.$ г $/ \mathrm{kм}^{2}$ в сутки, что в 500 раз выше фонового). Однако, время воздействия невелико (несколько лет), и геохимическая аномалия в почвах пока проявлена слабо.

В другой промзоне с приборостроительными предприятиями, существующей уже более 30 лет, при близких порядках уровня выпадений оценены запасы металлов, привнесенных в почву. Установлено, что за время существования зоны количество Ві в почвах возросло в 60 раз, Sb и $\mathrm{As}-$ в 20 раз, $\mathrm{Cd}$ и $\mathrm{Mo}-$ в 10 раз, $\mathrm{Pb}, \mathrm{Zn}, \mathrm{Cи}, \mathrm{Ag}$ и 5 п - в 7 раз. Это довольно высокий темп загрязнения - до 200\% в год.

Синхронный анализ ореолов рассеяния в транспортирующих и депонирующих природных средах показывает динамику процесса и позволяет охарактеризовать новейшую историю загрязнения окружающей среды. Более «древние» этапы истории также запечатлены в геохимии компонентов окружающей среды. Это специальная задача, которая пока не очень хорошо разработана, особенно для локальных ситуаций - техногенных ореолов и потоков рассеяния. С этой целью перспективно прежде всего детальное изучение разрезов с исследованием абсолютного возраста. Для донных отложений, где скорость седиментации фиксируется довольно точно и разрез сравнительно легко расчленяется на 

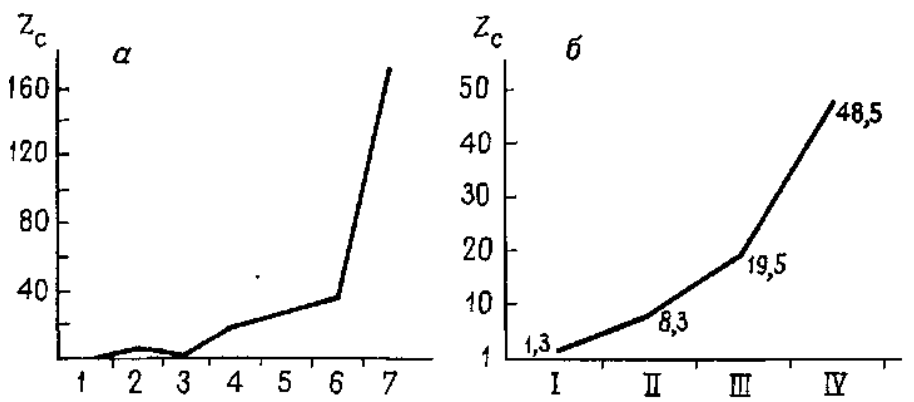

Рис. 15. Уровни загрязнения почв (а) и строительных материалов (б) в различные исторические эпохи:

1 -7 - почвы разного возраста (1 - ранее культурного слоя, 2 - I в до н э.VII в н э, 3 - XIII в , 4 - XIV-XVI вв, 5 - XVII -XVIII вв, 6 - XIX - XX вв, 7 - XX в), I-IV - строительные материалы разного возраста (I - известняк XVI в, II - кирпич XVI-XVIII вв, III - кирпич XX в, IV - бетон XX в)

хронологически привязанные горизонты, данных такого рода довольно много [30]. Для почвенного покрова материалов почти нет. Приведем полученные результаты по геохимическому сопоставлению разновозрастных горизонтов культурного слоя г. Москвы и строительных материалов (рис. 15). Тенденция к расширению геохимической ассоциации и росту концентрации химических элементов в мелкоземе по мере развития города выражена весьма отчетливо. По сравнению с началом нашей эры суммарный уровень загрязнения вырос в десятки раз При этом до XIX в. рост был существенно меньшим. Обращает внимание возросший уровень концентрации химических элементов в современных строительных материалах. Это делает их серьезным потенциальным источником загрязнения.

Одна из важнейших задач прикладных геохимических исследований окружающей среды - установление пространственной структуры еe загрязнения, дифференцирующей территорию по степени экологической опасности. Техногенные ореолы определяют общий размер и морфологию зоны воздействия отдельного источника загрязнения или группы сближенных источников. - Внутренняя структура ореола может быть дифференцирована лишь условно, так как миграционные процессы чаще всего создают непрерывное распределение, внутри которого нет естественных природных границ. Общая структура загрязнения территории зависит от пространственного соотношения источников загрязнения и взаимоналожения контуров техногенных ореолов и потоков, сопровождающих эти источники. Таким образом, при всех вариантах пространственного анализа морфоструктуры загрязнения границы могут быть лишь условными.

В пределах ореола удобно различать ядро и периферическую часть. 
Ядро ореола - зона наиболее сильного загрязнения, наблюдаемого в связи с данным источником. Структурно ядро ореола характеризует центр воздействия отдельного предприятия или блока предприятий и по ассоциации загрязняющих веществ четко фиксируется источник загрязнения. По особенностям пространственного распределения отдельных загрязняющих веществ или их ассоциаций внутреннее строение территории ядра ореола однородно.

Периферическая часть ореолов - зона среднего и слабого загрязнения. На территории со множеством мозаично расположенных источников загрязнения из-за взаимных наложений ореолов по периферическим частям источники загрязнения не всегда четко идентифицируются.

Следующей таксономической единицей пространственной структуры является очаг ореолов (очаг загрязнения) Он представляет собой территорию сплошного проявления загрязнения. В ее пределах ореолы и потоки отдельных источников сливаются на уровне зон среднего уровня загрязнения. Таким образом, очаг ореолов представляет собой создаваемое несколькими источниками некое поле загрязнения среднего уровня, в пределах которого могут быть ядра загрязнения, характеризующие зоны наибольшего воздействия. Часто очаги загрязнения приурочены к промышленным зонам.

Очаги ореолов, соприкасаясь зонами слабого уровня загрязнения, образуют узлы ореолов. Узлы, также как и очаги, представляют собой территорию с практически сплошным развитием поля загрязнения, но на более слабом уровне. Узлы ореолов являются геохимическим пространственным проявлением воздействия промышленного района.

Серия сближенных узлов ореолов формирует региональное поле. Оно обычно не является хорошо прослеживаемой сплошной геохимической структурой и оконтуривается очень условно по границам зон слабого загрязнения периферических частей узлов загрязнения.

Загрязнение окружающей среды, связанное с формированием региональных геохимических полей и узлов, в гигиене окружающей среды и в гидрометеорологии называют фоновым загрязнением (уровень загрязнения, сложившийся на данной территории от всей совокупности источников загрязнения в настоящее время) .

Для количественного анализа особенностей и интенсивности развития загрязнения в пространстве может быть использована плотность загрязнения. Она рассчитывается как соотношение площадей ядер, очагов и узлов или как отношение их площади к некой общей исследуемой площади загрязненной геотории (например, площади административного района). В каждом случае может быть намечена или задана критическая плотность 
Т а б л ц а 6 Зависимость площадей техногенных аномалий химических элементов в почвах от характеристик промышленного выброса

\begin{tabular}{|c|c|c|c|c|c|c|c|c|}
\hline \multirow[b]{2}{*}{ Элемент } & \multicolumn{2}{|c|}{ Выбросы } & \multirow{2}{*}{$\begin{array}{c}\text { Об } \\
\text { щая } \\
\text { пло } \\
\text { щадь } \\
\text { ано } \\
\text { малий, } \\
\text { ки }^{2}\end{array}$} & \multicolumn{5}{|c|}{$\begin{array}{c}\text { Площади аномалий }(\text { в км²) } \\
\text { в контуре } \mathrm{K}_{i}\end{array}$} \\
\hline & $\begin{array}{l}\mathrm{P} \\
\text { т/год }\end{array}$ & $K_{\mathrm{c}}^{1}$ & & 1,5 & 3 & 10 & 30 & 100 \\
\hline Свинец & 12,6 & 383 & 24,2 & 11,2 & 9,5 & 2,1 & 0,8 & 0,6 \\
\hline Цинк & 7,4 & 112 & 12,3 & 8,6 & 2,7 & 0,7 & 0,3 & 0 \\
\hline Медь & 2,1 & 62 & 6,6 & 4,4 & 0,9 & 0 & 0,2 & 0 \\
\hline Никель & 0,7 & 30 & 0,6 & 0,6 & 0 & 0 & 0 & 0 \\
\hline Хром & 1,1 & 19 & 0,4 & 0,4 & 0 & 0 & 0 & 0 \\
\hline
\end{tabular}

Примечания Р - количество металла, поступившее с пылевым выбросом в атмосферу, $\mathbf{K}_{t},-$ коэффициент концентрации метдлыа в промышленной пыли, $\mathbf{K}_{r}^{2}-$ коэффициент концентрации металла в почвах

(например, отношение площади, выделенной под промышленную деятельность, к общей площади) .

Морфоструктурные особенности аномалий обусловлены, с одной стороны, пространственными закономерностями распределения потоков рассеяния, с другой стороны, ландшафтными условиями территории, испытывающей техногенное геохимическое воздействие. Общая морфология ореолов химических элементов в аэрогенных аномалиях определяется розой ветров, при этом центр высоких содержаний обычно близок к кругу и обрамляет источник выброса.

Размеры аномалий корреляционно связаны с интенсивностью выбросов. Это особенно хорошо прослеживается при наблюдении за единичными источниками с выбросом полиэлементной ассоциацией (табл. 6).

Естественно, что размеры аномалий сильно связаны с временем воздействия. И. В. Токарев наблюдал однотипные источники выбросов свинца, функционирующие соответственно около 10, около 20 и около 100 лет. На участках наблюдения (1 км²) общая плотность аномалий свинца составила соответственно 10, 70 и 100\%. Аномалии свинца с содержанием более 500 кг/км в первом случае отсутствовали, во втором - занимали около $1 \%$, а для столетнего объекта - 50\% территории.

Контуры аномалий чаще всего извилисты. Очень характерно снижение интенсивности аномалии выпадений на участках сельскохозяйственной деятельности (рис. 16). При этом уменьшение концентрации происходит не только за счет механического перемешивания при вспашке, но и за счет общего уменьшения техногенного запаса. Это установлено специальными исследованиями, проведенными И. Л. Борисенко в ходе параллельного изучения естественных и сельскохозяйственных почв в зоне равных выпадений из атмосферы (рис. 17). 
Рис. 16. Влияние ландшафта на морфологию акомалий: 1 -3 - ландшафты (1 - лесные, 2 - сельскохозяйственные, 3-луговые, старопахотные земли), 4 - источник загрязнения

Рис. 17. Концентрация $K_{c}$ и техногенный запас $T_{\text {м }}$ меди и свкнца в лесных (сплошная лннкя) н пахотных (пунктнр) почвах
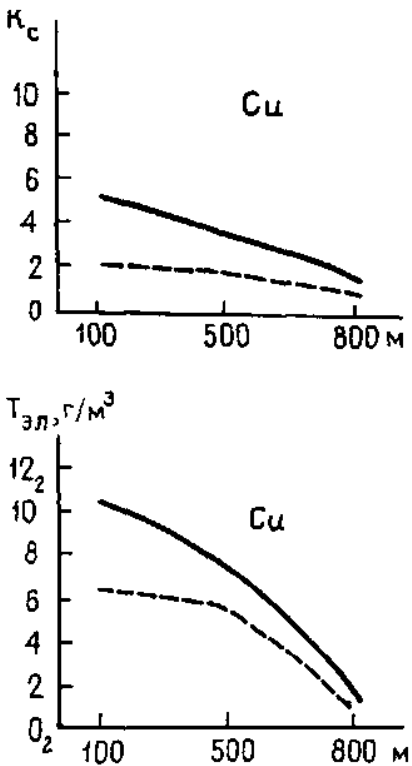
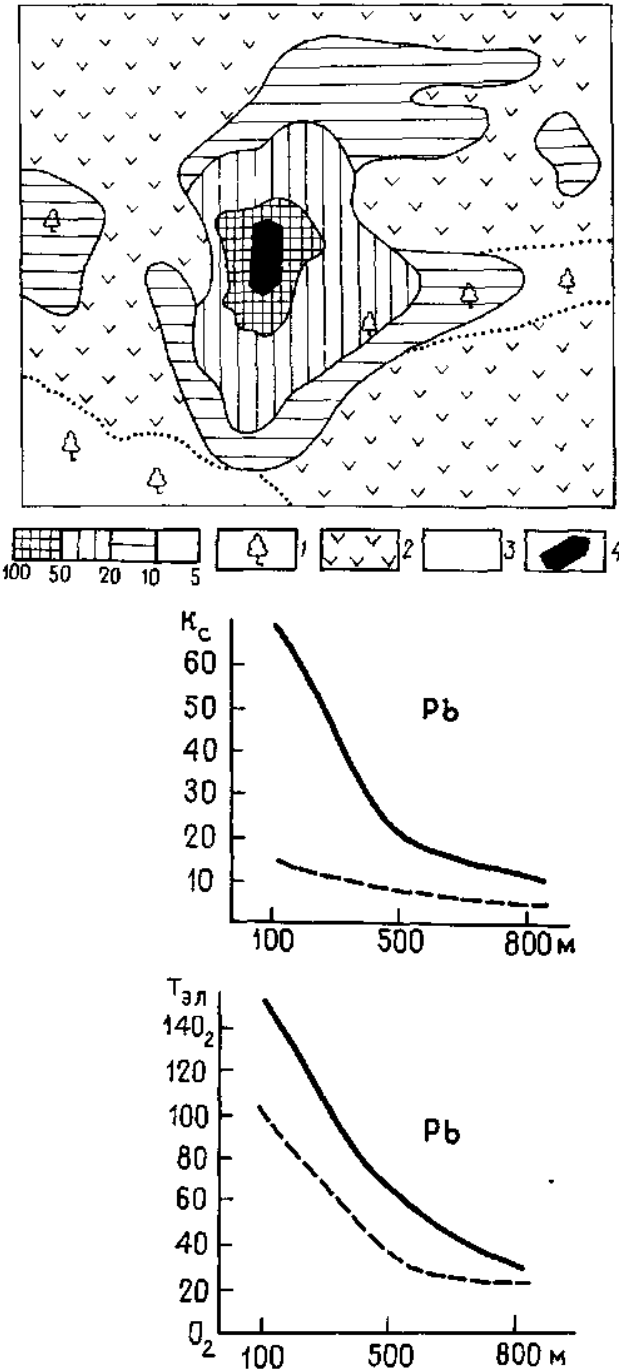

Большое значение имеет и расчлененность рельефа, определяющая многие морфологические черты техногенных аномалий.

Для техногенных аномалий в донных отложениях речных систем в связи с природной дифференциацией условий накопления аллювиального и техногенного материала (участки замедления течения, микрогрязи и т. д.), а также из-за обычно существующих искусственных механических барьеров (гидрятехнические сооружения), характерна неоднородная (пятнистая) морфология геохимической аномалии на площади дна даже небольших водотоков. 


\section{Оценка результатов антропогенного геохимического воздействия на живые организмы}

Техногенные геохимические аномалии фиксируют пространственные положения зон воздействия источников загрязнения, т. е. территорий на которых современными методами исследования фиксируются неблагоприятные последствия загрязнения окружающей среды как для живых организмов, так и для природных систем, определяющих условия жизни (состояния воздуха, воды, пищи) .

Углубленное изучение и оценка биологических и медицинских последствий загрязнения выходит за рамки предмета исследований прикладной геохимии и является задачей геогигиены (гигиены окружающей среды) - науки о медицинских последствиях воздействия человека на природные системы, и экологии - науки, исследующей взаимосвязь между живыми организмами и средой их обитания.

Геохимические данные позволяют изучить пространственные и статистические связи между геохимическими аномалиями различной интенсивности и состоянием биоты - совокупности всех категорий живых организмов, населяющих исследуемую территорию. Эти связи изучаются прежде всего на уровне биогеохимии - т. е. на основе распределения химических элементов в биоте в связи с их миграцией в среде обитания - компонентах окружающей среды.

Изучение результатов геохимического воздействия на живые организмы проводится на стыке различных научных и отраслевых направлений изучения окружающей среды. Именно здесь необходимы взаимопонимание между специалистами различного профиля и увязка различных понятийных баз.

Система контроля за состоянием окружающей среды и последствиями ее загрязнения состоит из трех групп регламентирующих (нормативных) показателей, оценивающих состояние: 1) источника загрязнения; 2) природных сред в зоне загрязнения; 3) биоты в зоне воздействия.

Оценка и контроль источника загрязнения происходит по предельно-допустимому выбросу (сбросу), т. е. массы (объема) загрязняющих веществ, рассеяние которых в природных условиях данного конкретного источника загрязнения с учетом уровня общего фонового загрязнения от совокупности других источников, не создаст за границей так называемой санитарно-защитной зоны превышения допустимых уровней загрязнения. Санитарно-защитной зоной называется часть общей зоны воздействия, в пределах которой происходит рассеяние (разбавление) концентраций поллютантов до безопасных уровней или их разложение (нейтрализация) до безопасных соединений.

В санитарно-защитной зоне в связи с реальным или прогно- 
зируемым неблагоприятным воздействием, выраженным прежде всего в отклонении показателей состояния окружающей среды от гигиенических норм - предельно-допустимых концентраций (ПДК),- запрещено размещение жилья; в ряде случаев запрещена всякая деятельность.

В основе большей части оценок состояния природных сред лежат представления о наличии сложных корреляционных связей между концентрацией загрязняющих веществ в компонентах окружающей среды, их поступлением в биоту и появлением неблагоприятных биологических реакций живых организмов, достоверно фиксируемых существующими методами исследований. Под биологическими реакциями подразумеваются любые отклонения в организмах, достоверно связанные с загрязнением окружающей среды. Во многих случаях считается, что наличие у живых организмов адаптационных (приспособительных) свойств - способности переносить изменяющиеся условия внешней среды - приводит к появлению вариации допустимых пределов физиологических характеристик, в частности биохимических Одной из таких характеристик считается уровень концентрирования в организме загрязненного вещества. Многочисленные наблюдения за биологическими реакциями на загрязнение, материалы токсикологии (науки о действии ядов на живые организмы) привели к представлению о пороговости воздействия. химических соединений на живой организм. Под пороговостью подразумеваются такие уровни поступления химического соединения (загрязняющего вещества) в живой организм, в пределах которых реакция не выходит за вариацию колебаний физиологической нормы.

При определении воздействия загрязняющего вещества (поллютанта) важно оценить его количество, поступившее в организм. Оно зависит от уровня содержания химического соединения в жизнеобеспечивающих природных средах и времени воздействия. Для отдельных поллютантов используются уже упоминавшиеся гигиенические нормативы допустимого загрязнения предельно-допустимые концентрации (ПДК). ПДК - максимальная концентрация поллютанта в природном теле за определенный период осреднения наблюдений (сутки, месяц, год), не оказывающая при принятой по результатам экспериментальных наблюдений вероятности появления какого-либо вредного воздействия на живой организм.

Предельно-допустимые концентрации по большей части ориентированы на человека. В этом случае они отмечают уровень, при котором не наблюдается ни прямых, ни косвенных вредных воздействий, включая отдаленные последствия для настоящего и следующих поколений, а также на снижение работоспособности или ухудшение самочувствия.

В последнее время начаты разработки ПДК, орнентирован- 
ные на ряд других категорий живых организмов (рыбы, растения)

Естественно, что ПДК - не постоянная величина ПДК меняется при установлении новых, ранее не замеченных эффектов воздействия.

Опасность воздейсгвия неодинакова для различных загрязняющих веществ. Это связано как с контрастным различием величин ПДК, так и с качественной неоднородностью тех неблагоприятных реакций организмов (лимитирующих признаков вредности), превышение которых послужило причиной для назначения норматива. В связи с этим поллютанты разделяются по классам опасности, т. е. группам, объединяющим их по признаку близости ПДК и типу реакции организма при воздействии. Эти классы устанавливаются раздельно для каждого природного тела.

Для случаев многокомпонентных комплексных по составу зон загрязнения (наиболее широко распространенных), эффект воздействия системы не эквивалентен воздействию индивидуальных загрязняющих веществ.

Как правило, фиксируется кумулятивное синергическод воздействие, при котором происходит усиление реакции организма на группу химических соединений, по сравнению с его реакцией на индивидуальные вещества, входящие в эту группу. Значительно менее изучены антагонистические реакции, когда регистрируется ослабление действия одного фактора под влиянием другого.

Данные по повсеместно проявленной комплексности (полиэлементности) состава зон загрязнения показывают, что предельно-допустимые уровни индивидуальных загрязняющих веществ не могут быть уточнены эпидемиологическими и фитопатологическими исследованиями. Это тем более верно, что большинство реакций живых организмов в зонах загрязнения неспецифичны для индивидуальных веществ, а итог воздействия столь большой суммы веществ (которая обычно наблюдается) предугадать трудно. При геохимических исследованиях особенно ярко выявилось, что пока нет способа их гигиенической оценки. Особенно это проявлено при изучении донных отложений. В ряде случаев уровни их загрязнения ураганны, но при анализе водной системы содержания выше предельно допустимых встречаются редко. Несмотря на выраженные последействия для гидробионтов, нет ғнгиенических причин для природоохранных мероприятий, и они организуются практически на эмоциональной основе (например, очистка русел).

В очень трудном положении оказались курортные зоны и заповедники. Так, на известнейшем грязевом курорте оз. Саки завод, загрязняющий его стоками и выбросами, формально не создает гигиенически опасной ситуации. И это несмотря на то, 48 
что экспериментальные и натурные исследования загрязнения донных отложений (в данном случае грязевой залежи) и лечебной рапы показали отрицательное воздействие на бентосные диатомовые водоросли, хирономиды, сульфатредуцирующие целлюлозоразрушающие и тионовокислые бактерии - гидробнонты, формирующие лечебные свойства озера.

Вероятно, для курортных, рекреационных и заповедных территорий должны быть разработаны свои критерии оценки, исходящие из флуктуации фоновых состояний.

Отсутствие полной адекватности экспериментальной нормативной модели, натурных параметров и методических технологических приемов выявления уровня и характера загрязнения в ряде случаев переводят нормы в разряд ориентирующих показателей вредности того или иного загрязняющего вещества. В peзультате создаются различия между замеренной и реальной опасностью загрязнения. Количественная оценка состояния среды становится недостоверной, и решения о затратах на ее охрану становится обоснованными.

Выход из создавшегося положения видится в создании эмпирических эколого-геохимических моделей «среда - организм», которые позволили бы по результатам исследований пространственной геохимической структуры экспертных оценок прогнозировать характер и объем неблагоприятных реакций организмов.

Реакции живых организмов на загрязнение рациональнее рассматривать по степени возрастающей опасности антропогенных воздействий. В этом плане возможно рассмотрение результатов воздействия как по уровням общей организации живой материи (онтогенетическим - для отдельных особей, популяционным - видовом и биогеошенотическим - биосферным), так и по глубине ущерба, наносимого в среднем отдельному организму, испытывающему антропогенную геохимическую нагрузку [48, 49].

Онтогенетические и популяционно-видовые аспекты оценок состояния живых организмов в зонах загрязнения более близки к возможностям, следующим из материалов прикладных геохимических исследований. Важнейшими ранжированными по опасности уровнями реакций организмов на состояние окружающей среды в антропогенных геохимических аномалиях являются: 1) биологическое (биохимическое) концентрирование поллютантов; 2) появление физиологических и функционально-морфологических отклонений; 3) рост заболеваемости (общей и по конкретным группам болезней); 4) снижение функций размножения и воспроизводства, уменьшение биопродуктивности, генеративной способности, мутагенные изменения; 5) смертность и (или) уменьшение численности популяции.

Изучение интенсивности проявления перечисленных реакций в соответствии с геохимической структурой загрязнения окру- 
жающеи среды, выявленной при изучении техногенных ореолов и потоков рассеяния, позволяет подойти к построению эмпирической биогеохимической и геогигиенической модели «среда организм». Разработка таких моделей даст возможность (мы это покажем ниже) по методу «аналогии» проводить оценку неблагоприятных последствий загрязнения окружающей среды и обосновывать природоохранные мероприятия

Биологическое (биогеохимическое поглощение) - способность живых организмов извлекать из окружающей среды и накапливать химические элементы. Склонность химических элементов к концентрированию, выраженная в виде того или иного соотношения между содержанием элемента в живом организме и его содержанием в окружающей среде, определяется его биофильностью. При любом способе количественного выражения биофильности отмечается лишь относительный уровень содержания химического элемента в организме, доля его участия в химической структуре организма, но не его значимость, «нужность»

Широко распространены для растений расчеты коэффициента биологического поглощения - отношение содержания химического элемента в золе к его содержанию в почве или почвообразующей породе Эти расчеты позволяют построить ряды биологического поглощения - ассоциации элементов по интенсивности их концентрирования растениями.

Степень концентрирования элементов различными видами организмов и разными органами и тканями одного организма неодинакова. Это связано с существованием физиологических барьеров, ограничивающих возможность поступления элементов в организм и регулирующих остаточную концентрацию элемента после завершения биохимических процессов использования элементов в ходе минерального обмена Физиологические барьеры определяют величину содержания, до которого может происходить накопление химических элементов органами и тканями. В связи с наличием таких барьеров коэффициент биологического поглощения является не очень удачным показателем для характеристики интенсивности концентрирования химических элементов в связи с геохимическими аномалиями. Кроме того, для техногенных аномалий содержание химических элементов в растениях, например, определяется не только биологическим концентрированием из почв, но и механической способностью листьев удерживать пыль и аэрозоли.

Химические элементы или соединения, поступающие в живые организмы и вызывающие в них неблагоприятные биологические реакции, называются ксенобиотиками.

При проведении биогеохимических исследований в зависимости от поставленной задачи проводится отбор проб какоголибо выбранного для исследования вида живого организма (биообъекта). Отбираемые в пробу части организма (орган, вид тка50 
ни) в общем виде называют биоматериалом или биосубстратом. Биообъекты (или биосубстраты) наиболее чутко отражающие состояние окружающей среды, изменения в которых корреляционно связаны с уровнями загрязнения, являются диагностическими Они чаще всего используются при проведении биогеохимического опробования, причем обычно это такие органы и ткани, отбор которых не наносит сколько-нибудь серьезного ущерба организму (плоды, листья, ветви, волосы, шерсть, кровь, моча и т д.).

Следует отличать критический орган - т. е. орган, в котором накопление ксенобиотика наносит максимальный ущерб организму.

При гигиеническом исследовании выявление уровней накопления ксенобиотиков называют тестом накопления. Анализ результатов изучения тестов накопления проводится путем сравнения данных с усиленно разрабатываемыми сейчас биохимическими нормативами - допустимыми уровнями накопления. Допустимыми называются такие уровни, при которых еще не фиксируются изменения в состоянии здоровья. Критический уровень - содержание химического элемента в организме, при котором проявляются выраженные биохимические изменения.

На основании результатов собственных исследований, а также с учетом опыта отечественных и зарубежных работ установлена информативность биосубстратов человека при индикации воздействия загрязнения окружающей среды химическими элементами (табл. 7).

Т а 6 ли и а 7 Информативность диагностических биосубстратов для оценки воздействия химических элементов на человека

\begin{tabular}{|c|c|c|c|c|c|}
\hline Элемент & Кровь & Moud & Волосы & Ногти & Зубы \\
\hline Фтор & - & ++ & ++ & - & ++ \\
\hline Хром & + & + & + & + & + \\
\hline Марганец & + & +2 & $+t$ & - & - \\
\hline Кобальт & + & - & $+x$ & + & - \\
\hline Никель & $+x$ & $+x$ & $+x$ & - & - \\
\hline Медь & $+x$ & + & $+x$ & $+x$ & + \\
\hline Цинк . & - & $t$ & $+x$ & + & + \\
\hline Мышьяк & $+x$ & + & $t+$ & + & - \\
\hline Селен & - & + & + & + & - \\
\hline Кадмий & $+x$ & ++ & + & + & +2 \\
\hline Сурьма & - & - & t & - & - \\
\hline Ртуть & + & $+t$ & t & + & - \\
\hline Свинец & ++ & + & $+t$ & + & ++ \\
\hline
\end{tabular}

Примечания « ++ -- увеличение содержаний элемента в данном бносубстрате про является раньше, чем в других, и корреляционные связи с показателями среды всегда надежны, «+»-увеличение содержаний проявлено четко, но корреляционные связи с показателями среды выражены слабее, «+ $\chi »-$ үвеличение содержании проявлено только при высоких уровнях воздействия, «+ »- -данные противоречивы, «-»-дан ные отсутствуют 



Рис. 18. Содержание свинца в волосах $\left(C_{B}\right)$ в зависимостн ог его концентрации в почве (II - сплошная линия) и в во3духе (В - пунктир)

Рис. 19. Распределение химнческих элементов в организмах детей $(\sigma, 2)$ н взрослых $(a, \theta)$, занятых на пронзводстве минеральных удобрений $(a, 6)$ и в металлургии $(8,2)$

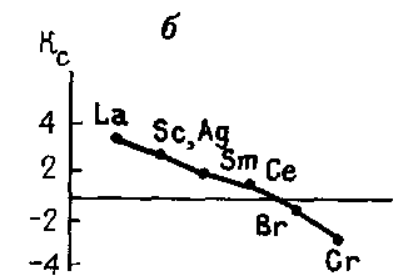


Закономерности накопления химических элементов живыми организмами (прежде всего, человеком) сейчас интенсивно исследуются.

Важно подчеркнуть установленные надежные корреляционные связи в синхронно изученных системах «источники загрязнения - среда» и «среда - организм». Пример таких связей приведен для свинца - элемента, изученного лучше многих других (рис. 18). Аналогичные данные имеются по ртути, кадмию, никелю и другим элементам.

Все больше появляется материалов, показывающих, что практически все химические элементы, фиксируемые в техногенных ореолах и потоках рассеяния, в той или иной степени усваиваются организмами и фиксируются в виде биогеохимических аномалий в одном из информативных биосубстратов. На рис. 19 показаны биогеохимические спектры взрослых и детей, находящихся в центрах геохимических аномалий, контрастно различных по ассоциациям загрязняющих веществ. Сравнивая аэрогенные аномалии комбината цветных металлов (выбросы содержат обычный комплекс токсичных тяжелых металлов) и комбината по производству минеральных удобрений (выбросы содержат совершенно не изученные с биогеохимических позиций редкие земли и немного тяжелых металлов), мы видим, что в обоих случаях в волосах детей и взрослых полностью проявились ассоциации геохимических аномалий.

В случае аномалии металлургического комбината можно отметить накопление малоизученных элементов (5b, Te, $\mathrm{Ag})$. Для аномалий минеральных удобрений еще более необычно очень большое накопление группы редких земель.

Таким образом, можно сделать принципиальный вывод о том, что техногенные геохимические потоки всех элементов проникают в организмы и фиксируются в них. Трудность их выявления в технической сложности обработки и анализа проб с необходимой чувствительностью, а, главное, в невозможности получения необходимого биоматериала. Мы еще очень мало знаем о взаимосвязях химических элементов в организме (ниже показано, что некоторые биологические важные элементы в зонах загрязнения даже снижают концентрации). Для многих элементов неясна их экологическая опасность. Однако важен сам факт существования аэрогенных техногенных биогеохимических потоков, который свидетельствует о факте воздействия геохимических аномалий на организмы и взаимосвязи между ними.

Поступление и накопление ксенобиотиков в организме определяет появление ответных биологических реакций, выраженных в виде тех или иных функциональных нарушений и морфологических отклонений, в росте заболеваемости, и, в конечном итоге, в увеличении смертности.

Функциональные нарушения - изменения, отклонения от 
нормы в работе основных систем (иммунной, кроветворной, сердечно-сосудистой и т. д.). Морфологические отклонения - изменения в строении организма, в форме, размерах, цвете или соотношении отдельных его частей.

При исследовании функционально-морфологических изменений в связи с загрязнением среды изучается довольно широкий спектр реакций организмов. Это связано с тем, что функционально-морфологические нарушения и отклонения наиболее чувствительный вид реакции. По ним проводится так называемая донозологическая диагностика, т. е. установление состояний предболезни, когда наиболее эффективны профилактические меры. Кроме того (это особенно важно), изучение функциональноморфологических характеристик проводится экспрессно и чаще всего позволяет получить количественные характеристики, выявляемые объективными приборными способами. При оценке воздействия загрязнения на человека объектами исследования обычно являются дети, состояние организма которых более тесно связано со средой обитания. В последнее время в качестве признака, наиболее чутко реагирующего на загрязнение среды, используются иммунологические реакции, т. е. специфические защитные реакции организма, определяющие его способность противостоять повреждающим агентам и определяемые с помощью хорошо разработанных приемов биотестирования. Эффективно также исследование гемотологических показателей (лейкоцитоз, гемоглобин), оценка изменения показателей дыхательной системы (частота дыхания, объем легких, проходимость бронхов и т. д.). Среди морфологических отклонений человека обычно исследуют отклонения физического развития, т. е. изменения веса и роста какой-либо однородной половозрастной группы детей.

Функционально-морфологические отклонения для растений проявлены в нарушении фенофаз (сроков наступления морфологически фиксируемых этапов развития - вегетации растительного организма), в некрозах (полном или частичном омертвлении тканей), в хлорозах (обесцвечивании листьев), гигантизме (увеличении размеров, чаще всего плодов, листьев), карликовости (уменьшении размеров отдельных органов или растения в целом) и в других более тонких изменениях.

Следует отметить, что различают специфическое и общетоксическое действие ксенобиотиков.

Специфическое действие - способность оказывать избирательное или преимущественное действие на определенные функциональные системы, орган или группу органов живого организма.

Общетоксичное действие - способность вызывать изменение в ряде органов и систем, приводящее к общему ухудшению состояния организма в целом.

Суммарный результат этих действий определяют показатели 54 
здоровья (физическое развитие, заболеваемость, инвалидизация и демографические характеристики).

Примером специфических воздействий (и, соответственно, реакций), наиболее четко связанных с уровнями загрязнения окружающей среды, являются: аллергенное действие - способность изменять иммунологические свойства, повышать, таким образом, чувствительность организма к раздражителям и вызывать, так называемые, аллергические заболевания - диатез, бронхиальная астма и т. д.- наиболее распространенные сейчас типы детских заболеваний; гонадотоксическое действие (свойство нарушать развитие и функциональные способности половых клеток); канцерогенное действие (способность индуцировать злокачественные опухоли); мутагенное действие (способность вызывать мутации половых клеток и соматических клеток тела живых организмов); тератогенное действие (способность инду цировать уродства) и эмбриотоксические действия (неблагоприятное влияние на формирование и развитие эмбрионов снижение их веса, размера, гибель).

Общетоксическое действие фиксируется прежде всего заболеваемостью. При оценке влияния фактора загрязнения окружающей среды используется изучение общей заболеваемости (т. е суммарный показатель числа любых видов болезней, рассчитанный на определенное количество населения).

Часто более контрастно связаны с характеристиками загрязнения отдельные группы болезней. При оценке следствий загрязнения воздуха наиболее эффективно изучение острых заболеваний органов дыхания (бронхит, фарингит, тонзиллит).

При оценке связей показателей здоровья населения с состоянием окружающей среды используются хорошо разработанные эпидемиологические методы - методы количественного изучения пространственных закономерностей распределения болезней. В прикладных эколого-геохимических исследованиях в отличие от принятых гигиенических систем анализа структуры заболеваемости, она увязывается с пространственной структурой проявления техногенных геохимических аномалий.

На основе материалов геохимических исследований загрязнения городов тяжелыми металлами авторы выполнили пространственные структуры распределения очагов загрязнения. Тяжелые металлы при этом использованы и как показатели появления в окружающей среде опасных загрязняющих веществ, и как индикаторы-трассеры, фиксирующие пространственное положение зон воздействия источников выбросов в присущим этим источникам более широкими комплексами загрязняющих веществ (газы, органические соединения).

Это позволило разделить население городов (прежде всего, детское) для изучения пространственно-дифференцированной оценки ответных реакций организма на загрязнение и создать 




Рис. 20. Эколого-геохимическая модель «среда-здоровье» (зависимость частоты отклонения состояния здоровья детей () от интенсивности загрязнения почв $Z_{c}$ : I-IV - уровни загрязнения почв (в мг г) : I - менее 16, II - 16-32, III 32-64, IV - 64-128. Цифры в кружках - виды заболеваний: 1 - изменение показателей иммунной системы, 2 - заболевания органов дыхания (21 - острый фарингит и тонзиллит, 2 2 -- острый бронхит), 3 - функционально-морфологические отклонения (3-) - - увеличение количества лейкоцитов, 3-2-нарушения физического развития, 3- 3 - функциональные отклонения сердечно-сосудистой системы, 3-4 - сниженне количества гемоглобина), 4 -хронические заболевания

своего рода экологическую или геогигиеническую модель «среда - организм».

В подавляющем большинстве случаев в связи с загрязнением наблюдается однотипная структура изменения показателей здоровья детей. Отклик организма на интенсивность загрязнения атмосферного воздуха, фиксируемую геохимическими аномалиями в почвах, снеговом покрове, других природных средах, в порядке уменьшения образует ряд: 1) иммунологическая реактивность; 2) острые заболевания органов дыхания аллергического характера); 3) отклонения от норм функциональных и физиологических показателей - нарушение гармоничности физического развития, увеличение числа лейкоцитов при снижении гемоглобина; 4) рост хронических заболеваний (рис. 20). Это дало возможность создать шкалу оценки опасности геохимических аномалий. По опасности загрязнения аномалии разделены на 4 категории: 1) допустимые - фоновый уровень, в сущности пока еще плохо изученный и определяемый в каждом случае как исходная для сравнения зоны с низким уровнем заболеваемости и минимальной частотой проявления функциональных отклонений; 2) умеренно-опасные - увеличение общей заболеваемости; 3) опасные - увеличение частоты хронических заболеваний, функциональных отклонений; 4) чрезвычайно опасные - увеличение нарушений репродуктивных функций и других отдаленных 56 


\begin{tabular}{|c|c|c|}
\hline $\begin{array}{c}\text { Уровень загряз- } \\
\text { нения }\end{array}$ & $\begin{array}{c}\text { Состояние атмосферного } \\
\text { воздуха }\end{array}$ & $\begin{array}{c}\text { Показатели загрязнения снегового } \\
\text { покрова и почв }\end{array}$ \\
\hline $\begin{array}{l}\text { Средний уме- } \\
\text { ренно опасный }\end{array}$ & $\begin{array}{l}\text { Превышение ПДК от- } \\
\text { дельных загрязняющих } \\
\text { веществ (пыль, оксиды } \\
\text { углерода и азота, серни- } \\
\text { стый ангидрид): содер- } \\
\text { жание тяжелых металлов } \\
\text { выше фона }\end{array}$ & $\begin{array}{l}\text { Средний уровень загрязнения почв } \\
\left(Z_{c} \quad 16-32\right) \text { и снегового покрова } \\
\left(Z_{c} 64-128\right) \text {. Повышенная запылен- } \\
\text { ность снегового покрова (среднесуточ- } \\
\left.\text { ная нагрузка } 250-450 \text { кг } / \text { км }^{2}\right) \text {. Содер- } \\
\text { жание } \mathrm{Pb} \text { в почве более } 100 \text { мг/kг } \\
\end{array}$ \\
\hline $\begin{array}{l}\text { Высокий опас- } \\
\text { ный }\end{array}$ & $\begin{array}{l}\text { Превышение ПДК комп- } \\
\text { лекса загрязняющих ве- } \\
\text { ществ (пыль, оксиды уг- } \\
\text { лерода-и азота, сернис- } \\
\text { тый ангидрид); содержа- } \\
\text { ния отдельных металлов } \\
\text { (главным образом свин- } \\
\text { ца) выше ПДК }\end{array}$ & $\begin{array}{l}\text { Высокий уровень загрязнения почв } \\
\left(Z_{c} 32-128\right) \text { и снегового покрова } \\
\left(Z_{c} 128-256\right) \text { в составе аномалий } \\
\text { присутствуют химические элементы и } \\
\text { загрязняющие вещества I класса опас- } \\
\text { ности (особенно Рb, Cd, Hg) в высоких } \\
\text { концентрациях (Қс }>10) \text {. Содержание } \\
\text { РЬ в почве более } 250 \text { мг/кг. Средне- } \\
\text { суточный уровень выпадения пыли } \\
450-800 \text { кг } / \text { км }^{2}\end{array}$ \\
\hline $\begin{array}{l}\text { Очень высокий } \\
\text { чрезвычайно } \\
\text { опасный }\end{array}$ & $\begin{array}{l}\text { Превышение ПДК (иног- } \\
\text { да многократное) комп- } \\
\text { лекса загрязняющих ве- } \\
\text { ществ, в том числе ряда } \\
\text { тяжелых металлов }\end{array}$ & $\begin{array}{l}\text { Очень высокий уровень загрязнения } \\
\text { почв }\left(Z_{c}>128\right) \text { и снегового покрова } \\
\left(Z_{c}>256\right) \text {. В составе аномалий в почве } \\
\text { присутствуют РЬ }(>400 \text { мг/кг) и Нg } \\
(2,1 \text { мг/кг), что является индикатором } \\
\text { превышения ПДК этих ингредиентов в } \\
\text { воздухе. } \\
\text { Очень высокая запыленность снегово- } \\
\text { го покрова (среднесуточная нагрузка } \\
\left.800 \text { кг } / \text { км }^{2}\right)\end{array}$ \\
\hline
\end{tabular}

Примечания: $Z_{c}$ - суммарный показатель загрязнения, $\mathrm{K},-$ коэффициент концентрации относительно фонового содержания.

Т а б ли ца 9. Ориентировочная шкала оценки загрязнения водных систем

\begin{tabular}{|c|c|c|}
\hline Уровень загрязнения & $\begin{array}{c}Z_{c} \text { токсичных } \\
\text { элементов в донных } \\
\text { отложениях }\end{array}$ & Содержания токсичных элементов в воде \\
\hline Слабый & Менее 10 & Слабоповышенные относительно фона \\
\hline Средний & $10-30$ & $\begin{array}{l}\text { Повышенные относительно фона; эпи- } \\
\text { зодическое превышение ПДК }\end{array}$ \\
\hline Сильный & $30-100$ & $\begin{array}{l}\text { Во много раз выше фона; стабильное } \\
\text { превышение отдельными элементами } \\
\text { уровней ПДК }\end{array}$ \\
\hline Очень сильный & Более 100 & $\begin{array}{l}\text { Практически постоянное присутствие } \\
\text { многих элементов в концентрациях вы- } \\
\text { ше ПДК }\end{array}$ \\
\hline
\end{tabular}

Примечание: $\boldsymbol{Z}_{\boldsymbol{c}}$ - суммарный показатель загрязнения. 
последствий. Оценочная шкала такого рода вошла в Методические указания, утвержденные Минздравом СССР.

Более детальные шкалы, оценивающие уровни загрязнения аэрогенных и гидрогенных аномалий в связи с формируемыми ими неблагоприятными последствиями, приведены в табл. 8, 9.

Эколого-геохимической нормой условий обитания человека в биосфере является кларковая концентрация. Этот уровень приближенно определяет наиболее распространенную обстановку жизни. Природные вариации содержаний довольно узки и, как правило, отклонения от кларка не превышают двух-трехкратного уровня.

Экстремальные геохимические ситуации в природе, т. е. обстановки резко повышенных концентраций химических элементов образуются чаще всего в связи с рудными месторождениями - территориями, где, как правило, население не концентрируется.

Антропогенные геохимические преобразования окружающей среды по своему уровню превышают интенсивности воздействия, наблюдаемые в районах рудных месторождений (табл. 10).

Сложные цепи миграции загрязняющих веществ, формируемые в связи с рассеянием в природных системах твердых отходов, выбросов, стоков и средств химизации (рис. 21), неизбежно приводят к формированию геохимических аномалий и биогеохимическому концентрированию химических элементов в окружающей среде городов и сельскохозяйственных территорий. Таким образом, экстремальные ситуации горно-рудных районов распространяются на громадные территории, являющиеся средой обитания значительной части человечества.

Т а блица 10. Интенсивность накопления химических элементов живыми организмами в природных и антропогенных аномалиях (в коэффициентах концентрации по отношению к фону)

\begin{tabular}{|c|c|c|c|}
\hline \multirow{2}{*}{ Элемент } & \multicolumn{2}{|c|}{ Антропогенные аномалии } & \multirow{2}{*}{$\begin{array}{c}\text { Растения и животные } \\
\text { в природных } \\
\text { аномалиях }\end{array}$} \\
\hline & Человек и животные & Растения & \\
\hline $\begin{array}{l}\text { Литий } \\
\text { Олово } \\
\text { Хром } \\
\text { Свинец } \\
\text { Кадмий } \\
\text { Сера } \\
\text { Марганец }\end{array}$ & $\begin{array}{c}1,5-2,5 \\
1,5-2 \\
1,2-3 \\
2-10 \\
1,5-3 \\
2-17 \\
2,5-10\end{array}$ & $\begin{array}{c}1,5-6 \\
1,5-15 \\
1,2-2 \\
\text { до } 50 \\
3-8 \\
2-10 \\
1,5-15\end{array}$ & $\begin{array}{c}1,5--2,5 \\
2-8 \\
1,5-3 \\
1,5-3,5 \\
2-3,5 \\
2-5 \\
1,5-2,5\end{array}$ \\
\hline
\end{tabular}




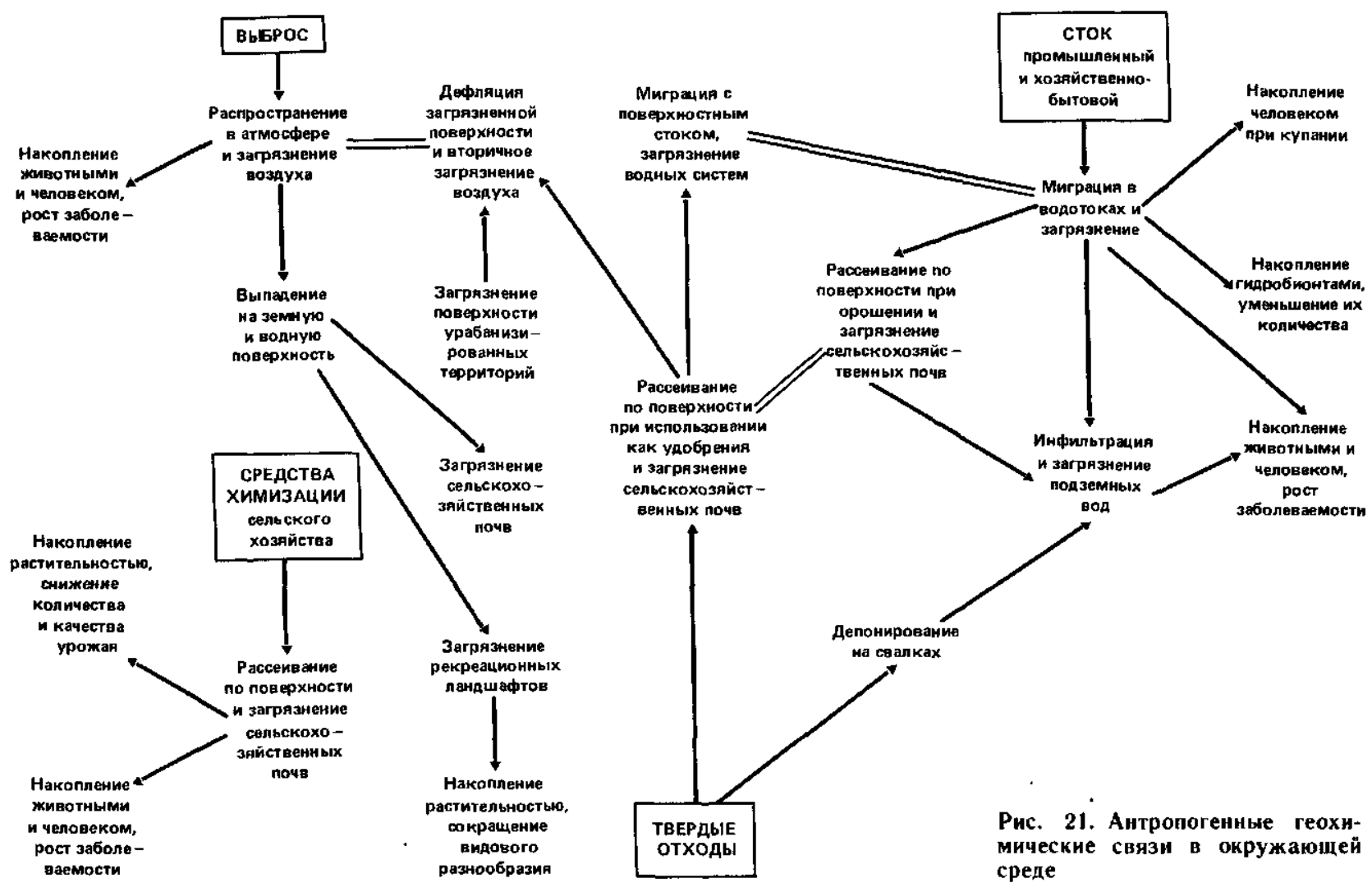


Гл а в а 2

\section{ТЕХНОЛОГИЯ ГЕОХИМИЧЕСКИХ РАБОТ}

Геохимическая оценка состояния окружающей среды базируется на данных, получаемых при проведении специализированных эколого-геохимических исследований, направленных на установление источников загрязнения, прослеживание всех возможных путей миграции загрязняющих веществ и выявление территорий, где их концентрация становится опасной для живых организмов.

\section{1. ОБЩАЯ СХЕМА}

\section{ПРИКЛАДНЫХ ГЕОХИМИЧЕСКИХ ИССЛЕДОВАНИЙ}

В геохимических исследованиях загрязнения окружающей среды химическими элементами рационально выделить три основных этапа, различающихся решаемыми задачами и комплексируемыми методами [26-30]:

1) начальный - рекогносцировочные исследования геохимических особенностей состояния окружающей среды (рекогносцировочно-геохимические работы);

2) средний (основной) - выделение и оконтуривание на местности антропогенных ореолов рассеяния (геохимическое картирование);

3) завершающий - детальные геохимические и биогеохимические исследования аномалий (детальные эколого-геохимические исследования).

Рекогносцировочные геохимические работы проводятся с целью выявления основных источников загрязнения и геохимической специфики зон их воздействия, а также установления природных условий формирования техногенных ореолов рассеяния и особенностей распределения фоновых параметров.

Важнейшая часть этапа - опробование компонентов природных сред фоновых ландшафтов: почв, растительного покрова (в необходимых случаях), выпадений, донных отложений, воды. При выборе фоновых территорий важно изучить наиболее распространенные типы ландшафтно-геохимических обстановок исследуемой территории.

Для автономных ландшафтов водоразделов и склонов выбор фоновых эталонов с естественными (природными) параметрами распределения химических элементов обычно лимитируется возможностью подбора территорий, не испытывающих локальных воздействий в результате выпадения загрязняющих веществ из атмосферы. Для рек (даже малых) такие территории уже редки, и в ряде случаев для этих целей приходится использовать водотоки меньшего порядка.

Геохимическое исследование фоновых территорий - спе60 
Т а 6 л и ц а 11 Средние содержания микроэлементов в некоторых видах сельскохозяйственной продукции, мг/кг сухой массы

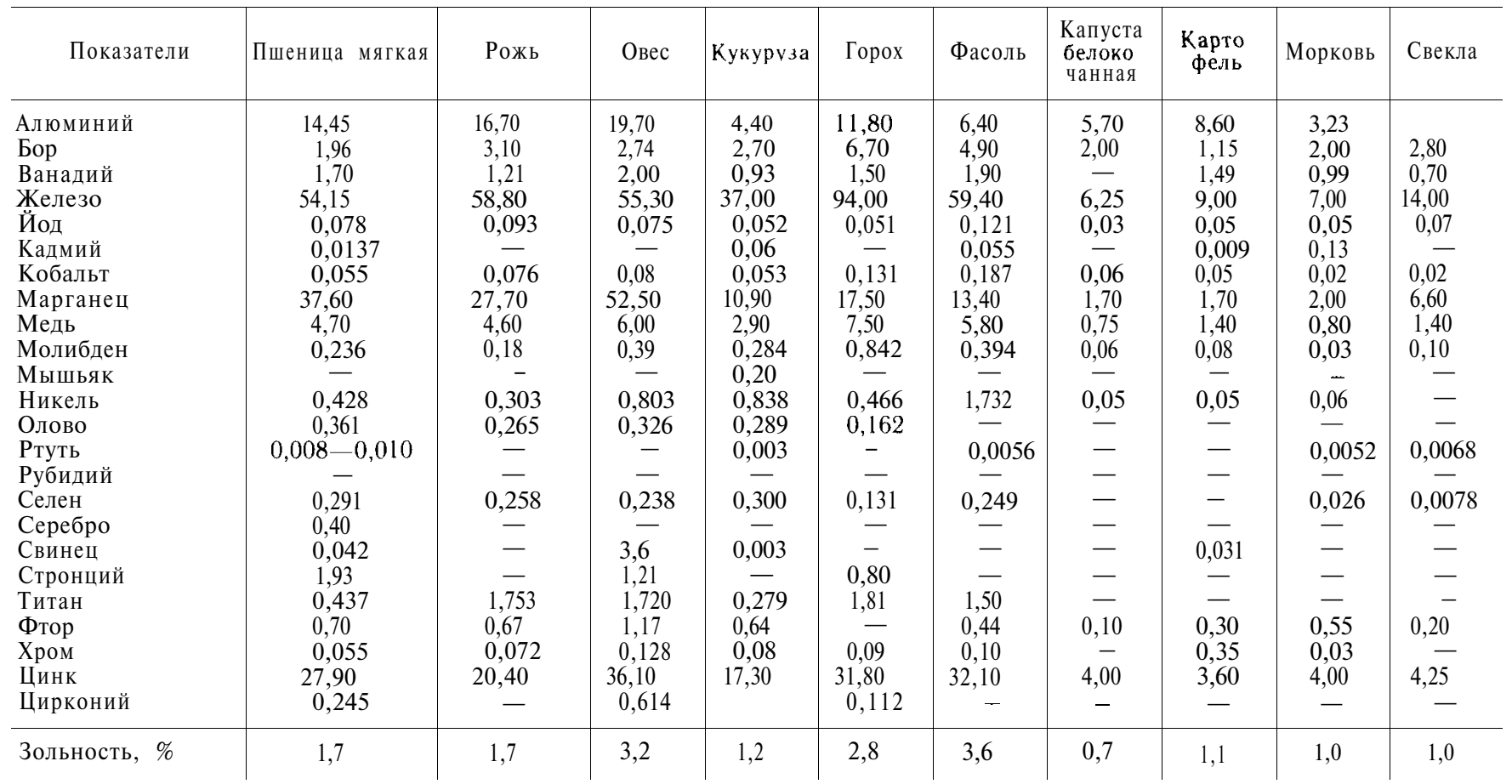

Примечание Для свинца и кадмия данные очень противоречивы 
Т аблиц а 12 Глобальные, зональные и региональные оценки фона микроэле

\begin{tabular}{|c|c|c|c|c|c|}
\hline \multirow[b]{2}{*}{ Элемент } & \multicolumn{3}{|c|}{ Глобальные оценки } & \multicolumn{2}{|r|}{ Зональные } \\
\hline & $\begin{array}{c}\text { Кларк в зем } \\
\text { нои коре }\end{array}$ & $\begin{array}{l}\text { Осадочные } \\
\text { породы (гли } \\
\text { ны и сланшы) }\end{array}$ & Почвы мира & Подзолистые & Серые лесные \\
\hline Литий & 32,0 & 60,0 & 30,0 & 23,5 & 26,4 \\
\hline Бериллий & 3,8 & 3,0 & 6,0 & 1,5 & 3,0 \\
\hline Бор & 12,0 & 10,0 & 10,0 & 5,8 & 12,3 \\
\hline Фтор & 660,0 & 500,0 & 200,0 & 208,0 & 312,0 \\
\hline Фосфор & 930,0 & 770,0 & 800,0 & 700,0 & 1500,0 \\
\hline Cepa & 470,0 & 3000,0 & 850,0 & 720,0 & 720,0 \\
\hline Титан & 4500,0 & 4500,0 & 4600,0 & 4045,0 & 4400,0 \\
\hline Ванадий & 90,0 & 130,0 & 100,0 & 63,5 & 118,0 \\
\hline Хром & 83,0 & 100,0 & 90,0 & 180,0 & 250,0 \\
\hline Марганец & 1000,0 & 670,0 & 850,0 & 715,0 & 1025,0 \\
\hline Кобальт & 18,0 & 20,0 & 10,0 & 8.4 & 12,4 \\
\hline Никель & 58,0 & 95,0 & 40,0 & 23,2 & 30,3 \\
\hline Медь & 47,0 & 57,0 & 20,0 & 15,3 & 23,5 \\
\hline Цинк & 83,0 & 80,0 & 50,0 & 41,3 & 60,0 \\
\hline Мышьяк & 1,7 & 6,6 & 5,0 & 3,0 & 4,7 \\
\hline Стронций & 340,0 & 450,0 & 300,0 & 238,0 & 258,0 \\
\hline Иттрий & 29,0 & 30,0 & - & - & - \\
\hline Цирконий & 170,0 & 200,0 & 300,0 & 150,0 & 442,0 \\
\hline Молибден & 1,1 & 2,0 & 2,0 & 1,7 & 3,2 \\
\hline Серебро & 0,07 & 0,1 & 0,1 & 0,1 & 0,3 \\
\hline Кадмий & 0,13 & 0,3 & 0,5 & 0,7 & 0,7 \\
\hline Олово & 2,5 & 10,0 & 10.0 & 2,9 & 2,8 \\
\hline Иода & 0,4 & 1,0 & 5,0 & 5,8 & 3,2 \\
\hline Барий & 65,0 & 80,0 & 50,0 & - & - \\
\hline Иттербий & 0,33 & 3,0 & - & - & - \\
\hline Вольфрам & 1,3 & 2,0 & - & - & - \\
\hline Ртуть & 0,08 & 0,4 & 0,01 & - & - \\
\hline Свинец & 16,0 & 20,0 & 10,0 & 11,5 & 12,5 \\
\hline
\end{tabular}

циальная, хорошо разработанная проблема. Методика ее решения детально описана в работах М. А. Глазовской, В. В. Добровольского, А. И. Перельмана. Ниже мы приводим основные данные по характеру фоновых распределений, полезных как справочный материал (табл. $11-13$ ).

При изучении источников загрязнения на данном этапе исследований проводится геохимическое опробование лишь наиболее объемных видов отходов: канализационных осадков, бытового мусора, осадков сточных вод групповых очистных coоружений.

Геохимическое опробование объектов окружающей среды на рекогносцировочном этапе должно выявить наиболее общую структуру загрязнения территории и его важнейшие природные геохимические особенности. В сущности, цель опробования выявление участков для геохимического картирования антропогенных ореолов и потоков рассеяния.

62 


\begin{tabular}{|c|c|c|c|c|c|c|c|}
\hline \multicolumn{4}{|c|}{ оценки (почвы СССР) } & \multicolumn{4}{|c|}{ Региональные оценки (данные авторов) } \\
\hline \multirow[b]{2}{*}{ Черноземы } & \multirow[b]{2}{*}{$\begin{array}{c}\text { Кашта- } \\
\text { новые }\end{array}$} & \multirow[b]{2}{*}{ Сероземы } & \multirow{2}{*}{$\begin{array}{l}\text { Солонча- } \\
\text { кн и со- } \\
\text { лонцы }\end{array}$} & \multicolumn{2}{|c|}{ Кавказ } & \multirow{2}{*}{$\begin{array}{c}\text { Крым } \\
\begin{array}{c}\text { Черно- } \\
\text { земы }\end{array}\end{array}$} & \multirow{2}{*}{$\begin{array}{c}\text { Моск обл } \\
\text { Дерново- } \\
\text { подзо- } \\
\text { листые }\end{array}$} \\
\hline & & & & $\begin{array}{l}\text { Черно- } \\
\text { земы }\end{array}$ & $\begin{array}{l}\text { Корнч } \\
\text { невые }\end{array}$ & & \\
\hline 33,8 & 34,2 & 37,2 & 35,0 & 10,0 & 50,0 & 30,0 & 16,0 \\
\hline 3,2 & 4,0 & 1,0 & - & - & - & - & 1,5 \\
\hline 19,7 & 30,0 & 46,0 & 53,2 & - & 92,0 & 50,0 & 38,0 \\
\hline 285,0 & 158,0 & 170,0 & - & - & - & - & 210,0 \\
\hline 700,0 & 700,0 & 700,0 & - & - & 500,0 & 2000,0 & - \\
\hline 720,0 & 720,0 & 720,0 & 720,0 & - & - & $\gamma-$ & - \\
\hline 4780,0 & 4075,0 & 1990,0 & 2120,0 & - & 3500,0 & 1800,0 & 6000 \\
\hline 145,0 & 79,0 & 86,0 & 83,0 & 140,0 & 200,0 & 100,0 & 64,0 \\
\hline 286,0 & 328,0 & 467,0 & - & 24,0 & 90,0 & 48,0 & 46,0 \\
\hline 885,0 & 722,0 & 725,0 & 670,0 & - & 2800,0 & 800,0 & 590,0 \\
\hline 13,2 & 11,7 & 6,9 & 9,6 & 12,0 & 33,0 & 14,0 & 7,2 \\
\hline 72,1 & 46,0 & 19,0 & 29,5 & 31,0 & 60,0 & 30,0 & 20,0 \\
\hline 28,9 & 15,8 & 24,0 & 20,2 & 30,0 & 67,0 & 50,0 & 27,0 \\
\hline 62,0 & 52,3 & 50,0 & 54,6 & 140,0 & 160,0 & 50,0 & 50,0 \\
\hline 5,9 & 5,2 & 2,5 & - & - & - & - & 3,0 \\
\hline 260,4 & 287,0 & 305,0 & 335,0 & 80,0 & 40,0 & 206,0 & 28,0 \\
\hline - & - & - & - & - & 20,0 & 40,0 & 18,0 \\
\hline 299,0 & 420,0 & 112,0 & - & 60,0 & 83,0 & 100,0 & 423,0 \\
\hline 4,2 & 3,2 & 3,0 & 2,4 & 1,7 & 2,0 & 0,7 & 1,0 \\
\hline 0,5 & 0,4 & - & - & 0,1 & - & 0,06 & 0,1 \\
\hline 0,5 & 0,4 & & - & & & & 0,3 \\
\hline 3,2 & 3,3 & 4,0 & - & 4,7 & 4,3 & 3,6 & 5,2 \\
\hline 4,0 & 4,2 & 1,8 & - & - & - & - & 230,0 \\
\hline - & - & - & - & 270,0 & 130,0 & 270,0 & 330,0 \\
\hline - & & & - & - & - & - & 2,0 \\
\hline - & - & - & - & - & - & - & 1,0 \\
\hline - & - & - & - & - & - & - & 0,009 \\
\hline 13,2 & 10,0 & 6,3 & 7,2 & 80,0 & 63,0 & 49,0 & 25,0 \\
\hline
\end{tabular}

Геохимическое опробование ореолов рассеяния проводится в районе известных и потенциальных источников загрязнения таким образом, чтобы можно было сформировать представительные геохимические выборки для выявления ореолов и потоков рассеяния и оценки соответствующих им ассоциаций химических элементов. Для крупных урбанизированных территорий эти выборки рационально дополнять опробованием почв и снегового покрова с детальностью 1 точка наблюдения на 1 км $^{2}$, что позволяет выявить все основные очаги загрязнения.

Как следует из материалов по геохимическим особенностям формирования техногенных ореолов рассеяния, почвы фиксируют в своем составе атмосферные выпадения металлов за многолетний период.

Хранителем информации об атмосферных выпадениях, характеризующих современный уровень состояния атмосферного воздуха, является снежный покров. 
Т а б л и ц а 13. Концентрация химических элементов в пылевых выпадениях из атмосферы

\begin{tabular}{l|c|c|l|c|c}
\hline \multicolumn{1}{|c}{ Элемент } & $\begin{array}{c}\text { Содержание } \\
\text { в пылях } \\
\text { мг/кг }\end{array}$ & $\begin{array}{c}\text { Среднесуточная } \\
\text { нагрузка выпа- } \\
\text { дений, мг/км² }\end{array}$ & Элемент & $\begin{array}{c}\text { Содержание } \\
\text { в пылях, } \\
\text { мг/кг }\end{array}$ & $\begin{array}{c}\text { Среднесуточная } \\
\text { нагрузка выпа- } \\
\text { дений, мг } / \text { км² }^{2}\end{array}$ \\
\hline Бериллий & 1,5 & $15-30$ & Никель & 20 & $200-400$ \\
Ванадий & 64 & $640-1280$ & Олово & 5,2 & $52-104$ \\
Висмут & 1,0 & $10-20$ & Ртуть & 0,01 & $0,1-0,2$ \\
Вольфрам & 1,0 & $10-20$ & Стронций & 50 & $500-1000$ \\
Кадмий & 0,3 & $3-6$ & Сурьма & 2 & $20-40$ \\
Кобальт & 7 & $70-140$ & Свинец & 50 & $500-1000$ \\
Марганец & 570 & $5700-11400$ & Серебро & 0,1 & $1-2$ \\
Молибден & 1,0 & $10-20$ & Хром & 50 & $500-1000$ \\
Медь & 80 & $800-1600$ & Цинк & 70 & $700-1400$ \\
& & & & &
\end{tabular}

Примечание. Нагрузки рассчитаны для уровней общего выпадения пыли, варьирующих в фоновых условиях континентальных территорий в пределах $10-20$ мг $/ \mathrm{km}^{2}$ в сут.

Результаты исследований рекогносцировочного этапа позволяют составить геохимическую схему территории (масштаб $1: 100000-1: 50000)$, обобщающую сведения о ее функциональной дифференциации и геохимической характеристике основных источников загрязнения, а также обосновать программу исследований следующего этапа.

Геохимическое картирование - наиболее объемный этап исследования особенностей загрязнения территорий химическими элементами. Практические цели работ этого этапа:

1) выявление всех значимых источников загрязнения окружающей среды, установление основных видов отходов производственной и сельскохозяйственной деятельности, обогащенных химическими элементами и потенциально перспективных для вторичной переработки или требующих специальных условий безопасного депонирования;

2) прослеживание потоков распространения химических элементов в окружающей среде - как естественных, природномиграционных, так и искусственных, обусловленных транспортировкой отходов или загрязненной продукции в места депонирования или вторичного применения;

3) изучение морфоструктурных особенностей пространственного распределения загрязнений, установление зон влияния источников загрязнения, и, в конечном счете, дифференциация исследуемой территории по качественным характеристикам и интенсивности отрицательного воздействия.

При изучении источников загрязнения основной вид работ, входящий в комплекс характеризуемого этапа - выявление и опробование всех основных видов отходов и предварительная оценка их объемов.

Изучение ореолов рассеяния, связанных с выпадениями из атмосферы или депонированием отходов, проводится путем пла- 
номерных геохимических съемок почв и пыли, осажденной на снеговой покров.

При исследовании потоков рассеяния в поверхностных водотоках применяется маршрутная геохимическая съемка донных отложений, сочетающаяся с опробованием вод на наиболее устойчивый во времени комплекс макроэлементов.

По результатам геохимических исследований второго этапа составляются геохимические карты всех основных очагов загрязнения изученной территории, являющиеся основой природоохранных практических мероприятий и выявляющие локальные «горячие точки» для детальных геохимических и биогеохимических исследований.

Детальные геохимические и биогеохимические исследования техногенных аномалий - завершающий этап работ. Они проводятся с целью углубленной оценки качества среды, получения данных для прогноза изменения его при продолжающемся воздействии, выявлении характера реакции живых организмов на загрязнение. Задачи этого этапа во многом совпадают с задачами санитарно-гигиенической службы и служб контроля за состоянием среды, поэтому работы должны проводиться в тесном контакте с соответствующими специалистами.

Детальные геохимические и биогеохимические исследования проводятся главным образом в центрах выявленных аномалий.

В пределах антропогенных ореолов и потоков рассеяния комплекс детальных работ включает: 1) гигиеническую оценку степени загрязнения атмосферного воздуха и поверхностных вод (организуется совместно со специальными службами); 2) исследование биогеохимических показателей населения и оценку состояния его здоровья (также организуется совместно со специальными службами); 3) детальное изучение комплекса химических элементов и определение объема загрязненных почв, донных отложений, грунтов и сельхозпродукции.

\section{2. МЕТОДИКА ОТБОРА И ОБРАБОТКИ ПРОБ}

\section{Изучение источников загрязнения}

Опробование - основной метод изучения источников загрязнения окружающей среды. Оно проводится с целью получения достоверных данных о составе и особенностях загрязняющих веществ.

Отбор проб производится в местах образования отходов, с транспортировочных средств (с конвейерной ленты, из вагонеток и др.), в местах выпуска в окружающую среду (стоки и выбросы на выходе), в местах складирования и захоронения отходов (площадки, свалки).

Для изучения источников загрязнения используются разно- 
образные приемы отбора и обработки проб в зависимости от характера загрязнителей (агрегатного состояния, степени однородности и др.) и условий опробования (в отвалах, на потоке и т. д.). Так, при опробовании плотных отложений, отвалов, свалок могут быть применены бороздовый, керновый или шпуровой методы отбора проб. Рыхлые, сыпучие отходы из емкостей, с площадок или транспортных лент могут быть опробованы горстевым методом.

Обработка геохимических проб может производиться способами, применяемыми для проб полезных ископаемых. Некоторые виды бытовых и промышленных отходов настолько неоднородны и сложны по составу, что требуют применения специальных приемов для гомогенизации материала и подготовки проб к анализу.

Наиболее простой случай - опробование металлоабразнвных пылей, уловленных очистными установками. Как правило, пыли характеризуются довольно равномерным распределением компонентов .(коэффициент вариации менее $30 \%)$, поэтому для получения надежной характеристики их состава достаточно отобрать небольшое число проб $(3-10)$. Они отбираются из бункеровнакопителей горстевым методом, причем каждая порция из разных точек бункера.

Гальванические осадки образуются при нейтрализации и обезвреживании стоков гальванических отделений предприятий. Осадки, накапливающиеся в отстойниках, полужидкие, с влажностью 95-99\%; обезвоженные осадки имеют влажность 60$70 \%$ и консистенцию густой сметаны, осадки, как правило, тонкодисперсные (преобладают частицы размером 0,010,05 мм). Химические элементы в них распределяются довольно равномерно, поэтому обычно достаточен отбор небольшого числа проб (3-10). При длительном накоплении осадков в отстойниках опробование может быть разовым; если же осадки удаляются часто, отбор следует производить через соответствующие интервалы времени. Пробы сырых осадков отбираются из отстойников; пробы обезвоженных осадков - из бункеров или других емкостей. Для повышения представительности проб каждая из них составляется из нескольких порций материала, отобранного с разной глубины и из разных точек отстойника. Опробование производится раздельно по всем существующим на предприятиях типам гальванических осадков. Подготовка проб осадка к анализу состоит в высушивании и измельчении материала.

Примером более сложного для изучения объекта могут служить продукты заводской переработки бытового мусора - остатки от сжигания.

Пробы продуктов сжигания отбираются с конвейера готовой продукции горстевым методом, в них включается весь материал. Пробы отбираются в течение рабочего дня, каждая проба 66 
сумма отдельных навесок (более 25). Затем пробы объединяются в сменные и недельные. Таким образом, каждая объединенная проба состоит из большого числа навесок, достаточного, чтобы достоверно характеризовать опробуемый материал даже при весьма неравномерном распределении химических элементов. Отбор проб проводится в течение месяца по каждому сезону года. Из-за резкого различия физико-химических свойств отдельных компонентов пробы очень сложно довести до однородного состояния, необходимого для аналитических исследований. Поэтому производится подготовка проб к анализу по схеме, позволяющей "разделить продукты сжигания на однородные по физикомеханическим свойствам фракции и получить надежные характеристики их состава [29].

Особенности изучения состава жидких отходов рассмотрим на примере сточных вод отделений физико-химической очистки.

Для оценки степени стабильности состава сточных вод на двух предприятиях были проведены работы по изучению его динамики. Изучались необработанные стоки на выходе из гальванических отделений, стоки после обезвреживания и стоки после прохождения отстойников. Изучение сопровождалось отбором среднечасовых и среднесменных проб стоков. Установлено, что все виды стоков - промывные воды непосредственно из цехов, обезвреженные неосветленные стоки и осветленные стоки после отстойников - отличаются значительной изменчивостью содержаний металлов во времени. Поэтому для характеристики стоков предприятий не могут быть использованы отдельные разовые пробы, а также объединенные пробы, отобранные за небольшой временной интервал (например, среднечасовые). Усредненные значения содержаний металлов в стоках можно получить по среднесменным пробам или по сериям разовых проб с последующим усреднением результатов.

В целом характер опробования источников загрязнения зависит от конкретных технологических особенностей исследуемого объекта и не имеет пока стандартизированной методики.

\section{Изучение техногенных ореолов}

Организация опробования имеет свою специфику на различных этапах работ. На рекогносцировочном этапе опробование дает характеристику отдельных «кустов», т. е. ограниченных фрагментов территории, расположенных на различном расстоянии от источника. По результатам кустового опробования проводится исследование геохимических выборок и дается сравнительная оценка загрязнения различных частей зоны влияния.

На этапе съемки сеть опробования равномерно покрывает всю территорию предполагаемой зоны влияния. При этом возможны различные варианты сетей опробования, густота которых 
определяется данной детальностью выявления структуры аномалий.

Организация отбора почвенных проб требует обоснования выбора представительного горизонта опробования и оценки представительности единичной пробы в точке отбора. Выбор представительного горизонта определяется глубиной проникновения элементов-загрязнителей по почвенному профилю. На основе литературных и экспериментальных данных установлено, что максимальная концентрация элементов-загрязнителей приурочена к верхнему горизонту почв мощностью до 10 см. В общем случае рекомендуется отбирать пробу из слоя, соответствующего по мощности гумусовому горизонту природных почв.

Представительность единичной пробы определяется размером площадки, в пределах которой отклонения результатов отдельного определения от среднего содержания в представительной выборке несущественны, т. е. не превышают заданного предела ошибки. Для фоновых почв эта величина определяется закономерностями природного варьирования. Как показано ранее [28], оценкой варьирования содержаний микроэлементов в пределах площадки размерами $10 \times 10$ м установлено, что для большинства изучаемых элементов коэффициент вариации содержаний не превышает $30 \%$ (в среднем от 6 до 20\%). Таким образом, достаточно 3-4 проб, чтобы оценить среднее содержание элементов на площадке $10 \times 10$ м с ошибкой $20 \%$ и $1-2$ пробс ошибкой $30 \%$.

В пределах антропогенных ореолов эти характеристики иные. В табл. 14 приводятся вариации содержаний в пределах равномерно опробованных малых площадок размерами $10 \times 10$ м и $1 \times 1$ м, заложенных в центральной части очага загрязнения, и соответствующие оптимальные количества проб, достаточные для достоверной количественной оценки средних содержаний. Единичная проба характеризует только ближнюю окрестность точки отбора. Даже с площадки размером 1 м $^{2}$ для характеристики комплексного ореола необходимо отобрать 9 проб при заданном уровне ошибки $\lambda=20 \%$ и $4-5$ проб при $\lambda=30 \%$. Для площадки размерами $10 \times 10$ м эти оптимальные величины составляют соответственно 30 и 12 проб. Таким образом, при опробовании для получения представительных результатов следует применять способ смешанных образцов. Образец предлагается составлять из проб, отобранных с площадки размерами $10 \times 10$ м. На участках фона и слабых аномалий число смешиваемых проб составляет 4-5, в очагах загрязнения - $12-15$. Это позволяет охарактеризовать фон с ошибкой до 20\%, а антропогенный ореол - с ошибкой до $30 \%$.

Средний объем почвенной пробы 300-400 г. При подготовке к анализу проба просушивается, растирается в фарфоровой ступке и просеивается через сито с отверстиями 1 мм. 
Т а 6 л и ц а 14. Характеристики распределения и оптимальные числа проб в выборке для малых площадок в центральной части аномалии

\begin{tabular}{|c|c|c|c|c|c|c|c|c|c|c|c|c|}
\hline $\begin{array}{c}\text { Размер } \\
\text { площадки }\end{array}$ & $\begin{array}{c}\text { Показа- } \\
\text { тели }\end{array}$ & $\mathrm{Pb}$ & $2 \Pi$ & Си & $5 \Pi$ & $\mathrm{Cr}$ & $\mathrm{N} 1$ & $\mathrm{~S}_{\mathrm{r}}$ & $M n$ & V & Mo & $\mathrm{Ga}$ \\
\hline $10 \times 10 \mathrm{~m}$ & $\begin{array}{l}\mathrm{C} \\
\mathrm{V} \\
\ll 1 \\
\ll 2\end{array}$ & $\begin{array}{c}190 \\
42 \\
18 \\
8\end{array}$ & $\begin{array}{r}385 \\
52 \\
27 \\
12\end{array}$ & $\begin{array}{r}127 \\
52 \\
27 \\
12\end{array}$ & $\begin{array}{c}68 \\
76 \\
58 \\
25\end{array}$ & $\begin{array}{r}139 \\
22 \\
5 \\
2\end{array}$ & $\begin{array}{r}43 \\
24 \\
6 \\
3\end{array}$ & $\begin{array}{c}37,5 \\
27 \\
8 \\
4\end{array}$ & $\begin{array}{r}1220 \\
38 \\
15 \\
7\end{array}$ & $\begin{array}{c}128 \\
26 \\
7 \\
3\end{array}$ & $\begin{array}{r}1,3 \\
35 \\
13 \\
6\end{array}$ & $\begin{array}{r}18 \\
33 \\
11 \\
5\end{array}$ \\
\hline $1 \mathrm{X} 1 \mathrm{M}$ & $\begin{array}{l}\mathrm{C} \\
\mathrm{V} \\
n_{1} \\
\ll 2\end{array}$ & $\begin{array}{r}86 \\
30 \\
9 \\
4\end{array}$ & $\begin{array}{r}210 \\
29 \\
8 \\
4\end{array}$ & $\begin{array}{r}66 \\
23 \\
6 \\
3\end{array}$ & $\begin{array}{r}27 \\
19 \\
4 \\
2\end{array}$ & $\begin{array}{r}117 \\
26 \\
7 \\
3\end{array}$ & $\begin{array}{r}44 \\
18 \\
4 \\
2\end{array}$ & $\begin{array}{r}31 \\
28 \\
8 \\
4\end{array}$ & $\begin{array}{r}1245 \\
28 \\
8 \\
4\end{array}$ & $\begin{array}{r}119 \\
24 \\
6 \\
3\end{array}$ & $\begin{array}{r}1,2 \\
33 \\
11 \\
5\end{array}$ & $\begin{array}{r}21 \\
31 \\
10 \\
5\end{array}$ \\
\hline
\end{tabular}

Примечания С - среднее содержание в выборке, мг/кг, $V-$ коэффициент вариации, \%, $n-$ оптимальное число проб $n_{1}-$ при $\lambda=20 \%, n_{2}-$ при $\lambda=30 \%$

При отборе снеговых проб необходимо оценить нагрузку изучаемых загрязнителей. С этой целью тщательно замеряется площадь шурфа и фиксируется время (в сутках) от начала снегостава. Опробование снега предполагает раздельный анализ снеговой воды, полученной при оттаивании, и твердого осадка, который состоит из атмосферной пыли, осажденной на поверхность снегового покрова. Пробы отбираются из шурфов, вскрывающих всю мощность снегового покрова. Масса снеговой пробы 5-7 кг, что позволяет получить при оттаивании не менее $4-3$ л воды и 1 кг твердого материала (пыли). Оттаивание проводится при комнатной температуре. Твердая нерастворимая фракция выделяется путем центрифугирования или фильтрования, просушивается, просеивается для освобождения от посторонних примесей и взвешивается. Отбор проб целесообразнее всего проводить в конце зимнего сезона (до начала интенсивного таяния), чтобы учесть загрязнение за максимальный отрезок времени.

Масса пыли в снеговой пробе служит основой для определе-

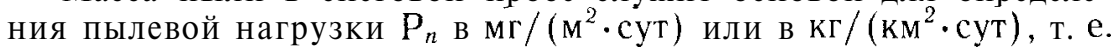
количества твердых выпадений за единицу времени на единицу площади. Расчет ведется по формуле:

$$
\mathrm{P}_{n}=\frac{P_{o}}{(S \cdot l)}
$$

где $\mathrm{P}$ - масса пыли в пробе; $S$ - площадь шурфа; $t$ - время от начала снегостава.

\section{Изучение техногенных потоков рассеяния}

Техногенные потоки рассеяния наиболее четко фиксируются в донных отложениях. Опыт работ и данные по распределению химических элементов в различных гранулометрических фракциях свидетельствуют о том, что отбор средней пробы, объединяющей фракции менее 1 мм, позволяет достаточно объективно 
оценить уровень техногенного загрязнения. В связи с неоднородностью донных отложений каждую пробу целесообразно составлять из нескольких (обычно 3-5) частных проб, отбираемых вблизи заданной точки опробования. На небольших и неглубоких водотоках, русло которых выстлано однородным материалом, возможен отбор осредненной по поперечному профилю пробы. На крупных водотоках пробы отбираются у уреза воды в местах видимой аккумуляции наносов. При развитии техногенных илов на значительных участках русла отбор донных проб проводится створовым методом с отбором вертикальных колонок на максимальную мощность илов.

Существует большое количество различных приборов, которые применяются при отборе донных отложений в соответствии со свойствами исследуемых грунтов. Как правило, масса отбираемых образцов донных отложений составляет обычно $200-$ 300 г. В принципе она зависит от планируемых в дальнейшем литолого-минералогических и химико-аналитических исследований. После морфологического описания отобранные для химических анализов пробы высушиваются до воздушно-сухого состояния, растираются в фарфоровых или агатовых ступках, просеиваются через сито с диаметром отверстий 1 мм и распределяются в пакеты из кальки или пластиковые контейнеры. На гранулометрический анализ и для изучения форм нахождения химических элементов в' пластиковые плотно закрываемые контейнеры отбираются свежие образцы огложений.

При изучении донных отложений как источников вторичного загрязнения вод необходимо знать состав иловых вод. В настоящее время для выделения иловых вод используется ряд методов: под давлением, центрифугированием, замещением различными жидкостями, отсасывание под вакуумом. Наиболее эффективен метод выделения иловых вод отжиманием под давлением. Для одновременного отбора проб ила, иловой и придонной воды наиболее удобны приборы М. В. Мартыновой, Вайта, К. Сатаке.

Отбор и обработка проб воды и взвешенного материала наиболее сложная задача при изучении техногенных потоков. На неглубоких водотоках (до 2-3 м) пробы воды на ствоpax наблюдения отбираются с глубины $0,2-0,5$ м от поверхности. При небольшой ширине русла (до 20-30 м) возможен отбор одной такой пробы в центре потока (на стержне). На всех водотоках более оправдан отбор трех проб (на стержне и ближе к берегам), которые затем осредняются на месте отбора.

При работах на очень крупных реках возможен отбор проб с различных горизонтов. Как правило, пробы берутся по трем вертикалям (на стержне и ближе к берегам) с трех уровней (поверхностный, срединный и придонный). Пробы в этом случае в зависимости от поставленной задачи могут анализироваться раздельно либо осредняться на месте отбора. 
На малых и средних реках поверхностные пробы воды отбираются специально предназначенным для этой цели белым полиэтиленовым или винилпластовым ведром. На более крупных реках и водоемах (особенно при отборе с глубин) применяются различные виды винилпластовых батометров, хорошо известных и описанных в литературе.

Общим требованиям, предъявляемым к сосудам и емкостям для транспортировки и хранения проб, лучше всего отвечает посуда, изготовленная из прозрачного химически стойкого стекла. Более практична (особенно на этапе отбора и транспортировки проб) полиэтиленовая посуда. Емкости и приборы для отбора и транспортировки проб тщательно моются концентрированной соляной кислотой. Для обезжиривания используются синтетические моющие средства. Остатки использованного для мытья реактива полностью удаляют тщательной промывкой емкостей водопроводной и дистиллированной водой. Подобную процедуру рекомендуется проводить периодически. При отборе пробы емкости следует несколько раз ополаскивать исследуемой водой. При проведении работ обычно определенные емкости закрепляют за конкретными створами. Этот методический прием позволяет значительно уменьшить вероятность вторичного загрязнения пробы.

В настоящее время разработаны различные схемы разделения и анализа форм нахождения химических элементов в природных водах [23, 50]. Многие из предложенных схем предварительного фракционирования достаточно сложны, поэтому ниже описаны те процедуры, проведение которых обязательно при изучении техногенных водных потоков рассеяния.

После отбора и доставки водных проб в лабораторию они немедленно фильтруются. Это производится для разделения растворенных и взвешенных форм химических элементов. Критерием их разделения является ультрафильтрация через мембранные фильтры с диаметром пор 0,3-0,5 мкм. Фильтрование производят на специальных воронках из оргстекла под вакуумом или под давлением инертного газа [23, 50]. Для фильтрования наиболее широко используются мембранные нитроцеллюлозные ультрафильтры Мытищинской фабрики ультрафильтров, а также фильтры Синпор. В последние годы начал серийно выпускаться новый вид фильтров - ядерные фильтры на лавсановой основе, изготовляемые в Объединенном институте ядерных исследований (г. Дубна). В зарубежной практике применяются мембранные фильтры Milliporre H. A., Sartorius, волокнистые стеклянные Whatman Fiber Glass, ядерные ультрафильтры Nuclepore. Cпециальные исследования Л. В. Деминой показали, что наиболее репрезентативными являются фильтры типа Nuclepore и ядерные на лавсановой основе ОИЯИ. Мембранные фильтры перед употреблением необходимо прокипятить в $0,03-0,05 \%$-й соляной 
кислоте особой чистоты в течение 5-10 мин. и высушить при $60-70^{\circ} \mathrm{C}$.

Перед началом фильтрации проба воды тщательно перемешивается. Эта процедура (необходимая для усреднения распределения взвесей) повторяется перед каждым наполнением воронки. Для последующих расчетов тщательно фиксируется объем воды, пропускаемый через фильтр.

Фильтрование для определения мутности проводят через специально взвешенные для этих целей фильтры. Фильтры перед взвешиванием помещаются в эксикаторы на несколько дней для достижения постоянной массы. Взвешивание производится на аналитических весах несколько раз (первое взвешивание через 10 дней после нахождения в эксикаторе, затем через 3 дня и, при выявлении устойчивой постоянной массы, еще через 3 дня).

Определенная часть отобранной пробы (как правило, большого объема - 40-60 л) отстаивается в течение суток в белых полиэтиленовых бочках или баках. Это необходимо для получения больших количеств взвеси, используемой для изучения форм нахождения элементов, гранулометрического и минералогического анализов, а также для определения тех элементов, которые невозможно исследовать на фильтрах (очень малые содержания в навеске и необходимость фильтрования больших объемов воды, что трудоемко). Особенно эффективен анализ отстоя на широкий спектр элементов при выявлении комплекса последних в зонах загрязнения. После отстаивания вода сливается с помощью сифона. Отстой с небольшим количеством воды помещается в бюксы и досушивается в сушильных шкафах при температуре $50-60^{\circ} \mathrm{C}$.

В современных океанологических исследованиях для отделения больших объемов взвеси используют центрифугирование с многокамерными и барабанными сепараторами непрерывного действия. При этом получают так называемую сепарационную взвесь. Обычно применяют промышленные сепараторы $\mathrm{HCM}-2$, НСМ-3, САЖ-3М, СЦС-3М с тарельчатыми вставками. Корпус и тарелки сепараторов выполнены из нержавеющей стали, трубопроводы и краны - из пластика. Этот способ эффективен и для пресноводных объектов.

Таким образом, после предварительной обработки водных проб мы получаем: взвесь на фильтрах (которые высушиваются и хранятся в чашках Петри); отстой или сепарационную взвесь (хранятся в пакетиках из кальки или бюксах); фильтрат - та часть воды, которая прошла через фильтры.

Взвесь на фильтрах, отстой и сепарационная взвесь не требуют немедленного анализа и могут храниться в соответствующих условиях (прохладное темное место). Однако необходимо непосредственно после их получения разделить и приготовить пробы к соответствующим видам анализа. Следует помнить, что 
даже в твердом материале возможны различные фазовые превращения химических элементов, особенно в непригодных для хранения условиях. Поэтому анализ твердого взвешенного материала необходимо проводить как можно быстрее.

Даже кратковременное хранение проб фильтрата без необходимой предосторожности может привести к заметным изменениям концентраций и форм нахождения химических элементов. Главное требование к фильтрату - немедленное проведение анализов на компоненты которые не могут без существенных потерь долго находиться в пообах. Далее осуществляется консервация проб на химические компоненты, которые могут определенное время храниться. Затем производится концентрирование проб на наиболее важные компоненты (экстракция, осаждение, упаривание и т. д.), после чего пробы могут храниться достаточно долго перед отправкой на анализ.

Следует отметить необоснованность мнения о том, что пробы на тяжелые металлы могут храниться длительное время при комнатной температуре, причем подкисление азотной кислотой (до pH 3-4) можно делать непосредственно перед анализом. Дело в том, что даже если в некоторых случаях не меняются валовые содержания элементов, то несомненно изменяются их фазовые состояния.

Отбор проб для биогеохимических исследований при изучении загрязнения вод в зависимости от решаемых задач в каждом конкретном случае имеет свои особенности и осуществляется в соответствии с действующими руководствами и указаниями [34] .

\section{Отбор проб атмосферного воздуха}

Исследование химических элементов в атмосферном воздухе проводится на стационарных, маршрутных и передвижных постах. Стационарные посты служат для проведения систематических наблюдений. Они оборудованы специальными павильонами, оснащенными необходимой аппаратурой для отбора проб воздуха и приборами для определения метеорологических параметров. На маршрутных постах отбор проб воздуха и метеорологические наблюдения проводятся с помощью автолаборатории. Передвижные (подфакельные) посты служат для разовых наблюдений в зонах непосредственного влияния промышленных выбросов. Их местоположение выбирается каждый раз в зависимости от поставленной задачи и метеорологических условий.

При оценке общей картины загрязнения атмосферного воздуха преимущественное значение имеют данные стационарных постов наблюдения, но при оценке дальности распространения. загрязнения необходимо использовать материалы подфакельных наблюдений.

Размещение стационарных постов наблюдений производится в 
зонах, где атмогеохимические аномалии стабильны во времени и пространстве и в большей степени ощущается влияние промышленных предприятий. Для правильного размещения стационарных постов, в первую очередь, необходимо проанализировать данные по территориальной структуре загрязнения, выполненной по результатам геохимического опробования почв и выпадений из атмосферы.

В зависимости от ассоциации загрязняющих веществ применяют ту или иную программу исследования атмосферного воздуха.

При организации подфакельных наблюдений для получения характеристики площадного распространения выбросов необходимо как минимум три поста.

При оценке атмогеохимических аномалий должно использоваться не менее 200-250 проб в год на стационарных постах и такое же количество проб при подфакельном исследовании по каждой зоне в течении нескольких лет (при условии, что физико-химический состав выбросов за период опробования не меняется).

Для отбора проб атмосферного воздуха используют серийно выпускаемые установки типа ЭА-1, ЭА-2, ЭА-2С, ЭА-1А, М-828 и др. Фильтры для улавливания аэрозолей и пыли разделяются по типу материала, из которого они изготовляются. В частности, специальные улавливающие фильтры АФА-ХА изготовляются из ацетилцеллюлозы, АФА-ХП из перхлорвинила, АФА-ХС - из полистирола.

Аналитические аэрозольные фильтры предназначены: для определения массовой концентрации аэродисперсных примесей (АФА-ВП), для проведения их химического анализа (АФА-ХА). Эффективность улавливания аэрозолей металлов применяемыми фильтрами зависит от скорости протягивания воздуха. Так, фильтр АФА-ХА наиболее эффективен для улавливания аэрозолей свинца при скорости 10 л/мин. При увеличении скорости аспирации до 20 л/мин процент проскока аэрозолей увеличивается до 8\%. Длительное прокачивание через фильтр запыленного воздуха постепенно приводит к накоплению в них осадка и росту сопротивления, что ухудшает сорбционные способности материала. Значительным недостатком наиболее широко применяемых в атмохимических исследованиях фильтров АФА-ХА является нестабильность их химического состава. Это свойство фильтров особенно важно при определении микроконцентраций химических элементов в атмосферном воздухе фоновых территорий. Кроме того, указанные типы фильтров недостаточно полно улавливают мелкодисперсный аэрозоль, который представляет наибольшую гигиеническую опасность. В последние годы у нас в стране созданы новые типы фильтров, позволяющие задержать и мелкодисперсные фракции. Например, трехслойный 
фильтр типа ФПАР позволяет задерживать частицы аэрозоля более 1 мкм на верхнем слое, 0,5 мкм - на внутреннем.

При исследовании микроэлементного состава атмосферного воздуха приходится сталкиваться с фактом проскока субмикронных частиц $(<0,003$ мкм $)$ через фильтр ФП. В связи с этим разрабатываются новые виды фильтров, способные эффективно улавливать из воздуха химические элементы, находящиеся в различных агрегатных состояниях. Для изготовления таких фильтров используется тонковолокнистый фильтр ФП и мелко измельченный сорбент. Для улавливания паров газовой составляющей различных химических элементов и соединений применяется фильтр с активным углем (АФАС-У) .

Для изучения дисперсного состава атмосферных аэрозолей применяют разного типа импакторы, принцип действия которых основан на избирательной сепарации частиц по размерам при пропускании воздуха через ряд последовательно установленных сопл уменьшающегося сечения.

Более детально методы опробования и обработки проб атмосферного воздуха изложены в специальных методических руководствах [33].

\section{3. ИССЛЕДОВАНИЕ НЕБЛАГОПРИЯТНЫХ РЕАКЦИЙ НАСЕЛЕНИЯ НА ЗАГРЯЗНЕНИЕ ОКРУЖАЮЩЕЙ СРЕДЫ}

Оценка возможного неблагоприятного воздействия техногенной геохимической нагрузки на состояние здоровья населения проводится путем изучения микроэлементного состава диагностических биосубстратов, установления функциональных показателей, характеризующих состояние различных систем организма, а также показателей физического развития и уровня заболеваемости. Такие исследования целесообразно проводить совместно с организациями и учреждениями медицинского профиля.

На основании карт распределения химических элементов в почвах и снежном покрове выбираются жилые территории, характеризующиеся различной интенсивностью загрязнения и качественным составом ассоциации. Первым этапом медико-геохимических исследований является изучение накопления химических элементов в различных группах населения.

При формировании групп населения для изучения биогеохимических показателей целесообразно использовать направленный отбор, т. е. составлять однородные выборки, в которых можно выявить влияние неизвестных факторов при устранении влияния известных. Так, при изучении влияния микроэлементного состава вод на уровень содержания химических элементов в биосредах должна быть исключена возможность поступления в организм больших доз изучаемых химических элементов с продуктами питания и атмосферным воздухом. При подборе кон- 
тингентов населения за основу принимаются следующие группировки населения: общая группировка по признаку одинакового во времени употребления питьевых вод или проживания в данной местности и раздельная группировка по разным концентрациям изучаемых химических элементов.

Из подобранных групп населения исключаются лица, имеющие контакт с различными бытовыми и профессиональными вредностями (употребление алкоголя, курение, интенсивное применение фармакологических средств) Наиболее приемлемы для обследования детские организованные коллективы (детские сады, школы), в которых достаточно легко можно устранить влияние индивидуальных и профессиональных факторов на микроэлементный состав биосред.

Химические элементы обладают, как отмечалось, различной способностью накапливаться в тех или иных диагностических биосубстратах и поэтому перед началом исследований с учетом интенсивности действующего загрязнения выбирают биосубстраты, которые в наилучшей степени отражают влияние того или иного элемента Как показывает опыт, в первую очередь на воздействие повышенных концентраций химических элементов реагирует состав волос. Это характерно для таких распространенных загрязняющих веществ как свинец, мышьяк, кадмий, ртуть. Значительное накопление в волосах наблюдается также для фтора, группы редкоземельных элементов, серебра, брома и некоторых других

При изучении микроэлементного состава волос подбираются группы населения, идентичные по возрасту, полу и цвету волос, с точной фиксацией их места жительства. Отбор проб волос у исследуемых групп населения следует проводить унифицированным методом, т е. состригать прядь волос определенной длины с локального участка (затылок, теменная часть головы). При этом также необходимо учитывать и используемые населением средства ухода за волосами, так как некоторые из них (йодсодержащие шампуни, ртутьсодержащие косметические средства) могут влиять на микроэлементный состав волос. Для снятия поверхностного загрязнения и обезжиривания волос применяют два способа. Первый способ - мытье волос при помощи детергента (лаурилсульфата натрия или трилона X-100). Детергент (4 мл) добавляют на 3 литра воды и заливают волосы, помещенные в боксы, так, чтобы раствор покрывал всю пробу. Через 2 часа детергент сливают, пробы волос заливают бидистиллированной водой, постоянно перемешивая. Так повторяют дважды, затем волосы обезжиривают в течение 45 мин. в спиртоэфировой смеси. После этого волосы высушивают при $60^{\circ} \mathrm{C}$ в течение 72 часов. Второй способ подготовки проб волос рекомендован МАГАТЭ, и он заключается в обработке проб ацетоном $X 4$ в течение $10-15$ мин, затем трехкратное промывание бидистилли- 
рованной водой по 10-15 мин и далее снова 10-15-минутная обработка ацетоном.

В отдельных случаях эффективен отбор проб мочи, который проводят в полиэтиленовые емкости, обработанные 0,1 н раствором азотной кислоты с регистрацией диуреза.

Изучение других показателей состояния здоровья населения в связи с воздействием загрязненной окружающей средой проводится по принятым в практике эпидемиологических исследований методикам [7]. Исследование показателей иммунологической реактивности детально изложено в работах сотрудников кафедры гигиены Самаркандского медицинского института.

\section{4.ХИМИКО-АНАЛИТИЧЕСКИЕИССЛЕДОВАНИЯ}

Геохимические исследования окружающей среды связаны с отбором проб исключительно разнородных по составу, характеру материала и объему технически достижимой навески. Это приводит к необходимости организации сложной системы анализов. В общем случае комплекс используемых аналитических методов зависит от поставленных задач и различается по этапам изучения окружающей среды.

Основные требования к результатам исследований начального этапа связаны с необходимостью экспрессного получения данных по максимально широкому комплексу химических элементов, формирующих зоны загрязнения, и оценки примерных количественных соотношений между элементами с целью выявления приоритетных загрязняющих веществ. Материал получаемых проб достаточно стандартен для прикладной геохимии, а размеры навесок практически неограничены. Большинству изложенных условий и требований отвечает экспресный приближенно-количественный или количественный метод с просыпкой анализируемого материала и с применением трехфазной дуги постоянного тока на дифракционном спектрографе типа ДФС-13. Метод в различных модификациях широко применяется в прикладной геохимии и хорошо известен. Однако, по некоторым элементам (очень важным для экологических исследований) чувствительность метода явно недостаточна и позволяет выделить лишь очень контрастные аномалии. Прежде всего это касается $\mathrm{Hg}, \mathrm{As}, \mathrm{Cd}$ и Р. В этой связи во всех случаях приходится проводить дополнительный анализ проб специальными высокочувствительными экспрессными количественными методами на As (спектральный метод из камерного электрода с пределом обнаружения 1 г/т) и $\mathrm{Hg}$ (на ртутном анализаторе РАФ или ИМГРЭ - 4 с пределом обнаружения 0,001 г/т), а в случае, когда на исследуемых территориях ожидаются источники выбросов или стоков фтора, то и на этот элемент (количественный спектральный метод). Для кадмия сколько-нибудь чувствительного экспрессного метода, пригодного 
для массовых определений, пока не имеется. Этот исключительно важный для экологии элемент может быть изучен только специализированными исследованиями, обычно проводимыми на конечном этапе работ.

При геохимическом картировании большая часть поставленных задач с удовлетворительной чувствительностью и точностью решается использованием приближенно-количественного спектрального метода для анализа проб почв, донных отложений и пылей, извлекаемых из снегового покрова. Также как и при исследованиях начального этапа, необходим специальный анализ проб более высокочувствительными методами на $\mathrm{Hg}$ и, желательно, As. Аномалии $\mathrm{Cd}$ и некоторых других элементов (5b, Bi, $W)$, как правило, не фиксируются. Тем не менее, основные задачи этого этапа исследований решаются неплохо. Специальный дорогостоящий анализ проб на эти элементы необходим лишь в случаях, когда известны конкретные источники подобных воздействий.

Для снегового покрова на рассматриваемом этапе исследований рационально (помимо анализа пылевой фракции) изучать водную фазу на комплекс приоритетных выбросов - оксиды азота и серы,-- зоны воздействия которых хорошо фиксируются снеговыми водами. Определение этих соединений проводится стандартными для вод химическими методами и при обычно наблюдаемых уровнях не вызывает затруднений.

При маршрутном опробовании донных отложений также рационально проведение экспрессного анализа водной фазы на соединения азота, фосфора, серы и хлора, хорошо маркирующие устойчивые водные техногенные потоки. Методика анализа на перечисленные ингредиенты хорошо разработана в гидрохимических руководствах.

Значительную сложность представляет анализ бытовых и промышленных отходов и средств химизации, изучаемых на данном этапе исследований. Задача изучения отходов - не только оценка их как загрязнителей, но и выявление перспективных источников вторичного минерального сырья. В этой связи необходимы достаточно точные определения широкого круга химических элементов. В частности, для осадков очистных сооружений, зол и шлаков - Pe, A1, Си, 2п, $\mathrm{Ni}, \mathrm{Cr}, 5 \Pi, \mathrm{Pb}, \mathrm{Cd}, \mathrm{Ag}, 5 \mathrm{e} ;$ для шламов мазутных ТЭЦ - Сг, V, Со; для металлоабразивных пылей - дополнительно Мо и W; для удобрений - F, TR, 5г, U [29].

Уровни содержаний химических элементов в отходах довольно высоки, размеры навесок неограничены. Основную сложность при организации химико-аналитических исследований отходов представляет этап подготовки проб к анализам, не имеющий пока стандартных решений. Это связано прежде всего с трудностью гомогенизации анализируемых проб, большими содержа- 
ниями во многих отходах органического материала, необычностью и разнообразием состава макроосновы проб Для органосодержащих отходов обычно приходится проводить отдельно анализы на летучие элементы ( $\mathrm{Hg}$, Аз) после разложения смесью кислот в автоклавных «бомбах» и на прочие элементы после озоления. Однако и для минеральных отходов мокрого разложения часто не удается избежать. Так, для плохо дробимых и крайне неоднородных золошлаковых металлосодержащих материалов мокрое разложение - единственный способ усреднения состава пробы. Поэтому атомно-абсорбционный анализ - основной метод в этих условиях. Большие содержания чаще всего позволяют обходиться без процедур концентрирования. Однако в связи со сложностью состава проб для отделения мешающих элементов часто приходится применять сорбцию и ионный обмен.

При исследовании удобрений, где главные элементы-примеси F, 5г, TR, также приходится применять комплекс методов (фторионо-селектнвные электроды; стронций-атомная абсорбция, редкие земли и уран-нейтронно-активационный анализ). Все методы стандартны и при существующих концентрациях особых затруднений не возникает.

Завершающий этап работы - детальные эколого-геохимические исследования в пределах выявленных ранее техногенных и агрогенных ореолов и потоков рассеяния - наиболее сложен в химико-аналитическом отношении.

Основное требование к аналитическим исследованиям на данном этапе изучения окружающей среды - получение количественных характеристик для широкого круга химических элементов. При этом, исходя из приведенного выше перечня решаемых задач, очевидны разнообразие вида материалов, поступающих на анализы, и сложность их химического состава. Для некоторых видов анализируемых материалов большую трудность представляет уже само получение проб в сколько-нибудь значительных навесках. Эти сложности, в частности, возникают при изучении водных взвесей, для выделения которых при мутностях вод порядка 10-20.мг/л приходится проводить фильтрование через мембранные фильтры значительных объемов воды. Еще сложнее получение проб атмосферных аэрозолей. Важный показатель воздействия загрязнений на человека - уровень биогеохимической концентрации - определяется по содержанию химических элементов в волосах [28]. Для детского населения возможная масса пробы волос не больше десятков - нескольких сотен миллиграммов сухого вещества (или несколько миллиграммов золы). Таким образом, во многих случаях неизбежно проведение анализа из малых навесок.

Перечисленные требования и условия приводят к необходимости привлечения к химико-аналитическим исследованиям самого современного и разнообразного арсенала методов. 


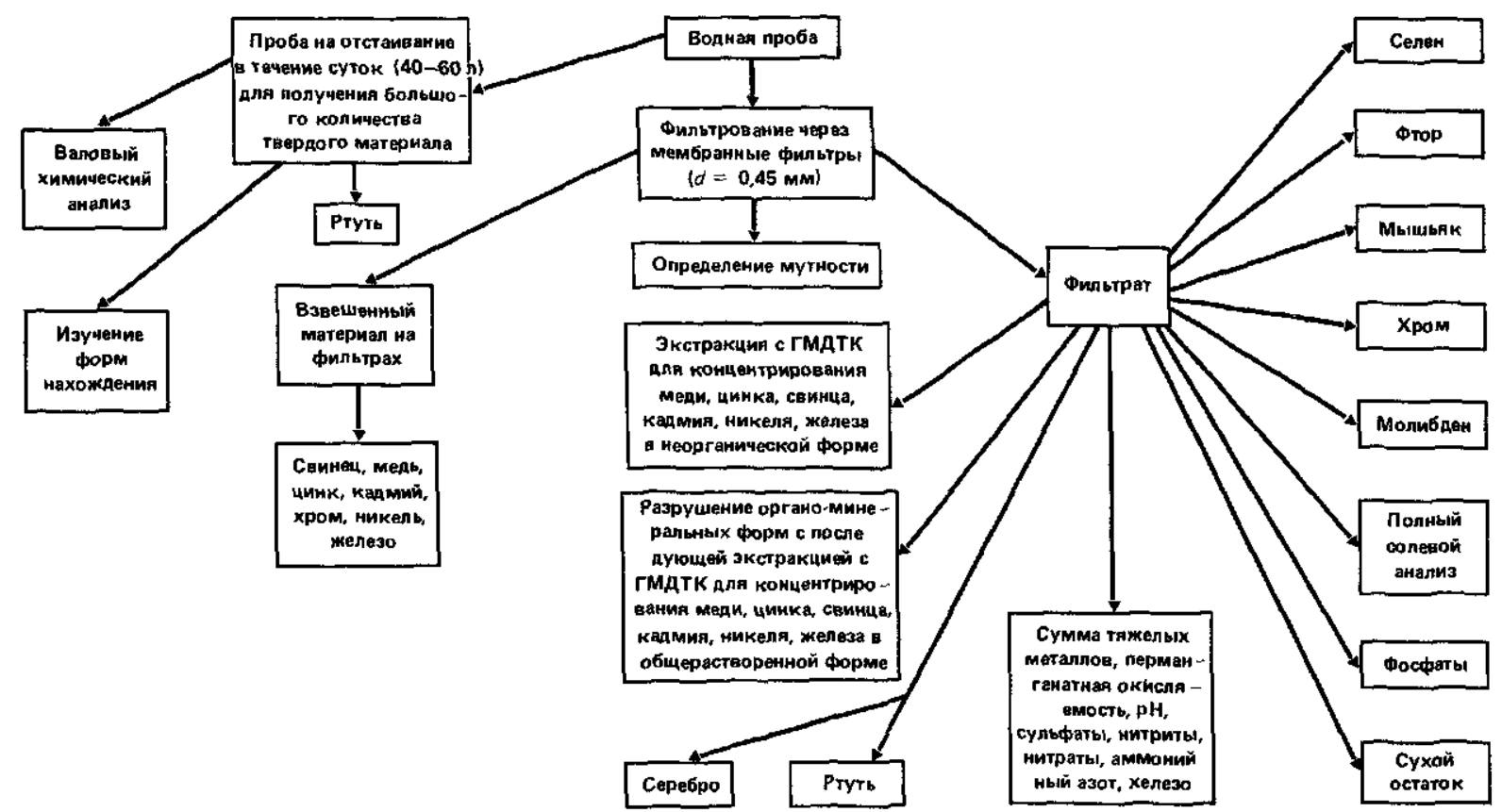

Рис. 22. Схема обработки и анализа водных проб при проведении детальных эколого-геохимических работ 
При анализе атмосферного воздуха возникает целая серия сложных химико-аналитических задач. Они связаны прежде всего с необходимостью определения химических элементов в малых навесках атмосферного аэрозоля, получаемых при фильтровании воздуха через специальные фильтры. При обычном содержании аэрозолей порядка $0,1 \mathrm{~m} / \mathrm{m}^{3}$ и скорости отбора около $100 \mathrm{r} / \mathrm{мин}$ за приемлемое для стандартного пробоотборного оборудования время удается, как правило, собрать не более 10 мг взвеси. Это определяет необходимость применения высокочувствительных методов анализа из малых навесок (нейтронно-активационного, рентгенофлюоресцентного, химико-спектрального). Исследование атмосферной взвеси - специальная задача, подробно рассмотренная в ряде работ, обобщенных, например, в обзоре [18].

При анализе проб водных потоков рассеяния в растворенной и взвешенной фазах исследования проводятся обычно на довольно широкий круг ингредиентов загрязнения. Это обусловливает необходимость проведения довольно трудоемкой процедуры преданалитической подготовки водных проб (рис. 22). Реализация этой схемы требует развертывания в полевых условиях сложной лаборатории, предназначенной для фазового разделения, консервации, концентрирования проб, а также для экспрессного определения некоторых элементов и соединений.

Для соблюдения сопоставимости данных взвешенное вещество и растворенные формы желательно определять одним методом. Для значительной группы элементов наиболее удобны в этих случаях атомно-абсорбционные методы.

Для полноценной характеристики уровня загряниения водных систем необходимо исследовать основные формы нахождения химических элементов как в водной фазе, так и в донных осадках.

В частности, для речных донных отложений в зонах загрязнения нами апробирована следующая схема.

\section{Растворители}

Раствор ацетатного буфера (рH 4,2) Раствор пирофосфатного натрия $(\mathrm{pH} 10,0)$

Раствор 0,15 н $\mathrm{HC} 1$

Раствор 6 н $\mathrm{HCl}$

\section{Извлекаемые формы}

Сорбционно-карбонатный комплекс

Металлы, связанные с гумусовыми веществами

Металлы, связанные со свежеосажденными оксидами и гидроксидами

Металлы, связанные с кристаллическими оксидами и гидроксидами

Содержания металлов в вытяжках определяются атомноабсорбционными методами.

С целью расширения круга элементов, анализируемых в растворенной форме, используется количественный спектральный анализ сухого остатка (из 1 л воды). Для этого Л. Г. Логинова и Р. М. Арапова применяли малый камерный электрод, повы- 
шающии чувствительность и точность определения многих элементов. Несмотря на довольно высокую трудоемкость пробоподготовки и анализа, получаемые результаты очень важны и интересны. Они, в частности, позволяют выявить очень широкий комплекс обычно не изучаемых химических элементов, накапливающихся в техногенных гидрогеохимических аномалиях (например, Вa, Be, V, TR, 5п, Ag, 5b, Ti, A1, образующие очень контрастные потоки рассеяния).

Биогеохимические исследования в пределах техногенных геохимических аномалий также связаны с организацией довольно сложного и разнообразного комплекса химико-аналитических исследований.

Для сельскохозяйственных и природных территорий цель этих исследований - количественное изучение взаимодействия химических элементов в системе «почва - растение» и оценка уровня содержаний токсичных элементов в растительных тканях, особенно в пищевой продукции человека и кормах. Для решения этих задач изучается уровень валовых содержаний всех выявленных химических элементов-загрязнителей в почвах и растениях, а также валовые и подвижные (усвояемые растениями) содержания биологически важных элементов - P, K, 5, (макроэлементы) и Си, 2п, Со, Ре, В, Mn (микроэлементы).

Основу комплекса аналитических методов, используемых при организации этих исследований, составляет атомно-абсорбционный анализ (Си, 2п, $\mathrm{Pb}, \mathrm{Cd}, \mathrm{Ni}, \mathrm{Pe}, \mathrm{Co}, \mathrm{Hg})$, дополняемый количественным спектральным анализом. Последний позволяет расширить комплекс оцениваемых химических элементов, что дает возможность выявить более широкий список химических элементов, контрастно концентрирующихся в растениях при антропогенных воздействиях (Мп, Sn, V, Ti, Ni, 2г, Cr, Ba).

Анализ растений на большую часть микроэлементов проводится из зол (температура озоления не более $400^{\circ} \mathrm{C}$ ). На летучие элементы (Hg, P, As), а также на макроэлементы (P, K, N, 3 и др.) проводится анализ сухого вещества. Во всех случаях для оценки результатов необходим пересчет концентраций на сырую массу.

\section{5. ОБРАБОТКА РЕЗУЛЬТАТОВ ИЗУЧЕНИЯ ОРЕОЛОВ И ПОТОКОВ РАССЕЯНИЯ}

Одна из главных характеристик геохимической антропогенной аномалии - ее интенсивность, которая определяется степенью накопления элемента-загрязнителя по сравнению с природным фоном.

Показателем уровня аномальности содержаний элементов является коэффициент концентрации $K_{c}$, который рассчитывается как отношение содержания элемента в исследуемом объекте С к 
среднему фоновому его содержанию Сф:

$$
\mathrm{K}_{\mathrm{c}}=\frac{\mathrm{C}}{\mathrm{C}_{\phi}}
$$

По данным снегового опробования рассчитывается аналогичный показатель и для нагрузки загрязнения (элемента) на окружающую среду - массы загрязнителя, выпадающей на единицу площади за единицу времени. Для этого учитывается общая масса потока загрязнителей - среднесуточная пылевая нагрузка $\mathrm{P}_{n}\left(\right.$ в кг $\left./ \mathrm{kм}^{2}\right)$ и концентрация элемента С (в мг/кг) в снеговой пыли.

На этом основании рассчитываются:

1) общая нагрузка, создаваемая поступлением химического элемента в окружающую среду $\mathrm{P}_{\text {общ }}=\mathrm{C} \cdot \mathrm{P}_{n}$;

2) коэффициент относительного увеличения общей нагрузки элемента $\mathrm{K}_{p}=\mathrm{P}_{\text {общ }} / \mathrm{P}_{\phi}$ при $\mathrm{P}_{\phi}=\mathrm{C}_{\phi} \cdot \mathrm{P}_{n_{\phi}}$; где $\mathrm{C}_{\phi}-$ фоновое содержание исследуемого элемента; $\mathrm{P}_{n_{\phi}}-$ фоновая пылевая нагрузка; например, для Нечерноземной зоны фоновая пылевая нагрузка составляет $10 \mathrm{kг} /\left(\mathrm{kм}^{2} \cdot\right.$ сут $)$; $\mathrm{P}_{\phi}-$ фоновая нагрузка исследуемого элемента.

Поскольку техногенные аномалии обычно имеют полиэлементный состав, для них рассчитываются суммарные показатели загрязнения $Z_{c}$ и нагрузки $Z_{p}$, характеризующие эффект воздействия группы элементов. Показатели рассчитываются по следующим формулам:

$$
Z_{c}=\sum_{i=1}^{n} K_{\mathrm{c}}-(n-1) ; \quad Z_{p}=\sum_{t=1}^{n} K_{\mathrm{p}}-(n-1)
$$

где $n$ - число учитываемых аномальных элементов.

Все перечисленные показатели могут быть определены как для содержания в отдельной пробе, так и для участка территории (района, функциональной зоны, природной ландшафтной единицы, очага ореола). В последнем случае исследование ведется по геохимическим выборкам.

Главная задача исследования выборок - выявить химические элементы, накапливающиеся в почвах или в выпадениях изучаемого объекта, и провести сравнительную характеристику качественных и количественных особенностей накопления в объектах разного типа.

Для каждой выборки подсчитываются основные параметры распределения химических элементов:средние значения С и стандартное отклонение 5, а также коэффициент вариации $V$, который отражает меру неоднородности выборки. Если в выборке преобладают пробы, в которых содержание элемента находится ниже предела чувствительности анализа, то дисперсия и стандартное отклонение не рассчитываются. В этих случаях выборка характеризуется не средним содержанием, а встречаемостью зна- 
чимых содержаний в процентах общего числа проб в выборке.

После расчета коэффициентов концентрации и коэффициентов относительного увеличения общей нагрузки каждая выборка представляется в виде набора относительных характеристик аномальности химических элементов. Такой набор позволяет дать качественную и количественную оценку геохимической ассоциации исследуемого объекта. Например, городская ассоциация может быть представлена следующей формулой накапливающихся элементов:

$$
\mathrm{Hg}_{30}-\mathrm{Pb}_{10}-\mathrm{Zn}_{8}-\mathrm{Cu}_{4}-\mathrm{Ni}_{3}-\mathrm{Cr}_{2}
$$

(цифровые индексы около символов элементов представляют собой коэффициенты концентрации $\mathrm{K}_{c}$ ).

В целом, для обработки материалов могут быть использованы стандартные методы и программы, детально описанные в руководствах по прикладной геохимии.

Гл а в а 3

\section{ГЕОХИМИЧЕСКОЕ ИЗУЧЕНИЕ ОКРУЖАЮЩЕЙ СРЕДЫ ГОРОДОВ}

Антропогенные потоки вещества, образующиеся в ходе производственно-бытовой деятельности городского населения, чрезвычайно многообразны (рис. 23), содержат высокие концентрации широкого круга химических элементов, в том числе и токсичных. Включаясь в природные циклы миграции, антропогенные потоки приводят к быстрому распространению загрязняющих веществ в природных компонентах городского ландшафта, где неизбежно их взаимодействие с человеком. Анализ путей миграции антропогенных потоков и их сложности взаимодействия с окружающей средой - необходимое звено в цепи многофакторной оценки состояния экологической обстановки в городах.

\section{1. ОСНОВНЫЕ ИСТОЧНИКИ ЗАГРЯЗНЕНИЯ ОКРУЖАЮЩЕЙ СРЕДЫ ГОРОДОВ ОБЩАЯ ОЦЕНКА ИХ ВОЗДЕЙСТВИЯ}

\section{Основные источники загрязнения}

В результате различных видов деятельности человека создаются огромные количества отходов: По прогнозным исследованиям Международной корпорации по научным исследованиям и технологии в 1970 г. в мире образовалось 5 млрд т твердых отходов, 19,8 млрд т газообразных загрязнителей, 0,2 млрд т пыли, 84 


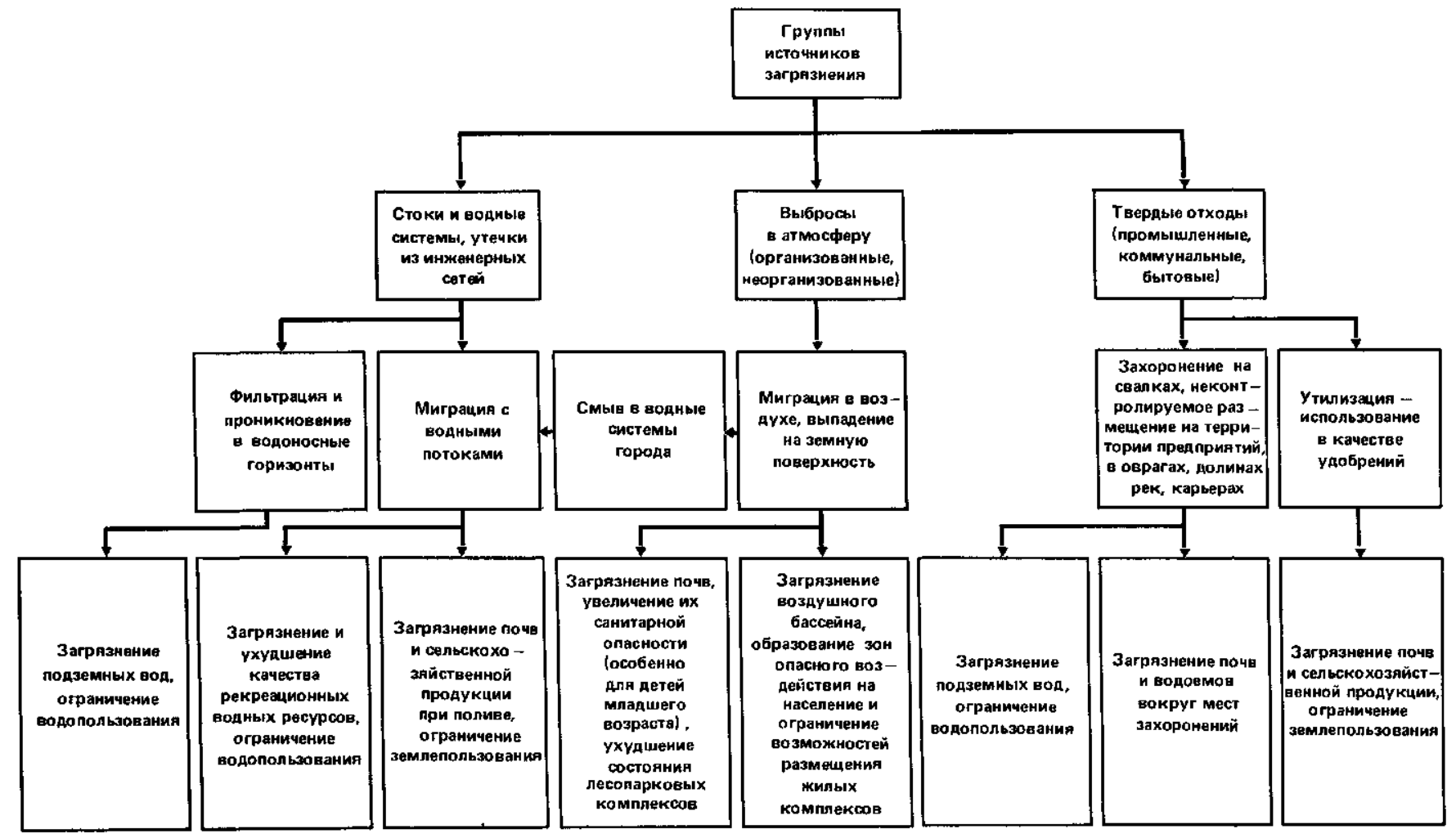

Рис. 23. Источники загрязнения окружающей среды, распространение загрязняющих веществ и последствия их воздействия 
9145 млрд т стоков. К 2000 г. ожидается увеличение количества отходов в 3 раза. Подавляющая их часть образуется в городах, где проживает большая часть населения земли и сконцентрирована основная масса различных производств.

В целом, несмотря на существование большой литературы, характеризующей отходы, их химический состав, особенно распределение в них токсичных химических элементов, изучены плохо.

Химический состав отходов весьма разнообразен. Их характерной чертой является наличие широкой ассоциации накапливающихся элементов, совместное нахождение которых обусловлено не только общностью свойств, но и (в отличие от природных ассоциаций) спецификой производственной и бытовой деятельности.

По частоте встречаемости в отходах среди химических элементов преобладают $\mathrm{Zn}, \mathrm{Cu}, \mathrm{Cd}, \mathrm{Hg}, \mathrm{Pb}, \mathrm{Ag}, \mathrm{Sn}, \mathrm{Cr}, \mathrm{Ni}$.

Каждый вид деятельности характеризуется своей специфической ассоциацией накапливающихся химических элементов. Вместе с тем, ассоциации элементов в промышленных и бытовых отходах поразительно схожи. Общим является большая комплексность состава.

Для производств, связанных с первичной или вторичной переработкой " неорганических материалов (металлообработка, химическая промышленность, промышленность стройматериалов, энергетика) характерна концентрация химических элементов во всех типах отходов (выбросы, стоки, твердые отходы). При этом качественный состав ассоциаций сонахождения близок. Для производств, обрабатывающих органическое сырье (пищевая, текстильная промышленность), более характерно накопление химических элементов в стоках.

Важнейшая особенность практически всех видов отходов преимущественное накопление в них малых и редких химических элементов, отличающихся повышенной технофнльностью и, как правило, повышенной экологической токсичностью. Здесь прежде всего отметим $\mathrm{Hg}, \mathrm{Pb}, \mathrm{Cd}, 2$; чрезвычайно характерными загрязнениями являются также W, Sn, Ag.

Значительная часть твердых и жидких отходов утилизируется. Наиболее полно используется лом металлов, отходы пищевой, мясомолочной промышленности, отходы бумаги, текстиля, маслои нефтесодержащие отходы. В 1980 г. в нашей стране из отходов была произведена каждая третья тонна стали, четвертая тонна бумаги и картона, пятая тонна цветных металлов и серной кислоты [38].

Большая часть неутилизируемых отходов вывозится на свалки, в результате чего поблизости от населенных пунктов концентрируются огромные массы свалочного материала, обогащенного тяжелыми металлами. Свалки - потенциальные источники по- 
ступления металлов в подземные и поверхностные воды, в прилегающую почву.

Некоторая часть отходов размещается в отвалах, на специальных полигонах и на внутризаводских свалках. В этих случаях также создаются локальные скопления значительных масс металлов. Например, на внутризаводской свалке одного крупного приборостроительного завода за 30 лет скопилось около 75 тыс. т свалочного материала, содержащего более тысячи тонн 2п, сотни тонн W, Си, Pb, 5п, десятки тонн Co, Ni, Cr, Bi. Изучение баланса распределения отходов в пределах промышленного района, в котором имелись внутризаводские свалки, показало, что значительная масса отходов и заключенных в них химических элементов остается в городе.

Для некоторых видов отходов (например, для гальванических шламов, которые содержат токсичные металлы и соединения, не имеется установленных мест захоронения). Отходы удаляются предприятиями самостоятельно, что не позволяет контролировать объемы отходов и распространение от них загрязнения.

Высокими концентрациями многих тяжелых металлов отличаются коммунально-бытовые отходы - твердые бытовые отходы и осадки городских очистных сооружений. Часть их перерабатывается в компост, используемый в качестве удобрения, и становится источником загрязнения сельскохозяйственных почв и продукции.

Коммунально-бытовые и производственные стоки поступают в поверхностные водные объекты или непосредственно (условно чистые стоки) или после заводских и (или) городских очистных сооружений. При этом взвесь, не уловленная при локальной очистке стоков, задерживается на городских очистных сооружениях, обогащая металлами осадки, которые иногда вывозятся в качестве удобрений на сельскохозяйственные поля. Растворенные металлы также частично задерживаются очистными сооружениями, а частично поступают в водные объекты, увеличивая в них содержания металлов.

Газовые и пылегазовые выбросы от работающего оборудования (организованные и неорганизованные выбросы), от складируемых и транспортируемых отходов и сырья (как правило, неорганизованные выбросы) загрязняют воздушный бассейн.

Таким образом, промышленные выбросы и стоки определяют современное качество вод, атмосферы и (через выпадения) почв в урбанизированных зонах и их обрамлении. Твердые отходы (бытовые и промышленные) образуют фиксированные скопления химических элементов - источники загрязнения почв и воды

Рассмотрим особенности химического состава различных отходов, объединенных по близости связанных с ними цепей распространения загрязняющих веществ в окружающей среде: твердые отходы, выбросы, стоки. 
Твердые отходы. В эту группу включают преднамеренно собираемые твердые промышленные и бытовые отходы и пастообразные осадки очистных сооружений. В высокоразвитых странах на одного человека приходится в год до $3-5$ т промышленных и около 0,3-0,4 т бытовых отходов [29]. Каждый год количество отходов возрастает на несколько процентов.

Виды промышленных отходов многообразны. Наиболее объемные отходы образуются на металлургических комбинатах, машиностроительных заводах, предприятиях стройиндустрии и в энергетике - это шлак, зола, формовочные материалы, разнообразная уловленная пыль. Наряду с отходами, специфическими для определенных производств, на предприятиях разного профиля накапливаются большие объемы одинаковых отходов: древесины, резины, пластмассы, краски, растворителей, нефтепродуктов и др. Помимо этого, на каждом предприятии имеется производственный и строительный мусор, который по объему часто превосходит все остальные виды отходов.

Отходы разнообразны по химическому составу. Некоторые из них отличаются высокими концентрациями отдельных химических элементов, в том числе токсичных.

В табл. 15 приведены ассоциации химических элементов, накапливающихся (относительно средних содержаний в земной коре) в главных видах твердых отходов на типичных для городов производствах.

Основными отходами в черной металлургии являются шлаки, шламы, пыль, отходы производства кокса.

При выплавке 1 т чугуна и стали получают 0,2-1 т шлака. Ежегодно в стране на предприятиях черной металлургии накапливается более 52 млн. т доменных, 24 млн. т сталеплавильных и 2,4 млн. т ферросплавных шлаков [38].

Доменные шлаки состоят из оксидов $\mathrm{Si}(44-40 \%)$, A1 (5$16 \%)$, Ca (30-50\%), Mg (1-7\%), Pe (0,2-4,5\%), Mn $(0,5-$ $3 \%)$. Сталеплавильные шлаки отличаются от доменных более высоким содержанием оксидов Ре $(5-16 \%)$, Мп (5-9\%) и P. Микроэлементный состав шлаков зависит от перерабатываемого сырья. Так, в изученных шлаках комбинатов Урала концентрируются $\mathrm{O}$ и $\mathrm{V}$; в доменных шлаках в 2-3 раза выше кларковых содержаний, в ферросплавных и мартеновских - более, чем в 100 раз; V накапливается в доменных и ферросплавных шлаках соответственно в 3 и 11 раз. В доменных шлаках комбинатов европейской части Союза ССР содержания названных элементов низкие, но в них накапливается В $\left(\mathrm{K}_{\mathrm{c}} 3-10\right)$ и 5г (Кс 2-13). Содержание других микроэлементов в шлаках не превышает средних в земной коре. Большая часть доменных шлаков используется для получения различных строительных материалов. Из сталеплавильных и ферросплавных шлаков, обладающих высокой нейтрализующей способностью и содержащих 
Т а бли ц а 15 Ассоциация химических элементов в твердых промышленных отходах

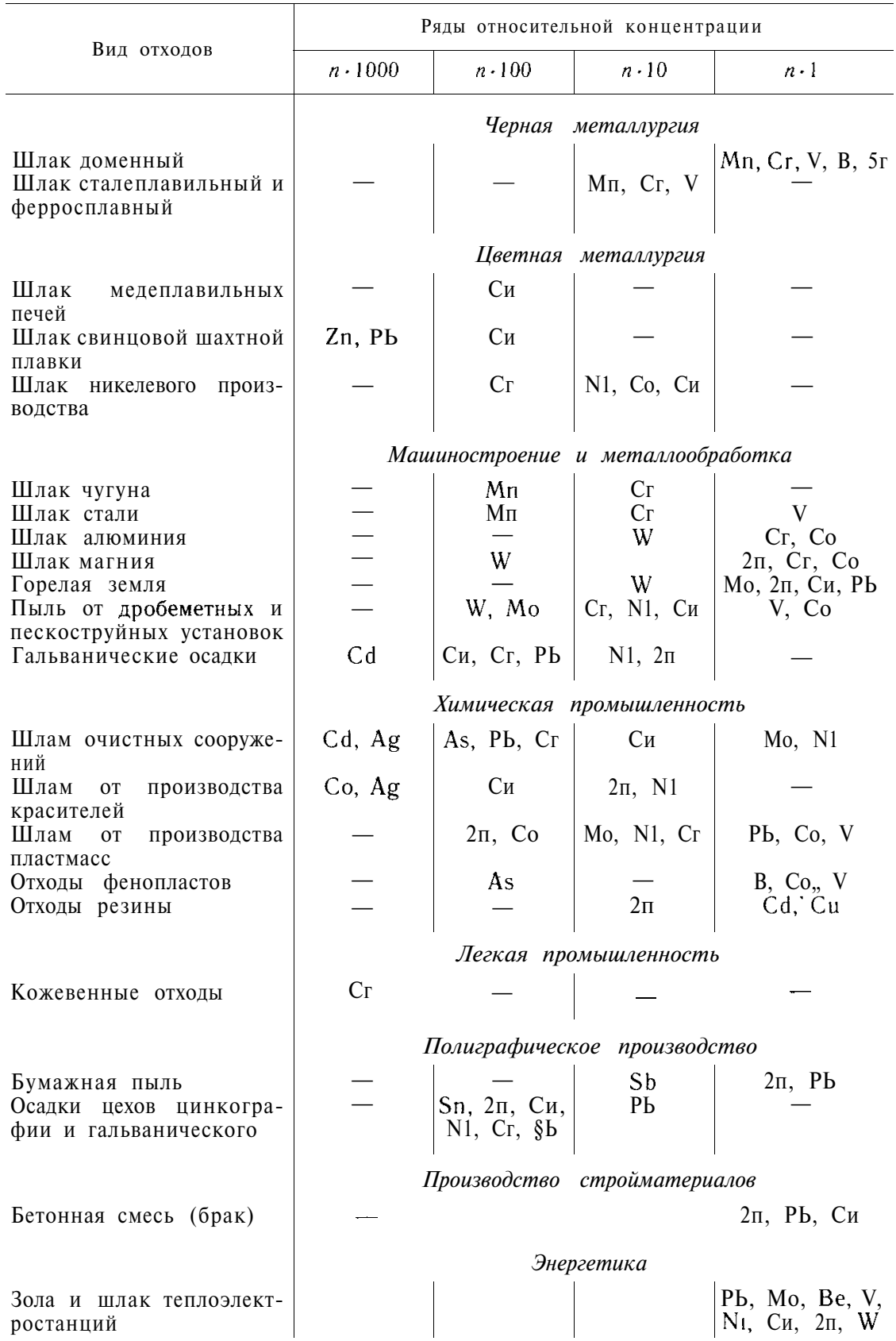


в небольшом количестве необходимые растениям микроэлементы (В, Мо, Си, 2п, Со, V и др.) и Р, производят известковую муку для сельского хозяйства. Учитывая высокие концентрации в шлаке токсичных металлов (например, хрома) этот способ требует экологического обоснования. Применяют шлак также в дорожном строительстве и литейном производстве.

Кроме шлака в металлургическом процессе образуется много шламопылевых отходов - до 100 кг на 1 т стали. Большая часть доменной пыли (87\%) улавливается и идет на приготовление окатышей для металлургического производства; пыль состоит из оксидов Ре $(50-90 \%)$, оксидов Са и $\mathrm{Mg}(1-10 \%)$, $\mathrm{A} 1, \mathrm{P}, \mathrm{Si}$ (несколько процентов) содержит тяжелые металлы. Особенно высокими концентрациями металлов (4-6\% 2п, 1$2 \% \mathrm{~Pb}$, а также $\mathrm{Cr}, \mathrm{Ni}, \mathrm{Cd})$ отличается пыль электроплавильных печей. Из-за вредных примесей она не используется и является источником загрязнения окружающей среды легко вымываемыми токсичными металлами (СA, Сг, $\mathrm{Pb}, \mathrm{Se})$.

На коксохимических заводах, входящих в комплекс производств металлургических комбинатов, в процессе обогащения, коксования угля, улавливания и переработки отходов образуются фусы, кислотные смолки, кубовые остатки, полимеры, составляющие $0,1-0,15 \%$ массы угольной шихты. Содержание химических элементов в отходах углеобогащения обычно не превышает содержаний в литосфере.

Весьма многоотходной отраслью производства является цветная металлургия, объединяющая сотни горнодобывающих, обогатительных, металлургических и обрабатывающих предприятий, на которых перерабатываются десятки типов руд и извлекается более 70 химических элементов.

Основные отходы производства отрасли - хвосты обогащения руд, шлламы, шлаки, пыль. Объем накопленных вскрышных пород в отвалах и отходах обогатительных фабрик, в хвостохранилищах составлял в стране в 1980 г. 2,5 млрд т, а объемы отвальных шлаков и шламов - соответственно, 317 и 114 млн т [38].

В зависимости от видов перерабатываемого сырья выход шлака в цветной металлургии колеблется от 10 до 200 т на 1 т получаемого металла. Отвальные шлаки имеют состав (в \%): $\mathrm{SiO}_{2} 35-40, \mathrm{Al}_{2} \mathrm{O}_{3} 6-10, \mathrm{CaO} 16-18, \mathrm{MgO} 2-7, \mathrm{Fe}_{2} \mathrm{O}_{3} 1-2$, $\mathrm{FeO} 20-35, \mathrm{MnO} 0,1-0,4, \mathrm{SO}_{3} 0,5-2$. Как правило, шлаки содержат значительные количества ценных компонентов. Так, в отвалах шлаков медных заводов страны заключено около 27 млн т Pe, 335 тыс т Си и 2 млн т 2п, а шлаковые отвалы свинцовых заводов содержат около 3 млн т Ре, более 900 тыс т 2П, 150 тыс т РЬ и 70 тыс т Си. Отвальные шлаки отличаются јчень высокими содержаниями многих цветных металлов. Шлаки медеплавильных печей содержат $0,4-0,6 \%$ Си (коэффициент концентрации $\left.\mathrm{K}_{c} 85-130\right)$, шлаки свинцовой шахтной плавки 
$6-22 \% \mathrm{Zn}(\mathrm{Kc} 720-2650), 1-3,5 \% \mathrm{~Pb}\left(\mathrm{~K}_{\mathrm{c}} 620-2180\right), 0,15-$ $0,7 \%$ Си (Кс 30-150); при производстве никеля получается шлак, содержащий $1 \% \mathrm{Cr}\left(\mathrm{K}_{\mathrm{c}} 120\right), 0,08-0,18 \% \mathrm{Ni}\left(\mathrm{K}_{\mathrm{c}} 14-30\right)$, $0,03-0,1 \%$ Си (Кс 6-20), 0,02-0,03\% Со (Кс 12-17). Использование шлаков в отрасли не превышает $15 \%$.

Ежегодно в цветной металлургии улавливается и обезвреживается около 30 млн т пыли и газообразных вредных веществ. В зависимости от профиля производства пыль содержит Си, РЬ, $\mathrm{Zn}, \mathrm{Ni}, 5 п$, Аз, Bi, Cd и другие элементы.

Места хранения неутилизируемых отходов предприятий отрасли часто не имеют хорошей изоляции и являются мощным потенциальным источником поступления токсичных химических элементов в окружающую среду.

Предприятия машиностроительного профиля при исключительном многообразии выпускаемой продукции потребляют близкое по составу сырье и используют сходные технологические приемы при его обработке. Поэтому отходы машиностроительных предприятий имеют ограниченную номенклатуру и, как правило, мало изменчивы по составу, хотя количество того или иного отхода может колебаться в широких пределах.

Обследование, проведенное кафедрой технологии машиностроения ЛИЭИ на 30 предприятиях машиностроительного профиля г. Ленинграда [29] показало, что на одном предприятии образуются в среднем (в т/год): металлы черные - до 8750; металлы цветные - до 400; шлак, окалина, зола - до 4000; горелая формовочная смесь - до 3800; шлам, флюсы - до 600; абразивы - 0,5-48; древесина (опилки, обрезки, стружка, упаковка) $-100-1500$; пластмасса - до 780; бумага и картон - 2,6 12; мусор (древесина, ветошь, бумага, картон, резина, пластмассы, стекло) - $150-20000$.

Наиболее объемные виды твердых отходов приходятся на литейные цехи машиностроительных заводов. В основном это шлаки и горелая земля; общее их количество на предприятиях крупного индустриального города может достигать сотен тысяч тонн в год.

На обследованных авторами предприятиях - состав шлаков от литья черных металлов варьирует в широких пределах. Кислые ваграночные и электропечные шлаки содержат в \%: 42-59 $\mathrm{SiO}_{2}, 3-13 \mathrm{Al}_{2} \mathrm{O}_{3}, 4-29 \mathrm{PeO}+\mathrm{Fe}_{2} \mathrm{O}_{3}, 2-17 \mathrm{MnO}$, до $8 \% \mathrm{MgO}$ и до $19 \mathrm{CaO}$. Основные шлаки имеют состав (в \%): 12-34 $\mathrm{SiO}_{2}, 6-40 \mathrm{Al}_{2} \mathrm{O}_{3}, 2-12 \mathrm{PeO}+\mathrm{Fe}_{2} \mathrm{O}_{3}, 1-20 \mathrm{MпO}, 3-35 \mathrm{MgO}$ и 2-27 СаО. Из микроэлементов в шлаках накапливаются Сг (Кс 10-12 для шлаков от плавки чугуна, 48 для сталелитейных шлаков) и V (Kс 2). Другие микроэлементы в этих шлаках не концентрируются.

При плавке алюминия с большим количеством флюса образуется шлак, дробимая часть которого содержит от 4 до $42 \%$ 
алюминия в металлических включениях, количество которых составляет несколько процентов. В шлаке концентрируются W (в 10 раз выше кларка), Cr, Co (в 7 раз).

Состав шлака от плавки магниевых сплавов довольно выдержанный; Mg (18-26\%), А1, Ре, К, Ва (несколько процентов), $\mathrm{Si}, \mathrm{Ca}, \mathrm{Na}$ (доли процента), хлориды и фториды. В шлаке повышены концентрации W (в 100 раз выше кларка), Zn (5) Сг (2) $\operatorname{Co~(2).~}$

Шлаки алюминия частично перерабатываются на заводах вторичных металлов. Переработка магниевых шлаков в отечественной промышленности пока не производится. Имеются сообщения об использовании за рубежом магниевых шлаков для извлечения магния и приготовления удобрений.

В атмосферных условиях алюминий и магний в шлаках в течение года почти полностью окисляются, из шлаков вымываются хлориды и фториды, засоляя почву, загрязняя водоемы и грунтовые воды.

Объемными отходами литейных цехов являются использованные формовочные материалы и, в первую очередь, горелая земля. Хотя их частично регенерируют и возвращают в производство, неиспользуемая часть велика по объему - десятки тысяч тонн в год на одном предприятии. Основой формовочных материалов являются кремнезем (кварцевый песок) и алюмосиликаты (глина). Содержания микроэлементов в свежих материалах близки к кларковым значениям. При заливке металлов происходит небольшое обогащение формовочных материалов некоторыми химическими элементами, но существенного их концентрирования не происходит.

Количество уловленной пыли от дробеметных и пескоструйных установок, в которых отливки очищаются от частиц земли, достигает на заводах десятков - сотен тонн в год. Пыль отличается повышенными концентрациями Mo, W (в 100-300 раз выше кларка), Сг, Ni, Си (в 20-30 раз), V (в 2 раза). Пыль не используется.

Значительную по объему группу составляют отходы механической обработки металлов (лом, стружка, окалина, уловленная пыль и шлам). Утилизируются лом, стружка металлов и частично окалина и пыль от заточки инструмента.

Количество пыли, образующейся при механической обработке металлов, зависит как от типа станка, так и от обрабатываемого материала. По исследованиям Л. Я. Градуса (1983), при полной нагрузке режущего станка за смену выделяется 40-300 г пыли чугуна, 20-150 г пыли цветных металлов, 300-2000 г пыли пластмасс. Еще больше пыли выделяется при обработке металлов абразивом, за смену количество ее может достичь $2-3$ кг, при мокрой обработке накапливается 4-5 кг шлама на станок. Содержания тяжелых металлов в уловленной пыли 
Т а бли ц 16 Параметры распределения химических элементов в гальванических осадках

\begin{tabular}{|c|c|c|c|c|}
\hline \multirow{2}{*}{ Элемент } & \multicolumn{3}{|c|}{ Содержания, \% } & \multirow{2}{*}{$\begin{array}{c}\text { Средний } \\
\text { коэффициент } \\
\text { концентрации }\end{array}$} \\
\hline & мальные & преобладающие & средние & \\
\hline Кадмий & 16,8 & $0,01-1 \quad$. & 0,1 & 7690 \\
\hline Висмут & 0,16 & - & 0,003 & 3330 \\
\hline Олово & 9,5 & $0,-1$ & 0,4 & 1600 \\
\hline Медь & 38,6 & $0,--10$ & 1,3 & 275 \\
\hline Хром & 18,4 & $0,-10$ & 1,6 & 190 \\
\hline Цинк & 15,2 & $0,-10$ & 1,2 & 145 \\
\hline Свинец & 19,2 & $0,-1$ & 0,2 & 125 \\
\hline Серебро & 0,08 & $0,00001-0,0001$ & 0,0008 & 115 \\
\hline Никель & 6 & $0,01-1$ & 0,3 & 50 \\
\hline
\end{tabular}

изменяются в широких пределах. В пыли и шламе от различных видов механической обработки черных металлов преобладают следующие концентрации (в \%): 2п и $\mathrm{Cr} 0,01-1$, (максимальный $\left.\mathrm{K}_{c} 120\right)$, Ni 0,01-0,3 ( $\left.\mathrm{K}_{\mathrm{c}} 50\right)$, V и Со 0,001-0,1 ( $\mathrm{K}_{\mathrm{c}} 20$ и $50)$, Си 0,01-2 ( $\left.\mathrm{K}_{\mathrm{c}} 400\right), 0,001-0,04$ ( $\mathrm{Kc} \mathrm{25),} \mathrm{Мо} \mathrm{до} \mathrm{0,1} \mathrm{(} \mathrm{Kc}$ 1000), W до 0,6 (Кс 6000). В пыли от обработки цветных металлов содержание Си и 2п достигает десятков процентов, а $\mathrm{Pb}$ и 5п - нескольких процентов. Пыль и шлам, как правило, вывозятся на свалку.

С процессами химического травления и гальванического покрытия металлических поверхностей связано образование на заводах накопления больших количеств одного из наиболее токсичных видов отходов - осадков физико-химической очистки стоков.

Авторами изучен состав осадков более чем 130 предприятий различных отраслей машиностроения. В осадках большинства из них обнаружены очень высокие концентрации Си, 2п, Cd, $\mathrm{Ni}$, $\mathrm{Cr}, \mathrm{Sn}$, реже встречаются $\mathrm{Pb}, \mathrm{Ag}, \mathrm{Bi}$.

Параметры распределения металлов предприятий приведены в табл. 16. Состав осадков весьма невыдержан. Размах содержаний всех элементов составляет несколько порядков.

Наиболее широкие ассоциации металлов с повышенными концентрациями характерны для осадков предприятий автомобилестроения, электротехнического машиностроения, приборостроения, машиностроения для легкой и пищевой промышленности, химического и нефтехимического машиностроения. Причем в осадках этих производств наблюдаются очень высокие уровни содержаний металлов: автомобилестроение - 2 п $(2,3 \%), \quad \mathrm{Pb}$ $(1,2 \%)$; приборостроение - Зп $(2,1 \%)$, Си (1,9\%), РЬ (1,4\%), $\mathrm{Bi}(0,09 \%)$; электротехническое машиностроение - Си $(7,2 \%)$; $2 \Pi(5,6 \%), \mathrm{Ni}(3,3 \%), \mathrm{Cd}(2,6 \%)$; машиностроение для легкой промышленности - Сг $(3,7 \%)$, РЬ $(2,2 \%)$; химическое и нефте- 
химическое машиностроение - Си $(4,6 \%), \operatorname{Cr}(3,8 \%), 5 п(3,3 \%)$ Ag $(0,0017 \%)$.

В среднем гальванические осадки содержат по сравнению с земной корой в тысячи раз больше $\mathrm{Cd}$, в сотни раз - Си, Сг, $\mathrm{Pb}$ в десятки раз - Ni и 2п (максимальные коэффициенты концентрации на один - два порядка выше).

Осадки, содержащие токсичные металлы и соединения, официально не подлежат вывозу на городские свалки. Вместе с тем полигонов для размещения таких отходов пока нет и поэтому предприятия, на которых образуются осадки, захоранивают их неорганизованно на территории предприятий и за городом, сбрасывают в канализацию, вывозят в смеси с другими отходами на городские свалки, что создает мощные зоны загрязнений различных природных систем.

В крупном промышленном городе ежегодно образуются десятки тысяч тонн осадка (в пересчете на сухое вещество) со средними содержаниями Си, 5п и $\mathrm{Cd}$, сопоставимыми с их содержаниями в природном сырье. Кроме того, осадки разных предприятий могут быть объединены таким образом, чтобы получить наиболее высокие концентрации интересующих металлов. Это позволяет считать гальванические осадки перспективным сырьем ценных металлов. Поиски экономически эффективных способов извлечения металлов из осадков ведутся в нашей стране и за рубежом.

Особенность предприятий химической промышленности - широкий круг вовлекаемого в переработку сырья, специфичность технологических процессов, многообразие номенклатуры выпускаемой продукции и изделий. Отходы в больших объемах накапливаются на предприятиях, связанных с обогащением и переработкой минерального сырья. К многотонным отходам относятся фосфогипс, пиритные огарки, галитовые отходы, железный купорос и др. В настоящее время налажена частичная утилизация только фосфогипса и пиритных огарков. Для предприятий, не производящих переработку горнохимического сырья, характерен относительно малый объем образования специфических отходов по отдельным процессам, что является серьезным препятствием для их утилизации.

Так, в шламе от получения химических реактивов содержится $\mathrm{Cd}$ в количестве 0,08\% (в 2300 раз выше кларка) и $\mathrm{Ag}$ в количестве большем, чем 0,01\% (более чем в 1400 раз); $\mathrm{As}, \mathrm{Pb}, \mathrm{C}$ п превышают кларковые значения в сотни раз, Си - в десятки. Хлорид натрия, который накапливается при изготовлении красителей, содержит (в \%): 0,01 Ag (в 1400 раз выше кларка), 3,6 Со (в 1300), $1,3 \%$ Си (в 300 раз), 2п и Ni (в десятки раз выше кларка). В отходах производства пластмасс накапливаются 2п, Си, As (в среднем в сотни раз выше кларка), Mo, $\mathrm{Ni}$, Сг (в десятки раз) и другие элементы. В отходах резины содержится более 0,1\% 2п (в десятки 94 
раз выше кларка), в несколько раз повышены содержания Cd и Си. Из перечисленных отходов только резина подвергается повторному использованию, остальные отходы поступают на свалки.

Разнообразные отходы текстиля, пластмасс, кожи, бумаги, шлама, и других материалов накапливаются на предприятиях легкой промышленности. Большая их часть используется. Частично утилизируются и отходы от обработки кожи, но в основном они вывозятся на свалки. Вместе с тем отходы, связанные с крашением, дублением и раскроем выделанных кож, содержат до $2-3 \%$ Сг. За рубежом такие отходы используют для извлечения хрома.

В типографиях наиболее объемным видом отходов является вывозимая на свалки бумажная пыль. При сравнительно низких концентрациях основных металлов она содержит в среднем 0,0015\% 5b ( К с 30), 0,05\% Zn ( К с 6), 0,008\% РЬ ( Кс 5). Осадки от обезвреживания стоков участков цинкографии и гальванических покрытий металлами литейных досок и литер при сравнительно небольшом объеме накопления характеризуются той же ассоциацией металлов, что и аналогичные осадки машиностроительных предприятий и очень богаты тяжелыми металлами - 5п (коэффициент концентрации $\left.\mathrm{K}_{\mathrm{c}} 800\right), \mathrm{Zn}\left(\mathrm{K}_{\mathrm{c}}\right.$ более 400), Си (K, более 200), $\mathrm{Ni}$ (Кс 200), Сг (Кс 120) и 5ь (Кс 400).

Производство строительных материалов связано с переработкой огромных объемов природных (известняк, глина, песок, гранит и др.) и искусственных (пластмассы и др.) материалов. Широко используются в отрасли отходы других промышленных предприятий - металлургический шлак, зола электростанций, пиритные огарки, древесные опилки, резина и др. Большая часть отходов предприятий, выпускающих строительные материалы (уловленная пыль, брак и бой изделий и др.), возвращается в производство, остальные отходы вывозят на свалки, используют при планировке территорий. Отходы, как правило, не концентрируют тяжелые металлы.

Накоплением громадных масс твердых отходов сопровождается работа теплоэлектростанций на твердом топливе - угле, горючем сланце, торфе. Основным топливом служит уголь, которого ежегодно сжигается около 5 млрд. т. Доля в топливном балансе других видов твердого топлива невелика (в нашей стране не более $0,5 \%$ ).

Зольность ископаемых углей $4-45 \%$, горючих сланцев до 50\%, торфа 6-10\%. Состав золы твердых топлив меняется в широких пределах (в \%): $\mathrm{SiO}_{2} 30-60, \mathrm{Al}_{2} \mathrm{O}_{3} 18-39, \mathrm{Fe}_{2} \mathrm{O}_{3} 5-21$, $\mathrm{CaO} 1-40, \mathrm{MgO} 0,6-7, \mathrm{~K}_{2} \mathrm{O} 0,2-3,8, \mathrm{Na}_{2} \mathrm{O} 0,02-2,3$. Кроме макроэлементов в золе присутствуют в меньших количествах многие химические элементы.

Зола ископаемых углей обогащена по сравнению с земной корой $\mathrm{B}, \mathrm{Mo}, \mathrm{A} 3, \mathrm{Ge}, \mathrm{Be}, \mathrm{Pb}, 2 \Pi, 5 \Pi, \mathrm{W}$ (табл. 17). Если в среднем 
для углей степень концентрации элементов невелика, то для углей отдельных бассейнов и месторождений она достигает для отдельных элементов нескольких раз, а для углей, добываемых некоторыми предприятиями - десятков раз. При этом углям разных бассейнов и регионов свойственны свои ассоциации элементов. Широкими ассоциациями накапливающихся элементов и наиболее высокими их концентрациями ( $\mathrm{K}_{\mathrm{c}}$ до 10) отличается зола углей Подмосковного (Be, B, Zn, $\mathrm{Zr}, \mathrm{Nb}, \mathrm{Mo}, \mathrm{Ag}, 5 п, \mathrm{~Pb})$, Львовско - Волынского ( $\mathrm{Li}, \mathrm{Be}, \mathrm{B}, \mathrm{V}, \mathrm{Co}, \mathrm{N} 1, \mathrm{C}$, Ge, Mo, Ag, 5п, РЬ) и Иркутского (Ll, Be, B, Ge, Mo, Sn, W, Рb) бассейнов. Более бедны микроэлементами угли Қанско - Ачинского (В, 2п, 5г) и Кузнецкого (В, 2г, Мо, РЬ) бассейнов. Горючие сланцы часто концентрируют Мо, V, Re, Си, а торф - Си, Мо.

Из минеральной части топлива образуются шлак и летучая зола. В зависимости от конструкции топки выход шлака колеблется от 10-20\% до 85-90\%; 94-98\% массы золы задерживается пылеулавливающими установками и направляется в отстойники и отвалы.

Т а б ли ц а 17 Среднее содержание химических элементов в золе углей, г/т

\begin{tabular}{|c|c|c|c|c|}
\hline \multirow{2}{*}{ Элемент } & \multirow{2}{*}{ Угли СССР } & \multicolumn{2}{|c|}{ Угли мира (по Я Э Юдовнч) } & \multirow{2}{*}{$\begin{array}{c}\text { Земная кора } \\
\text { (по А П Вино } \\
\text { градову) }\end{array}$} \\
\hline & & бурые & каменные & \\
\hline Литий & 32 & 80 & ПО & 32 \\
\hline Бериллий & 5 & 11 & 21 & 3,8 \\
\hline Бор & 190 & 560 & 680 & 12 \\
\hline Скандий & 6 & 15 & 20 & 10 \\
\hline Титан & 6600 & 2600 & 4600 & 4500 \\
\hline Ванадий & 120 & 120 & 180 & 90 \\
\hline Хром & 45 & 70 & 86 & 83 \\
\hline Марганец & 890 & 510 & 460 & 1000 \\
\hline Кобальт & 18 & 20 & 34 & 18 \\
\hline Никель & 36 & 51 & 90 & 58 \\
\hline Медь & 65 & 48 & 80 & 47 \\
\hline Цинк & 142 & 100 & 150 & 83 \\
\hline Галлий & 16 & 36 & 51 & 19 \\
\hline Германий & 4 & 9 & 20 & 1,4 \\
\hline Мышьяк & - & 60 & 90 & 1,8 \\
\hline Стронций & 410 & 1100 & 460 & 340 \\
\hline Иттрий & 33 & 37 & 47 & 29 \\
\hline Цирконий & 270 & 160 & 250 & 170 \\
\hline Ниобий & 15 & 5 & 12 & 20 \\
\hline Молибден & 7 & 13 & 25 & 1,1 \\
\hline Кадмий & - & 3 & 6.5 & 0,13 \\
\hline Серебро & 0,007 & - & - & 0,07 \\
\hline Олово & 4 & 4,1 & 7,5 & 2,5 \\
\hline Барий & 830 & 890 & 930 & 650 \\
\hline Лантан & 25 & - & - & 29 \\
\hline Иттербий & 3 & 5 & 7 & 0,33 \\
\hline Вольфрам & 2 & - & - & 1,3 \\
\hline Свинец & 36 & 53 & 170 & 16 \\
\hline
\end{tabular}


На электростанции, сжигающей 1 млн т угля со средней зольностью 20\%, ежегодно скапливается около 190 тыс. т золы и шлака. В целом по стране золошлаковые отходы энергетики оцениваются не менее, чем в 100 млн т. Около 1 млрд т шлака и золы уже находятся в отстойниках и отвалах. Они обогащены по сравнению с литосферой отдельными элементами обычно не более, чем в несколько раз.

Утилизация золошлаковых отходов в СССР не превышает $10 \%$ (используются в производстве строительных материалов). В США используется $20 \%$ отходов, в Великобритании - $60 \%$, в ФРГ - 72\%, в Финляндии - $84 \%$ [38].

Отходы, образующиеся в населенных пунктах в процессе коммунально-бытовой деятельности, сопоставимы по объему с промышленными отходами. Коммунально-бытовые отходы включают городской мусор (твердые бытовые отходы). осадки городских очистных сооружений и очистных сооружений поверхностного стока.

Количество твердых бытовых.отходов на душу населения составляет в городах нашей страны $0,15-0,3$ т/год и продолжает увеличиваться в связи с усилением процесса урбанизации и расширением производства товаров потребления

Морфологический состав твердых бытовых отходов (ТБО) сложен и меняется в зависимости от степени благоустройства жилищного фонда, сезона года, климатических и других условий. Химический состав непосредственно ТБО определить сложно, но представление о нем дает состав материалов, оставшихся от сжигания городского мусора на специализированных мусолисжигательных заводах.

Продукты сжигания городского мусора условно можно разделить на составные компоненты: лом черных металлов (выход $14,1 \%)$, лом цветных металлов $(0,7 \%)$ и золошлаковый материал - дробимая часть продуктов сжигания $(83,6 \%)$.

Лом черных металлов на $92,6 \%$ состоит из железа В ломе цветных металлов содержится в среднем (в \%): A1 -59,2, Си $23,4, \mathrm{Zn}-8,6, \mathrm{Pe}-2,3$. В золошлаковом дробимом материале концентрации всех металлов, кроме железа и алюминия, не превышают долей процента, но из-за того, что эта фракция имеет самый большой выход, именно в ней заключены основные количества большинства металлов. В целом продукты сжигания твердых бытовых отходов различных крупных городов имеют сходный микроэлементный состав (табл. 18), они обогащены по сравнению с литосферой $\mathrm{Bi}$ (в сотни - тысячи раз), $\mathrm{Ag}, 5 \Pi, \mathrm{Pb}, \mathrm{Cd}, 5 \mathrm{~b}$ (в десятки - сотни раз), Си, 2п (в десятки раз), $\mathrm{Cr}, \mathrm{Hg}$ (в несколько раз). В осевшей на электрофильтрах летучей золе содержание перечисленных химических элементов еще выше.

Около 98\% ТБО в нашей стране вывозится на свалки. Расчеты показывают, что с мусором города с миллионным населе- 
Т а блица 18 Содержание химических элементов в продуктах сжигания твердых бытовых отходов разных городов

\begin{tabular}{l|c|c|c|c}
\hline \multirow{2}{*}{ Элемент } & \multicolumn{2}{|c|}{ Продукты сжигания ТБО } & \multicolumn{2}{c}{ Летүчая зола } \\
\cline { 2 - 5 } & Содержание, \% & $\begin{array}{c}\text { Коэффициент } \\
\text { концентрации }\end{array}$ & Содержание, \% & $\begin{array}{c}\text { Коэффициент } \\
\text { концентрации }\end{array}$ \\
\hline Висмут & $0,0003-0,0013$ & $300-1300$ & 0,01 & 10000 \\
Серебро & $0,0006-0,0021$ & $86-300$ & $0,003-0,01$ & $430-1430$ \\
Олово & $0,02-0,18$ & $80-720$ & $0,22-0,3$ & $880-1200$ \\
Свинец & $0,155-0,186$ & $97-116$ & $0,45-1$ & $281-625$ \\
Кадмий & $0,0005-0,0012$ & $38-923$ & $0,005-0,01$ & $380-770$ \\
Сурьма & $0,003-0,009$ & $60-180$ & $0,01-0,02$ & $200-400$ \\
Медь & $0,15-0,4$ & $32-85$ & $0,07-0,3$ & $15-64$ \\
Цинк & $0,18-0,56$ & $22-68$ & $1-3$ & $120-360$ \\
Хром & $0,06-0,16$ & $7-20$ & $0,08-0,6$ & $10-200$ \\
Ртуть & $0,00004-0,00009$ & $5-10$ & - & -
\end{tabular}

Примечание Коэффициенты концентрации рассчитаны относительно содержания эле ментов в литосфере

нием на свалку ежегодно поступает $200-250$ т 2 п и Си, $70-80$ т 5п и РЬ 4 т 5b, 0,5-I т Ag и Cd, 0,02 т Hg.

В ряде городов налажена промышленная переработка части бытовых отходов - сжигание, компостирование. Обогащенные металлами продукты сжигания также поступают на свалку, а компост используют в сельском хозяйстве в качестве биотоплива и удобрения, что требует серьезных ограничений.

Осадки городских очистных сооружений накапливаются на станциях аэрации при очистке и обезвреживании хозяйственнобытовых и промышленных сточных вод.

Ежегодно в стране образуется 4-4,6 млн т осадка (в пересчете на сухое вешество), к 1990 г. количество их составит 6-6,6 млн т [37]. Около $10 \%$ осадков перерабатывается и используется как удобрение на сельскохозяйственных полях, остальная масса скапливается на территории станций аэрации или сгружается в отвалы.

Осадки представляют многокомпонентную смесь минеральных и органических веществ, содержание последних колеблется от 35 до 80\%. В зависимости от способа обработки они имеют влажность $50-97 \%$.

Осадки всех городов, как правило, в высокой степени обогащены тяжелыми металлами (табл. 19). Среди повсеместно накапливающихся химических элементов присутствуют токсичные $\mathrm{Hg}$, $C A, \mathrm{~Pb}$, Сг. Даже в городах, где имеется только легкая промышленность, осадки в десятки раз обогащены $\mathrm{Ag}, \mathrm{Hg}$, Си, иногда $\mathrm{Bi}, C A$. Широкие ассоциации элементов с высокими уровнями концентрации характерны для осадков городов, в которых имеются предприятия машиностроения и химической промышленности, причем ассоциации совпадают с перечнем используемых на производствах металлов: $\mathrm{Ag}, \mathrm{Hg}, C A$ (накопление в сотни раз), $\mathrm{Bi}, 5 \Pi, 2 \Pi$, Си, РЬ, Сг, W, Ni. (в десятки раз). 
Т а бли ц 19 Содержание химических элементов в осадках сточных вод городов с различными видами промышленности

\begin{tabular}{|c|c|c|c|c|c|c|}
\hline \multirow{2}{*}{ Элемент } & \multicolumn{2}{|c|}{$\begin{array}{c}\text { Машиностроение, химиче } \\
\text { ская и легкая промыш- } \\
\text { ленность }\end{array}$} & \multicolumn{2}{|c|}{$\begin{array}{c}\text { Машиностроение и } \\
\text { легкая } \\
\text { промышленность }\end{array}$} & \multicolumn{2}{|c|}{$\begin{array}{c}\text { Легкая } \\
\text { промышленность }\end{array}$} \\
\hline & $\underset{\text { С/т }}{\text { Содержание, }}$ & $\begin{array}{l}\text { Коэффициент } \\
\text { Концентрации }\end{array}$ & $\begin{array}{c}\text { Содержание, } \\
\text { г/T }\end{array}$ & $\begin{array}{c}\text { Коэффи- } \\
\text { циент } \\
\text { концент } \\
\text { рации }\end{array}$ & $\begin{array}{l}\text { Содержа } \\
\text { ние, г/т }\end{array}$ & $\begin{array}{c}\text { Коэф- } \\
\text { фициент } \\
\text { концент- } \\
\text { рации }\end{array}$ \\
\hline $\begin{array}{l}\text { Кадмий } \\
\text { Ртуть } \\
\text { Серебро } \\
\text { Медь } \\
\text { Цинк } \\
\text { Хром } \\
\text { Висмут } \\
\text { Олово } \\
\text { Никель } \\
\text { Стронций } \\
\text { Вольфрам } \\
\text { Свинец }\end{array}$ & $\begin{array}{l}44(97) \\
2,3(10) \\
13(30) \\
2610(6780) \\
3200(11670) \\
2635(11015) \\
17(30) \\
220(675) \\
625(2770) \\
360(780) \\
13(28) \\
218(900)\end{array}$ & $\begin{array}{l}520(750) \\
245(1110) \\
205(510) \\
85(250) \\
65(225) \\
60(240) \\
55(100) \\
40(130) \\
33(140) \\
13(30) \\
13(28) \\
8(35)\end{array}$ & $\begin{array}{l}3(10) \\
0,3(0,8) \\
9(14) \\
1265(2230) \\
835(1875) \\
320(645) \\
12(33) \\
210(470) \\
160(635) \\
165(390) \\
10(23)\end{array}$ & $\begin{array}{l}24(80) \\
30(90) \\
155(240) \\
45(80) \\
15(35) \\
7(14) \\
40(110) \\
40(90 \\
8(30) \\
6(15) \\
10(23)\end{array}$ & $\begin{array}{l}0,5(1,7) \\
0,2(0,3) \\
1,3(1,4) \\
240(375) \\
520(510) \\
0.9(3)\end{array}$ & $\begin{array}{c}4(13) \\
22(33) \\
22(24) \\
9(14) \\
10(29) \\
3(10)\end{array}$ \\
\hline
\end{tabular}

Примечание В скобках указаны максимальные значения параметров

Выработанный из таких осадков компост - крупный источник поступления тяжелых металлов в сельскохозяйственную почву.

Осадки очистных сооружений поверхностного стока образуются при очистке стока с городских территорий в виде дождевых, талых, поливомоечных вод, которые содержат в основном взвешенные, а также растворенные минеральные и органические вещества. Поступление поверхностного стока в водные объекты приводит к их заиливанию и загрязнению.

Накапливающиеся в различного типа очистных сооружениях в большом количестве донные осадки концентрируют широкий круг химических элементов (табл. 20). В первую очередь, это Cd и $\mathrm{Ag}$, средние концентрации которых превышают фоновые значения в 860 и 140 раз. В десятки раз выше фона накапливаются в осадках Си, Ni, Cr, Co, 2п, V, Pb, Mo, W, 5п, 5b. Причем максимальные концентрации обычно в $1,5-3$ раза выше средних.

Осадки из очистных сооружений используют для засыпки оврагов, пониженных частей пойм (часто в пределах города, где они могут представлять опасность для почв и воды из-за высоких содержаний токсичных химических элементов).

Выбросы. Пылегазовыевыбросы промышленных предприятий , энергетических установок и транспорта являются основными источниками поступления в атмосферу населенных пунктов загрязняющих веществ. Самые распространенные из них - оксиды азота, серы, углерода, углеводорода, твердые частицы. Наибольшее количество оксида углерода и углеводородов выделяется 
Т а бли ц а 20 Накопление химических элементов в осадках прудов-отстойников

\begin{tabular}{l|c|c|c|r}
\hline \multirow{2}{*}{$\begin{array}{c}\text { Химический } \\
\text { элемент }\end{array}$} & \multicolumn{2}{|c|}{ Содержание, \% } & \multicolumn{2}{c}{ Коэффициент концентрации } \\
\cline { 2 - 5 } & среднее & максимальное & средний & максимальный \\
\hline Кадмий & 87 & 200 & 860 & 2000 \\
Серебро & 14 & 30 & 140 & 300 \\
Медь & 3000 & 10500 & 80 & 300 \\
Никель & 585 & 1500 & 56 & 145 \\
Хром & 880 & 2000 & 40 & 66 \\
Кобальт & 147 & 500 & 39 & 125 \\
Цинк & 1750 & 2900 & 26 & 43 \\
Свинец & 370 & 450 & 22 & 75 \\
Молибден & 24 & 75 & 24 & 80 \\
Ванадий & 660 & 2100 & 23 & 30 \\
Олово & 55 & 90 & 19 & 35 \\
Сурьма & 16 & 35 & 16 & 19 \\
Вольфрам & 32 & 1300 & 6 & 10 \\
Стронций & 470 & 1300 & 5 & 3 \\
Барий & 820 & 2 & 4 & 3 \\
Висмут & 1 & 6000 & 2 & 2 \\
Титан & 4500 & 1700 & 2 & \\
Марганец & 550 & & & \\
\end{tabular}

Примечание Коэффициенты концентрации рассчитаны относительно донных отложений в фоновых водотоках

при эксплуатации автомобильного транспорта и от промышленных источников. Оксиды азота поступают в основном от энергоустановок и автотранспорта, а оксиды серы - от сжигания твердого и жидкого топлива. Твердые частицы имеются в выбросах всех названных источников, особенно много их в выбросах промышленных предприятий и энергетических установок. Кроме того, в атмосферу городов поступают и другие вредные вещества, количество их в настоящее время превышает 500.

Промышленные предприятия выбрасывают в воздух самые разнообразные загрязнения. Практически при всех видах промышленной деятельности происходят выделения пыли. Особенно много ее поступает в атмосферу от предприятий черной и цветной металлургии; машиностроительных заводов и заводов по выпуску строительных материалов. На предприятиях черной металлургии главными источниками пыли являются доменное (выбросы пыли 64-128 кг/т чугуна), агломерационное $(20-40$ г/м ) и в меньшей мере мартеновское $\left(0,3-0,5 \mathrm{r} / \mathrm{M}^{3}\right)$ производства. Пыль состоит из частичек железа, топлива, флюсов, присадок. При размоле угля, загрузке шихты в батареи и выгрузке кокса на коксохимических производствах выделяются угольная пыль и сажа.

В цветной металлургии источниками пыли служат печи различных типов, сушилки концентратов, дробнльно-помольное оборудование. Наибольшим уровнем запыленности отличаются криолитные и алюминиевые заводы. Пыль включает частицы топлива, металлической шихты, легирующих и металлургических присадок. 100 
На машиностроительных и металлообрабатывающих заводах массовое пылевыделение связано с работой литейных, кузнечнопрессовых, модельных и механических цехов. При работе вагранок выделяется $15-20$ кг пыли на 1 плавку, при работе электродуговых печей $-0,2-3,6$ кг/ч. Пыль состоит из оксидов Ре, Мп, в меньшей мере $\mathrm{Mg}$, A1, Р. Много пыли поступает в воздух от приготовления формовочной смеси, выбивки форм, галтовочных барабанов и другого оборудования. Литейный цех на 100 тыс. т литья при эффективности пылеулавливания 70-80\% выбрасывает в атмосферу до 1 тыс. т пыли в год.

Производство строительных материалов связано в большинстве случаев с измельчением и обжигом огромных масс природных и искусственных материалов. При этих процессах из агрегатов может выноситься до 25\%, а в атмосферу поступать (с учетом пылеулавливания) до $2 \%$ первоначальной массы материалов.

Изучение химического состава пыли дает исключительно важные данные для экологогеохимической оценки производства. В табл. 21 показаны ряды относительной концентрации химических элементов в пыли некоторых изученных авторами производств, типичных для крупных городов.

Т а бли ц а 21 Ассоциации химических элементов в пылях различных производств

\begin{tabular}{l|c|c|c|c}
\hline \multirow{2}{*}{ Процесс } & \multicolumn{4}{|c}{ Ряды относительной концентрации } \\
\cline { 2 - 5 } & $n \cdot 1000$ & $n \cdot 100$ & $n \cdot 10$ & $n \cdot 1$ \\
\hline
\end{tabular}

Переработка цветных металлов

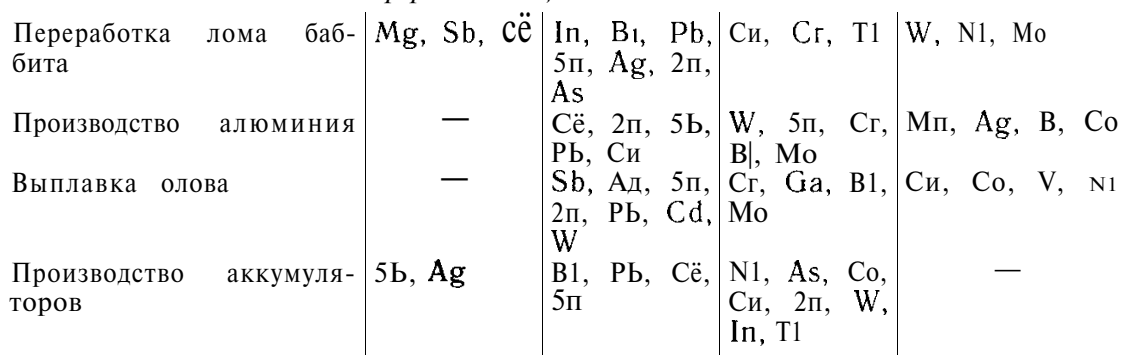
Машиностроение и металлообработка

\begin{tabular}{|c|c|c|c|c|}
\hline \multirow[b]{2}{*}{ Литье чугуна } & & & \\
\hline & - & 一 & $2 \pi$, W & $\begin{array}{l}\text { Мо, Sn, РЬ, Си, } \\
\text { Сг }\end{array}$ \\
\hline Литье стали & - & - & $5 \Pi, \mathrm{Sb}, \mathrm{N} 1$ & Мп, 2п, В, РЬ, \\
\hline Выбивка форм & 一 & W & & Мo, 2п, Со, РЬ \\
\hline $\begin{array}{l}\text { Очистка отливок в дробе } \\
\text { метных и пескоструйных } \\
\text { установках }\end{array}$ & - & W, Mo & Сг, N1, Си & V, Co \\
\hline $\begin{array}{l}\text { Кузнечно-прессовое про- } \\
\text { изводство }\end{array}$ & - & $\mathrm{Zn}$ & $\mathrm{W}, \mathrm{Mn}$ & $\begin{array}{l}\text { Mo, N1, 3п, Co, } \\
\text { Pb }\end{array}$ \\
\hline
\end{tabular}




\begin{tabular}{|c|c|c|c|c|}
\hline \multirow{2}{*}{ Процесс } & \multicolumn{4}{|c|}{ Ряды относительной концентрации } \\
\hline & $n \cdot 1000$ & $n \cdot 100$ & $n \cdot 10$ & $n \cdot 1$ \\
\hline $\begin{array}{l}\text { Механическая обработка } \\
\text { черных металлов } \\
\text { Механическая обработка } \\
\text { цветных металлов } \\
\text { Производство и заточка } \\
\text { инструмента } \\
\text { Сборка узлов машин }\end{array}$ & $\begin{array}{l}\text { Си, 2п, Рb } \\
\text { W }\end{array}$ & $\begin{array}{l}\text { ХV, Мо, Си } \\
\mathrm{Cr}, \mathrm{Ni} \\
\mathrm{Mo}, \mathrm{Co}, 5 \Pi, \\
\mathrm{Pb}, 5 \mathrm{~b}\end{array}$ & $\begin{array}{l}\mathrm{C}_{\Gamma}, \mathrm{N}_{1}, \mathrm{Co}, \\
2 \Pi \\
\mathrm{XV}, \mathrm{Sn} \\
\mathrm{Cг}, \mathrm{Cu}, \mathrm{N} 1, \\
\mathrm{~V}\end{array}$ & $\begin{array}{l}\mathrm{Mn}, \mathrm{V}, \mathrm{Pb}, \mathrm{Sn} \\
\mathrm{Co}, \mathrm{Mo}, \mathrm{V} \\
2 \Pi, \mathrm{Sc}\end{array}$ \\
\hline
\end{tabular}

Химические производства

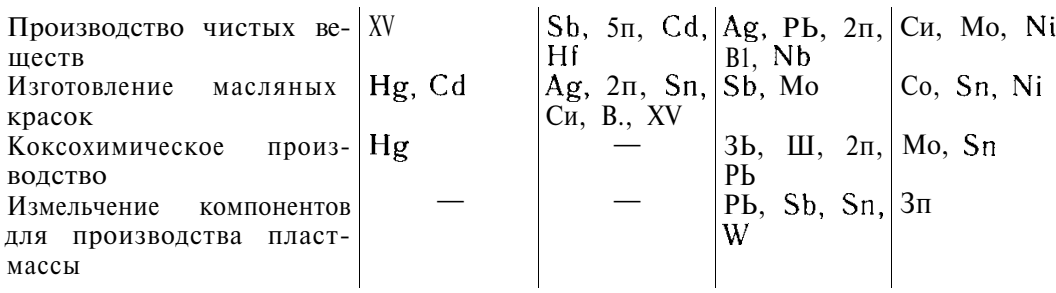

\begin{tabular}{|c|c|c|c|c|}
\hline & водс & строймс & цалов & \\
\hline Обжиг цементной шихты & & $\operatorname{Ag}$ & $\mathrm{Sb}, 2 \pi, \mathrm{Bi}$ & Sn, T1, Си, Мо, \\
\hline $\begin{array}{l}\text { Помол цементного клин- } \\
\text { кера }\end{array}$ & - & & $3 \mathrm{~b}$ & $\begin{array}{l}2 \pi, \text { Мо, Си, 5c, } \\
\text { Ва, Ag }\end{array}$ \\
\hline Производство керамзита & - & & $\begin{array}{l}\text { XV, Ag, B1, } \\
\text { Mo }\end{array}$ & $\begin{array}{l}\mathrm{Co}, 2 \text { 2П, Си, Li, } \\
\mathrm{Ni}, \mathrm{V}, \text { Сг }\end{array}$ \\
\hline $\begin{array}{l}\text { Производство перлитовых } \\
\text { плит } \\
\text { Производство } \\
\text { ного кирпича }\end{array}$ & - & $\begin{array}{l}\mathrm{XV}, 5 \mathrm{~b} \\
5 \mathrm{~b}, \mathrm{~Pb}\end{array}$ & $\begin{array}{l}\text { Mo, } \mathrm{Pb} \\
\mathrm{B} 1\end{array}$ & $\begin{array}{l}\mathrm{Sn}, \quad 5 г, \mathrm{~V}, \mathrm{Co}, \\
\mathrm{Ni}, 2 \Pi, \text { Си } \\
\text { V, Си, Сг, } \\
\mathrm{B}, \quad \text { (3a, } 2 п, \\
\text { Nb }\end{array}$ \\
\hline \multicolumn{5}{|c|}{ Энергетика } \\
\hline Сжигание угля на ТЭС & - & - & $\mathrm{B}, \mathrm{Pb}, \mathrm{Mo}$, & Be, Li, V, Ni, \\
\hline Сжигание мазута на ТЭС & - & $\mathrm{V}, \mathrm{N}_{1}$ & $\begin{array}{l}\mathrm{C}_{\Gamma}, 2 \Pi, \mathrm{Mo}, \\
\mathrm{XV}, \mathrm{Pb}\end{array}$ & Си, Аg, 5п \\
\hline
\end{tabular}

Пылевой выброс промышленных предприятий города характеризует исключительно широкая ассоциация химических элементов (в порядке убывания встречаемости): $\mathrm{Hg}, 5 \mathrm{~b}, 2 \Pi$, Си, $\mathrm{Pb}, 5 \Pi, \mathrm{W}, \mathrm{Mo}, \mathrm{Ni}, \mathrm{Ag}, \mathrm{Bi}, \mathrm{Co}, \mathrm{Cr}, \mathrm{V}, \mathrm{Cë.}$

Коэффициенты концентрации элементов варьируют очень широко: 5Ь - от 25 до 5000, W - от 10 до 10000, Си - от 3 до 370, РЬ - от 3 до 385, Ag - от 2 до 1000, Сг от 2 до 119 и др. В то же время в пыли одного производства химические элементы распределяются равномерно. Такое распределение химических элементов свидетельствует о специфичности пыли того или иного производства.

Высоким уровнем накопления металлов отличается пыль за102 
водов по переработке цветных металлов, по производству аккумуляторов. Она характеризуется весьма широким набором элементов, самые высокие концентрации (соответственно профилю производства) имеют Си, 5b, W (в тысячи раз выше кларковых значений), Рb, Bi, 5п, 2п, $\mathrm{Ag}, \mathrm{As}, \mathrm{Cd}$ (выше в сотни и десятки раз).

В литейных цехах машиностроительных предприятий отходящая от плавильных печей пыль в десятки раз обогащена 2п, W, 5b, Ni, 5п. Для пыли, которая образуется при различњых видах обработки черных металлов, характерно накопление (в десятки и сотни раз) W, Mo, Сг, Ni, Си. Причем наиболее широкий круг накапливающихся металлов имеет пыль предприятий электротехнического машиностроения, в котором широко применяются различные сплавы и легированные стали: W (Kс 13000), Сг (Kc 880), Mo (Kc 270), 2п ( $\left.K_{c} 37\right), \mathrm{Ni}\left(\mathrm{K}_{\mathrm{c}} 17\right)$. В пылях автомобилестроительного завода концентрируются Си (Кс более 200), $\mathrm{Ni}$ (Kс 50), Сг (Кс 37). Для пыли тех производств, где производится сварка, типичен $\mathrm{Mn}$. Особенно высоким уровнем накопления W (в тысячу раз), Мо, Сo, РЬ, 5П, 5Ь (в сотни раз) отмечается пыль от изготовления и заточки инструмента. Ассоциация накапливающихся металлов в пыли от обработки цветных металлов включает Си, 2п, Рb, Ag (накопление в тысячи раз), $\mathrm{Ni}, 5 \Pi, \mathrm{XV}, \mathrm{Cd}, 5 \mathrm{~b}, \mathrm{As}$ (в десятки - сотни раз). В пыли горелой земли уровень накопления тяжелых металлов не превышает 10-кратного.

Пыль химических производств, также как и отходы, отличается разнообразием накапливающихся химических элементов и высокими их концентрациями; многие элементы (Ш, Bi, Nb и др.) редко встречаются в других промышленных отходах. Так, пыль от производств по получению чистых веществ обогащена W (в тысячу раз), 5b, 5п, Cd, Ш (в сотни раз). В пыли от изготовления масляных красок накапливаются $\mathrm{Hg}, \mathrm{Cd}$ (в тысячу раз), Ag, 2п, 5п, Си, Bi, W (в сотни раз).

Для предприятий по производству строительных материалов характерно накопление Sb, Pb, W, Bi, Mo, Ag (в десятки сотни раз); в пыли, отходящей от обжигового оборудования, в выбросах присутствует Р. В пыли, образующейся при других технологических процессах, уровень концентрации химических элементов не превышает 10-кратного.

Значительно загрязняют атмосферу населенных пунктов теплоэнергетические установки, особенно в поставке пыли, оксидов серы и азота. Количество выбросов оксидов азота зависит от типа сжигающего оборудования и режима процесса горения и может составлять близкую величину для разных видов топлива - угля, мазута, газа. Оксиды серы (в основном, сернистый ангидрид) образуются при сгорании угля и мазута, количество их определяется содержанием серы в топливе. Поступление сер- 
нистого ангидрида от предприятий энергетики составляет большую часть общего его поступления в атмосферу. Выброс твердых частиц также зависит от вида и качества топлива. Наибольший выброс пыли дают установки, работающие на угле. Например, электростанция, сжигающая ежегодно 1 млн т угля с зольностью $20 \%$ даже при эффективности пылеулавливающего оборудования 94-98\% выбрасывает в атмосферу 4-12 тыс. т мелких частиц пыли.

Некоторые химические элементы находятся в зольной части угля в количествах, превосходящих в несколько раз кларковые концентрации. Кроме того, твердые частицы золы, из которых состоит прошедшая через очистные установки пыль, обогащаются некоторыми (в основном легко летучими) элементами. Дифференциация элементов не имеет четкой выраженности, хотя на ряде ТЭС наблюдается обогащение в несколько раз твердых частиц (отобранных из газового потока за электрофильтрами) $\mathrm{Ni}, \mathrm{Cи}, \mathrm{As}, \mathrm{Ag}$, Ge, Pb, Cr, Ga. По данным отечественных и зарубежных исследователей [29], в летучей золе могут накапливаться Mo, Zn, Co, Cd, 5e, 5b, А3, Ag, причем четыре последних элемента и $\mathrm{F}$ выбрасываются в воздух в значительной мере в парообразном состоянии.

При сгорании мазута образуется на два порядка меньше твердых частиц, чем при сжигании угля. В мазутной золе содержится 6-12\% V, 3-4\% Ni, а концентрации остальных элементов аналогичны содержаниям в угольной золе. Твердые частицы выбросов на отечественных мазутных электростанциях не улавливаются.

Сжигание природного газа дает в 10 раз меньше твердых частиц, чем сжигание мазута.

Загрязнение атмосферы пылью происходит и при сжигании твердых бытовых отходов открытым способом или на мусоросжигающих заводах. Как отмечалось, тонкая фракция продуктов сжигания мусора - летучая зола - отличается весьма высокими концентрациями Ві (в 10000 раз выше кларкового значения), $\mathrm{Ag}, 5 \Pi, \mathrm{Pb}, \mathrm{Cd}, 5 \mathrm{~b}, 2 \Pi$ (в сотни раз выше), причем металлы частично находятся в подвижной форме и могут легко вымываться из золы.

Одним из главных источников загрязнения атмосферного воздуха урбанизированных территорий является транспорт. Так, по данным Аксенова (1986) в США в 1980 г. на долю транспорта приходилось более 55\% общей массы загрязняющих воздушного бассейна веществ, т. е. больше, чем на остальные виды деятельности человека. В Нью-Йорке, Лос-Анджелесе, Токио, Тегеране вклад выхлопных газов в загрязнение воздуха достигает 90\%. В нашей стране на транспорт приходится примерно $25 \%$ всех загрязняющих атмосферу веществ, в том числе $50 \%$ оксида углерода. 
Из всех видов транспорта в наибольшей мере загрязняет окружающую среду в городах автомобильный, роль других видов - железнодорожного, водного, воздушного - значительно меньше.

В настоящее время в мире насчитывается более 400 млн автомобилей, в том числе $83-85 \%$ легковых, работающих на бензине, и 15-17\% грузовых и автобусов, потребляющих как бензин, так и дизельное топливо; сравнительно небольшое количество грузового транспорта работает на газовом топливе.

Большинство сортов бензина содержат в качестве антидетонационной присадки тетраэтилсвинец $(0,41-0,82$ г/л), а в дизельное топливо для уменьшения в составе отработавших газов сажи вводят металлоорганические соединения на основе $\mathrm{Pb}, \mathrm{Cи}$, $\mathrm{Ni}, \mathrm{Cr}(0,02-0,25 \%)$.

- Отечественные легковые автомобили расходуют около 10 л топлива на 100 км пробега, грузовые автомобили и автобусы 20-50 л. Среднегодовой пробег автомобилей составляет около 15 тыс. км, за это время он потребляет от 1,5 до 7,5 т топлива.

Выхлопные газы транспортных двигателей - чрезвычайно сложная смесь компонентов, в них обнаружено более 200 химических соединений и элементов, из которых наиболее вредными являются оксид углерода $(0,5-10 \%$ объемов выбросов), оксид азота (до $0,8 \%)$, несгоревшие углеводороды $(0,2-3 \%)$. Наибольшее количество загрязняющих веществ дают бензиновые карбюраторные двигатели - особенно оксид углерода, углеводороды, оксиды азота, свинца; в выхлопах дизельных двигателей больше сернистых соединений, сажи, присутствует бензапирен. Свинец (в виде кислородосодержащих соединений, карбонатов, фосфатов и др.) поступает в воздух при работе транспорта на этилированном бензине. При сжигании 1 л бензина в воздух попадает 200-400 мг свинца, в течение года один автомобиль выбрасывает в среднем около 1 кг этого металла. Несмотря на проводимые в стране и за рубежом разработки по обезвреживанию отработавших газов загрязнение воздушного бассейна транспортными выбросами остается значительным.

Загрязняет атмосферный воздух также пыль, которая поднимается с проезжей части магистралей при работе городского транспорта. Она обогащена не только свинцом, но и цинком, кадмием за счет истирания шин.

Стоки. Большое количество тяжелых металлов попадает в окружающую среду в виде стоков от коммунально-бытовой и производственной деятельности. Стоки поступают или непосредственно в водотоки (условно чистые промышленные стоки) или после различных видов очистки (загрязненные промышленные, коммунально-бытовые стоки, поверхностный сток с урбанизированных территорий).

Очистка коммунально-бытовых и загрязненных промышлен- 
Т а блин а 22 Химические элементы в сточных водах некоторых производств. По данным Р. Кейна

\begin{tabular}{|c|c|c|c|c|c|}
\hline \multirow{2}{*}{ Виды деятельности } & \multicolumn{5}{|c|}{ Средняя концентрация в стоках, мкг/л } \\
\hline & Медь & Хром & Никель & Цинк & Кадмий \\
\hline Мясная промышленность & 150 & 150 & 70 & 460 & 11 \\
\hline Производство жира & 220 & 210 & 280 & 3890 & 6 \\
\hline Рыбная промышленность & 240 & 230 & 140 & 1590 & 14 \\
\hline Производство хлеба & 150 & 330 & 430 & 280 & 2 \\
\hline Производство пива & 410 & 60 & 40 & 470 & 5 \\
\hline Производство безалкогольных & 2040 & 180 & 220 & 2990 & 3 \\
\hline напитков & & & & & \\
\hline Производство мороженого & 2700 & 50 & ПО & 7800 & 31 \\
\hline Окрашивание текстиля & 37 & 820 & 250 & 500 & 30 \\
\hline Выделка и окраска пушнины & 7040 & 20140 & 740 & 1730 & 115 \\
\hline Прачечные & 1700 & 1220 & 100 & 1750 & 134 \\
\hline Автомобильные мойки & 180 & 140 & 190 & 920 & 18 \\
\hline $\begin{array}{l}\text { Среднее содержание в водах } \\
\text { зоны гипергенеза }\end{array}$ & 5,58 & 2,9 & 3,31 & 34 & 0,33 \\
\hline
\end{tabular}

ных (часто прошедших перед этим локальную очистку) вод производится на городских очистных сооружениях. Расход воды на коммунально-бытовые нужды составляет в городах 115 125 л/сутки на 1 человека, а с учетом промышленных нужд, расход на 1 человека достигает 700 л/сут. С промышленными стоками в канализационную систему попадают разнообразные загрязняющие вещества, из которых наиболее распространены нефтепродукты, фенолы, пестициды, сложные химические соединения, минеральные и органические взвеси, тяжелые металлы. Широкие комплексы тяжелых металлов и высокие их соединения в сточных водах характерны для многих видов промышленности, причем не только тех, где эти элементы используются в технологическом цикле, но и многих других, в том числе производящих продукты питания и предметы первой необходимости

Т а б л и ц а 23. Химические элементы в различных видах стоков

\begin{tabular}{l|c|c|c|}
\hline \multirow{2}{*}{ Место сброса стоков } & \multicolumn{3}{|c}{ Содержание } \\
\cline { 2 - 4 } & Фтор & Хром & Медь \\
\hline
\end{tabular}

Городская канализация

$0,2-38,0$

$1,0-125,0$
$(100-12500)$

Гальванические

Городская канализация

Поверхностные водотоки

$$
\begin{aligned}
& 0,4-50,2 \\
& (50-6250)
\end{aligned}
$$

Различные

$0,01-15,0$

$(1-1875)$

$(0,01-0,2)$

$(1-25)$

$$
\begin{aligned}
& 0,5-10,4 \\
& (1-21) \\
& 0,2-5,5 \\
& (0,5-11)
\end{aligned}
$$

$0,01-0,5$

$(1-50)$

0,01

(1)

Примечание Коэффициенты концентрации (указаны в скобках) рассчитаны по отношению 106 
(табл. 22). Особенно высокие содержания металлов отличают стоки предприятий, имеющих гальванические производства. Здесь встречаются концентрации $\mathrm{Cr}, \mathrm{Cd}, \mathrm{Cn}, \mathrm{Zn}-$ в сотни и тысячи раз, а $\mathrm{Pb}$ - в десятки раз выше фоновых (табл. 23). Таким образом, промышленным стокам принадлежит ведущая роль в поставке тяжелых металлов в канализационную систему. По данным Савранской (1976), в праздничные дни на станции аэрации поступает в несколько раз меньше Ре, Сг (в 9 раз), Си (в 7), 2п, Ni (в 5), РЬ (в 3), чем в будние дни.

Городские очистные сооружения не дают $100 \%$ удаления металлов из стоков, часть их $(4-5 \%)$ проходит в водоемы. Учитывая большой объем канализационных стоков, принос с ними металлов в окружающую среду представляется значительным.

Условно чистые стоки промышленных предприятий, сбрасываемые непосредственно в водотоки городов, сравнительно чисты, хотя максимальные содержания в них Си, $\mathrm{Cd}, 5$, $\mathrm{F}$ могут превышать фоновые концентрации в десятки раз (см. табл. 23).

Другим крупным источником приноса металлов в водоемы является поверхностный сток с урбанизированной территории, загрязненной за счет смыва части почвы, твердофазных выпадений из атмосферы, размыва свалок и т. д. Даже после отстойников, в которых оседает основная масса взвешенных частиц, содержание металлов в стоке продолжает оставаться значительным (табл. 24), особенно Си (в 69 раз выше фона), $\mathrm{Ni}$ (в 16 раз), Сг (в 12 раз), 5г и $\mathrm{Hg}$ (в 9 раз).

Тяжелые металлы попадают в водотоки и со сбрасываемым при уборке городских территорий снегом. За счет атмосферных выпадений снег загрязняется тяжелыми металлами, а разбрасывание на дорогах соли приводит к накоплению в нем хлоридов. В талой снеговой воде крупного промышленного города содержалось хлор-иона в 150 раз больше, чем в воде фонового водо-

элементов, мг/л

\begin{tabular}{c|c|c|c|c}
\hline Цинк & Мышьяк & Стронций & Кадмий & Свинец \\
\hline
\end{tabular}

производства

$1,0-23,6$

$(20-472)$

$$
\begin{aligned}
& 0,002-0,030 \\
& (1-10)
\end{aligned}
$$

$0,05-0,5$
$(1-10)$

$\mid \begin{aligned} & 0,0-10,0 \\ & (\text { до } 10000)\end{aligned}$

$0,0-0,3$

(до 37)

производства

\begin{tabular}{l|l}
$0,05-4$ & $0,00-0,025$ \\
$(1-80)$ & $(1-8)$ \\
$0,05-0,2$ & 0,003 \\
$(1-4)$ & $(1)$
\end{tabular}

к фону в поверхностных водах

$$
\begin{aligned}
& 0,05-2 \\
& (1-40) \\
& 0,05-1,0 \\
& (1-20)
\end{aligned}
$$

$0,0-10,0$

(до 1250)

0,005

(до 1) 
Т а бл и а 24 Содержание химических элементов в воде на выходе из очистных сооружений поверхностного стока в устьевой части водотока, дренирующего промышленно-селитебную зону

\begin{tabular}{|c|c|c|c|c|}
\hline \multirow{2}{*}{ Элемент } & \multicolumn{3}{|c|}{ Содержание, мг/л } & \multirow{2}{*}{$\begin{array}{l}\text { Коэффициент } \\
\text { концентрации }\end{array}$} \\
\hline & $\begin{array}{c}\text { Растворенное } \\
\text { вещество }\end{array}$ & $\begin{array}{c}\text { Взвешенное } \\
\text { вещество }\end{array}$ & Всего & \\
\hline Медь & 0,2 & 0,288 & 0,488 & 69 \\
\hline Никель & 0,02 & 0,013 & 0,033 & 16 \\
\hline Хром & 0,02 & 0,029 & 0,049 & 12 \\
\hline Стронций & 0,8 & 0,06 & 0,86 & 9 \\
\hline Ртуть & 0,0015 & 0,0005 & 0,0020 & 9 \\
\hline Марганец & 0,2 & 0,076 & 0,276 & 5 \\
\hline Цинк & 0,03 & 0,054 & 0,084 & 3 \\
\hline Свинец & 0,01 & 0,017 & 0,027 & 3 \\
\hline Молибден & 0,006 & 0,0008 & 0,0068 & 1,5 \\
\hline Кадмий & 0,007 & 0,0001 & 0,0071 & 1,5 \\
\hline
\end{tabular}

Примечание Коэффициенты концентрации рассчитаны по отношению к фону в поверхностных водах

тока, а кобальта, стронция, меди - в несколько раз. Количество твердого материала, накопленного в снеге, колебалось от 4,7 до 24,5 г/кг снежной массы. В твердом осадке снега содержалось $\mathrm{Ag}, 2$ 2п и $\mathrm{Pb}$ в десятки раз, а 5п, $\mathrm{V}, \mathrm{Cи}, \mathrm{Cr}, \mathrm{Mn}-$ в несколько раз больше, чем в донных осадках на фоновых участках водотока (табл. 25). Максимальные содержания 2п, РЬ, Сг, $\mathrm{Ni}$ и 5г обнаружены в снеге, вывезенном из промышленных зон и с магистралей с интенсивным автомобильным движением.

Т а б и ц а 25 Содержание химических элементов в твердом осадке снега, сбрасываемого в реки

\begin{tabular}{l|c|c|c|c}
\hline \multirow{2}{*}{ Элемент } & \multicolumn{2}{|c|}{ Содержание, г/т } & \multicolumn{2}{c}{ Коэффициент концентрации } \\
\cline { 2 - 5 } & от-до & среднее & средний & максимальный \\
\hline Серебро & $0,05-20$ & 0,8 & 32 & 800 \\
Цинк & $100-3000$ & 700 & 18 & 75 \\
Свинец & $25-500$ & 140 & 13 & 46 \\
Олово & $2-60$ & 10 & 3 & 10 \\
Ванадий & $10-200$ & 66 & 3 & 9 \\
Хром & $5-200$ & 70 & 3 & 9 \\
Марганец & $200-4000$ & 1290 & 3 & 4 \\
Медь & $30-600$ & 132 & 2,2 & 3 \\
Никель & $10-100$ & 37 & 1,4 & 3 \\
Кобальт & $2-20$ & 7 & 1,1 & 2,7 \\
Стронций & $15-1500$ & & 0,9 & 3 \\
Молибден & $0,5-4$ & 1,2 & 0,8 & 0,15 \\
Титан & $500-5000$ & 1780 & 73 & 0,15 \\
Стронций & $15-1500$ & 73 &
\end{tabular}

Примечание Коэффициенты концентрации рассчитаны относительно донных осадков на фоновых участках водотоков 


\section{Общая оценка важнейших источников антропогенного геохимического загрязнения окружающей среды}

Общий анализ данных по составу и концентрации химических элементов в выбросах, стоках и твердых отходах показывает, что практически все виды деятельности формируют отходы, содержащие широкий и разнообразный комплекс химических элементов - источников загрязнения окружающей среды.

Для оценки эколого-геохимического значения того или иного источника загрязнения необходим более точный учет массы химических элементов, поставляемой им в окружающую среду. Такой учет возможен только по результатам анализа итогов воздействия источников загрязнения - геохимических аномалий в окружающей среде.

Геохимическая оценка нагрузки на окружающую среду, формируемой источниками загрязнения урбанизированных зон (выбросами, стоками, твердыми отходами). Фактическая нагрузка на среду определяется объемами отходов, а также количественными и пространственными соотношениями различных видов деятельности, концентрирующихся на определенной территории Прямой учет такой нагрузки пока не удается. Ниже мы попытаемся оценить ее с помощью косвенных методов на примере материалов геохимических исследований ряда урбанизированных территорий.

Для обобщения оценки выброса использованы материалы по концентрации, распределению и химическому составу атмосферной пыли, осажденной на снеговой покров.

Оценка стоков произведена раздельно для основных групп источников загрязнения вод: 1) поступление в водотоки и водоемы условно чистых стоков промышленных предприятий; 2) поступление ливневых вод, загрязненных при их контакте со зданиями и сооружениями, стихийными свалками отходов и сырья, почвами, концентрирующими промышленные выбросы; 3) поступление канализационных стоков после городских очистных сооружений.

Среди твердых отходов наиболее объемные виды, концентрирующие химические элементы: бытовые отходы, золы и шлаки, шламы очистных сооружений, пыли.

Bсе категории иеточников химических элементов синхронно изучены для одних и тех же урбанизированных территорий и хорошо сопоставимы.

Таким образом, полученные оценки определяют общий порядок геохимической нагрузки на окружающую среду, формируемой в урбанизированных зонах, и соотношения отдельных химических элементов в этой нагрузке.

Для удобства сопоставлений все оценки выражены в трех формах: 1) массе химического элемента, поступающей на единицу площади за единицу времени; 2) массе химического эле- 
Т а 6 ли и а 26. Распределение содержаний

нагрузок химических элементов в твердофазных выпадениях из атмосферы

\begin{tabular}{|c|c|c|c|c|c|}
\hline \multirow{2}{*}{ Элемент } & \multirow{2}{*}{$\begin{array}{c}\text { Среднее } \\
\text { содержание, } \\
\text { мг/кг }\end{array}$} & \multirow{2}{*}{$\begin{array}{l}\text { Коэффициент } \\
\text { концентрации }\end{array}$} & \multicolumn{2}{|c|}{ Среднесуточная нагру зка } & \multirow{2}{*}{$\begin{array}{c}\text { Превышение } \\
\text { нагрузки } \\
\text { над фоновой }\end{array}$} \\
\hline & & & на $1 \mathbf{~ к м}^{2}$, I & на 1 чел, мгк & \\
\hline Бериллий & 2,3 & 1,2 & 0,874 & 98,3 & 44,7 \\
\hline Бор & 29,3 & 0,6 & 11,324 & 1274,0 & 21,8 \\
\hline Литий & 33,8 & 1,7 & 12,844 & 1445,1 & 65,7 \\
\hline Титан & 3800,0 & 0,6 & 1440,0 & 162450,0 & 24,6 \\
\hline Ванадий & 151,0 & 2,0 & 57,330 & 6455,3 & 76,2 \\
\hline Хром & 173,0 & 2,0 & 65,740 & 7395,6 & 80 \\
\hline Марганец & 1170,0 & 1,4 & 444,6 & 50017,5 & 36 \\
\hline Кобальт & 19,1 & 1,9 & 7,258 & 816,5 & 74 \\
\hline Никель & 132,6 & 4,0 & 50,388 & 5668,6 & 156 \\
\hline Медь & 155,0 & 5,2 & 58,900 & 6626,2 & 274 \\
\hline Цинк & 500,0 & 6,8 & 190,0 & 21375,0 & 374 \\
\hline Стронций & 83,1 & 0,6 & 31,578 & 3552,5 & 25 \\
\hline Иттрий & 27,5 & 0,7 & 10,450 & 1175,6 & 27 \\
\hline Цирконий & 329,0 & 0,6 & 125,020 & 14064,7 & 23,7 \\
\hline Ниобий & 19,2 & 1,0 & 7,296 & 820,8 & 34 \\
\hline Молибден & 4,7 & 4,7 & 1,786 & 200,9 & 183 \\
\hline Серебро & 0,31 & 0,6 & 1,178 & 13,2 & 22 \\
\hline Кадмий & 2,52 & 19,4 & 0,957 & 107,7 & 769 \\
\hline Олово & 10,4 & 2,7 & 3,952 & 444,6 & 104 \\
\hline Сурьма & 15,4 & 14,0 & 58,520 & 658,3 & 548,3 \\
\hline Барий & 350,0 & 0,8 & 133,0 & 14952,3 & 31,6 \\
\hline Лантан & 15,7 & 0,4 & 5,966 & 671,2 & 15,9 \\
\hline Иттербий & 2,7 & 0,7 & 1,026 & 115,4 & 26,1 \\
\hline Вольфрам & 22,8 & 22,8 & 8,664 & 974,7 & 886 \\
\hline Свинец & 129,0 & 8,1 & 49,020 & 5514,8 & 313,3 \\
\hline Висмут & 0,55 & 1,8 & 0,209 & 23,5 & 71,2 \\
\hline Ртуть & 1,2 & 12,0 & 0,456 & 51,3 & 466,4 \\
\hline
\end{tabular}

Примечание. Коэффициенты концентрации рассчитаны огноснтельно фоновых содержаний

мента, приходящейся на одного человека в этот же период; 3) коэффициенте относительного увеличения нагрузки в урбанизированной зоне по сравнению с показателем фоновой нагрузки.

В качестве фоновых величин приняты:

для атмосферной пыли - масса выпадающей пыли на удалении 90-100 км от урбанизированных зон при концентрации химических элементов, равной средним содержаниям в наиболее богатых микроэлементами почвах - черноземных и сероземных (предполагается, что в условиях фоновой нагрузки состав атмосферной пыли в основном формируется за счет почвенных частиц) ;

для поверхностного стока - существующий объем вод при содержаниях химических элементов, аналогичных содержаниям в поверхностных водах на участках той же территории, не испытывающих антропогенного воздействия; 
для твердых отходов - кларковые запасы химических элементов в объеме исследованного отхода (очень условная величина, так как фактически такого продукта в природе не существует).

В табл. 26 сведены данные по распределению рассматриваемых химических элементов в твердофазных выпадениях на урбанизированной территории.

Анализ средних содержаний химических элементов в атмосферной взвеси позволяет разделить их на три группы (в порядке уменьшения показателя концентрации, приводимого в скобках):

элементы, накапливающиеся по сравнению с фоном,- W (23), Cd (19), 5b (14), Hg (12), Pb (8), Zn (7), Mo (5), Ni (4), $5 п$ (3), $\mathrm{Cr}$ (2), V (2), Bi (2), Со (2), 1л (2);

элементы с содержаниями, близкими к фоновым,- Be, $\mathrm{Mn}$, $\mathrm{Nb}, \mathrm{V}, \mathrm{Yb}$;

элементы, содержание которых ниже фонового,- $\mathrm{Ag}(0,6)$, 5г $(0,6), \mathrm{B}(0,6), \mathrm{Zn}(0,6), \mathrm{Ti}(0,6)$, La $(0,4)$.

Состав химических элементов в перечисленных выше трех группах весьма закономерен.

Накапливаются преимущественно халькофилы и элементы группы железа. Все химические элементы, перечисленные в группе накапливающихся, активно используются в промышленном производстве и типичны для промышленных пылей и твердых отходов.

Напротив, химические элементы, содержащиеся в атмосферных взвесях на уровне фоновых или более низких концентраций, являются почти исключительно литофильными. Они слабо используются в промышленности и не накапливаются ни в промышленных пылях и твердых отходах, ни в выбросах электростанций.

Накапливающиеся элементы резко варьируют по величине коэффициентов концентраций (K от 2 до 23), тогда как элементы с пониженным содержанием очень близки по этому показателю ( $K=0,6$ или в 1,7 раза ниже фонового). Это свидетельствует о том, что большая часть пылевой нагрузки на территории урбанизированных территорий формируется однородным материалом, отличающимся равномерным составом с пониженным относительно почвенной пыли содержанием B, Ti, Zn, La и близкими к ней содержаниями $\mathrm{V}, \mathrm{Yb}, \mathrm{Be}, \mathrm{Nb}$.

Указанные соотношения показывают, что минеральной основой-матрицей являются выбросы электростанций и строительные пыли, формирующие большую часть общего количества выпадения из атмосферы на территорию (около 70\%).

Вклад особенно промышленных твердых выбросов в общее количество выпадений из атмосферы значительно меньше (около $30 \%)$, и наблюдаемое распределение средних содержаний хими- 




Рис. 24. Оценка относительной интенсивности поступления химических элементов с выпадениями из атмосферы в крупном городе:

1 - нагрузка, формируемая за счет выпадения пыли с аномальным содержанием химических элементов, 2- нагрузка, формируемая за счет выпадения пыли с фоновыми содержаниями химических элементов, К-коэффициент интенсивности нагрузки

ческих элементов может быть объяснено рассеянием в атмосфере сравнительно небольших масс пыли от разнооб.разных источников, резко варьирующей по составу и с очень высокими содержаниями химических элементов.

В табл. 26 и на рис. 24 для крупной урбанизированной территории приведены оценки поставки химических элементов в окружающую среду за счет выпадения взвешенного в атмосфере материала. Иными словами эти оценки определяют нагрузку на окружающую среду, создаваемую в результате загрязнения атмосферы.

В условиях урбанизированных зон все химические элементы отличает повышенная по сравнению с фоном нагрузка на окружающую среду и, соответственно, на живые организмы.

Это касается даже тех элементов, содержание которых в атмосферной пыли близко к фоновому или ниже его. Повышенные нагрузки с коэффициентами относительного накопления до 38 (в среднем) формируются в данном случае за счет увеличения общего количества выпадающей пыли.

Для элементов же с высокими средними (и тем более экстремальными) содержаниями относительное увеличение нагрузки в урбанизированных зонах очень велико: W - в среднем около 900, $\mathrm{Hg}$ - около 500, Рb и Си - около 300, $\mathrm{Cr}$ и $\mathrm{V}-$ около 100.

В табл. 27 приведены материалы по оценке поставки химических элементов в воды с растворенным и взвешенным стоком 
Таблица 27 Оценка среднегодового поступления химических элементов в воды источниками различного типа

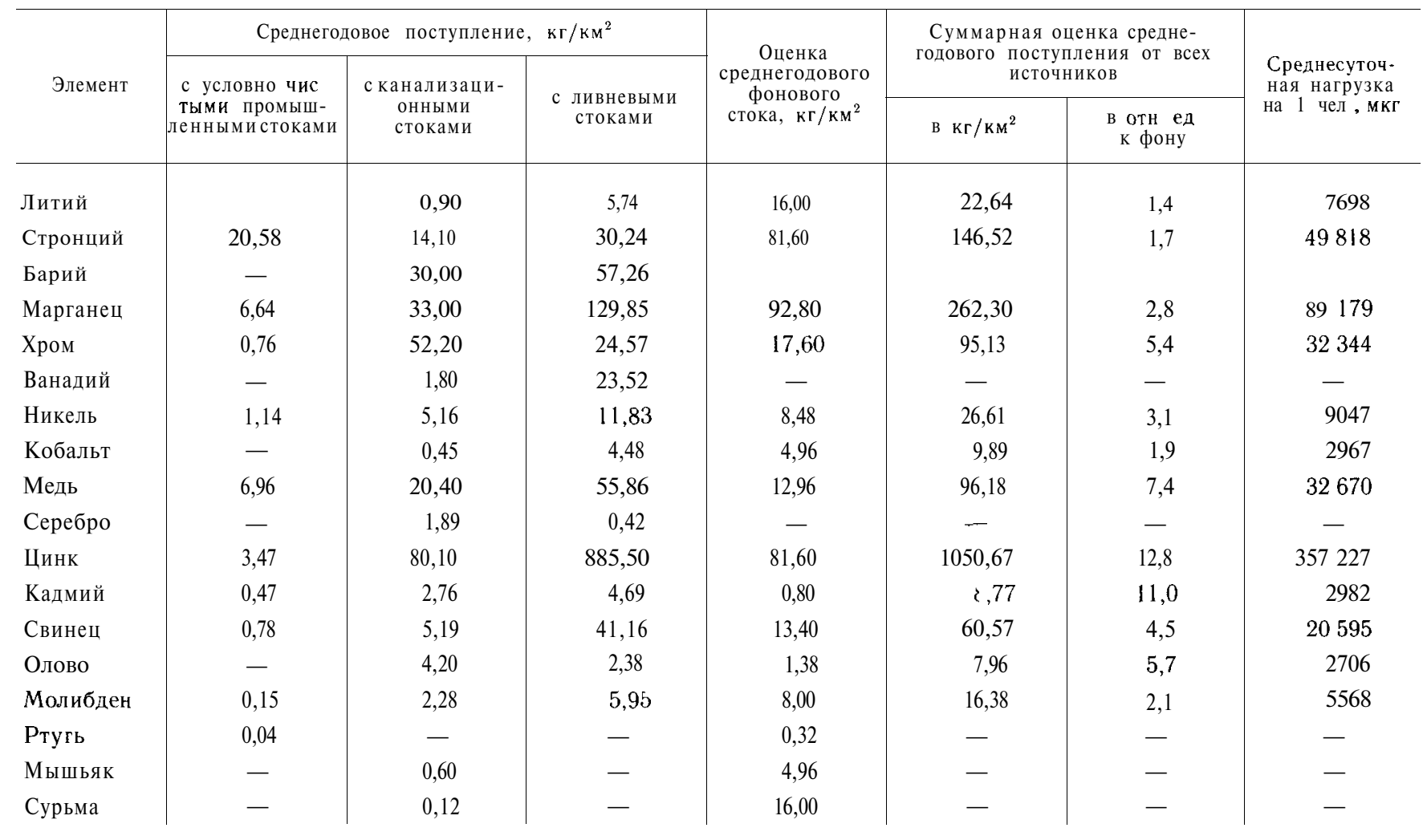




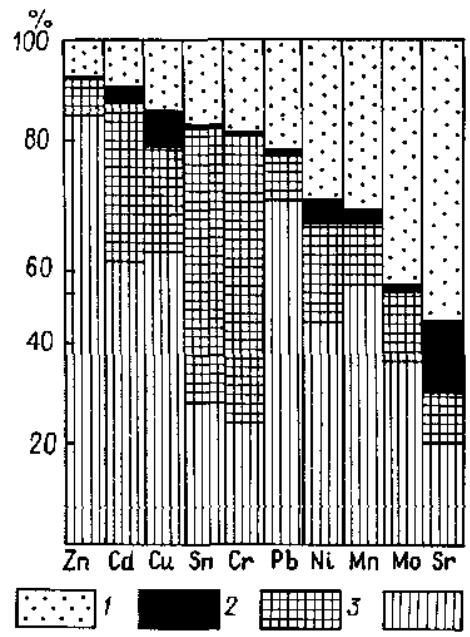

Рис. 25. Баланс поставки химических элементов в поверхностном стоке крупного города:

1-4- стоки: 1 - фоновый, 2 - условно чистых промышленных вод, 3 - канализационный, 4 - ливневый

от источников различного типа, рассчитанной в массах поступления элементов в воды с 1 км² урбанизированной территории В гоД.

Объем условно чистого промышленного стока, сбрасываемого в водоемы, обычно точно не фиксируется. В этой связи может быть взят объем стока химических элементов, рассчитанный по водотокам, дренирующим промзоны, и распространен на все количество промышленных зон урбанизированной территории.

Суммарное поступление химических элементов в воды урбанизированной территории для всех рассмотренных элементов выше фонового. Особенно оно значительно для $\mathrm{Zn} \mathrm{и} \mathrm{Cd}$ (общий коэффициент концентрации К соответственно в 13 и 11 раз выше фонового) .

Высокая интенсивность поставки отличает Си $(\mathrm{K}=7,4)$, $\mathrm{Sn}$ и $\mathrm{Cr}(\mathrm{K}=5,7-5,4), \mathrm{Pb}(\mathrm{K}=4,5), \mathrm{Ni}(\mathrm{K}=3,1), \mathrm{Mn}(\mathrm{K}=2,3)$. Для Мo, Co, 5г, Li количества, поставляемых техногенезом, также довольно велики (от $40 \%$ до $100 \%$ фоновых количеств коэффициенты концентрации от 1,4 до 2,0).

Сопоставление интенсивностей поступления химических элементов в водотоки от источников различного типа (рис. 25) показывает, что для большей части химических элементов важнейшим источником является ливневый сток. Так, с ливневым стоком в водоемы и водотоки попадает до 85\% 2П, $68 \%$ РЬ, $50-68 \%$ Cd, Си, Мп, около $40 \%$ Мо и Ni.

Для 5п и Сг наиболее значительная поставка осуществляется с канализационным стоком (53\% и $55 \%$ соответственно). Для остальных химических элементов вклад канализационного стока в общую поставку химических элементов составляет 10 $20 \%$. 
Т а бл и ц 28. Сравнение масс поступления химических элементов с атмосферной взвесью и поставка в водотоки с поверхностным ливневым стоком, т/год

\begin{tabular}{l|c|c}
\hline \multirow{2}{*}{ Элемент } & $\begin{array}{c}\text { Поступление на территорию } \\
\text { с атмосферной взвесью }\end{array}$ & $\begin{array}{c}\text { Поступление в водотоки } \\
\text { со взвешенным веществом } \\
\text { в ливневом стоке }\end{array}$ \\
\hline Стронций & 10,4 & 5,7 \\
Марганец & 146,1 & 125,0 \\
Хром & 21,6 & 23,8 \\
Никель & 16,6 & 11,5 \\
Медь & 19,4 & 55,3 \\
Свинец & 16,1 & 40,5 \\
Олово & 1,3 & 2,3 \\
Цинк & 62,4 & 882,0 \\
Кадмий & 0,3 & 4,7
\end{tabular}

Поступление химических элементов с условно чистыми промышленными стоками против ожидания окалалось небольшим. Лишь для 5г оно составляет $14 \%$, что несколько выше, чем поставка 5г с канализационным стоком. Для Си, $\mathrm{Cd}, \mathrm{Ni}$ прямое поступление промышленных стоков в водотоки обеспечивает около 5\% поставки, для всех остальных элементов эта доля около $1 \%$ и менее.

В целом, техногенное поступление химических элементов в водотоки крупных урбанизированных зон превышает фоновое (природное). Среди техногенных источников вклад в загрязнение водотоков увеличивается в ряду: промышленный сток условно чистых вод - канализационный сток после очистных coopyжений - ливневый поверхностный сток.

Подчеркнем, что канализационный сток оценивается после очистных сооружений, на которых задерживается в $15-20$ раз больше химических элементов, чем попадает в водотоки.

Состав ливневого стока, являющегося важнейшим техногенным поставщиком химических элементов в водоемы, формируется за счет смыва почв, смыва пыли с асфальтированных поверхностей, эрозии зданий и сооружений, размыва небрежно хранящихся материалов и свалок. Несомненно, что в загрязнении взвешенного вещества ливневого стока значительно влияние выпадений из атмосферы. Действительно, данные по приносу вещества с пылью, выпадающей из атмосферы, и его поступлению в водотоки со взвесью в ливневом стоке имеют близкий порядок (табл. 28).

Для 5г, $\mathrm{Mn}, \mathrm{Cr}$ и $\mathrm{Ni}$ поступление из атмосферы или несколько выше, чем из поверхностного стока. Для Си, $\mathrm{Pb}, 5$, наоборот, приход со стоком в 2 раза, а для $2 п$ и $\mathrm{Cd}$ в 10 раз больше, чем с выпадениями из атмосферы. Далеко не весь материал, выпадающий из атмосферы, смывается поверхностным стоком (коэффициент стока даже в городах не более 0,6$)$, что свидетельствует о значительной роли неатмосферных источников поставки техногенных частиц в ливневый сток. 
Т а блиц а 29. Химические элементы твердых отходов различных типов

\begin{tabular}{|c|c|c|c|c|}
\hline \multirow[b]{2}{*}{ Элемент } & \multicolumn{4}{|c|}{ Среднегодовое поступление элементов из различных } \\
\hline & $\begin{array}{c}\text { Золы и шлаки } \\
\text { бытового мусора }\end{array}$ & $\begin{array}{c}\text { Шламы сооруже- } \\
\text { ний физико- } \\
\text { химической } \\
\text { очистки }\end{array}$ & $\begin{array}{c}\text { Осадки канали- } \\
\text { зационных } \\
\text { стоков }\end{array}$ & $\begin{array}{c}\text { Металлоабра- } \\
\text { зивные пыли }\end{array}$ \\
\hline Титан & 1100 & 0 & 684 & 13 \\
\hline Ванадий & 7,7 & 0 & 11,5 & 46 \\
\hline Хром & 412 & 750 & 331 & 2600 \\
\hline Марганец & ? & 60 & 209 & 260 \\
\hline Кобальт & 6,6 & 0,2 & 2,8 & 100 \\
\hline Никель & 43,3 & 150 & 32,7 & 80 \\
\hline Медь & 1320 & 500 & 129 & 150 \\
\hline Цинк & 3960 & 1000 & 507 & 44 \\
\hline Молибден & 4,8 & 4 & 14,5 & 80 \\
\hline Серебро & 15,8 & 2,5 & 12,0 & 0,2 \\
\hline Қадмий & 7,4 & 30 & 17,5 & ? \\
\hline Олово & 161 & 100 & 26,6 & 0,2 \\
\hline Сурьма & 76 & 0 & 0,8 & $?$ \\
\hline Вольфрам & 6,5 & 1,5 & 1,1 & 430 \\
\hline Свинец & 1050 & 18 & 32,9 & 3 \\
\hline Висмут & 2,8 & 27 & 3,8 & ? \\
\hline Стронций & 135 & 2 & 89 & 0 \\
\hline Цирконий & 34 & 0 & 76 & 1 \\
\hline
\end{tabular}

По данным Mance, Harman (1978), процентное содержание химических элементов воздушного происхождения в поверхностном дождевом стоке урбанизированных территорий может составлять от 35 до $54 \%$ для $\mathrm{Mn}, 2$ п, $\mathrm{Pb}$ и $96 \%$ - для Си.

Установленное влияние рассмотренных нами источников на поставку химических элементов в водотоки неоднозначно совпадает с эколого-гигиенической оценкой этих источников.

Например, ливневый сток обогащен в основном за счет взвешенного вещества и, следовательно, легко может быть очищен путем канализнрования и создания эффективных сооружений механической очистки.

Потенциальная опасность собственно канализационных и промышленных стоков много выше, так как мы рассматриваем стоки уже прошедшие очистку.

Твердые отходы по общему объему поставляемого в окружающую среду техногенного материала, вероятно, наиболее мощный источник.

Большая их часть, поступая на официальные и неофициальные свалки, становится локальными центрами загрязнения подземных вод (инфильтрация атмосферных осадков через материал свалки), почв и атмосферы (дефлюкация). Канализационные осадки и некоторая часть бытового мусора перерабатывается на органо-минеральное удобрение (компост) и становится рассеянным источником сельскохозяйственных почв и продукции. 


\begin{tabular}{|c|c|c|c|c|c|}
\hline \multicolumn{3}{|c|}{ твердых отходов, кг $/ \mathbf{k м}^{2}$} & \multirow{2}{*}{$\begin{array}{c}\text { Запасы в } \\
\text { почвах ус- } \\
\text { ловного } \\
\text { фона, } \\
\text { кг/км }\end{array}$} & \multirow{2}{*}{$\begin{array}{c}\text { Относитель- } \\
\text { ный коэффи- } \\
\text { циент накоп- } \\
\text { ления в } \\
\text { отходах }\end{array}$} & \multirow[b]{2}{*}{$\begin{array}{c}\text { Среднесуточная } \\
\text { нагрузка на } \\
1 \text { чел., мг }\end{array}$} \\
\hline $\begin{array}{c}\text { Золы и шла- } \\
\text { ки электро- } \\
\text { станций }\end{array}$ & $\begin{array}{c}\text { Твердые от- } \\
\text { ходы внутри- } \\
\text { заводских } \\
\text { свалок }\end{array}$ & Всего & & & \\
\hline 5500 & 357 & 7654 & 4200 & 0,5 & 738 \\
\hline 180 & 13 & 258 & 45 & 1,7 & 27 \\
\hline ПО & 818 & 5021 & 32 & 154 & 1682 \\
\hline 5 & 5 & - & 379 & 1,7 & 178 \\
\hline 19 & 22 & 151 & 5 & 26,4 & 45 \\
\hline 75 & 61 & 443 & 14 & 26,3 & 126 \\
\hline 170 & 419 & 4008 & 19 & 203 & 1246 \\
\hline 190 & 1102 & 6803 & 35 & 189 & 2265 \\
\hline 4 & 21 & 128 & 0,7 & 177 & 42 \\
\hline 0,1 & 6 & 36,6 & 0,1 & 365 & 12 \\
\hline$?$ & 1 & 66 & 0,2 & 330 & 23 \\
\hline 3 & 57,6 & 348 & 3,6 & 96 & 118 \\
\hline 2 & ? & 77 & 1,4 & 55 & 26 \\
\hline 2 & 88 & 527 & 0,7 & 753 & 180 \\
\hline 42 & 221 & 1367,9 & 18 & 74 & 454 \\
\hline$?$ & ? & 0,6 & 0,2 & - & - \\
\hline 300 & 45 & 571,9 & 20 & $! 4$ & 93 \\
\hline 145 & 22 & 278,9 & 296 & 0,5 & 46 \\
\hline
\end{tabular}

Важнейшими поставщиками химических элементов среди твердых отходов являются; бытовой мусор, шламы очистных сооружений физико-химической очистки промышленных стоков, пыли (прежде всего, металлоабразивные), золы и шлаки ТЭЦ, осадки очистных сооружений канализационного стока, промышленные отходы (неутилизированные бракованные изделия, шлаки и т. п.), захороняемые чаще всего на внутризаводских территориях (масса точно неизвестна, предполагается около $20 \%$ общего объема отходов) .

Данные по массам химических элементов, заключенных в твердых отходах (табл. 29), определяют, вероятно, общий порядок цифр и соотношение между различными типами твердых"отходов.

Анализ относительного коэффициента накопления химических элементов в твердых отходах показывает, что среди исследованных химических элементов наиболее значительный уровень поступления характерен для W, Ag, Cd, Си, Zn, Mo, Cr, Pb (рис. 26) .

Продукты мусоропереработки поставляют основные количества РЬ (80\% общей поставки), 2п (60\%), 5п, Ag, Си (около $40 \%$ ). С металлоабразивными пылями поступают W и Со (около $80 \%)$, Мо, V и Сг $(50-60 \%)$. Со шламами физико-химической очистки промышленных стоков связаны основные количества $\mathrm{Ni}$ и Cd (40-45\%), а также 5п (30\%). Канализационные осадки содержат значительные массы $\mathrm{Cd}$ и $\mathrm{Ag}$ (около 30\%), в несколько 



Рис. 26. Относительный вклад (в \%) различных источников в поставку химических элементов твердыми отходами: I - канализационные осадки, Il - металлоабразивные пыли, III - шламы физико-химической очнстки промьшленных стоков, IV - золы и шлаки переработки мусора
Рис. 27. Сравнение абсолютных масс (в мг/чел в сутки) и относительной нагрузки $K_{c}$ химических элементов при воздействии выбросов, стоков, твердых отходов на окружаючцио среду крупного города

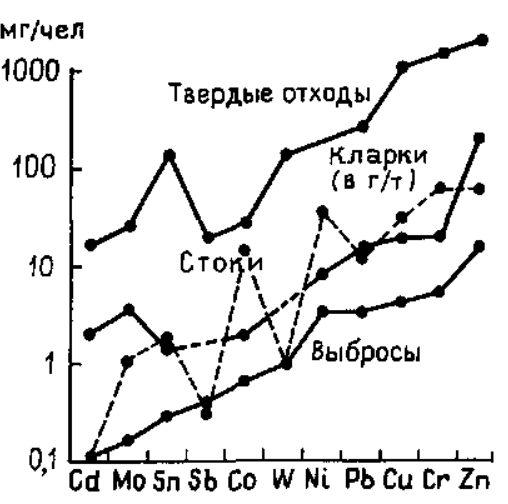

меньшем количестве $(10-15 \%)$ - практически все исследованные элементы.

Выбросы - стоки - твердые отходы (три основные группы источников загрязнения, поставляющие химические элементы в окружающую среду урбанизированных зон и формирующие геохимическую нагрузку на основные ее компоненты - почвы, воды, 
атмосферу,- а через них на биоту) различаются как по абсолютному уровню поставки химических элементов, так и по ее относительной (в сравнении с фоновыми природными данными) интенсивности (рис. 27).

Для удобства сопоставления абсолютные массы химических элементов, поступающие от техногенных источников в урбанизированных зонах, выражены в единицах массы, поставляемой ежесуточно в пересчете на одного человека. С целью сравнения приведены кларки химических элементов.

Анализ графиков показывает, что во всех группах источников загрязнения порядок расположения химических элементов по увеличению массы, поставляемой в окружающую среду, практически одинаков. Кривые распределения масс химических элементов в выбросах, стоках, твердых отходах хорошо корректируют и для исследованной (далее не полной) ассоциации химических элементов фиксируют следующий ряд увеличения абсолютной нагрузки: $\mathrm{Cd}-\mathrm{Mo}-5 \Pi-5 \mathrm{~b}-\mathrm{Co}-\mathrm{W}-\mathrm{Ni}-\mathrm{Pb}-\mathrm{Cu}-$ $\mathrm{Cr}-\mathrm{Zn}$.

Этот ряд грубо совпадает с рядом распределения кларков химических элементов. При этом своеобразно положение $\mathrm{Cd}, 5 \mathrm{~b}$, W, Си, Zn. Эти элементы поступают в окружающую среду в больших количествах, чем это следует из их положения в ряду кларков. Однако и для этой группы элементов объемы поступления пропорциональны их кларкам. Таким образом, эти химические элементы отличаются повышенной технофильностью.

Количественная оценка поступления химических элементов от трех характеризуемых групп источников загрязнения неодинакова. Для всей рассматриваемой ассоциации химических элементов в ряду «выбросы - стоки - отходы» абсолютные массы нагрузки увеличиваются для каждого химического элемента на два порядка. Так, если для выбросов нагрузка на окружающую среду отдельных химических элементов варьирует в пределах $(0, n-n)$ мг/чел. сут., то в стоках она составляет $(n-10 n)$ мг/чел. сут., а в твердых отходах $(10 n-100 n)$ мг/чел. сут. Таким образом, по абсолютным массам основным поставщиком химических элементов в окружающую среду являются твердые отходы.

Сопоставление относительных нагрузок химических элементов для различных групп источников загрязнения урбанизированных зон позволяет выяснить их сравнительную интенсивность (см. рис. 27). В сущности, только относительные величины появления той или иной абсолютной массы любого химического элемента являются критерием значимости для окружающей среды.

Для каждой группы источников загрязнения характерен специфический набор концентрирующихся химических элементов.

Интенсивность относительной нагрузки на окружающую среду наиболее высока для выбросов (увеличение нагрузки химических элементов в $10 n-100 n$ раз выше фоновой). Несколько меньший, 
но близкий уровень характеризует твердые отходы. Для стоков относительная интенсивность загрязнения меньше (до 10).

Сравнивая опасность загрязнения атмосферы выбросами, водотоков и водоемов - стоками, почвы и грунтов - размещаемыми в них отходами, следует учитывать не только абсолютное количество и относительную концентрацию, но и усвояемость живыми организмами, возможность попадания в системы жизнеобеспечения (пищу, воздух, питьевую воду). Все это обусловлено особенностями миграции химических элементов в техногенных ландшафтно-геохимических системах, изучаемых М. А. Глазовской $(1976,1978)$.

Для общих оценок полезно иметь в виду следующие обстоятельства:

1) загрязнение (исключая углекислый газ) в воздухе не накапливается, тогда как в водных системах и почвах оно может депонироваться на длительное время;

2) воду можно очищать перед использованием или подобрать другой источник водоснабжения, тогда как для воздуха и почвы это маловероятно;

3) загрязнение выбросами и стоками является рассеянным, тогда как загрязнение твердыми отходами обычно строго локализовано;

4) почва является многолетним (десятки - сотни лет) депонентом загрязнений.

Следует различать прямое и отдаленное экологическое воздействие. Прямое воздействие сказывается на ухудшении качества жизни, начиная с текущего поколения. Отдаленное экологическое воздействие скажется в ухудшении качества жизни в перспективе.

С изложенных позиций выбросы в атмосферу в урбанизированных зонах являются ныне наиболее опасным интенсивным источником загрязнения с прямым экологическим воздействием. Сток в водоемы и водотоки в равной степени обладают признаками прямого и отдаленного воздействия. Твердые отходы преимушественно загрязнитель с отдаленным воздейсгвием.

Вероятно, вложение средств и общая политика общества по охране окружающей среды от загрязнения должны базироваться на относительной значимости отдельных категорий источников вредных нагрузок.

\section{2. АЭРОГЕННЫЕ ОРЕОЛЫ РАССЕЯНИЯ}

Аэрогенные ореолы рассеяния обусловлены распространением в атмосфере промышленных, энергетических и транспортных выбросов, т. е. особенностями атмохимических миграционных потоков. Характер этих потоков определяется структурой функционального использования городской территории и, соответ120 
ственно, пространственными соотношениями между источниками выбросов (промзонами, шоссе) и страдающими объектами селитебными и рекреационными территориями.

Опыт геохимических исследований показывает, что по специфике пространственной функциональной структуры города могут быть разделены на три укрупненные группы: 1) городацентры, столичного типа (государства, области) с многоотраслевой промышленностью, включающей разнообразные по составу и мощности источники выбросов в атмосферу; 2) специализированные города, возникающие обычно в связи с крупными предприятиями или блоками однородных предприятий (металлургические, химические, машиностроительные, горнообогатительные комбинаты, энергетические центры) - часто наиболее мощными источниками выбросов в атмосферу; 3) города-спальни, включающие спутники (или отдаленные микрорайоны) крупных городов селитебного назначения, малые города с местной промышленностью, т. е. поселения, где источники выбросов в атмосферу, ограничиваются необходимым для жизнеобеспечения минимумом (главным образом, энергетическими и транспортными потребностями).

Характер использования городской территории фиксируется на картах функционального зонирования. К основным функциональным зонам относятся промышленные, селитебные, транспортные, рекреационные и др.

По специфике размещения промышленности, основной градообразующей базы, выделяются три главных типа структур: порфировидная (мозаичная, вкрапленная, точечная) и зональная (центрическая). Порфировидную структуру имеют города или отдельные их части, в градостроительной планировке которых промышленность, представленная многими объектами, сконцентрирована в промышленные зоны, разбросанные по городу. При такой структуре промышленность по отношению к другим функциональным зонам в городах типа «центр» занимает $30-50 \%$ площади (рис. 28).

Вкрапленная структура размещения характерна для городов, где появление промышленности совпало с началом развития фабрично-заводского производства. Жилые дома строились вплотную к производственным объектам. Площадь, занятая низкоэтажной жилой застройкой значительно превосходила территории фабрик и заводов. Таким образом, промышленность была как бы вкраплена в жилую зону. Для городов группы «центр» площадь промышленных объектов при такой структуре размещения обычно составляет 10--30\% других функциональных зон (см. рис. 28). Для фоновых городов эта площадь значительно меньше, она занимает всего лишь 5-10\% общей территории.

Зональный тип структуры формируется около крупных современных промышленных объектов или их блоков, объединенных 


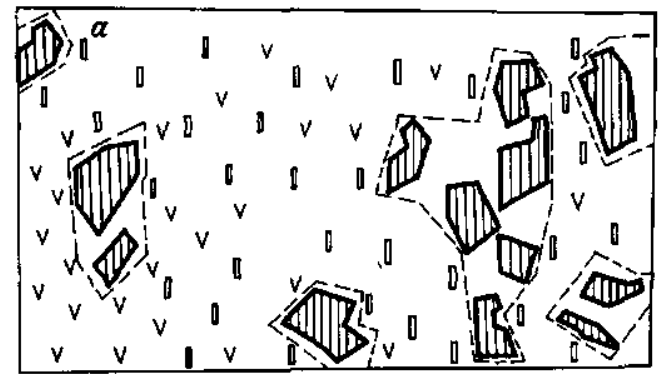

\section{$024 \mathrm{KM}$}

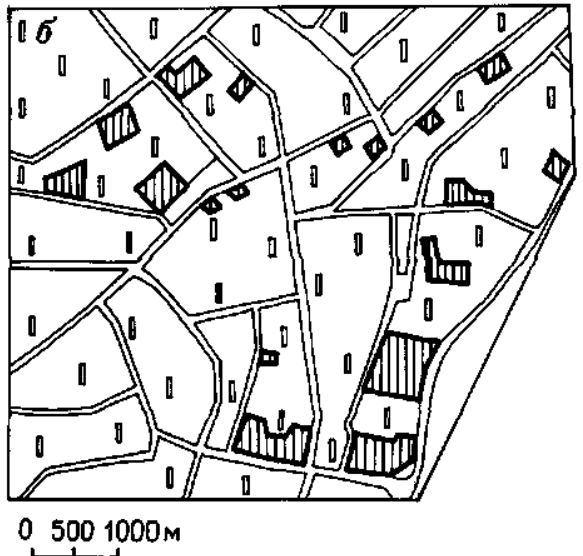

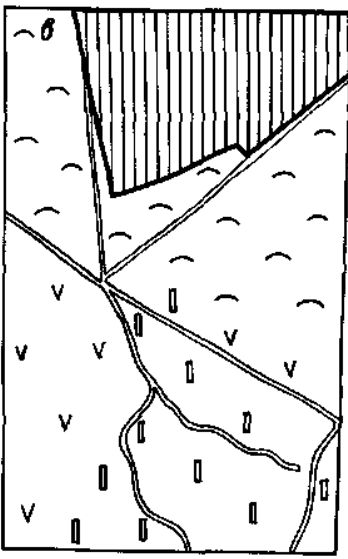




Рис. 28. Структура размещения промышленности в городах (а - порфировидная, б - вкрапленная, в - зональная):

1 - промышленный объект, 2 - селитебная зона, 3 - зеленая зона, 4 - буферная зона, 5 - контуры промышленных зон

единым производственным циклом. Функциональные зоны непроизводственного профиля пространственно удалены от места локализации промышленности и как бы опоясывают промплощадку, которая чаще всего размещается на окраине города. Зональная структура характерна для многих «специализированных» городов.

Условия распространения потоков атмосферного воздуха, загрязненного выбросами и оценка опасности их воздействия на объекты окружающей среды и населения во многом различна для рассмотренных типов городов.

\section{Атмохимические аномалии}

Техногенные геохимические преобразования атмосферы и загрязнение воздуха в городах - один из наиболее актуальных вопросов для этих территорий. Ему посвящена огромная литература, рас- 
сматривающая, главным образом, общие тенденции, характеризующие состояние атмосферы по так называемым приоритетным загрязняющим веществам - общей пыли, оксидам азота, серы и углерода [17].

В большинстве промышленных городов по всем этим ингредиентам наблюдаются обширные атмохимические аномалии. По ориентировочным средним оценкам в большинстве промышленных зон концентрации оксидов серы и азота выше фоновой в 5-8 раз, а пыли - в 15-20 раз. В селитебных зонах промышленных городов интенсивность загрязнения значительно меньше, но остается достаточно высокой (в 3-10 выше пригородных территорй̈) .

В последние годы появились исследования Ю. А. Израэля, Ф. Я. Ровинского, И. М. Назарова с соавторами, В. А. Михайлова с соавторами, работы других отечественных и зарубежных исследователей [8, 18], свидетельствующие о высоких и очень высоких уровнях концентрации в воздухе городов токсичных химических элементов.

Обобщение этих материалов, а также данные авторов показывают очень контрастную структуру изменения микроэлементного состава атмосферы в ряду «воздух условного антарктического эталона - пригородные территории, удаленные от промышленных источников выбросов - города типа «центр» - специализированные металлургические города» (табл. 30).

Т а бл и ц а 30 Концентрации химических элементов (в мкr/m ${ }^{3}$ ) в атмосферном воздухе различных типов территорий. По $B A$ Михайлову с дополнениями

\begin{tabular}{|c|c|c|c|c|}
\hline Элемент & $\begin{array}{c}\text { Южный полюс, } \\
n \cdot 10^{-1}\end{array}$ & $\begin{array}{c}\text { Пригородный } \\
\text { фон }\end{array}$ & $\begin{array}{c}\text { Промышленные } \\
\text { города }\end{array}$ & $\begin{array}{c}\text { Центры очагов } \\
\text { загрязнения } \\
\text { около мощных } \\
\text { источников } \\
\text { загрязнения }\end{array}$ \\
\hline $\begin{array}{l}\text { Алюминий } \\
\text { Титан } \\
\text { Ванадий } \\
\text { Хром } \\
\text { Марганец } \\
\text { Железо } \\
\text { Кобальт } \\
\text { Никель } \\
\text { Медь } \\
\text { Цинк } \\
\text { Мышьяк } \\
\text { Селен } \\
\text { Бром } \\
\text { Молибден } \\
\text { Серебро } \\
\text { Кадмий } \\
\text { Сурьма } \\
\text { Вольфрам } \\
\text { Ртуть } \\
\text { Свинец }\end{array}$ & $\begin{array}{l}0,082 \\
0,010 \\
0,013 \\
0,004 \\
0,001 \\
0,062 \\
0,00005 \\
- \\
0,003 \\
0,003 \\
0,003 \\
0,084 \\
0,260 \\
0,000002 \\
0,00004 \\
0,0015 \\
0,00008\end{array}$ & $\begin{array}{l}0,9 \\
0,1 \\
0,07 \\
0,009 \\
0,06 \\
1,5 \\
0,001 \\
0,06 \\
0,07 \\
0,3 \\
0,005 \\
0,001 \\
0,05 \\
0,01 \\
0,001 \\
0,006 \\
0,01 \\
0,001 \\
0,001 \\
0,3\end{array}$ & $\begin{array}{l}18 \\
1,4 \\
0,17 \\
0,12 \\
0,6 \\
24 \\
0,04 \\
0,12 \\
1,1 \\
1,7 \\
0,1 \\
0,019 \\
1,3 \\
\\
0,002 \\
0,13 \\
0,4 \\
0,02 \\
0,005 \\
3,0\end{array}$ & $\begin{array}{r}- \\
12 \\
\\
100 \\
1000 \\
8 \\
7 \\
6 \\
10 \\
60 \\
10 \\
-\end{array}$ \\
\hline
\end{tabular}


Т а бли ц 31 Концентрации химических элементов в атмосферном воздухе и снежном покрове фоновых территорий

\begin{tabular}{|c|c|c|c|c|c|c|}
\hline \multirow{2}{*}{ Элеменг } & \multicolumn{3}{|c|}{ Атмосферный воздvх мкг $/ \mathrm{m}^{3}$} & \multicolumn{3}{|c|}{ Пыль в снежном покрове мг/кг } \\
\hline & $\begin{array}{c}\text { Региональ } \\
\text { ный фон }\end{array}$ & $\begin{array}{c}\text { Фоновый } \\
\text { район города }\end{array}$ & K & $\begin{array}{c}\text { Региональ } \\
\text { ный фон }\end{array}$ & $\begin{array}{c}\text { Фоновый } \\
\text { район города }\end{array}$ & $\mathrm{K}_{\mathrm{c}}$ \\
\hline Магний & 049 & 148 & 3 & & & - \\
\hline Титан & 0,09 & 0,10 & 1 & - & - & - \\
\hline Ванадий & 0,003 & 0,012 & 4 & 50 & 150 & 3 \\
\hline Хром & 0,006 & 0,034 & 56 & 52 & 70 & 1,3 \\
\hline Марганец & 0,013 & 0,032 & 2,5 & 520 & 550 & 1,1 \\
\hline Никель & 0004 & 0,024 & 6,0 & 57 & 62 & 1.1 \\
\hline Медь & 0,020 & 0067 & 3,3 & 100 & 220 & 2,1 \\
\hline Цинк & 0,023 & 0,143 & 6,2 & 610 & 340 & 0,6 \\
\hline Мышьяк & $\mathrm{Ho}$ & 0,010 & - & - & - & - \\
\hline Бром & 0,007 & 0,017 & 2,4 & - & - & - \\
\hline Кадмий & $\mathrm{H} \quad \mathrm{o}$ & 0070 & - & 0,5 & 2,6 & 5,2 \\
\hline Олово & 0,004 & 0,008 & 2 & 40 & 50 & 1,2 \\
\hline Лантан & $\mathrm{Ho}$ & 0,005 & - & - & - & - \\
\hline Самарий & $\mathrm{Ho}$ & 0,0007 & - & - & - & - \\
\hline Европий & $\mathrm{Ho}$ & 0,00005 & - & - & - & - \\
\hline РТVTb & 0,002 & 0,007 & 35 & 022 & 0,90 & 4,1 \\
\hline Свинец & 0,006 & 0,0034 & 57 & 90 & 180 & 2 \\
\hline
\end{tabular}

Примечания $\mathrm{K}$ - коэффициент концентрации рассчитанный по отношению к регио нальному фону Н о- -элемент не обнаружен «-»- элемент не определя тся

В воздухе сельских территорий, урбанизированных регионов, находящихся под каким-то количественно неясным антропогенным, воздействием, концентрации большинства микроэлементов выше, чем на Южном полюсе, в десятки и сотни раз Для таких территорий даже ориентировочно пока нельзя оценить количе ственно уровень глобального и регионального загрязнения Для этого необходимо получить представительные данные по содержанию микроэлементов в воздухе в наиболее отдаленных от урбанизации континентальных районах в различных ландшафтных зонах Мира В городах типа «центр» степень концентрирования многих химических элементов (Pb, Си, $\mathrm{Mn}, \mathrm{Br}, \mathrm{Cr}, \mathrm{Mo}$, 5 e, W) возрастает по сравнению с выбранным фоном в $5-20$ раз, a Cd и As - в сотни раз При этом довольно контрастно в воздухе городов увеличивается содержание таких малоизученных в экологическом плане элементов, как Al, T1, Pe В ядрах атмохимических аномалий металлургических городов - наиболее острые известные нам ситуации загрязнения воздуха селитебных территорий - уровни концентрации возрастают на один-два по рядка И здесь рост содержаний таких наиболее изученных тяжелых металлов как $\mathrm{Pb}, \mathrm{Zn}, \mathrm{W}, \mathrm{Cn}, \mathrm{Cd}, \mathrm{C}$ не так уж контрастен (в 3-5-10 раз) Очень контрастно увеличиваются в этих случаях содержания Ре, Мп, 5e, Co, As (в сотни раз) - элементов, которым обычно придается меньшее значение 
Рис. 29 Распределение химических элементов в почве (сплошная линия) и снежном покрове (пунктир) на фоновой территории

Рис. 30. Среднесуточное выпадение химических элементов на, фоновых и аномальных участках:

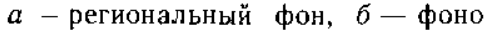
вые территории города, $8-$ завод по вторичной переработке цветных металлов 2 - крупный машино строительный завод с литейным про изводством, $I, 2$ - содержания эле ментов $(l-$ в снеговой воде, $2-$ в пыли)

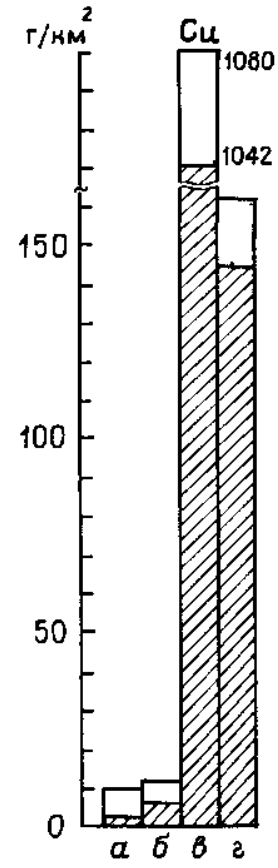


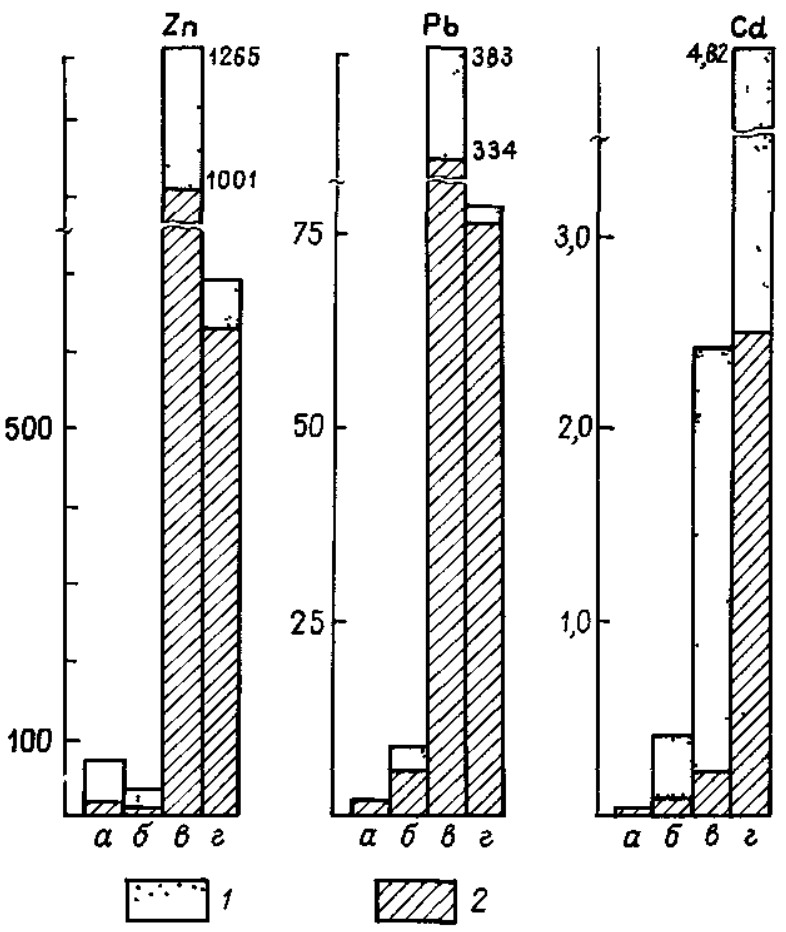

Проблема фона при анализе атмохимических аномалий в городах довольно сложна, что связано с существованием плохо исследованных региональных полей загрязнения атмосферного воздуха Для получения данных о фоновых содержаниях хими ческих элементов в атмосферном воздухе, урбанизированных территориях нами на протяжении нескольких лет проводились сопряженные исследования воздуха и снежного покрова в мест- 
Таблица 32 Концентрации химических элементов в атмосферном воздухе

\begin{tabular}{|c|c|c|c|c|c|}
\hline \multirow{2}{*}{$\begin{array}{l}\text { Положение се.иитебнои } \\
\text { территории }\end{array}$} & \multirow{2}{*}{$\begin{array}{l}\text { Чис.ло } \\
\text { гроб }\end{array}$} & \multicolumn{2}{|c|}{ Ванадий } & \multicolumn{2}{|c|}{ Хром } \\
\hline & & $\mathrm{C}_{\mathrm{cp}}$ & $\mathrm{K}_{\iota p}$ & $C_{c p}$ & $K_{c p}$ \\
\hline $\begin{array}{l}\text { Зона влияния выбросов машино- } \\
\text { строительных производств }\end{array}$ & 78 & $0,02(0,39)$ & $7(130)$ & $0,09(0,83)$ & $15(140)$ \\
\hline $\begin{array}{l}\text { Центральная часть города с до- } \\
\text { минирующим влиянием авто- } \\
\text { транспорта } \\
\text { Периферийный фоновый район }\end{array}$ & 73 & $0,01(0,05)$ & $3(17)$ & $0,08(0,74)$ & $13(120)$ \\
\hline
\end{tabular}
мальные значения параметров

ности, являющейся дальней периферией крупной городской агломерации, отстоящей на 70 км от промышленного центра и на 20 км от ближайшего небольшого городка, где промышленность отсутствует (в дальнейшем мы будем условно называть полученные данные по этому участку исследований региональным фоном), а также на городских территориях нового освоения, находящихся на расстоянии не менее 10 - 15 км от промышленных предприятий и являющихся по сути дела городами-спальнями (фоновый район города, табл. 31).

Степень загрязнения воздуха в пределах региональных полей антропогенного воздействия прямыми замерами установить нелегко. Косвенно существование таких полей подтверждается при сопоставлении содержаний химических элементов в пыли, осажденной снеговым покровом, и почве (рис. 29). При общем сходстве рядов содержаний пыль выпадений обогащена техногенными элементами: Hg (в 24 раза), 2П (в 12 раз), 5П (в 8 раз), Cd (в 5 раз), Си (в 4 раза), $\mathrm{Pb}$ (в 3,5 раза), № (в 2,5 раза). Можно предположить, что из-за существования таких полей наши оценки уровня загрязнения городов всегда несколько занижены.

По сравнению с «региональным фоном» уровень содержаний химических элементов в городах-спальнях (фоновых микрорайонах) отчетливо выше (см. табл. 31).

В атмосферном воздухе здесь можно выделить несколько групп элементов, по степени накопления отличающиеся от регионального фона. Во-первых, элементы, характерные для выбросов энергетических установок - Ni, V, Hg (коэффициенты концентрации 6-3,5). Во-вторых, элементы, присутствующие в выбросах большинства машиностроительных производств - $\mathrm{Cr}, \mathrm{Mn}, \mathrm{Pb}$. $\mathrm{Pb}$, как и $\mathrm{Br}$, характерен для состава воздуха, загрязненного выхлопными газами автомобилей. Типоморфными элементами, встречающимися в окружающей среде любого промышленного города, являются 2П и Си, которые могут выделяться в воздух с промышленными выбросами, при коррозии металлических частей зданий и инженерных сооружений. Есть также и элементы, 126 
селитебных территорий различных зон города, мкг $/ \mathrm{m}^{3}$

\begin{tabular}{c|c|c|c|c|c|c|c}
\hline \multicolumn{2}{c|}{ Марганец } & \multicolumn{2}{c|}{ Никель } & \multicolumn{2}{c|}{ Цинк } & \multicolumn{2}{c}{ Свинец } \\
\hline$C_{c p}$ & $K_{\iota p}$ & $C_{\varsigma p}$ & $K_{c p}$ & $C_{c p}$ & $K_{c p}$ & $C_{c p}$ & $K_{\iota p}$ \\
\hline $0,12(0,90)$ & $9(69)$ & $0,04(0,36)$ & $10(90)$ & $0,23(1,85)$ & $10(80)$ & $0,13(0,70)$ & $22(117)$ \\
$0,10(0,84)$ & $8(65)$ & $0,04(0,44)$ & $10(110)$ & $0,13(0,45)$ & $6(20)$ & $0,04(0,22)$ & $7(37)$ \\
& & & & & & & \\
$0,03(0,42)$ & $2(33)$ & $0,02(0,41)$ & $5(102)$ & $0,05(0,67)$ & $2(29)$ & $0,01(0,09)$ & $2(15)$
\end{tabular}

среднего содержания по отношению к регионыьномұ фону, в скобках даны макси

происхождение повышенных концентраций которых в воздухе не совсем понятно - Mg и 5п. Исследование микроэлементного состава пыли, осажденной на снежный покров, в основном подтверждает состав ассоциации аномальных элементов, наблюдаемых в воздухе.

Изучение форм нахождения в атмосферных выпадениях (рис. 30) показывает, что аномалии в «фоновых» городах во многом обусловлены поступлением химических элементов в виде пыли. С нерастворимой частью выпадений здесь связывается $70-90 \%$ аномальных конденсаций. В фоновых условиях большая часть химических элементов находится в растворенной форме. Это же фиксируется и ростом массы пылевых выпадений в городах-спальнях. При фоновом уровне выпадений $10-20 \mathrm{kr} / \mathrm{km}^{2}$ в сутки выпадение здесь возрастает до $30-45$ кг.

При изучении состояния окружающей среды городов большое значение имеет выявление пространственной структуры загрязнения воздушного бассейна. Оценка качества атмосферного воздуха внутри городов дается на основании сведений, поступающих с стационарных постов общегосударственной службы наблюдения и контроля атмосферного воздуха. В соответствии с существующими нормами стационарные посты устанавливаются в городах из расчета один пост на $10-20 \mathrm{kм}^{2}$ в равнинной местности и на $5-10 \mathrm{~km}^{2}$ в пересеченной местности. В большинстве городов имеется 5-6 стационарных постов, в крупнейших - 6-20 постов. Результаты наблюдений на стационарных постах позволяют получить осредненную характеристику степени загрязнения атмосферного воздуха, проследить в течение ряда лет тенденции изменения уровня степени загрязнения. Получение детальной пространственной картины распределения токсичных веществ в различных зонах города с множественными источниками загрязнения при принятой сети контроля довольно сложно. Так, по данным К. А. Буштуевой и авторов, в крупном городе по данным 22 стационарных постов контрастность различия уровней загрязнения отдельных его частей всего 1,7. В то же время даже расчетные поля концентрации загрязняющих 
Т аблица 33 Концентрации химических элементов в атмосферном воздухе

\begin{tabular}{|c|c|c|c|c|c|c|c|c|c|}
\hline \multirow{2}{*}{ Источник загрязнения } & \multicolumn{3}{|c|}{ Ванадий } & \multicolumn{3}{|c|}{ Хром } & \multicolumn{3}{|c|}{ Марг анец } \\
\hline & $\mathrm{C}$ & $\mathrm{K}$; & $K_{i}$ & $\mathrm{C}$ & $\mathrm{K}:$ & Кг & $\mathrm{C}$ & $\mathrm{K} ;$ & $\mathrm{K}_{1}^{2}$ \\
\hline $\begin{array}{l}\text { Машиностроительный за- } \\
\text { вод и ТЭЦ на мазутном } \\
\text { топливе }\end{array}$ & 0,16 & 16 & 53 & 0,11 & 4 & 18 & 0,14 & 5 & 11 \\
\hline $\begin{array}{l}\text { Завод транспортного ма- } \\
\text { шиностроения }\end{array}$ & 0,02 & 22 & 7 & 0,03 & 1 & 5 & 0,11 & 4 & 8 \\
\hline Чугунолитейныйзавод & 0,05 & 5 & 17 & 0,39 & 13 & 65 & 1,31 & 44 & 101 \\
\hline Сталеплавильный завод & 0,22 & 22 & 73 & 0,06 & 2 & 10 & 0,12 & 4 & 9 \\
\hline Шлифолитейный завод & 0,01 & 1 & 3,3 & 0,04 & 1,3 & 7 & 0,11 & 3,7 & 8 , \\
\hline $\begin{array}{l}\text { Производство вычисли- } \\
\text { тельной техники }\end{array}$ & $\mathrm{Ho}$ & - & - & 0,02 & 1 & 3 & 0,04 & 1 & 3 \\
\hline $\begin{array}{l}\text { Маı истраль с интенсив- } \\
\text { ным движением автотран- } \\
\text { спорта }\end{array}$ & $\mathrm{Ho}$ & - & - & 0,04 & 1,3 & 7 & 0,05 & 1,7 & 4 \\
\hline
\end{tabular}

Примечания $\mathrm{C}-$ средняя концентрация за цикл наблюдения Кс - коэффициент кон фона), $\mathrm{H}$ о-не обнаружено

веществ в воздухе, устанавливаемые по официальным (обычно заниженным) сведениям в массе их выброса в атмосферу показывают различия в $3--5$ и более раз. Фактические вариации содержаний значительно больше. Обобщение материалов по загрязнению атмосферного воздуха крупного промышленного города металлами при осреднении для разных типов территорий показало (табл. 32), что средние уровни содержаний металлов в жилых территориях, примыкающих к промышленным зонам, обычно более чем в 10 раз выше фонового. Наблюдаемая ассоциация (Pb, 2п, Ni, Cr, Mg, W) фиксирует все наиболее распространенные в городах типы источников загрязнения - транспорт, энергетику, промышленность. Максимальные концентрации всех химических элементов выше примерно на порядок. Характерно, что в центре города, где сколько-нибудь крупная промышленность отсутствует, уровни загрязнения воздуха в 1,5 раза меньше. Это характерно для большинства городов и, возможно, связано с особенностями циркуляции воздуха при условии формирующегося над ним острого тепла.

В табл. 33 приведены материалы по среднесуточным концентрациям ряда химических элементов в ядрах геохимических аномалий близ наиболее характерных для городов источников загрязнения - машиностроительных и приборостроительных предприятий, небольших литейных заводов, автотранспортных магистралей, полиграфического производства. Во всех случаях наблюдается широкий спектр химических элементов в воздухе. Специфика источника подчеркивается лишь относительным уровнем концентрации того или иного металла. Например, свинец по вполне понятным причинам наиболее контрастен близ чугуноли- 
в центрах очагов загрязнения, $\mathrm{mr} / \mathrm{m}^{3}$

\begin{tabular}{c|c|c|c|c|c|c|c|c|c|c|c}
\hline \multicolumn{3}{c|}{ Никель } & \multicolumn{3}{c|}{ Цинк } & \multicolumn{3}{c|}{ Олово } & \multicolumn{3}{c}{ Свннец } \\
\hline C & $\mathrm{K}_{!}$ & $\mathrm{K}_{!}^{2}$ & $\mathrm{C}$ & $\mathrm{K} !$ & $\mathrm{K} ?$ & $\mathrm{C}$ & $\mathrm{K} ;$ & $\mathrm{K} ?$ & $\mathrm{C}$ & $\mathrm{K} ;$ & $\mathrm{K}_{c}^{2}$ \\
\hline 0,06 & 3 & 15 & 0,29 & 2 & 13 & 0,015 & 1,5 & 4 & 0,09 & 3 & 15 \\
& & & & & & & & & & & \\
0,05 & 2,6 & 13 & 0,15 & 1 & 6 & 0,021 & 2 & 5 & 0,04 & 1 & 7 \\
0,35 & 17 & 87 & 0,7 & 5 & 30 & 0,12 & 12 & 30 & 0,19 & 6 & 32 \\
0,09 & 5 & 28 & 0,24 & 1,7 & 10 & 0,08 & 1,8 & 4,5 & 0,14 & 5 & 23 \\
0,06 & 3 & 14 & 0,23 & 1,6 & 10 & 0,13 & 13 & 32 & 0,48 & 16 & 80 \\
0,03 & 1,5 & 7,5 & 1,0 & 7 & 43 & 0,023 & 2,3 & 6 & 0,10 & 3 & 17 \\
0,02 & 1 & 5 & 0,17 & 1 & 7 & $\mathrm{H}$ о & - & - & 0,45 & 15 & 75 \\
& & & & & & & & & & &
\end{tabular}

центрации ( $\mathrm{K}^{1}$ относительно городского фона, $\mathrm{K}_{c}^{2}$ - относительно регионального

тейного завода и у автомагистрали. Однако в первом случае он сочетается с оловом, которое у дорог не проявлено.

Марганец наблюдается повсеместно ( $\mathrm{K}_{\mathbf{c}}$ около 10 ), но очень контрастно выражен около чугунолитейного завода ( $\left.K_{c} 100\right)$. Содержания ванадия контрастно увеличены около всех «горячих» производств: ТЭЦ на мазуте, сталеплавильный и чугунолитейный цеха. Цинк проявлен стабильно на уровне в $7-10$ раз выше фона, но около чугунолитейного цеха и приборостроительного завода степень концентрации цинка много выше. Данные табл. 33 еще раз подчеркивают поликомпонентность атмохимических аномалий в городах, их высокую контрастность по отношению к более представительному региональному фону, специфичность ассоциации тяжелых металлов для различных типов источников загрязнения воздуха.

Общая пространственная структура загрязнения атмосферного воздуха - суммарный 'итог сложения атмохимических потоков всей существующей совокупности источников выбросов.

Прямое изучение распределения содержаний химических элементов в воздухе из-за динамических особенностей и невозможности синхронных наблюдений в достаточно большом количестве точек не позволяет при современном техническом уровне закартировать пространственную структуру загрязнения атмосферы.

В этой связи интересно проследить основные закономерности пространственного распределения химических элементов в воздушных потоках, определяющие размеры зон воздействия типичных для городов источников выбросов.

Такие закономерности выявляются главным образом по дан- 

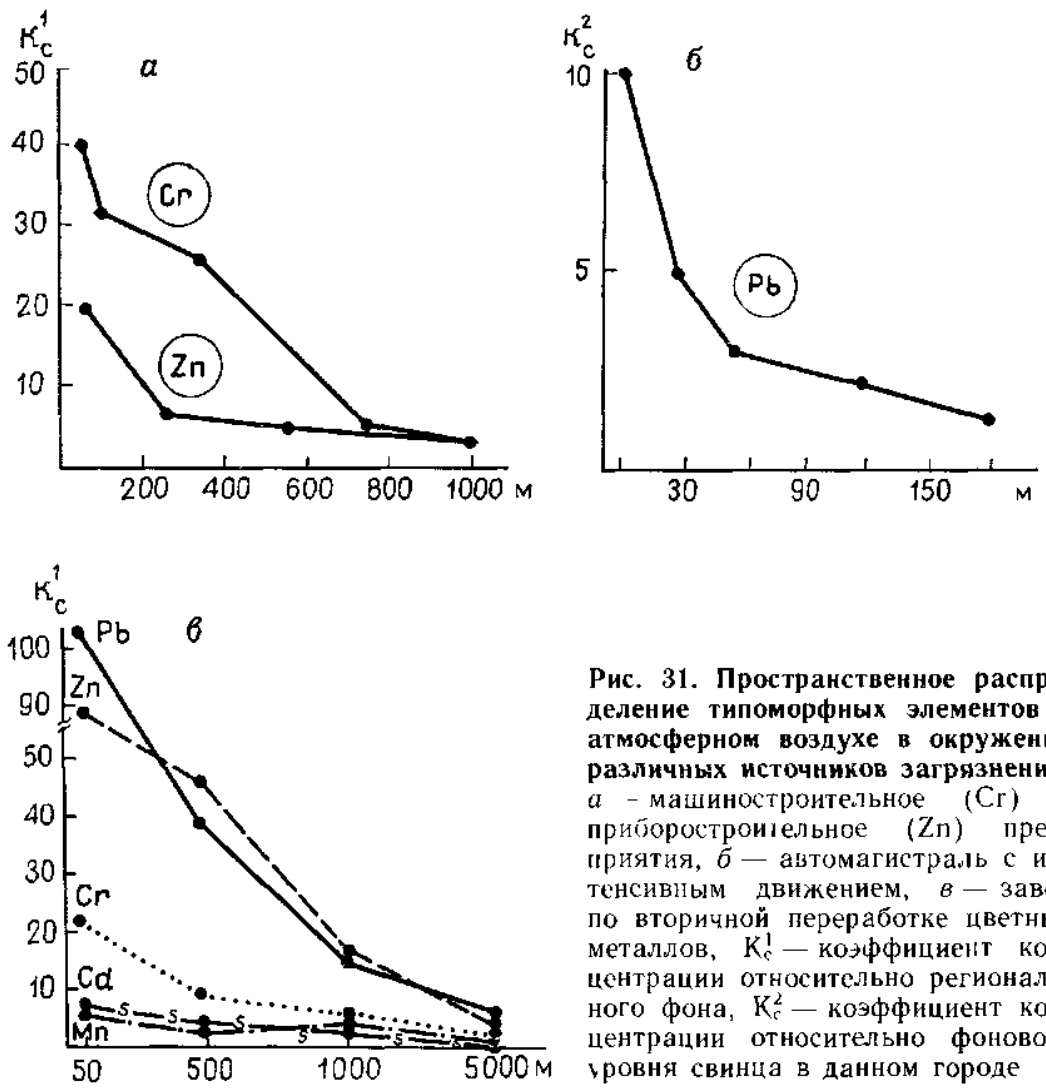

Рис. 31. Пространственное распределение типоморфных элементов в атмосферном воздухе в окружении различных источников загрязнения: $a$ - машиностроительное (Cr) и прио̆оростроиельное ( $\mathrm{Zn})$ предприятия, $\sigma$ - автомагистраль с интенсивным движением, $\quad B-$ завод по вторичной переработке цветных металлов, $\mathrm{K}_{c}^{1}-$ коэффнциент концентрации относительно региональ ного фона, $\mathrm{K}_{r}^{2}-$ коэффициент концентрации относительно фонового чровня свинца в данном городе

ным подфакельных наблюдений, т. е. синхронного опробования на различных расстояниях по направлению течения ветрового потока.

На рис. 31 демонстрируются графики пространственного распределения серии типоморфных химических элементов в воздухе для зон воздействия, характерных в городах видов производств (машиностроительных, приборостроительных, вторичной переработки цветных металлов), а также транспорта На рис. 32 представлены аналогичные графики для типичных мощных источников выброса - медеплавильного завода и мазутной ТЭЦ.

Для всех перечисленных источников выбросов мы наблюдаем близкий характер структуры распределения. Выделяется две зоны: ближняя, где происходит резкое убывание концентраций элементов, и дальняя - территория, где градиент значительно меньше и происходит плавное уменьшение содержаний до фоно- 


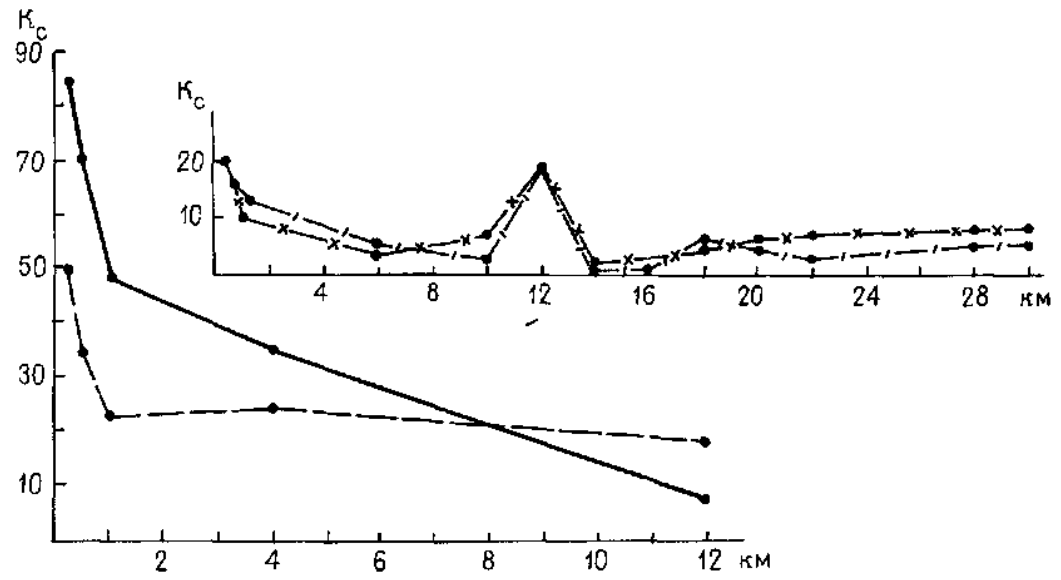

Рис. 32. Пространственное распределение химических элементов в атмосферном воздухе около ТЭЦ на мазутном топливе (вверху) и медеплавильного комбината.

$\mathbf{K}$, - коэффициент концентрации относительно регионального фона

вых Первая зона во всех случаях сравнительно небольшая вторая примерно на порядок больше.

Абсолютные размеры зон зависят от характера источника загрязнения. Для ТЭЦ и металлургических предприятий размеры первой (наиболее опасной по уровням загрязнения) зоны сотни метров, общие размеры потока достигают 15 км. Даже для небольших предприятий вторичных цветных металлов параметры аномалий примерно такие же. Для машиностроительных предприятий зона воздействия - первые сотни метров, для градостроения несколько меньше, для транспорта - десятки метров. Характерно, что зоны воздействия по тяжелым металлам и по выпадению осадков азота, серы, фтора, практически совпадают (рис. 33). Таким образом, типоморфные элементы-индикаторы достаточно точно фиксируют общую зону воздействия выбросов предприятия.

Анализ пространственных характеристик атмохимнческих потоков показал, что не во всех случаях они строго увязываются с факелом выброса. Так, в ходе синхронных динамических наблюдений в зоне влияния аккумуляторного завода повышенные содержания в воздухе фиксируются даже в тех случаях, когда факел выброса направлен в противоположную от места наблюдения сторону (рис. 34). Это может быть связано с несколькими причинами: неорганизованными выбросами, вторичным загрязнением приземного слоя воздуха частицами почв, неблагоприятными метеоусловиями, препятствующими рассеиванию примесей. Наблюдается и влияние ландшафта на уровень загрязнения 
$\kappa_{p}$
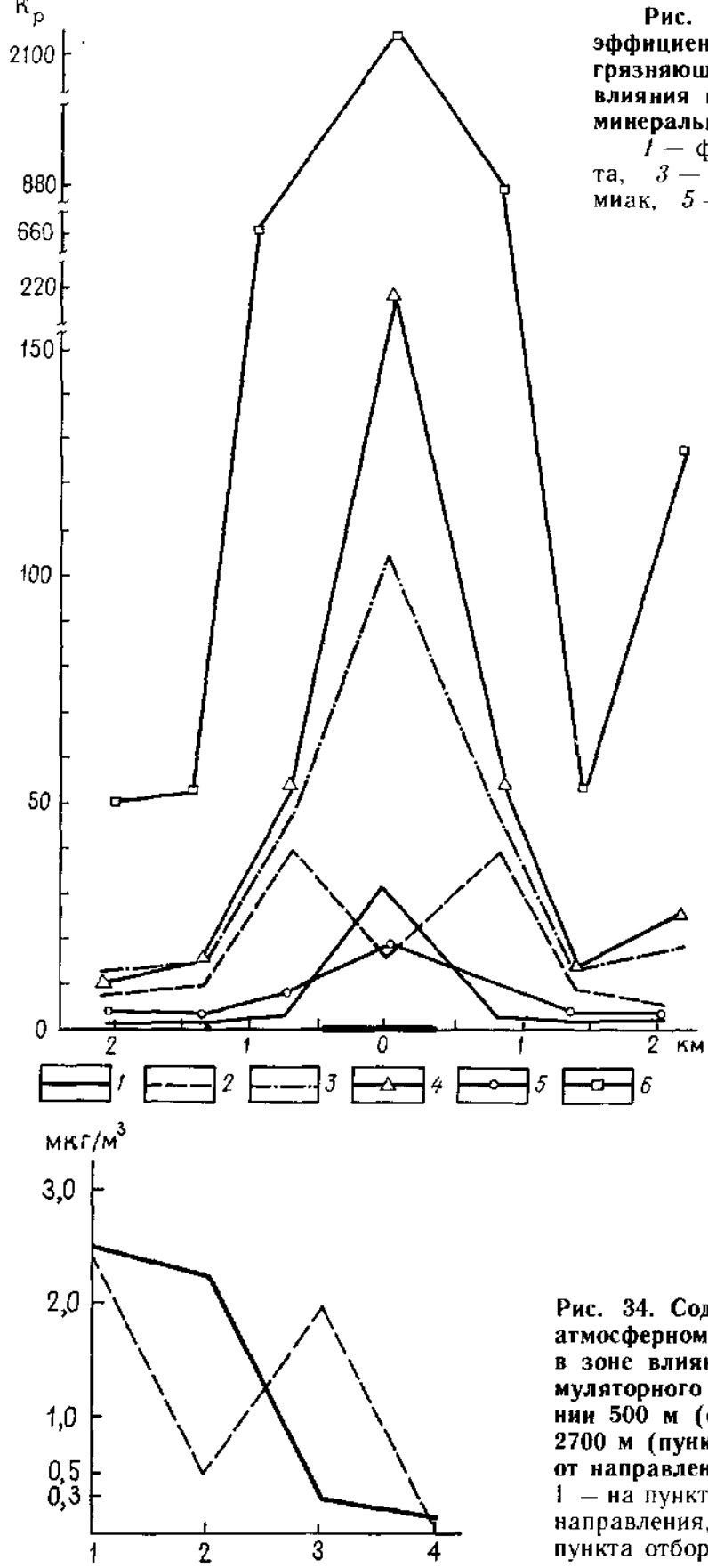

Рис. 33. Распрсцеление коэффнциентов нагрузки $K_{p}$ загрязняющих веществ в зоне влияния выбросов пронзводства 1 - фтор, 2 - дноксид азота, 3-сульфат-нон, 4-аммиак, 5 - пыль, 6 - стронций 
воздуха. В штилевой период (наиболее опасный для загрязнения воздуха) содержание свинца в низине увеличилось более значительно, чем на водоразделе. Этот пример хорошо иллюстрирует потенциальную опасность пониженных участков городских территорий. Во многих городах, построенных в долинах рек, центральные их части с плотной жилой застройкой наиболее загрязнены.

Атмохимические аномалии подразделяются на две основные части - ядро, где наблюдаются наиболее высокие концентрации, приуроченные к промышленной площадке и их ближайшему обрамлению (в основном 0,5 км от предприятий машиностроительного типа и до 1,5 км по метатлургическим комбинатам), и периферическую часть аномалии, где содержание химических элементов обычно не превышает гигиенических нормативов, но выше фоновых значений в несколько раз. В табл. 34 приведены обобщенные данные среднесуточных наблюдений по содержанию химических элементов в ядрах и перифериях аномалий около предприятий машиностроительного типа, типографий, предприятий приборостроения и для сравнения показаны концентрации в наиболее чистых, фоновых районах городов, являющихся по уровню загрязнения гереходными территориями между атмохимическими аномалиями и региональными фоновыми значениями. Мы видим, что в ядрах аномалий средние концентрации $\mathrm{Pb}, 2$, $\mathrm{Ni}, \mathrm{Cr}, \mathrm{Mn}$ в 17-63 раза выше значений регионального фона, а максимальные концентрации - в сотни раз. На периферии аномалий коэффициент превышения средних концентраций снижается до 3-14, но эпизодически возникающие максимальные концентрации (максимальные из среднесуточных) по большинству элементов выше фоновых значений в 12-33 раза, $\mathrm{Pb}-$ в 127 раз. В воздухе наиболее чистых районов города средние концентрации в основном в три раза выше фоновых. На этих территориях продолжают оставаться высокими максимальные концентрации металлов.

Соотношение площадей между структурными частями атмохимических аномалий в городах варьирует очень широко в зависимости от количества источников, планировочной структуры: имеющаяся сеть стационарных постов наблюдений за атмосферным воздухом не может выявить такую сложную мозаичную картину распределения металлов в атмосфере. В связи с этим трудно выделить и контингенты населения, подвергающиеся наибольшему воздействию загрязненного атмосферного воздуха. Способствовать решению этой задачи помогают исследования техногенных геохимических аномалий, фиксирующих выпадения химических элементов из атмохнмическнх потоков.

Использование в качестве индикатора загрязнения воздуха снежного покрова в этом же городе позволило выделить значительно более сложную и дробную структуру распределения химических элементов и пыли, причем аномалии фиксируются не 
Т а б.тиц а 34 Химические элементы в атмосферном воздухе города машино

\begin{tabular}{|c|c|c|c|c|c|}
\hline \multirow{2}{*}{ Геохнмическая ситуация } & \multirow{2}{*}{$\begin{array}{l}\text { Число } \\
\text { проб }\end{array}$} & \multicolumn{2}{|c|}{ Хром } & \multicolumn{2}{|c|}{ Марганец } \\
\hline & & $\mathrm{C}_{c p}$ & $K_{\leftarrow p}$ & $\mathrm{C}_{c, p}$ & $K_{c p}$ \\
\hline $\begin{array}{l}\text { Ядро аномалий около маши- } \\
\text { ностроительных, приборо- } \\
\text { строительных предприятии, } \\
\text { полиграфических производств, } \\
\text { опытных заводов }\end{array}$ & 302 & $0,12(3,10)$ & $20(516)$ & $0,28(4,18)$ & $22(322)$ \\
\hline $\begin{array}{l}\text { Периферические части ано- } \\
\text { малий около этих произ- } \\
\text { водств }\end{array}$ & 122 & $0,02(0,2)$ & $3(33)$ & $0,098(0,15)$ & $8(12)$ \\
\hline $\begin{array}{l}\text { Переходные территории - } \\
\text { фоновые районы города }\end{array}$ & 191 & $0,03(0,53)$ & $5(88)$ & $0,03(0,42)$ & $2(32)$ \\
\hline Региональный фон & 26 & 0,006 & 1 & 0,013 & 1 \\
\hline
\end{tabular}

Примечание $\mathrm{C}_{\mathrm{c} p}-$ средняя концентрация, $\mathrm{K}_{\llcorner p}-$ коэффициент концентрации среднею значения параметров

только около ТЭЦ или крупных промышленных зон, но и вблизи отдельно расположенных машиностроительных иредприятий. На карте распределения пыли (рис. 35), построенной на основе опробования снежного покрова по равномерной сети $1 \times 1$ км, четко выявляются основные источники пылевых выбросов - ТЭЦ, крупные машиностроительные предприятия. Зоны влияния отдельных промышленных предприятий машиностроительного типа или крупных промышленных объединений составляют $3-10$ км$^{2}$. Содержание пыли в снежном покрове более контрастно, чем в атмосферном воздухе. Так, среднесуточное выпадение пыли в различных районах этого города колеблется от 100 до $1000 \mathrm{kг} / \mathrm{kм}^{2}$, т. е. различается в 10 pаs. (в атмосферном воздухе только в $2-3$ раза).

Значительная контрастность прослеживается при рассмотрении распределения отдельных химических элементов или их суммы в снежном покрове (см. рис. 35). Сравнение карт распределения пыли и химических элементов в снежном покрове показывает, что зона влияния выбросов ТЭЦ, фиксируемая по выпадениям пыли, не выделяется по показателю $Z_{c}$ в связи с относительно низким содержанием в пыли изученного комплекса химических элементов. С другой стороны, выбросы машиностроительных производств насыщены металлсодержащей пылью, и около них проявляются аномалии химических элементов. На изученных территориях выделено 10 аномалий, а посты контроля воздуха расположены только в двух из них. Принятая в настоящее время система наблюдений за загрязнением воздуха на стационарных постах не обладает необходимой разрешающей способностью для выделения столь дробной структуры, как это возможно при исследовании структуры выпадений на земную поверхность. 
строительного типа, мкг $/ \mathbf{M}^{3}$

\begin{tabular}{|c|c|c|c|c|c|}
\hline \multicolumn{2}{|c|}{ Никель } & \multicolumn{2}{|c|}{ Цинк } & \multicolumn{2}{|c|}{ Свинец } \\
\hline$C_{i p}$ & $\mathbf{K}_{\mathrm{c} p}$ & $C_{c p}$ & $K_{(p)}$ & $C_{10}$ & $K_{\text {ip }}$ \\
\hline $0,07(2,6)$ & $17(260)$ & $0,47(5,50)$ & $20(239)$ & $0,19(1,80)$ & $63(630)$ \\
\hline $0,03(0,10)$ & $8(25)$ & $0,12(0,32)$ & $5(14)$ & $0,04(0,38)$ & $13(127)$ \\
\hline $0,02(0,41)$ & $5(102)$ & $0,07(0,43)$ & $3(19)$ & $0,02(0,19)$ & $7(63)$ \\
\hline 0,004 & 1 & 0,02 & 1 & 0,003 & 1 \\
\hline
\end{tabular}

содержания по отношению к региональному фону, в скобках хказаны максимальные

\section{Техногенные ореолы рассеяния}

Пространственная картина распространения техногенных потоков в условиях города наиболее четко устанавливается по изменению химического состава тех природных сред, которые надолго депонируют поступающие загрязняющие вещества. Прежде всего это относится к почве - наиболее устойчивому компоненту ландшафта.

Изучение распределения химических элементов в почвах, находящихся в зоне влияния выбросов различных промышленных предприятий, позволило определить характер и степень их загрязнения за счет выпадений из атмосферы.

В табл. 35 демонстрируются ассоциации химических элементов, наблюдавшиеся в центральных частях техногенных ореолов рассеяния, образовавшихся в зонах воздействия выбросов различных промышленных предприятий, достаточно типичных для современных урбанизированных территорий. Около большей части источников загрязнения техногенные ореолы в почвах представлены очень широкой и качественно сходной ассоциацией химических элементов: $\mathrm{Pb}, \mathrm{Cи}, \mathrm{Zn}, 5$ п, $\mathrm{W}, \mathrm{Mo}, \mathrm{Ni}, \mathrm{Co}, \mathrm{Cr}$, $\mathrm{Hg}$, Bi. Таким образом, современное производство сопровождается появлением комплексных полиэлементных аномалий. Расчеты суммарного показателя загрязнения $Z_{c}$ показывают, что особенно интенсивные аномалии в зоне воздействия предприятий цветной металлургии (средняя оценка $Z_{c}$ порядка 450), приборостр.ения $(280)$, и черной металлургии (240). Менее загрязнены почвы вблизи машиностроительных и химических предприятий $\left(Z_{c}\right.$ порядка $\left.80-85\right)$. Очень слабо проявлено загрязнение почв химическими элементами на территориях, примыкающих к предприятиям энергетики и строительной индустрии $\left(Z_{c} 10-\right.$ 



Рис. 35. Структура загрязнения выпадений на территории крупного города.

A - распределение суммарного показателя загрязнения $Z_{c}$ в снеговом покрове 1 - менее 32, 2-32-64, 3-64-128, 4-128-256

Б - среднесуточное выпадение пыли $\left(\right.$ кг $\left./ \mathrm{km}^{2}\right) \quad l$ - менее $160,2-160-320,3-$ $320-480,4-480-640,5-640-800,6-$ более 800 Буквы в кружках $M-$ машиностроительные предприятия, Э - энергетические предприятия (ТЭЦ)

20). Исследования состава почв в небольших промышленных городах, городах-спальнях (источники загрязнения - транспорт, котельни, предприятия общественного питания) показали, что структурированные в пространстве ореолы рассеяния здесь выражены плохо (за исключением участков скопления транспорта)

Здесь, как правило, наблюдаются мозаично распределенные точки со слегка (до $1,5-2,0$ раз) повышенным содержанием 
Т абли « а 35 Ассоциации химических элементов в почвенных аномалиях предприятий

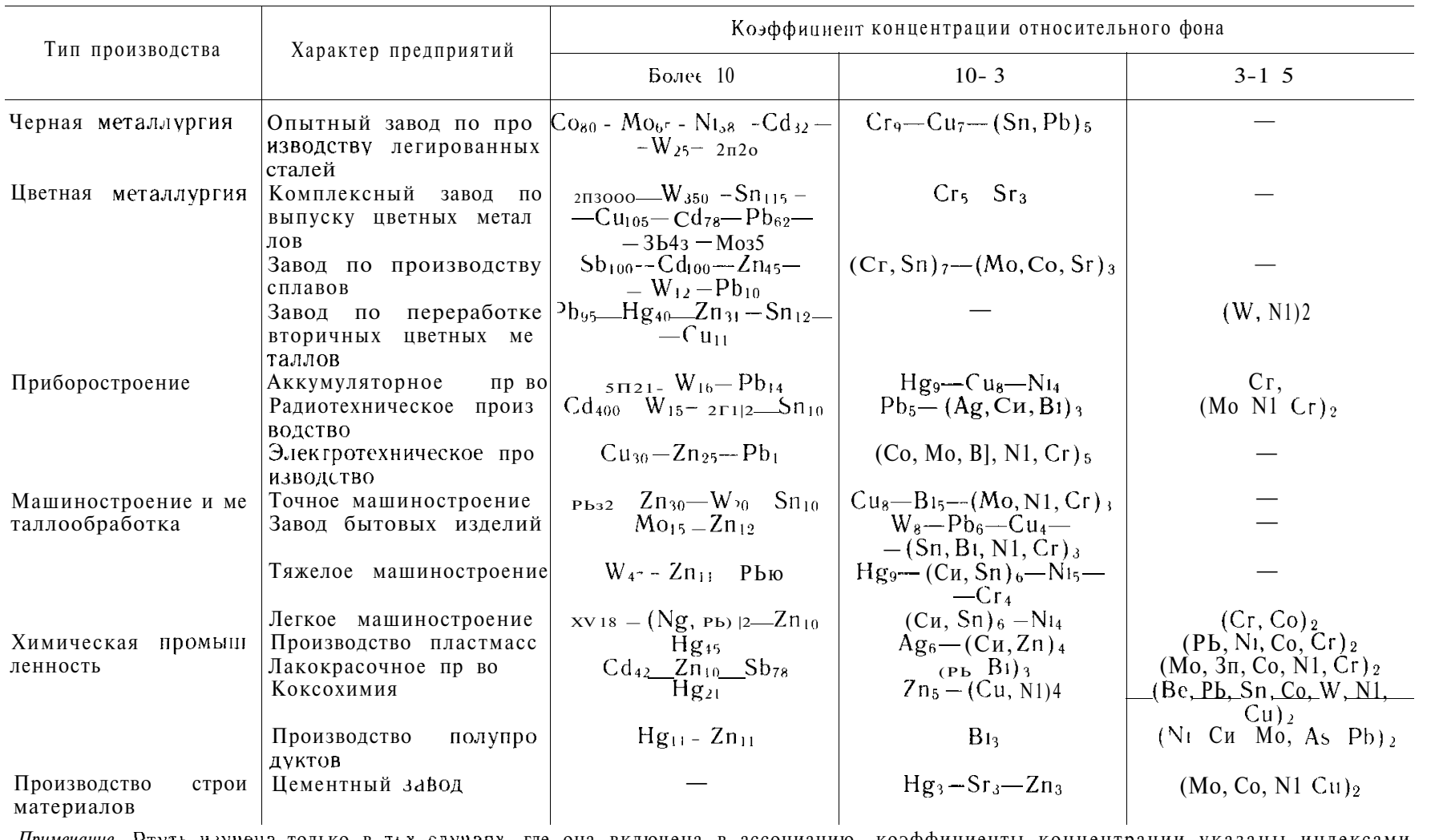

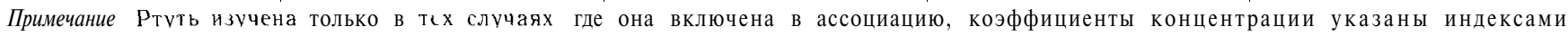
элементов 
$\mathrm{Pb}, \mathrm{Zn}$, иногда $\mathrm{V}, \mathrm{Cr}, \mathrm{Mo}, \mathrm{Ni}$. Суммарный показатель загрязнения почв в таких городах обычно около 8-10, что, вероятно, является бытовым селитебным «фоновым» уровнем.

Специфичность отдельных производств проявляется прежде всего в количественных характеристиках геохимической структуры ассоциации, в соотношениях между уровнями аномальностей тех или иных групп химических элементов. Например, упомянутая выше ассоциация химических элементов, наблюдаемая в городах-спальнях, типична для транспортных (бензин, дизтопливо) и энергетических (мазутные котельни) источников выбросов. Близкий комплекс элементов наблюдается и близ заводов черной металлургии. Однако уровни концентрации $\mathrm{Ni}$, Mo, Co, Сг здесь резко возрастают ( $\mathrm{K}_{r} 10$ и более).

В ряде случаев появляются и специфические типоморфные ассоциации, четко индицирующие то или иное предприятие. Так, интенсивные аномалии $\mathrm{W}$, Мо совместно с $\mathrm{C}_{\Gamma}$, Со отличают точное машиностроение, рассеянные элементы - Ge, Yn, 5e в сочетании с друг ими тяжелыми металлами и, особенно, Cd, Sn, Cu приборостроительные предприятия; F, TR, 8г - заводы по производству удобрений.

Морфоструктурные особенности техногенных ореолов довольно сложны и определяются характером источника загрязнения, метеорологическими условиями исследуемой местности, ее геоморфологическими особенностями и характером застройки. Материалов, детально характеризующих территориальную структуру техногенных ореолов, накоплено очень мало. Лишь для одиночно стоящих мощных источников загрязнения известны попытки схематично (серией геохимических профилей) получить представление о пространственных особенностях распределения загрязняющих веществ в атмосферных выпадениях, зафиксированных почвой и снеговым покровом.

Широкое использование более информативного метода площадного геохимического картирования природных компонентов окружающей среды позволило выявить морфологическую структуру техногенных ореолов рассеяния химических элементов от многочисленных источников загрязнения.

Рассмотрим особенности морфологии техногенных ореолов, связанных с наиболее типичными промышленными объектами городов. Основное внимание будет обращено на характеристику общих контуров ореолов и специфику их внутренней структуры, создаваемых всей совокупностью химических элементов, которые определяют повышенную нагрузку на окружающую среду. При этом еще раз напомним, что наиболее широкие по площади ореолы рассеяния образуют химические элементы, масса которых преобладает в техногенных выбросах, хотя содержание может быть и не очень высоким. Наиболее же контрастные ореолы по степени концентрации относительно фонового уровня связаны с элемен138 
тами, типоморфными для того или иного производства. Их содержание в выбросах весьма значительно.

Морфология ореола рассеяния в значительной степени определяется характером рельефа. На равнинных территориях они особенно широки по площади и обычно имеют структуру, близкую к концентрической: максимальное содержание металлов в ядре ореола, которое приурочено к источнику выброса. К периферической части ореола уровень содержания металлов постепенно убывает. Такие ореолы подробно описаны Н. Г. Зыриным. Л. И. Обуховым, Д. С. Орловым, С. Г. Малаховым, П. В. Елпатьевским и др.

На рис. 36 приведен пример техногенного ореола рассеяния химических элементов в почвах от крупного комбината по производству цветных и тугоплавких металлов. Комбинат расположен в условиях равнинного рельефа, что способствует широкому разносу загрязняющих веществ. Общая площадь ореола занимает около 400 км² $^{2}$ В образовании аномалии принимает участие широкий комплекс химических элементов $\mathrm{Pb}, \mathrm{Zn}, \mathrm{Cu}, \mathrm{Ag} . \mathrm{Cd}$, W, 5п, Mo, Sb, Bi. As.

Хорошо просматривается изометрическая форма ореола с центром максимального уровня загрязнения на территории одной из промплощадск завода. Высокий и опасный уровень загрязнения для человека, фиксируемый величиной суммарного показателя загрязнения почв 32 и выше (см. табл. 8), отмечается в радиусе 3-4 км на территории $100-120$ км. В зону опасной экологической ситуации наряду с городским населением попадают мелкие прилегающие населенные пункты, приусадебные участки, сельскохозяйственные и рекреационные земли.

Принципиально иной характер имеют ореолы рассеяния от предприятий цветной металлургии, которые находятся в горнодолинных ландшафтах (рис. 37). Формирование ореолов в таких условиях определяется долинными ветрами. Техногенный воздушный поток «локализуется» между горами, что определяет вытянутую по долине конфигурацию ореола.

Представленный на рисунке техногенный ореол от медеплавильного комбината также отличается широкой ассоциацией аномальных химических элементов (As, Си, Ag, 5b, Рb, 2п, Mo) . Создаваемый ими высокий и опасный для здоровья уровень загрязнения прослеживается на расстоянии $4-7$ км от комбината. А очень высокий и чрезвычайно опасный уровень целиком охватывает город, который в рассматриваемом случае (очень типичном) строился одновременно с комбинатом и в непосредственной близости к нему. Принимая во внимание интенсивное сельскохозяйственное освоение долин (что тоже характерно) можно ожидать, что и продукция не будет отвечать принятым нормативам. Таким образом, металлургические предприятия создают опасные экологические ситуации в радиусе $4-7$ км. 


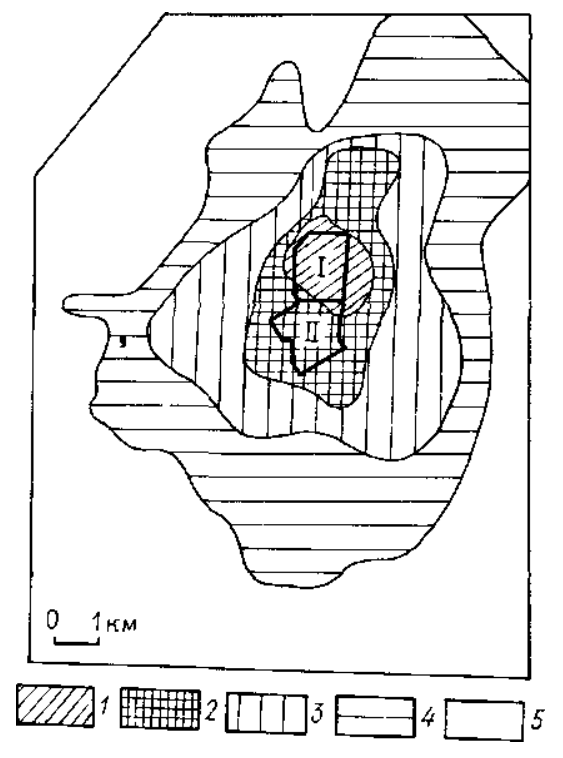

Рис 36. Техногенный ореол рассеяния в почвах зоны влияния металлургического комбината по производству цветных металлов:

I II - промышленные площадки 1 5 - контуры техногенных ореолов на городской территории по показателю загрязнения $Z_{c}$, суммирующему аэро генное накопление свинца, цинка, меди, серебра, кадмия, вольфрама, олова молибдена сурьмы, висмутаи мышьяка $(1-$ более $128,2-64-128,3-32-$ $64,416-32,5-$ менее 16)

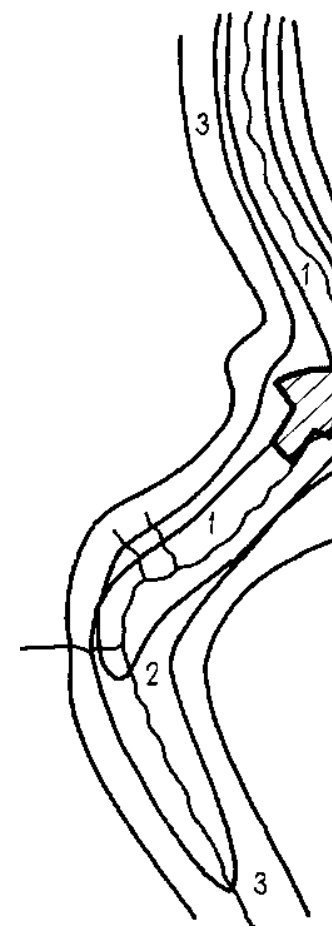

Рис. 37. Структура техногенного ореола в почвах в зоне влияния медеплавильного комбината в горно-долинном ландшафте.

$1-3$ - контуры техногенного ореола по показателю $Z_{\text {c }}$, сүммирующему аэрогенные концентрации мышьяка, сүрьмы, серебра, свинца, молибдена, меди, цинка (1 $64-256,2-32-64,3-16-32)$ 


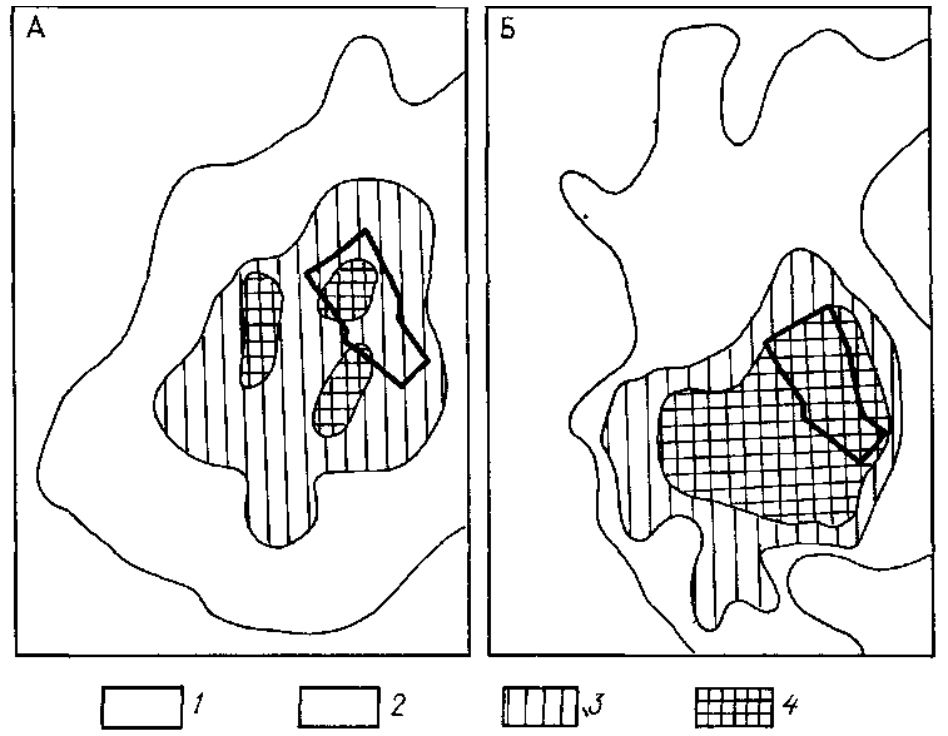

Рис. 38. Техногенный ореол рассеяния в почвах города в зоне влияния группы предприятий электротехнического профиля

1 -4-контуры техногенного ореола А - по показателю 2 суммирующему аэрогенное накопление свинца, цинка меди, ртути и олова ( 1 - менее 16,2 $16-32,3-32-128,4-$ более 128$)$, Б - по коэффнцненту концентрации свинца ( 1 - менее $32-3-6,36-10,4-10-30)$ фоновое содержание свинца $26 \mathrm{Mr} / \mathrm{kr}$

Рассмотренные металлургические производства являются представителями так называемых специализированных городов, для которых они явились градостроительной базой Предприятия же по переработке цветных металлов часто находятся в промышленных городах типа «центр» К таким металлоемким предприятиям можно отнести кабельное, аккумуляторное произ водство, заводы по обработке цветных металлов и др Образуемые ими мощные техногенные потоки по радиусу воздействия в ряде случаев практически не уступают выше описанным

На рис 38 приведен пример комплексной техногенной гео химической аномалии на равнинной территории в почвах города от блока предприятий с большим потреблением свинца Она имеет изометрическую форму Некоторая извилистость контуров наблюдается там, где аномалия проходит по сельскохозяйственным угодьям, и связана с разубоживанием концентраций во время перепахивания

Загрязнение, характеризуемое как среднее и умеренно опасное по суммарному показателю $Z_{c}(16-32)$, прослеживается до 7 км от источника Более высокий и опасный уровень для чело- 
века $(Z, 32-128)$ устанавливается в радиусе $4-5$ км от предприятий.

Загрязнение носит комплексный характер. Оно создается такими металлами как $\mathrm{Pb}, 2 п$, Си, $\mathrm{Hg}$ и 5п. Однако ведущую роль в этом процессе играет свинец. Об этом свидетельствует морфологическое сходство его ореола рассеяния с аддитивным ореолом, а также наибольшая относительная степень концентрации по сравнению с другими металлами (см. рис. 38).

Размер санитарно-защитных зон для таких промышленных объектов в городах, как правило, составляет около 1 км. Таким образом, по геохимическим данным в экологически неблагоприятных условиях оказываются жители районов за пределами этой зоны. Прямые определения содержания металлов в атмосферном воздухе жилых кварталов, удаленных до трех километров от предпрнягий, подтвердили существующий опасный уровень загрязнения окружающей среды.

К одной из ведущих отраслей промышленности в крупных городах можно отнести машиностроение. Создаваемые в зоне влияния машиностроительных заводов техногенные ореолы отличаются специфическим составом. Среди элементов концентрации появляются $W, M o$, в отдельных случаях - Be, Ti (типичные для легированных сталей). В то же время в ореоле присутствуют химические элементы, характерные для любого металлоемкого производства - 2п, РЬ, Си. Интенсивность проявления техногенных ореолов рассеяния вокруг машиностроительных заводов зависит от наличия в составе производства «горячих» литейных цехов.

Общая зона влияния машиностроительных объектов даже при наличии горячих цехов значительно более локальна, чем у металлургии. На рис 39 показан техногенный ореол рассеяния, проявленный в снеговом покрове от двух машиностроительных заводов авиационного профиля. Как и для большей части других источников, находящихся в сходных равнинных условиях, ореол имеет изоморфную структуру. Ядро ореола с максимальной концентрацией металлов занимает промышленные площадки и прилегающие территории в радиусе $200-400$ м. Общая зона фиксируемого влияния распространяется почти на 4 км. Однако по почвам ореол рассеяния химических элементов прослеживается на меньшей площади $(1-1,5$ км), но центрическая структура и комплексность состава геохимической аномалии сохраняется (см. рис. 39, б).

Высокий и опасный уровень загрязнения, отмеченный значениями суммарного показателя в почвах более 32 и в снеге более 128 , установлен на площади в радиусе 1,5 км. Это не исключает неблагоприятную экологическую ситуацию в жилых массивах, которые находятся в непосредственной близости от завода.

Приведенные примеры демонстрируют техногенные ореолы 




6

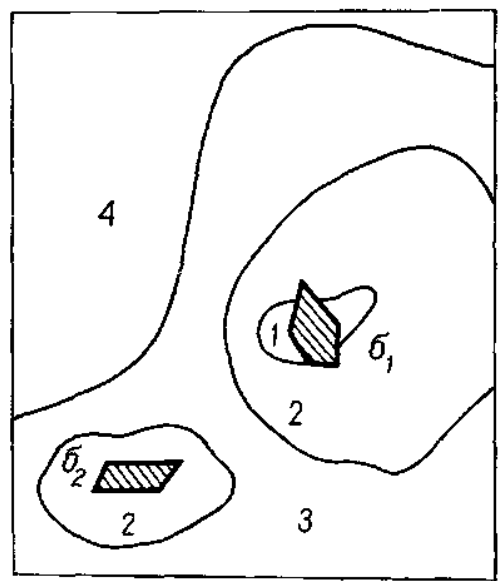

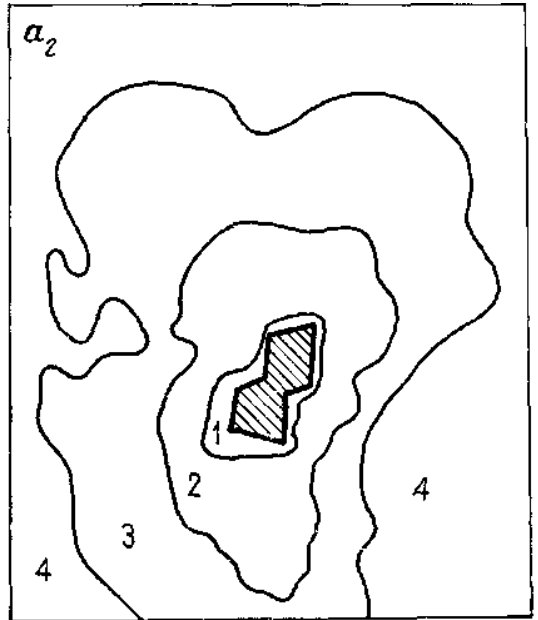

B
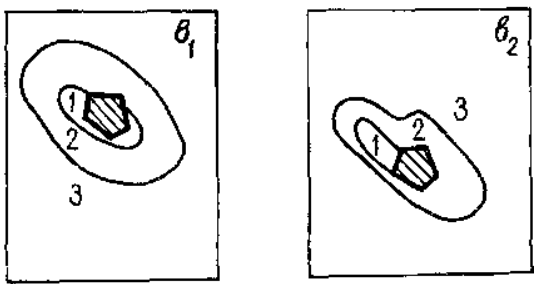

Рис. 39. Техногенные ореолы рассеяния вокруг предприятий точного машиностроения (А: $a_{1}-$ почвы, $a_{2}-$ снеговой покров), тяжелого машиностроения (Б: б] транспортное, $\sigma_{2}$ - станкостроительное), приборостроительных (В: $\theta_{1}$ - электроника, $\boldsymbol{B}_{2}-$ измерительная техника):

I-4- контуры зон ореолов, выделенные по суммарному показателю загрязнения комплексом типоморфнных для каждого предприятия химических элементов (А -

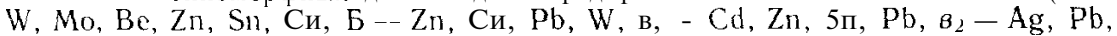
5п, Си, Zn, Ni, Cd) 
рассеяния от машиностроительных заводов, где существенную роль в образовании ореола играет выброс загрязняющих веществ. Значительно меньшую площадь занимают ореолы рассеяния от машиностроительных заводов с обработкой металлов только механическим способом (металлорезание, шлифование и т. д.). Образующаяся при этом грубодисперсная пыль осаждается вблизи таких заводов. Экологически опасная зона редко превышает $0,5-1$ км.

Техногенные ореолы рассеяния химических элементов в почвах образуются в зоне двух крупных заводов тяжелого машиностроения (см. рис. 39, в). Четко видно, что зоны их влияния меньше, а экологически опасный уровень высокого загрязнения не выходит далее чем за 400-1200 м от источника. Существенна уже и геохимическая ассоциация. Относительно фонового уровня здесь накапливаются 2п, $\mathrm{Pb}$, Си и $\mathrm{W}$.

Таким образом, с предприятиями машиностроительного профиля связано образование экологически опасных зон в радиусе не более $1,5 \mathrm{kм}$.

В современных крупных городах типа «центр» к наиболее распространенному виду производства можно отнести приборостроение. С геохимических позиций оно в экологическом отношении в принципе наименее опасно. Зона воздействия со средним и умеренно опасным уровнем загрязнения для здоровья человека устанавливается не далее чем на 200-600 м, а высокий и опасный всего лишь на $100-150$ м от источников (см. рис. 39, А,Б) .

Техногенный ореол рассеяния от приборостроительных предприятий представлен обычно чрезвычайно широкой ассоциацией химических элементов, который включает такие токсичные как $\mathrm{Cd}, \mathrm{Pb}, \mathrm{Ag}$. Интересно отметить появление экзотических элементов в геохимической ассоциации отдельных специализированных предприятий - In, Cs, Ge.

Несмотря на небольшие размеры зон загрязнения вокруг приборостроительных предприятий они могут иметь неблагоприятные последствия для населения. Это связано со спецификой размещения таких предприятий в городах - они, как правило, вкраплены среди жилых массивов.

Особо остановимся на двух видах загрязнения, которые проявлены в городах повсеместно и связаны с предприятиями энергетики и автотранспортом. Для ТЭЦ, работающих на угле, характерна большая масса выброса загрязняющих веществ с низким содержанием химических элементов. Таким образом, геохимические аномалии в почвах выражены обычно слабо. Главную опасность для здоровья населения здесь представляют пыль и оксиды серы. Ореолы рассеяния пыли четко фиксируются снеговым покровом.

На рис. 40, А показан ореол твердофазных выпадений из атмосферы от крупной ТЭЦ, потребляющей более 3 млн т угля 


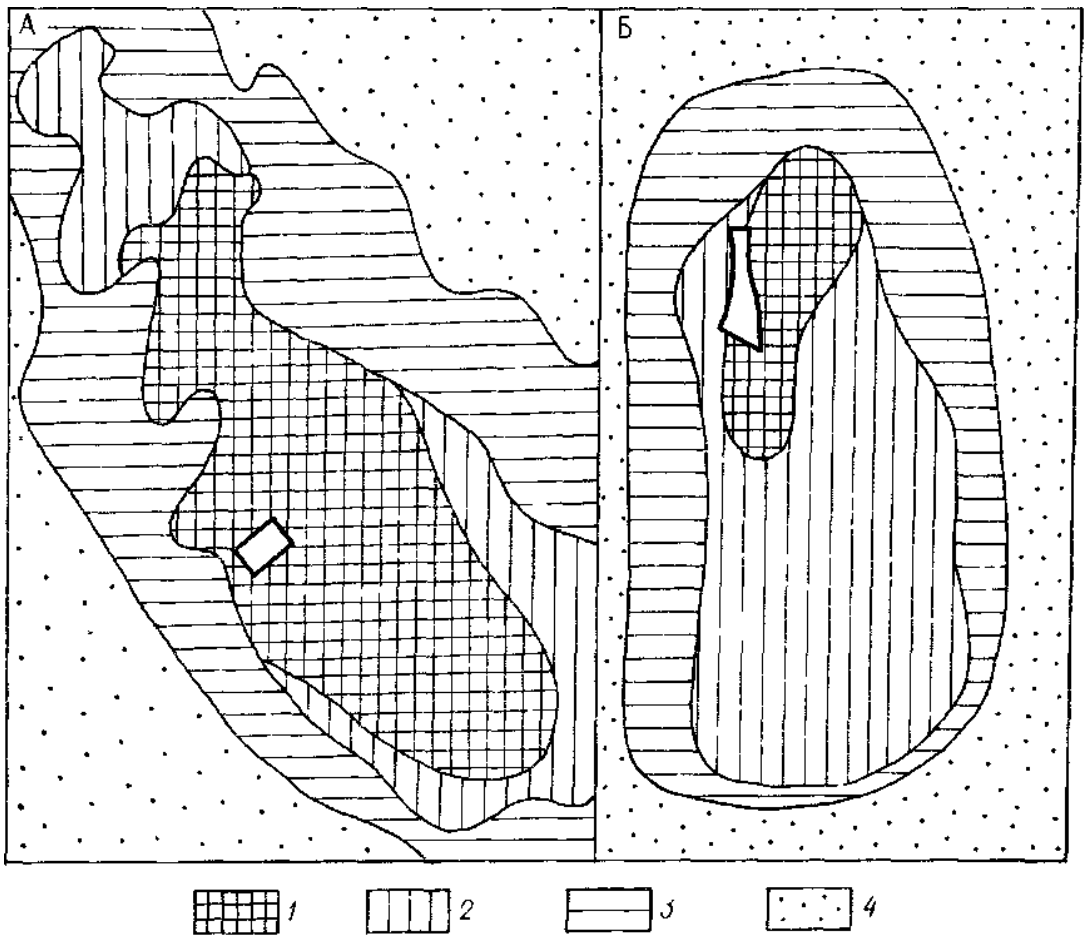

Рис. 40. Техногенные ореолы рассеяния в райопах ТЭЦ:

A - распределение пыли в зоне влияния угольной ТЭЦ, $1-4$ - nонтуры гехногенных аңомалий по уровню выпадення пыли (кг $/ \mathrm{km}^{2}$ в сттки) 1 более 800 , $2-640-800,3-480640,4-160-320$ Б распределение ванадия в зоне влияння мазутной ТЭЦ, $1-4-$ конгуры техногенных аномалии ванадия (г/км² в сутки। 1 - более $10,2-7-10,3-3-7,4-1-3$

ежегодно. Площадь ореола составляет около $400 \mathrm{kм}^{2}$, ч го позволяет по общему маснтабу воздействия сравнить ГЭЦ с крупным металлургическим комбинатом. При этом зона высокого и опасного уровня выпадения пыли (более $400 \mathrm{kr} / \mathrm{kM}^{2}$ в сутки) наблюдается на территории $75-120 \mathrm{~km}^{2}$.

Столь же крупные по потреблению топлива мазутные ТЭЦ не создают пылевой нагрузки на окружающую среду. Степень опасности воздействия таких объектов изучена плохо. Однако по ванадию (элементу-индикатору мазутных ТЭЦ) зона влияния прослеживается на 15 км в направлении господствующих ветров (см. рис. 40, б) при ширине ореола до 6 км Степень концентрации металла в 7--10 раз выше фонового уровня.

Выбросы ТЭЦ осуществляются обычно на большую высоту. чем другими предприятиями городов. Поэтому поля загрязнения, связанные с выпадением материала этих выбросов, лучше кор- 


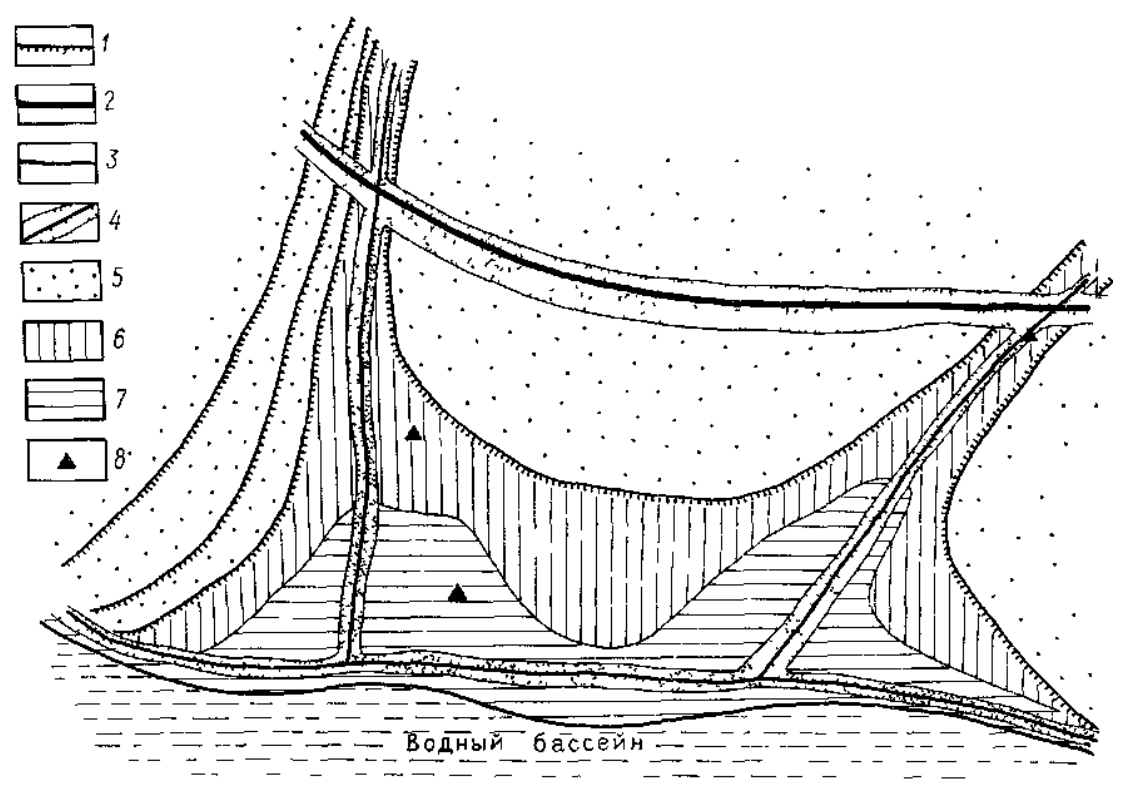

Рис. 41. Аномалии свинца в почвах города с интенсивной автомобильной нагрузкой около 1000 автомашин на квадратный километр в горно-долинном ландшафте. 1 - крутые склоны, 2 - шоссе основные, 3 - шоссе вспомогательные, 4 - линей ные аномалии свинца с содержанием в почве $250-500$ мг/hг, 5-7 - площадные аномалии свинца (5 - менее 250 мг/кг, 6-250-500 мг/кг, 7 - более 500 мг/кг), 8 - пункты, где установлены превышения ПДК свинца в атмосферном воздухе

релируют с розой ветров и имеют эллипсоидальный вид. Тем не менее, центры высоких концентраций и здесь пространственно приурочены к источнику загрязнения.

Несмотря на то. что большая часть крупных ТЭЦ расположена на окраине городов, с учетом радиуса их воздействия можно говорить о их значительном влиянии на экологическую обстановку. Кроме того, в городах находится много мелких котелен, которые вносят существенный суммарный вклад в их загрязнение.

Автотранспорт - один из хорошо известных и наиболее изученных источников загрязнения. В научной литературе описываются линейные придорожные аномалии, занимающие первые десятки метров от полотна дороги. В городах значительный интерес представляют большие по площади техногенные ореолы от автотранспорта, в образовании которых сказывается влияние ландшафтных условий.

На рис. 41 приведен пример такой аномалии свинца на территории города с горно-долинным амфитеатровидным характером рельефа. Особенности режима циркуляции воздуха в таких условиях привели к формированию широкого площадного ореола 
свинца в партерной части города за счет «стекання» выбросов автотранспорта в понижения рельефа.

Общая площадь ореола рассеяния свинца занимаег около $60 \%$ территории города. При этом высоко опасный уровень загрязнения наблюдается почги на половине этой площади.

Такое явление в распространении выбросов от автогранспорта практически никогда не учитывалось, хотя огромное количество городов, в том числе и крупных, имеют сходную ландшафтную структуру, способствующую конценграции выбросов от низких источников загрязняющих веществ

В обобшенном виде важнейшие типы источников загрязнения городов по размерам зон неблагоприятного воздействия (высокий и средний уровень загрязнения) могут быть ранжированы следующим образом: 1) металлургия и крупные ТЭЦ - 5-6 до 10 км; 2) машиностроенне - 1,5-2 км; 3) приборостроенне до $0,5 \mathrm{KM}$; автотранспорт - $0,1 \mathrm{Kм}$.

Мы рассмотрели основные морфологические особенности техногенных ореолов рассеяния загрязняющих веществ от отдельных промышленных объектов, определяющих неблагоприятную экологическую ситуацию в зоне их влияния. Для большей части городов характерно развитие многоотраслевой промышленности. Совокупное воздействие всех источников загрязнения прогнозируется с трудом. И только геохимическое картирование природных компонентов ландшафта городов позволяет оценить суммарный эффект влияния на окружаюшую среду различных производственных объектов. При этом важно отметнть, что ведущую роль в характере распространения загрязняюших вешеств при множественности источников загрязнения играет структура их размещения. Техногенные ореолы рассеяния химических элементов, сформировавшиеся при порфировицной и вкрапленной сгруктуре размещения промышленности, различны. Сравнение суммарного уровня загрязнения почв по величине $Z$. и площадного соотношения высокого и опасного уровня загрязнения $\left(Z_{\iota}\right.$ больше 32) указывает на экологически более неблагоприятную ситуацию при вкрапленной структуре, т. е. когда предприятия «рассыпаны» среди других функциональных зон.

В таких условиях происходит смешение техногенных ореолов от индивидуальных источников и создается высокий уровень загрязнения практически на всей территории, заключенной между предприятиями.

Для крупных городов предпочтительна порфировидная структүра размещения промышленности, при которой отдельные промышленные предприятия комплектуются в блоки, формирующие так называемые промышленные зоны. От других функциональных зон (селитебной, зеленой и др.) они должны быть отдетены буферной зоной, учитывающей размеры зон воздействия предпрнятий промзоны. В то же время для малых и специализи- 


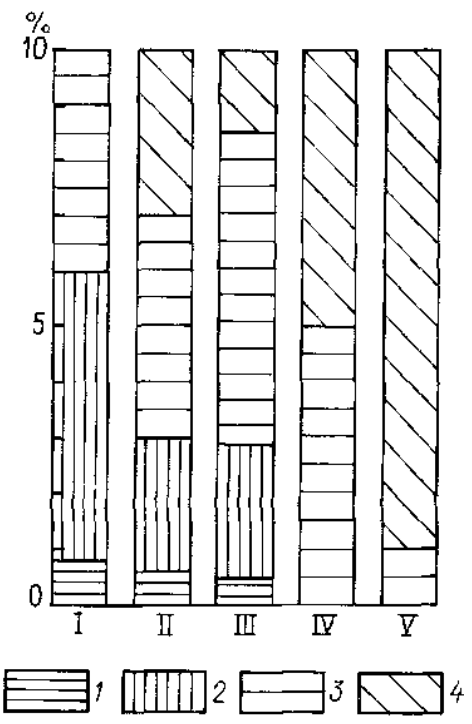

Рис. 42. Типичные структуры загрязнения территорий городов.

$I$ - 7 - уровни загрязнения: $I$ - чрезвычайно опасный $\left(Z_{i}\right.$ - более 128$)$, $2-$ опасный $\left(Z_{t}-32-28\right), 3-$ умеренно опасный $\left(Z_{c}-16-32\right), 4-$ неопасный (2, - менее 16) Типы городов I - специализированный металлургический, 【I - многоотраслевой типа «центр», III - автотранспортный, IV - машиностроительный, V - малый непромышленный

рованных городов эффективен только зональный тип функциональной структуры.

Геохимическая оценка состояния окружающей среды, проведенная более чем в 30 городах, позволила выявить типовые структуры загрязнения для трех основных групп городов: многоотраслевых типа «центр», специализированных и фоновых. В основу выделения структур положено соотношение площадей с различным уровнем загрязнения и степенью опасности для человека. Уровень загрязнения оценивался по четырем установленным категориям: огносительно чистая, умеренно опасная, опасная и чрезвычайно опасная (см. табл. 8).

Типовые структуры загрязнения городов представлены на рис. 42. Самая опасная экологическая обстановка характерна для городов с преобладанием в промышленности металлургического производства. Для некоторых из них почти вся территория может находиться в опасной зоне загрязнения химическими элементами. Уровень загрязнения, сказывающийся в городах с плохими ландшафтными условиями для рассеивания пылевыброCOB, даже Іири небольшой промышленности, но с интенсивным движением автотранспорта, соизмерим с уровнем загрязнения крупных городов с многоотраслевой промышленностью. В средних и малых городах с малозагрязняющими среду машиностроительными предприятиями структура загрязнения складывается вполне удовлетворительно. Опасных и чрезвычайно опасных ситуаций здесь практически нет.

Идеальные условия для жизнедеятельности человека наблюдаются в небольших городах с ограниченным развитием про148 
мышленности местного назначсния, в микрорайонах крупных городов, удаленных от предприятий на 5-10 км, в городахспальнях. Умеренно опасный уровень загрязнения обнаруживается не более чем на $10-20 \%$ территории. Основными загрязнителями выступают здесь мелкие котельни, автотранспорт, мастерские и т. д. Содержание в почвах таких элементов как V, Pb и Ag может быть в 1,5-2 раза выше фонового уровня. Суммарный же показатель загрязнения в городах фонового типа по почвам не превышает 8, по снегу - 64. Уровень выпадения пыли находится в пределах $30-100 \mathrm{kг} / \mathrm{kм}^{2}$ в сутки.

Пространственная геохимическая структура загрязнения в городах определяет особенность ответной реакции живых организмов на сложившийся уровень загрязнения, на его специфику, проявленную в преобладании среди загрязненных веществ тех или иных токсичных химических элементов.

\section{3. ТЕХНОГЕННЫЕ ПОТОКИ РАССЕЯНИЯ}

В общем случае влияние городов на водные системы определяется тремя основныги факторами: 1) вовлечением во влагооборот больших масс воды, которые после их использования, приобретая иной химический состав, сбрасываются в гидрографическую сеть; 2) климатическими изменениями, связанными с загрязнением атмосферы, нарушением теплового режима и воздушной циркуляции; 3) изменением условий формирования стока и характера русловых процессов.

Водоподача и водоотведение составляют главные элементы водного баланса городских территорий, резко изменяя его природные сосгавляюшие. Так, сопоставление водного баланса городских (Москва, Минск, Курск) и прилегающих сельских территорий показало, что под влиянием города полный речной сток возрастает на $20-97 \%$, подземный сток сокращается на $6-34 \%$, поверхностный сток увеличивается на $26-186 \%$, испарение снижается на 4-42\% [25]. Уменьшение доли подземного стока характерно для большей части городских территорий. Однако снижение испарения, увеличение поверхностного стока и большие объемы сточных вод приводят, как правило, к возрастанию расходов рек на выходе из города.

В городах за счет покрытий (асфальт, крыши домов и т. д.) проницаемость поверхности намного ниже, чем в естественных условиях. Площади непроницаемых для воды территорий во многом определяются размерами и благоустроенностью городов. Так, по данным Г. М. Черногаевой [12], для малых и средних городов с численностью населения менее 300000 человек они не превышают 20\%; в крупных городах их размеры возрастают до 30\%; в городах с населением более 1 млн человек колеблются от 35 до 80\%. Все это приводит к изменению коэффициента 
стока, который в условиях города значительно выше $(0,3-0,9)$, чем в естественных условиях (редко превышает $0,2-0,3$ ). В целом, наличие непроницаемых покрытий и дренажной сети способствует быстрому цобеганню поверхностных вод в местные бассейны стока.

Городские территории отличаются принципиально иным характером эрозии и твердого стока. Как правило, твердый сток в условиях города заметно увеличивается. Например, p. Потомак, имеющая в районе г. Вашингтон площадь водосбора


которых 1/5 часть поступаег с урбанизированных территорий, занимающих 1/50 площади водосбора [22]. Поставка твердого матернала осуществляется как со сточными водами, так и с поверхностным стоком. Поступление гвердого материала со сточными водами практически не учитывалось до недавнего времени. Однако простые расчеты показывают, что они являются существенным источником. Например, в р. Москву в пределах города сбрасывается примерно 5 млн м $^{3}$ сточных вод. Поскольку (по литературным данным) их средняя мутность составляет 10$15 \mathrm{mr} / \Omega$ (реально намного больше), то со сточными водами ежегодно поступает до 20-30 тыс. т взвешенного. материала. Модуль стока взвешенных наносов для данного природного

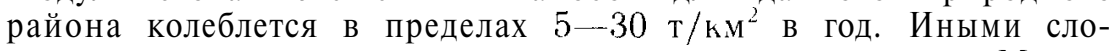
вами, с природного участка, равного по площади г. Москве $\left(900 \mathrm{~km}^{2}\right)$, может поступать до 4,5-27 гыс. т твердого вещества. Таким образом, поставка твердого материала со сточными водами не только соотносится с природной, но даже может заметно превышать еe.

Еще более значительные объемы поступают с поверхностным стоком, отличающимся высоким содержанием взвешенных веществ (до 2--6 г/л). Так, по данным американских авторов, сток наносов с водосборов, находящихся под застройкой колеблется от 300 до $2200 \mathrm{~T} / \mathrm{KM}^{2}$ в год, что превосходит смыв с естественных площадей в 2-100 раз, причем нижний предел относится к большим бассейнам, верхний - к малым [22]. В поверхностном стоке даже с наиболее благоустроенных городских территорий содержится в среднем 1400-1500 мг/л взвешенных веществ. Таким образом, с поверхностным стоком с территории г. Москвы может поступать до 500 тыс. т взвешенного материала ежегодно (исходя из среднегодового количества осадков 700 мм и коэффициента стока примерно 0,6), что во много раз превышает сток с естественных водосборов центра Русской равнины.

Территории городов существенно отличаются изменениями характера русловых процессов. В частности, происходит непосредственное изменение гидрографической сети. Это связано с целенаправленным преобразованием морфологии русел, берегов и пойм за счет мелиорирования территории, канализации или 
засыпки отдельных ее участков, создания каналов, плотин и других гидротехнических сооружений.

Специфический гидрологический режим, определяемый характером водного баланса и источников загрязнения, а также своеобразие руслового процесса в условиях города приводят к изменению геохимического облика водных систем в зоне его воздействия. Это проявляется как в общем их преобразовании (изменение основных физико-химических параметров воды и донных отложений, трансформация гидробиоценозов), так и в формировании техногенных потоков рассеяния химических элементов в различных компонентах водных систем. Характеристики потоков - состав, степень концентрации, формы нахождения, интенсивность водной миграцни и биологического поглощения химических элементов - определяют качество водной среды.

\section{Общий геохимический анализ состава техногенных потоков рассеяния}

В результате техногенного рассеяния происходят резкие изменения основных физико-химических и биологических параметров водных систем.

Главное изменение водных масс, связанное с воздействием городов, проявляется в перестройке их гидрохимического облика. Например, в пределах бассейна малой реки $\left(1700 \mathrm{~km}^{2}\right)$, испытывающей значительное техногенное воздействие, естественным фоном являются гидрокарбонатно-кальциевые воды с минерализацией не более 400 мг/л. В зонах загрязнения на значительных участках реки и ее притоков отмечено изменение не только типа и группы, но даже класса воды. Начинают преобладать гидрокарбонатно-натриевые, хлоридно-натриевые, сульфатнокальциевые, азотные воды. Таким образом, на сравнительно небольшой и однородной в ландшафтном отношении территории наблюдается резко выраженная мозаичность гидрохимического состава воды. Подобная пестрота в природных условиях практически не фиксируется.

Трансформация состава вод Іюросходит на общем фоне заметного возрастания минерализации воды. Это, в первую очередь, связано с увеличением содержаний хлоридов, сульфатов, калия, фосфатов, соединений азота, натрия (табл. 36). Во многих случаях отмечается переход вод из пресных в солоноватые, что приводит к появлению очень редко встречающихся в природе гидрокарбонатных вод с минерализацией свыше 1000 мг/л. Кроме того, отмечается значительная пространсгвенная и временная неоднородность распределения компонентов солевого состава воды на коротких интервалах времени, что связано с особенностями динамики поступления сточных вод и поверхностного сто- 
Т а бл и а 36 Интенсивность техногенных изменений макрокомпонентов поверх

\begin{tabular}{|c|c|c|c|c|c|c|c|c|c|}
\hline \multirow{2}{*}{ Источник здгрязнения } & \multirow{2}{*}{$\mathrm{pH}$} & \multicolumn{2}{|c|}{$\mathrm{HCO}$, } & \multicolumn{2}{|c|}{$\mathrm{SO}_{4}$} & \multicolumn{2}{|c|}{$\mathrm{Cl}$} & \multicolumn{2}{|c|}{$\mathrm{NJ}_{3}^{-}$} \\
\hline & & чг $/$ i & $\mathrm{K}$ & $\mathrm{MF} / \mathrm{s}$ & $K_{e}$ & ч г/л & $\mathrm{K}$, & ч г/л & $\mathrm{K}$, \\
\hline Средний город (ирупный & 7,2 & 357 & 1,2 & 74 & 4,9 & 119 & 11,9 & 15 & 7,5 \\
\hline $\begin{array}{l}\text { промышленный центр) } \\
\text { Средний город (металлооб } \\
\text { работка и машноостооение) }\end{array}$ & 6,8 & 333 & 1,1 & 73 & 4,9 & 1344 & 134 & 4 & 2 \\
\hline $\begin{array}{l}\text { Средний город (крупный } \\
\text { промышленный центр) }\end{array}$ & 7,1 & 317 & 1,1 & 52 & 3,5 & 89 & 6,9 & 8,8 & 4.4 \\
\hline $\begin{array}{l}\text { Малый город (химический } \\
\text { хавод) }\end{array}$ & 6,2 & 363 & 1.2 & 91 & 6,1 & 255 & 25,5 & 3,5 & 1,8 \\
\hline $\begin{array}{l}\text { Малый город (коксохимиче- } \\
\text { ский завод) }\end{array}$ & 6.3 & 262 & 0,9 & 159 & 10,6 & 161 & 16,1 & 7,5 & 3,65 \\
\hline $\begin{array}{l}\text { Малый город (научный } \\
\text { центр физического направле- } \\
\text { ния) }\end{array}$ & 6,7 & 357 & 12 & 35 & 2,3 & 49 & 4.9 & 16 & 8 \\
\hline Свалка промышленных и бы- & 7,6 & 574 & 2,0 & 160 & 10,7 & 1764 & 176,5 & 1 & 2 \\
\hline товых отходов со стоком в & 7,7 & 235 & 0,9 & 76 & 3,7 & 1498 & 119,8 & 8 & 4 \\
\hline разные водотоки & 8,7 & 9,5 & 0,3 & 79 & 5,3 & 6317 & 631,7 & 2 & 1 \\
\hline $\begin{array}{l}\text { Малый город (машинострое- } \\
\text { ние) }\end{array}$ & 7,0 & 280 & 1,0 & 70 & 4,7 & 66 & $\underline{6,6}$ & 9 & 4,5 \\
\hline
\end{tabular}

Примечания $\mathrm{pH}$ фонового водотока 7,91. К

рнциент копнентрании относитетьно

ка, а также с пространственным положением источников загрязнения.

Одна из ярких особенностей техногенных потоков рассеяния увеличение количества дисперсных частиц (мутности), что имеет принципиальное геохимическое значение. Техногенная взвесь по сравнению с природной резко обеднена оксидами кремния и обогащена оксидами железа, кальция, магния и органическим веществом (табл. 37). Для нее также характерна резко выраженная неравномерность распределения во времени.

Техногенно загрязненные воды отличаются своеобразными изменениями $\mathrm{pH}$ и Eh среды, электропроводности воды. газового и температурного режима и других физико-химических характеристик. К сожалению, эти параметры для условий загрязнения изучены недостаточно полно, а их характер трудно предсказуем и зависит от целого ряда различных факторов. В то же время они во многом определяют поведение химических элементов в водных системах и их эколого-токсикологическое значение. В частности, для зон загрязнения в урболандшшфтах характерно широкое развитие термофикации (тепловое загрязнение) вод. Известны сообщения о том, что в условиях повышенных температур токсическое воздействие некогорых металлов может быть более острым и быстрым, они активнее включаются в пищевую цепь.

Для загрязненных вод характерно присутствие разнообразных синтетических органических веществ - фенолов, нефтепро- 


\begin{tabular}{|c|c|c|c|c|c|c|c|c|c|c|c|c|c|}
\hline \multicolumn{2}{|c|}{$\mathrm{NO}_{2}$} & \multicolumn{2}{|c|}{$\mathrm{PO}_{4}^{3}$} & \multicolumn{2}{|c|}{$\mathrm{Nd}^{+}$} & \multicolumn{2}{|c|}{$\mathrm{Ca}^{2}$} & \multicolumn{2}{|c|}{$\mathrm{Mg}^{+}$} & \multicolumn{2}{|c|}{$\mathrm{K}^{-}$} & \multicolumn{2}{|c|}{$\begin{array}{l}\text { Общая мине } \\
\text { ры.ाияция }\end{array}$} \\
\hline $\mathrm{Mr} / \mathrm{J}$ & $K_{r}$ & $\mathrm{Mr} / \mathrm{J}$ & $\mathrm{K}$, & $\mathrm{M} \Gamma / \pi$ & $k_{c}$ & $\mathrm{Mr} / \mathrm{J}$ & K & иг $/ .1$ & K & $\mathrm{M} \Gamma / \mathrm{I}$ & $\mathrm{K}_{\mathrm{e}}$ & $\mathrm{MI} / \pi$ & K. \\
\hline 0,6 & 30 & 5,0 & 250 & 95 & 7,8 & 80 & 1.3 & 2,7 & 1,6 & 17 & 17 & 810 & 1,9 \\
\hline 0,4 & 20 & 1,5 & 75 & 768 & 64 & 134 & 2,2 & 42 & 2,5 & 54 & 54 & 2773 & 5,4 \\
\hline 0,6 & 30 & 5,8 & 290 & 81 & 6,8 & 65 & 1 & 18,5 & 1,1 & 18,5 & 18,5 & 663 & 1,5 \\
\hline 0,07 & 3,5 & 6,3 & 315 & 223 & 18,6 & 67 & 1 & 21 & 1,2 & 12 & 12 & 1062 & 2,5 \\
\hline 0,03 & 1,5 & 1,4 & 70 & 102 & 8.5 & 95 & 1,5 & 31 & 1,8 & 12 & 12 & 858 & 1,9 \\
\hline 8 & 400 & 15 & 750 & 57 & 4,8 & 69 & 1 & 25 & 1,5 & 12 & 12 & 663 & 1,5 \\
\hline 1,2 & 60 & 3,5 & 175 & 899 & 75 & 274 & 4,4 & 54 & 3,2 & 19 & 19 & 3764 & 3,7 \\
\hline 0,9 & 45 & 5 & 250 & 816 & 63 & 161 & 2,6 & 42 & 2,5 & 55 & 55 & 2345 & 6,8 \\
\hline 1,5 & 75 & 0,02 & 1 & 2434 & 203 & 256 & 4,1 & 84 & 4,3 & 2200 & 2200 & 11497 & 27 \\
\hline 1,1 & 55 & 4 & 20 & 54 & 3,7 & 73 & 1,2 & 22 & 1,3 & 9,5 & 9,5 & 604 & 1,4 \\
\hline
\end{tabular}

фонового содержания, поднеркиты компонеит, значительии преныпдюпие фон

Таб 6.7 и д 37 Химический состав (в \%) твердого взвешенного вещества и донных отложений малой реки

\begin{tabular}{|c|c|c|c|c|c|c|}
\hline Место отбора проб & $\mathrm{S}_{1} \mathrm{O}_{2}$ & $\mathrm{~T}_{1} \mathrm{O}_{2}$ & $\mathrm{Al}_{2} \mathrm{O}_{3}$ & $\mathrm{Fe}_{2} \mathrm{O}_{3}$ & reo & $\mathrm{MnO}$ \\
\hline \multicolumn{7}{|c|}{ Взвешенное вещество } \\
\hline Ниже очистных сооружсний & 28,3 & 0.40 & 5,50 & 4,16 & 3,20 & \\
\hline $\begin{array}{l}\text { города } \\
20 \text { км ниже города }\end{array}$ & 67.74 & 0,67 & 9,47 & 1,73 & 2,60 & 0,29 \\
\hline \multicolumn{7}{|c|}{ Донные огложения } \\
\hline $\begin{array}{l}\text { Ниже очистных сооружений } \\
\text { города }\end{array}$ & 69,92 & 0,40 & 6,20 & 3,21 & & 0,08 \\
\hline Выше города & 83,75 & 0,22 & 4,43 & 1,94 & - & 0,003 \\
\hline Место отбора проб & $\mathrm{MgO}$ & $\mathrm{CaO}$ & $\mathrm{Na}_{2} \mathrm{O}$ & $\mathrm{K}_{2} \mathrm{O}$ & $\mathrm{P}_{2} \mathrm{O}_{3}$ & ПІ1ГІ \\
\hline
\end{tabular}

\section{Взвешенное вещество}

\begin{tabular}{l|c|c|c|c|c|c} 
Ниже очистных сооружений & 2,32 & 8.14 & 0,88 & 1,15 & & 41 \\
$\begin{array}{l}\text { города } \\
20 \text { км ниже города }\end{array}$ & 1,84 & 3,90 & 0,80 & 2,12 & 0.7 & 8,0
\end{tabular}

\section{Донные отложения}

\begin{tabular}{l|c|c|c|c|c|r} 
Ниже очистных сооружений & 0,42 & 5,44 & 0,72 & 1,97 & 0.69 & 4,90 \\
$\begin{array}{l}\text { города } \\
\text { Выше города }\end{array}$ & 0,50 & 2,73 & 0,57 & 1,12 & 0,39 & 1,2
\end{tabular}

Примечание ППП - потери при прокаливании « »-компонент не определялся 
дуктов, ПАВ и других, которые оказывают огромное влияние на миграцию химических элементов. В таких водах заметно снижается относительное содержание природных органических веществ типа «водный гумус», но резко увеличивается доля органики техногенного происхождения, что имеет определенные геохимические последствия. Например, фенолы играют существенную роль в процессах аккумуляции тяжелых металлов высшими водными растениями; поверхностно активные вещества способны формировать устойчивые хелаты с химическими элементами и оказывать на них десорбирующее действие. В последнее время выявлен новый фактор в загрязнении водных систем так называемая редистрибуция (перераспределение) основных загрязняющих веществ, обусловленная присутствием ПАВ и заключающаяся в переходе химических веществ из объема воды на ее поверхность с формированием поверхностной пленки микроскопической толщины, обладающей повышенной реакционной способносьью и отличающейся чрезвычайно высокими содержаниями различных загрязняющих веществ, в том числе тяжелых металлов.

Существенные изменения отмечаются и в другом важнейшем компоненте водных систем - донных отложениях, определяющих многие важные черты геохнмии природных вод.

В водоемах и водотоках в зонах влияния городов отмечаются своеобразные донные отложения - техногенные илы, для которых характерны тонкодисперсный состав, повышенная пластичность, иногда желеобразная консистенция, наличие частиц техногенного происхождения, маслянистость, специфический запах (фекальный, нефтяной, сероводородный), окраска темных и пепельных тонов. Самые верхние слои таких илов (10-20 см) часто представляют собой коллоидную массу (суспензию или гидрозоль). Участки русла с подобными илуми могут прослеживаться на десятки километров даже в средних и крупных реках. Они могут выстилать значительные части современного русла рек, достигая мощности в несколько метров. В сравнении с фоновыми условиями в их грануломегрическом составе отмечаются заметные изменения (табл. 38). В пределах города происходит увеличение доли крупного песка (влияние поверхностного стока) и глинистой фракции (сточные воды предприятий). Ниже очистных сооружений заметно преобладают фракции алеврита и глинистых частиц. Изменения в минералогическом составе проявились в уменьшении количества кварца и в увеличении содержания карбонатных минералов, лимоннтизированных обломков и гидроксидов железа. Техногенные илы обогащены органическим веществом, карбонатами, оксидами и гидроксидами железа и алюминия (см. табл. 37), а также повышенными количествами органических загрязняющих веществ - нефгепродуктов, ПХБ и др. 
Т аблиц а 38. Механический состав (в \%) донных отложений малой реки в зоне влияния города

\begin{tabular}{|c|c|c|c|c|c|}
\hline \multirow{3}{*}{ Участок реки } & \multicolumn{5}{|c|}{ Состав отложений в \% (размеры фракции в им) } \\
\hline & \multirow{2}{*}{$\begin{array}{c}\text { Крупный } \\
\text { песок } \\
(1-0,25)\end{array}$} & \multirow{2}{*}{$\begin{array}{c}\text { Мелкий } \\
\text { песок } \\
(0,25-0,1)\end{array}$} & \multirow{2}{*}{$\begin{array}{c}\text { Алекриг } \\
(U, 1 \quad 0,01)\end{array}$} & \multicolumn{2}{|c|}{ Гілина } \\
\hline & & & & $(0,01-0,005)$ & $(<0,005)$ \\
\hline $\begin{array}{l}\text { Выше города (фон) } \\
\text { Центр города } \\
\text { Ниже очистных соом } \\
\text { жении города }\end{array}$ & $\begin{array}{l}19,8 \\
29 \\
8,7\end{array}$ & $\begin{array}{l}53,1 \\
34,9 \\
33,5\end{array}$ & $\begin{array}{l}26,2 \\
33,4 \\
49,2\end{array}$ & $\begin{array}{r}0,5 \\
1,3 \\
3,8\end{array}$ & $\begin{array}{l}0,4 \\
1,4 \\
4,8\end{array}$ \\
\hline
\end{tabular}

В поверхностных водных объектах идет активный процесс формирования особых донных отложений - техногенных илов, образование которых в первую очередь связано с увеличеннной поставкой техногенной взвеси и ее последующим перераспределением в руслах и акваториях. Техногенные илы - основная арена развития техногенных потоков рассеяния химических элементов.

Многочисленные литературные данные свидетельствуют о высоких содержаниях химических элементов в различных компонентах водных систем в связи с их техногенным преобразованием [27, 34, 50]. К сожалению, круг изучаемых элементов не очень широк, тогда как практически все виды человеческой деятельности и производства, связанные с городами, образуют отходы, содержащие разнообразный комплекс химических элементов.

В табл. 39 приведены упорядоченные по величине коэффициентов концентрации ряды распределения химических элементов в донных отложениях водотоков, дренирующих различные типы поселений и промышленных предприятий. Это позволяет выявить и сравнить формирующиеся здесь техногенные геохимические ассоциации. Исследования проводились в пределах крупного экономического района, отличающегося достаточно однородным .тандшафтно-геохимическим строением. Как видим, техногенные потоки рассеяния в городах характеризуются широким комплексом химических элементов и очень высокими концентрациями многих из них Качественный анализ техногенных геохимических ассоциаций в целом слабо выявляет специфику отдельных производств, промышленных зон или городов, поскольку обширная группа микроэлементов характерна для большинства объектов. В то же время, несмотря на видимую качественную близость состава, количественные соотношения целого ряда элементов как внутри ассоциации, так и по отношению к ассоциациям других источников загрязнения заметно различны. В peзультате аномалия каждого конкретного объекта обладает специфическим геохимическим обликом. 
Т а бл и ц 39. Ассоциации химических элементов в донных отложениях

\begin{tabular}{|c|c|c|c|c|c|c|}
\hline \multirow{2}{*}{ Тип поселения } & \multirow{2}{*}{$\begin{array}{l}\text { Основные виды } \\
\text { промышленностн } \\
\text { или производства }\end{array}$} & \multicolumn{5}{|c|}{ Қоэффициент концентрации К. } \\
\hline & & Более 100 & $100 \quad 80$ & $30 \quad 10$ & 103 & $3-1,5$ \\
\hline \multirow[t]{2}{*}{$\begin{array}{l}\text { Города с населени- } \\
\text { ем } 100 \text { тыс. человек }\end{array}$} & $\begin{array}{l}\text { Тяжелое машиностро- } \\
\text { енис, металлообработ- } \\
\text { ка, кабельная, акку- } \\
\text { муляторная, строи- } \\
\text { тельная, пищевая про- } \\
\text { мышленность и др. }\end{array}$ & $\mathrm{Hg} g_{317} \mathrm{Ag}_{153}$ & $\mathrm{Cd}_{60} \mathrm{Zn}_{33}$ & $\begin{array}{c}\mathrm{Cu}_{20} \mathrm{Ni}_{21} \mathrm{~Pb}_{22} \mathrm{Snl}_{15} \\
\mathrm{Sb}_{14} \mathrm{Se}_{11}\end{array}$ & 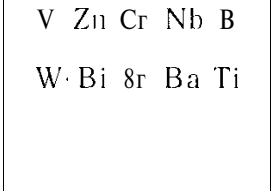 & Co Be Mo 8c Yb $\mathrm{P}$ \\
\hline & $\begin{array}{l}\text { Металлообработка, } \\
\text { химическая, текстиль- } \\
\text { ная, окраска тканей, } \\
\text { электронная, строи- } \\
\text { тельная промышлен- } \\
\text { ность }\end{array}$ & $\mathrm{Ag}_{921} \mathrm{Hg}_{398}$ & $\begin{array}{c}\mathrm{Bi}_{48} \mathrm{Zn}_{44} \mathrm{CO}_{38} \\
\mathrm{Ni}_{36} \mathrm{P}_{31}\end{array}$ & $\mathrm{Cd}_{17} \mathrm{Sr}_{14} \mathrm{Cr}_{11}$ & $\mathrm{Sr} \mathrm{Pb} \mathrm{Ba} \mathrm{Co}$ & W Mo V Mn \\
\hline \multirow[t]{5}{*}{$\begin{array}{l}\text { Города с населени- } \\
\text { ем } 30-100 \text { тыс.че- } \\
\text { ловек }\end{array}$} & $\begin{array}{l}\text { Металлообработка, } \\
\text { машиностроение, } \\
\text { строительная про- } \\
\text { мышлешность }\end{array}$ & $m$ & $\mathrm{Ag}_{41}$ & $\mathrm{Cd}_{12} \mathrm{Ce}_{11}$ & $\begin{array}{l}\mathrm{Zn} \mathrm{Hg} \mathrm{Sb} \\
\mathrm{S} n \mathrm{~Pb} \mathrm{Sc}\end{array}$ & $\begin{array}{c}\text { PCi 8c } 8 \text { г 7r TiCo } \\
\text { Bi } \mathrm{Ni} \mathrm{Ba}\end{array}$ \\
\hline & Экскаваторный завод & - & $\mathrm{HE}_{37}$ & - & $\mathrm{Pb} \mathrm{Ag} \mathrm{Sr} \mathrm{Ba}$ & ( 11 Zn мо Мп \\
\hline & $\begin{array}{l}\text { Коксохимический } \\
\text { комбипат }\end{array}$ & - & - & $\mathrm{Hg}_{15}$ & $\operatorname{Zn~} \mathrm{Mo}_{\text {Си }} 8 г \mathrm{Ni}$ & $\mathrm{Ag}$ Co $\mathrm{Nb} 8 \mathrm{c} \mathrm{L}_{1}$ \\
\hline & $\begin{array}{l}\text { Строительная про- } \\
\text { мышленность, метал- } \\
\text { лообработка }\end{array}$ & - & - & $\mathrm{Hg}_{12} \mathrm{Cd}_{11}$ & Вi 8г Си Zn 8c 8п & $\mathrm{Ba} \quad \mathrm{Pb} \quad 8 \mathrm{c} \quad 7 \imath$ \\
\hline & $\begin{array}{l}\text { Строительная про- } \\
\text { мышленность, метал- } \\
\text { лообработка }\end{array}$ & $\mathrm{Ag}_{457} \mathrm{Hgg}_{399}$ & 一 & Си 17 & $\begin{array}{c}\mathrm{Cd} \underset{\mathrm{C}}{\mathrm{Zn}} \mathrm{Bi} \mathrm{P}^{8}{ }^{8} \\
\end{array}$ & Ba Co $\mathrm{Pb} 8 \mathrm{c} \mathrm{Zr}$ Mo \\
\hline
\end{tabular}




\begin{tabular}{|c|c|c|c|c|c|c|}
\hline & $\begin{array}{l}\text { Химическая, строи- } \\
\text { тельная промышлен- } \\
\text { ность }\end{array}$ & - & $\mathrm{Ag}_{73} \mathrm{Hg}_{31}$ & Си 17 & Zn Sг 8п Р РЬ & Ві Сг Со Мо Ва \\
\hline \multirow[t]{5}{*}{$\begin{array}{l}\text { Города с населени- } \\
\text { ем до } 30 \text { тыс. чело- }\end{array}$} & Ткацкая фабрика & - & $\operatorname{Hg}_{5.3} A g_{52}$ & $B i_{19}$ & $\underset{8 \pi}{\text { Си W }} \underset{8 \pi}{ }$ & $\mathrm{Sr}$ Mo Co $\mathrm{V}$ Сг $\mathrm{Ni}$ \\
\hline & Тексгиылая фабрика & & & $\Lambda g_{22} \mathrm{Hg}_{21} \mathrm{Cu}_{12}$ & Zı Ba Pb & 8г Сo Sn Мо Сг Р \\
\hline & $\begin{array}{l}\text { Химическая промыш- } \\
\text { ленность (производ- } \\
\text { ство грампластинок) }\end{array}$ & $\mathrm{Hg}_{5}{ }_{2} \mathrm{Ag}_{1178}$ & $N_{135}$ & $\mathrm{Cd}_{25} \mathrm{Sr}_{2,1}$ & $7 л \mathrm{~Pb}$ & $\mathrm{Sn} \mathrm{C} r \mathrm{Bi}$ \\
\hline & $\begin{array}{l}\text { Научный центр физи- } \\
\text { ческого направления }\end{array}$ & $A g_{108}$ & $\mathrm{Cd}_{44}$ & $\mathrm{Hg}_{16}$ & Ві Си $2 n P$ Sn $\mathrm{Pb}$ & 8г Сo $\mathrm{Ni} 8 \mathrm{c}$ Сг $\mathrm{Ba}$ \\
\hline & $\begin{array}{l}\text { Научный центр радио- } \\
\text { технического паправ- } \\
\text { ления }\end{array}$ & $\mathrm{Ag}_{210}$ & $\mathrm{Bi}_{5,4} \mathrm{Hg}_{4,3}$ & $\mathrm{P}_{14}$ & $7 л$ Си Сг 8c Cd &  \\
\hline \multirow[t]{5}{*}{$\begin{array}{l}\text { Поселки юродско- } \\
\text { го тина }\end{array}$} & $\begin{array}{l}\text { Химическая промыш- } \\
\text { ленность (нронзвод- } \\
\text { ство пластмасс) }\end{array}$ & & - & $1 \operatorname{lgg}_{2 \hbar}$ & $\mid \begin{array}{c}\text { Sn } \operatorname{Ag} 8 \text { c Сг Ga } \mathrm{P} \\
\mathrm{Pb} \text { Мо }\end{array}$ & $\begin{array}{c}\text { Tı Со Nb Си V } 8 г \\
\mathrm{Ba}\end{array}$ \\
\hline & $\begin{array}{l}\text { Вторичная переработ- } \\
\text { ка цветных металлов }\end{array}$ & $H g_{i x \mid} A g_{1711}$ & $\mathrm{~Pb}_{34} \mathrm{Bi}_{i 4}$ & $P_{11} \mathrm{Cu}_{11} \mathrm{Zn}_{11}$ & $\mathrm{Sh}_{\mathrm{S}} \mathrm{BaCd}$ & Со Сг 8 г \\
\hline & К ир пичны й завод & & $\| g_{35}$ & $\mathrm{Ag}_{28}$ & Си Ва V Со & 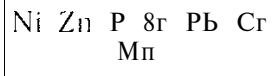 \\
\hline & $\begin{array}{l}\text { Керамико плтиочиый } \\
\text { завод }\end{array}$ & & III & B Ig & 7л Zr Sr РЬ Ва Си & $\mathrm{Ag} \mathrm{Co} \mathrm{Ca}$ \\
\hline & $\begin{array}{l}\text { Переработка сельхоз- } \\
\text { продукции }\end{array}$ & - & - & - & $\mathrm{Ag}$ Ва Си Р Со V & Сг $\mathrm{Oa} \mathrm{Pb}$ Mo $\mathrm{Ni}$ \\
\hline Сельские поселения & $\begin{array}{l}\text { Поселок сельского } \\
\text { типа }\end{array}$ & -- & - & & АО Со Р Си & $\mid \begin{array}{c}\text { V Zn Pb } \\
\text { у } \\
\text { Уа }\end{array}$ \\
\hline
\end{tabular}




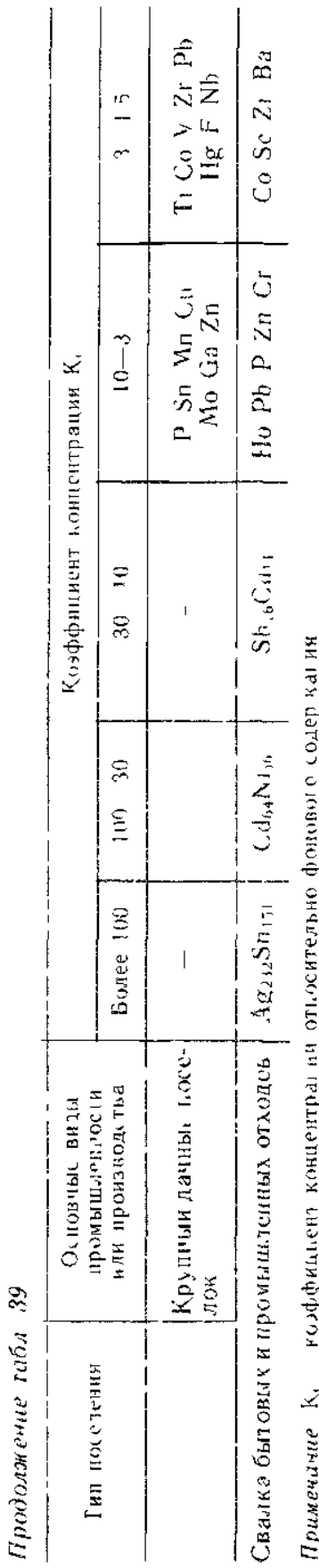

Характерная особенность техногенных аномалий в донных отложениях - - преимуцесівенное концентрирование халькофнльных элементов ( $\mathrm{Hg}, \mathrm{Ag}, \mathrm{Cd}, \mathrm{Pb}$ и др.; коэффициенты конценграции этих элементов достигают нескольких десятков и даже сотен). Как правило, $\mathrm{Hg}, \mathrm{Ag}, \mathrm{Cd}$ и в меньшей степени РЬ являются типоморфными элементами большинства техногенных ассоциацнй в донных отложениях. Очень часто именно в степени их концентрации и проявляется специфичность техногенной ассоциации. Анализ литературных данных также указывасг на ведущую роль $\mathrm{Hg}, \mathrm{Ag}, \mathrm{Cd}$, а также РЬ в загрязнении водных систем.

1сследования состава техногенных илов дает обшее представление об основных загрязняющих всществах. Следуст, однако, помнить, что в донных отложениях фиксируетгя результат дослаточно длительного антропогенного воздействия на данную водную систему. Поэтому со став донных отложений отражает несовершенство систем очистки сточных вод не в настоящее время, а в более ранние периоды воздействия.

Для выяьлення комплекса элементовиндикаторов современ;ого загрязнения необходимо проведение специальных исследований состава воды вблизи источнкков заірязнения. Эти исследования показали, что комплекс химических элементов, участвующих в загрязнении вод, очень широк. Это хорошо видно на приводимых примерах, характеризующих наиболее часто встречающиеся в урболандшафтах ситуацин. В тастносли, в зоне влияния многопрофильного города (рис. 43) кроме сравнительно хорошо изученных и описанных в литературе элементов (Cd, Hg. Си, Рb, Ni, Cr, некоторые другие), в техногенной ассоциации присутствуют эле менгы, геохимическое поведение и экольгогигиеническое значение которых в водных системах практически не изучено илн изучено очень слабо. Эти элементы (5b. 
Рис. 43. Геохимические спектры в воде ручья, принимающею сточные воды города.

Сплошная линия - среднне значения коэффициентов конценграции $K_{\text {, раст }}$ ворениых форм за месячный период наблюдения, пунктир - максимальные значения $\mathrm{K}$, за тот же период

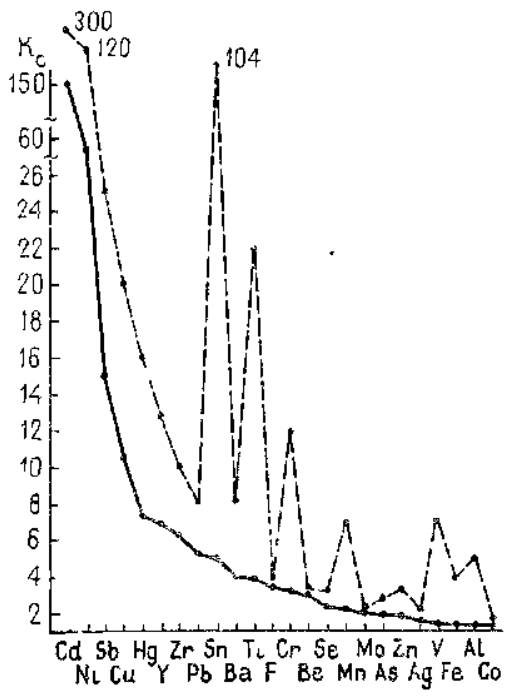

$\mathrm{Ag}, \mathrm{V}, 2$ г, Ва. Ti, Be, V, A1) не учитываются существующими службами контроля за состоянием вод. В то же время для многих из них установлено отрицательное воздействие на жизнедеятельность многих организмов, в том числе и на человека.

Широкий комплекс химических элементов фиксируется в растворенной фазе потоков в зоне влияния двух других промзон (рис. 44). Зона А отличается высокими содержаниями ряда элементов и прежде всего Cd и $\mathrm{Hg}$; характерная особенность повышенные содержания, V, Ga, Mo, Sn, Ba, Ce, Al, Yb, Bi In, Ti. Геохимический облик выявленной техногенной сссоциации практически всецело определяется элеменгами, техьогенная миграция которых изучена очень слабо и когорые никогда не учитываются при проведении контроля за качеством вод. В зоне Б обращает на себя внимание высокое содержание приоритет ных $\mathrm{Cr}, \mathrm{Cd}, \mathrm{Hg}, \mathrm{Ni}$ - гипоморфиых элементов внявленной ассоциации. В то же время характерно увеличение концентраций Mo, Ba, Уb, Ga, Ge, A1, в меньшей степени - Bi и In. Специфично появление $\mathrm{Tl}$ - элемента, обладающего куммулятивным действием и высокотоксичного для водных организмов и человека.

Таким образом, несмотря нз существенное различие пронзводственного профиля рассматриваемых промзон, качественныи состав характерных для них ассоциаций довольно близок. Выяяленные аномалии в водах отличаются комплексностью и, кромс традиционно контролируемых, включают широкую группу мало изученных с экологических позиций химических элементов. Раз 



Рис. 44. Геохимические спектры в воде реки выше (сплошная линия) и ниже (пунктир) прудов-отстойников.

$K_{c}$ - коэффициент концентрацин относительно фона. Характернстика зон А и Б приведена в тексте

личне ассоциаций проявляется главным образом в характере концентрации химических элементов и в меньшей степени в качественном отношении, т. е. в появлении специфичных лишь для данной зоны элементов. Выявленные особенности проявляются в составе взвешенной фазы водных потоков и иловых вод.

\section{Геохимические процессы распределения и формы миграции химических элементов в водных потоках рассеяния}

Для выявления и понимания процессов формировапия зон загрязнения водных систем целесообразно рассмотреть характеристики распределения химических элементов в структуре водного потока рассеяния. В общем случае можно выделить зону смешения сточных и речных зон (зона смешения) и зону распределения загрязняющих веществ природными факторами миграции (зона распределения). Зона смешения четко разделяется на верхний и нижний участки. На практике верхние участки зоны смешения представляют собой ручьи, принимающие сточные воды города. В их пределах происходит смешение всех видов сточных вод и осуществляется начальный этап разбавления за счет поступления поверхностного стока. Качественные и количественные параметры потоков определяются технологическим режимом источников загрязнения. В пределах нижних участков 
данной зоны происходит непосредственное смешение сточных вод с речными, а характеристики зависят прежде всего от степени разбавления. В зоне распределения параметры потоков рассеяния в большей степени зависят от природных факторов миграции, обуславливающих естественное рассеивание, дифференциацию и трансформацию загрязняющих веществ, их накопление в донных отложениях и биоте.

Основные задачи исследования геохимических процессов распределения химических элементов в структуре водного потока рассеяния: 1) изучение динамики распределения элементов в разных зонах потока с целью получения достоверной оценки общего уровня загрязнения вод, выявления закономерностей миграции элементов, установления форм нахождения и их соотношения в зависимости от технологического режима источника поступления; 2) изучение пространственного распределения элементов и их форм нахождения в структуре потока для выявления зональности, установления дальности, скорости и их механизма миграции. Для решения этих задач необходимо проведение комплекса динамических наблюдений (режимные наблюдения за составом воды в определенные отрезки времени) и прослеживаний (изучение изменения состава воды вниз по потоку от источника загрязнения с определенным шагом опробования и с учетом скорости добегания водной массы) состава вод на створах в основных структурных частях потока, а также в фоновых условиях. Таких данных очень мало. Авторам удалось изучить характеристики водных потоков рассеяния в зоне влияния города, обладающего многопрофильной и хорошо развитой промышленной структурой. Приводимые ниже материалы базируются на детальном изученни бассейна типичной равнинной реки в условиях интенсивного антропогенного воздействия. Выявленные особенности формирования техногенных водных потоков рассеяния могут быть характерны и для других аналогичных водных систем.

\section{Особенности распределения}

химических элементов в фоновых условиях

В фоновых условиях химические элементы мигрируют в виде двух основных потоков - растворенных и взвешенных форм (табл. 40). В динамическом ряду наблюдения растворенные формы отличаются в целом слабо выраженным и незакономерно варьирующим распределением. Для взвешенных форм выявлена высокая степень неоднородности распределения. Отмеченные особенности хорошо прослеживаются на графиках фактического распределения элементов в динамическом ряду наблюдения (рис. 45) и находят отражение в значениях коэффициентов вариации многих из них. 

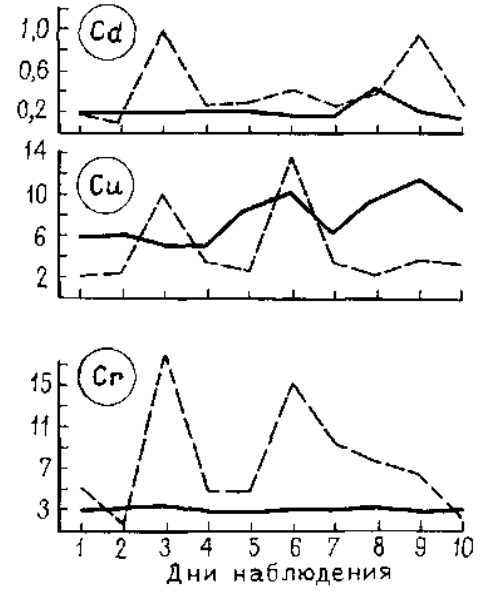

Рис. 45. Динамика распределения взве шенных (пунктир) и растворенных (сплошная линия) форм химических элементов в воде фонового водотока

Корреляционный анализ не выявил каких-либо динамических связей между двумя основными миграционными потоками. Это свидетельствует о том, что закономерности поведения взвешенной и растворенной форм внутри водной массы достаточно различны. В частности, распределение растворенных форм химических элементов в фоновых условиях определяется сложным взаимодействием различных физико-химических, биогеохимических и гидродинамических факторов, по разному сказывающихся на их поступлении и миграции в водной толще. Так, в течение всего

Т а б л и ц а 40 Формы нахождения химических элементов в воде фонового водотока

\begin{tabular}{|c|c|c|c|c|c|}
\hline Элемент & $\begin{array}{c}\text { Форма } \\
\text { нахождения }\end{array}$ & $\begin{array}{c}\text { Срсдине } \\
\text { содержание, } \\
\text { мкг/л }\end{array}$ & $\begin{array}{l}\text { Коэффициент } \\
\text { вдриаци, \% }\end{array}$ & $\begin{array}{l}\text { Содержание, } \\
\text { В + Р, мкг/л }\end{array}$ & $\begin{array}{c}\text { Доля } \\
\text { в звешенных } \\
\text { форм, \% }\end{array}$ \\
\hline Хром & $\begin{array}{l}\mathrm{B} \\
\mathrm{P}\end{array}$ & $\begin{array}{l}9,80 \\
3,00\end{array}$ & $\begin{array}{c}115 \\
0\end{array}$ & 12,8 & 76,6 \\
\hline Никель & $\begin{array}{l}B \\
p\end{array}$ & $\begin{array}{l}4,13 \\
2,60\end{array}$ & $\begin{array}{l}76 \\
73\end{array}$ & 6,73 & 61,4 \\
\hline Медь & $\begin{array}{l}B \\
p\end{array}$ & $\begin{array}{l}4,69 \\
7,62\end{array}$ & $\begin{array}{l}84 \\
30\end{array}$ & 12,31 & 38,1 \\
\hline Цинк & $\begin{array}{l}\mathrm{B} \\
\mathrm{p}\end{array}$ & $\begin{array}{l}14,59 \\
28,56\end{array}$ & $\begin{array}{l}42 \\
40\end{array}$ & 43,15 & 33,8 \\
\hline Кадмий & $\begin{array}{l}\mathrm{B} \\
\mathrm{p}\end{array}$ & $\begin{array}{l}0,404 \\
0,240\end{array}$ & $\begin{array}{l}78 \\
25\end{array}$ & 0,644 & 63,7 \\
\hline Ртуть & $\begin{array}{l}\mathrm{B} \\
\mathrm{p}\end{array}$ & $\begin{array}{l}0,0015 \\
0,6600\end{array}$ & $\begin{array}{c}240 \\
81\end{array}$ & 0,6615 & 0,2 \\
\hline Свинец & $\begin{array}{l}\mathrm{B} \\
\mathrm{p}\end{array}$ & $\begin{array}{l}5,27 \\
2.20\end{array}$ & $\begin{array}{l}63 \\
29\end{array}$ & 7,47 & 70,6 \\
\hline
\end{tabular}

Примечание «В» и «Р»- соответственно взвешенные и растворенные формы, приведены средние данные за 10-дневный период опробования в межень 
Т а бл и ц 41 Сравнительная характеристика содержаний химических элементов во взвесях, донных отложениях и почвах в фоновых условиях, мr/kr

\begin{tabular}{l|c|c|c|c}
\hline \multirow{2}{*}{ Этемент } & \multicolumn{2}{|c|}{ Взвеси } & \multirow{2}{*}{$\begin{array}{c}\text { Донные } \\
\text { отложения }\end{array}$} & ІІочвы \\
\cline { 2 - 3 } & Среднее & $\begin{array}{c}\text { Кожффициенг } \\
\text { вариация, \% }\end{array}$ & \\
\hline Хром & 409 & 90 & 51 & 45 \\
Никель & 283 & 151 & 18 & 20 \\
Медь & 195 & 89 & 30 & 26 \\
Цинк & 710 & 49 & 123 & 52 \\
Кадмий & 28 & 152 & 0,3 & 0,3 \\
Ртуть & 0,089 & 156 & 0,01 & 0,01 \\
Свинец & 439 & 98 & 29 & 25 \\
& & & &
\end{tabular}

периода исследования растворенные формы отличались резко выраженной асинхронностью распределения. Более того, если для растворенных форм меди четко фиксировалась обратная зависимость от расхода воды в реке, то для растворенных форм ртути, кадмия и цинка отмечена слабая положительная связь. Уровни содержания свинца и кадмия в речном растворе не зависели от водообильности потока. Таким образом, растворенные формы химических элементов отличаюгся незакономерным характером поведения в фоновых условиях.

Во взвешенной форме химические элеменгы в фоновых условиях мигрируют более согласным потоком. Исключение составляет ртуть. В отличие от других элементов, для ее взвешенных форм фиксируется челкая прямая зависимость от расхода и мутности воды. Это позволяет предположить, что для нее преобладает поступление с твердыми частицами с водосбора в периоды дождей. Это подтверждается хорошей корреляционной связью абсолютных конценграций ртути во взвеси с мутностью $(г 0,69)$ и расходом воды (г 0,64), не установленной для других элементов.

Вероятно, в составе поверхностного стока существенное значение имеют техногенные атмосферные выпадения, связанные с региональным переносом ртути от промышленных источников. Для остальных элементов взвешенные формы формируются главным образом за счет внутриводоемных процессов вторичного перераспределения речного материала.

В результате естественной дифференциации фоновая речная взвесь, представленная очень тонкодисперсным материалом, более обогащена химическими элементами, нежели почвы и донные отложения (габл. 41). Подобная закономерность отмечается и для ряда крупнейших рек мира. Для средних и малых рек данное явление может быть выражено еще резче, поскольку гранулометрический состав их взвесей в большей степени формируется за счет тонкодисперсных фракций.

В целом в условиях фона для $\mathrm{Hg}$ характерна преимущественная миграция в растворенном состоянии; для Си и $\mathrm{Zn}$ 
Га бли и а 42 Растворенные формы химических элементов в фоновых условиях, мгк/л

\begin{tabular}{l|c|c|c|c}
\hline \multicolumn{1}{c|}{ Форма нахождения } & Ni & Cu & Ln & Cd \\
\hline Органическая & 4,00 & 2,73 & 6,54 & 0,03 \\
Неорганическая & 4,00 & 4,67 & 26,36 & 0,58 \\
Общая растворенная & 8,00 & 7,40 & 32,90 & 0,61 \\
Доля органической фор- & 50,0 & 36,9 & 19,9 & 5,0 \\
мы,\% & & & &
\end{tabular}

Примечание Приведены средние данные за 9 дневный период наблюдения

растворенные формы в среднем составляют около 60-65\% д для

Сг, $\mathrm{Pb}, \mathrm{Cd}$ и $\mathrm{Ni}$ преобладают взвешенные формы $(60-70 \%$ валового содержания). Выявленные соотношения взвешенных и растворенных форм изученных элементов укладываются в рамки существующих глобальных оценок [23]. Практически для всех элементов в течение всего периода исследования соотношение двух основных форм миграции было достаточно стабильным, хотя в отдельные дни отмечались изменения как в сторону увеличения доли взвешенных форм, так и наоборот. Растворенные формы складываются из неорганических и органических компонент (табл. 42), причем для всех изученных элементов характерно преобладание неорганических составляющих и лишь для никеля велико значение органических форм в растворе. Во взвесях химические элементы также закреплены в различных формах. В частности, для никеля характерно преобладание сорбционно-карбонатных форм, а для меди - органических и сорбиионно-карбонатных.

Особенности распределения химических элементов в техногенных водных потоках рассеяния

В условиях загрязнения поведение химических элементов определяется сложным взаимодействием техногенных и природных факторов.

В пределах верхнего участка зоны смешения, характеризующего поставку химических элементов источниками загрязнения, техногенные аномалии в водах формируются в результате поступления двух основных потоков - потока взвешенных и потока растворенных форм (табл. 43). Для всех элементов велико значение взвешенных форм, причем для Сг, РЬ, Си и 2п они являются преобладающими.

Сумма растворенных форм складывается из неорганической и органической компонент (табл. 44), причем техногенные аномалии проявились, хотя и в разной степени, в обеих компонентах. Для растворенных Си, 2п и $\mathrm{Ni}$ характерно преимущественное поступление в неорганических формах, а для $\mathrm{Cd}-$ в органических. Такое соотношение может быть связано с тем, что в загрязненных 164 
Т а б ли ц а 43 Химические элементы во взвешенной (В) и растворенной (Р) формах в пределах верхнего участка зоны смешения водного потока рассеяния

\begin{tabular}{|c|c|c|c|c|c|c|c|}
\hline Элемент & $\begin{array}{c}\text { Форма } \\
\text { нахожде- } \\
\text { ния }\end{array}$ & $\begin{array}{l}\text { Сред- } \\
\text { нее, } \\
\text { мкг/л }\end{array}$ & $\begin{array}{c}\text { Коэффи } \\
\text { инент вд- } \\
\text { риации, \% }\end{array}$ & $\mathrm{K}_{\mathrm{e}}$ & $\begin{array}{c}\text { Общее со } \\
\text { держание, } \\
\text { В十P, } \\
\text { мкг /л }\end{array}$ & $\mathrm{K}$ & $\begin{array}{c}\text { Доля взве- } \\
\text { шенной фор } \\
\text { мы от обще } \\
\text { го содержа } \\
\text { ния \% }\end{array}$ \\
\hline Хром & $\stackrel{\mathrm{B}}{\mathrm{P}}$ & $\begin{array}{c}29,50 \\
10,60\end{array}$ & $\begin{array}{l}60 \\
87\end{array}$ & $\begin{array}{l}3,02 \\
3,53\end{array}$ & 40,1 & 3,1 & 73,57 \\
\hline Никель & $\stackrel{\mathrm{B}}{\mathrm{P}}$ & $\begin{array}{l}26,1 \\
48,0\end{array}$ & $\begin{array}{l}86 \\
49\end{array}$ & $\begin{array}{c}6.32 \\
19,5\end{array}$ & 74,1 & 11 & 35,22 \\
\hline Медь & $\stackrel{\mathrm{B}}{\mathrm{P}}$ & $\begin{array}{l}73,70 \\
34,30\end{array}$ & $\begin{array}{l}67 \\
86\end{array}$ & $\begin{array}{c}15,71 \\
4,5\end{array}$ & 108 & 8,8 & 68,24 \\
\hline Цинк & $\stackrel{\mathrm{B}}{\mathrm{P}}$ & $\begin{array}{l}69,8 \\
48,2\end{array}$ & $\begin{array}{l}62 \\
34\end{array}$ & $\begin{array}{l}4,78 \\
1,69\end{array}$ & 118 & 2,8 & 59,15 \\
\hline Кадмий & $\stackrel{\mathrm{B}}{\mathrm{P}}$ & $\begin{array}{l}3,22 \\
6,14\end{array}$ & $\begin{array}{r}68 \\
238\end{array}$ & $\begin{array}{c}7,97 \\
25,6\end{array}$ & 9,36 & 14,5 & 34,40 \\
\hline Ртуть & $\stackrel{\mathrm{B}}{\mathrm{P}}$ & $\begin{array}{l}0,552 \\
0,730\end{array}$ & $\begin{array}{r}137 \\
52\end{array}$ & $\begin{array}{l}368 \\
1,11\end{array}$ & 1,282 & 1,94 & 43,1 \\
\hline Свинец & $\stackrel{B}{\mathrm{P}}$ & $\begin{array}{c}63,50 \\
5,63\end{array}$ & $\begin{array}{l}178 \\
105\end{array}$ & $\begin{array}{l}13,10 \\
2,56\end{array}$ & 69,13 & 9,4 & 91,85 \\
\hline
\end{tabular}

Примечание Приведенные средние данные за 32 дневный период паблюдения в летнюю межень, К - коэффициент концентрации относительно фонового содержания

водах заметно снижается относительная доля высокомолекулярных природных органических веществ типа «водный гумус» и начинает преобладать техногенная низкомолекулярная органика. Хорошо известно, что комплексообразующая способность последней в отношении Си и N1 немного ниже, чем у гумусовых веществ [23]. Поэтому в условиях загрязнения доминируют их комплексы с неорганическими лигандами, а также ионные формы. За счет более выраженного сродства цинка к низкомолекулярным органическим лигандам в условиях загрязнения отмечается некоторое увеличение доли его органических растворенных форм. Кадмий, как известно, отличается невысокой комплексообразующей способностью; малохарактерна для него и связь с природными органичес-

Т а блиц а 44 Растворенные формы химических элементов в зоне смешения техногенного потока рассеяния

\begin{tabular}{l|r|c|c|c|c|c|c|c}
\hline \multirow{2}{*}{\multicolumn{1}{c|}{ Форманахождения }} & \multicolumn{2}{|c|}{ Медь } & \multicolumn{2}{c|}{ Цинк } & \multicolumn{2}{c|}{ Нике.ıь } & \multicolumn{2}{c}{ Кадмий } \\
\cline { 2 - 9 } & \multicolumn{1}{|c|}{ I } & II & I & II & I & II & I & II \\
\hline Органическая & 7,30 & 2,90 & 11,46 & 11,30 & 10,21 & 4,40 & 0,40 & 0,72 \\
Неорганическая & 33,60 & 12,48 & 39,27 & 26,14 & 45,88 & 13,80 & 4,85 & 0,98 \\
Общаярастворенная & 40,08 & 15,38 & 50,73 & 37,44 & 56,09 & 18,20 & 9,25 & 1,70 \\
Доля органической & 17,85 & 18,66 & 22,59 & 30,18 & 18,20 & 24,18 & 47,57 & 42,35 \\
формы, \% & & & & & & & &
\end{tabular}

Примечание I и II coответственно верхний и нижний участки зоны приведены средние данные за 30 -дневный период наблюдения в межень 
Та а 1 и ll а 45. Формы нахождения химических элементов в техногенной взвеси в зоне смешения техногенного потока рассеяния

\begin{tabular}{|c|c|c|c|c|c|c|}
\hline \multirow{2}{*}{$\begin{array}{l}\text { Эле- } \\
\text { мент }\end{array}$} & \multirow{2}{*}{$\begin{array}{c}\text { Участок } \\
\text { зоны сме- } \\
\text { шения }\end{array}$} & \multirow{2}{*}{$\begin{array}{c}\text { Вало- } \\
\text { вое со- } \\
\text { держа- } \\
\text { ние, } \\
\text { мг/кг }\end{array}$} & \multicolumn{4}{|c|}{$\begin{array}{c}\text { Среднее содержание (в мл/кг) э.леменіов, находящихся } \\
\text { в форме }\end{array}$} \\
\hline & & & $\begin{array}{l}\text { сорбинонно- } \\
\text { карбонатной }\end{array}$ & органической & Гицроксидной & $\begin{array}{l}\text { кристалли- } \\
\text { ческой }\end{array}$ \\
\hline Ни- & Верхний & 425,00 & $178,88--(42,09)$ & $75,08(17,65)$ & $81,22(19,11)$ & $88,89(21,15)$ \\
\hline ke.th & Нижний & 257,50 & $128,88-(50,00)$ & $35,92(13,75)$ & $35,58(14,03)$ & $57,20(22,20)$ \\
\hline \multirow[t]{2}{*}{ Меп и } & Верхний & 1412,25 & $123,81(16,96)$ & $261,28(17,79)$ & $332,22(23,52)$ & $757,69(54,35)$ \\
\hline & Нижиий & 730,00 & $61,30(4,34)$ & $189,00(25,89)$ & $233,97(32,05)$ & $183,22(25,10)$ \\
\hline Кад- & Верхний & 71,25 & $50,35(70,66)$ & $0,67(0,94)$ & $12,41(17,42)$ & $7,82(10,98)$ \\
\hline мии & Нижний & 35,67 & $27,58(77,32)$ & $0,33(0,92)$ & $7.05(19,78)$ & $0,71(1,98)$ \\
\hline $\mathrm{CaH}-$ & Верхний & 516,67 & I $18,54(12,44)$ & $71,27(7,48)$ & $255,67(31,03)$ & $467,38(49,05)$ \\
\hline неШ & Нижний & 952,86 & $96,57(18,69)$ & $72,80(14,09)$ & $171,22(33,14)$ & $176,08(34,08)$ \\
\hline
\end{tabular}

Примечания В скобках указана доля формы в валовом содержании, приведены средние значения за 30-дневный период наблюдения в Ітеннюю межень, ичтиость воды в пределах верхнего и нижнего участков соответственно равна 53,1 и 28,0 иг/.

кими лигандами, поэтому в природных условиях его преобладающей формой является неорганическая ионная [23]. В то же время для Cd установлена способность активно формировать достаточно устойчивые хелатные соединения с синтетическими органическими веществами (например, с ПАВ) [34], По-видимому, это и объясняет высокую долю органически связанного растворенного кадмия в сильно загрязненных водах, содержащих большие количества техногенных органических веществ.

Принципиальное значение имеет выяснение форм нахождения химических элементов в техногенной взвеси. Установлено, что для многих элементов характерно преимущественное закрепление в геохимически подвижных (сорбционно-карбонатных, органических, гидроксидных) формах (табл. 45). Это свитетельствует о высокой миграционной способности, потенциальной возможности преобразования и экологической опасности химических элементов, связанных со взвесью.

Яркой особенностью как для взвешенных, так и для растворенных форм в динамическом ряду наблюдения в пределах верхнего участка зоны смешения является резко выраженная неоднородность их распределения на коротких интервалах времени (рис. 46). Характерно, что неоднородность фиксируется на общем высоком фоне их содержаний. Для большинства элементов техногенные аномалии устойчивы во времени (табл. 46).

Для всех элементов корреляционный анализ не показал временной связи их распределения во взвешенной и растворенной формах. Таким образом, техногенная поставка загрязняющих веществ осуществляется двумя независимыми способами - со взвесью и в растворе. Вместе с тем при анализе распределения во времени ассоциаций химических элементов устанавливается различие между растворенными и взвешенными формами. Взвешенные формы всех элементов варьируют согласованно. В раст- 



Рис. 46. Динамика распределения взвешенных (пунктир) и растворенных (сплошная линия) форм химических элементов в воде ручья в пределах верхнего участка зоны смешения 
Т а бл и ц 46 Встречаемость дней с высокими содержаниями взвешенных (B) и растворенных (P) форм нахождения химических элементов в водном потоке рассеяния (в \% от всего периода наблюдения)

\begin{tabular}{|c|c|c|c|c|c|c|c|c|c|c|c|c|c|}
\hline \multirow{3}{*}{ Элемент } & \multirow{3}{*}{$\begin{array}{c}\text { Форма } \\
\text { нахож- } \\
\text { дения }\end{array}$} & \multicolumn{12}{|c|}{ Превышение фонового содержания в зонах } \\
\hline & & \multicolumn{8}{|c|}{ смешения потока } & \multicolumn{4}{|c|}{$\begin{array}{c}\text { распределения } \\
\text { потока }\end{array}$} \\
\hline & & бо & $\begin{array}{c}3 \\
\text { pasa }\end{array}$ & $\begin{array}{c}5 \\
\text { раз }\end{array}$ & $\begin{array}{c}10 \\
\text { pa3 }\end{array}$ & $\begin{array}{l}\text { лю- } \\
\text { бое }\end{array}$ & $\begin{array}{c}3 \\
\text { раза }\end{array}$ & $\begin{array}{c}5 \\
\text { раз }\end{array}$ & $\begin{array}{c}10 \\
\text { pa3 }\end{array}$ & $\begin{array}{l}\text { лю } \\
\text { бое }\end{array}$ & $\begin{array}{c}3 \\
\text { раза }\end{array}$ & $\begin{array}{c}5 \\
\text { раз }\end{array}$ & $\begin{array}{r}10 \\
\text { pas }\end{array}$ \\
\hline Xpom & $\stackrel{\mathrm{B}}{\mathrm{P}}$ & $\begin{array}{l}\text { Bep } \\
97 \\
56\end{array}$ & \begin{tabular}{|c|} 
pxнuй \\
41 \\
56
\end{tabular} & $\begin{array}{c}\text { yuad } \\
16 \\
22\end{array}$ & $\begin{array}{r}\text { TOK } \\
6\end{array}$ & $\begin{array}{l}H u \\
41 \\
56\end{array}$ & $\begin{array}{c}\text { жний } \\
3 \\
41\end{array}$ & $\begin{array}{c}\text { учас } \\
16\end{array}$ & $\begin{array}{r}\text { TOK } \\
3\end{array}$ & $\begin{array}{l}47 \\
44\end{array}$ & 22 & 3 & - \\
\hline Никель & $\stackrel{\mathrm{B}}{\mathrm{P}}$ & $\begin{array}{l}97 \\
97\end{array}$ & $\begin{array}{l}81 \\
97\end{array}$ & $\begin{array}{l}41 \\
97\end{array}$ & $\begin{array}{l}19 \\
78\end{array}$ & $\begin{array}{l}59 \\
66\end{array}$ & $\begin{array}{l}13 \\
59\end{array}$ & 41 & 6 & $\begin{array}{l}59 \\
78\end{array}$ & $\begin{array}{r}3 \\
69\end{array}$ & 50 & 6 \\
\hline Медь & $\stackrel{\mathrm{B}}{\mathrm{P}}$ & $\begin{array}{c}100 \\
97\end{array}$ & $\begin{array}{l}97 \\
66\end{array}$ & $\begin{array}{l}34 \\
31\end{array}$ & $\begin{array}{l}6 \\
6\end{array}$ & $\begin{array}{l}97 \\
84\end{array}$ & $\begin{array}{l}41 \\
13\end{array}$ & 16 & 6 & $\begin{array}{l}94 \\
88\end{array}$ & $\begin{array}{l}9 \\
3\end{array}$ & $\begin{array}{l}3 \\
3\end{array}$ & 3 \\
\hline Цинк & $\stackrel{\mathrm{B}}{\mathrm{P}}$ & $\begin{array}{l}97 \\
72\end{array}$ & $\begin{array}{r}78 \\
3\end{array}$ & 28 & 9 & $\begin{array}{l}88 \\
56\end{array}$ & $\begin{array}{l}9 \\
3\end{array}$ & - & 工 & $\begin{array}{l}84 \\
81\end{array}$ & 6 & - & - \\
\hline Кадмий & $\stackrel{\mathrm{B}}{\mathrm{P}}$ & $\begin{array}{l}97 \\
94\end{array}$ & $\begin{array}{l}84 \\
88\end{array}$ & $\begin{array}{l}56 \\
72\end{array}$ & $\begin{array}{l}34 \\
47\end{array}$ & $\begin{array}{l}66 \\
63\end{array}$ & $\begin{array}{l}16 \\
50\end{array}$ & $\begin{array}{r}3 \\
22\end{array}$ & 3 & $\begin{array}{l}63 \\
63\end{array}$ & $\begin{array}{r}9 \\
31\end{array}$ & 9 & I \\
\hline Ртуть & $\stackrel{\mathrm{B}}{\mathrm{P}}$ & $\begin{array}{l}97 \\
50\end{array}$ & 97 & 97 & 97 & $\begin{array}{r}100 \\
31\end{array}$ & $\begin{array}{r}94 \\
3\end{array}$ & $\begin{array}{c}91 \\
3\end{array}$ & 69 & $\begin{array}{c}100 \\
31\end{array}$ & $\begin{array}{r}88 \\
3\end{array}$ & 69 & 53 \\
\hline Свинец & $\stackrel{\mathrm{B}}{\mathrm{P}}$ & $\begin{array}{l}97 \\
47\end{array}$ & $\begin{array}{l}88 \\
22\end{array}$ & $\begin{array}{l}63 \\
13\end{array}$ & $\begin{array}{r}19 \\
3\end{array}$ & $\begin{array}{l}90 \\
63\end{array}$ & $\begin{array}{l}45 \\
28\end{array}$ & $\begin{array}{l}15 \\
19\end{array}$ & $\begin{array}{l}5 \\
6\end{array}$ & $\begin{array}{l}78 \\
69\end{array}$ & $\begin{array}{r}9 \\
31\end{array}$ & $\begin{array}{l}3 \\
9\end{array}$ & 3 \\
\hline
\end{tabular}

Примечание Период наблюдения 32 дня

воре распределение большинства элементов независимое. Поступление растворенных форм элементов от источника загрязнения отличается незакономерным и варьирующим во времени характером. Взвешенные формы поступают и мигрируют синхронно, согласованным во времени появлением максимальных содержаний.

Верхний участок зоны смешения характеризуется поступлением двух очень динамичных и самостоятельных потоков загрязняющих веществ. В целом поставка химических элементов осуществляется в темпах, содержаниях и формах, существенно отличающихся от фоновых. Для многих элементов ведущее значение имеют их взвешенные формы, что связано как с увеличением мутности потоков, так и с повышением их абсолютных концентраций в самой взвеси. Аномалии во взвешенной форме более устойчивы и синхронны и в значительной мере определяют уровень загрязнения водных систем.

Поведение химических элементов в пределах нижнего участка зоны смешения во многом зависит от гидродинамических факторов, которые обуславливают разбавление поступающих сточных вод речными. Как известно, перемешивание загрязняющих веществ в речном потоке в случае длительного их поступления при 
Т а бл и а 47 Сопоставление фактических и расчетных концентраций некоторых компонентов в зоне смешения сточных и речных вод

\begin{tabular}{|c|c|c|c|c|c|}
\hline \multirow[b]{2}{*}{ Элеменг } & \multirow[b]{2}{*}{$\begin{array}{l}\text { Форма на- } \\
\text { хождения }\end{array}$} & \multicolumn{3}{|c|}{ Фактические данные } & \multirow{2}{*}{$\begin{array}{c}\text { Расчетные } \\
\text { концентрации } \\
\text { Ілия створа } \\
\text { полног о сме- } \\
\text { шения }\end{array}$} \\
\hline & & $\begin{array}{c}\text { Речная } \\
\text { фоновая } \\
\text { вода }\end{array}$ & $\begin{array}{c}\text { Верхний } \\
\text { участок } \\
\text { зоньы } \\
\text { (мепшения }\end{array}$ & $\begin{array}{c}\text { Нижний үчdс } \\
\text { ток (створ } \\
\text { полного сме } \\
\text { шения) }\end{array}$ & \\
\hline Никель & $\begin{array}{l}B \\
p\end{array}$ & $\begin{array}{r}1,25 \\
10,80\end{array}$ & $\begin{array}{l}23,73 \\
22,40\end{array}$ & $\begin{array}{c}5,50 \\
15,20\end{array}$ & $\begin{array}{r}8,70 \\
14,70\end{array}$ \\
\hline Медь & $\begin{array}{l}B \\
p\end{array}$ & $\begin{array}{l}4,29 \\
8,80\end{array}$ & $\begin{array}{l}61,24 \\
38,60\end{array}$ & $\begin{array}{l}20,80 \\
15,40\end{array}$ & $\begin{array}{l}23,20 \\
18,70\end{array}$ \\
\hline Цинк & $\begin{array}{l}B \\
p\end{array}$ & $\begin{array}{l}19,18 \\
16,60\end{array}$ & $\begin{array}{l}75,46 \\
29,40\end{array}$ & $\begin{array}{l}30,80 \\
21,80\end{array}$ & $\begin{array}{l}37,80 \\
20,90\end{array}$ \\
\hline Хром & B & 3,87 & 32,57 & 9,47 & 13,44 \\
\hline Кадмий & B & 0,11 & 2,61 & 0,78 & 0,84 \\
\hline Свинец & B & 2,68 & 52,21 & 13,55 & 19,19 \\
\hline
\end{tabular}

Примечание «В» и «Р»- соответственно взвешенные и растворенные формы

установившемся процессе оценивается соответствующими уравнениями баланса, хорошо известными и применяемыми в гидрологических исследованиях и позволяющими рассчитать уровень загрязнения на различных расстояниях от источника.

Натурные исследования и расчетные данные показали, что для растворенных форм химических элементов в условиях нижнего участка зоны смешения ведущее значение имеет физическое разбавление. Об этом свидетельствует неплохая сходимость расчетных и фактических данных по этим формам (табл. 47), т. е. поведение этих форм определяется преимущественно процессами гидродинамического перемешивания и соответственно разбавления исходных концентраций в сточных водах речной водой. Для взвешенных форм элементов в зоне смешения, кроме того, существенны процессы ускоренного механического выпадения из миграционного потока в составе прежде всего грубой взвеси. Это является следствием подпруживания потока сточных вод и уменьшения скорости течения. Возможно определенное значение имеет коагуляция тонкой взвеси и ее последующее осаждение. В частности, здесь может выпадать до $30 \%$ аномальных количеств взвешенных $\mathrm{Cr}, \mathrm{Ni}, \mathrm{Pb}$, до 20\% 2п и Си, связанных преимущественно с кристаллическими формами (см. табл. 45). Потери растворенных форм невелики, и, по-видимому, происходят главным образом за счет попутной сорбции взвешенным веществом. Это приводит к заметному снижению содержаний всех элементов. Однако, аномалии по-прежнему достаточно стабильны во времени (см. табл. 46), а распределение химических элементов в 



Рис. 47. Динамика распределения взвешенных (пунктир) и растворенных (сплошная линия) форм химических элементов в воде реки в замыкающем створе зоны смешения

динамическом ряду наблюдений также остается резко неоднородным (рис. 47, табл. 48). Следует отметить, что варьирующий характер распределения в большей мере связан с появлением единичных экстремально высоких содержаний как растворенных, так и взвешенных форм. Характерно, что вследствие процессов гидродинамического перемешивания и разбавления между двумя миграционными потоками элементов - взвешенным и растворенным - устанавливается неплохо выраженная динамическая связь. 
I а б.ти и а 48 Химические элементы во взвешенной (В) и раслворенной (Р) формах в нижнем участке зоны смешения (замыкающий створ зоны) водного потока рассеяния

\begin{tabular}{|c|c|c|c|c|c|c|c|}
\hline  & $\begin{array}{l}\text { Фориd } \\
\text { нахо } \\
\text { ж 16 } \\
\text { нин }\end{array}$ & $\begin{array}{l}\text { (pedisee } \\
\text { unr } / \pi\end{array}$ & $\begin{array}{l}\text { Козффиииент } \\
\text { вариацин \% }\end{array}$ & $\mathrm{K}$ &  & $\mathrm{K}$ & $\begin{array}{l}\text { Доля взвешен } \\
\text { ной формы о7 } \\
\text { общего содер } \\
\text { жания, \% }\end{array}$ \\
\hline Хром & $\stackrel{B}{P}$ & $\begin{array}{l}10,60 \\
8,47\end{array}$ & $\begin{array}{r}59 \\
113\end{array}$ & $\begin{array}{l}1,1 \\
2,92\end{array}$ & 19,07 & 1,5 & 55,58 \\
\hline Нике.ть & $\stackrel{\mathrm{B}}{\mathrm{P}}$ & $\begin{array}{r}6,48 \\
11,0\end{array}$ & $\begin{array}{l}72 \\
82\end{array}$ & $\begin{array}{l}1,6 \\
4,4\end{array}$ & 17,58 & 2.5 & 36,9 \\
\hline Медь & $\stackrel{\mathrm{B}}{\mathrm{p}}$ & $\begin{array}{l}15,9 \\
13,8\end{array}$ & $\begin{array}{l}84 \\
79\end{array}$ & $\begin{array}{l}3,4 \\
1,91\end{array}$ & 29,70 & 2,4 & 53,55 \\
\hline Цинк & p & $\begin{array}{l}26,3 \\
33,8\end{array}$ & $\begin{array}{l}47 \\
45\end{array}$ & $\begin{array}{l}1.9 \\
1,2\end{array}$ & 60.10 & 1,4 & 43,76 \\
\hline Кадмий & $\stackrel{\mathrm{B}}{\mathrm{P}}$ & $\begin{array}{l}0,753 \\
0,800\end{array}$ & $\begin{array}{r}89 \\
129\end{array}$ & $\begin{array}{l}2 \\
3,33\end{array}$ & 1553 & 2,4 & 48,49 \\
\hline PTVtb & $\beta$ & $\begin{array}{l}0,045 \\
0,696\end{array}$ & $\begin{array}{l}153 \\
101\end{array}$ & $\begin{array}{l}46 \\
1,1\end{array}$ & 0,741 & 1,12 & 6,07 \\
\hline Свинеи & $\stackrel{\mathrm{B}}{\mathrm{P}}$ & $\begin{array}{r}13,50 \\
6,66\end{array}$ & $\begin{array}{r}90 \\
136\end{array}$ & $\begin{array}{l}2,6 \\
3,03\end{array}$ & 20.16 & 2,6 & 67 \\
\hline
\end{tabular}

Прииечание Приведены средние данные за 32 -дневный период наблюдения в межень. $\mathrm{K}_{1}$ - ноэффициент концснтрании овносительно фоновою содержыния

Это проявляется наиболее четко для Си, 2п, $\mathrm{Ni}$ и $\mathrm{Cr}$. Заметно возрастает в динамическом ряду наблюдения согласованность в распределении ассоциации элементов в растворе. Еще более она увеличивается для взвешенных форм.

Процессы разбавления и гидравлического осаждения грубой взвеси привели к определенному изменению в соотношении различных форм миграции химических элементов. Это выражается прежде всего в увеличении относительной доли растворенных форм почти для всех элементов (см. табл. 48). Для большинства элементов характерно и более стабильное соотношение двух основных форм в течение всего периода исследования, что также указываст на установление определенного динамического равновесия в водной массе. Характерно, что существенных изменений в соотношении растворенных неорганических и органических форм не отмечено (см. табл. 44). Это подтверждает вывод о преобладающем влиянии на поведение растворенных форм в зоне смешения процессов физического разбавления. Дальнейшее распределение химических элементов в русле реки определяется, главным образом, естественными факторами их миграции.

Поведение химических элементов в пределах зоны распре- 

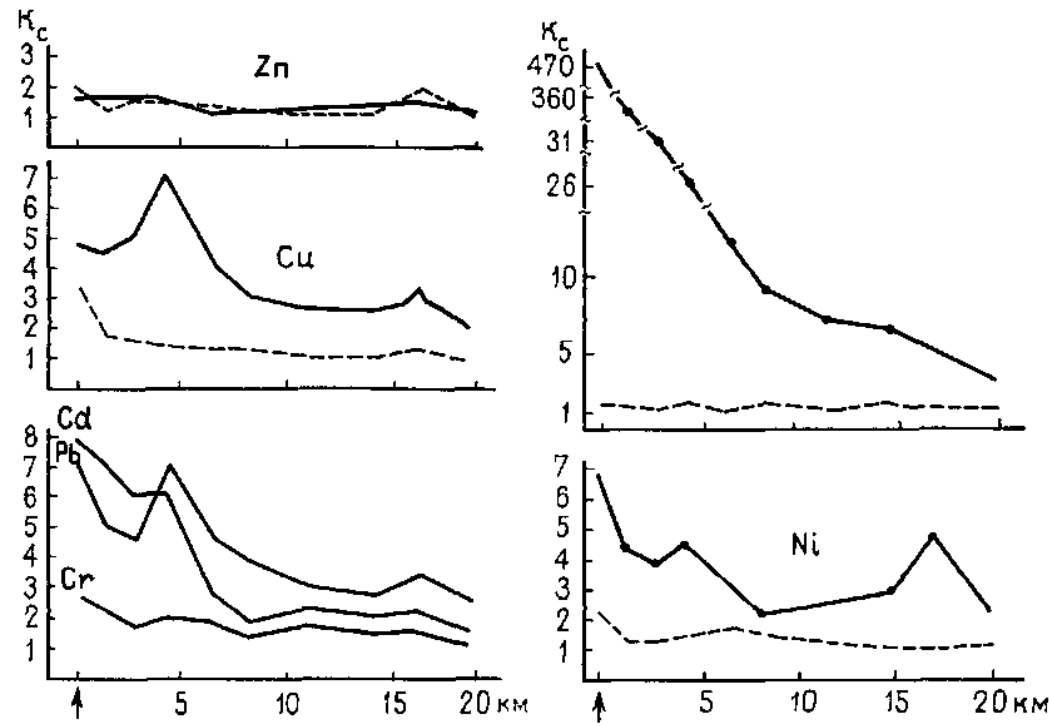

Рис. 48. Распределение взвешенных (сплошная линия) и растворенных (пунктир) форм химических элементов в техногенном потоке рассеяния.


зоны распределения

деления загрязняющих веществ природными факторами миграции, определяется взаимодействием двух групп разнонаправленных процессов: 1) способствующих их выведению из водной массы в донные отложения и биоту; 2) обусловливающие их поступление из донных отложений и биоты в водную массу. При наличии постоянно действующих источников загрязнения преобладают процессы первой группы, что и приводит к формированию в донных отложениях контрастных и протяженных техногенных аномалий. Естественно, что в процессе миграции может происходить преобразование первоначальных форм нахождения химических элементов в результате взаимодействия различных физико-химических процессов в системе «вода - взвесь донные отложения - бнота».

Распределение химических элементов в данной зоне потока рассеяния характеризуется несколько неоднородным, но в целом постепенным убыванием содержаний по мере удаления от источника загрязнения (рис. 48). Наиболее стабильно и контрастно' техногенные аномалии проявляются для взвешенных форм. Аномалии растворенных форм менее контрастны, а для ряда элементов отмечено лишь эпизодическое появление значимых содержаний на отдельных участках потока.

Существующие различия в интенсивности миграции химиче- 




Рис. 49. Зональность распределения химических элементов в техногенном потоке рассеяния:

$a$ растворенные формы, $\sigma$ - концентрации элементов во взвеси, $B$ - абсолютные массы, переносимые со взвесью, $\mathrm{K}_{\mathrm{r}}$ - коэффициент накопления относительно фоновых концентраций

ских элементов обусловливают неплохо выраженную зональность их распределения в потоке рассеяния (рис. 49). Это позволяет предположить существенное значение процессов вторичного переотложения речного материала для формирования зон загрязнения в донных отложениях, особенно в краевых частях потоков рассеяния. В целом, протяженность гидрохимических аномалий велика и для наиболее контрастно концентрирующихся элементов достигает 20--25 км и более.

Динамические параметры потоков рассеяния в данной зоне отличаются более спокойным характером (рис. 50, табл. 49).

Т а бли ц а 49 Химические элементы в растворенной (Р) и взвешенной (В) формах в зоне распределения техногенного водного потока рассеяния

\begin{tabular}{|c|c|c|c|c|c|c|c|}
\hline Элемент & $\begin{array}{c}\text { Форма } \\
\text { нахож } \\
\text { дения }\end{array}$ & $\begin{array}{l}\text { Среднее, } \\
\text { мкг/л }\end{array}$ & $\begin{array}{l}\text { Коэффичиен1 } \\
\text { вдрнацин, \% }\end{array}$ & $\mathrm{K}$ & $\begin{array}{c}\text { Общее содер } \\
\text { жаник В }+P \\
\text { мк। /Л }\end{array}$ & $k$ & $\begin{array}{c}\text { До чя в знешен } \\
\text { нон фюр мb от } \\
\text { общею содер } \\
\text { яння, \% }\end{array}$ \\
\hline Хром & $\stackrel{\mathrm{B}}{\mathrm{P}}$ & $\begin{array}{l}10,3 \\
5,50\end{array}$ & $\begin{array}{l}55 \\
78\end{array}$ & $\begin{array}{l}1,1 \\
1.93\end{array}$ & 15,8 & 1.2 .3 & 65.19 \\
\hline Никель & $\stackrel{\mathrm{B}}{\mathrm{P}}$ & $\begin{array}{c}5,27 \\
13,4\end{array}$ & $\begin{array}{l}56 \\
78\end{array}$ & $\begin{array}{l}1,3 \\
5,2\end{array}$ & 18,67 & 2,8 & 29,23 \\
\hline Медь & $\beta$ & $\begin{array}{l}12 \\
15\end{array}$ & $\begin{array}{r}58 \\
102\end{array}$ & 2,6 & 27 & 2,2 & 44,4 \\
\hline Цинк & $\stackrel{\mathrm{B}}{\mathrm{P}}$ & $\begin{array}{l}23,4 \\
23,6\end{array}$ & $\begin{array}{l}62 \\
31\end{array}$ & $\begin{array}{l}1,5 \\
0,93\end{array}$ & 58,0 & 1,34 & 40,3 \\
\hline Кадмий & $\stackrel{\mathrm{B}}{\mathrm{P}}$ & $\begin{array}{c}0,626 \\
0,543\end{array}$ & $\begin{array}{l}81 \\
65\end{array}$ & $\begin{array}{l}1,6 \\
2,26\end{array}$ & 1,169 & 1,92 & 53,55 \\
\hline Ртуть & $\mathrm{B}$ & $\begin{array}{l}0,062 \\
0,596\end{array}$ & $\begin{array}{l}37 \\
78\end{array}$ & $\begin{array}{r}43,3 \\
0,9\end{array}$ & 0,658 & 1 & 9.42 \\
\hline Свинец & $\stackrel{\mathrm{B}}{\mathrm{P}}$ & $\begin{array}{l}9,24 \\
5,94\end{array}$ & $\begin{array}{c}61 \\
103\end{array}$ & $\begin{array}{l}1,75 \\
2,7\end{array}$ & 15,18 & 2,03 & 60,9 \\
\hline
\end{tabular}

Примечание Приведены средние данные за 32-дневный период наблюдення, К, - коэффициент концентрации относительно фоновогосодержания 



Дни наблюдений

Рис. 50. Динамика распределения взвешенных (пунктир) и растворенных (сплош ная линия) форм химических элементов в зоне распределения техногенного потока рассеяния

Однако для растворенных форм элементов неоднородность достаточно велика. Они отличаются и более частым появлением высоких конценграций (см. габл 46). Корреляционный анализ не показал четкнх временных взаимосвязей между двумя основными миграционными потоками химических элементов, т. е. миграция загрязняющих веществ осуществляется в виде двух независимых потоков. Вместе с тем, если растворенные формы химических элементов, входящих в выявленную ассоциацию, мигрируют асинхронно, то распределение взвешенных форм отличается высокой согласованностью. 



Рис. 51. Формы нахождения химических элементов во взвешенных частицах техногенного потока рассеяния:

1 - сорбционно-карбонатные, 2 - органические, 3 - гидроксидныс, 4 - кристаллические

При общем убывании уровней содержания элементов за счет их выведения из миграционного потока или поступления в него происходит процесс химической дифференциации переносимого материала. Это проявляется в неколорои изменении соотношения различных миграционных форм химических элементов. Так, установлено относительное увеличение доли взве- 
Т а блица 50 Растворенные формы химических элементов в зоне распределения техногенного потока рассеяния, мкг/л

\begin{tabular}{l|c|c|c|c}
\hline \multicolumn{1}{c|}{ Формднахождения } & N & Cu & /n & Cd \\
\hline Органическая & 4,90 & 2,09 & 10,55 & 0,12 \\
Неорганическая & 11,60 & 10,11 & 26,15 & 0,61 \\
Общая раслворенная & 16,50 & 12,20 & 36,70 & 0,73 \\
Доля органической формы & 29,7 & 17,1 & 28,8 & 16,4
\end{tabular}

Примечание Приведены сретнне данные зд 30 дневный период наблюдения в межень

шенных форм для $\mathrm{Hg}, \mathrm{Cd}$ и $\mathrm{Cr}$ (см. табл. 49), доли растворенных неорганических форм Cd (табл. 50). Для взвешенных форм $\mathrm{Hg}, \mathrm{Ni}$ и Си вниз по потоку отмечено увеличение относительной доли органических соединений Кроме того, для Ni характерно относительное возрастание сорбционно-карбонатных форм (рис. 51).

Изменение соотношения различных форм нахождения химических элементов указывает, что их поведение и миграция в зоне распределения обусловливаются не только процессами гидравлического осаждения взвеси или взмучивания донных отложений, но и различными физико-химическими процессами, происходящими в толще воды и донном осадке (сорбционные процессы, поглощение биотой, выщелачивание из твердого материала и др.).

Таким образом, поступление химических элементов в водотоки от техногенных источников загрязнения превышает природное, резко отличается от него динамическими параметрами, формами нахождения и характером ассоциаций, создаваемых прежде всего накоплением элементов с малым кларком и повышенной токсичностью. Это проявляется в развитии комплексных аномалий микроэлементов, фиксирующихся в растворенных формах. Для многих элементов ведущее значение имеет концентрирование во взвешенной форме, что связано как с повышенными их содержаниями во взвеси, так и с увеличением в антропогенных потоках общего ее количества. Закономерности миграции и распределения химических элементов в водном потоке определяются наличием двух зон - зоны смешения сточных вод и зоны распределения антропогенных веществ природными факторами миграции. Для первой зоны характерны высокая изменчивость содержаний элементов на коротких интервалах времени, нестабильность соотношения форм миграции. Динамические характеристики потока хорошо коррелируюг с режимом поступления элементов от источников загрязнения, уровни содержаний определяются степенью разбавления и механическим осаждением взвеси. Вторая зона отличается уменьшением пространственно-временных флюктуации содержаний элементов, более стабильным соотношением их миграционных 
форм и иногда пространственной зональностью. Распределение химических элементов в водной массе определяется скоростями осаждения взвеси, сорбции из раствора и процессами вторичного поступления их донных отложений.

\section{Потоки рассеяния в донных отложениях}

Многочисленные исследования указывают на то, что ведущую роль в загрязнении водных систем играют донные отложения (техногенные илы), формирующиеся в результате седиментации взвешенного в воде материала и его взаимодействия с водной фазой Донные отложения, являясь конечным звеном ландпшафтно-геохимических сопряжений, интегрируют геохимические особенности водосборной площади. Это позволяет по их химическому составу выделить техногенные потоки и оценить степень техногенной нагрузки на водоток. Их изучение важно само по себе, так как, являясь по выражению В. И. Вернадского «подводной почвой», донные отложения определяют многие особенности экологии водных систем Имеющийся литературный материал свидетельствует в ряде случаев о сублетальной токсичности загрязненных металлами донных отложений для водных организмов. Результаты натурных и экспериментальных наблюдений указывают на возможность перехода загрязняющих веществ из донных отложений в водную фазу. При этом, в случае интенсивного загрязнения, время их отрицательного воздействия может быть очень велико даже при прекращении сброса сточных вод Вывод химического элемента из водной фазы свидетельствует лишь о временном «самоочищении» водной массы, но не водного объекта (как экологической системы).

При изучении потоков рассеяния в донных отложениях принципиальное значение имеег выяснение их морфологических особенностей и форм нахождения химических элементов.

Задача изучения пространственного строения потоков рассеяния состоит прежде всего в том, чтобы: 1) установить характер их территориальной связи с источниками загрязнения вод, 2) определить размеры воздействия различных источников, 3) оценить пространственное соотношение распределения концентраций различных химических элементов, обусловленное различием в интенсивности их миграции; 4) исследовать характер связи распределения химических элементов с геоморфологическими особенностями водотоков; 5) выявить типы геохимических барьеров, обусловливающих высокие уровни накопления загрязнений в водотоках и водоемах, и, следовательно, наиболее вероятные учасгки опасного влияния на живые организмы.

Рассмотрим морфологические особенности потоков рассеяния в пределах типичного равнинного урболандшафта, представлен- 




Рис. 52. Распределение серебра и никеля в донных отложениях реки в зоне влияния города.

Тонкая линия -. факгическое распределение, жирная линия - осредненное распределение, стрелкой показано место сброса основного объема промышленных и бытовых сточных вод города, римскими цифрами обозначены выделяемые ұчастки (см. таб.т 53)

ного средним городом с многопрофильным характером производства и связанной с ним свалкой отходов (рис. 52, табл. 51). Характер распределения химических элементов в донных отложениях всецело определяется либо типом воздействия, либо особенностями геоморфологического строения русла малой реки. Это позволяет выделить в водотоке ряд участков с характерным лишь для них распределением элементов.

В пределах участка I (жилой зоне города) формирование потоков рассеяния связано с влиянием поверхностного стока и сточных вод отдельных предприятий (металлообработки и среднего машиностроения), поступающих в реку по ручью. В пределах участка II, расположенного в промышленной зоне города (тяжелое машиностроение, металлообработка, аккумуляторное, кабельное, химикометаллургическое и другие виды производств) осуществляется сброс основных объектов промышленных и бытовых вод города, также поступающих в реку по ручью. Участок III представляет собой геохимический барьер, обусловленный 
Т а б.ли а 51 Химические элементы в донных отложениях малой реки в зоне влияния города

\begin{tabular}{|c|c|c|c|c|c|c|c|c|c|c|}
\hline \multirow{2}{*}{ Элемснт } & \multicolumn{2}{|c|}{ Уч dсток I } & \multicolumn{2}{|c|}{ Участок 11} & \multicolumn{2}{|c|}{ Участок III } & \multicolumn{2}{|c|}{ Участок IV } & \multicolumn{2}{|c|}{ Участок V } \\
\hline & $\mathrm{K}_{\mathrm{c}}$ & ' & $\mathrm{k}$. & $v$ & $K_{t}$ & 'L & $\mathrm{K}_{\mathrm{r}}$ & 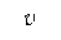 & $\mathrm{K}_{\mathrm{t}}$ & $v$ \\
\hline Pтуть & 76 & 510 & 29 & 91 & 58 & 67 & 21,6 & 116 & 3,5 & 298 \\
\hline Серебро & 13 & 199 & 138 & 93 & 256 & 73 & 113 & 94 & 27 & 150 \\
\hline Олово & 3 & 140 & 7.1 & 84 & 18 & 103 & 43 & 302 & 5 & 145 \\
\hline Свинец & 2,7 & 136 & 12 & 15 & 22 & 74 & 5,7 & 114 & 1,5 & 130 \\
\hline Медь & 2,6 & 224 & 10,7 & 66 & 19 & 59 & 83 & 62 & 5,3 & 210 \\
\hline Стронции & 1,9 & 61 & 1.9 & 39 & 1,9 & 52 & 1,5 & 28 & 1,2 & 22 \\
\hline Ццинк & 1,8 & 130 & 4.6 & 57 & 5,2 & 65 & 2,6 & 77 & 2 & 154 \\
\hline Нике.ль & 1,8 & 95 & 7,8 & $6 i$ & 49 & 87 & 15 & 103 & 2,4 & 69 \\
\hline Кобальт & 1,71 & 48 & 1,9 & 33 & 1,7 & 35 & 1,8 & 20 & 1,6 & 34 \\
\hline Ванадий & 1,11 & 53 & 1,1 & 39 & 1,4 & 32 & 1,0 & 46 & 0,7 & 67 \\
\hline Хром & 0,91 & 46 & 3,2 & 67 & 9.7 & 85 & 6,3 & 181 & 1,3 & 68 \\
\hline Молиблен & 0,8 & 62 & 1.7 & 175 & 1.4 & 70 & 1 & 46 & 0,8 & 50 \\
\hline Кадмий & - & - & 28 & 106 & 786 & 125 & 111 & 181 & 12 & 179 \\
\hline Индий & - & - & 20 & 180 & & - & - & - & - & \\
\hline
\end{tabular}

Примчиние $\mathrm{K}, \quad$ коэффициент концентрации относ игельно фонового содержания, ‘' коэффнщнент варидци, \%/, выделенные участки сочтвететвуют аналолидым на рис 83

геоморфологическим строением русла --- резкое выполаживание его продольного профиля, наличие островов и затонов, с интенсивным развитием в последних водной растительности, заметное сужение русла реки, что создает определенный подпор речных вод, т. е. наличием условий, способствующих аккумуляции переносимых взвешенных и донных насосов. В пределах зоны влияния крупной свалки бытовых и промышленных отходов (участок IV) химические элементы поступают с поверхностным стоком по системе ручьев, а также при разгрузке загрязненных грунтовых вод. Распределение химических элементов в периферийной части потока (участок V) связано с разубоживанием техногенного материала природным и с естественным затуханием аномалий.

Потоки рассеяния в пределах жилого района города характеризуются сравнительно невысокими содержаниями элементов и довольно отчетливо выраженной вариацией их распределения (см. табл. 51, рис. 52). В отдельных точках фиксируются контрастные локальные аномалии $\mathrm{Hg}$ ( $\mathrm{K}_{\text {с }}$ до 2200), Ag (до 150), 5п (до 20), в меньшей степени Zn и $\mathrm{Pb}$. Протяженность аномалий невелика (до 4-5 км). Для пространственного распределения наиболее контрастно накапливающихся элементов отмечена достаточно высокая степень корреляции. Это указывает на единство источника их поступления - с поверхностными и сточными водами по ручью.

Промышленный район города отличается резким увеличением содержаний многих элементов (см. рис. 52). Здесь фиксируются контрастные аномалии $\mathrm{Cd}$ и Jn, являющихся типоморфными 
элементами для данной зоны (см. табл. 51). Наиболее значительные по интенсивности аномалии образуют $\mathrm{Ag}$ ( $\mathrm{K}_{\mathrm{c}}$ до 400-500), $\mathrm{Hg}$ и Cd (Кс до 100-150), Pb, Ni, Sn, Си, Jn (Кс до 20-40). Если в пределах жилой зоны содержания даже в соседних точках опробования варьировали от высокоаномальных до фоновых, то здесь аномалии элементов очень стабильны и вариации проявляются в высоких областях аномальности. Например, коэффициенты концентрации Cd меняются в соседних точках от 15-20 до 30-50, редко до 100; Ag от 70 до 300-500, 5п от 5 до 15-20; Hg от 10 до 40-50, редко до 70-100; РЬ от $8-10$ до 15-20, что находит отражение в уменьшении их коэффициентов вариации. Поскольку основным источником поступления загрязняющих веществ являются сточные воды, то для большинства химических элементов отмечается очень высокая степень пространственной корреляции (коэффициенты парной корреляции превышают значение доверительного уровня при $0,1 \%$ уровня значимости).

Отличительной особенностью следующего участка реки (см. табл. 51, рис. 52, участок III) является максимальное накопление практически всех элементов, прежде всего $\mathrm{Cd}, \mathrm{Ag}, \mathrm{Hg}$, а также нарушение корреляционных связей между ними, фиксируемых на других участках. Это связано с тем, что данный участок является геохимическим барьером, на котором создаются благоприятные условия для осаждения (но с разной интенсивностью) химических элементов, прежде всего их взвешенных форм, а также влекомых наносов.

В пределах участка IV на поток рассеяния города как бы накладывается воздействие свалки отходов. Это находит отражение в очень высоких, но резко варьирующих концентрациях многих элементов и особенно $\mathrm{Cd}, 5$, $\mathrm{Ag}, \mathrm{Ni}, \mathrm{Cr}$ (см. табл. 51). Контрастные аномалии 5п, возможно, обусловлены захоронением в прошлые годы отходов с завода по его переработке (около 40 лет назад).

Непосредственно ниже свалки графики распределения элементов остаются относительно варьирующими, а для всех элементов четко проявлена тенденция к снижению уровней содержания. Общая протяженность изученного потока рассеяния широкой группы химических элементов, связанного с воздействием города и свалки отходов, составляет более 40 км. По степени контрастности накопления, особенностям изменения концентраций элементов и их соотношения в пространстве в строении изученного потока выделяется ряд характерных участков, закономерно связанных со структурой урболандшафта и геоморфологическим строением русла. В то же время, несмотря на наличие этих участков, химические элементы прослеженной ассоциации в целом мигрируют с неплохой степенью согласованности, которая локально нарушается на геохимических барьерах 
и в зонах поступления дополнительных потоков от второстепенных источников загрязнения. Особенно сильно корреляция проявляется вблизи источника; по мере удаления корреляционные связи несколько нарушаются. По-видимому, при удалении от основного источника воздействия возрастает роль вторичного переотложения речного материала, приводящая к возрастанию неоднородности распределения элементов в донных отложениях.

Обычно потоки рассеяния в донных отложениях описываются как линейные объекты. В действительности же они обладают реальной шириной и мощностью. Изучение формы потоков рассеяния имеет большое методическое и практическое значение, поскольку оно позволит детализировать процессы их формирования в руслах водотоков, реально оценить общий уровень загрязнения реки и ее отдельных участков, получить материал, необходимый для прогнозирования развития потока загрязняющих веществ в водотоках; важен этот материал и для организации отбора проб.

Русло равнинных рек представляет собой сложно построенный комплекс разнообразных форм рельефа, структурно-морфологические особенности которого определяются гидродинамическими параметрами водотока и литологией руслоформирующих отложений. Речное русло создается в процессе взаимодействия движущейся водной массы и взвешенного в ней твердого материала с подстилающими ее донными отложениями. Течение рек вследствие сложности формы естественных русел почти никогда не бывает равномерным и носит неустановившийся характер. Даже в меженные периоды, когда расходы воды в реке не меняются, неустановившееся движение воды отличается, как правило, турбулентным характером. Осаждение химических элементов, мигрирующих с водной массой (в первую очередь, со взвесью), определяется выше названными процессами, а их распределение по руслу носит неоднородный характер. Кроме того, в процессе перемещения наносов речной поток непрерывно обменивается твердыми частицами с дном, что также способствует дифференциации речного аллювия и связанных с ним химических элементов.

Анализ распределения химических элементов по площади русла в зоне смешения сточных и речных вод показал зависимость пространственной структуры аномалий от гидродинамических особенностей водотока, отчасти определяемых геоморфологией устьевой зоны ручья, дренирующего сток города (рис. 53). Наиболее контрастные аномалии связаны с участками замедления течения и приурочены к местам накопления техногенных илов. Сложное гидродинамическое поле рассматриваемого участка обусловливает значительную литологическую пестроту донных отложений, что приводит к формированию мозаичной структуры техногенных аномалий в плане. По мере удаления от устьевой 


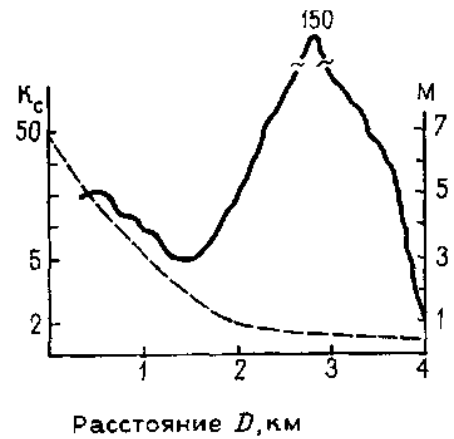

Рис. 53. Распределение кадмия (сплошная линия) на различном расстоянии от места сброса сточных вод города.

$\mathrm{K}_{\mathrm{c}}-$ коэффициент концентрации кадмия от носительно фона, $M$ - превышения над уре зом устья ручья (в м), пунктир - линия продольного профиля ручья

зоны гидродинамический режим потока становится более установившимся и спокойным, что находит отражение в формировании сплошной зоны техногенных илов и в более широком развитии техногенных аномалий

Изучение распределения химических элементов на участке русла реки, характеризующегося развитием свободных излучин, также указывает, что площадная структура техногенных аномалий всецело определяется литолого-геоморфологическими особенностями строения русла (рис 54). Места наиболее интенсивной аккумуляции илистых отложений отличаются повышенным накоплением химических элементов, что и обусловливает мозаичность аномалий в плане Приводимый пример свидетельствует о том, что гидротехнические сооружения могут оказывать существенное влияние на пространственные особенности потоков рассеяния в донных отложениях В частности, для большинства изученных элементов в потоке (см. рис 54) характерно довольно отчетливое разделение на две зоны: первая (до бывшей плотины) характеризуется в целом более широким распределением аномальных участков, вторая (ниже плотины) - большим распространением участков с фоновым содержанием элементов Вероятно, плотина играла роль барьера для основной массы твердого материала, что нашло отражение и в характере распространения песчано-илистых отложений.

Особенности пространственного строения потоков рассеяния в донных отложениях во многом зависят от геоморфологических особенностей русла и долины рек В частности, характер распределения элементов в потоке рассеяния может сильно меняться при прохождении озеровндных расширений или прудов, созданных на реках Как правило, такие водоемы являются перехватчиками существенной части взвешенного вещества, что оказывает влияние на пространственную дифференциацию ассоциаций химических элементов (табл 52). В то же время следует помнить, что такие барьеры могут являться и вторичными источниками загрязнения водной фазы Большое значение имеет 


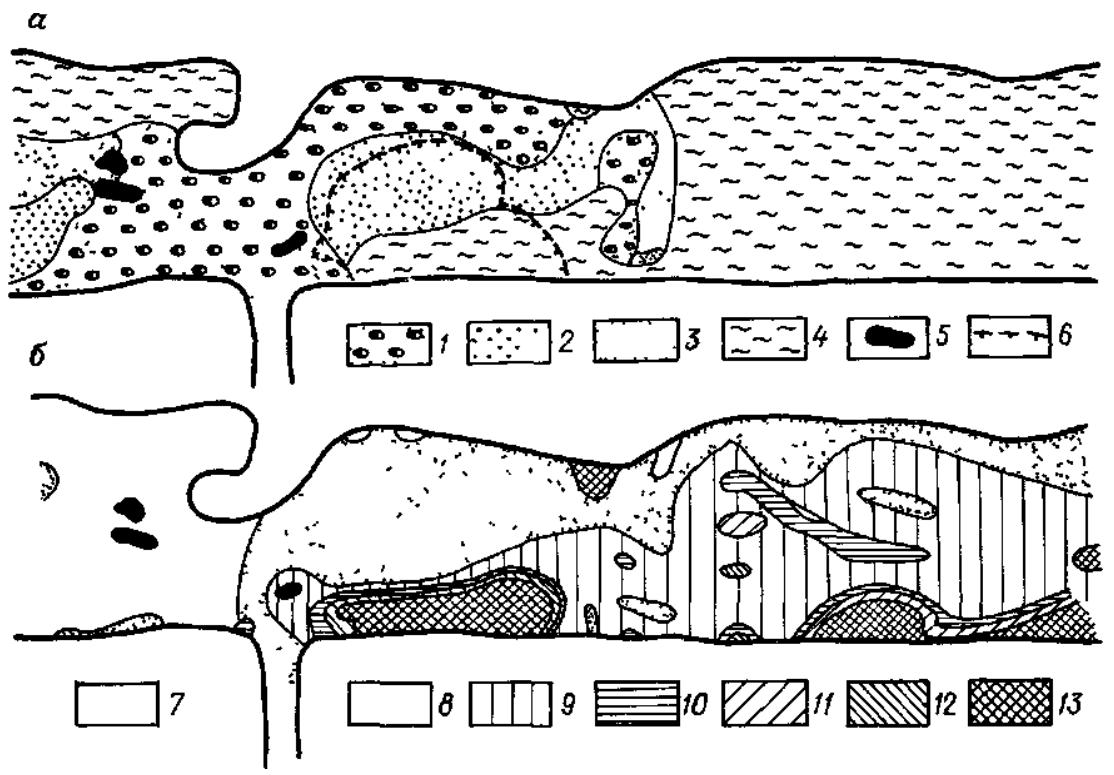

Рис. 54. Литологическая схема (а) и распределение меди (б) в донных отложениях реки в зоне смешения сточных и речных вод:

1 - гравийно галечн ље отложения с песчаным заполнителем, 2 - крупнозер нистые пески, 3 - тонкие илистые пески, 4- ил, 5- острова, 6 - граница речной отмели, $7-13$ - коэффициенты концентрации меди $(7-$ менее $1,5,8-1,5-3$, $9-3-6,10-6-9,11-9-12, / 2-12-15,13-$ более 15)

характер продольного профиля водотоков Так, ручьи, выходящие на поймы рек, отличаются резким выполаживанием. Это приводит к изменению гидродинамических параметров водотоков и отражается в формировании на устьевых участках геохимических барьеров (рис 55)

Т а блица 52 Пространственная дифференциация ассоциаций химических элементов в донных отложениях малой реки в зоне влияния химического завода

\begin{tabular}{|c|c|c|c|c|c|}
\hline \multirow{2}{*}{$\begin{array}{c}\text { Участок } \\
\text { реки }\end{array}$} & \multicolumn{5}{|c|}{ Коэффициент концентрации } \\
\hline & Более 100 & $100-30$ & $30-10$ & $10-3$ & $3-1,5$ \\
\hline $\begin{array}{l}\text { Выше } \\
\text { прудов }\end{array}$ & $\mathrm{Hg}_{93}$ & & & $\mathrm{Zn}_{9} \mathrm{Cu}_{8} \mathrm{Cr}_{4}$ & \\
\hline $\begin{array}{l}\text { Пруд I } \\
\text { Пруд II } \\
\text { Ниже } \\
\text { прудов }\end{array}$ & - & $\mathrm{Hg}_{52} \mathrm{Ag}_{50} \mathrm{Ni}_{42}$ & $\begin{array}{c}\mathrm{Cu}_{18} \mathrm{Cr}_{18} \mathrm{Sr}_{11} \\
\mathrm{Hg}_{11}\end{array}$ & $\begin{array}{c}\mathrm{Pb}_{4} \mathrm{Cd}_{35} \\
\mathrm{Cd}_{5} \mathrm{Ag}_{4} \mathrm{Hg}_{3} \text { । } \\
\mathrm{N}_{16} \mathrm{Ag}_{5} \mathrm{Sr}_{4}\end{array}$ & $\begin{array}{cc}2 \Pi & 5 \Pi \\
5 г & \mathrm{~N} 1 \\
\text { Си } & 2 \Pi \mathrm{Cr}\end{array}$ \\
\hline
\end{tabular}

Примечание Коэффициенты концентрации (относительно фонового содержания) указаны в индексах химических элементов 




Рис. 55. Литологическая схема (a) и распределение меди (б) и свинца (в) в донных отложениях реки.
Условные обозначения см на рис 54 
Потоки рассеяния в донных отложениях в условиях урболандшафтов характеризуются значительными размерами и высокими содержаниями широкой группы химических элементов с резко варьирующим распределением по профилю. По величине аномалий и характеру изменений концентраций в строении потоков рассеяния достаточно четко проявляется связь с особенностями размещения источников загрязнения, планировочной структуры городских зон, а также с литолого-геоморфологическим строением русла и долины и гидродинамическими параметрами водотоков Все это в совокупности с существующей в реках естественной дифференциацией и накоплением речного материала в русле, осложняющейся воздействием гидротехнических сооружений, приводит к ярко выраженной мозаичности техногенных аномалий в плане. Мозаичность выражается в чередовании участков с различной степенью аномальности, причем их расположение всецело определяется литологогеоморфологическими и гидродинамическими параметрами водотока. Изменения в пространственном распределении элементов связаны в основном с разной степенью их концентрации, что в конечном счете определяется различием в интенсивности их поставки в водный поток и разнообразием форм миграции на отдельных участках потока. Выявленные геохимические барьеры в руслах рек могут являться не только участками резкого концентрирования химических элементов, но и при изменении условий среды источниками их вторичного поступления в водную фазу По мере удаления от источника загрязнения для формирования потоков рассеяния огромное значение имеют процессы вторичного переотложения аллювия Это, в частности, подтверждается несоответствием между протяженностью потоков в донных отложениях и в водно-взвешенной фазе. Как правило, длина первых заметно больше вторых.

Проблема загрязненных донных осадков как источника вторичного загрязнения вод в первую очередь имеет значение для крупных водоемов - озер и водохранилищ, где они в значительной мере определяют режим и поведение химических элементов, и, соответственно, качество воды. Высокая динамичность состава природных вод во многом определяется процессами, регулирующими скорость движения веществ через границу вода/грунт. Для их реальной оценки необходимо изучение форм нахождения элементов в донных отложениях, а также состава иловых и природных вод, сочетающееся с углубленными исследованиями физикохимической обстановки в водах и их динамики Сколько-нибудь законченных целенаправленных исследований этой проблемы пока нет, хотя значимость проблемы и сущность слагающих ее задач отмечена многими исследователями. Установлено, что в загрязненных донных отложениях химические элементы находятся в значительной мере в геохимически подвижной форме, способной к взаимодействию с водной фазой и живыми организ- 
мами. В иловых водах интенсивно накапливаются компоненты, активно участвующие в формировании качества воды (табл. 53).

$\mathrm{K}$ сожалению, работ по изучению форм нахождения химических элементов в загрязненных донных отложениях и иловых водах рек урболандшафтов не очень много. Наибольший интерес представляет изучение распределения химических элементов в гранулометрическом спектре донных отложений и их физикохимических форм нахождения.

Полученные нами данные позволяют наметить некоторые особенности распределения элементов по гранулометрическим фракциям загрязненных донных отложений (табл. 54). Техногенные аномалии в донном осадке образовались за счет увеличения концентраций практически во всех выделенных фракциях. Почти для всех изученных элементов характерно увеличение их चбсолютных содержаний от фракции крупного песка (1-0,25 мм) к глинистым частицам, достигая максимума в самой тонкой фракции $(<0,005$ мм), причем абсолютные концентрации элементов во фракциях $0,01-0,005$ и $<0,005$ мм в целом незначительно разнятся.

Рассмотрение особенностей пространственного распределения абсолютных содержаний элементов в разных фракциях показало, что для большинства из них наиболее протяженные аномалии фиксируются во фракциях физической глины $(<0,01$ мм $)$; для $\mathrm{Hg}$ - во фракции крупного песка; для 5п - во фракции мелкого песка. Для абсолютных концентраций в тонких фракциях характерна более выраженная пространственная вариация, особенно вблизи источника загрязнения. Для всех изученных элементов основным носителем является фракция алеврита $(0,1-0,01$ мм), с которой связано до 50-70\% валового содержания. Это обусловливается высокой долей данной фракции в отложениях (в среднем до $30-40 \%$ ) и сравнительно высокими абсолютными концентрациями элементов в данной фракции. На долю фракций песка приходится в среднем по 10--20\% валового содержания элементов. Распределение запасов элементов, связанных с конкретными фракциями, вниз по потоку довольно однородное. Однако на геоморфологических барьерах отмечается увеличение в балансе доли более крупных фракций.

Наибольший интерес представляет изучение физико-химических форм нахождения химических элементов в донных отложениях (табл. 55). В условиях наиболее сильного загрязнения в сравнении с участком реки выше города большая часть элементов (при увеличении их валовых концентраций) связана с легкоподвижными формами - до $90 \% \mathrm{Cd}, 80-90 \%$ Си, 80-85\% № и $\mathrm{Pb}$, что для первых трех элементов в среднем на $10-\mathbf{1 5 \%}$, а для свинца на $30-35 \%$ больше, чем на участке реки выше города (см. табл. 55). Для $\mathrm{Ni}$ и РЬ характерна преимущественная связь с сорбционно-карбонатными и гидроксидными фор- 
Т а б л и а 53 Сравнительная характеристика состава иловых и придонных вод малой реки

\begin{tabular}{|c|c|c|c|c|c|c|c|c|}
\hline \multirow{2}{*}{ Характеристика пробы } & $\mathrm{NH}_{4}^{+}$ & $M n$ & $\mathrm{Pe}$ & V & Си & $\mathrm{Zn}$ & $\mathrm{Cd}$ & $\mathrm{Pb}$ \\
\hline & \multicolumn{3}{|c|}{$\mathrm{Mr} / л$} & \multicolumn{5}{|c|}{ мкг/л } \\
\hline & \multicolumn{8}{|c|}{ Выше города } \\
\hline \multirow[t]{2}{*}{$\begin{array}{l}\text { Иловая вода } \\
\text { Придонная вода }\end{array}$} & $\begin{array}{r}15,0 \\
7,5\end{array}$ & $\begin{array}{l}0,248 \\
0,014\end{array}$ & $\begin{array}{l}0,340 \\
0,100\end{array}$ & $\begin{array}{l}2,48 \\
2,68\end{array}$ & $\begin{array}{l}4 \\
3\end{array}$ & $\begin{array}{l}58 \\
16\end{array}$ & $\begin{array}{l}1,0 \\
1,2\end{array}$ & $\begin{array}{r}52,50 \\
4,08\end{array}$ \\
\hline & \multicolumn{8}{|c|}{ Ниже города } \\
\hline $\begin{array}{l}\text { Иловая вода } \\
\text { Придонная вода }\end{array}$ & $\begin{array}{l}9,0 \\
8,1\end{array}$ & $\begin{array}{l}0,400 \\
0,073\end{array}$ & $\begin{array}{l}0,600 \\
0,320\end{array}$ & $\begin{array}{l}6,80 \\
2,73\end{array}$ & $\begin{array}{l}38 \\
13\end{array}$ & $\begin{array}{r}180 \\
25\end{array}$ & $\begin{array}{l}3,6 \\
1,0\end{array}$ & $\begin{array}{r}400,00 \\
8,25\end{array}$ \\
\hline
\end{tabular}

Та бли ц 54 Распределение химических элементов в техногенных илах на участке реки ниже города

\begin{tabular}{|c|c|c|c|c|c|c|c|c|c|c|c|c|}
\hline \multirow{3}{*}{ Элемент } & \multicolumn{10}{|c|}{ Фракции, мм } & \multirow{2}{*}{\multicolumn{2}{|c|}{$\begin{array}{c}\text { Валовое } \\
\text { содержание }\end{array}$}} \\
\hline & \multicolumn{2}{|c|}{$1-0,25$} & \multicolumn{2}{|c|}{$0,25-0,1$} & \multicolumn{2}{|c|}{$0,1--0,001$} & \multicolumn{2}{|c|}{$0,01-0,005$} & \multicolumn{2}{|c|}{$<0,005$} & & \\
\hline & $x$ & $K_{e}$ & $x$ & $\mathrm{~K}_{\mathrm{c}}$ & $x$ & Kc & $x$ & $\mathrm{~K}$ & $x$ & $\mathrm{Kc}$ & $x$ & $\mathrm{~K}_{c}$ \\
\hline Алюминий & 18400 & 0,8 & 26900 & 0,9 & 52800 & 1,8 & 75600 & 1,8 & 87000 & 3,3 & 43700 & 1.4 \\
\hline Титан & 305 & 0,9 & 663 & 2,7 & 2617 & $\begin{array}{l}1,0 \\
1,9\end{array}$ & 3414 & 1.5 & 4671 & 1,2 & 1887 & 1,5 \\
\hline Ванадий & 28 & 2,8 & 24 & 1,7 & 45 & 1,4 & 70 & 1.2 & 116 & 1,3 & 41 & 2,2 \\
\hline Хром & 108 & 6,8 & ПО & 37 & 350 & 6 & 429 & 5,1 & 449 & 7,5 & 247 & 5 \\
\hline Марганец & 250 & 3,1 & 344 & 2,5 & 448 & 1,2 & 492 & 0,8 & 472 & 0,7 & 354 & 1,8 \\
\hline Железо & 42800 & 24 & 57400 & 24 & 85800 & 36 & 18200 & 8,7 & 15400 & 24 & 79475 & 34 \\
\hline Никель & 86 & 2,8 & 97 & 7,5 & 154 & 6,2 & 274 & 7 & 353 & 7,5 & 143 & 6 \\
\hline Цинк & 218 & 1,8 & 321 & 2,8 & 422 & 3,5 & 511 & 2,1 & 570 & 2,6 & 380 & 3,1 \\
\hline Серебро & 1,99 & 3 & 1,58 & 4 & 3,7 & 8 & 4.7 & 6,7 & 4,6 & 5,8 & 2,84 & 22 \\
\hline Олово & 68 & 22,6 & 58 & 18 & 143 & 24 & 256 & 13,5 & 261 & 8,2 & 117 & 19 \\
\hline Ртуть & 0,083 & 83 & 0,04 & 40 & 0,26 & 5,2 & 0,22 & 1 & 0,22 & 1.1 & 0,1645 & 4 \\
\hline Свинец & 182 & 6,5 & 212 & 16,3 & 431 & 19,6 & 761 & 23 & 914 & 15,8 & 328 & 15 \\
\hline
\end{tabular}

Примечание $\mathrm{K}_{c}-$ коэффициент концентрации относительно содержания в соответствующих фракциях нлов выше города, $\kappa-$ среднее содержание, $\mathrm{m} \boldsymbol{\Gamma} /$ кг 


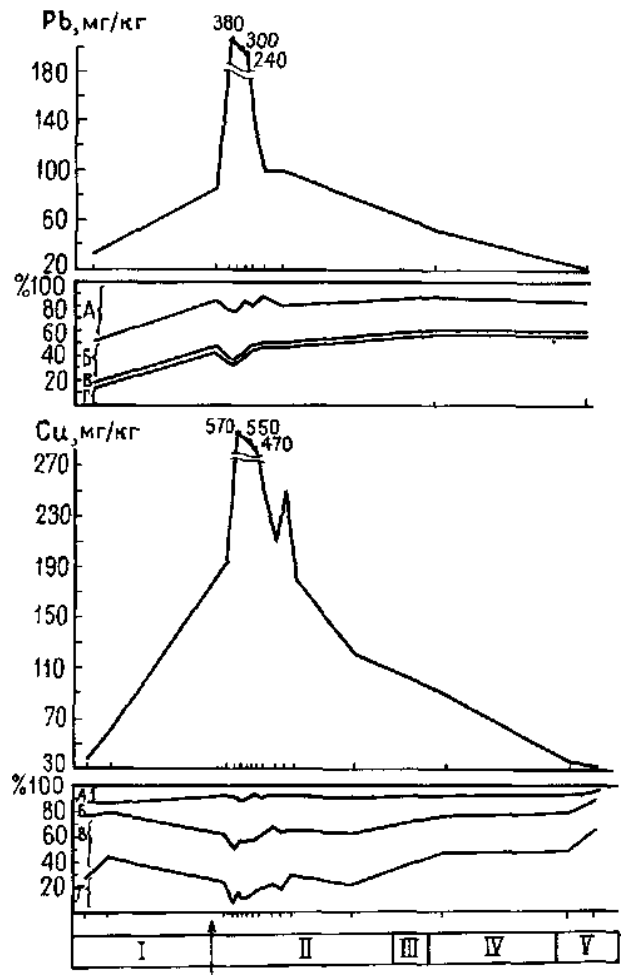

Рис. 56. Распределение валовых содержаний свинца и меди и баланс форм их нахождения в донных отложениях реки в зоне влияния города:

A-Г - формы нахождения элементов А - кристаллическая, Б - гидроксидная, В органическая, Г - сорбционно карбонатная, остальные усл обозначения см на рис 52

мами. Медь наиболее активно закрепляется в органической форме, а также связана с гидроксидами железа. Для Cd преобладающее значение имеют сорбционно-карбонатные формы.

При удалении от источника загрязнения отмечаются изменения в соотношении форм нахождения элементов в общем их балансе. Например, для Си и $\mathrm{Pb}$ отмечается в целом постепенное и закономерное увеличение доли сорбционно-карбонатных форм (рис. 56). Если вблизи источника загрязнения кадмий фиксировался преимущественно в сорбционно-карбонатной форме (до 80-90\%), то в краевой части потока до $50 \%$ его связано с органической формой (см. табл. 55). Никель отличается от остальных изученных элементов относительно стабильным соотношением различных форм по всему потоку. Таким образом, с удалением от источника загрязнения для большинства химических элементов отмечается активная трансформация форм нахождения как в ходе миграции, так и в самом донном осадке. Вблизи источника, по всей видимости, преобладает механическое осаждение первичных форм, т. е. образовавшихся при технологических производственных процессах или в результате процессов на очистных сооружениях.

188 
Т а б и ц 55 Формы нахождения химических элементов в донных отложениях малой реки

\begin{tabular}{|c|c|c|c|c|c|c|c|c|c|c|c|c|c|c|c|}
\hline \multirow{3}{*}{ Элемент } & \multirow{3}{*}{$\begin{array}{c}\text { /Ч асток } \\
\text { реки }\end{array}$} & \multicolumn{2}{|c|}{$\begin{array}{c}\text { Валовое } \\
\text { содержание в } \\
\text { донных } \\
\text { отложениях }\end{array}$} & \multicolumn{3}{|c|}{$\begin{array}{l}\text { Сорбционно- } \\
\text { карбонатная }\end{array}$} & \multicolumn{3}{|c|}{ Органическая } & \multicolumn{3}{|c|}{ Гидроксидная } & \multicolumn{3}{|c|}{ Кристаллическая } \\
\hline & & \multirow{2}{*}{$X \mathrm{M} \Gamma / \mathrm{K} \Gamma$} & \multirow{2}{*}{$\mathrm{K}$} & \multicolumn{2}{|c|}{$X$} & \multirow{2}{*}{$\mathrm{K}$} & \multicolumn{2}{|c|}{$x$} & \multirow{2}{*}{$\mathrm{K}$} & \multicolumn{2}{|c|}{$x$} & \multirow{2}{*}{$\mathrm{K}$} & \multicolumn{2}{|c|}{$X$} & \multirow{2}{*}{$\mathrm{K}_{\mathrm{c}}$} \\
\hline & & & & $\%$ & $\mathrm{M} \Gamma / \mathrm{K} \Gamma$ & & $\%$ & Мг/КГ & & $\%$ & мг / Кг & & $\%$ & Мг/КГ & \\
\hline \multirow[t]{5}{*}{ Никель } & I & 24 & & 42,95 & 10,31 & - & 21,43 & 5,14 & - & 12,76 & 3,06 & & 22,86 & 5,49 & \\
\hline & II & 106 & 4,42 & 48,63 & 51,55 & 5 & 12,90 & 13,67 & 2,66 & 22,31 & 23,65 & 7,73 & 16,17 & 17,14 & 3,12 \\
\hline & III & 45 & 1,88 & 58,46 & 26,31 & 2,55 & 8,99 & 4,05 & 0,79 & 16,86 & 7,14 & 2,33 & 16,69 & 7,51 & 1,37 \\
\hline & IV & 35 & 1,46 & 57,14 & 19,99 & 1,94 & 2,11 & 0,74 & - & 19,85 & 6,95 & 2,27 & 20,90 & 7,32 & 1,33 \\
\hline & V & 11,5 & 0,48 & 42,82 & 4,92 & 0,48 & 19,02 & 2,18 & - & 16,01 & 1,84 & - & 22,11 & 2,57 & 0,45 \\
\hline \multirow[t]{5}{*}{ Медь } & I & 40 & $\underline{-. .}$ & 27,56 & 11,02 & & 48,23 & 19,29 & 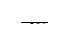 & 10,91 & 4,36 & & 13,3 & 5,32 & \\
\hline & II & 366 & 9,15 & 15,51 & 56,77 & 5,15 & 42,17 & 154,34 & 8 & 32,69 & 119,64 & 27,44 & 9,63 & 33,24 & 6,25 \\
\hline & III & 120 & 3 & 21,95 & 26,34 & 2,39 & 40,27 & 48,32 & 2,5 & 28,57 & 34,28 & 7,86 & 9,21 & 11,05 & 2,08 \\
\hline & IV & 90 & 2,25 & 47,23 & 42,5 & 3,86 & 28,98 & 26,08 & 1,35 & 16,14 & 14,53 & 3,33 & 7,66 & 6,89 & 1,3 \\
\hline & V & 30 & 0,75 & 67,72 & 19,72 & 1,79 & 22,31 & 6,69 & 0,35 & 7,57 & 2,27 & 0,25 & 4,4 & 1,32 & 0,25 \\
\hline \multirow[t]{3}{*}{ Кадмий } & I & 0,3 & & 28,57 & 0,086 & & 42,85 & 0,13 & & 14,29 & 0,043 & & 14,24 & 0,043 & \\
\hline & II & 8,71 & 29 & 88,96 & 7,83 & 91 & 2,55 & 0,222 & 1,7 & 1,79 & 0,16 & 3,72 & 5,7 & 0,50 & 11,63 \\
\hline & V & 0,5 & 1,7 & 16,79 & 0,0815 & 0,95 & 49,94 & 0,256 & 2,0 & 16,67 & 0,0815 & 1,9 & 16,67 & 0,0815 & 1,9 \\
\hline \multirow[t]{4}{*}{ Свинец } & I & 33 & & 13,79 & 4,55 & & 3,42 & 1,13 & & 34,55 & 11,4 & & 48,25 & 15,92 & \\
\hline & II & 192 & 5,8 & 41,26 & 79,22 & 17,4 & 2,17 & 5,2 & 4,6 & 38,45 & 73,82 & 6,48 & 18,42 & 28,45 & 1,79 \\
\hline & IV & 53 & 1,61 & 58,27 & 30,88 & 6,79 & 2,93 & 1,55 & 1,37 & 26,84 & 14,23 & 1,25 & 11,96 & 6,34 & 0,4 \\
\hline & V & 20 & 0,61 & 58,19 & 11,64 & 2.56 & 3,79 & 0,76 & 0,67 & 22,80 & 4,56 & 0,4 & 15,22 & 3,04 & 0,7 \\
\hline
\end{tabular}

Примечания Участки реки I - выше города, II - ниже места сброса основного объема сточных вод города, III - геохимический (механический) барьер перед свалкой, IV - зона дополнительного влияния свалки отходов, V - периферийная часть потока рассеяния $\mathbf{K}_{\mathbf{c}}$ - коэффициент концентрации относительно значений выше города, \% - доля фракции в валовом содержании 
Т а блиц а 56. Содержание некоторых химических элементов в воде водотоков

\begin{tabular}{|c|c|c|c|c|c|c|}
\hline \multirow{2}{*}{$\begin{array}{c}\text { Водоток, источник } \\
\text { загрязнения }\end{array}$} & \multicolumn{2}{|c|}{ Хром } & \multicolumn{2}{|c|}{ Медь } & \multicolumn{2}{|c|}{ Цинк } \\
\hline & $\mathrm{C}$ & K, & $\mathrm{C}$ & $\mathrm{K}$, & $\mathrm{C}$ & K, \\
\hline p. Майн (устье) & 3,8 & 7,6 & 8,3 & 4,6 & 222 & 22,2 \\
\hline p. Рейн (ниже р. Рур) & 11 & 22 & 17 & 9,4 & 201 & 20,1 \\
\hline р. Мала Панев (Поль- & 4,5 & 9 & 6,25 & 3,5 & 43100 & 4310 \\
\hline $\begin{array}{l}\text { ша) цинковый завод } \\
\text { p. Мала Панев (Поль- }\end{array}$ & 25 & 50 & 12,5 & 6,9 & 7700 & 770 \\
\hline $\begin{array}{l}\text { ша) промышленный } \\
\text { район }\end{array}$ & & & & & & \\
\hline $\begin{array}{l}\text { p. Тава, Юж. Уэльс } \\
\text { (промышленный рай- } \\
\text { он) }\end{array}$ & - & - & 5,4 & 3 & 764 & 76,4 \\
\hline $\begin{array}{l}\text { p. Қамбилеевка, Сев. } \\
\text { Осетия (завод «Элек- } \\
\text { троцинк») }\end{array}$ & - & 一 & 60 & 33,3 & 8500 & 850 \\
\hline $\begin{array}{l}\text { p. Тама (Япония) } \\
\text { (промышленный рай- } \\
\text { он) }\end{array}$ & - & - & 150 & 83,3 & 90 & 9 \\
\hline $\begin{array}{l}\text { рр. Гаронна и Дерзе- } \\
\text { на, Франция }\end{array}$ & $10-30$ & $20-60$ & $300-500$ & $166-277$ & - & - \\
\hline р. Мозель (устье) & 3,8 & 7,6 & 3,0 & 1,7 & 146 & 14,6 \\
\hline Фоновые воды & 0,5 & - & 1,8 & - & 10 & - \\
\hline
\end{tabular}

Примечание С - содержание химического элемента, мкг/л, $\mathrm{K}_{\mathrm{c}}-$ коэффициент концент

Данные по формам нахождения химических элементов в донных отложениях позволяют наметить группы геохимических процессов, способствующих переводу этих элементов в водную фазу: увеличение минерализации природных вод (процессы десорбции и ионного обмена), понижение $\mathrm{pH}$ (растворение карбонатов), развитие анаэробной слабовосстановительной (глеевой) обстановки (разложение оксидов), деятельность микроорганизмов (разложение органических веществ и железомарганцевых оксидов), появление в водах природных и синтетических комплексообразователей, процессы взмучивания. Эти факторы в водотоках и водоемах проявляются достаточно интенсивно, так как связаны с реально существующими природными и техногенными процессами.

Таким образом, зоны воздействия источников загрязнения наиболее полно фиксируются в донных отложениях (техногенных илах). В них формируются полиэлементные аномалии, отличающиеся высокой корреляцией пространственного распределения химических элементов и преобладанием подвижных форм нахождения. Морфологические особенности потоков рассеяния связаны с русловой дифференциацией аллювия, что определяет неоднородную структуру аномалий в водотоке. 
антропогенных ландшафтов и степень их концентрации [27]

\begin{tabular}{|c|c|c|c|c|c|c|c|}
\hline \multicolumn{2}{|c|}{ Серебро } & \multicolumn{2}{|c|}{ Кадмий } & \multicolumn{2}{|c|}{ Ртуть } & \multicolumn{2}{|c|}{ Свинец } \\
\hline $\mathrm{C}$ & K, & $\mathrm{C}$ & $\mathrm{K}_{\mathrm{c}}$ & $\mathrm{C}$ & K, & $\mathrm{C}$ & $\mathrm{K}$, \\
\hline $\begin{array}{l}0,24 \\
0,51\end{array}$ & $\begin{array}{l}0,8 \\
1,7\end{array}$ & $\begin{array}{c}0,5 \\
3,7 \\
1325\end{array}$ & $\begin{array}{r}7,1 \\
53 \\
18929\end{array}$ & $\begin{array}{l}0,14 \\
0,49\end{array}$ & $\begin{array}{l}14 \\
49\end{array}$ & $\begin{array}{l}0,7 \\
4,2 \\
175\end{array}$ & $\begin{array}{r}3,5 \\
21 \\
875\end{array}$ \\
\hline- & - & 130 & 1857 & - & - & 15 & 75 \\
\hline- & - & 6,2 & 88,6 & - & & 6,9 & 34,5 \\
\hline - & - & 20 & 285 & - & - & - & - \\
\hline - & - & до 9 & до 129 & $0,08-1$ & $8-100$ & $20--40$ & $100-200$ \\
\hline $\begin{array}{l}0,12 \\
0,3\end{array}$ & 0,4 & $\begin{array}{l}0,4 \\
0,07\end{array}$ & 5,7 & $\begin{array}{l}0,04 \\
0,01\end{array}$ & 4 & $\begin{array}{r}43 \\
0,2\end{array}$ & 6,5 \\
\hline
\end{tabular}

рации относительно фонового содержания, «-》- данные отсутствуют

\section{Общая оценка последствий загрязнения водных систем}

Техногенное воздействие, связанное с городами, привело к резкому и быстрому изменению геохимического состояния водных систем во многих районах мира. Это проявилось в многократном увеличении содержаний широкого комплекса химических элементов (в том числе токсичных) в различных компонентах водных объектов (табл. 56, 57).

Постоянно растушее водопотребление в урболандшафтах приводит к увеличению объемов сбрасываемых в поверхностные водные системы сточных вод. Сток крупных рек, протекающих по урбанизированным районам промышленно развитых стран, обычно в среднем на $10-20 \%$ состоит из сточных вод, а в периоды межени - в еще большей степени. Небольшие реки в индустриальных районах состоят на $30-40 \%$ (иногда на 90\%) из сточных вод городов. Так, в США к категории наиболее загрязненных относятся $72 \%$ всех водных объектов страны. В Нидерландах сильно загрязнены 95\% вод, в Швейцарии - 75\%, в ГДР $87 \%$, в Болгарии - 46\%, Испании - 37\%, ПНР - 35\%, в Австралии - 27\%. Аналогичная картина наблюдается и в других странах $[6,50]$.

В то же время экономические и эколого-гигиенические последствия загрязнения водных систем в урболандшафтах выявлены и изучены недостаточно полно. Во многих экспертных оценках, 


\begin{tabular}{|c|c|c|c|c|c|}
\hline \multirow{2}{*}{ Водоток } & \multirow{2}{*}{ Источник загрязнения } & \multicolumn{2}{|c|}{ Хром } & \multicolumn{2}{|c|}{ Медь } \\
\hline & & $\mathrm{C}$ & $\mathrm{K}_{\mathrm{c}}$ & $\mathrm{C}$ & $\mathrm{K}$, \\
\hline р Гранд-Калумет, США & $\begin{array}{l}\text { Крупный сталелитейный за- } \\
\text { вод }\end{array}$ & - & - & - & - \\
\hline р. Мала Панев, ПнР & Цинковый завод & - & - & - & - \\
\hline p. Мала Панев, ПНР & Химический завод & - & - & - & - \\
\hline p. Эльба, ФРГ & г. Гамбург & 359 & 4,1 & 359 & 8 \\
\hline p. Гудзон, США & Производство батарей & - & - & 104 & 2,3 \\
\hline p. Тама, Япония & $\begin{array}{l}\text { Крупный урбанизированный } \\
\text { район }\end{array}$ & - & - & 2600 & 57,8 \\
\hline p. Рейн в нижнем течении & $\begin{array}{l}\text { Крупный промынленно-ур- } \\
\text { банизированный район }\end{array}$ & 397 & 4,4 & 376 & 8,4 \\
\hline р. Бяла Пжемша, ПНР & $\begin{array}{l}\text { Металлургические предпри- } \\
\text { ятия, производство серной } \\
\text { кислоты }\end{array}$ & 21 & - & 156 & 1,2 \\
\hline p. Кер'д'Ален, Франция & $\begin{array}{l}\text { Горнодобывающая и метал- } \\
\text { лургическая промышлен- } \\
\text { ность, добыча и производст- } \\
\text { во Pb и 2п }\end{array}$ & - & - & 115 & 2,6 \\
\hline
\end{tabular}

Примечание С - содержание химического элемента, мг/кг; $\mathrm{K}_{c}-$ коэффициент концент ствуют

как правило, речь идет о потенциальном риске и уровне, которые в полной мере смогут проявиться лишь в дальнейшем. Но более тщательный анализ проблемы взаимодействия «город водоток» позволяет выявить ряд проблемных ситуаций, которые уже в настоящее время имеют негативные последствия.

Во многих районах мира города и связанные с ними промышленные предприятия испытывают существенную нехватку воды высокого качества. Это связано с тем, что в результате техногенного загрязнения из хозяйственно-питьевого и промышленного водопользования изымаются крупные водные системы либо использование их вод очень затруднено и требует больших материальных затрат. Качество водопроводной питьевой воды существенно зависит от качества исходной воды. Существующие технологии очистки питьевой воды малоэффективны в отношении многих загрязняющих веществ и особенно металлов. Более того, во многих случаях разбавление сточных вод, сбрасываемых в малые реки, очень незначительно. Поэтому в крупных агломерациях при небольших расстояниях от пункта сброса стоков до пункта водопользования, когда нельзя ожидать существенного самоочищения воды (для металлов практически невозможного), сточные воды почти в неизменном виде используются в самых различных целях. В результате подпитки и инфильтрации возможно загрязнение вод аллювиальных горизонтов, которые во многих районах широко используются для питьевого водоснабжения.

Загрязнение негативно сказывается не только на состоянии вод 192 
антропогенных ландшафтов и степень их концентрации [27]

\begin{tabular}{|c|c|c|c|c|c|c|c|}
\hline \multicolumn{2}{|c|}{ цинк } & \multicolumn{2}{|c|}{ Кадмий } & \multicolumn{2}{|c|}{ Ртуть } & \multicolumn{2}{|c|}{ Свинец } \\
\hline C & $K_{\text {c }}$ & C & $K_{c}$ & C & $K_{e}$ & C & KC \\
\hline 2060 & 21,7 & 7,85 & 26,2 & - & - & 811 & 40,6 \\
\hline 3000 & 31,6 & 15,2 & 50,7 & & & 200 & . 10 \\
\hline 5000 & 52,6 & 116 & 386 & - & - & 150 & 7,5 \\
\hline 2499 & 21,3 & 16,9 & 56,3 & 16,9 & 42,3 & 262 & 13,1 \\
\hline $\begin{array}{r}388 \\
1700\end{array}$ & $\begin{array}{r}4,1 \\
17,9\end{array}$ & $\begin{array}{c}908 \\
9,8\end{array}$ & $\begin{array}{c}3026 \\
32,6\end{array}$ & - & - & $\begin{array}{l}179 \\
370\end{array}$ & $\begin{array}{r}9 \\
18,5\end{array}$ \\
\hline 1098 & 11,5 & 28 & 93 & 18 & 45 & 333 & 16,5 \\
\hline 2000 & 21,1 & - & - & - & - & 500 & 25 \\
\hline 3800 & 40 & 43 & 143,3 & 6 & 15 & 3700 & 185 \\
\hline
\end{tabular}

рации относительно среднего содержания в осадочных породах, «-》-данные отсут-

как экономического ресурса, но и оказывает воздействие на ценности, не имеющие прямой экономической оценки. Это прежде всего урон, наносимый водным системам, используемым для рекреационных целей, что связано не только с ухудшением их эстетического состояния, но и с прямой угрозой для здоровья людей. В настоящее время уже есть попытки экономических оценок влияния загрязнения на рекреационные ресурсы водных систем. Например, ущерб для рекреационных ресурсов в результате загрязнения вод в 1973 г. в США оценивался в 6,3 млрд долларов. Особую опасность представляет загрязнение водных систем в районах крупных курортных зон. В частности, авторы наблюдали, как в результате загрязнения поверхностных вод бытовым стоком города, гидравлически связанных с подземными, происходило загрязнение минеральных вод, широко используемых в бальнеологических целях.

В последние годы интенсивно развивается орошение сельскохозяйственных угодий на местном стоке. Применение загрязненных стоками городов речных вод для полива приводит к накоплению токсичных элементов в сельскохозяйственных почвах и продукции. Аналогичные явления могут отмечаться и при разливах рек во время половодий и паводков. Все это увеличивает вероятность попадания загрязняющих веществ в организм человека. Уже известны случаи отравления людей и сельскохозяйственных животных, употреблявших в пищу растения, орошаемые загрязненными речными водами.

Техногенноя воздействие приводит к изменению бногеохими- 
ческих циклов и существенной перестройке водных биоценозов. Способность гидробионтов аккумулировать химические элементы более или менее пропорционально их содержаниям в воде и донных отложениях приводит к обогащению пищевой цепи токсичными элементами, что в конечном итоге способствует нарушению естественных циклов химических элементов и деградации водных экосистем. Живыми организмами, испытывающими воздействие загрязнения, прежде всего являются гидробионты, совокупность которых не в меньшей степени, чем физико-химические факторы, определяет качество воды.

Пресные воды - биокосные системы. Влияние изменений в гидробионтах сказывается далеко не сразу. Эти процессы сейчас являются предметом интенсивного изучения, но, к сожалению, прямые корреляции биогеохимических параметров с геохимическими характеристиками потоков в водотоках пока еще очень мало известны.

В ряде случаев прослеживается связь с накоплением химических элементов в водах и биогеохимическими реакциями человека или животных. К сожалению, отработанной методики исследований, позволяющей получить достоверные данные, до сих пор нет. Наиболее разработаны подходы к изучению вопросов эпидемиологии - влияния микробного загрязнения вод на инфекционную заболеваемость населения [44].

Широко известны случаи массового отравления людей в Японии в районе залива Минамата и в Ниигата, которые были вызваны промышленными сбросами ртутных соединений химическими заводами по синтезу ацетатальдегида и винилхлорида, что привело к накоплению ртути в промысловой рыбе, крабах, устрицах. При употреблении в пищу таких продуктов возникали симптомы поражения центральной нервной системы, паралич, потеря слуха, разума, зрения. К 1974 г. в Минамате было выявлено более 700 случаев ртутных отравлений и более чем 500 случаев в Ниигате. Признаки болезни Минамата, а также случаи отравления людей другими химическими элементами в результате загрязнения природных вод известны и в других районах мира.

Таким образом, загрязнение водных систем в городах приводит к невозможности использования их ресурсов в самых различных целях (питьевого, промышленного и сельскохозяйственного водоснабжения, рекреации), увеличивает вероятность воздействия токсичных элементов на живые организмы и человека, вызывая у них отрицательные биогеохимические реакции, а в отдельных случаях - даже гибель. 


\section{4. БИОГЕОХИМИЧЕСКАЯ И ГЕОГИГИЕНИЧЕСКАЯ ОЦЕНКИ ТЕХНОГЕННЫХ АНОМАЛИЙ}

Окружающая среда современных индустриальных городов искусственно созданная среда обитания. Химический состав атмосферного воздуха, вод, уровень шума, электромагнитных полей, ультрафиолетовой радиации и другие факторы в городах резко отличаются от природных условий, в которых ранее существовало человечество. Поступление химических элементов в организм человека происходит с продуктами питания, водой и воздухом. Но в условиях большинства городов доминирующее значение приобретает ингаляционный путь. Это связано с тем, что качество питьевой воды в большинстве городов является более стабильным фактором, чем состав атмосферного воздуха. Если иногда наблюдаются значительные отклонения в химическом составе воды, связанные с его природной вариацией или антропогенным преобразованием источников водоснабжения, то обычно это относится ко всей территории города или к его очень крупным частям. Нивелируется в городе и влияние состава продуктов питания, так как они поступают из различных источников и в городах обычно смешиваются. Даже если в общий «котел» города и поступают продукты с отклонениями от нормального микроэлементного состава, то, как правило, они рассеиваются по всей территории.

Для небольших городских поселений возле крупных промышленных предприятий с расположением водозаборных сооружений в зоне влияния выбросов или золоотвалов, возможны случаи, когда избыточные количества металлов или других загрязняющих веществ проникают в питьевую воду. Повышенное поступление токсичных веществ по всем основным путям с воздухом, питьевой водой и продуктами питания наиболее вероятно в рабочих поселках около крупных металлургических, горнодобывающих и химических производств, где люди живут в зонах интенсивных аэрогенных аномалий. Здесь же расположены источники водоснабжения и жители широко применяют продукты питания из подсобных хозяйств.

Для оценки воздействия на человека геохимической обстановки в городах необходимо понять закономерности проникновения техногенных геохимических потоков в организм человека и установить их влияние на изменение его микроэлементного статуса. Таким образом, необходимо создание индикационной биогеохимической модели «техногенная аномалия - организм человека». Формирование такой модели возможно на основе изучения диагностических биосубстратов (кровь, волосы, моча и другие) населения в городах различного типа и техногенного воздействия различной интенсивности. Наличие биогеохимических связей в системе «среда - человек» обосновывает принципиаль- 
Т а блиц а 58 Содержание свинца, кадмия, меди и цинка в волосах населения

\begin{tabular}{l|c|c|c|c}
\hline \multirow{2}{*}{ Регион (ландшафт) } & \multicolumn{2}{|c|}{ Число проб } & \multicolumn{2}{c}{ Свинец } \\
\cline { 2 - 5 } & дети & взрослые & дети & взрослые \\
\hline Нечерноземный (равнйнный) & 136 & 38 & $3,58+0,34$ & $2,97+0,46$ \\
Центральночерноземный (равнин- & 37 & 24 & $7,24+0,96$ & $3,07+0,6$ \\
ный) & 17 & & $4,0+0,54$ & \\
Закавказский (говрно-долинный) & 25 & 29 & $4,8+0,74$ & $1,83+0,22$ \\
Закавказский (горный) & 27 & 14 & $4,8 \pm 1,7$ & $3,3+0,5$ \\
Крым (горно-долинный) & 236 & 105 & $4,4+0,31$ & $2,7+0,5$ \\
\hline Среднее значение по регионам & & & & \\
\end{tabular}

ную возможность перехода к изучению состояния здоровья человека и, в последующем, к формированию эколого-геохимических моделей городов, в рамках которых можно провести геогигиеническое структурирование территорий с выделением групп населения повышенного риска.

\section{Биогеохимические особенности организма человека в городе}

Изучению микроэлементного состава тех или иных диагностических органов и тканей посвящено уже довольно много исследований. Особенно детально изучается микроэлементный состав волос - доступного для массовых исследований диагностического биосубстрата, чутко отражающего уровень поступления химических элементов в организм [28]. Тем не менее работы, показывающие связь микроэлементной структуры организма с химическими характеристиками окружающей среды, пока немногочисленны. Практически не изучено влияние ландшафтноклиматических и ландшафтно-геохнмических характеристик и природной геохимической неоднородности окружающей среды. Особенно мало исследований, посвященных фоновой характеристике распределения химических элементов в биосубстратах.

Совершенно ясно, что понятие о «фоновом содержании» применительно к биосубстратам человека весьма условно. Природной «биологически обусловленной» картины распределения химических элементов в организме человека наблюдать, вероятно, уже не удастся. Использование в качестве эталона сравнения при анализе бионакопления химических элементов в городах, состав биосубстратов у сельских жителей не всегда правомерно из-за резкого различия характера используемых продуктов питания и источников водоснабжения.

В табл. 58 приведены данные по содержанию наиболее распространенных в техногенных геохимических аномалиях тяжелых металлов ( $\mathrm{Pb}, \mathrm{CM}, C u$ u $\mathrm{Zn})$ в образцах волос взрослых и детей, проживающих в различных ландшафтных зонах СССР. 
ффоновых» районов городов различных регионов, мкг/r

\begin{tabular}{c|c|c|c|c|c}
\hline \multicolumn{2}{c|}{ Кадмий } & \multicolumn{2}{c|}{ Медь } & \multicolumn{2}{c}{ Цинк } \\
\hline дети & взрослые & дети & взрослые & дети & взрослые \\
\hline $0,19+0,07$ & $0,26+0,03$ & $11,0+0,35$ & $14,3+0,7$ & $132,8+22,0$ & $195,3 \pm 10,0$ \\
$0,38+0,10$ & $0,27+0,05$ & $10,1 \pm 0,5$ & $13,3+1,8$ & $131,5+7,1$ & $198,6+8,3$ \\
& & $10,1 \pm 0,46$ & & $121,4+6,1$ & \\
$0,15+0,03$ & & $10,5+0,38$ & $12,3+1,0$ & $155,7+3,9$ & $166,0+11,1$ \\
$0,35+0,06$ & $0,34+0,11$ & $10,30+0,0$ & $147,0+86,0$ & $212,0 \pm 10,0$ \\
$0,30+0,07$ & $0,30+0,03$ & $14,1 \pm 0,32$ & $26,3+3,9$ & 140 & 1,0 \\
\hline $0,24+0,04$ & $0,29+0,07$ & $11,1 \pm 0,43$ & $15,1+1,85$ & $135,8+2,1$ & $190,2 \pm 12,0$
\end{tabular}

Отметим, что среди перечисленных элементов два ( $\mathrm{Pb}$ и $\mathrm{Cd})$ являются высокотоксичными, а два (Си и 2п) - биологически важными. Отметим также, что в окружающей среде изученных территорий кадмий, цинк и медь имели надежные фоновые характеристики. В отношении свинца имеются определенные сомнения, так как в любых городах некоторое количество автотранспорта с выбросом свинца всегда имеется.

Приведенные материалы показывают некоторые различия в биоконцентрациях этих элементов. Для всех элементов, кроме свинца, содержания у детей и взрослых в фоновых условиях

Т а бли ц 59 Содержание химических элементов в волосах детей фоновых районов городов различных регионов, мкг/г

\begin{tabular}{|c|c|c|c|c|}
\hline \multirow{2}{*}{ Элемент } & \multicolumn{2}{|c|}{ Нечерноземье $\quad(я=20)$} & \multicolumn{2}{|c|}{ Закавказье $(n=33)$} \\
\hline & $x$, мкг /г & $0, \%$ & $X$, МКГ/Г & $\sigma, \%$ \\
\hline Натрий & $12,01+1,16$ & 43 & $28,3+2,54$ & 52 \\
\hline Алюминий & $12,8 \pm 1,27$ & 44 & $14,7 \pm 1,82$ & 71 \\
\hline Скандий & $0,007+0,001$ & 64 & $0,004+0,001$ & 144 \\
\hline Титан & $7,09+0,50$ & 32 & - & - \\
\hline Ванадий & $0,07+0,014$ & 89 & - & \\
\hline Хром & $0,62+0,20$ & 144 & $0.65+0,07$ & $\overline{62}$ \\
\hline Марганец & $0,27+0,04$ & 66 & $0,53+0,08$ & 87 \\
\hline Железо & $18,5 \pm 1,86$ & 45 & $21,7+2,21$ & 58 \\
\hline Кобальт & $0,07+0,009$ & 57 & $0,04+0,004$ & 57 \\
\hline Мышьяк & $0,16+0,02$ & 56 & $0,14+0,02$ & 82 \\
\hline Селен & $0,42+0,03$ & 32 & $0,58+0,04$ & 40 \\
\hline Бром & $2,13+0,05$ & 10 & $2,81 \pm 0,35$ & 72 \\
\hline Рубидий & $1,80+0,31$ & 77 & $1,40+0,17$ & 70 \\
\hline Серебро & $0,16+0,02$ & 56 & $0,15+0,03$ & 115 \\
\hline Сурьма & $0,18+0,07$ & 174 & $0,12+0,04$ & 109 \\
\hline Теллур & $0,52+0,08$ & 69 & - & - \\
\hline Лантан & $0,039+0,003$ & 34 & $0,044+0,005$ & 65 \\
\hline Церий & $0,09+0,03$ & 149 & - & - \\
\hline Самарий & $0,004+0,0004$ & 45 & $0,009+0,001$ & 65 \\
\hline Европий & $0,014+0,001$ & 32 & - & - \\
\hline Золото & $0,006+0,001$ & 47 & $0,06+0,015$ & 144 \\
\hline Ртуть & $0,99+0,14$ & 63 & $1,06+0,17$ & 92 \\
\hline
\end{tabular}


различаются слабо. Для свинца во всех случаях наблюдается повышенное (в 1,5-2,0 раза) содержание в волосах детей. Объяснить это явление можно тем, что накопление токсичных элементов в молодом растущем организме в результате активных метаболических процессов происходит более интенсивно.

Для описываемой группы элементов в пределах изученных случаев ландшафтных различий в распределении содержаний не отмечается. На основе нейтронно-активационного анализа проведено сопоставление распределения большой группы элементов в двух районах, контрастно отличающихся по климатическим и ландшафтно-геохимическим характеристикам (табл. 59). Мы видим, что большинство редких элементов содержится в близких концентрациях. Однако для $\mathrm{Na}, \mathrm{Mn}$, а также 5e, Аи, 5п зафиксировано контрастное увеличение в волосах детей из субаридной зоны (Закавказье), тогда как Со и 5с имеют более высокие содержания у детей из гумидной зоны (Нечерноземье).

В табл. 60 сведены данные по содержаниям химических элементов в волосах взрослого населения из разных стран (всюду приведены результаты нейтронно-активационного анализа). Имеющиеся сведения не позволяют дать ландшафтно-геохимические интерпретации этим данным. Тем не менее, результаты позволяют оценить наблюдаемые пределы вариации фоновых содержаний. Интересно отметить, что для Канады демонстрируется широкая вариация фоновых содержаний по ряду макроэлементов окружающей среды (Na, Ca, A1, Ti, Mп), а также некоторым микроэлементам (Аи, $\mathrm{Ag}, \mathrm{As}, \mathrm{Br}$ ). Это позволяет предположить более важную, чем нам представляется значимость ландшафтных факторов в биоконцентрировании химических элементов.

Биогеохимическое исследование влияния загрязнения окружающей среды города проведено для ряда групп населения, контрастно отличающихся по условиям воздействия на них потоков загрязненного воздуха.

Максимально возможные уровни накопления изучались на примере рабочих, имеющих профессиональный контакт с химическими элементами. Биоконцентрирование для наиболее высоких уровней загрязнения окружающей среды изучалось на рабочих и служащих тех же предприятий, не связанных по условиям работы с профвредностью. Эта группа рабочих обычно находится в ядрах формируемых геохимических аномалий.

Кинетика биоконцентрирования исследовалась на сопряженных выборках детей и взрослых, проживающих на различных расстояниях от источников выбросов.

Биогеохимические последствия загрязнения окружающей среды городов изучены как в условиях многоотраслевых городов, так и на примере серии производств, где прослеживается цепь получения, переработки и использования таких токсичных эле198 
Т а бл и ц а 60. Микроэлементный состав волос взрослого населения разных стран мира, мкг/г

\begin{tabular}{|c|c|c|c|c|c|c|c|c|c|c|c|}
\hline \multirow{2}{*}{$\begin{array}{c}\text { Химический } \\
\text { элемент }\end{array}$} & \multicolumn{5}{|c|}{ Европа } & \multicolumn{2}{|c|}{ Америка } & \multicolumn{4}{|c|}{ Азия } \\
\hline & $\begin{array}{l}\text { СССР (Нечерно- } \\
\text { земный регион) }\end{array}$ & ГДР & Италия & ПНР & Бельгия & США & Канада & Индия & $\begin{array}{l}\text { Южная } \\
\text { Корея }\end{array}$ & Япония & $\begin{array}{c}\text { Паки- } \\
\text { стан }\end{array}$ \\
\hline Натрий & $12,9+0,75$ & & & 24 & 20 & 289 & $516-1205$ & & 64 & 10 & \\
\hline Алюминий & $9,04 \pm 1,31$ & 17,7 & - & 20 & 12 & 24 & $3,7-9,0$ & - & 7,49 & 10 & - \\
\hline Кальций & $678+161$ & - & - & 560 & $5: 0$ & 1854 & $135-1150$ & - & 1630 & 790 & - \\
\hline Скандий & $0,0098+0,0015$ & - & - & - & - & 0,07 & - & - & - & 0,006 & - \\
\hline Титан & $4,35+0,55$ & - & - & - & - & - & $3,9-24,0$ & - & 63 & - & - \\
\hline Ванадий & $0,033+0,020$ & - & - & 0,18 & 0,062 & 0,05 & - & - & 0,22 & 0,03 & - \\
\hline Хром & $1,09+0,10$ & 0,54 & $0,9-1,7$ & 2,07 & - & 1,6 & $1,3-2,0$ & 0,46 & $2,3 ?$ & 0,58 & 1,42 \\
\hline Марганец & $0,66+0,18$ & 1,34 & - & 1,42 & 1,20 & 2,6 & $1,7-8,8$ & 3,36 & 3,54 & 0,48 & 4,27 \\
\hline Железо & $87+20,5$ & 20 & $30-60$ & 145 & 40 & 30,0 & $73-100$ & 60 & 152 & 29 & 5,11 \\
\hline Кобальт & $0,13+0,014$ & 0,38 & $0,1-0,3$ & 0,56 & 0,13 & 0,30 & $0,24-0,34$ & 0,07 & 0,48 & 0,042 & 0,33 \\
\hline Мышьяк & $0,09+0,010$ & - & - & 0,14 & 0,11 & 1,9 & $0,06-1,2$ & 0,038 & 0,27 & 0,085 & 0,26 \\
\hline Селен & $0,50+0,04$ & 0,31 & $0,3-0,7$ & 0,98 & 0,80 & 1,3 & $0,48-0,79$ & 1,28 & - & 0,70 & 1,03 \\
\hline Бром & $2,37+0,70$ & - & - & 2,7 & 3,0 & 8,0 & $0,2-2,1$ & - & 3,45 & 7,0 & - \\
\hline Рубидий & $1,97+0,016$ & - & 2,0 & - & - & - & $0,20-0,23$ & - & - & - & - \\
\hline Серебро & $0,18+0,02$ & 0,24 & 0,6 & 0,59 & 0,80 & 0,41 & $0,4-2,56$ & 0,68 & - & 0,27 & 0,47 \\
\hline Сурьма & $0,10+0,007$ & - & 0,05 & 0,26 & 0,15 & 0,7 & - & 0,12 & 0,60 & 0,078 & 0,15 \\
\hline Теллур & $0,63+0,07$ & 一 & - & - & - & - & 一 & - & - & - & - \\
\hline Лантан & $0,085+0,014$ & - & - & 0,054 & - & 0,06 & $0,49-0,83$ & - & 0,025 & 0,024 & - \\
\hline Церий & $0,18+0,02$ & - & - & - & - & - & - & - & - & - & - \\
\hline Самарий & $0,009+0,002$ & - & - & - & - & - & - & - & - & 0,004 & - \\
\hline Европий & $0,001 \pm 0,0005$ & - & - & - & - & - & - & - & - & 0,003 & - \\
\hline Золото & $0,020+0,008$ & 0,019 & - & 0,036 & 0,037 & 0,15 & $0,001-0,005$ & 0,66 & 0,041 & 0,01 & 0,31 \\
\hline Ртуть & $1,81+0,15$ & - & $1,5-2,2$ & - & - & 6,3 & $1,1-1,5$ & - & 1,88 & 3,9 & 1,73 \\
\hline
\end{tabular}

Примечание: «—»- данные отсутствуют 
ментов как $\mathrm{Pb}$, Cd и $\mathrm{Hg}$. С этой целью обследовано население, проживающее в окружении различных источников загрязнения (металлургические комбинаты, машиностроительные заводы, производства аккумуляторов, минеральных красок, термометров, минеральных удобрений). Перечисленные выше элементы относятся к первому классу опасности и входят в списки приоритетных загрязняющих веществ, подлежащих обязательному контролю по рекомендациям ВО3 и Программы ОOH по охране окружающей среды. Рассмотрим закономерности накопления в организме человека этих химических элементов.

Свинец. В организм человека большая часть свинца поступает с пищей, 1\% может попадать с питьевой водой и $0,1 \%-$ из атмосферного воздуха. Курильщики получают дополнительно по 1 мкг свинца от каждой сигареты. Неорганические соединения свинца всасываются при прохождении через респираторный и желудочно-кишечный тракты. Количество свинца, задерживаемого в респираторном тракте или проникающего через него в кровь, зависит от размера частиц и частоты дыхания. Крупные частицы задерживаются в верхних дыхательных путях, а мелкие поступают в легкие, где и осаждается $30 \%$ достигающего их свинца [42].

Большая часть свинца выводится из организма через желудочно-кишечный тракт. Часть элемента элиминируется с желчью, мочой, волосами. Выведение свинца из организма происходит медленно, что способствует его накоплению в органах и тканях человека. Преодолев биологический барьер (альвеолярную стенку легких или слизистую оболочку кишечника), свинец попадает в кровоток, где большая часть его (95\%) связывается с эритроцитами.

Воздействие свинца на организм человека проявляется прежде всего в нарушении синтеза гемоглобина и отклонениях показателей состояния нервно-психической системы. Важно отметить, что установленные в ряде работ психоневрологические изменения у детей могут быть связаны с воздействием свинца на организм матери. У беременных женщин, которые использовали воду с повышенным содержанием свинца или подвергались влиянию этого металла на производстве, концентрации свинца в крови, а также в плаценте, крови и пупочном канатике новорожденного достоверно выше, чем в контрольной группе. Свинец может поступать в организм ребенка и с молоком кормящей матери. Между концентрацией свинца в молоке матери и крови ребенка обнаружена прямая корреляция.

Вопросы накопления свинца в биосубстратах, определение связей между биоконцентрациями и показателями воздействия на состояние здоровья населения широко освещены в литературе. Основные результаты проведенных работ содержатся в резюмирующем документе международной группы экспертов ВО3 [42]. 200 
Наиболее информативным биосубстратом является кровь. Содержание свинца в крови отражает текущее состояние динамического равновесия между количеством свинца, поступающего в организм, переходящего в кровь и отлагающегося в тканях. Предполагается, что у населения, не имеющего профессионального контакта со свинцом, существует длительное устойчивое равновесие концентраций свинца в крови, а у промышленных рабочих устойчивого состояния нет из-за значительных колебаний свинца в воздухе рабочей зоны.

Выделение свинца с мочой зависит не только от содержания этого металла в крови, но и от других факторов: прямых заключений об уровне воздействия и поглощения свинца на основании данных о его содержании в моче делать нельзя. Комплексные исследования, проведенные советскими учеными, позволили установить, что для промышленных рабочих допустимым уровнем содержания свинца в крови является 40 мкг/100 мл крови, критическим - 60 мкг/100 мл крови. В качестве допустимого уровня свинца в моче предложено его содержание 50 мкг/л [28].

Параллельное изучение свинца в крови и волосах рабочих позволило определить, что допустимому уровню свинца в крови 40 мкг/100 мл соответствует содержание свинца в волосах $70 \mathrm{MKr} /$ г [28].

Во всем мире проводятся широкие эпидемиологические исследования по оценке воздействия атмосферного воздуха, загрязненного свинцом, на состояние здоровья населения. Результатом исследований явилось, в частности, понимание закономерностей распределения свинца в крови взрослого населения, не имеющего производственного контакта со свинцом. По нормам Европейского экономического сообщества содержание свинца в крови не должно превышать 20 мкг/100 мл крови у 50\% населения, 30 мкг/100 мл у 10\%. населения и 35 мкг/100 мл у 2\% населения. Такой путь нормирования микроэлементов в биосубстратах представляется наиболее перспективным, так как он отражает статистические закономерности распределения свинца в крови. Рекомендаций по допустимому уровню содержания свинца в волосах и моче взрослого населения нет, но анализ результатов исследований во многих странах мира показывает, что в городских условиях вне зон высокого загрязнения свинцом содержание свинца в волосах не превышает 30 мкг/г, т. е. примерно в 2 раза ниже допустимого уровня свинца в этой среде для производственного контингента.

Результатом эпидемиологических исследований с определением свинца в различных биосубстратах явились и рекомендации по допустимому содержанию этого металла в организме ребенка. Если в 1976 г., основываясь на показателях нарушения порфиринового обмена, для детей была предложена величина содержания свинца в крови, равная 20-29 мкг/100 мл, то проведение 
Т а б л и ц 61 Содержание свинца в биосубстратах рабочих

\begin{tabular}{|c|c|c|c|c|c|c|c|c|}
\hline \multirow{3}{*}{ Производство } & \multicolumn{4}{|c|}{ Содержание в волосах, мкг/г } & \multicolumn{4}{|c|}{ Содержание в моче, мкг/л } \\
\hline & \multicolumn{2}{|c|}{ Число проб } & \multirow[b]{2}{*}{$\begin{array}{c}\text { Среднее } \\
\text { значение и } \\
\text { его ошибка }\end{array}$} & \multirow[b]{2}{*}{$\mathrm{K}_{c}$} & \multicolumn{2}{|c|}{ Число проб } & \multirow[b]{2}{*}{$\begin{array}{c}\text { Среднее } \\
\text { значение и } \\
\text { его ошибка }\end{array}$} & \multirow[b]{2}{*}{$\mathrm{Kc}$} \\
\hline & всего & $\begin{array}{c}\text { более } \\
70 \\
\text { мкд/г, } \\
\%\end{array}$ & & & всего & \begin{tabular}{|c|} 
более \\
50 \\
мкг/л, \\
$\%$ \\
$\%$
\end{tabular} & & \\
\hline $\begin{array}{l}\text { Свинцового гле- } \\
\text { та }\end{array}$ & 29 & 93 & $596 \pm 113,2^{*}$ & 220 & - & - & - & - \\
\hline $\begin{array}{l}\text { Минеральных } \\
\text { красок }\end{array}$ & 14 & 43 & $102,8+21,7^{*}$ & 38 & 40 & 75 & $93,6+8,7^{*}$ & 8 \\
\hline Производство & 8 & 0 & $56,0+8,0^{*}$ & 22 & 16 & 90 & $78,4+4,1^{*}$ & 7 \\
\hline $\begin{array}{l}\text { Вторичная пе- } \\
\text { реплавка цвет- }\end{array}$ & 25 & 24 & $52,6 \pm 17,4^{*}$ & 19 & 26 & 38 & $50,0+14,5^{*}$ & 4 \\
\hline $\begin{array}{l}\text { ных металлов } \\
\text { Электродов для } \\
\text { аккумуляторов }\end{array}$ & 19 & 7 & $45,1 \pm 2,9^{*}$ & 17 & - & - & - & - \\
\hline $\begin{array}{l}\text { Производство } \\
\text { меди }\end{array}$ & 11 & 0 & $7,9+1,1$ & 3 & - & - & - & - \\
\hline $\begin{array}{l}\text { Фоновые терри- } \\
\text { тории }\end{array}$ & 105 & 0 & $2,72+0,5$ & 1 & 10 & 0 & $11,7+2,7$ & 1 \\
\hline
\end{tabular}

Примечание * - различия с контрольной группой достоверны с вероятностью ошибки $0,1 \%$, Кс - коэффициент концентрации относительно фоновых территорий

параллельного изучения содержания свинца в крови детей и уровня интеллектуального развития послужило основанием для более жесткого норматива - 12 мкг/100 мл, т. е. почти в 2 раза ниже, чем у взрослого населения. Аналогичные исследования, в которых сопоставлены концентрации свинца в волосах детей и изменения со стороны зрительного восприятия (увеличение числа ошибок, удлинение времени психомоторных реакций и др.), позволили американским исследователям рекомендовать в качестве допустимого уровня содержания свинца в волосах 9 мкг/г.

Изучение состояния здоровья детей, подверженных воздействию повышенных концентраций свинца, проведенное в СССР И. Е. Кунцевичем и О. В. Тарасенко [21], показало, что содержание свинца $9,8 \pm 1,9$ мкг/г в волосах детей $5-7$ лет является верхней границей физиологической нормы. Таким образом, за допустимый уровень содержания свинца в волосах детей можно принять нижнюю границу -8 мкг/г. За критическое содержание свинца в волосах принята величина 24 мкг/г, при которой у детей регистрируется повышенная заболеваемость нервной системы. К этой величине близки показатели содержания свинца в волосах - 30 мкг/г, при которых наблюдаются специфические изменения в костях детей.

С целью изучения закономерностей накопления свинца в организме рабочих и жителей промышленных городов в различных 202 
регионах страны проведено исследование биосубстратов детей, подвергающихся воздействию различных концентраций свинца в цехах или проживающих в техногенных геохимических аномалиях, в центрах которых и располагались источники выбросов свинца. Естественно, что наибольшую свинцовую нагрузку испытывают рабочие свинцовых предприятий, в воздушной среде цехов которых очень высоки концентрации свинца. Особенно неблагоприятная ситуация на производстве свинцового глета, где концентрации свинца в воздухе цехов превышают допустимые нормативы в сотни раз. Естественно, что это отразилось и на накоплении свинца в организме рабочих (табл. 61). У $93 \%$ рабочих содержание свинца в волосах превышало допустимый уровень. На этом производстве постоянно выявляются рабочие "с выраженными формами свинцовой интоксикации. Значительно число рабочих с превышением допустимых и критических уровней содержания свинца в волосах на производстве минеральных красок. Еще более контрастны различия в концентрациях свинца в организме этих рабочих по сравнению с физиологическими, фоновыми концентрациями этого элемента (см. табл. 61). Коэффициенты концентраций свинца в волосах достигают (в относительных единицах): $220-$ у рабочих производства свинцового глета, 38 - у рабочих производства минеральных красок, 21 17 - у рабочих других производств.

С биогеохимических позиций такую ситуацию можно оценить как экстремальную, так как в природны биогеохимических условиях биоконцентрации элементов редко достигают столь высокого уровня.

По содержанию свинца в моче коэффициенты концентрации несколько ниже по сравнению со значениями в контрольной группе и колеблются от 8 у рабочих производства минеральных красок до 4 у рабочих завода по вторичной переплавке металлов

Центры химических аномалий локализуются всегда на промышленных площадках предприятий и поэтому людьми, которые испытывают максимальную техногенную нагрузку, хотя и не имеют профессионального контакта с металлами, являются служащие свинцовых производств. Это хорошо видно на примере изучения свинца в волосах сотрудников заводов по производству аккумуляторов и свинцового глета. Среднее содержание этого металла в волосах составило соответственно 49,7+5,5 мкг/г и $14,1 \pm 2,0$ мкг/г, т. е. было значительно выше (в 18-5 раз) фоновых значений этого элемента. Более высокое содержание свинца в организме служащих завода по производству аккумуляторов объясняется и более мощной геохимической свинцовой аномалией на территории этого завода. Несмотря на то, что служащие не имеют непосредственного производственного контакта со свинцом, у 10\% обследованных лиц на аккумуляторном 
заводе биоконцентрации свинца превышали допустимый уровень его содержания в волосах.

Загрязнение воздуха свинцом не ограничивается территорией промышленной площадки и распространяется за еe пределы, захватывая жилые массивы, территории расположения детских и медицинских учреждений, спортивных сооружений, зон рекреации. С целью изучения закономерностей накопления свинца в организме жителей городов, подвергающихся воздействию различных концентраций этого металла, оце', г зон влияния различных источников в различных ландшаф. .' условиях проведен сравнительный анализ содержания свинц. зллосах и моче населения в городах с развитой машиностр. , :льной промышленностью, отдельными свинцовоемкими предприятиями (например, производство минеральных красок) и работой автомобильного транспорта на неэтилированном бензине; с доминирующим влиянием автотранспорта; со смешанным влиянием машиностроительных производств и автотранспорта; с доминирующим влиянием металлургических производств.

Анализ свинца в питьевой воде этих городов показал, что содержание свинца было в пределах гигиенического норматива и поэтому накопление свинца в организме жителей городов связано с воздействием загрязненного атмосферного воздуха.

Одновременно с проведением биогеохимических работ было проведено исследование свинца в атмосферном воздухе, преимущественно в течение месячных циклов, а также в почве и снежном покрове. Это позволило в дальнейшем перейти к получению количественных зависимостей между концентрациями свинца в атмосферном воздухе, выпадениях из атмосферы, фиксируемых в почве, снежном покрове, и биоконцентрациями свинца в волосах и моче. В качестве «контрольных» групп в каждом городе выбрано население, проживающее в наиболее «чистых» микрорайонах в отдалении от источников выбросов свинца. Содержание свинца в биосубстратах этих групп населения было достаточно близким и принято за фоновое значение.

Данные о концентрации свинца в волосах населения, проживающего в техногенных геохимических аномалиях различных источников загрязнения (табл. 62), показывают, что наиболее выражено накопление свинца в зоне воздействия предприятий по выплавке и переработке свинца. Это металлургические комбинаты, аккумуляторные производства. Так, в ядре аномалий около свинцово-кадмиевого комбината, (на расстоянии 0,5 км от завода) среднее значение свинца в волосах детей $(31,1 \pm$ $\pm 4,7$ мкг/г) было в 7 раз, а у взрослых $(14,5 \pm 4,8$ мкг/г) в 5 раз выше фоновых значений. Только у 6\% детей, проживающих в непосредственной близости от предприятия, содержание свинца в волосах было в пределах физиологической нормы, a доля детей, у которых накопление этого металла превышало 
Т а бли ц 62 Содержание свинца в волосах населения, проживающего в техногенных геохимических аномалиях, мкr/г

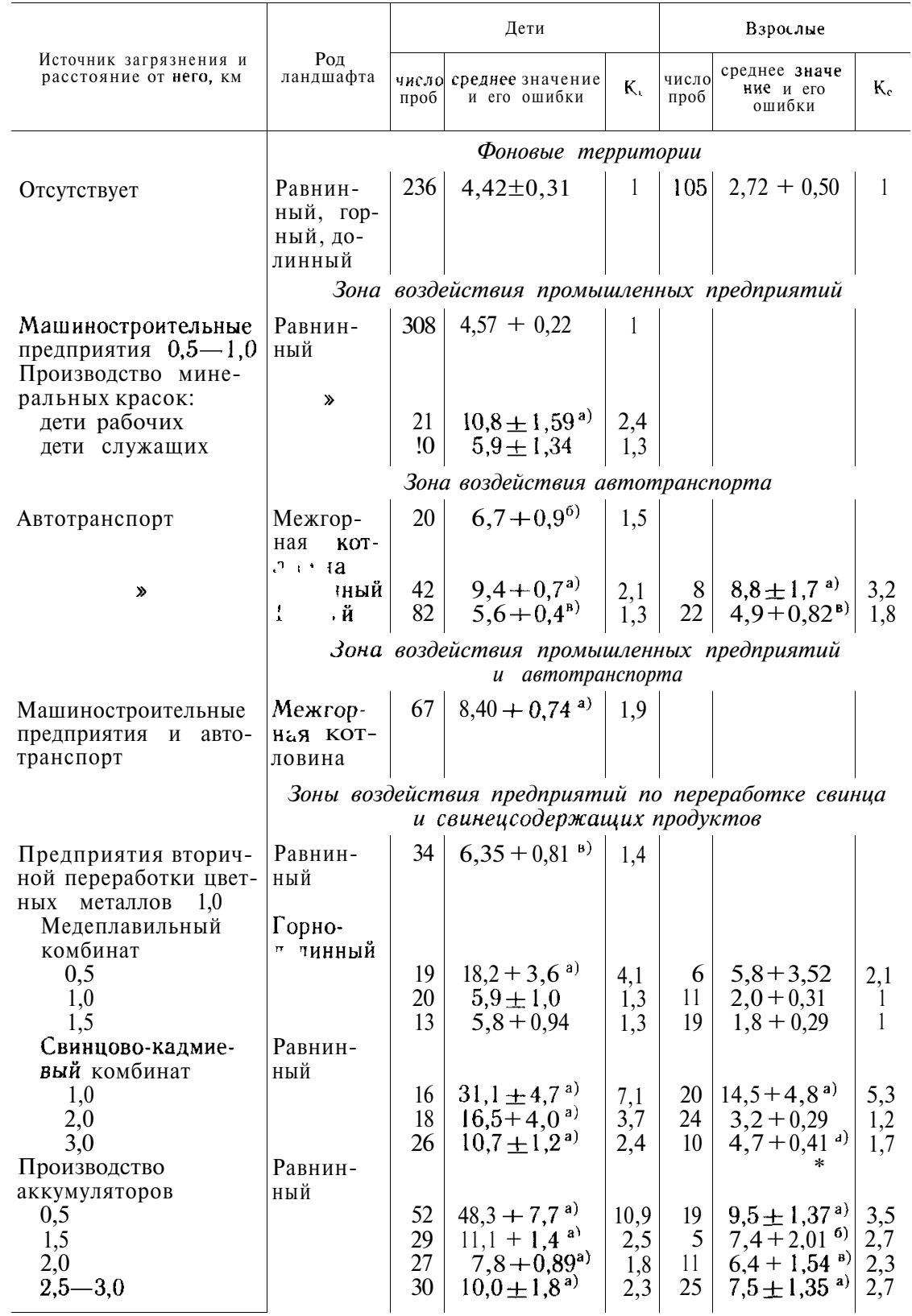

Примечание а), б), в) - различия с населеннем на фоновых территориях достоверны с вероятностью ошибки $0,1 \%, 1 \%$ и $5 \%$ соответетвенно. $\mathbf{K}_{\mathbf{e}}$ - коэффициент концентрации относительно фона 




Рис. 57. Распределение свинца в волосах детей:

$1-3-$ частота встречаемости $\omega_{t}$ детей с содержанием свинца в волосах $($ в мкг $/ \mathbf{r})$ : 1 - менее $8,2-8-24,3$ - более 24. А - зоны воздействия машиностроительных предприятий и автотранспорта (I - фоновые территории, II - зона влияния машиностроительных предприятий, III - зона влияния машиностроительных предприятий и автотранспорта, IV - зона влияния автотранспорта в горном ландшафте, V - зона влияния автотранспорта в долинном ландшафте); Б, В зоны воздействия предприятий по переработке свинца и свинецсодержащих продуктов (Б - ядро аномалий. VI - медеплавильного комбината, VII - свинцовокадмиевого комбината, VIII - аккумуляторного завода, В - центральные области аномалий: IX - медеплавильного комбината, X - свинцово-кадмиевого комбината, XI - аккумуляторного завода)

критический уровень, достигала 76\% (рис. 57). Еще более высоки биоконцентрации свинца у детей, проживающих около аккумуляторного завода $(0,5$ км). У них в волосах в 10 раз больше свинца, чем в контрольных группах, а у взрослого населения - соответственно в 3 раза. В этой зоне у $27 \%$ детей содержание свинца в волосах выше допустимого и у $65 \%$ - выше критического уровня, т. е. только у $8 \%$ детей находится в пределах физиологической нормы.

Воздействие атмосферного воздуха, загрязненного свинцом, поступающего с выхлопными газами автотранспорта и с выбросами машиностроительных производств, не приводит к столь резко выраженному накоплению металла, как около металлургических производств, но отклонения от фоновых значений достаточно значительны. Например, в городе машиностроительного типа содержание свинца в волосах детей, проживающих на расстоянии 0,5-1,0 км от предприятий варьировало от 1 до 
9 мкг/г, составляя в среднем 4,6 мкг/г, что только на 5\% выше, чем в контрольной группе. Однако оценка распространения содержания свинца в волосах детей показывает, что в $13 \%$ случаев его концентрация выше допустимого уровня 8 мкг/г. Критический уровень 24 мкг/г не был превышен ни у одного ребенка (см. рис. 57). В контрольной группе также было небольшое число детей с содержанием свинца в волосах выше допустимого уровня $(6,6 \%)$, что соответствует общим закономерностям распределения свинца в организме, но около машиностроительных производств доля таких детей была в 2 раза выше. В зоне влияния выбросов машиносіроительных предприятий содержание свинца в моче детей составило $17,3 \pm 1,16$ мкг/г, что в 2 раза выше, чем в «чистых» районах. Функционирование небольших машиностроительных производств, в окружении которых содержание свинца в атмосферном воздухе не достигает ПДК, а в почве выше фона в 2-3 раза, все же вызывает двукратное увеличение числа детей, имеющих повышенные концентрации свинца в организме.

Загрязнение атмосферного воздуха городов автотранспортом приводит к значительно более интенсивному поступлению свинца в организм горожан, чем в результате выбросов машиностроительных производств. Например, в городе на равнинной территории с достаточно хорошими условиями проветривания среднее содержание свинца в волосах детей составило 6,7 $\pm 0,9$ мкг/г, т. е. было выше в 1,5 раза, чем в зоне влияния выбросов машиностроительных производств. Еще более неблагоприятная ситуация сложилась в городе с горно-долинным ландшафтом, где загрязненные массы воздуха практически не выносятся за пределы данного ландшафта и формируются обширные и интенсивные геохимические аномалии, занимающие значительную часть его территории. Наиболее высокий уровень загрязнения атмосферного воздуха фиксируется в долинах небольших рек, куда и стекаются массы загрязненного воздуха. На рис. 58 представлен биогеохимический профиль города, построенный на основании данных о содержании свинца в волосах детей. При изменении рельефа и уровня загрязнения почв свинцом соответственно происходит изменение и содержания свинца в волосах детей и взрослых. У жителей, проживающих в партерной части города, происходит более интенсивное накопление свинца в организме (в 1,7 раза), чем у людей, чьи дома находятся на склонах гор. В жилых кварталах этого города, примыкающих к магистралям с интенсивным движением автомобилей в прибрежной части города, где задерживаются потоки загрязненного воздуха, у 64\% детей содержание превышает допустимый уровень, т. е. биогеохимическая ситуация четко совпала с геохимической структурой города. Можно констатировать, что по выраженности изменений биогеохимических показателей населения этот не- 


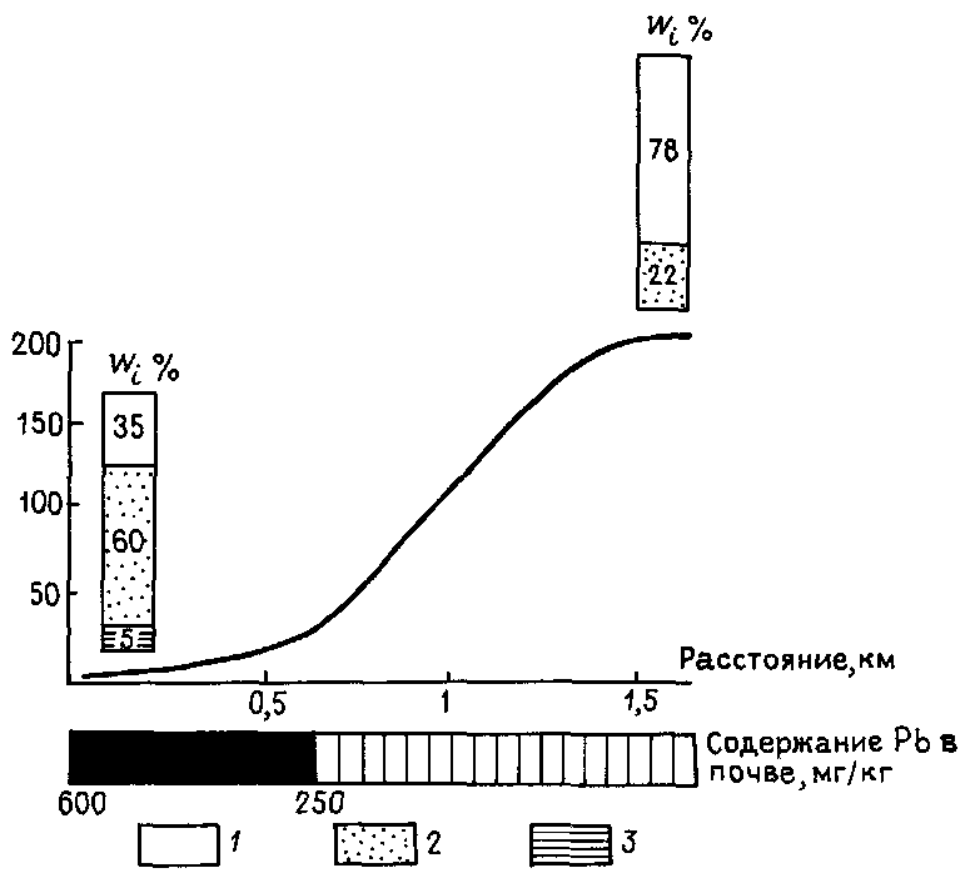

Рис. 58. Распределение свинца в волосах детей в городе с горно-долинным ландшафтом и интенсивной автотранспортной нагрузкой.

$\boldsymbol{\omega}_{1}$ - частота встречаемости детей с содержанием свинца в волосах (в мкг/г): 1 - менее $8 ; 2-8-24 ; 3-$ более 24

большой город, где отсутствуют крупные промышленные предприятия, но высокий уровень загрязнения воздуха в результате движения автотранспорта и застойного состояния воздушных масс, сопоставим с металлургическими городами.

Оценка воздействия одновременно двух источников загрязнения окружающей среды свинцом - машиностроительных предприятий и автотранспорта - показала почти двукратное среднее увеличение накопления свинца в организме детей, а у $48 \%$ детей уровень свинца превышал допустимые значения. Учитывая интенсивный рост автомобильного транспорта, отсутствие в большинстве городов необходимых защитных планировочных мероприятий, можно считать, что значительное число городских жителей, проживающих вблизи автомагистралей, имеют высокое содержание свинца в организме.

Проследить пространственные изменения биоконцентраций свинца в организме жителей в условиях техногенного воздействия различной интенсивности можно на примере изучения свинца в волосах детей, проживающих на территориях геохими- 


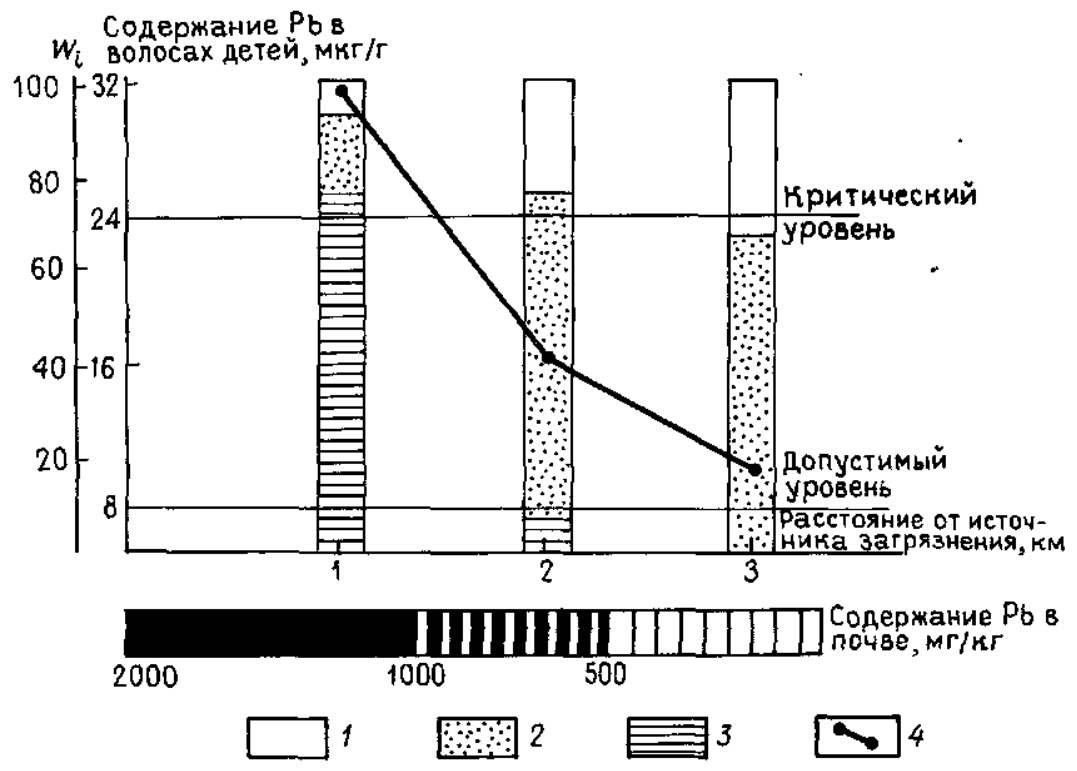

Рис. 59. Распределение свинца в волосах детей в зоне влияния выбросов свинцово-кадмиевого комбината.

$\omega_{t}$-- частота встречаемости детей с содержанием свинца в волосах (в мкг/г): 1 - менее $8 ; 2-8-24 ; 3-$ более $24 ; 4$ - среднее содержание свинца

ческих аномалии уже упоминавшихся аккумуляторного производства и металлургических комбинатов. Практически даже на расстоянии до 3 км от этих источников загрязнения содержание свинца в волосах детей продолжало оставаться несколько повышенным, хотя и резко снижалось по сравнению с ближайшей к заводам зоне.

На расстоянии 2 км от свинцово-кадмиевого комбината происходит снижение биоконцентраций, однако у $69 \%$ детей содержание свинца в волосах превышает допустимый, а у $8 \%$ - критический уровень. Даже на расстоянии 3 км от предприятия, несмотря на уменьшение средней концентрации элемента в волосах до $10,7 \pm 1,2$ мкг/г, продолжает оставаться достаточно большой доля детей с превышением допустимого уровня - 69\%, но превышения критического уровня содержания свинца в волосах уже нет (рис. 59). У взрослого населения, проживающего в этой зоне, биоконцентрации свинца снижаются до физиологического значения. Аналогичная ситуация наблюдается и в зоне влияния выбросов медеплавильного комбината, выбросы которого содержат значительные количества свинца. Если на расстоянии 0,5 км от этого завода содержание свинца в волосах детей в 4 раза было больше, чем на фоновых территориях, то уже на расстоя- 


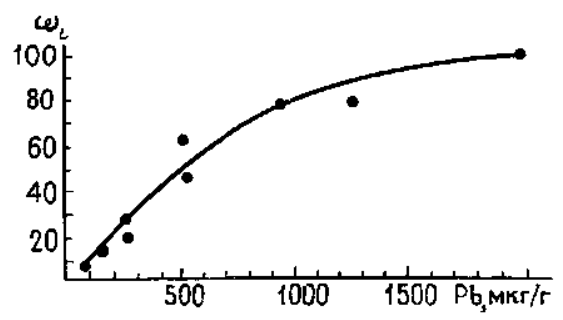

Рис. 60. Частота встречаемости $\omega_{1}$ детей с повышенным (более 8 мкг/г) содержанием свинца в волосах в зависимости от загрязнения почв свинцом

нии 1,0-1,5 км только в 1,3 раза. Аналогичная закономерность проявилась в накоплении свинца в организме взрослых, у которых кратность превышения фоновых значений в зоне завода достигала двух, а на расстоянии 1 км снижалась до уровня фона.

В городе, где расположен медеплавильный комбинат, в зоне максимального загрязнения у 64\% детей превышен допустимый, a y $14 \%$ детей критический уровень содержания свинца в волосах. На расстоянии 1,0 км число детей с превышением допустимого уровня свинца в волосах уменьшается до $34 \%$ и на расстоянии 1,5 км до 22\%. Резкое снижение биоконцентраций свинца в организме людей по мере удаления мест жительства от источника загрязнения прослеживается также в окружении крупного аккумуляторного завода. Концентрации свинца в волосах детей на расстоянии 1,5 км от завода в 4 раза меньше, чем в ядре геохимической аномалии, и далее на расстоянии $2-3$ км находятся примерно на одном уровне $(7,8-10,0$ мкг/г), т. е. продолжают оставаться довольно высокими, превышая фоновые значения в 2 раза. Такая же закономерность прослеживается и по биоконцентрациям свинца у взрослых. Биогеохимический профиль, который характеризует убывание средних концентраций свинца в волосах детей, также хорошо показывает постепенное уменьшение доли лиц с повышенным уровнем накопления свинца в волосах. На расстоянии 1,5 км более чем у половины детей (55\%) нет отклонений от нормативных значений, хотя и велика доля лиц с повышенными биоконцентрациями свинца. В жилой застройке, отдаленной на 2 км от источника загрязнения, нет детей с очень высоким уровнем содержания свинца в волосах, но в $41 \%$ случаев его содержание выше допустимого.

Сравнение уровней содержания свинца в волосах детского и взрослого населения, подвергающихся воздействию загрязненного атмосферного воздуха, подтвердило приведенные ранее данные о более интенсивном поглощении свинца детьми в фоновых регионах. Практически во всех группах обследованного населения (см. табл. 62) содержание свинца в волосах детей в 2-3 раза больше, чем у взрослых, проживающих в условиях той же геохимической ситуации, причем, чем выше интенсивность загрязнения окружающей среды свинцом, тем более контрастны эти различия. 
Интересно отметить, что на накопление свинца в организме детей влияет не только состояние окружающей среды, но и загрязнение свинцом воздуха жилых помещений в результате десорбции этого металла с одежды и открытых частей тела рабочих. Например, среднее содержание свинца в волосах детей рабочих производства минеральных красок, имеющих контакт со свинцом, составляет $10,8 \pm 1,59 \mathrm{mkr} / \Gamma$, что в 1,8 раза выше, чем у детей сотрудников заводоуправления. Среди этих детей в $50 \%$ случаев содержание свинца в волосах превышало допустимый уровень

Оценивая с биогеохимических позиций «свинцовую» ситуацию в промышленных городах, следует сказать, что в них достаточно велика доля лиц с повышенным содержанием свинца в организме. На рис. 60 показано увеличение доли детей с повышенным содержанием свинца в волосах (более 8 мкг/г) в зависимости от содержания свинца в почве мест их проживания. При содержании свинца в почве более 500 мг/кг число детей с повышенным содержанием свинца в волосах достигает 50\%. На основании карт распределения свинца в почве городов с различными источниками загрязнения можно определить, что в жилой застройке площадь со столь высоким содержанием свинца занимает ориентировочно $50 \%$ в зоне влияния выбросов свинцовокадмиевого комбината, $5 \%$ - в городе с интенсивным движением автотранспорта, $2 \%$ - в городе преимущественно машиностроительного профиля.

Можно предположить, что среди детского населения промышленных городов у значительного количества детей содержание свинца в волосах выше допустимого уровня. Это свидетельствует и о возможных отклонениях в состоянии их здоровья, в частности об изменениях нервно-психического статуса. Значительное увеличение доли детей с содержанием свинца в волосах выше критического уровня (24 мкг/г) фиксируется на территориях с содержанием этого металла в почве более 2000 мг/кг, хотя до $15 \%$ таких детей выявляется и при меньшем уровне загрязнения - 1000 мг/кг. Такие столь высокие уровни загрязнения практически отсутствуют в городах машиностроительного профиля, но могут занимать до $10 \%$ территорий, где расположены металлургические предприятия. В таких городах, следовательно, у 8\% детей можно ожидать повышенную заболеваемость нервной системы и другие отклонения в состоянии здоровья, характерные для воздействия высоких доз свинца.

Кадмий. Основное потребление кадмия происходит с продуктами питания и колеблется в зависимости от индивидуальных или региональных особенностей от 4 до 170 мкг/сутки. Доля кадмия, поступающего в организм человека с водой, в общей суточной дозе незначнтельна - 5-10\% общего количества. Даже в сильно загрязненном районе бассейна р. Дзннцу (Япо- 
ния), где расчетное суточное поступление кадмия составляет 600 мкг, поступление Cd из системы водоснабжения составляет полько 2 мкг/сутки (менее 5\%). Количество Cd, поступающего в организм с воздухом, в незагрязненных районах равно 0,4\% суточной дозы, но загрязнение атмосферного воздуха $\mathrm{Cd}$ в концентрациях, выше допустимых (более 0,5 мкг $/ \mathrm{m}^{3}$ ), увеличивает долю ингалированного кадмия в 50 раз.

Дополнительным источником поступления кадмия в организм является курение. Одна сигарета содержит $1-2$ мкг кадмия и около $10 \%$ его может вдыхаться, причем сигаретные фильтры не способны задерживать кадмий. Выкуривание 20 сигарет в день увеличивает суточное потребление кадмия на 2-4 мкг, а у лиц, потребляющих до 30 сигарет в день, за 40 лет в организме накапливается $13-52$ мкг кадмия, что превышает его количество, поступившее с пищей.

Всасывание кадмия у человека не превосходит 5-10\% и поэтому его количество, реально попавшее в ткани организма, значительно меньше, чем поступающее с пищей. Поглощенный кадмий выводится через почки, желудочно-кишечный тракт и волосы, и только небольшая часть поглощенного кадмия выделяется с фекалиями и мочой.

Период биологического полувыведения кадмия в организме человека достаточно длителен (может длиться более 20-30 лет). Суточное отложение кадмия составляет всего несколько микрограмм (2-3), однако кадмий обладает специфической особенностью накапливаться в печени и почках. С возрастом содержание кадмия в почках неуклонно возрастает и затем снижается, что является характерным для процесса старения результатом потери почечной ткани. Сравнительное определение кадмия в почечной ткани людей XIX в. и умерших от различных болезней в течение 1973 и 1979 гг., проведенное G. G. Elinder (1977), показало, что концентрация кадмия в 4 раза выше в почках людей XX в (57,1 мкг/Г и 15,1 мкг/г соответственно).

У рабочих, профессионально контактирующих с кадмием, в зависимости от степени интоксикации регистрируется высокое содержание кадмия в почках. Нарушение функций почечных канальцев - один из характерных признаков кадмиевой интоксикации, наблюдается при концентрации кадмия в коре надпочечника около 200 мкг/г сырой массы. У населения, не имеющего производственного контакта с кадмием, критическая концентрация кадмия в почках при современном режиме питания не достигается. Кроме почек, кадмий аккумулируется в печени, трубчатых костях и селезенке, которые при кадмиевой интоксикации являются органами-мишенями. Аккумуляция в печени зависит от возраста и привычек, связанных с курением.

Опубликованные в последние годы работы бельгийских, шведских и японских исследователей позволяют считать мочу диагно- 
стической средой при определении нагрузки кадмия на организм Физиологическое содержание кадмия у жителей различных регионов колеблется в пределах 1,0-1,8 мкг/л мочи.

Высокие концентрации этого элемента регистрируются в производственных помещениях, где получают кадмий и его соли при производстве щелочных аккумуляторов, катодолюминофоров, минеральных красок, при использовании кадмийсодержащих припоев, при кадмировании в гальванике.

Клинические симптомы профессионального отравления соединениями кадмия проявляются в виде легочной патологии, нару шении функций почек, что фиксируется повышенным выделением белка с низкой молекулярной массой $\beta_{2}-$ микроглобулина. Показателем почечной дисфункции является увеличение содержания этого белка в моче.

Растущее загрязнение окружающей среды кадмием может нанести серьезный ущерб здоровью человека, не имеющего профессионального контакта с металлом. Это объясняется незначительной разницей между нормальной суточной дозой кадмия, потребляемой человеком с пищей $(10-50$ мкг), и критической дозой в 200 мкг, которая может привести к необратимому ухудшению функций организма. Впервые C последствиями загрязне ния окружающей среды кадмием столкнулись в Японии, где в 1955 г. была зарегистрирована вспышка болезни Итай-Итай, возникшей в результате интенсивного загрязнения бассейна p. Дзинцу сточными водами, содержащими кадмий, и последующего поступления высоких концентраций кадмия в рис, выращиваемый в этой местности. Потребление риса привело к увеличению суточного поглощения кадмия почти в 10 раз (до 600 мкг). Заболевали в основном женщины среднего возраста и старше. Всего было зарегистрировано 223 случая заболевания (56 с летальным исходом). У лиц, пораженных болезнью Итай-Итай, отмечалось повышенное по сравнению с нормой содержание кадмия в моче, повышенное выделение белка, заболевания почек и костей. Проявление нарушений функций почек почти не отли чалось от подобного заболевания, обнаруживаемого у лиц, имеющих постоянный профессиональный контакт с кадмием.

Данные о влиянии атмосферного воздуха, загрязненного кадмием, на состояние здоровья немногочисленны. Детальные ис следования на протяжении многих лет проводятся в Льеже (Бельгия) в окружении металлургического завода, выбрасывающего в атмосферу соединения кадмия. У женщин, проживающих в окружении завода, отмечались высокие показатели смертности от заболевания почек (нефрозов и нефритов). В ряде экспериментальных работ приводятся данные о том, что у животных, получавших высокие дозы кадмия, повышалось артериальное давление.

Критическим уровнем содержания кадмия в моче профессио- 
Т а бли ц а 63. Распределение кадмия в биосубстратах рабочих

\begin{tabular}{|c|c|c|c|c|c|c|c|c|}
\hline \multirow{3}{*}{ Производство } & \multicolumn{3}{|c|}{ Содержание в волосах, мкг/г } & \multirow{3}{*}{$\mathrm{K}_{c}$} & \multicolumn{3}{|c|}{ Содержание в моче, мкг/л } & \multirow[b]{3}{*}{$\mathrm{K}_{\mathrm{e}}$} \\
\hline & \multicolumn{2}{|c|}{ Число проб } & \multirow[b]{2}{*}{$\begin{array}{l}\text { Среднее значение } \\
\text { и его ошибка }\end{array}$} & & \multicolumn{2}{|c|}{ Число проб } & \multirow[b]{2}{*}{$\begin{array}{c}\text { Среднее значение } \\
\text { и его ошибка }\end{array}$} & \\
\hline & всего & $\begin{array}{l}\text { более } 2 \\
\text { мк } \% \text { г, } \\
\text { क }\end{array}$ & & & всего & $\begin{array}{c}\text { более } \\
14 \\
\text { м кбл, } \\
\%\end{array}$ & & \\
\hline $\begin{array}{l}\text { Кадмиевых } \\
\text { электродов для }\end{array}$ & 29 & 100 & $133,2+41,0^{d}$ & 459 & 32 & 100 & $54,4+6,4^{d)}$ & 36 \\
\hline $\begin{array}{l}\text { аккумуляторов } \\
\text { Получение кад- } \\
\text { мия и его солей }\end{array}$ & 8 & 100 & $92,0 \pm\left(7,0^{\text {a) }}\right.$ & 317 & 16 & 87 & $40,9 \pm 15,7^{6)}$ & 27 \\
\hline $\begin{array}{l}\text { Минеральных } \\
\text { красоқ }\end{array}$ & 14 & 100 & $25,1 \pm 6,7^{\text {a) }}$ & 86 & 40 & 23 & $9,18+1,72$ & 6,1 \\
\hline $\begin{array}{l}\text { Вторичная } \\
\text { переплавка }\end{array}$ & 25 & 16 & $2,5+0,97^{\text {в })}$ & 8,6 & 26 & 19 & $9,93 \pm 1,98$ & 6,6 \\
\hline $\begin{array}{l}\text { цветных метал- } \\
\text { лов }\end{array}$ & & & & & & & & \\
\hline $\begin{array}{l}\text { Свинцового } \\
\text { глета }\end{array}$ & 29 & 0 & $0,63+0,20$ & 2,2 & - & - & - & - \\
\hline Получение & 11 & 0 & $0,73+0,16^{6)}$ & 2,5 & - & - & - & - \\
\hline $\begin{array}{l}\text { Кеди } \\
\text { Контрольная } \\
\text { группа }\end{array}$ & 105 & 0 & $0,29+0,07$ & 1 & 10 & - & $1,5+0,11$ & 1 \\
\hline
\end{tabular}

Примечание а), б), в) - различия с контрольной группой достоверны с вероятностью ошибки $0,1 \%, 1 \%$ и $5 \%$ соответственно, $\mathrm{K}_{c}-$ коэффициент концентрации относительно фоновых территорий

нальных групп населения, работающих с кадмием и его соединениями, является 14 мкг/л. Согласно данным японских исследователей такое содержание кадмия в моче наблюдается при содержании кадмия в воздухе рабочей зоны на уровне $0,05 \mathrm{mr} / \mathrm{m}^{3}$

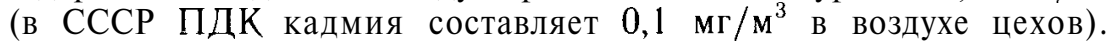
В организме людей, не имеющих профессионального контакта с кадмием, допустимым уровнем в моче, установленным ВО3, является величина 7 мкг/л. Эта величина определена японскими исследователями на основании полученных количественных зависимостей между числом почечных нарушений, содержанием P2микроглобулина и концентрациями кадмия в моче. Рекомендаций по допустимому уровню кадмия в волосах населения нет, физиологическое содержание этого элемента у жителей различных регионов мира не превышает 2 мкг/г, поэтому эта цифра может быть принята условно в качестве допустимого уровня. У детей содержание этого металла в волосах не должна превышать 1 мКг/г.

По кадмию, так же как и по свинцу, мы постарались проследить закономерности накопления этого элемента у различных 214 
групп населения, подвергавшихся воздействию различных концентраций кадмия.

Наиболее высокие биоконцентрации кадмия наблюдаются у рабочих, имеющих профессиональный контакт с этим металлом, причем весьма высока доля лиц с повышенным уровнем содержания кадмия в моче (табл. 63). Так, у всех рабочих, занятых в производстве кадмиевых электродов, содержание кадмия в моче превышало критическую концентрацию (14 мкг/л). Эта величина также превышена у $87 \%$ рабочих электролизного цеха производства кадмия, у $23 \%$ рабочих производства минеральных красок и у 29\% рабочих плавильного и баббитового цехов завода по вторичной переплавке цветных металлов. Содержание кадмия в волосах большинства рабочих в сотни и десятки раз превышало верхнюю границу физиологического уровня.

Геохимические исследования различных компонентов ландшафта (атмосферного воздуха, почв, снежного покрова) в окружении кадмиевых источников показывают, что повышенные содержания элемента локализуются практически всегда только на территории промышленной площадки и ближайшем окружении завода. Эта закономерность проявилась и при исследовании кадмия в биосубстратах населения. В отличие от свинца, накопление которого в организме городских жителей выявляется повсеместно из-за множества промышленных источников и воздействия автотранспорта, повышенные биоконцентрации кадмия проявились только в организме жителей микрорайонов, непосредственно примыкающих к мощным кадмиевым источникам - свинцово-кадмневому комбинату, аккумуляторному заводу, медеплавильному комбинату (табл. 64).

Наиболее высокие биоконцентрации кадмия характерны для населения, проживающего в центре геохимической аномалии (в полукилометровой зоне от аккумуляторного завода). Накопление кадмия в организме жителей в зоне влияния выбросов этого предприятия резко снижается уже на расстоянии 1,5 км. Так, если вблизи завода у 44\% детей содержание кадмия в волосах превышает допустимый уровень 1 мкг/г, то у детей, проживающих на расстоянии 1,5-2 км от предприятия и на фоновых территориях, такие значения не обнаруживаются. По сравнению со всеми остальными обследованными группами у детей, находящихся в зоне влияния выбросов аккумуляторного завода, максимально и содержание кадмия в моче, причем у некоторых детей уровень кадмия в моче превышает допустимое значение. Сопоставление накопления кадмия в волосах и моче этих детей выявило сходную контрастность по сравнению с фоновыми уровнями содержаний кадмия в моче (выше в 4,9 раза) и в волосах (выше в 6,5 раза). У взрослого населения, проживающего в ближайшем к заводу жилом массиве, содержание кадмия в моче составило 7,26士1,02 мкг/л (в 4,8 раза выше фонового значе- 
ния) и в $31 \%$ случаев превышало допустимый уровень. В волосах взрослых накопление кадмия было выражено не столь ясно, как у детей. Аккумуляторное производство является мощным источником выбросов кадмия в воздушный бассейн, но так как аномалия выражена достаточно локально, то и повышенное накопление кадмия в организме жителей других микрорайонов около завода не проявилось, в то время как накопление свинца у них было достаточно ярко выражено.

Интенсивными поставщиками кадмия в окружающую среду являются также металлургические производства, привлекающие особое внимание исследователей как у нас в стране, так и за рубежом. Характерной особенностью свинцово-кадмиевого предприятия, в окружении которого нами проводились исследования, было расположение кадмиевого производства в глубине промышленной площадки, в результате чего несмотря на большой выброс кадмия его концентрации в атмосферном воздухе оказались невелики. Однако, в ядре аномалии (1,0 км от территории завода) содержание кадмия в волосах и моче детей в 3 раза выше фоновых значений, у взрослых соответственно в 2,4 и 4,8 раза. У $10 \%$ детей и у $26 \%$ взрослых содержание кадмия в моче было выше допустимого уровня. При отдалении от источника выбросов содержание металла в волосах жителей снижается и отличия от фоновых содержаний уже не достоверны.

На медеплавильном производстве кадмий не является основным ингредиентом выбросов, как на предыдущих производствах, но высокое его содержание в сырье обусловливает возможность его попадания и в окружающую среду. Геохимическая аномалия кадмия в окружении медеплавильного производства не столь выражена, но содержание кадмия в почве превышало фоновые значения в жилой застройке, примыкающей к комбинату, в 16 раз. Повышенное накопление кадмия в волосах характерно только для жителей этой зоны, причем кратность увеличения содержания кадмия в волосах по отношению к фоновому уровню одинакова для детей (1,7 раза) и взрослых (1,8 раза). Более выражено повышение кадмия в моче, хотя его концентрации и не достигали допустимого уровня. По сравнению с накоплением свинца в биосубстратах населения, проживающего вблизи этих же источников загрязнения можно заметить значительно большую локальность в распространении повышенных биоконцентраций кадмия. Воздействию повышенных концентраций этого металла подвержено значительно меньшее число жителей, чем воздействию свинца.

Ртуть. Основной путь поступления неорганической ртути ингаляционное поглошение. С атмосферным воздухом в среднем поступает около 1 мкг ртути в сутки. Большая часть вдыхаемых паров ртути задерживается в легких. Ртуть, попадая в кровь, быстро окисляется до ионной ртути [40]. В ряде международных 
Т аблиц а 64 Содержания кадмия в биосубстратах населения, проживающего

\begin{tabular}{|c|c|c|c|c|c|c|c|c|c|c|c|c|c|}
\hline \multirow{3}{*}{$\begin{array}{c}\text { Источники } \\
\text { загрязнения }\end{array}$} & \multirow{3}{*}{$\begin{array}{c}\text { Расстояние } \\
\text { от нсточ } \\
\text { ника км }\end{array}$} & \multicolumn{6}{|c|}{ Дети } & \multicolumn{6}{|c|}{ Взрослые } \\
\hline & & \multicolumn{3}{|c|}{ Содержание в волосах мкг/г } & \multicolumn{3}{|c|}{ Содержание в моче, мкг/л } & \multicolumn{3}{|c|}{ Содержание в волосах мкг/г } & \multicolumn{3}{|c|}{ Содержание в моче мкг/л } \\
\hline & & \begin{tabular}{|l|} 
число \\
проб
\end{tabular} & \begin{tabular}{|c} 
среднее \\
и еначение \\
и егобки \\
\end{tabular} & Ко & \begin{tabular}{|l|} 
число \\
проб
\end{tabular} & $\begin{array}{c}\text { среднее } \\
\text { и егачение } \\
\text { ишибки }\end{array}$ & ко & \begin{tabular}{|l|} 
число \\
проб
\end{tabular} & $\begin{array}{c}\text { среднее значение } \\
\text { и его ошибки }\end{array}$ & K & $\begin{array}{l}\text { чите ло } \\
\text { ироб }\end{array}$ & \begin{tabular}{|c|} 
среднее значение \\
И его ошибки
\end{tabular} & $\mathrm{K}$, \\
\hline $\begin{array}{l}\text { Фоновые } \\
\text { территории } \\
\text { Медеплавиль- } \\
\text { ный комбинат }\end{array}$ & $\begin{array}{l}0,5 \\
1,0 \\
1,5\end{array}$ & \begin{tabular}{r|}
236 \\
19 \\
20 \\
13
\end{tabular} & $\begin{array}{l}0,24+0,04 \\
0,42+0,05^{6)} \\
0,27+0,03 \\
0,30+0,02\end{array}$ & $\begin{array}{l}1,7 \\
1,1 \\
1,2\end{array}$ & $\begin{array}{l}59 \\
12 \\
11\end{array}$ & $\begin{array}{l}1,21+0,18 \\
3,50+0,80^{\text {a) }} \\
4,50+0,80^{\text {a) }}\end{array}$ & $\begin{array}{l}1 \\
2,9 \\
3,7\end{array}$ & $\begin{array}{r}105 \\
6 \\
11 \\
19\end{array}$ & $\begin{array}{l}0,29+0,07 \\
0,52+0,13 \\
0,28+0,02 \\
0,40 \pm 0,14\end{array}$ & $\begin{array}{l}1 \\
1,8 \\
1 \\
1,3\end{array}$ & 10 & $1,50+0,11$ & 1,0 \\
\hline $\begin{array}{l}\text { Свинцово-кад } \\
\text { мневый ком- } \\
\text { бинат }\end{array}$ & $\begin{array}{l}1,0 \\
2,0 \\
3,0\end{array}$ & $\begin{array}{l}16 \\
18 \\
26\end{array}$ & $\begin{array}{l}0,75+0,11^{\text {a) }} \\
0,38+0,08 \\
0,37+0,04\end{array}$ & \begin{tabular}{|l|}
3,1 \\
1,6 \\
1,5
\end{tabular} & 29 & $3,65+0,65$ d) & 3,0 & \begin{tabular}{l|}
20 \\
24 \\
10
\end{tabular} & $\begin{array}{l}0,70+0,11^{\text {a) }} \\
0,36+0,12 \\
0,37+0,04\end{array}$ & $\begin{array}{l}2,4 \\
1,2 \\
1,3\end{array}$ & 23 & $7,26 \pm 1,02^{\text {a) }}$ & 4,8 \\
\hline $\begin{array}{l}\text { Производство } \\
\text { аккумуляторов }\end{array}$ & $\begin{array}{c}0,5 \\
1,5 \\
2,0 \\
2,5-3,0\end{array}$ & $\begin{array}{l}52 \\
31 \\
30 \\
32\end{array}$ & $\begin{array}{l}1,56+0,19 \text { a) } \\
0,32+0,04 \\
0,32+0,03 \\
0,36+0,03\end{array}$ & $\begin{array}{l}6,5 \\
1,3 \\
1,3 \\
1,5\end{array}$ & $\begin{array}{r}9 \\
20\end{array}$ & $\begin{array}{l}5,9 \pm 1,10^{d)} \\
1,94+0,47\end{array}$ & $\begin{array}{l}4,9 \\
1,6\end{array}$ & $\begin{array}{r}19 \\
7 \\
11 \\
25\end{array}$ & $\begin{array}{l}0,44+0,10 \\
0,28+0,05 \\
0,30+0,05 \\
0,32+0,03\end{array}$ & $\begin{array}{l}1,5 \\
1 \\
1 \\
1\end{array}$ & 13 & $6,2 \pm 1,18^{a)}$ & 4,1 \\
\hline
\end{tabular}

Примечание Различия в биоконцентрациях на фоновых территориях достоверны с вероятностью ошибки а) - $0,1 \%$, б) - $1 \%$, К коэффициент концентрации относительно фоновых территорий 
документов и обзорах по ртути высказывается мнение, что низкое содержание паров ртути в атмосфере не представляет для населения в целом опасности. Однако не исключены случаи, когда поглощение ртути человеком может быть значительно более высоким.

В желудочно-кишечный тракт ртуть поступает преимущественно с питьевой водой и продуктами питания. Ртуть, содержащаяся в питьевой воде, составляет менее 0,4 мкг общего суточного поступления ее в организм. Основным источником ртути для населения, не имеющего производственного контакта с ртутью, является пища (главным образом, рыба и рыбные продукты). В районах с высоким местным загрязнением еe суточное потребление может достигать 300 мкг, что приводит к вспышкам отравления метилртутью. Ввиду широкого распространения ртути в окружающей среде и ее кумулятивных свойств Международная организация по питанию и Всемирная организация здравоохранения ввели норматив еженедельного потребления: 300 мкг общей ртути на человека в неделю, из которых в виде метилртути не более 200 мкг. Уровень поглощения ртути в организме в значительной степени зависит от пути ее поступления и форм соединений ртути. Так, если до $80 \%$ вдыхаемых паров неорганической ртути задерживается в организме, то поглощение такой ртути из пищи намного меньше - 7\%. Метилртуть, которая поступает с продуктами питания, в желудочно-кишечном тракте всасывается практически полностью. Период выведения из организма 50\% поступающей ртути составляет около 70 дней. Выделение ртути с мочой примерно пропорционально концентрации ее в воздухе. Хорошей индикаторной средой для людей, подвергающихся воздействию ртути, являются волосы, причем содержание ртути в волосах пропорционально ее концентрации в крови.

Ртуть, попадающая в организм в виде паров, способна быстро проходить через плаценту, а метилртуть проникает и в грудное молоко. Высокое содержание ртути в грудном молоке служит причиной накопления ртути в крови детей.

Распределение ртути при отравлении обусловлено характером соединений и способом их поступления в организм. При ингаляционном поступлении ртути основным ее депо являются почки. Это согласуется с известным фактом «сулемовой почки», которая является характерным признаком ртутной интоксикации. Ртуть также накапливается в тканях головного мозга, этим объясняются те нервные поражения при ртутной интоксикации у людей, которые проявляются через несколько лет после прекращения экспозиции. К первым проявлениям ртутной интоксикации относятся психомоторные нарушения, которые проявляются при содержании ртути в крови рабочих выше $1-2$ мкг/100 мл крови (допустимый уровень). В моче рабочих нормальным содержа- 
нием ртути считается до 10 мкг/л. Аналогичные нормативы для детей пока не установлены.

Для непрофессиональных групп населения воздействие ртути обычно описывается по болезни Минамата, возникшей в результате сброса промышленных сточных вод, содержащих соединения ртути, в реку и последующим ее накоплением в промысловой рыбе в виде высокотоксичной метилртути. В результате этого отравления погибли десятки людей, а у родившихся в это время детей отмечались симптомы церебрального паралича. Ранние эффекты воздействия метилртути приблизительно в 5\% случаев наблюдались у наиболее чувствительной части взрослого населения при концентрации ртути в волосах 50 мкг/г. Однако японские ученые считают, что при содержании ртути в волосах 20 мкг/г уже необходимо медицинское наблюдение, т. е. этот уровень можно считать критическим.

Значительное накопление ртути в организме зафиксировано и у людей, подвергающихся воздействию повышенных концентраций неорганической ртути. У работников завода по производству электрических ламп среднее содержание ртути в моче составляло 204 мкг/л (в 20 раз выше допустимого уровня). В литературе приводятся данные о высоких биоконцентрациях ртути у рабочих завода по производству хлора, где применяется в качестве катода металлическая ртуть (в моче до 200 мкг/л, в волосах до 72 мкг/г, что выше фоновых значений в сотни и десятки раз). Известно, что в десятки раз выше биоконцентрации ртути у населения, проживающего в зоне влияния выбросов таких наиболее мощных источников загрязнения, как предприятия по производству ртути, хлорщелочные заводы.

Более локальные техногенные аномалии ртути возникают в результате деятельности предприятий, которые расходуют ртуть в значительно меньшем количестве, чем указанные выше источники, но выброс ее все же составляет десятки килограммов в год. Это производства люминесцентных ламп, измерительных приборов (термометров, манометров, барометров), ртутных выпрямителей.

Рассмотрим распределение ртути в окружающей среде в зоне влияния выбросов завода по производству термометров. Около этого предприятия содержание ртути в атмосферном воздухе не превышало ПДК, но было в 3 раза выше фоновых значений, и аномалии ртути в почве и снежном покрове были выражены еще ярче. В непосредственной близости от завода отсутствуют жилые дома, но обследование детей, проживающих на периферии аномалии, показало повышенное накопление ртути в их моче, причем это накопление заметнее у детей работников ртутного предприятия. При среднем содержании ртути в моче детей, родители которых работают на заводе (2 мкг/л), более высокие показатели (3 мкг/л) обнаружены у детей рабочих, имеющих 


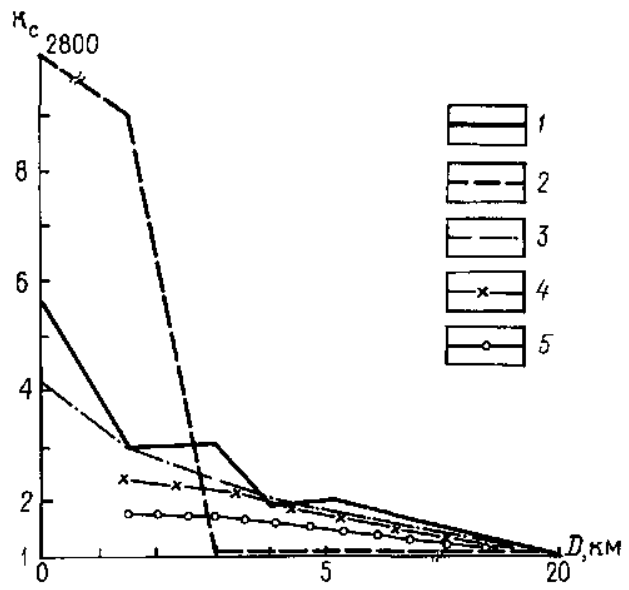

Рис. 61. Содержание ртути в моче детей на различном расстоянии от завода ртутных приборов:

1 - атмосферный воздух, 2 почва, 3 - снежный покров, 4 - моча детей рабочих заводов ртутных приборов, 5 моча детей сотрудников других предприятий

непосредственный контакт с ртутью (отметчицы, делильщицы, вакуумщицы, градуировщицы). По-видимому, как и в случае со свинцом, это связано с сорбцией паров ртути одеждой рабочих и последующим их выделением в жилых помещениях. Содержание ртути в моче детей коррелируется с уровнями загрязнения различных компонентов окружающей среды (рис. 61).

Кроме «ртутных» производств в воздух больших городов определенное количество этого металла поступает от сжигания органического топлива, эксплуатации ртутьсодержащих ламп, измерительных приборов и другого оборудования. Попадает ртуть в воздух и с выбросами металлургических производств, так как она является сопутствующим компонентом большинства руд. Поэтому в атмосферном воздухе промышленных городов содержание ртути в 3--5 раз выше фоновых значений, хотя и не достигает нормативных величин. Однако, даже при таких уровнях воздействия ртути концентрация ртути в волосах жителей около машиностроительных и металлургических производств в 1,6-2 раза выше, чем в фоновых условиях (табл. 65).

Т а блица 65. Содержание ртути в волосах детей, проживающих в техногенных геохимических аномалиях, мкг/г

\begin{tabular}{|c|c|c|c|}
\hline $\begin{array}{l}\text { Источник загрязнения и } \\
\text { расстояние от него, км }\end{array}$ & Число проб & $\begin{array}{l}\text { Среднее значе- } \\
\text { ние и его ошибка }\end{array}$ & $\begin{array}{l}\text { Коэффициент } \\
\text { концентрации }\end{array}$ \\
\hline Фоновые территории & 20 & $0,99+0,14$ & 1 \\
\hline $\begin{array}{l}\text { Машиностроительные предприятия и } \\
\text { автотранспорт в городе; } 0,5\end{array}$ & 55 & $0,93+0,09$ & 1 \\
\hline Машиностроительные предприятия; 0,5 & 33 & $1,19+0,14$ & 1,2 \\
\hline $\begin{array}{l}\text { Предприятия по вторичной перера- } \\
\text { ботке цветных металлов, 1,0 }\end{array}$ & 22 & $1,64+0,17 *$ & 1,6 \\
\hline Свинцово-кадмиевый комбинат; 0,5 & 29 & $2,02+0,24 *$ & 2,0 \\
\hline
\end{tabular}

* - различия с контрольной группой достоверны с вероятностью ошибки $0,1 \%$ 
Техногенные геохимические аномалии в городах почти всегда характеризуются полиэлементным составом ассоциации концентрирующихся элементов. В зависимости от мощности источника и качественного состава выбросов в составе ассоциации обнаруживаются 5-7 химических элементов. Мы рассмотрели особенности накопления отдельных микроэлементов в биосубстратах населения, однако для экологической и геогигиенической характеристик интенсивности техногенных воздействий важно оценить особенности концентрирования в организме более широкого спектра химических элементов, присутствующих в окружающей среде. На примерах мощных источников выбросов, отличающихся широкой ассоциацией химических элементов, хорошо видно, что как у рабочих, так у населения происходит накопление основных компонентов выбросов и сопутствующих им элементов. Например, у рабочих производства кадмия биогеохимические изменения наиболее выражены и в состав биогеохимической ассоциации кроме кадмия, превышения фоновых значений очень велики (317 раз), входят также элементы с десятикратным накоплением ( $\mathrm{Pb}, 5 \mathrm{~b}, \mathrm{Te})$, а также $\mathrm{As}, 5 \mathrm{~T}, \mathrm{Ag}, \mathrm{Co}, \mathrm{Hg}, 2 п$, Си, присутствующие в виде примесей в исходном сырье. На этом производстве, выплавляющем среди прочих металлов и цинк, в волосах рабочих в 2 раза выше содержание цинка,- явление, которое не отмечалось ни в одной группе населения. Если на свинцово-кадмиевом производстве в организме рабочих произошло наиболее интенсивное накопление основных элементов, поступающих в воздушную среду цехов ( $\mathrm{Cd}$ и $\mathrm{Pb})$, то у рабочих медеплавильного комбината отмечается, в первую очередь, повышение содержания As. По сравнению с контрольной группой у рабочих, связанных с выплавкой меди, наиболее выражены различия по $\mathrm{As}, \mathrm{Cd}, 5 \mathrm{~b}, \mathrm{Te}$; у рабочих цеха рафинирования меди - по Аз, Те, Си, $\mathrm{Ag}, 5 \mathrm{~b}$.

Основными объектами исследования неблагоприятного воздействия загрязненной металлами производственной и окружающей среды на биогеохимические показатели населения являются металлургические производства. Однако интенсивное поступление химических элементөв в воздух рабочей зоны и для других технологий, использующих сырье с богатым элементным составом. Так, у рабочих производства минеральных красок интенсивность накопления токсичных химических элементов в волосах почти не отличается от аналогичных показателей на металлургическом производстве, а ассоциация даже шире и включает 13 элементов (табл. 66). По сравнению с контрольной группой у рабочих производства минеральных красок наиболее достоверно выражены различия по $\mathrm{Cd}, 5 \mathrm{~b}, \mathrm{~Pb}, \mathrm{Co}, 5 \mathrm{e}, \mathrm{Cr}, \mathrm{Rb}, \mathrm{Te}, \mathrm{Eu}(\mathrm{P}<0,1 \%)$, $\mathrm{As}, \mathrm{Ag}$ (P 1\%), и определенная тенденция прослеживается по самарию (Р 5\%). Повышенные концентрации большинства химических элементов на этом производстве практически локали- 
Т а блиц а 66. Ассоциации химических элементов в волосах рабочих различных производств

\begin{tabular}{|c|c|c|c|c|}
\hline \multirow{2}{*}{ Производство } & \multicolumn{4}{|c|}{$\begin{array}{c}\text { Коэффициент концентрации относительно фоновых } \\
\text { территорий }\end{array}$} \\
\hline & Более 50 & $50-25$ & $25-10$ & $10-5$ \\
\hline $\begin{array}{l}\text { Кадмия: } \\
\text { Меди }\end{array}$ & $\mathrm{Cd}_{317}$ & & $\mathrm{~Pb}_{21} \mathrm{Sb}_{14}$ & $\mathrm{Te}_{10} \mathrm{As} \mathrm{s}_{8}$ \\
\hline $\begin{array}{l}\text { выплавка } \\
\text { рафинирование }\end{array}$ & - & $A s_{61}$ & - & $\begin{array}{c}\mathrm{Cu} \\
\mathrm{As}_{10} \mathrm{Cu}_{6}\end{array}$ \\
\hline $\begin{array}{l}\text { Минеральных удобрений } \\
\text { Минеральных красок }\end{array}$ & $\mathrm{Cd}_{86}$ & $\mathrm{Sb}_{46} \mathrm{~Pb}_{38}$ & $\begin{array}{c}\mathrm{Sm}_{16} \\
\mathrm{Co}_{21} \mathrm{Se}_{15}\end{array}$ & $\begin{array}{l}\mathrm{La}_{7} \mathrm{~F}_{7} \mathrm{Sb}_{6} \\
\mathrm{As}_{8} \mathrm{Cr}_{6}\end{array}$ \\
\hline
\end{tabular}

Продолжение табл. 66

\begin{tabular}{|c|c|c|}
\hline \multirow{2}{*}{ Производство } & \multicolumn{2}{|c|}{$\begin{array}{c}\text { Коэффициент концентрации относигельно фоновых } \\
\text { территорий }\end{array}$} \\
\hline & $5-3$ & $3-1,5$ \\
\hline $\begin{array}{l}\text { Кадмия: } \\
\text { Меди } \\
\text { выплавка } \\
\text { рафинирование } \\
\text { Минеральных удобрений } \\
\text { Минеральных красок }\end{array}$ & $\begin{array}{c}\mathrm{Sm}_{4} \mathrm{Ag}_{4} \mathrm{Co}_{3} \\
\mathrm{Te}_{3}[\mathrm{Sb}, \mathrm{Cd}]_{3} \\
\mathrm{Ag}_{3} \\
\mathrm{Ce}_{4} \\
\mathrm{Te}_{4}[\mathrm{Al}, \mathrm{Ti}]_{3}\end{array}$ & $\begin{array}{c}{[\mathrm{Zn}, \mathrm{Hg}, \mathrm{Au}]_{2} \mathrm{Cu}_{1,6}} \\
{\left[\mathrm{~Pb}, \mathrm{Ag}_{2}\left[\mathrm{Sm}_{1}, \mathrm{Au}\right]_{1.5}\right.} \\
\mathrm{Pb}_{2} \mathrm{Sb}_{15} \\
\mathrm{As}_{2} \\
{[\mathrm{Rb}, \mathrm{Ag}, \mathrm{Sm}]_{2}}\end{array}$ \\
\hline
\end{tabular}

зуются в пределах промышленной площадки и поэтому изучение широкого комплекса микроэлементов в волосах населения прилегающих кварталов не производилось.

Совершенно иная по качественному составу биогеохимическая аномалия проявилась при исследовании волос рабочих производства минеральных удобрений из Кольских апатитов. В отличие от микроэлементного состава рабочих других производств здесь на первое место выступает накопление редких земель 5т, La, Ce, a также F, который определялся при помощи ионселективного метода.

Т а блиц а 67. Ассоциации химических элементов в волосах детей, проживающих в техногенных геохимических аномалиях

\begin{tabular}{l|c|c|c|c}
\hline & \multicolumn{4}{|c}{ Коэффициент концентрации относительно фоновых } \\
Перриторий \\
$\begin{array}{l}\text { Производство (расстояние } \\
\text { от источника загрязнения) }\end{array}$
\end{tabular}


Геохимические аномалии в окружении рассмотренных производств не ограничиваются территорией промышленной площадки и распространяются за ее пределы, охватывая жилые кварталы. Биогеохимическая ассоциация в волосах детей, проживающих в ядре аномалии около свинцово-кадмиевого комбината, повторяет по своему составу ассоциацию у рабочих, хотя и не столь выраженную (табл. 67). Если у рабочих накопление металлов в волосах в десятки и даже сотни раз превышало фоновые значения, то у детей содержание большинства химических элементов превышено в $2-7$ раз. Имеются различия и в качественном составе биогеохимической ассоциации. Так, у детей не происходит накопление в волосах $\mathrm{Zn}$, Си, 5т и Аи. Подобное совпадение состава биогеохимической ассоциации проявилось у рабочих и детей, проживающих в ядре аномалии, возникшей при производстве минеральных удобрений. Так же как у рабочих, в волосах детей повышено содержание редкоземельных элементов - La, Sm, Ce, а также 5e. В экологическом отношении эти элементы изучены слабо.

Проследить зональность распространения комплекса элементов в волосах населения в зависимости от отдаленности мест их проживания по отношению к ядру техногенной аномалии можно на примере жителей поселка медеплавильного завода.

На рис. 62 представлено изменение содержаний трех основных накапливающихся элементов (As, Cи и $\mathrm{Pb}$ ) в волосах детей дошкольного возраста и взрослого населения, находящегося на различном расстоянии от комбината. В качестве допустимого содержания Аз в волосах детей нами принята величина верхней границы физиологического уровня - 2 мкг/г [28]. Обращает на себя внимание резко выраженная локальность накопления наиболее высоких концентраций у населения, проживающего в 0,5 км зоне от завода. Уже на расстоянии 1,0 км биоконцентрации резко снижаются, хотя у $30 \%$ детей содержание $\mathrm{Pb}$ и Аз в волосах превышает допустимый уровень. С расстояния 2,5 км

Рис. 62. Содержание Си, РЬ, Аз в волосах (C, мкг/г) на различном расстоянии (Д, км) от медеплавильного завода: $1-5$ - содержания Си, РЬ, As в волосах людей разного возраста: 1 - Си у взрослых, $2-C u \quad y$ детей, $3-\mathrm{Pb}$ у взрослых, 4 - РЬ у детей, 5 As y детей




от источника загрязнения происходит закономерное постепенное уменьшение концентраций $\mathrm{Pb}$ в волосах детей. На этом рисунке отчетливо видна и другая, уже упоминавшаяся закономерность - более высокое накопление РЬ в организме детей по сравнению с взрослым населением.

Приведенные примеры характеризуют изменения микроэлементного состава волос населения, подвергающегося воздействию наиболее мощных источников загрязнения, т. е. отражают изменения по довольно ограниченному контингенту населения. Значительно большая часть населения в городах испытывает влияния более низкого уровня загрязнения атмосферного воздуха, создаваемого выбросами многочисленных машиностроительных производств, типографий, автотранспортом. Результаты изучения микроэлементного состава волос в городе с доминирующим влиянием машиностроительной промышленности показывают, что в условиях относительно низкого загрязнения атмосферного воздуха влияние машиностроительной промышленности проявляется слабо, хотя все же происходит накопление 3 - 4 элементов (Pb, Br, $\mathrm{Cr}, \mathrm{Ag})$ с малоконтрастными коэффициентами концентрации (не более 2 ).

Информация о содержании в волосах значительного числа микроэлементов позволила оценить изменения и самого микроэлементного баланса, т. е. количественных взаимосвязей. При воздействии высоких концентраций металлов происходит разделение токсичных элементов и биоэлементов. Например, у рабочих металлургического производства возникают устойчивые связи между Си и 2п $(r=0,52)$, РЬ и Сd $(r=0,73)$, что не наблюдается в контрольной группе. У детского населения проявляется антагонизм между концентрациями РЬ и 2П, т. е. с увеличением содержания в волосах РЬ происходит снижение содержания 2п. По отдельным группам населения коэффициенты отрицательной корреляции достаточно велики и составляют $r=-0,77$ у детей, находящихся в полукилометровой зоне от полиметаллического комбината. Можно предположить, что снижение содержания 2П в организме детей отражает и снижение иммунологической резистентности организма ребенка, так как 2 иг игет определенную роль в поддержании иммунных свойств.

Биоконцентрации зависят от токсичности вещества и исходного уровня его содержания в организме. Например, фоновые содержания РЬ в биосубстратах минимальны (в волосах 1 3 мкг, в моче - 5-10 мкг/л) и даже небольшое увеличение содержаний этого элемента в окружающей среде вызывает контрастное возрастание биоконцентраций. По-другому выглядит накопление $F$, содержание которого в организме значительно выше (фоновое содержание $\mathrm{P}$ в волосах 80 мкг/г, в моче - более 1000 мкг/л, т. е. практически на один-два порядка выше, чем РЬ). Даже значительное увеличение содержания Р в воздухе 
(в 250 раз) приводит только в 6-8-кратному увеличению его содержания в моче и волосах.

Интенсивное загрязнение окружающей среды городов ком плексом химических элементов вызывает не просто увеличение биоконцентраций тех или иных элементов в организме человека, но приводит к появлению определенной части населения, проживающей в ядрах аномалий с содержанием химических элементов выше допустимого и критического уровня. Исходя из геохимической ситуации в городах можно предположить, что значительно больше жителей с не столь явно выраженными отклонениями микроэлементного статуса организма, но с 1,5-2кратным увеличением содержания ряда химических элементов. Оценить непосредственную опасность чакоплення столь невысокого уровня химических элементов для состояния здоровья человека трудно, но повышение биоконцентраций указывает на проникновение техногенных потоков в организм человека. Следует отметить, что биоконцентрации токсичных элементов отражают уровень загрязнения атмосферного воздуха не только металлами, но и другими веществами. Так, в атмосферном воздухе ряда городов США и ФРГ установлена тесная корреляция между концентрациями $\mathrm{Pb}$ и другими токсикантами - оксидами углерода, ацетиленом, этиленом, различными углеводородами

Задача геогигиенической оценки опасности загрязнения окружающей среды городов может быть решена при сопоставлении данных о состоянии здоровья населения с геохимической структурой изучаемых городов.

\section{Состояние здоровья населения в связи с геохимической структурой территории городов}

В условиях современного города человек подвергается воздействию широкого комплекса средовых, социальных и биологических факторов, во многом определяющих неблагоприятные изменения состояния его здоровья. Мы показали, что ведущим фактором, дифференцирующим территорию города по состоянию среды обитания, является загрязнение атмосферного воздуха, фиксируемое в виде техногенных геохимических аномалий в природных средах и биогеохимических реакций населения. Атмосферные загрязнения нельзя рассматривать только как причину, непосредственно вызывающую повышенную заболеваемость. Прежде всего этот фактор оказывает влияние на общую резистентность (сопротивляемость) организма, результатом снижения которой могут стать повышенная заболеваемость и другие изменения состояния здоровья населения. Во многих научных исследованиях описаны количественные связи между концентрациями отдельных загрязняющих веществ в атмосфере (или их комплекса) и показатолями состояния здоровья населения. В то 
же время работы, в которых пространственная структура загрязнения городов соотносится с данными о состоянии здоровья населения, носят единичный характер. Авторы настоящей работы поставили задачу совместить имеющиеся материалы о геохимической структуре городов с собственными данными и данными литературы об изменениях различных показателей состояния здоровья населения. При этом геохимической оценке территории придается индикационная роль, поскольку она показывает структуру загрязнения воздуха не только металлами, но косвенно отражает и закономерности распределения некоторых других загрязняющих веществ.

Показателями неблагоприятного влияния загрязнения окружающей среды, наряду с повышением в. организме человека концентраций токсичных химических элементов, являются различные функциональные и морфологические нарушения, которые у детей возникают практически с момента их рождения. Это связано с влиянием атмосферных загрязнений на мать в период беременности и непосредственно перед ее началом. Физическое развитие новорожденных является существенной характеристикой дальнейшего развития и здоровья ребенка. Например, вес новорожденных, родившихся у матерей, проживающих на территории с высоким уровнем загрязнения почв, в среднем на 400 г меньше $(10 \%)$, чем в районе без геохимических аномалий. Факт ухудшения показателей физического развития новорожденных подтвержден также в городах и поселках с развитой металлургической и горнообрабатывающей промышленностью. В этих городах также увеличено число детей с крайними значениями антропометрических признаков. Нарушение нормальных закономерностей распределения детей по антропометрическим показателям сопровождается снижением устойчивости организма к широкому спектру заболеваний. У детей в городах с металлургической промышленностью по сравнению с контрольными группами замедлено физическое и нервно-психическое развитие, проявляющееся в отставании времени, с которого ребенок начинает ходить, говорить, в более позднем появлении молочных зубов.

Нарушения нормального физического развития детей отмечаются и в более старшем возрасте. Так, среди детей в возрасте 5-7 лет, проживающих в упоминавшихся очагах загрязнения, на 5\% детей меньше с нормальным физическим развитием и почти в 2 раза больше детей с дефицитом и избытком массы тела. Указывается также на дисгармоничность физического развития детей и школьного возраста, причем установленная для них избыточная масса тела связывается с неблагоприятными воздействиями атмосферных загрязнений [7]. Среди других функционально-морфологических показателей, наиболее широко изучаемых при оценке влияния загрязненного атмосферного воздуха на состояние здоровья детей, являются гематологические пока- 
затели, характеристика нервно-психического и иммунного статуса ребенка. По мере увеличения интенсивности загрязнения воздушного бассейна, определенное на основании оценки степени опасности загрязнения почв число детей с повышенным содержанием лейкоцитов увеличивается в промышленных районах в 1,6 раза и до .2 раз в центре города с опасным уровнем загрязнения. У детей, проживающих в зоне интенсивного загрязнения близ отдельных производств, изменения гематологических показателей еще более выражены. Так, в районе расположения эмалевого производства у них на $7 \%$ снижено содержание в крови гемоглобина, вблизи нефтехимического комплекса - выражен рост лейкоцитов при снижении гемоглобина. Эти морфо-функциональные сдвиги в системе крови свидетельствуют о напряжении адаптационных резервов в организме. В случаях чрезвычайно высокого уровня загрязнения атмосферного воздуха изменения картины крови свидетельствуют о выраженной анемизации населения. В центре металлургической промышленности, где на всей территории города загрязнение почв соответствует опасному и чрезвычайно опасному уровню, у жителей города не производится забор донорской крови из-за низкого содержания в ней гемоглобина.

Воздействие атмосферных загрязнений сопровождается изменением функции внешнего дыхания, сердечно-сосудистой системы. Например, в зоне влияния выбросов нефтехимического комплекса и вблизи автомагистралей у детей жизненная емкость легких, резервные объемы вдоха и выдоха снижены на $10-30 \%$, a у детей вблизи придприятий стройнндустрии с большим пылевым выбросом - на 70\%. Дети, проживающие в загрязненных районах с опасным уровнем загрязнения почв, чаще жалуются на одышку и утомляемость, у них учащен пульс, удлинен восстановительный период, нарушены возрастные нормы пределов отклонений других функциональных показателей состояния сердечно-сосудистой системы.

Наиболее быстро и чутко на изменения качества окружающей среды реагируют показатели иммунологической реактивности. По сравнению с другими показателями функционального состояния организма количественные различия показателей иммунологической реактивности в загрязненных и контрольных районах наиболее выражены. Среди детей, проживающих вблизи машиностроительных производств, число детей с высокой степенью обсемененности слизистой оболочки носа было в 3 раза выше, чем в контрольной группе [48]. В результате снижения общей сопротивляемости организма увеличивается опасность действия различных патогенных факторов - инфекции, стресса, переохлаждения и др. В последнее время установлена взаимосвязь между состоянием иммунологической резистентности детского организма и частотой респираторных заболеваний у детей, проживающих в условиях химической нагрузки. При высоком уров- 
не загрязнения атмосферного воздуха у детей происходит изменение всего комплекса указанных функциональных показателей.

Различия в уровне заболеваемости населения рассмотрены во многих исследованиях. В большинстве работ дана сравнительная оценка заболеваемости детей «чистых» и «загрязненных» районов одного города или разных городов, которые отличаются интенсивностью загрязнения атмосферного воздуха. Наличие связей между уровнем заболеваемости и интенсивностью загрязнения атмосферы показано на большом фактическом материале. Установлены достоверные связи между заболеваемостью органов дыхания, кожи, пищеварительного тракта, глаз и концентрациями в атмосферном воздухе сернистого ангидрида, сажи, оксидов углерода и азота, пыли [14]. Эти зависимости носят, как правило, линейный и (или) логарифмический характер. Анализ заболеваемости детей в зависимости от уровня загрязнения атмосферного воздуха, питьевой воды, интенсивности воздействия физических факторов (шума, электромагнитных полей), содержания в продуктах питания пестицидов социальнобытовых условий выявил, что наиболее Ӟначимым в увеличении общей заболеваемости в данном исследовании оказался комплекс факторов «концентрация оксида углерода в атмосферном воздухе + городской шум + низкий уровень дохода семьи». Иными словами, контрастно проявилось химическое и шумовое воздействие автотранспорта, наиболее четко фиксируемое в принятой системе контроля загрязнения окружающей среды. По распространенности отдельных групп заболеваний установлена связь и с некоторыми другими факторами - концентрацией сернистого ангидрида и пыли в атмосферном воздухе, неблагоприятными жилищными условиями и др. Постоянным фактором являлось загрязнение атмосферного воздуха оксидом углерода [47].

Наиболее часто при изучении заболеваемости населения фиксируется увеличение частоты респираторных заболеваний детей, проживающих в условиях химических нагрузок. Учитывая, что у детей суммарная заболеваемость в значительной степени обусловлена заболеваниями органов дыхания $(60-70 \%)$, увеличение частоты последних влечет за собой увеличение и суммарной заболеваемости. Накоплено много данных по контрастности различий в уровне респираторной заболеваемости детей, проживающих в центре зон загрязнения и в выбранных для сравнения «чистых» районах. Например, в зоне влияния химических производств респираторная заболеваемость у детей в 2 раза выше, чем в фоновом районе; нефтехимических и нефтеперерабатывающих производств - в 2 раза; сланцевых производств - в 2,5 раза; металлургического комбината - в 4-5 раз и т. д. Эти цифры характеризуют заболеваемость детей, подвергающихся наибольшему воздействию загрязненного воздуха вблизи производств. При общепринятом анализе заболеваемости 
детей по более крупным территориальным единицам (например, административный район), включающим зоны как с максимальным, так и со средним уровнем загрязнения, контрастность различий в заболеваемости органов дыхания снижается. Так, в городах с высоким уровнем загрязнения воздуха при анализе заболеваемости детского населения в масштабе целого района контрастность различий в заболеваемости органов дыхания в 1,3-1,6 раза выше, чем при анализе заболеваемости по зонам максимального загрязнения.

В ряде работ отмечается, что снижение заболеваемости наступает довольно резко по мере удаления от источника загрязнения и снижения интенсивности загрязнения атмосферного воздуха. В городе с металлургической промышленностью вблизи комбината частота OP3 у детей в $3-5$ раз вын, чем в фоновом районе; на расстоянии 1,5 км контрастность роста заболеваемости снижается до $2-3$; на расстоянии 6 км - до 1,5 .

В большинстве работ з ґболег пеость детей в зонах загрязнения сравнивается с анаг эгичными показателями по контрольной группе детей, проживағ щих на окраине этого же города. При этом не учитывается д:ффузный характер загрязнения, который может обусловливать повышенную заболеваемость детей и в относительно чистых районах промышленных городов. Это проявилось и при анализе заболеваемости детей окраинных микрорайонов промышленных городов по сравнению с городом-спутником, практически не имеющим промышленности и выбранным в качестве фонового. В считающихся «чистыми» районах промышленных городов у детей на $20 \%$ выше суммарная заболеваемость, чем в фоновом городе.

Основными проектными документами, определяющими направление природоохранных работ в городах (генпланы городов, схемы районной планировки и территориальные комплексные схемы охраны природы), требуются выявление в городах наиболее неблагоприятных гигиенических ситуаций, определение их приоритетности, установление основных вредных веществ," вызывающих изменения состояния здоровья населения, т. е. необходимо комплексное зонирование территории города как по интенсивности загрязнения окружающей среды и, в первую очередь, атмосферного воздуха, так и по изменениям показателей здоровья населения. Наличие эмпирически установленных корреляционных связей в системе «показатели загрязнения атмосферного воздуха - показатели здоровья», подробно охарактеризованные выше, позволяют помочь решению этой задачи.

Результаты анализа пространственной структуры заболеваемости, проведенного на основе эколого-геохимической модели, могут быть продемонстрированы на примере широко распространенной ситуации крупного промышленного города со сложной промышленной структурой и мозаично расположенными про- 


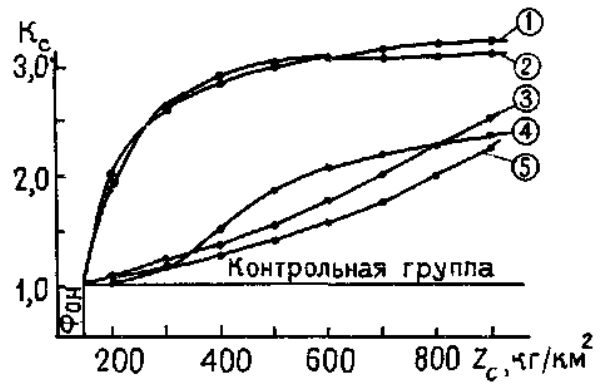

Рис. 63 Зависимость между распространенностью заболеваний среди детей и уровнем выпадения пыли. $\mathbf{K}_{\mathbf{c}}$ - показатель увеличения забо леваемости детей относительно за болеваемости на фоновых террито риях $Z_{\text {c }}$ - показатель суммарного среднесуточного выпадения загряз нителей Цифры в кружках - забо левания 1 - бронхиальная астма 2 конъюнктивит 3 - отит 4 острый фарингит и острый тонзил лит, 5 - острый бронхит

мышленными, селитебными и рекреационными территориями

В городе изучены показатели здоровья населения в соответствии с выявленной территориальной структурой распределения химических элементов и выпадений пыли Заболеваемость детей (по данным первичной обращаемости) бронхиальной астмой, острым бронхитом, острым фарингитом, острым тонзиллитом, хроническим отитом, конъюнктивитом в 2-3 раза выше в районах с высоким выпадением пыли На рис 63 представлены показатели заболеваемости детского населения в связи с разным уровнем пылевой нагрузки Показатели заболеваемости в районе с минимальной пылевой нагрузкой приняты за 1 При увеличении нагрузки, фиксируемой картированием снегового покрова, наиболее интенсивно возрастает заболеваемость бронхиальной астмой, конъюктивитом (до 3 раз)

Пространственное распределение выпадений пыли в vсловнях этого города и изменения уровня заболеваемости детей хорошо также иллюстрирует приведенная ниже схема (рис 64) Районы, в которых уровень заболеваемости наиболее высок, характери зуются высокой концентрацией промышленности и влиянием выбросов ТЭЦ Для определения связи между показателями заболеваемости детского населения и геохимической ситуацией (количеством выпадений на снеговой покров) рассчитаны коэффициенты парной корреляции Достоверная положительная связь сильной и средней интенсивности выявлена в разных возрастных группах по острым заболеваниям органов дыхания - острому бронхиту $(r=0,4-0,65)$, острому назофарингиту $(r=0,32-$ $0,48)$, бронхиальной астме $(2=0,47)$, хроническим и острым отитам $(\Gamma=0,41-0,65)$ Показатели заболеваемости детей срав нивались также с содержанием пыли в воздухе и с показателем опасности загрязнения воздуха по сумме ингредиентов, определенных на стационарных постах наблюдений Зависимости меж ду этими показателями и заболеваемостью населения не установлено ни по одному из видов заболеваний По-видимому, это связано с тем, что информация с редкой сети стационарных постов в городе неполностью отражает действительный уровень 




Рис 64 Карта-схема зонирования урбанизированной территории по уровню заболеваемости детей

$1-5-$ уровни загрязнения территорий (среднесуточное выпадение пыли в кг $/ \mathrm{km}^{2}$ ) 1 - низкий неопасный (менее 250, наиболее низкий vровень заболеваемости), 2 - средний vмеренно опасный $(250-450$, повышена заболеваемость преимуще ственно бронхиальной астмой и конъюктивитом) 3 - высокий, опасный (450 850, повышена заболеваемость органов дыхания и органов чувств), 4 - очень высокий и чрезвычайно опасный (более 850 увеличение заболеваемости более, чем в 2 раза) 5- промышленные зоны включающие отдельные жилые массивы (очень высокий и чрезвычайно опасный), 6 - зеленые насаждения, неосвоенные и неудобные земли 
загрязнения в местах их расположения. Геохимическое картирование позволяет более четко выявить сгруктуру распространения загрязняющих веществ на территории города, чем данные действующей в настоящее время сети стационарных постов.

Одним из заболеваний, наиболее быстро реагирующим на загрязнение атмосферного воздуха, является бронхиальная астма. Изучение зависимостей между частотой встречаемости этой патологии среди детского населения крупного промышленного города и широким комплексом показателей, отражающих загрязнения окружающей среды, позволило выделигь основные средовые факторы, определяющие изиенчивссть показателей распространенности бронхиальной астмы, к которым относятся: суммарный показатель загрязнения снегового покрова мегаллами, суммарный показатель загрязнения атмосферного воздуха ( $\left.K_{\text {сум }}\right)$, рассчитанный по максимальным расчетным конценграциям четырех основных загрязняющих веществ (оксиды углерода и азота, сера и пыль); максимальные расчетные концентрации: оксидов азота от ТЭЦ, оксидов азота от районных котельных, оксидов азота от выбросов промышленных предприятий, оксида углерода от автотранспорта и пыли от промышленных и энергетических выбросов. Все эти факторы определяют только $70 \%$ дисперсии заболевания. Между интенсивностью проявления аэрогенных геохимических аномалий и уровнем заболеваемости бронхиальной астмой можно выделить два основных типа соотношений: коррелирующие и некоррелирующие (рис. 65).

Коррелирующий тип соотношения развит примерно на $70 \%$ территории города. Здесь видно хорошее пространственное сопряжение высокой (5 случаев на 1000), средней (5-15 случаев на 1000) и низкой (менее 5 случаев на 1000) распространенности бронхиальной астмы с высоким, средним и низким уровнем загрязнения. Более детальный анализ распространенности бронхиальной астмы выявил территории с наибольшей распространенностью заболевания. Выделенные «очаги» или, как опреде ляют их медицинские географы, «локусы» патологии, составляют примерно 5\% общего числа участков. Они совпали с центрами геохимических аномалий возле предприятий, связанных с переработкой цветных металлов, локализованы вдоль автомагистралей с интенсивным движением, а также близ предприятий парфюмерной, пищевой и медицинской промышленности.

Повсеместно наблюдаемый рост частоты рождения детей с аномалиями развития связывают и $c$ загрязнением окружающей среды городов. Наиболее ярко нарушения репродуктивной функции проявлены в металлургических городах. Например, в «медных» городах в 2 и более раз чаще, чем в «фоновых» городах, регистрируются токсикозы у беременных женщин, самопроизвольные выкидыши, мертворожденность, рождение детей с врожденными уродствами и аномалиями развития. Высокий уровень 


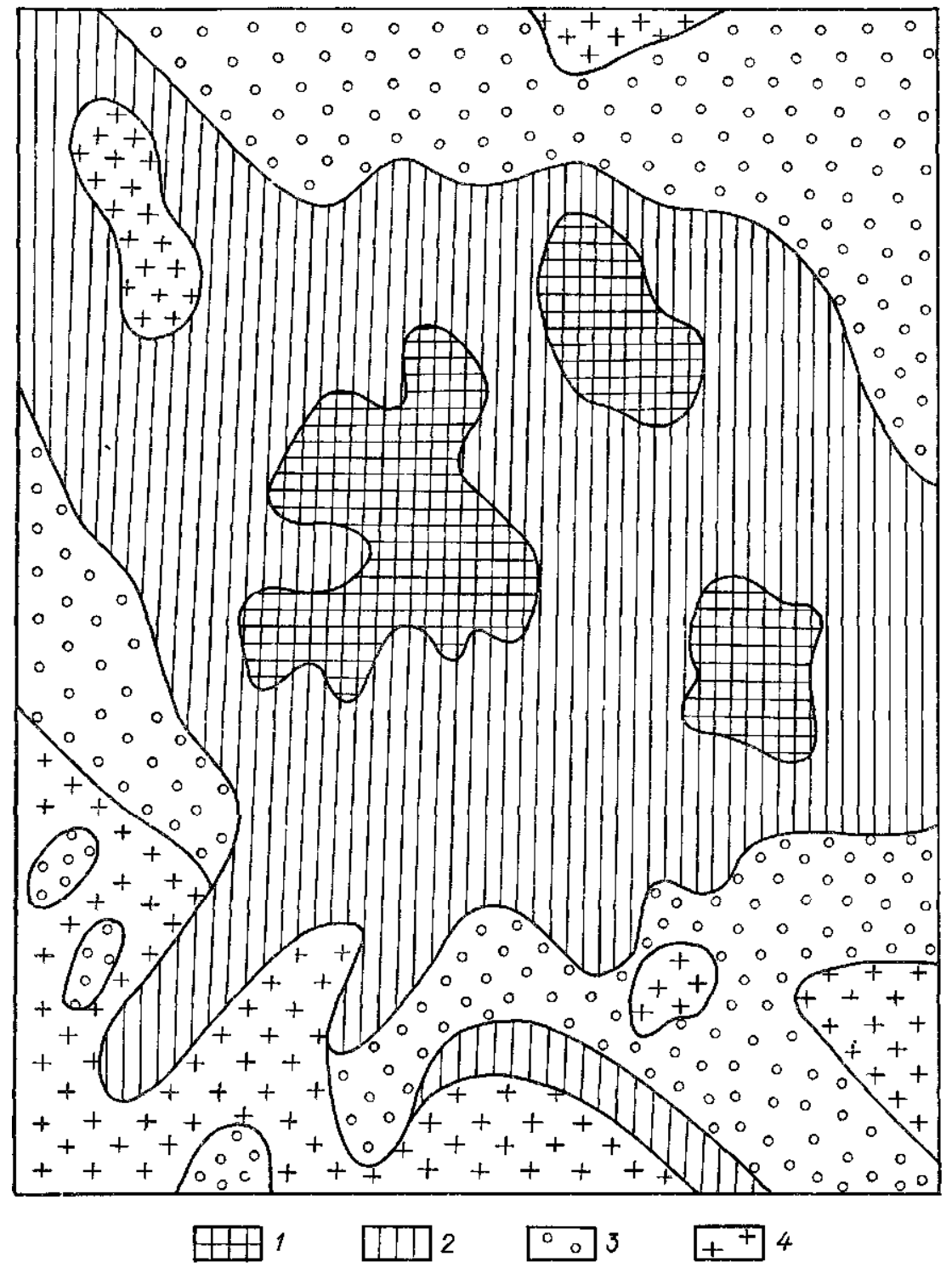

Рис. 65. Карта-схема распространенности бронхиальной астмы среди детей в связи с геохимической структурой аэрогенных аномалий в снеговом покрове: $1-4-$ территории с различными условиями уровнями распространенности бронхиальной астмы $I$-- высокий уровень (более 15 случаев на 1000), 2 - средний уровень (5-15 случаев на 1000), 3 - относительно низкий уровень (менее 5 случаев на 1000), 4 -- относительно высокий и средний уровни распространенности бронхиальной астмы при относительно низком уровне загрязнения депонирующих сред 
распространения этой патологии выявлен в центрах черной металлургии и химической промышленности. Наиболее выражены изменения детородной функции у женщин, работающих на промышленных предприятиях и проживающих вблизи них в зоне наибольшего загрязнения. Так, проведенный нами анализ историй родов работниц крупного машиностроительного производства показал, что у женщин, проживающих в загрязненной части города и работающих на заводе, достоверно выше, чем в контрольной группе (на 30\%), угроза выкидыша во время текущей беременности, число стремительных родов (в 2 раза), гипотрофия новорожденных (на 20\%).

Приведем еще примеры геогигиенической оценки геохимической структуры территорий городов, один из которых характеризуется высоким уровнем выпадения пыли, выбрасываемой цементным заводом, а другой - высоким уровнем загрязнения окружающей среды металлами от крупных электротехнических предприятий с выбросами свинца и других металлов. Выпадение пыли в поселке вблизи цементного завода достигает $400 \mathrm{kr} / \mathrm{kм}^{2}$, что оценивается как опасный уровень загрязнения (рис. 66).

Уровень выпадения пыли быстро снижается, и на расстоянии 1 км, где и расположен следующий жилой массив, составляет $150 \mathrm{kг} / \mathrm{kм}^{2}$ в сутки. Дальняя часть города отличается небольшим количеством поступающей пыли (50 кг/км² в сутки). Изучение частоты хронических заболеваний среди детей этого города показало, что высокий уровень выпадения пыли приводит к резкому увеличению числа хронических заболеваний миндалин и аденоидов.

В городе, загрязненном металлами (этот пример описывался при характеристике патологии беременности и родов), даже на периферии аномалий по сравнению с фоновыми городами отмечается увеличение частоты хронических пневмоний на 15$20 \%$ и хронических заболеваний миндалин на 20\%. В центрах же аномалий уровень этих заболеваний возрастает еще в $1,5-2$ раза. Здесь же проявляется повышенная заболеваемость отитом (рис. 67).

Влияние автотранспорта, проявленное наиболее ярко в зонах воздействия крупных шоссе, сказывается в увеличении (до 6 раз) числа острых респираторных заболеваний, острых бронхитов и фарингитов (в 3 раза). Для городов с хорошими условиями рассеивания примесей эти цифры характеризуют лишь зоны, примыкающие к шоссе.

В связи с неблагоприятными ландшафтными условиями проветривапия многих городов, расположенных в котловинах и долинах рек, роль автотранспорта в загрязнении и заболеваемости может резко возрасти.

В городах с плохими условиями рассеивания на $10 \%$ территории наблюдаются чрезвычайно опасные уровни загрязнения, на $30 \%$ - опасные, на 50-60\% - умеренно опасные. В чрезвычайно опасных и опасных зонах отмечается превышение ПДК свинца в атмосфере и накопление этого элемента в организме детей больше физиологической нормы. В результате у детей местных жителей наблюдается рост заболеваемости верхних дыхательных путей на 40-100\% и органов чувств на $100-140 \%$.

Приведенными выше данными об изменениях состояния здоровья населения в промышленных городах мы показали реальный уровень увеличения отклонений функциональных показателей и заболеваний в различных возрастных группах населения. При этом, как правило, в каждом случае анализировалось распространение той или иной патологии, поэтому

Рис. 66. Частота распространения хронических заболеваний среди детей в городе с различным уровнем выпадения пыли:

$1-5$ - уровни среднесуточного выпадения пыли (в кг/км $\left.{ }^{2}\right): 1$ - менее $20 ; 2$ $20-50 ; 3-50-150 ; 4-150-400 ; 5-$ более $400 ; 6-$ граница промышленной зоны. На гистограммах показана частота распространения хронических заболеваний: I - отит, II - заболевания миндалин и аденоидов, III - пневмонии 


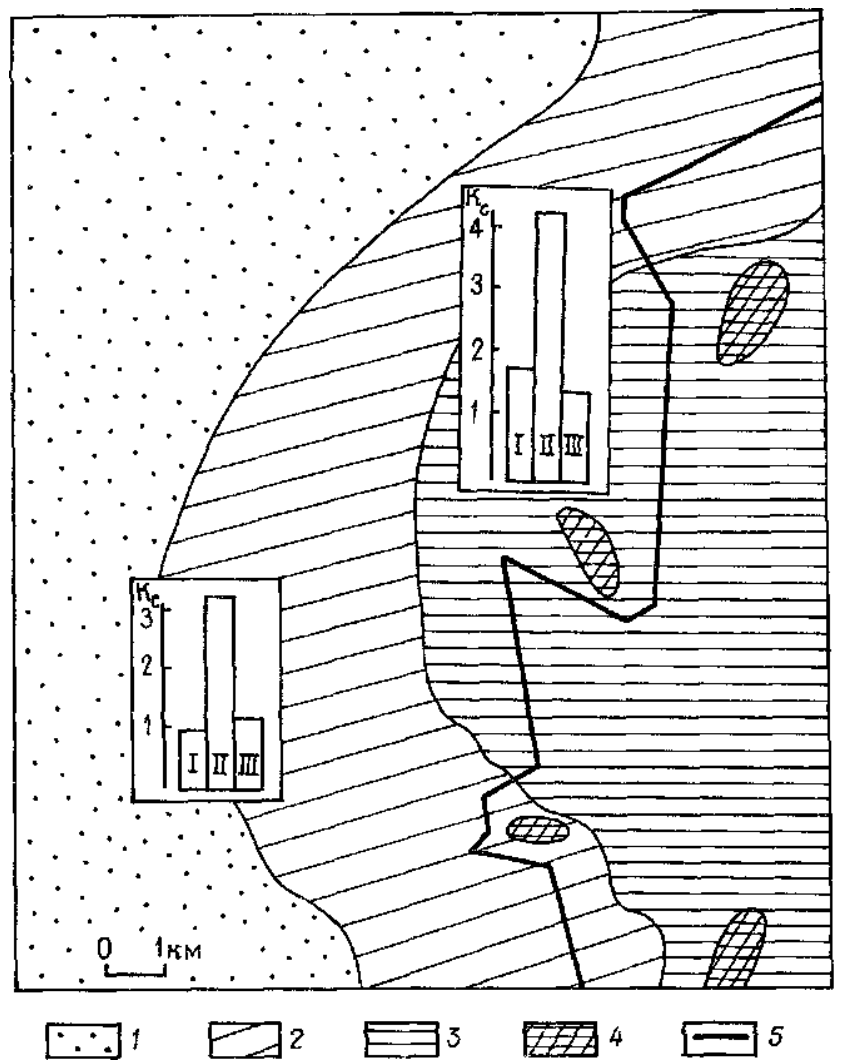

Рис. 67. Частота распространения хронических заболеваний среди детей в городе с разным уровнем загрязнения почв металлами относительно фонового городского уровня:

$1-4-Z_{\text {c }}$ почв $(1-$ менее $16,2-16-32,3-32 \quad 128,4$ - более 128), 5 граница промышленной зоны На гистограммах показаны частоты рдспростра нения хронических заболеваний I - отит, II - заболевания миндалин и аде нондов, III - пневмонии

интересно проследить на примере города с многоотраслевой промышленностью и сложной геохимической структурой территории более широкий спектр показателей изменения состояния здоровья В таком городе только у 50\% детей из новых жилых кварталов в отдалении от промышленных зон отмечается сравнительно низкий уровень заболеваемости и наибольшее число здоровых детей с нормальным физическим развитием (рис 68)

Рис. 68. Карта-схема зонирования урбанизированной территории по степени изменения состояния здоровья детей в связи с геохимической структурой аэрогенных аномалий в снеговом покрове: 


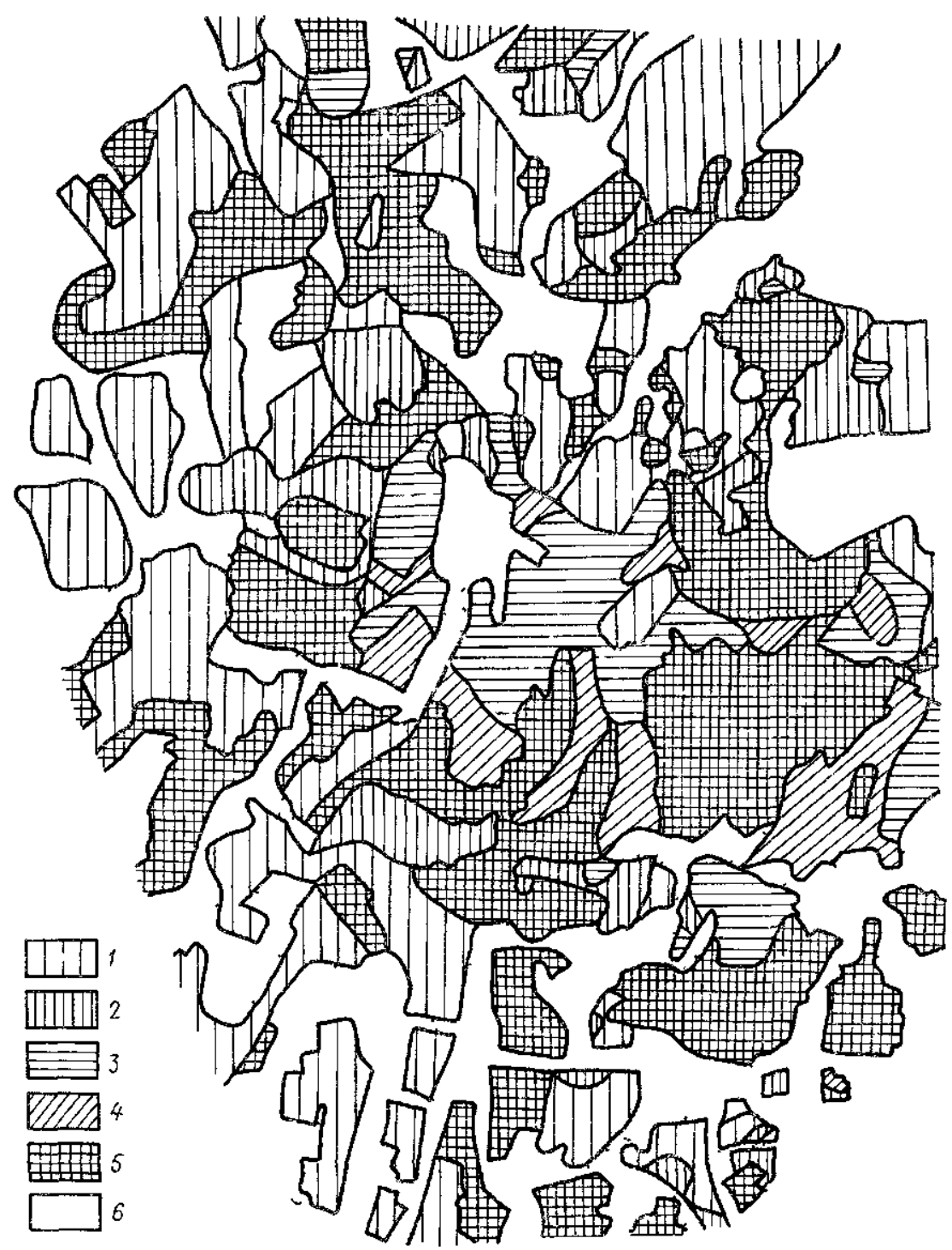

$1-4-$ уровни загрязнения 1 - низкий, неопасный $\left(Z_{c}\right.$ менее 64 наименьшее изменение показателей здоровья детей $), 2$ - средний, умеренно опасный $\left(Z_{\mathrm{c}}-\right.$ $64-128$, повышение суммарной заболеваемосги), 3 - высокий, опасный $\left(Z_{\mathrm{c}}-\mathrm{m}\right.$ $128-256$, повышена суммарная заболевдемость, увеличено число болеющих и часто болеющих детей $), 4$ - очень высокий и чрезвычайно опасный $\left(Z_{c}-\right.$ более 256, значительно повышена заболеваемость, увеличено число болеющих, часго болеющих детей, детей с хроническими заболеваниями и отклонениями от нор мального физического развитня), 5 - промышленные зоны с небольшими жилыми массивами (очень высокий и чрезвычайно опасный уровень загрязнения), $6-$ зеленые насаждения, неосвэенные и неудобные земли 
Т а б л и ц а 68. Изменение функциональных показателей и рост заболеваемости населения в зонах загрязнения (в \% по отношению к относительно не загрязненным территориям)

\begin{tabular}{|c|c|c|c|}
\hline \multirow{2}{*}{ Реакция организма } & \multicolumn{3}{|c|}{ Характеристика очагов загрязнения } \\
\hline & $\begin{array}{l}\text { умеренно } \\
\text { опасная }\end{array}$ & опасная & $\begin{array}{c}\text { чрезвычайно } \\
\text { опасная }\end{array}$ \\
\hline $\begin{array}{l}\text { Функционально-морфологические } \\
\text { отклонения } \\
\text { Суммарная заболеваемость } \\
\text { Заболевание органов дыхания }\end{array}$ & $\begin{array}{l}+10-30 \\
+10-20 \\
+10-50\end{array}$ & $\begin{array}{r}\text { I. Дети } \\
+30-100 \\
+20-60 \\
+50-100 \\
\text { II. Взросл }\end{array}$ & $\begin{array}{c}100 \\
30-100 \\
+100-300\end{array}$ \\
\hline $\begin{array}{l}\text { Патология беременности и родов } \\
\text { Сердечно-сосудистые заболевания } \\
\text { Онкологические заболевания } \\
\text { (рак легкого) } \\
\text { Временная утрата трудоспособности }\end{array}$ & - & $\begin{array}{l}+20-30 \\
+50\end{array}$ & $\begin{array}{c}\text { Ло } 100 \\
\text { До } 300-400 \\
\text { до } 100 \\
\text { до } 100\end{array}$ \\
\hline
\end{tabular}

Примечания 1 Характеристика очагов загрязнения по Методическим указаниям по оценке степени опасности загрязнения почвы химическими веществами, утвержденным Минздравом СССР (№ 4266-87) В качестве индикагора загрязнения атмосферного воздуха принят показатель суммарного загрязнения почв $-Z_{c}$, величина которого до 16 оценивается как допустимая, от 16 до 32 как умеренно опасная, от 32 до 128 как опасная, и более 128 как чрезвычайно опасная 2 «+»- процент увеличения относительно фоновых территорий $3 \ll-\gg-$ данные отсутствуют

По мере приближения жилых кварталов к промышленным зонам, увеличения суммарных показателей загрязнения почв и снегового покрова до средних умеренно опасных уровней происходит увеличение числа детей с отклонениями в состоянии здоровья. В таких зонах города проживает 40\% детского населения, у которого проявляется тенденция к росту общей заболеваемости на $15-20 \%$ и заболеваний органов дыхания на $20-90 \%$. Около $10 \%$ жителей города находится вблизи промышленных предприятий и автомагистралей с интенсивным движением машин в зонах с опасным и очень опасным уровнями загрязнения. Среди них сильно выражена тенденция ухудшения показателей состояния здоровья: общая заболеваемость и отклонения от нормального физического развития возрастают на $30-50 \%$, заболеваемость органов дыхания на $100-150 \%$, число часто болеющих детей на $20-30 \%$.

Имеющиеся материалы однозначно свидетельствуют, что загрязнение окружающей среды повсеместно сопровождается неблагоприятными реакциями организма человека. Взаимосвязи между показателями загрязнения окружающей среды и показателями здоровья весьма сильные. Количественные оценки этих взаимосвязей варьируют в широких пределах. Они зависят (при близкой социальной и биологической структуре населения) от типа источников воздействия (ассоциации загрязняющих веществ), их мощности (интенсивности воздействия) и 
Т а бл и а 69. Типичные структуры загрязнения территорий городов (в \% общей площади)

\begin{tabular}{|c|c|c|c|c|}
\hline \multirow{2}{*}{ Характериетика города } & \multicolumn{4}{|c|}{ Степень загрязнения } \\
\hline & $\begin{array}{c}\text { относительно } \\
\text { чистая }\end{array}$ & $\begin{array}{c}\text { умеренно } \\
\text { опасная }\end{array}$ & опасная & $\begin{array}{c}\text { чревычайно } \\
\text { опасная }\end{array}$ \\
\hline $\begin{array}{l}\text { Крупнейшие и крупные го- } \\
\text { рода с многоотраслевой } \\
\text { промышленностью }\end{array}$ & $30-50$ & $30-50$ & $10-20$ & $1--5$ \\
\hline $\begin{array}{l}\text { Средние и малые специа- } \\
\text { лизированные города с ме- } \\
\text { таллургическими источника- } \\
\text { ми выбросов }\end{array}$ & 0 & $30-50$ & $50-100$ & $10-20$ \\
\hline $\begin{array}{l}\text { Средние и малые специа- } \\
\text { лизированные города маши- } \\
\text { ностроительного профиля }\end{array}$ & 50 & 50 & 0 & 0 \\
\hline $\begin{array}{l}\text { Средние и малые города с } \\
\text { небольшой промышленной } \\
\text { нагрузкой, интенсивным } \\
\text { движением автотранспорта } \\
\text { и плохими природными усло- } \\
\text { виями рассеивания выбросов }\end{array}$ & $10-20$ & $50-60$ & $20-30$ & до 10 \\
\hline $\begin{array}{cc}\text { Малые города с } & \text { небольшой } \\
\text { промышленной } & \text { нагрузкой } \\
\text { (фоновый тип) } & \end{array}$ & $80-90$ & $10-20$ & 0 & 0 \\
\hline
\end{tabular}

градостроительной структуры - соотношения промышленных и селитебных территорий (площади жилых массивов, попадающих в зоны загрязнения той или иной интенсивности). Исследование этих зависимостей только начинается, еще не доведено до уровня надежного количественного прогноза. Это связано прежде всего с отсутствием комплексных работ, одновременно оценивающих интенсивность воздействия, его пространственную структуру и широкий спектр реакций организма в связи с этой структурой. Тем не менее, ориентировочные количественные оценки влияния загрязнения окружающей среды на состояние здоровья населения (в том числе рост заболеваемости) все же могут быть даны.

Обобщение собранных авторами материалов по сопряженному геохимическому и эпидемиологическому анализу уровня загрязнения окружающей среды городов и показателей состояния здоровья населения в крупных промышленных агломерациях и городах с доминирующим влиянием отдельных видов производства (цветная металлургия, машиностроительная промышленность, многоотраслевой промышленный комплекс и другие) позволило оценить интенсивность реакции организма человека в зонах загрязнения различного уровня. В частности, установлены типовые вариации изменения (в \% от контроля относительно чистых территорий тех же городов) для умеренно опасных, опасных и чрезвычайно опасных очагов загрязнения по суммарному показателю загрязнения почв (табл. 68); гра- 


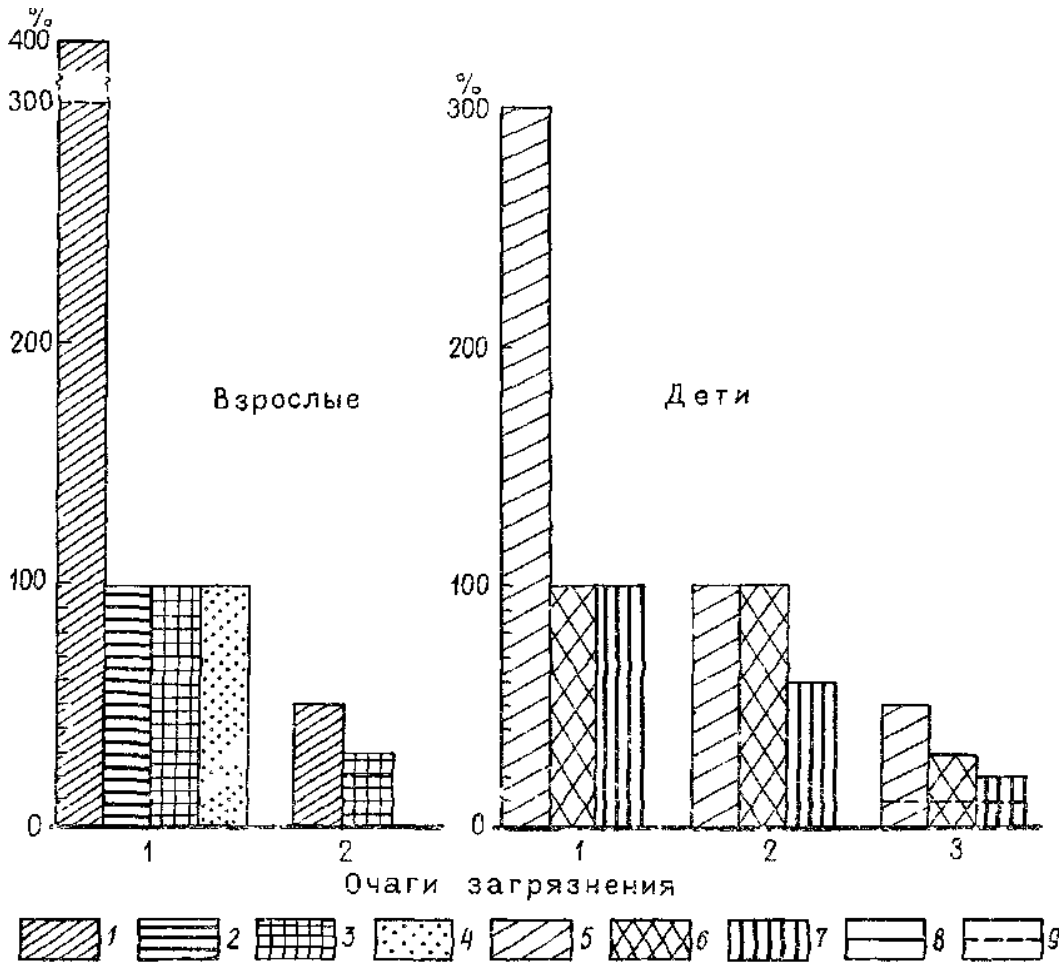

Рис. 69. Изменение функциональных повазателсй $u$ уровня заболеваемости населения в зоне загрязнения (в процентах относнтельюо малозагрязненных территорий):

1 -4-заболевания взрослых $(1$-- сердечно-сосудистые, 2 - онкологические 3 - патология беременности и родов, 4- временная утрата трудоспособности), $5-7-$ заболевания детей $(5-$ заболевания органов дыхания, 6 - функционально-морфологические отклонения, 7 - суммарная заболеваемость), 8 - верхний предел, 9- иижний предел. $1-3$ - характеристика очагов загрязнения: 1 очень интенсивные и чрезвычайно опасные, 2 - интенсивные и опасные, 3 - срелней интенсивности и умеренно опасные

фическое выражение изменения функциональных показателей и уровня заболеваемости по отдельным видам патологии представлено на рис. 69.

При характеристике техногенных ореолов в городах мы сделали попытку оценить общую структуру загрязнения городов различного типа (табл. 69). С учетом проведенных нами оценок состояния здоровья населения в зонах загрязнения различного уровня и степени опасности можно ошенить вариацию показателей средневзвешенной интенсивности проявления неблагоприятных реакций населения на загрязнение окружающей среды 
Т а бли д 70. Средневзвешенные показатели изменения функциональных характеристик и роста заболеваемости населения в городах разного типа (в \% к относительно чистым территориям городов того же типа)

\begin{tabular}{|c|c|c|c|c|}
\hline \multirow[b]{2}{*}{ Показатели } & \multicolumn{4}{|c|}{ Типгорода } \\
\hline & $\begin{array}{c}\text { крупнейший } \\
\text { многоотрас- } \\
\text { левой }\end{array}$ & $\begin{array}{c}\text { крупный с } \\
\text { мощным ис- } \\
\text { (мегаллург) }\end{array}$ & $\begin{array}{c}\text { средний } \\
\text { машино- } \\
\text { строн- } \\
\text { тель- } \\
\text { ный }\end{array}$ & $\begin{array}{c}\text { средний ав- } \\
\text { тотранспорт- } \\
\text { ный }\end{array}$ \\
\hline Иммунологическая реактив- & $+50-150$ & $+150-300$ & $+50-100$ & $+120-200$ \\
\hline $\begin{array}{l}\text { ность организма } \\
\text { Функциона тьные отклонения } \\
\text { (дыхания, сердечно-сосу- } \\
\text { дистой системы) }\end{array}$ & $+6-35$ & $+20-120$ & $+5-15$ & $+15-48$ \\
\hline $\begin{array}{l}\text { Суммарная заболеваемость } \\
\text { детского населения }\end{array}$ & $+6-27$ & $+20-90$ & $+5-10$ & $+15-30$ \\
\hline $\begin{array}{l}\text { Заболеваемость органов } \\
\text { дыхания детей }\end{array}$ & $+9-60$ & $+30-180$ & $+\quad 5-25$ & $+20-60$ \\
\hline $\begin{array}{l}\text { Нарушение детородной } \\
\text { функции }\end{array}$ & $+2-10$ & $+15--20$ & 0 & $+3-9$ \\
\hline
\end{tabular}

Примечание «+»- процент увеличения показателей относительно фоновых территорий.

(табл. 70) и, соответственно, осредненный вклад загрязнения в ухудшение функциональных характеристик и рост заболеваемости населения (табл. 71).

Ухудшение иммунного статуса организма детей примерно на $50 \%$ связано с факторами загрязнения. Если в средних и малых городах машиностроительного профиля суммарная заболеваемость лишь не более чем на $10 \%$ связана с загрязнением, то в крупных городах этим фактором определяется до $25 \%$ всех заболеваний, а в городах близ особо мощных источников вредных

Т а б л и ц а 71. Вклад загрязнения окружающей среды в рост заболеваемости на. селения и изменение функциональных показателей (в \% средневзвешенных показателей по городу)

\begin{tabular}{|c|c|c|c|c|}
\hline \multirow[b]{2}{*}{$\begin{array}{r}\text { Показатели состояния } \\
\text { здоровья }\end{array}$} & \multicolumn{4}{|c|}{ Типгорода } \\
\hline & $\begin{array}{c}\text { крупнейший } \\
\text { многоотрас- } \\
\text { левой }\end{array}$ & $\begin{array}{c}\text { крупный с } \\
\text { мощным ис- } \\
\text { точником }\end{array}$ & $\begin{array}{c}\text { средний ма- } \\
\text { шинострои- } \\
\text { тельный }\end{array}$ & $\begin{array}{c}\text { средний ав- } \\
\text { тотранспорт- } \\
\text { ный }\end{array}$ \\
\hline $\begin{array}{l}\text { Иммунологическая реактив- } \\
\text { ность орг анизма }\end{array}$ & $33-60$ & $60-75$ & $55-67$ & $33-50$ \\
\hline $\begin{array}{l}\text { Функциональные откло- } \\
\text { нения (дыхания, сердечно-со- } \\
\text { судистой системы) }\end{array}$ & $5-29$ & $17-55$ & $17-33$ & $4-17$ \\
\hline $\begin{array}{l}\text { Суммарная заболеваемость } \\
\text { детского населения }\end{array}$ & $5-25$ & $17-47$ & $12-23$ & $4-9$ \\
\hline Заболеваемость органов & $10-40$ & $33-64$ & $17-40$ & $4--20$ \\
\hline $\begin{array}{l}\text { Нарушение детородной } \\
\text { функции }\end{array}$ & $2-9$ & $12-33$ & 0 & 0 \\
\hline
\end{tabular}


выбросов (металлургия, химия, горнообогатительное производство) загрязнение определяет иногда до $50 \%$ роста заболеваний. Особенно интенсивен вклад загрязнения в уровень заболеваний органов дыхания. В крупных городах с этой нозологией связано до $40 \%$ болезней, в городах близ мощных источников выбросов до $60 \%$.

Рост патологии беременности и родов обусловливает загрязнение окружающей среды примерно на $10 \%$ в крупных городах и на $30 \%$ - в наиболее загрязненных.

Эпидемиология сердечно-сосудистых заболеваний в связи • с загрязнением среды изучена мало. Тем не менее, самая предварительная оценка позволяет считать, что для крупных городов около $10 \%$ этой патологии может быть связано с состоянием окружающей среды.

Для особо загрязненных городов с мощными источниками выбросов загрязнение окружающей среды определяет $30-70 \%$ общего числа заболеваний. В этих же городах в связи с загрязнением возникает до $40 \%$ онкологических заболеваний некоторых локализаций. Потери рабочего времени в связи с загрязнением воздуха увеличиваются на 20-26\%. Приведенные данные свидетельствуют, что загрязнение окружающей среды - один из ведущих факторов, определяющих состояние здоровья населения.

\section{5. МЕТОДИЧЕСКИЕ ОСОБЕННОСТИ И ПРАКТИЧЕСКИЕ ВОЗМОЖНОСТИ ИСПОЛЬЗОВАНИЯ ГЕОХИМИЧЕСКИХ МЕТОДОВ}

Города, в которых урбанизация сводит на одной территории большие массы населения и наиболее совершенную технологию, являются концентром проявления техногенных воздействий на условия обитания человека.

Результаты геохимических исследований показывают возможность экспрессно и точно выявить распространение химических элементов по цепи «источник загрязнения - геохимическая аномалия в окружающей среде - живые организмы». Геохимические данные позволяют установить пространственную структуру экологически опасных зон загрязнения, создавая тем самым опорный фактический материал для всестороннего анализа проблем окружающей среды городов.

\section{МЕТОДИЧЕСКИЕ ОСОБЕННОСТИ РАБОТ}

Общие принципы организации и характеристика работ на конкретном этапе прикладных геохимических исследований окружающей среды городов детально рассмотрены в методических рекомендациях [28, 29] .

Главной целью рекогносцировочных работ начального этапа эколого-геохимических исследований в городах является выяв- 
ленне основных источников загрязнения и геохимической специфики зон их воздействия, а также установление природных и антропогенных условий формирования ореолов и потоков рассеяния. Предусматривается сбор и обобщение материалов, необходимых для конкретизации задач и интерпретации результатов геохимических исследований. Для крупных урбанизированных территорий необходимо составление ландшафтно-геохимических схем.

Ландшафтные схемы строятся на базе топографической, геологической, почвенной и других специальных карт местности, имеющихся в фондах и архивах. Они корректируются в процессе полевых рекогносцировочных исследований и детализируются при отборе проб.

Для городских территорий аналогом ландшафтной карты является карта-схема функциональных зон, отражающая структуру городского ландшафта, которая складывается из отдельных промышленных предприятий, жилых домов, бульваров, улиц и т. д.

На среднемасштабных картах функциональных зон показываются промышленные зоны, где могут быть сосредоточены десятки разнопрофильных предприятий. Каждая промышленная зона характеризуется по основному направлению функционирования (промышленное, складское, транспортное или их сочетания), по преобладающему виду промышленности (черная металлургия, машиностроение и т. д.), по плотности мест труда. Солитебные зоны (жилые массивы) разделяются по плотности населения и по типу застройки (капитальная, индивидуальная). Транспортные зоны различаются по интенсивности потоков.

Предварительные варианты карт функциональных зон города составляются на основе фондовых архитектурно-планировочных материалов. Уточнение контуров проводится в рекогносцировочных маршрутах и непосредственно в процессе опробования. Карты-схемы должны сопровождаться инвентаризационным списком предприятий, характеризующим их как потенциальные источники загрязнения. Список должен содержать характеристику типа производства, объем выбросов и стоков.

Выявление источников загрязнения начинается со сбора и анализа данных о действующих в городе производствах, сопровождающихся образованием выбросов, стоков, жидких и твердых отходов: выясняется структура производственных узлов, преобладающие виды производства; выявляются многоотходные и вредные производства; собираются данные по неутилизируемым отходам - количеству, составу, степени токсичности, способам удаления и ликвидации, местам складирования или захоронения.

Статистическая отчетность предприятия по выбросам и стокам содержит сведения о количестве всех видов отходов и от- 
части об имеющихся в них загрязняющих веществах. Данные поступают в статистические управления, в санитарно-эпидемиологические станции, в инспекции по регулированию использования и охраны вод и по контролю за работой газоочистных и пылеулавливающих установок. Хуже обстоит дело с жидкими и твердыми неутилизируемыми промышленными отходами: регулярной отчетности по ним нет, учет отходов производится эпизодически.

В архитектурно-планировочных организациях на основе обобщения данных о разных видах отходов составляются кадастры потенциальных промышленных источников загрязнения окружающей среды с указанием видов и объемов загрязнителей.

Сведения о бытовых источниках загрязнения (объемы отходов, способы обезвреживания и утилизации) имеются в управлениях коммунального хозяйства.

Сбор данных продолжается и на выбранных для изучения объектах, где производятся паспортизация видов отходов, ознакомление с технологическими процессами, связанными с образованием отходов, уточнение количества отходов, выяснение состояния и эффективности очистных сооружений, способов удаления неутилизируемых отходов и мест их размещения. Для изучения состава загрязнителей проводится геохимическое опробование $[29]$.

Геохимическое опробование ореолов и потоков рассеяния на данном этапе проводится в районе известных и потенциальных источников загрязнения. Как правило, опробуются наиболее информативные компоненты - пыль, снег, донные отложения. Это позволяет сформировать представительные геохимические выборки уже выявленных аномалий и оценить соответствующие им ассоциации химических элементов. Кроме того, эти выборки рационально дополнять опробованием почв и снега с детальностью 1 проба на $1 \mathrm{kм}^{2}$. Гидрохимическому опробованию подлежат устьевые участки всех водотоков, дренирующих промышленные зоны города.

Основой эколого-геохимических исследований на следующем (среднем) этапе изучения городов является метод геохимического картирования распределения химических элементов в почвах, снеговом покрове, донных отложениях, что позволяет выявить пространственную структуру состояния среды и установить очаги ее загрязнения.

Сущность геохимического картирования заключается в отборе проб характеризуемого компонента по равномерной сети пунктов наблюдения с последующим анализом проб на содержание химических элементов, сравнении полученных результатов с фоновыми аналогами и выделении геохимических аномалий по результатам проведенных исследований.

Методика исследования антропогенных ореолов и организа- 
ция работ по их изучению основаны на следующих закономерностях [28].

1. Антропогенная аномалия характеризуется полиэлементным составом с четко выраженным градиентом характеристик от центра - источника загрязнения - к периферии.

2. Размеры аномалий, связанных с промышленным загрязнением, и для урбанизированных территорий с высокой концентрацией производства могут достигать сотен и тысяч квадратных километров. Непосредственно вокруг источника выброса формируется ореол наиболее интенсивного загрязнения. Центральные части ореолов, в которых особенно отражается индивидуальная характеристика источника выброса, характеризуются наибольшей концентрацией всего комплекса элементов-загрязнителей. Площади этих частей составляют $10-200$ га, т. е. обычно не превы-


шим числом рядом расположенных предприятий ореолы их, сливаясь, образуют своеобразный «очаг» загрязнения. На территории промышленных городов площади очагов могут изменяться от единиц до $100-150 \mathrm{KM}^{2}$.

3. Аномалии в снеговом покрове отражают состояние окружающей среды сегодняшнего дня, аномалии в почвах - более стабильное многолетнее загрязнение. Поэтому обычно не наблюдается полной идентичности в расположении контуров ореолов в почвах и снеге.

4. Распределение воздушных потоков и выпадение на городской территории зависит от типа застройки, распределения дворов и улиц.

Перечисленные закономерности необходимо учитывать при организации опробования городской территории и зоны влияния отдельно стоящего источника.

При изучении промышленных районов с высокой концентрацией производства, где происходит формирование крупных очагов загрязнения, исходя из их характерных размеров (десятки квадратных километров), оптимальная густота опробования может быть принята $1-5$ точек на 1 км$^{2}$, т. е. расстояние между точками опробования может варьировать от 400 до 1000 м.

Равномерная сеть опробования обычно дополняется специальным выборочным геохимическим опробованием около заведомо известных крупных источников загрязнения и на наиболее интересных (приоритетных по социальным или ландшафтным особенностям) участках. Рекомендуется размещать точки опробования жилых зон в глубине дворов или на полузамкнутых участках, заслоненных домами от уличного движения. Это позволяет уменьшить долю случайного загрязнения, не связанного с выпадениями из атмосферы.

Геохимическое изучение структуры загрязнения поверхностных водных систем и выявление зон влияния конкретных источ- 
ников загрязнения проводятся путем маршрутного геохимического опробования донных отложений [27]. В пределах крупных промышленно-урбанизированных зон проводится съемка всех основных водотоков. При изучении отдельных источников загрязнения обычно достаточно проследить поток рассеяния до устья водотока.

Опыт работы показывает, что при отборе проб по водотокам через 200-400 м потоки рассеяния зоны влияния городов выявляются достаточно надежно. При опробовании небольших рек и ручьев в пределах городской территории с целью получения пространственной картины распределения загрязнения необходимо уменьшить шаг опробования до 100 м.

В очагах загрязнения, установленных по результатам геохимического картирования, проводятся детальные эколого-геохимнческие работы. Они включают детализацию геохимического опробования с целью уточнения морфологии зон загрязнения. Из опыта работ для выявления пространственной геохимической структуры окружающей среды почвы опробуются по сети $200 \mathrm{X} 200$ м, а снеговой покров, имеющий более широкий ореол рассеяния загрязняющих веществ от источника,-- по сети $400 \mathrm{X}$ $\times 400 \mathrm{M}$.

Главная задача опробования природных вод на данном этапе состоит в изучении пространственно-временных параметров распределения и форм нахождения химических элементов. Организуются на исследуемых водотоках серии стационарных створов, как правило, на наиболее загрязненных участках русел, выявленных литохимической съемкой донных отложений на этапе геохимического картирования.

Изучение кинетики распределения химических элементов и форм их миграции в водном потоке проводится путем прослеживания распределения элементов от источника загрязнения вниз по реке. Отбор водных проб при этом производится с учетом скорости, добегания воды. Опробование проводится на расстоянии от источника загрязнения не меньшем, чем протяженность антропогенного потока рассеяния в донных отложениях. Полученные данные позволяют установить механизм миграции химических элементов, дальность их переноса, наличие зональности в потоке. Изучение динамики распределения химических элементов и форм их нахождения осуществляется путем проведения наблюдений и опробования в течение определенных отрезков времени на эталонных створах с учетом пространственной структуры водного потока. Полученные данные позволяют выявить особенности динамики распределения элементов и форм их нахождения, оценить достоверный общий уровень загрязненности водной массы и установить комплекс элементов-индикаторов загрязнения и, главное, характер отношения различных форм миграции и закономерности поведения элементов в зависимости от 
режима работы источника загрязнения и гидрологических характеристик водотока.

На промышленных предприятиях, для которых установлена пространственная связь с геохимическими аномалиями, изучается технология производства, определяются все каналы утечки загрязняющих веществ во внешнюю среду, устанавливаются виды отходов и их химический состав, характеризуются состояния почв на промплощадках как индикаторов максимального уровня загрязнения отходами предприятия. В итоге устанавливается участие предприятия в создании неблагоприятной ситуации по содержанию химических элементов в окружающей среде прилегающих территорий.

Опасность загрязнения окружающей среды для живых организмов может быть доказана превышением содержания химических элементов в гигиенически нормируемых компонентах - воздухе и воде - предельно допустимых концентраций (ПДК). С этой целью проводятся прямые определения содержания металлов в атмосферном воздухе. В пределах центров выявленных геохимических аномалий отбирается статистически значимое количество проб воздуха - 25 (одна проба в день).

Изучение реакции живых организмов на загрязнение окружающей среды химическими элементами проводится главным образом по двум направлениям - для растительности и для человека.

Реакция растений оценивается через изменение их химического состава, которое увязывается как с проявлением внешних признаков угнетения растений, так и с качеством продуктов питания. Отбор проб растений проводится по площадкам, которые расположены в зонах геохимических аномалий разной интенсивности.

Влияниезагрязненияхимическимиэлементамиразличныхкомпонентов окружающей среды на человека оценивается по изменению комплекса показателей здоровья населения. С этой целью в поликлиниках собираются первичные данные (учетные карточки) по заболеваемости (наиболее целесообразно это делать на примере детского населения) и обобщенные учетные медицинские сведения, отражающие состояние здоровья населения на отдельных территориях. Сравнением уровней загрязнения, состава загрязняющих веществ с заболеваемостью устанавливаются количественные соотношения в ответной реакции человека на состояние окружающей среды.

На наиболее интенсивных аномалиях выполняются определения содержаний металлов в биосубстратах населения (кровь, моча, волосы и др.). При этом может использоваться метод групповых проб, при котором индивидуальные пробы населения объединяются по основным признакам (место жительства, профессия, возраст, пол и др.). Это позволяет получить достаточные для 
химико-аналитических исследований навески биологических материалов, что обычно непросто при работе с детьми.

Выбор районов и групп наблюдения за содержанием микроэлементов в биосредах проводится совместно с территориальными органами здравоохранения в соответствии с общими гигиеническими принципами, принятыми при изучении здоровья населения.

Перед началом биогеохимических исследований выбираются диагностические среды, которые в наилучшей степени отражают влияние того или иного элемента. Методика отбора биопроб, сроки проведения работ также согласовываются с местными органами здравоохранения и санитарного надзора, а при работе в детских учреждениях -c отделами народного образования [28].

Материалы геохимического картирования и данные по связи очагов загрязнения с показателями здоровья населения дают возможность:

усовершенствовать систему контроля состояния окружающей среды города (выбор расположения стационарных посгов и уточнение перечня контролируемых ингредиентов загрязнения);

проводить градостроительные разработки с обоснованием архитектурно-планировочной структуры, границ промышленных и санитарно-защитных и водоохранных зон, условий водопользования, размещение рекреаций;

установить производства и процессы с повышенным выбросом и стоком токсичных химических элементов, требующие специализированного обследования с целью технологического и проектноконструкторского улучшения пылегазоочистного и водоочистного оборудования;

проводить специализированную медико-организационную и профилактическую работу на конкретных территориях с условиями повышенного риска для здоровья населения;

выявить участки водных систем и городских территорий, уровни загрязнения которых требуют проведения санирования и очистки природных сред (снятие зараженного грунта, чистка донных отложений) .

\section{Основные практические выводы}

Общий анализ всей совокупности материалов по эколого-геохимическим исследованиям окружающей среды городов показывает необходимость общей корректировки структуры и характера природоохранной деятельности в городских агломерациях и городах.

Геохимические исследования показали возможность разработки методов комплексного межотраслевого природоохранного экологического проектирования, учитывающего всю совокупность и взаимосвязь проблем, связанных с последствиями загрязнения окружающей среды.

Организация экологического проектирования требует разра- 
ботки принципов и системы экологической экспертизы и, главное, проведения комплексных экологических изысканий. Это в перспективе приведет к созданию специализированной сети проектноизыскательских организаций. В основу изысканий должны быть положены экологическое картографирование территорий, создание и регулярное подтверждение экологических паспортов, что позволило бы структурировать проблемы и дифференцировать территории по типу и интенсивности вредных воздействий, по уровню неблагоприятного отклика живых организмов на воздействия.

Необходимо кардинально изменить структуру и содержание системы контроля за состоянием окружающей среды урбанизированных территорий и экологическими последствиями еe загрязнения.

Существующие системы выборочного контроля на закрепленной сети стационарных постов и створов по плотности расположения, частоте наблюдений и перечню наблюдаемых загрязняющих веществ не соответствуют характеристикам и масштабу проявления процесса загрязнения. Контроль за состоянием здоровья также осуществляется лишь по единичным выборкам с неясной представительностью, включающим небольшую часть населения контролируемых городов.

Следует внедрить методы картографирования состояния среды с медико-географической оценкой состояния здоровья на основе постоянно действующей информационной системы автоматизированного анализа изменения пространственной структуры показателей неблагоприятных реакций населения на загрязнение среды (динамический контроль структуры заболеваемости и других показателей здоровья и на основе данных автомагизированного учета карт обращаемости и результатов функциональной диагностики). Необходима на единой методической основе система биомониторинга за содержанием токсичных веществ (металлы, пестициды) в различных группах населения.

В целях кардинального снижения уровня заболеваемости для городов со сложившейся структурой расселения и промышленностью необходимо разработать детальные проекты здравоохранительных мероприятий. Эти проекты должны основываться на результатах геохимических изысканий и анализе пространственной структуры загрязнения и заболеваемости.

Важнейшими элементами таких проектов должны явиться:

1. Архитектурно-планировочные решения по изменению границ промзон, санитарно-защитных зон, условий землепользования в соответствии с реально наблюдаемой в городе пространственной структурой дифференциации экологических условий, а не только по расчетно-нормативным планировочным показателям, принятым сейчас.

2. Обоснование характера первоочередных мероприятий для 
территорий с опасными уровнями загрязнения (около $10 \%$ площади крупных городов, для городов близ особо крупных предприятий иногда много больше), включающих либо полный вывод жилья и присоединение этих территорий к промышленным зонам, либо принципиальное изменение технологии особо опасных источников загрязнения вплоть до перепрофилирования предприятий.

3. Обоснование системы перестройки организационной структуры медицинского обслуживания в соответствии со структурой загрязнения и заболеваемости (усиление интенсивности и специализации медобслуживания для территорий с повышенной заболеваемостью населения).

4. Разработка территориальной структуры размещения детских учреждений, спортивных баз и режима их работы в зависимости от дифференциации состояния окружающей среды и здоровья населения).

Необходимо общее решение проблемы защиты окружающей среды и населения от прямого и косвенного вредных воздействий твердых бытовых и промышленных отходов. Следует коренным образом изменить распространенную сейчас практику фактически неконтролируемого рассеяния отходов в окружающей среде путем их захоронения на необорудованных свалках и экологически необоснованного применения их в качестве удобрений. Депонирование или утилизация в природных системах отходов, содержащих токсичные загрязняющие вещества, должна производиться в строго контролируемых условиях специализированными организациями.

Следует повсеместно, во всех промышленных городах организовать обезвреживание отходов физико-химической очистки (гальванических и пр.), являющихся одним из основных загрязнителей водных систем, канализационных осадков, в некоторых случаях почв. Полноценное решение этой проблемы возможно даже на уровне существующих разработок. Для охраны окружающей среды от загрязнения единственным способом является утилизация накапливающихся отходов. При этом стоимость получаемой продукции должна учитывать природоохранный эффект, что делает ее рентабельной для общества. Способы утилизации частично уже известны (но не применяются), частично могут быть созданы в обозримой перспективе. Необходимо уже сейчас, до полного решения проблем утилизации, создать достаточно широкую сеть полигонов-накопителей отходов. Расчеты показывают, что отсутствие сравнительно дешевых полигонов и является основной причиной загрязнения перечисленных выше природных сред, так как сейчас в связи с отсутствием официально признанной системы захоронения или утилизации эти отходы бесконтрольно рассеиваются в окружающей среде.

Рассмотрим конкретные практические рекомендации, которые 250 
могут быть даны по результатам комплексного эколого-геохимического исследования городов.

Типы практических рекомендаций, разрабатываемых при эколого-геохимическом изучении аэрогенных очагов загрязнения. Характер практических рекомендаций, следующих из геохимических, биогеохимических и геогигиенических материалов по изучению городов, дифференцируется в зависимости от количественной характеристики геохимических аномалий, разделяющихся на три категории по уровню загрязнения и их экологической оценке: 1) средний умеренно опасный; 2) высокий опасный; 3) очень высокий, чрезвычайно опасный (см. табл. 8).

Разрабатываемые мероприятия по своей направленности разделяются на две группы: 1) планировочно-изыскательские и контролирующие, ориентированные на источник загрязнения и компоненты природной среды; 2) медико-организационные, здравоохранительные мероприятия, ориентированные на профилактику и улучшение здоровья населения.

Для всех категорий очагов загрязнения в числе первоочередных мероприятий рекомендуется проведение сплошной инвентаризации выбросов предприятий, расположенных на территории этих очагов, исследование всех установленных полютантов, анализ и выявление технологических звеньев и производств, ответственных за выбросы химических элементов и других загрязняющих веществ. На основе данных инвентаризации проводится разработка мероприятий по снижению или прекращению выброcoB.

Рекомендации медико-организационного характера для всех категорий очагов загрязнения включают:

1. Организацию постоянно действующих систем автоматизированного анализа изменений пространственной структуры показателей неблагополучных реакций населения - динамической инфраструктуры показателей здоровья.

2. Перестройку организации структуры медицинского обслуживания в соответствии со структурой загрязнения и заболеваемости (увеличение числа врачей и специализация медицинской службы в очагах загрязнения и повышенной заболеваемости).

3. Проведение иммуномониторннга с целью выявления групп повышенного риска.

4. Организация загородного отдыха детей, усиление профилактической оздоровительной деятельности.

5. Усиление детской аллергологнческой службы и организация регистра аллергических заболеваний.

Для очагов с высоким опасным уровнем загрязнения среды практические рекомендации начинают ориентироваться на архитектурно-планировочные, градостроительные решения возникающих проблем. Здесь рекомендуются:

1. Архитектурно-планировочный анализ с целью определения 
необходимости и возможности изменения планировочной структуры и в частности: а) оздоровления территории при уменьшении выброса; б) выявления возможности расширения промзон (создания складских помещений, гаражей, незагрязняющих цехов) за счет вывода жилых массивов из очагов загрязнения.

2. Запрет на новое строительство детских, лечебных и рекреационных учреждений впредь до ликвидации выбросов.

3. Организация снегоуборки с вывозом снега на особые снегосвалки с последующей очисткой стока от вредных примесей.

4. Организация санации почв детских учреждений путем дернования и известкования.

5. Расширение сети стационарных постов слежения за атмосферой и организация контроля специфических для промышленности очагов загрязнения на этих постах.

Здравоохранительные рекомендации в очагах с высоким и опасным уровнем загрязнения включают:

1. Введение в детских учреждениях комплекса лечебно-профилактических мероприятий по оздоровлению часто болеющих детей, разработанных и утвержденных Минздравом СССР.

2. Увеличение сети специализированных детских дошкольных учреждений для детей с аллергическими заболеваниями.

3. Усиление детской поликлинической службы врачами узких специальностей (психоневролог, отоляринголог, окулист и др.) с целью улучшения ранней диагностики заболеваний. Развитие функциональных методов исследований сердечно-сосудистой системы, органов дыхания и других систем.

4. Перемещение детских дошкольных учреждений в чистые районы впредь до снижения уровня загрязнения до нормативного.

Очаги с очень высоким и чрезвычайно опасным уровнем загрязнения, естественно, требуют наиболее серьезных и дорогостоящих решений. Здесь необходимы:

1. Архитектурно-планировочный, технологический и экономический анализ территории с целью решения вопроса о выводе или перепрофилирования вредных производств либо о включении территорий очагов в пределы промзоны с ликвидацией жилых массивов и, в первую очередь,- с выводом детских учреждений.

2. Санация почв путем снятия верхнего слоя или перекрытия его новым слоем привозной почвы (на территории игровых площадок и скверах).

3. Запрет рекреации.

До решения технологических и организационных проблем следует организовать: 1) постоянное диспансерное наблюдение за детьми и взрослым населением; 2) составление санитарно-гигиенических характеристик «очагов» заболеваний; 3) введение биомониторинга за содержаниями токсичных элементов в биосредах различных групп населения.

Типы практических рекомендаций, разрабатываемых при эко- 
лого-геохимическом изучении гидрогенных аномалий. Для поверхностных водных систем характер практических рекомендаций определяется уровнем их загрязнения и типом хозяйственного использования: питьевое, сельскохозяйственное, рекреационное (см. табл. 9). Для водотоков всех типов при слабом и среднем уровне загрязнения следует провести инвентаризацию стоков промышленных предприятий и выявить технологии, требующие дополнительных систем более глубокой очистки сточных вод. Здесь может быть рациональным создание устьевых групповых очистных сооружений на притоках, дренирующих промзоны и организация створов и пунктов наблюдения для выявления и последующего контроля специфических для данных аномалий загрязняющих веществ. На участках использования вод для полива сельскохозяйственных угодий следует проводить их очистку от взвешенных веществ. Для сильно и очень сильно загрязненных водотоков необходимо временное ограничение всех видов водопользования с последующим проведением изыскательских работ для детализации структуры загрязнения и изъятия зараженных донных отложений. В ряде таких случаев требуется перепрофилирование особо опасных производств, создание на предприятиях систем глубокой очистки стоков "или систем замкнутого водоснабжения. На участках сельхозугодий в поймах, орошаемых водами загрязненных рек, необходимо проведение специализированных работ по изучению накопления токсичных химических элементов в почвах и сельскохозяйственной продукции для выявления участков, требующих санации или изъятия из использования. В пределах урбанизированных территорий при появлеңии аномалий такой интенсивности необходимо строительство групповых очистных сооружений в устьевых участках водотоков, локализующих загрязненный поверхностный сток.

Гл а в а 4

\section{ГЕОХИМИЧЕСКОЕ ИЗУЧЕНИЕ СЕЛЬСКОХОЗЯЙСТВЕННЫХ ТЕРРИТОРИЙ}

Масштабы и значение геохимической и биогеохимической дифференциации сельскохозяйственных территорий в должной мере еще не осознаны. Проблема эта была поставлена еще Н. И. Вавиловым, начавшим в 30-х годах широкие полевые и экспериментальные исследования географических закономерностей дифференциации биохимических свойств и показателей качества сельскохозяйственной продукции. Прямая задача географической изменчивости химического состава сельскохозяйственной продукции только намечена исследованиями специалистов по химии и биохимии растений, особенно в фундаментальных работах по 
микроэлементам. В последние годы возникла проблема загрязнения сельскохозяйственных почв и продукции, что расширяет сферу исследования геохимии сельскохозяйственных территорий.

Основная задача исследований геохимии сельскохозяйственных территорий - выявление природных и антропогенных закономерностей изменения состава, качества и количества сельскохозяйственной продукции.

Можно наметить три группы процессов, обусловливающих дифференциацию геохимической структуры 'сельскохозяйственных территорий:

агрогенные геохимические преобразования, связанные с технологией сельскохозяйственного производства;

техногенные преобразования, не вызванные потребностями сельскохозяйственного производства;

природная геохимическая дифференциация.

Агрогенные геохимические преобразования территорий преобразования, связанные с неизбежным воздействием на агроландшафты стандартных технологических циклов сельскохозяйственного производства: агротехнической обработки почв; водной и химической мелиорации; комплекс обработки почв и растений в период вегетации растительной массы и уборки урожая.

Отмеченные технологические циклы могут быть рассмотрены как геохимическое явление, интенсивность проявления которого зависит главным образом от социально-экономических факторов: уровня организации предприятий, их технической оснащенности, выбранной технологии, использования тех или иных средств химизации .

Типы агрогенных геохимических воздействий весьма разнообразны, и они также отличаются по масштабу проявления и его интенсивности.

Агрогенные геохимические воздействия разделяются на две крупные подгруппы: собственно агрогенные и агротехногенные.

Собственно агрогенные воздействия - планируемые, повсеместно проявленные воздействия, неизбежные при существующих принципах сельскохозяйственной технологии:

1. Агротехническая обработка почвы, сопровождающаяся уплотнением почвы, ее взаимодействием с истирающимися орудиями механической обработки и с выхлопами транспортных средств.

2. Внесение стандартных фосфорных, калийных и азотных удобрений в дозах, зависящих от агрохимических показателей.

3. Внесение почвенных мелиорантов - известкующих или раскисляющих материалов, торфа, в некоторых случаях песка или глины.

4. Проведение водной мелиорации (осушение или обводнение).

5. Обработка территорий фунгицидами, гербицидами, инсектицидами . 
Агротехногенные воздействия не являются неизбежным следствием агротехнологии. Они проявлены значительно локальнее собственно агрогенных воздействий и связаны с применением нестандартных загрязненных средств мелиорации:

1. Внесение в качестве удобрений бытовых отходов промышленных городов и промышленных отходов.

2. Использование в качестве удобрений отходов животноводческих комплексов.

3. Использование в качестве почвенных мелиорантов промышленных (энергетические золы, металлургические шлаки, фосфогипс) и горно-рудных (породы вскрыши) отходов.

4. Использование для водной мелиорации воды загрязненных рек.

Техногенные геохимические преобразования - следствие загрязнения сельскохозяйственных территорий при воздействии процессов, не связанных с сельскохозяйственной технологией:

1. Региональные поля выпадений из атмосферы, в составе которых суммируются те части промышленных выбросов в атмосферу, которые поступают в дальние циклы миграции.

2. Локальные поля выпадений из атмосферы - ближние зоны рассеяния выбросов в атмосферу на территориях, примыкающих к промышленным предприятиям.

3. Зоны воздействия автотранспорта.

4. Участки разлива загрязненных рек и поверхностного стока (аккумулятивные пойменные ландшафты).

5. Зоны воздействия хранилищ токсичных отходов, подвергающихся дефляции и размыву поверхностным стоком.

Агрогенные и собственно техногенные преобразования происходят на фоне природной геохимической дифференциации территорий.

Неоднородность природной геохимической структуры связана с ландшафтно-геохимическими факторами. Эти факторы, как хорошо известно [36], весьма разнообразны и обусловливают очень разные площади и уровни проявления химических различий в составе почв и растений. Наиболее важна дифференциация территорий, связанная с различиями типов и семейств ландшафтов. Она выявляется на уровне смены типов и подтипов почв и отличается большой и очень большой площадью проявления (примером могут служить общеизвестные геохимические и, соответственно, агрохимические различия степных ландшафтов с плодородными черноземными почвами и таежных ландшафтов со значительно менее плодородными дерново-подзолистыми почвами). Важны также и различия, связанные с геохимической дифференциацией элементарных ландшафтов, устанавливаемые на уровне класса водной миграции, вида или рода (положение в рельефе, приуроченность к тому или иному типу почвообразующей горной породы) и отличающиеся средней или 
сравнительно небольшой площадью выявления. Примером такого рода являются различия между ландшафтами на территории проявления первичных и вторичных ореолов рассеянных рудных полей и месторождений и обрамляющими их фоновыми территориями .

\section{1. АГРОГЕННЫЕ ГЕОХИМИЧЕСКИЕ АНОМАЛИИ}

Агрогенные геохимические аномалии представляют экологическую опасность в связи с особенно большими масштабами проявления, охватывающими практически всю существующую сельскохозяйственную продукцию.

Агротехническая обработка почв проводится многократно в течение вегетационного периода и включает дискование, вспашку, боронование, сев, культивацию, сбор урожая, внесение средств химизации. При обработке происходит механический износ орудий (лемехов, дисков) в процессе контакта с почвой, особенно обогащенной включениями. Кроме того, практически вся поверхность почв испытывает воздействие выбросов транспортных средств, прежде всего выхлопа дизельных установок, работающих на соляровом масле. Эти виды воздействия, обычно не рассматриваемые и не учитываемые, способны поставлять в почвы химические элементы из износоустойчивых сталей и из выхлопов ( $\mathrm{Mr}, \mathrm{Ni}, \mathrm{Cr}, \mathrm{Pe}, \mathrm{Co}, \mathrm{V})$.

Авторам удалось в зоне развития дерново-подзолистых почв выявить участки, где ряд лет проводилась агротехническая обработка, но не вносились удобрения и другие средства химизации. Участки расположены на территории, не подвергающейся воздействию выбросов. В результате такого достаточно чистого эксперимента выявилось, что в процессе агротехнической обработки происходит довольно интенсивное загрязнение почвы перечисленным выше комплексом элементов. При этом увеличение их валового содержания в почвах составило от 10 (ванадий) до $40 \%$ (никель).

Внесение в почвы минеральных удобрений - главный вид агрогенных воздействий. Применение удобрений, обеспечивающих сейчас более $50 \%$ урожая, приводит к глобальной химизации почв. Основными отрицательными последствиями применения минеральных удобрений считаются концентрирование потенциально токсичных и канцерогенных соединений азота в растительной продукции и эвтрофикация водных систем. Имеются сведения $[20,31]$ по излишней фосфатизации почв и по вредному воздействию элементов-примесей фосфатных удобрений.

В отличие от калийных и азотных удобрений, производимых из практически рафинированного природного сырья и близких по составу к химически чистым соединениям, фосфорные удобрения производятся исключительно на основе природных 256 


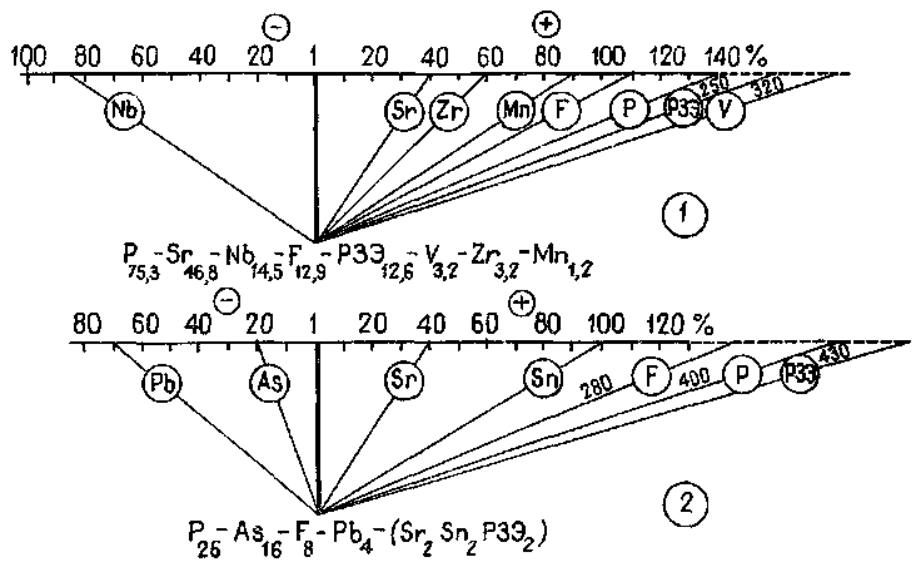

Рис. 70. Поведение химических элементов при обогащении фосфатного сырья (1 - апатитовые руды, 2 - ракушечные фосфориты).

В индексе элемента указан его коэффициент концентрации. Область выноса обозначена знаком «-», область накопления - знаком «+»


Рис. 71. Геохимнческие спектры фосфоритовых (I) и апатитовых (II) концентратов,

$\mathrm{K}_{c}$ - коэффициент концентрации относительно кларка в земной коре

фосфатов, являющихся по существу полиминеральным сырьем.

Материалы минералого-геохимических исследований различных видов фосфатного сырья магматогенных апатитовых руд и осадочных фосфоритовых руд свидетельствуют о его значительном обогащении широкой ассоциацией элементов-примесей (F, 5г, TR, U, иногда $\mathrm{Pb}, \mathrm{As}, 2 \pi, \mathrm{V}, \mathrm{Cë})$.

Анализ проведения химических элементов в цепи обогащения апатитовых руд (рис. 70) показывает, что при обогащении апатитовых руд выносится только ниобий. При коэффициенте обогащения фосфора порядка 2,4 редкоземельные элементы и 
Т а бл и а 72 Типоморфные элементы-примеси фосфорных удобрений и кормовых добавок

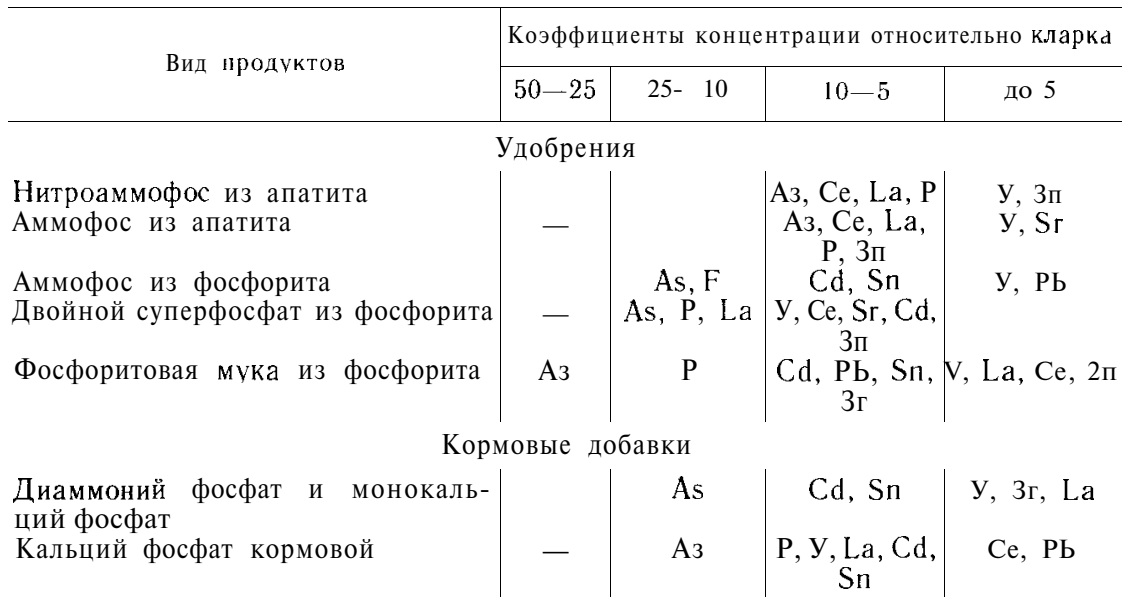

иттрий концентрируются интенсивнее (3,5 и 4,2 соответственно), а стронций накапливается меньше (в 1,4 раза).

При обогащении фосфоритовых руд выносится почти полностью РЬ, иногда частично As. Остальные элементы накапливаются почти с той же интенсивностью, что и фосфор. В конечном счете концентраты фосфорных руд, зачастую без дальнейшей переработки вносимые на поля, обогащены спектром элементов-примесей (рис. 71).

Результаты анализов состава удобрений для главных используемых сейчас продуктов приведены в табл. 72, 73. По содержанию элементов-примесей готовые продукты (удобрения и кормовые добавки) по сравнению с исходным сырьем качества своего не улучшают.

Для удобрений, производимых на основе апатитового сырья, отмечается сравнительно небольшое накопление в конечных продуктах мышьяка, редких земель и фтора. Для удобрений из фосфоритового сырья уровни накопления перечисленных элементов возрастают, появляются $\mathrm{Cd}$ и 5 г.

Расчет баланса элементов-примесей удобрений при внесении их в почву в оптимальных (200 кг/га) и максимальных (500 кг/га) дозах позволяет дать ориентировочную прогнозную оценку фосфорных удобрений как источника загрязнения агроландшафтов.

Подсчеты поступления химических элементов, проведенные для бедной питательными веществами дерново-подзолистой почвы (рис. 72) показывают, что для всех применяемых марок удобрений даже фосфор вносится в количестве лишь $1-3 \%$ природного запаса в почве. Естественно, что элементы-примеси 258 

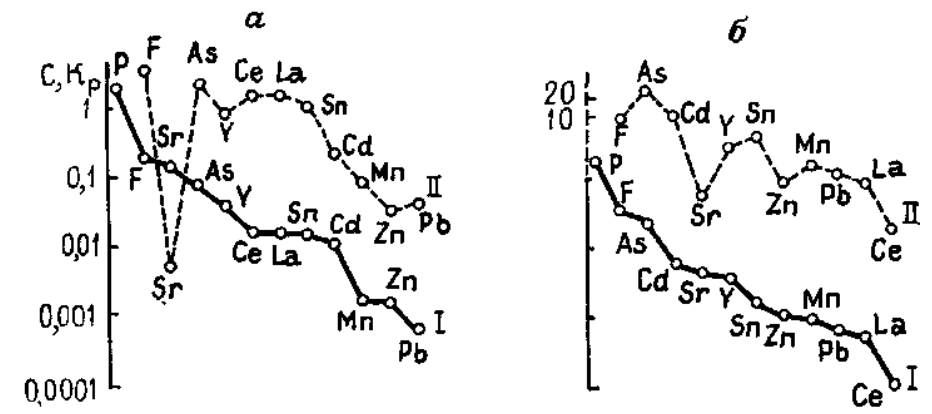

Рис. 72. Поступление химических элементов с фосфорными удобрениями (a аммофос из апатитового концентрата, б - аммофос из фосфоритового концентрата):

I, II - уровни поступления химических элементов (I - в процентах от природного запаса С, доза внесения удобрений - 200 кг/га, II - в процентах от поступления фосфора $\mathbf{K}_{\mathrm{p}}$ )

вносятся в значительно меньших количествах. Ранжируя их по уровню увеличения природного запаса при внесении удобрений, можно отметить ведущую позицию $\mathrm{F}, \mathrm{As}$, иногда 5г (десятые доли процента их природного запаса, около $10 \%$ поступления в почвы фосфора). Поступление с фосфорными удобрениями редких земель и тяжелых металлов составляет лишь сотые доли процента их природного запаса и несколько процентов уровня поступления фосфора.

Отчуждение фосфора с урожаем даже при дозе 200 кг/га составляет не более 50-70\% (рис. 73). Все остальные элементы выносятся в значительно меньшем количестве: для 5г, $\mathrm{Zn}, \mathrm{Pb}$, As, Cd - сотые доли процента запаса в почвах; для $\mathrm{P}$ и Th тысячные. Таким образом, даже без учета других источников выноса химических элементов (поверхностная эрозия, например), годовой прирост природных запасов фосфора составляет несколько процентов, а элементов-примесей - десятые доли процента.

Время удвоения природных запасов валовых содержаний химических элементов, вносимых с удобрениями, составляет десятки - сотни лет.

Рис. 73. Потребление химических элементов сельскохозяйственными культурами:

I - уровень потребления химических элементов капустой в процентах от природного запаса C, II - относительный уровень потребления (в процентах от потребления фосфора)




Т а бл и ц 73 Химические элементы в некоторых гипах фосфорных удобрений

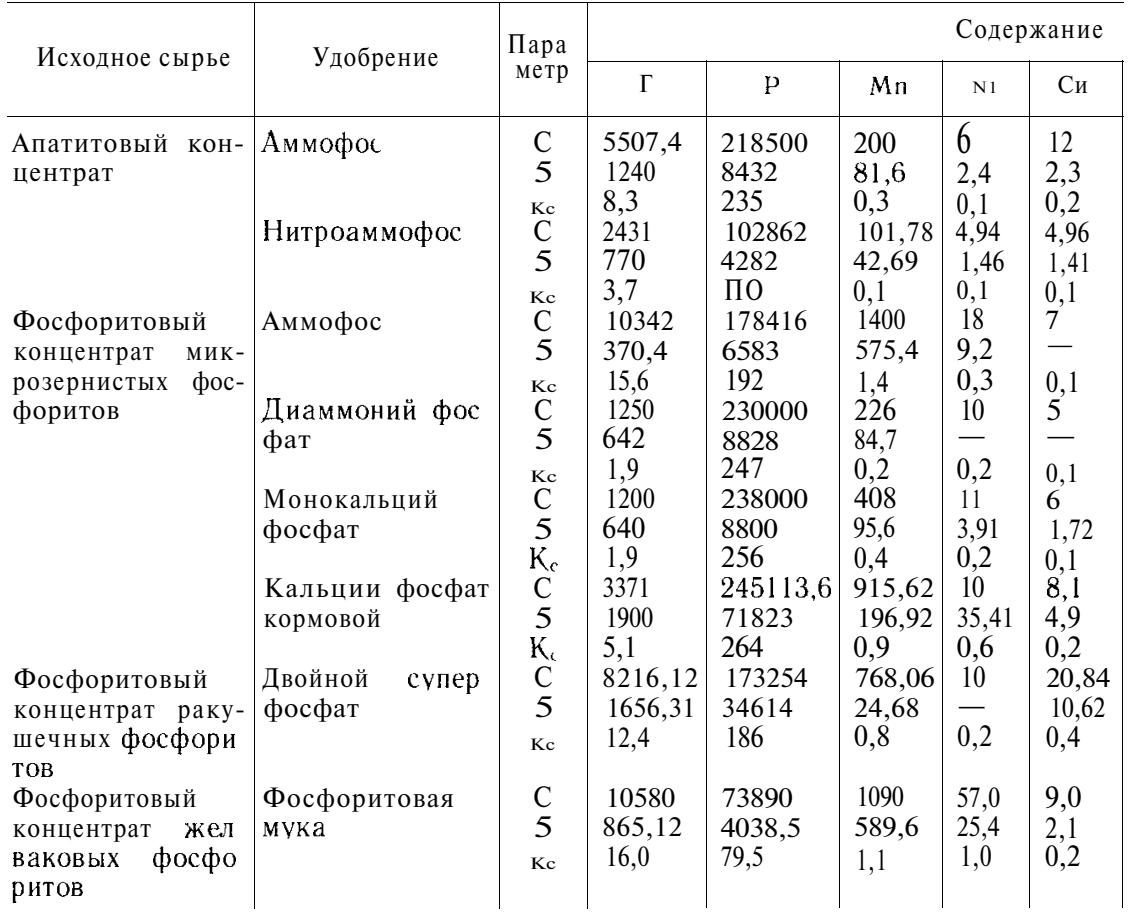

Примечание С - среднее содержание химического элемента, 5 - среднеквадратичное коры

Важно отметить, что малые уровни прибавки фосфора и элементов-примесёй при внесении фосфорных удобрений в почву не свидетельствуют об отсутствии экологических последствий. Об этом говорит прежде всего мощное положительное следствие - прибавка урожая, многократное увеличение биологической массы под воздействием этих доз.

Для оценки этой ситуации интересно провести сопоставление микроэлементной биогеохимической структуры растений и геохимической структуры ассоциаций химических элементов, вносимых с удобрениями в почву. При этом содержание микроэлементов удобно пронормировать по отношению к главному элементу удобрений - фосфору (рис 74). По сравнению с фосфором такие элементы, как As, Cd, P, Th, У, переходят в растения в значительно меньших количествах

Можно предположить, что чем меньше химический элемент накапливается растением в природных условиях, тем более опасен его избыток. При этом следует учитывать, что большая часть природного запаса элементов в почвах малодоступна для 
элементов в г/т

\begin{tabular}{l|l|l|l|l|l|l|l|l|l|l|l}
\hline \multicolumn{1}{c|}{$2 \pi$} & $\mathrm{A}$ & \multicolumn{1}{c|}{$\mathrm{Sr}$} & $\mathrm{V}$ & \multicolumn{1}{c|}{$2 \mathrm{r}$} & $\mathrm{Nh}$ & $\mathrm{Cd}$ & $5 \Pi$ & $\mathrm{Bd}$ & $\mathrm{La}$ & $\mathrm{Ce}$ & \multicolumn{1}{c}{$\mathrm{Pb}$} \\
\hline 12 & 14 & 565 & 91,1 & 50 & 25 & 0,2 & 8,7 & 26 & 143 & 260 & 2 \\
6,8 & - & 9,81 & 10,2 & 20,9 & 6,04 & - & 2,5 & 1,92 & 40 & 95 & 0,84 \\
0,1 & 8,2 & 1,6 & 3,1 & 0,3 & 1,2 & 1,5 & 3,4 & 0,04 & 4,8 & 4,3 & 0,12 \\
7,31 & 15,86 & 87,24 & 74,17 & 22,37 & 18,49 & 0,24 & 7,59 & 7,18 & 120,3 & 203,31 & 8,65 \\
2,74 & 4,56 & 33,70 & 12,37 & 9,23 & 22,56 & 0,16 & 3,63 & 1,13 & 44,2 & 75,24 & 13,09 \\
0,1 & 9,3 & 0,3 & 2,6 & 0,1 & 0,9 & 1,8 & 3,0 & 0,01 & 4,0 & 3,4 & 0,5 \\
65 & 34 & 160 & 84,5 & 22 & 6 & 0,9 & 10 & 84 & 23,22 & 14,03 & 20 \\
21,4 & & 90,5 & 15,84 & 9,4 & 2,48 & 0,5 & - & 30,6 & 7,4 & 5,8 & 14,9 \\
0,8 & 20,0 & 0,5 & 2,9 & 0,1 & 0,3 & 9,2 & 4,0 & 0,1 & 0,8 & 0,2 & 1,2 \\
52 & 22 & 17 & 12 & 11 & 8 & 0,5 & 13 & 20 & 19 & 17 & 22 \\
27,5 & 18,4 & 5,24 & - & 5,73 & 4,7 & - & 5,41 & 1,8 & - & - & 16,8 \\
0,6 & 13 & 0,05 & 0,4 & 0,06 & 0,4 & 3,8 & 5,2 & 0,04 & 0,2 & 0,1 & 1,4 \\
64 & 23,8 & 450 & 64 & 30 & 11 & 0,5 & 10 & 117 & 34,83 & 27,3 & 52 \\
51,9 & - & 95 & 10,8 & 3,74 & 5,4 & - & - & 9,4 & 5 & 12 & 34,6 \\
0,8 & 14 & 1,3 & 2,2 & 0,2 & 0,5 & 3,8 & 4,0 & 0,2 & 1,0 & 0,5 & 3,2 \\
62,18 & 15,0 & 1095,9 & 134,87 & 54,0 & 11,06 & 0,5 & 9,56 & 472 & 113,4 & 88,4 & 12,5 \\
79,09 & 27,2 & 274,2 & 65,81 & 29,31 & 5,39 & - & 1,45 & 116,95 & 9 & 5 & 22,76 \\
0,7 & 9,3 & 3,2 & 4,7 & 0,4 & 0,6 & 3,8 & 3,8 & 0,6 & 3,8 & 1,5 & 1,6 \\
24,03 & 26,2 & 1751,6 & 281,38 & 120,9 & 26,9 & 0,5 & 10,22 & 546,45 & 350,3 & 658,22 & 20,6 \\
12,27 & 33,0 & 881,47 & 20,26 & 24,35 & 6,26 & - & 1,17 & 44,76 & 98,74 & 137,6 & 16,17 \\
0,3 & 15,4 & 5,2 & 9,7 & 0,7 & 1,4 & 3,8 & 4,0 & 0,8 & 12 & 9,4 & 1,3 \\
127,0 & 48,5 & 1278,5 & 66,8 & 123,1 & 5,0 & 0,65 & 10,0 & 160 & 62,0 & 120 & 74,0 \\
33,92 & 24,5 & 24,27 & 7,0 & 12,6 & 2,84 & 0,47 & - & 10,5 & 4,2 & - & 12,6 \\
1,5 & 28,5 & 3,8 & 2,3 & 0,7 & 0,2 & 5,0 & 4,0 & 0,2 & 2,0 & 2,0 & 4,6 \\
& & & & & & & & & & &
\end{tabular}

отклонение, $\mathbf{K}_{\mathbf{\imath}}-$ коэффициент концентрации элемента относительно кларка земной

Рис. 74. Соотношение поступления и биологического поглощения элементов-примесей удобрений.

$\mathrm{Kp}_{\text {лост }} / \mathrm{Kp}_{\text {пог }}-$ соотношение уровней поступления и поглощения элементов примесей по сравнению с фосфором

растений, тогда как вместе с удобрениями они приносятся в значительно более доступных формах.

Сравнение потребления элементов растениями и их поступления с удобрениями показывает, что V, TR, As, Cd по сравнению с фосфором поступают в количествах в 1000 и более раз больших, чем используют-








Рис. 75. Увеличение содержаний элементов-примесей в почвах при внесении удобрений. По О. В. Кайдановой.

Сплошная линия - доза $\mathrm{N}_{180} \mathrm{P}_{180} \mathrm{~K}_{180}$, пунктир - доза $\mathrm{N}_{140} \mathrm{P}_{140} \mathrm{~K}_{140}$

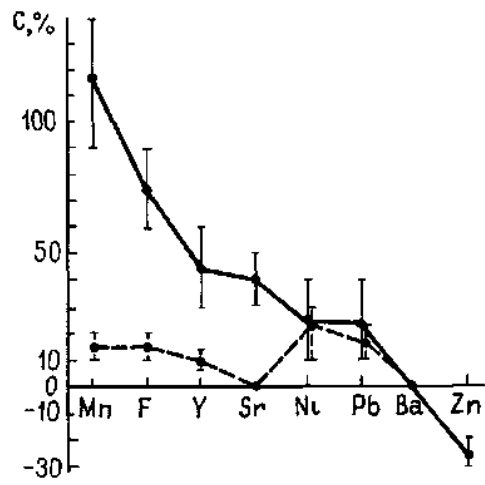

Рис. 76. Химические элементы в дерново-подзолистых легкосуглинистых почвах хозяйств, применяющих минеральные (сплошная линия) и органические (пунктир) удобрения

ся растениями. Для фтора поступление с удобрениями в сотни раз больше потребления растениями. Для $\mathrm{Sr}, \mathrm{Pb}, \mathrm{Mn}$ величина этого показателя около 1 (уровень поступления сбалансирован с фосфором), для $\mathrm{Zn}$ - меньше 1 (общеизвестен дефицит этого элемента в дерново-подзолистых почвах, который, естественно, не покрывается стандартными фосфорными удобрениями).

Таким образом, с одной стороны, уровень поступления элементов-примесей с удобрениями настолько низок, что при существующих дозах внесения загрязнение почв не всегда может надежно фиксироваться из-за природной вариации содержаний и аналитической ошибки. С другой стороны, даже при таком уровне внесения экологическая значимость элементов-примесей может оказаться очень значительной.

Действительно, даже в условиях строгого дозирования опыта, увеличение содержания элементов-примесей в почвах невелико и не всегда хорошо улавливается (рис. 75).

Из элементов-примесей фосфорных удобрений лучше всего исследовано поведение фтора. В хорошо известных работах Ю. А. Потатуевой установлено, что при очень больших дозах внесения содержание фтора в растениях возрастает от 2 до $30 \mathrm{мг/кг.} \mathrm{Это} \mathrm{происходит,} \mathrm{главным} \mathrm{образом,} \mathrm{на} \mathrm{второй} \mathrm{год}$ после внесения. Этот уровень считается в агрохимии неопасным для животных (допустимое содержание фтора в кормах 3050 мг/кг). Однако оценка его опасности для самих растений осталась неясной.

Авторам удалось изучить почвы серии хозяйств, различающихся по интенсивности использования минеральных удобре262 
ний (рис. 76). Для почв хозяйств, интенсивно использующих минеральные удобрения, мы видим небольшие, но устойчивые прибавки элементов-примесей удобрений $(\mathrm{Mn}, \mathrm{F}, \mathrm{y}, 5$ г) и элементов-примесей выхлопа транспортных средств $(\mathrm{Ni}, \mathrm{Pb})$. Для почв с внесением преимушественно органических удобрений (район животноводческого комплекса) аномальны только элементы выхлопа.

Влияние удобрений на геохимические особенности сельскохозяйственных территорий выражается не только в приносе элементов-примесей, но и в изменении физико-химической обстановки миграции, обусловливающей подвижность всех химических элементов почвы.

Э. И. Гапонюк с коллегами (1982) показала, что внесение фосфорных удобрений в дерново-подзолистую среднесуглинистую почву способствует резкому увеличению подвижности 2п (с 83 до 220-330 мг/кг элемента, экстрагируемого 0,1 н соляной кислотой), Мп (с 300 до 670 мг/кг), As (c 1,5 до $3-4$ мг/кг) и водорастворимого органического вещества (с 1,62 до 2,3$3,3 \%)$.

По многим данным азотные удобрения повышают в почвах подвижность $\mathrm{Ni}, \mathrm{V}, \mathrm{Cr}$ - элементов, загрязняющих почву в ходе агротехнического воздействия. По материалам Г. А. Соловьева и других, повышение норм внесения азота привело к росту содержания никеля в корнеплоде свеклы с 1,6 мг/кг сухого вещества до 8,9 мг/кг.

Мобилизация микроэлементов из почв в результате применения удобрений отмечается достаточно часто. В этой связи большое значение приобретает природная ландшафтно-геохимическая дифференциация сельскохозяйственных территорий. Это самостоятельная область исследований, подробно разрабатываемая почвоведением и геохимией ландшафта $[13,36]$. Важно отметить, что в большинстве случаев четко прослеживается зависимость в дифференциации суммарного накопления элементов от природных факторов: рельефа, почвообразующих пород. Обычно по сравнению с почвами автономных ландшафтов (водораздельных пространств) интенсивнее загрязнены сельскохозяйственные почвы более тяжелого механического состава трансэлювиально-аккумулятивных (склоны) и транссупераквальных (поймы) ландшафтов. Высокая загрязненность пойменных почв микроэлементами обусловлена геохимически подчиненной позицией, сочетающейся с типоморфным для условий исследованных южнотаежных ландшафтов развитием в долинах сорбционноглеевого геохимического барьера. Все это делает пойменные угодья своеобразной линейной геохимической аномалией (рис. 77).

Дифференцирующее воздействие природных факторов на перераспределение в почвах химических элементов, принесенных с минеральными удобрениями, прослеживается и на уровне 


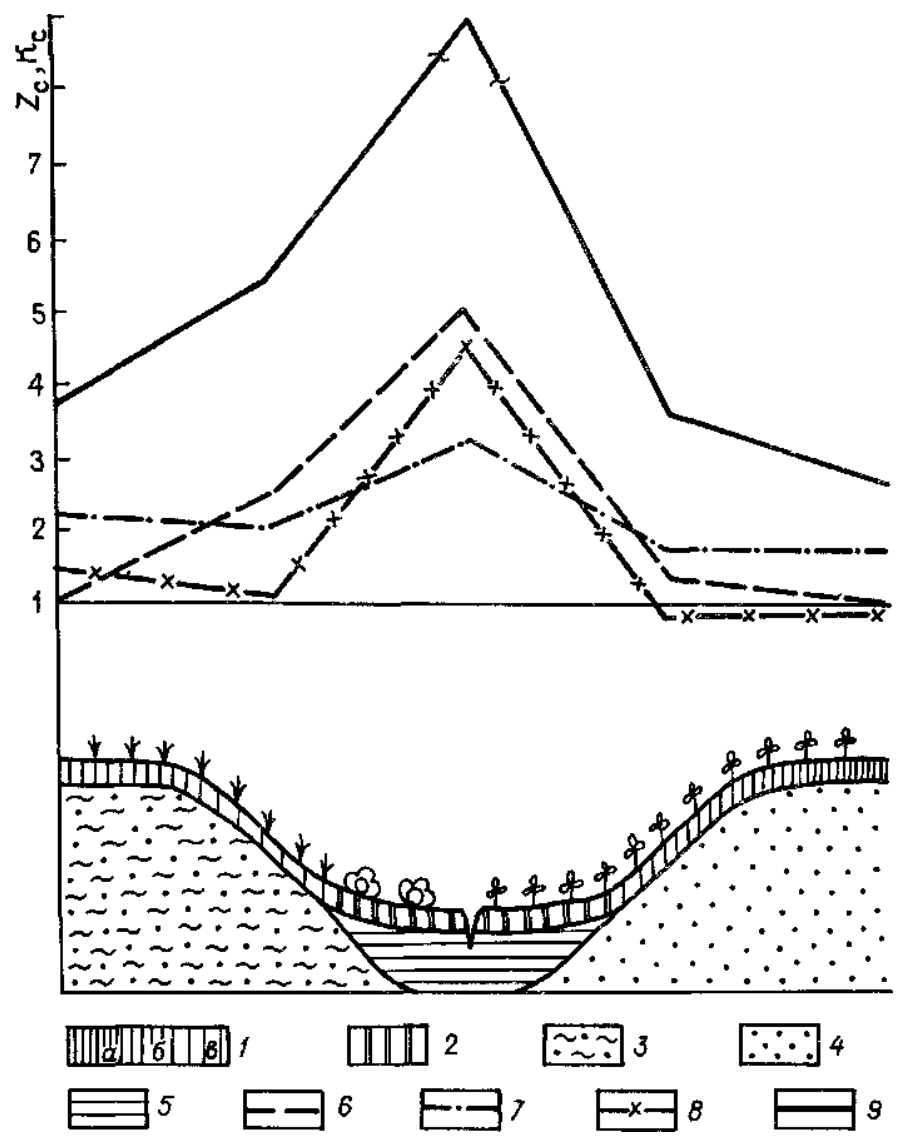

Рис. 77. Распределение химических элементов в сельскохозяйственных почвах с минеральными удобрениями (на примере южнотаежных ландшафтов Русской равнины):

1 - дерново-подзолистые ( $a-$ сильно, $\sigma-$ средне, в - слабо) почвы, 2 - пойменные почвообразующие породы, 3 - безвалунные суглинки, 4 - древнеаллювиальные супесчано-песчаные отложения, 5- современные аллювиальные суглинисто-глинистые отложения; $6-9-$ кривые распределения элементов. $6-$ фтора, 7 - группы железа $(\mathrm{Mn}, \mathrm{Co}, \mathrm{N} 1, \mathrm{~T} 1, V$, Cг), 8 - редких элементов (5c, La, V, Уb, 2г), 9 - суммы химических элементов (Сг, 2п, $\mathrm{Pb}, \mathrm{V}, \mathrm{Cu}, \mathrm{M}, \mathrm{Co}, \mathrm{Ag}, \mathrm{N} 1,5 \mathrm{c}$, $5 \Pi, 5 г, 2 г, \mathrm{У}, \mathrm{Уb}, \mathrm{Nb}, \mathrm{Ti}, \mathrm{B}, \mathrm{Ba}, \mathrm{La}, \mathrm{Mo}, \mathrm{F}$ )

микроструктуры ландшафта, который в ходе геохимических исследований обычно не фиксируется и рассматривается как естественная вариация в целом однородного ландшафта. Так, сложная структура распределения концентраций микроэлементов формируется в пахотном горизонте почв под влиянием микрорельефа, перераспределяющего их миграционные потоки, а также 264 

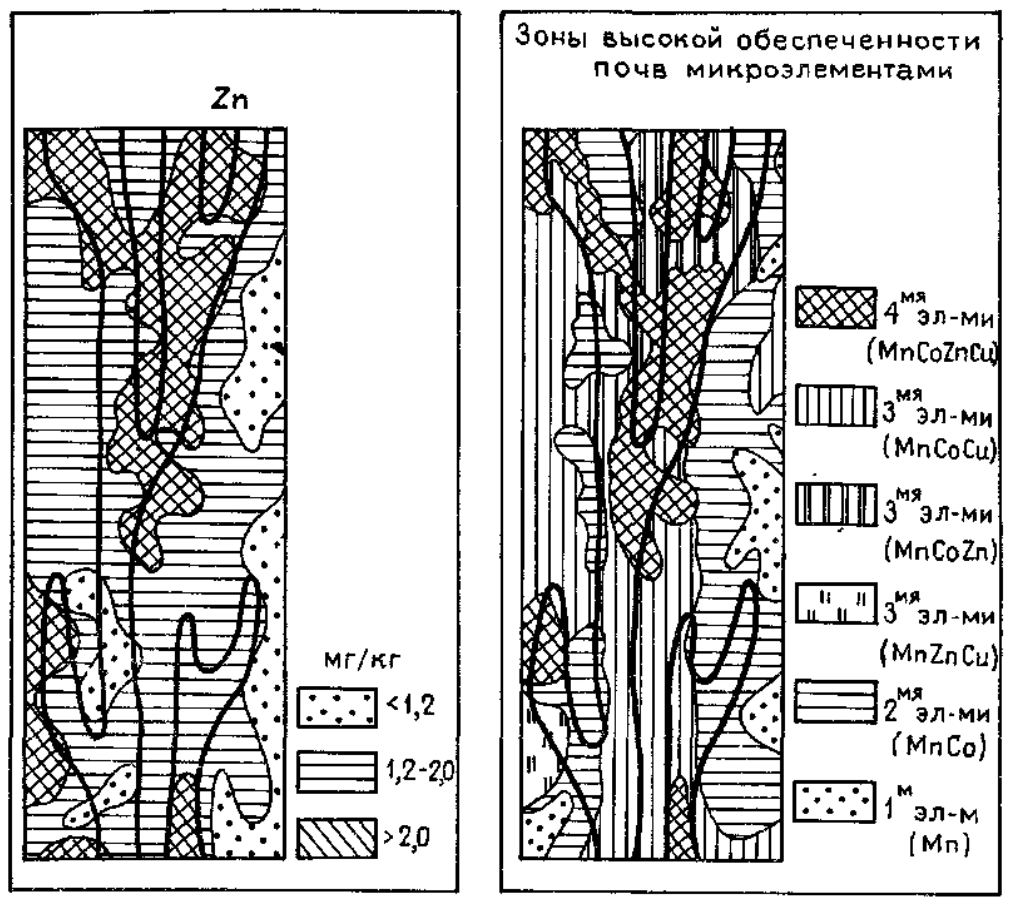

Рис. 78. Распределение подвижных форм микроэлементов в пахотном горизонте почв в зависимости от форм микрорельефа

определяющего различное увлажнение и различные окислительно-восстановительные условия (рис. 78). Детальное исследование (с шагом опробования 10 м) участка пахотных почв позволило выявить чередование зон высокой обеспеченности микроэлементами питания (Mn, Co, 2п, Си), приуроченных к микроложбинам, где происходит аккумуляция элементов на сорбционно-глеевом барьере в условиях периодического поверхностного переувлажнения, и зон низкой обеспеченности - на повышенных элементах микрорельефа.

Различная обеспеченность почв химическими элементами обусловливает и различное поступление их в сельскохозяйственные растения. Так, в многолетних травах, выращенных в условиях высоких содержаний элементов на пойменных почвах супераквальных ландшафтов, в сравнении с травами на бедных дерново-подзолистых песчаных почвах автономных ландшафтов водоразделов выявлено накопление многих химических элементов (табл. 74). Отмечено 9-кратное превышение общей суммы поглощенных элементов, а также 10-процентное увеличение зольности исследованных растений. Озимая пшеница, выра- 
Т а бл и а 74. Содержания микроэлементов в многолетних травах, выращенных в условиях элювиальных и супераквальных ландшафтов

\begin{tabular}{|c|c|c|c|}
\hline \multirow{2}{*}{ Элемент } & \multirow{2}{*}{$\begin{array}{c}\text { Элювиальные } \\
\text { водоразделы } \\
\begin{array}{c}\text { мг } / \text { кг } \\
\text { сухой массы }\end{array}\end{array}$} & \multicolumn{2}{|c|}{ Супераквальные микродолины } \\
\hline & & $\begin{array}{c}\text { мГ/кг } \\
\text { сухой массы }\end{array}$ & $\mathrm{c}$ \\
\hline $\begin{array}{l}\text { Бор } \\
\text { Титан } \\
\text { Ванадий } \\
\text { Хром } \\
\text { Марганец } \\
\text { Никель } \\
\text { Медь } \\
\text { Цинк } \\
\text { Стронций } \\
\text { Молибден } \\
\text { Серебро } \\
\text { Олово } \\
\text { Барий } \\
\text { Свинец }\end{array}$ & $\begin{array}{c}1,1 \\
19,6 \\
1,3 \\
1,2 \\
18,8 \\
0,6 \\
8,5 \\
3,3 \\
9,6 \\
0,4 \\
0,005 \\
0,1 \\
17,7 \\
1,4\end{array}$ & $\begin{array}{c}1,3 \\
13,1 \\
0,4 \\
0,7 \\
19,1 \\
0,7 \\
16,7 \\
14,4 \\
13,3 \\
0,6 \\
0,010 \\
0,2 \\
14,0 \\
1,4\end{array}$ & $\begin{array}{l}1,2 \\
0,7 \\
0,3 \\
0,6 \\
1,0 \\
1,2 \\
2,0 \\
4,4 \\
1,4 \\
1,5 \\
2,0 \\
2,0 \\
0,8 \\
1,0\end{array}$ \\
\hline 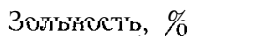 & 8,7 & 9,3 & 1,1 \\
\hline
\end{tabular}

нию элемента в элювиальном ландшафте.

щенная в зоне высокой обеспеченности элементами в области микроложбин, в сравнении с растениями в зоне низкой обеспеченности на микроповышениях увеличила уровень биологического поглощения ряда элементов (табл. 75). Суммарное превышение их концентраций составляет: для зерна - 410\%, для стеблей $-440 \%$, для корней $-60 \%$. Биологическая урожайность также оказалась выше на 4 ц (в пересчете на га), в микроложбинах $-26,5$ ц/га, на микроводоразделах - 22,6 ц/га.

Микроудобрения и ядохимикаты характеризуются небольшими объемами применения и значимость их как источников химических элементов уже по этой причине много меньше, чем других мелиорантов.

Многие годы в составе ядохимикатов широко использовались исключительно токсичные ртутьсодержащие соединения. Некоторые пестициды и сейчас являются органо-минеральными соединениями, содержащими $\mathrm{Zn}$, Си, Mn, В. Медь широко используется в виде чистых солей. В ГДР, например, ежегодно расходуется 7,5 т ртути в сельском хозяйстве, в Японии - 1000 т, в США - 400 т. Часть этих данных обобщена в работе [2].

Большей частью ртуть накапливается в верхних частях разреза почвы. Росс и Стюарт (данные Хайниш и др., 1979) на участке, где 21 раз проводилась обработка плодовых насаждений, через 5 лет обнаружили в слое $0-5$ см - 1,8 мг/кг; $5-10 \mathrm{~cm}-0,3$ мг/кг; $10-15$ см - следы. 
Т а 6 л и а 75. Содержание химических элементов в озимой пшенице в агроландшафтах с различной их обеспеченностью

\begin{tabular}{|c|c|c|c|c|c|c|c|c|c|}
\hline \multirow{3}{*}{$\begin{array}{c}\text { Химический } \\
\text { элемент }\end{array}$} & \multicolumn{3}{|c|}{$\begin{array}{l}\text { Микроводоразделы с низ- } \\
\text { кой обеспеченностью почв } \\
\text { микроэлементами }\end{array}$} & \multicolumn{6}{|c|}{$\begin{array}{c}\text { Микродолины с высокой обеспеченностью } \\
\text { почвмикроэлементами }\end{array}$} \\
\hline & \multirow{2}{*}{$\frac{\text { зерно }}{\mathrm{C}}$} & \multirow{2}{*}{$\begin{array}{c}\text { стебли } \\
\mathrm{C}\end{array}$} & \multirow{2}{*}{$\begin{array}{c}\text { корни } \\
\text { C }\end{array}$} & \multicolumn{2}{|c|}{ зерно } & \multicolumn{2}{|c|}{ стебли } & \multicolumn{2}{|c|}{ корни } \\
\hline & & & & $\mathrm{C}$ & $\mathrm{K}$, & $\mathrm{C}$ & $K_{\mathrm{s}}$ & $\mathrm{C}$ & $K_{c}$ \\
\hline $\begin{array}{l}\text { Бор } \\
\text { Хром } \\
\text { Марганец } \\
\text { Кобальт } \\
\text { Никель } \\
\text { Медь } \\
\text { Цинк } \\
\text { Молибден } \\
\text { Олово } \\
\text { Барий } \\
\text { Свинец } \\
\quad Z_{\text {, }}\end{array}$ & $\begin{array}{r}36,0 \\
7,8 \\
2400,0 \\
0,4 \\
24,0 \\
150,0 \\
800,0 \\
7,8 \\
1,6 \\
320,0 \\
14,0 \\
-\end{array}$ & $\begin{array}{r}30,0 \\
11,6 \\
840,0 \\
0,8 \\
24,0 \\
130,0 \\
66,0 \\
5,4 \\
2,2 \\
780,0 \\
40,0 \\
-\end{array}$ & $\begin{array}{r}120,0 \\
130,0 \\
3200,0 \\
18,0 \\
56,0 \\
130,0 \\
100,0 \\
2,5 \\
5,0 \\
420,0 \\
80,0 \\
-\end{array}$ & $\begin{array}{c}35,0 \\
17,5 \\
2500,0 \\
1,0 \\
35,0 \\
187,5 \\
650,0 \\
9,5 \\
1,8 \\
425,0 \\
11,3 \\
-\end{array}$ & $\begin{array}{l}1,0 \\
2,2 \\
1,0 \\
2,5 \\
1,5 \\
1,3 \\
0,8 \\
1,2 \\
1,1 \\
1,3 \\
0,8 \\
5,1\end{array}$ & $\begin{array}{r}57,5 \\
12,5 \\
1625,0 \\
1,0 \\
37,5 \\
137,5 \\
132,5 \\
8,3 \\
1,5 \\
775,0 \\
40,0 \\
-\end{array}$ & $\begin{array}{l}1,9 \\
1,1 \\
1,9 \\
1,3 \\
1,6 \\
1,1 \\
2,0 \\
1,5 \\
0,7 \\
1,0 \\
1,0 \\
5,4\end{array}$ & $\begin{array}{r}150,0 \\
127,5 \\
2750,0 \\
20,0 \\
57,5 \\
100,0 \\
100,0 \\
3,0 \\
4,8 \\
187,5 \\
57,5 \\
--\end{array}$ & $\begin{array}{r}, 3 \\
, 0 \\
0,9 \\
, 1 \\
, 0 \\
0,8 \\
, 0 \\
, 2 \\
1,0 \\
0,5 \\
0,7 \\
1,6\end{array}$ \\
\hline $\begin{array}{l}\text { Урожайность, } \\
\text { ц/га }\end{array}$ & 22,6 & - & - & 26,5 & - & - & - & - & - \\
\hline
\end{tabular}

Примечания. В обоих примерах обеспеченность Мп высокая, С - содержание в мг/кг золы; $\mathrm{K}_{t}$ - коэффициент концентрации, $Z_{f}-$ суммарный показатель загрязнения

И. А. Мырлян показал, что применение медьсодержащих препаратов на виноградниках Молдавии в десятки раз увеличивает концентрацию меди на почвенно-геохимических барьерах, создавая специфические «медные» ландшафты.

Как правило, ядохимикаты и удобрения применяются совместH(1)

Авторам удалось провести сравнение распределения химических элементов в почвах с полевыми (пшеница, картофель) и садово-огородными (дачные участки, частные огороды) севооборотами (рис. 79).

Уровни концентраций химических элементов удобрений во всех севооборотах примерно одинаковы. Резко отличается характер

Рис. 79. Интенсивность накопления химических элементов в почвах с полевым севооборотом (минеральные удобрения) и в садах и огородах (минеральные удобрения н ядохимикаты)



$\mathrm{Hg} \mathrm{Pb} \mathrm{Zn} \mathrm{Sr} \mathrm{Ni} \quad \mathrm{F}$ 
распределения ртути и цинка - химических элементов, входящих в состав ядохимикатов, широко используемых в садово-огородных севооборотах. Содержания этих элементов в почвах садов и огородов резко повышены. Прибавка цинка составляет от 90 до $280 \%$ сверх природного запаса, прибавка ртути - от 200 до $550 \%$. Особенно резко выделяются почвы личных огородов и дачных участков. Таким образом, частные хозяйства, где применение средств химизации не регламентируется, с геохимических позиций наиболее опасны.

\section{2. АГРОТЕХНОГЕННЫЕ ГЕОХИМИЧЕСКИЕ АНОМАЛИИ}

В последние годы наблюдается отчетливая тенденция к росту использования бытовых и промышленных отходов в качестве удобрений и мелиорангов. Это связано с многочисленными материалами по довольно высокой удобрительной ценности отходов. Речь идет прежде всего о повсеместно распространенных органоминеральных отходах (осадки сточных вод городских очистных сооружений крупных предприятий типа целлюлозно-бумажных комбинатов, бытовой мусор), применяемых вместо остродефицитных органических удобрений (навоз, торф). Известны попытки применения в сельском хозяйстве извести и гипссодержащих огходов (фосфогипс, металлургические шлаки), используемых в качестве почвоулучшителей. Отмеченная тенденция связана также с желанием утилизировать объемные виды отходов, занимающие большие и ценные земли в пригородных зонах. Масштабы применения отходов в сельском хозяйстве несопоставимо меньше, чем стандартных удобрений. Тем не менее эколого-

Т а блица 76 Химические элементы в компосте из бытового мусора крупных промышленных городов

\begin{tabular}{l|c|c}
\hline \multicolumn{1}{c|}{ Элемент } & $\begin{array}{c}\text { Пределы содержаний, } \\
\text { мг/кг }\end{array}$ & $\begin{array}{c}\text { Коэффициент концентрации } \\
\text { относительно кларка }\end{array}$ \\
\hline Ртуть & $2-7,5$ & $200-750$ \\
Серебро & $1,1-4,7$ & $11-43$ \\
Цинк & $114-1997$ & $23-40$ \\
Сурьма & $5-70$ & $2,5-35$ \\
Висмут & $6-10$ & $20-33$ \\
Свинец & $158-646$ & $6-25$ \\
Кадмий & $2-7$ & $6-23$ \\
Медь & $108-535$ & $4-20$ \\
Стронций & $73-351$ & $3-12,5$ \\
Вольфрам & $3-6$ & $3-6$ \\
Молибден & $1--4$ & $1-4$ \\
Никель & $6-38$ & $0,3-2$ \\
Бор & $50-61$ & $1,3-1,6$ \\
Кобальт & $3-11$ & $0,4-1,5$ \\
\hline Суммарный показатель загряз- & - & $270-984$ \\
нения & &
\end{tabular}


Т а бл ц а 77 Содержание химических элементов в осадке городских сточных вод

\begin{tabular}{|c|c|c|c|c|c|}
\hline \multirow{2}{*}{ Элемент } & \multicolumn{2}{|c|}{$\begin{array}{c}\text { Осадок промышленных } \\
\text { городов }\end{array}$} & \multicolumn{2}{|c|}{$\begin{array}{c}\text { Осадок малопро } \\
\text { мышленных } \\
\text { городов }\end{array}$} & \multirow{2}{*}{$\begin{array}{l}\text { Нормы на со } \\
\text { держание тя } \\
\text { желых метал- } \\
\text { лов (по зару } \\
\text { бежным дан- } \\
\text { с)хого осадка }\end{array}$} \\
\hline & $\mathrm{C}_{t p}$ & $\mathrm{~K}$, & $\mathrm{C}_{c p}$ & $\mathrm{~K}_{\mathrm{t}}$ & \\
\hline $\begin{array}{l}\text { Ртуть } \\
\text { Кадмий } \\
\text { Серебро } \\
\text { Хром } \\
\text { Молибден } \\
\text { Цинк } \\
\text { Медь } \\
\text { Вольфрам } \\
\text { Олово } \\
\text { Никель } \\
\text { Свинец } \\
\text { Стронций } \\
\text { Кобальт } \\
\text { Бор } \\
\text { Фтор } \\
\text { Барий } \\
\text { Висмут }\end{array}$ & $\begin{array}{c}1,29-1,77 \\
33,64-46,60 \\
13,42-36,23 \\
792,14-1260,39 \\
28,2-29,9 \\
258,6-1818,0 \\
503,5-518,3 \\
22,7-25,9 \\
45,29--58,26 \\
91,2-210,5 \\
191,57-235,8 \\
145,2-184,1 \\
2,1-15,0 \\
44,0-76,3 \\
450,0 \\
147,4-302,6 \\
2,5\end{array}$ & $\begin{array}{c}129-177 \\
112-165 \\
134-362 \\
17-27 \\
28-29 \\
5-35 \\
18-19 \\
23-26 \\
9-12 \\
5-11 \\
7-9 \\
5,2-6,6 \\
0,3-2,2 \\
1,2-2,0 \\
2 \\
0,6-1,3 \\
8\end{array}$ & $\begin{array}{c}0,75 \\
3,25 \\
13,03 \\
423,78 \\
14,79 \\
117,3 \\
220-2240 \\
22,8 \\
30,98 \\
391 \\
201,3 \\
42,4 \\
4,8 \\
43,0 \\
- \\
227,9 \\
-\end{array}$ & $\begin{array}{c}75 \\
11 \\
130 \\
9 \\
15 \\
2,3 \\
8-83 \\
23 \\
6 \\
2 \\
8 \\
1,5 \\
0,7 \\
1,2 \\
- \\
0,9 \\
-\end{array}$ & $\begin{array}{c}10-50 \\
- \\
500-1000 \\
20 \\
1500-3000 \\
500-1000 \\
- \\
- \\
50-200 \\
500-1000 \\
- \\
20-100 \\
- \\
- \\
-\end{array}$ \\
\hline $\begin{array}{l}\text { Суммарный показа- } \\
\text { тель загрязнения (без } \\
\text { учета серебра) }\end{array}$ & $-\infty$ & $370-610$ & - & 190 & - \\
\hline
\end{tabular}

Примечание $\mathrm{C}_{c p}-$ вариации средних содержаний, кг/кг, $\mathrm{K}_{c}-$ коэффициент концентрации

геохимическая оценка этого воздействия исключительно важна, в пригородных зонах оно затрагивает наиболее уязвимые виды сельскохозяйственной продукции, овощеводство и производство кормов.

$\mathrm{K}$ агротехногенным воздействиям относится также полив сельскохозяйственных угодий загрязненными речными водами, что также в основном распространено в пригородных зонах.

Проблема загрязнения химическими элементами бытовых и промышленных отходов, используемых в сельском хозяйстве, широко обсуждается в агрохимии. Многочисленные полевые и вегетационные опыты дают достаточно противоречивые результаты прежде всего из-за плохой сопоставимости данных различных исследователей и недостаточной комплексности самих исследований.

В табл. 76, 77 приведены материалы по вариации средних содержаний в удобрениях из бытовых отходов городов с различной промышленной нагрузкой. Мы видим, что они сильно загрязнены химическими элементами и прежде всего токсичными тяжелыми металлами. 
Для компостов из бытового мусора (которые производятся только в крупных промышленных городах с очень разнообразными источниками компостируемого материала, не исключающими участие промышленного мусора) суммарное содержание тяжелых металлов более чем в 250 раз (до 1000 раз) выше, чем в природных почвах. В таких компостах особенно много ртути, что связано с ртулными лампами и гальваническими элементами (см. табл. 76).

Осадок сточных вод также в большинстве случаев сильно загрязнен (см. табл. 77). В промышленных городах суммарный показатель концентрации химических элементов в осадках в сотни и тысячи раз, а в малопромышленных городах почти в десятки и сотни раз больше, чем в почвах. В промышленных городах высокий суммарный показатель обусловлен, прежде всего, такими токсичными элементами, как $\mathrm{Cd}, \mathrm{Hg}, \mathrm{Cr}, \mathrm{Cn}, \mathrm{Zn}, \mathrm{Ag}$, в меньшей степени $\mathrm{Mo}, \mathrm{W}, 5 п, \mathrm{Ni}, \mathrm{Pb}$. В непромышленных городах показатель загрязнения обусловлен медью, частично ртутью и в очень небольшой степени другими элементами. По литературным данным, осадок сточных вод загрязнен не только тяжелыми металлами, но и синтетическими органическими веществами, в частности токсичными и трудноразлагаемыми пестицидами, бензапиреном, нефтепродуктами.

Отечественные нормы на содержание в осадках тяжелых элементов не разработаны. Однако во многих странах такие нормы есть (табл. 78). Сравнение данных по составу осадков и компостов показывает, что осадки промышленных городов по степени загрязненности находятся у верхних пределов норм или значительно превосходят их по $\mathrm{Hg}, \mathrm{Cd}, 2 п$, Си, Сг, Ni. Загрязнение всегда комплексно, и в большинстве случаев бытовые отходы достаточно токсичны.

Дозы внесения отходов, определяемые по их удобрительной ценности и агрохимическому эффекту, строго не регламентируются и широко варьируют в зависимости от типа почвы и возделываемой культуры. В результате отечественных и зарубежных агрохимических опытов рекомендуется применение от

Т а бли ц 78 Нормы на содержание тяжелых металлов по зарубежным данным (в мг/кг сухого вещества осадка)

\begin{tabular}{l|c|c|c|c}
\hline \multicolumn{1}{c|}{ Элемент } & США & Австрия & Нидерланды & Швейцария \\
\hline Цинк & 1500 & 2000 & 2000 & 3000 \\
Медь & 750 & 500 & 500 & 1000 \\
Хром & 500 & 500 & 500 & 1000 \\
Свинец & 500 & 500 & 500 & 1000 \\
Никель & 150 & 200 & 50 & 200 \\
Кадмий & 50 & 10 & 10 & 30 \\
Ртуть & - & 10 & 10 & 10 \\
Кобальт & - & - & - & 20 \\
Молибден & - & & &
\end{tabular}


40 до 50 т/га. Минимальные известные нам опытные данные начинаются с дозы 15-20 т/га. Анализ реальных доз внесения осадка показывает, что они составляют не менее чем $100-$ 200 т/га.

Расчет доз внесения осадка по рекомендуемой в агрохимии схеме создает возможность прогнозной оценки осадков сточных вод и компостов из бытового мусора как источников загрязнения почв. Уже при однократном внесении осадка сточных вод запасы Cd в почвах возрастают в 5-30 раз, $\mathrm{Cr}-$ в 2-5 раз, $2 \Pi-$ в $1,5-4,5$ раза. Через $2-3$ внесения запасы многих химических элементов удесятеряются. Несколько меньшие уровни характеризуют компосты, но и в этом случае запасы химических элементов в почвах возрастают в $1,5-2,0$ раза.

Нельзя также забывать о том, что действующее «токсичное начало» связано с подвижной усвояемой растениями частью общего содержания металлов и составляет не более $2-3 \%$ их общего содержания в почве. Это определяет большую продолжительность отрицательного воздействия бытовых отходов на состояние почв.

В табл. 79 приведена характеристика концентрации химических элементов в почвах хозяйств, использовавших компосты. Это средние данные по десяти изученным полям, на каждом из которых отобрано около 20 проб. Мы видим очень высокие уровни обогащения почв $\mathrm{Hg}, \mathrm{Bi}, \mathrm{Pb}, 2 п, 5 \Pi$, Mo. В некоторых случаях

Т а бли ц 79 Валовые содержания химических элементов в сельскохозяйственных почвах, удобренных компостами из твердых бытовых отходов

\begin{tabular}{|c|c|c|c|c|c|c|}
\hline \multirow{2}{*}{ Эпемент } & \multicolumn{3}{|c|}{ Почвы полей } & \multicolumn{3}{|c|}{ Почвы теплиц } \\
\hline & $\mathrm{V}, \mathrm{M} \Gamma / \mathrm{K} \Gamma$ & $\mathrm{K}_{1}$ & $\mathrm{~K}_{2}$ & $X, \mathrm{M \Gamma / \textrm { } \Gamma ~}$ & $\mathbf{K}_{1}$ & $\mathrm{~K}_{2}$ \\
\hline Ртуть & $0,04-0,43$ & 10.7 & 25,0 & $0,60-1,51$ & 75,3 & 125,8 \\
\hline Серебро & $0,16-0,46$ & 5,0 & 19,0 & $0,30-1.24$ & 8,2 & 12,4 \\
\hline Олово & $3,95-13,47$ & 2,1 & 4,1 & $7,20-61,28^{\circ}$ & 9,1 & 17,5 \\
\hline Цинк & $46,00-154,00$ & 9 & 2,5 & $282,63-963,33$ & 18,1 & 26,2 \\
\hline Свинец & $37,00-76,55$ & ,6 & 2,4 & $86,42-180,00$ & 5,2 & 6,1 \\
\hline Медь & $18,85-42,35$ & 6 & 2,9 & $66,37-207,0$ & 10,7 & 15,5 \\
\hline Стронций & $27,00-41,00$ & ,2 & 3 & $106,32-250,0$ & 5,3 & 8,7 \\
\hline Марганец & $446,0-792,5$ & & ,5 & $524,21-743,13$ & 1,2 & 1,4 \\
\hline Хром & $46,20-77,30$ & & ,2 & $29,53-68,16$ & 1,0 & 1,3 \\
\hline Кобальт & $8,40-16,55$ & & , 4 & $5,13-10,67$ & 0,8 & 1,1 \\
\hline Никель & $9,80-21,15$ & & ,5 & $10,79-34,28$ & 1,7 & 2,6 \\
\hline Молибден & $0,42-1,61$ & & 1,6 & $1,87-8,50$ & 8,0 & 16,4 \\
\hline Ванадий & $84,50-170,00$ & 0,9 & 1,2 & $10,68-69,33$ & 0,4 & 0,6 \\
\hline Сурьма & - & - & - & $3,71-6,73$ & 2,3 & 3,4 \\
\hline Суммарный пока- & - & 18,7 & 53,6 & - & 135,1 & 226,4 \\
\hline затель & & & & & & \\
\hline ния & & & & & & \\
\hline
\end{tabular}

Примечание $\boldsymbol{K}_{\mathbf{I}}$ - коэффициент концентрации средних значений относительно фона, $\mathrm{K}_{2}$ - коэффициент концентрации максимальных значений относительно фона 
Т а блиц а 80. Валовое содержание химических элементов в почвах, удобренных осадками сточных вод

\begin{tabular}{|c|c|c|c|c|c|}
\hline \multirow{2}{*}{ Химический элемент } & \multirow{2}{*}{$\begin{array}{l}\text { Почвы конт- } \\
\text { рольных по- } \\
\text { лей, мг /кг }\end{array}$} & \multicolumn{2}{|c|}{$\begin{array}{c}\text { Почвы с осадком } \\
\text { малопромышленного } \\
\text { города }\end{array}$} & \multicolumn{2}{|c|}{$\begin{array}{c}\text { Почвы с осадком } \\
\text { промышленного города }\end{array}$} \\
\hline & & $\mathrm{Mг} / \mathrm{Kг}$ & $\mathrm{K}_{\mathrm{r}}$ & $\begin{array}{l}\text { вариации средних } \\
\text { содержаний, мг/кг }\end{array}$ & $\mathrm{K}$, \\
\hline $\begin{array}{l}\text { Ртуть } \\
\text { Молибден } \\
\text { Серебро } \\
\text { Мышьяк } \\
\text { Медь } \\
\text { Цинк } \\
\text { Хром } \\
\text { Олово } \\
\text { Никель } \\
\text { Свинец } \\
\text { Ванадий } \\
\text { Стронций }\end{array}$ & $\begin{array}{c}0,001 \\
0,62 \\
0,06 \\
1,8 \\
13,3 \\
37,5 \\
35,4 \\
3,7 \\
11,8 \\
19,75 \\
115,0 \\
24,75\end{array}$ & $\begin{array}{c}0,013 \\
0,74 \\
0,06 \\
1,6 \\
15,6 \\
30,0 \\
27,7 \\
3,0 \\
7,7 \\
15,4 \\
58,5 \\
23,2\end{array}$ & $\begin{array}{l}13 \\
1,2 \\
1 \\
1 \\
1 \\
1 \\
1 \\
1 \\
0,6 \\
0,8 \\
0,5 \\
0,9\end{array}$ & $\begin{array}{c}0,029-0,250 \\
0,71-0,9 \\
0,5--1,8 \\
6,2-27,0 \\
24,3-55,7 \\
95,3-145,5 \\
22,7-124,9 \\
4,0-10,8 \\
17,7-31,3 \\
34,35-50,1 \\
172,5-225,0 \\
33,5-40,0\end{array}$ & $\begin{array}{c}3-250 \\
1,1-1,4 \\
83-30 \\
3-15 \\
2-4 \\
2-4 \\
0,6-4 \\
1-3 \\
1,5-2,5 \\
1,7-2,5 \\
1,5-1,9 \\
1,3-1,6\end{array}$ \\
\hline $\begin{array}{l}\text { Суммарный пока- } \\
\text { затель загрязнения }\end{array}$ & - & - & 12,4 & - & $15,8-308,6$ \\
\hline
\end{tabular}
контрольных полей

наблюдались ураганные концентрации химических элементов. Так, на одном из обследованных полей содержание $\mathrm{Hg}$ было 2,05 мг/кг. Особенно интенсивно концентрируются тяжелые металлы в случае применения компоста как биотоплива в теплицах.

При внесении осадка сточных вод малопромышленного города (табл. 80) в почвах по сравнению с контролем слегка увеличилось содержание Си, Мо и сильно (в 13 раз) Hg. Однако ни один элемент не достиг уровня опасных концентраций.

При внесении осадков сточных вод промышленного города наблюдается довольно пестрая картина распределения концентраций. Во всех случаях наблюдается повышение содержаний довольно широкого спектра химических элементов, типичных для состава осадков промышленных городов.

Содержания $\mathrm{Pb}, \mathrm{V}, \mathrm{Ni}, 5 п$, Мо выше контрольных в 2-3 раза, $\mathrm{Cr}$, Си, 2п - в $3-4$ раза, As, Ag, Hg - более чем в 10 раз. Для Си, Zn, Рb, As уровни содержаний в почвах с учетом существующего фона часто превышают утвержденные нормативы предельно-допустимых концентраций. Суммарный показатель загрязнения почв с осадком от 15 до 300 раз выше, чем в контроле.

При оценке загрязнения почв необходимо учитывать суммарное воздействие комплекса загрязняющих веществ. Методика такого учета пока еще плохо разработана. Приводимые нами данные по показателю суммарного загрязнения характеризуют 
Т а бли ц 81. Средние значения и коэффициенты концентрации подвижных форм микроэлементов в почвах, удобренных осадком сточных вод и компостом из бытовых отходов

\begin{tabular}{|c|c|c|c|}
\hline Элемент & КонтРоЛЬ, мг/кі & Почва с осадком & Почва с компостом \\
\hline Марганец & 14,5 & $16,5-24,4$ & $12,7-29,9$ \\
\hline Никель & 0,31 & $\begin{array}{c}1-1,3 \\
0,12-3,97\end{array}$ & $\begin{array}{c}1-2 \\
0,25-0,65\end{array}$ \\
\hline Медь & 0,14 & $\begin{array}{c}0,4-13 \\
0,27-3,76\end{array}$ & $\begin{array}{c}1-2 \\
0,57-1,90\end{array}$ \\
\hline Цинк & 0,62 & $\begin{array}{c}2-27 \\
2,4-35,3\end{array}$ & $\begin{array}{c}4-14 \\
5,23-15,3\end{array}$ \\
\hline Кадмий & 0,03 & $\begin{array}{r}4-57 \\
0,03-0,8\end{array}$ & $\begin{array}{c}8,5-25,0 \\
0,09-0,39\end{array}$ \\
\hline \multirow[t]{2}{*}{ Свинец } & \multirow[t]{2}{*}{0,32} & $\begin{array}{c}1-27 \\
0,38-0,9\end{array}$ & $\begin{array}{c}3--13 \\
0,39-2,29\end{array}$ \\
\hline & & $1-3$ & $1-7$ \\
\hline $\begin{array}{l}\text { Суммарный показа- } \\
\text { тель загрязнения }\end{array}$ & & $5-123$ & $14-58$ \\
\hline
\end{tabular}

Примечание: В числителе даны вариации средних содержаний (мг/кг) химических элементов в почвах, а в знаменателе - коэффициентов концентрации, подвижная форма определялась путем экстракции элементов ацетатно-буферным раствором с $\mathrm{pH}$ 4,6-4

общую картину состояния среды, но не имеют количественной экологической оценки.

В ряде стран при определении опасности уровня загрязнения применяется так называемый «цинковый эквивалент» (суммарный коэффициент, учитывающий различную степень токсичности элементов). Коэффициент включает 2п (токсичность 1), Си (токсичность 2), № (токсичность 8), Cd (токсичность 50). Рекомендуемый уровень - не более 250 мг/кг суммы металлов с учетом коэффициента их токсичности.

Расчет такого эквивалента показал, что в почвах с осадком промышленных городов он варьирует от 290 до 480 или на уровне выше норматива (при этом не изучены валовые содержания кадмия, который в данном исследовании не анализировался по техническимпричинам).

Важно отметить, что почти все химические элементы, которые удалось проанализировать в почвах с осадком сточных вод и компостов, находятся в подвижных усвояемых растениями формах (табл. 81). Установлено, в частности, что токсичный кадмий в почвах образует довольно контрастную аномалию в подвижной форме.

Внесение бытовых отходов в почву из-за несовершенства агротехнической обработки производится, как правило, неравномерно. Поэтому возможны ситуации ураганных концентраций химических элементов (рис. 80). В этом случае участки высоких содержаний для разных элементов полностью совпадают. 

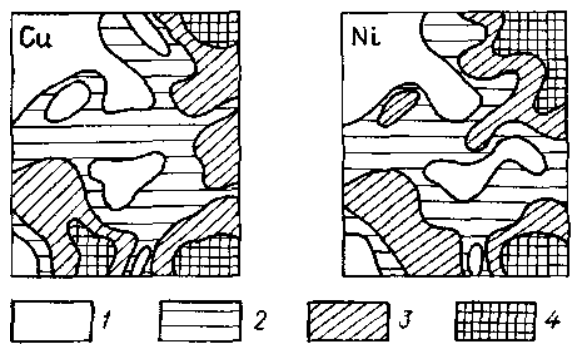

Рис. 80. Распределение микроэлементов в пахотном горизонте почв, обусловленное неравномерностью внесения осадков сточных вод:

1 -4-содержания Си, N1 (в мг/кг) 1 - менее 1,2 Си и менее $0,8 \mathrm{~N} 1,2$ $1,2-2,4$ Си и $0,8-1,6 \mathrm{Nl}, 3-2,4-7,2$ Си и 1,6-3,2 N1, 4-более 7,2 Си и более $3,2 \mathrm{~N} 1$



$\mathrm{Cu}$ 5n Ba Co AgCr Ni $\vee \mathrm{Zn} \mathrm{Pb}$

Рис. 81. Избыточное накопление химических элементов в салате, выращенном на участках с компостом (в процентах относительно контрольного участка)

О концентрировании химических элементов и прежде всего тяжелых металлов сельскохозяйственной продукцией в связи с применением в качестве удобрений отходов и сточных вод имеется много данных [37 и др.]. К сожалению, большинство исследований носило чисто агрохимический характер, и концентрация элементов в растениях часто не сопровождалась одновременным исследованием самих отходов. Тем не менее, во всех случаях, когда источник отходов и их характеристика были известны, выводы однозначны: внесение отходов больших промышленных городов с повышенными содержаниями токсичных элементов сопровождается их концентрированием растениями. Для малых непромышленных городов этого не наблюдается. Внесение бытовых сточных вод г. Кишинева [37] увеличивает в кукурузе и ячмене содержание В (в 1,7-1,8 раза), РЬ (1,1-1,8 раза), $\mathrm{Cr}$ (1,4 раза), Ni (0,6-1,9 раза), Mn (1,7 раза)

Авторами проведено широкое изучение влияния внесений компостов Московского мусороперерабатывающего завода на сод(жdния химических элементов в сельскохозяйственных растенняা

Для эксперимента в качестве растения-индикатора был выбран салат. Эксперимент проводился в теплице. Была приготовлена смесь кварцевого песка и компоста в различных дозах (3 кг $\left./ \mathrm{m}^{2}, 15 \mathrm{\kappa г} / \mathrm{м}^{2}, 25 \mathrm{kг} / \mathrm{m}^{2}\right)$. В каждый опыт добавлялась по агрохимической форме смесь Прянишникова, обеспечивающая основные питательные вещества $(\mathrm{N}, \mathrm{P}, \mathrm{K})$; на каждой дозе было 274 
Т а б л и ц 82 Средние содержания химических элементов в растениях, выращенных на почвах, удобренных компостами из твердых бытовых отходов

\begin{tabular}{|c|c|c|c|c|c|c|c|c|c|c|}
\hline \multirow{3}{*}{$\begin{array}{c}\text { Химический } \\
\text { элемен'т }\end{array}$} & \multicolumn{4}{|c|}{ Кормовая свекла } & \multicolumn{6}{|c|}{ Кукуруза } \\
\hline & \multicolumn{2}{|c|}{ листья } & \multicolumn{2}{|c|}{ корнеплод } & \multicolumn{2}{|c|}{ листья } & \multicolumn{2}{|c|}{ стебли } & \multicolumn{2}{|c|}{ корни } \\
\hline & $\mathrm{Mr} / \mathrm{K} \Gamma$ & $\mathrm{K}$, & Мг/Кг & $\mathrm{K}$, & мг/Кг & $\mathrm{K}$, & мг/Кг & $\mathrm{Kc}$ & $\mathrm{M \Gamma} / \mathrm{Kг}$ & $\mathrm{Kc}$ \\
\hline Свинец & 2,36 & 1,40 & 0,55 & 2,62 & 3,93 & 2,35 & 0,23 & 1,00 & 21,16 & ,97 \\
\hline Марганец & 171,56 & 2,62 & 14,30 & 6,47 & 35,93 & 1,07 & 4,18 & 1,63 & 281,90 & 14 \\
\hline Цинк & 36,70 & 3,06 & 10,10 & 5,15 & 38,58 & 4,09 & 17,58 & 4,00 & 82,22 & ,76 \\
\hline Кобальт & 0,20 & - & 0,19 & - & 0,47 & 2 & 0,15 & 1,07 & 6,80 & 61 \\
\hline Никель & 0,82 & 1,17 & 0,19 & 1,27 & 0,70 & 0,79 & 0,24 & 1,00 & 12,13 & ,28 \\
\hline Медь & 18,22 & 4,19 & 10,83 & 6,37 & 19,18 & 1,57 & 8,39 & 1,76 & 57,63 & 24 \\
\hline Хром & 1,22 & 0,95 & 0,33 & 2,06 & 4,98 & 2,65 & 0,49 & 1,00 & 34,03 & 68 \\
\hline Олово & 0,20 & 0,33 & 0,19 & - & 0,38 & 3,45 & 0,11 & 1,00 & 2,06 & 96 \\
\hline Кадмий & - & - & - & 一 & 0,112 & 1,49 & 0,062 & 1,09 & 0,225 & ,55 \\
\hline $\begin{array}{l}\text { Зольность, } \% \\
\text { Суммарный по } \\
\text { казатель загря- } \\
\text { знения }\end{array}$ & 13,63 & $\begin{array}{l}1,09 \\
8,76\end{array}$ & 5,90 & $\begin{array}{c}1,50 \\
17,94\end{array}$ & 9,33 & $\begin{array}{r}1,26 \\
11,44\end{array}$ & 7,48 & $\begin{array}{l}1,07 \\
5,45\end{array}$ & 40,87 & $\begin{array}{l}1,32 \\
6,19\end{array}$ \\
\hline
\end{tabular}

Примечание $\mathrm{K}_{c}$ - коэффициент концентрации относительно фона

выращено 10 проб салата. Аналогичный опыт проводился в полевых условиях на целинных дерново-подзолистых почвах.

Мы видим (рис. 81), что в сравнении с контролем (песчаная основа со смесью Прянишникова без компоста) при внесении компоста в салате накапливается 5п (в 9,5 раза), Си (в 8 раз), $\mathrm{Cr}$ и $\mathrm{Co}$ (в 3,5 раза), Ag, Ni, V (в 2,5 раза). Интенсивность биогеохимической концентрации не коррелирует с интенсивностью накопления химических элементов в компостах и почвах. Полевой опыт дал совпадающие результаты.

Изученное на следующий год последействие показало увеличение роста концентрации большинства элементов и, особенно, свинца, который в первый год накапливается слабо.

Оценка накопления химических элементов растениями проводилась также на 20 полях с одноразовым внесением компоста под кормовую свеклу, картофель, капусту и кукурузу. Полученные данные (табл. 82) также выявили биологическое концентрирование широкого круга элементов, но в несколько меньшей степени, чем в эксперименте (в 1,2-2,5 раза, редко 5-10 раз).

В растениях, выращенных на почвах, удобренных компостом, наблюдается рост зольности и увеличение биологического поглощения элементов, в число которых входят также те, которые по валовым содержаниям как загрязнители не выявляются. Химические элементы поглощаются растениями не в эквивалентных по отношению к их содержанию в почве количествах. Более того, участки концентрирования в растениях и почвах иногда не совпадают (рис. 82). Тем не менее, почти все элементы, кон- 

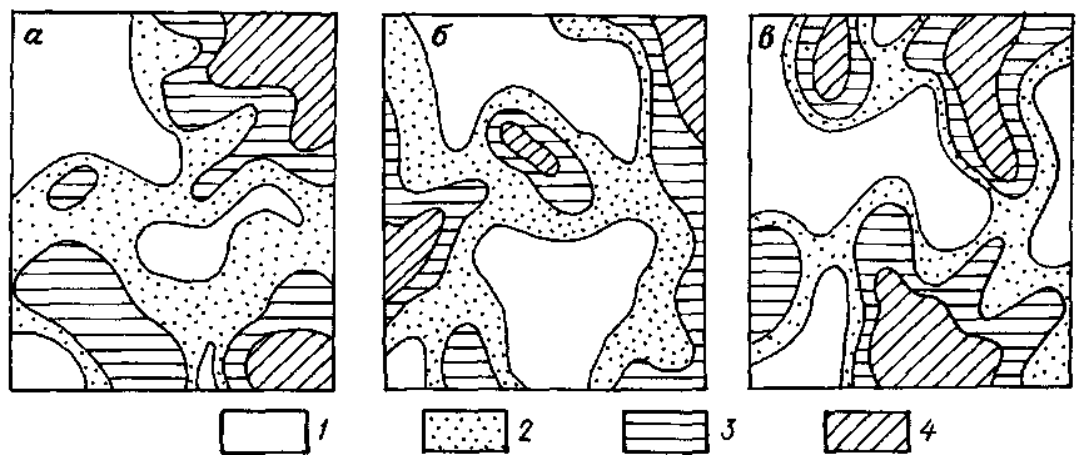

Рис. 82. Распределение никеля в почве (а) и кормовой свекле (б - корнеплоды, в - листья), выращенной на неравномерно удобренном поле:

1 -4-содержания № (в мг/кг): 1 - менее 0,8 (а), менее 0,05 (б), менее 0,3 (в); $2-0,8-1,6$ (а), $0,05-0,1$ (б), $0,3-0,6$ (в); $3-1,6-3,2$ (а), $0,1-0,2$ (б), $0,6-1,2$ (в), 4- более 3,2 (а), более 0,2 (б), более 1,2 (в)

центрирующиеся в осадках сточных вод и почвах, накапливаются и в растениях (табл. 83). Увеличение концентрации химических элементов в растениях довольно значительно - 3-14 раз. Для многолетних трав, произрастающих на почвах с осадком сточных вод, выявлен широкий спектр накапливающихся эле-

Т аблица 83. Средние содержания химических элементов в сельскохозяйственных растениях, выращенных на почвах с внесенными осадками сточных вод

\begin{tabular}{|c|c|c|c|c|c|c|}
\hline \multirow{3}{*}{ Элемент } & \multicolumn{2}{|c|}{ Многолетние травы } & \multicolumn{4}{|c|}{ Кормовая свекла } \\
\hline & \multirow{2}{*}{ м г / Кг } & \multirow{2}{*}{ K } & \multicolumn{2}{|c|}{ Листья } & \multicolumn{2}{|c|}{ Корнеплод } \\
\hline & & & $\mathrm{Mr} / \mathrm{K} \Gamma$ & $K_{\mathrm{t}}$ & мг/кг & $\mathrm{Kc}$ \\
\hline Бор & 15,26 & 14,26 & 16,73 & 1,04 & 1,52 & 2,98 \\
\hline Титан & 18,70 & 0,95 & 7,05 & 1,97 & 0,43 & 1,05 \\
\hline Ванадий & 1.66 & 1,29 & 0,17 & 1.21 & 0,04 & 1,00 \\
\hline Хром & 0,74 & 0,64 & 1,07 & 0,84 & 0,17 & 1,06 \\
\hline Марганец & 18,63 & 0,99 & 37,89 & 0,36 & 1,20 & 0,54 \\
\hline Никель & 2,57 & 4,15 & 1,22 & 1,74 & 0,20 & 1,33 \\
\hline Медь & 14,42 & 1,70 & 13,30 & 2,60 & 4,11 & 2,42 \\
\hline Цинк & 35,16 & 10,62 & 24,80 & 2,07 & 3,49 & 1,78 \\
\hline Стронций & 12,71 & 1,33 & 17,20 & 1,19 & 1,50 & 2,34 \\
\hline Молибден & 1,82 & 4,33 & 0,36 & 1,16 & 0,05 & 2,00 \\
\hline Серебро & 0,0157 & 3,41 & $0 ; 0095$ & 1,30 & 0,0029 & 2,07 \\
\hline Олово & 0,27 & 3,00 & 0,49 & 0,80 & - & - \\
\hline Барий & 31,31 & 1,77 & 47,73 & 0,68 & 5,25 & 0,77 \\
\hline Висмут & 0,15 & 2,50 & 0,10 & 0,56 & 0,06 & 1,50 \\
\hline $\begin{array}{l}\text { Зольность, \% } \\
\text { Суммарный показа- } \\
\text { тель загрязнения }\end{array}$ & $\begin{array}{r}10,40 \\
-\end{array}$ & $\begin{array}{r}1,12 \\
38,65\end{array}$ & $\begin{array}{r}17,16 \\
-\end{array}$ & $\begin{array}{l}1,12 \\
6,28\end{array}$ & $\begin{array}{r}6,17 \\
-\end{array}$ & $\begin{array}{r}1,57 \\
10,24\end{array}$ \\
\hline
\end{tabular}

Примечание Кс - коэффициент концентрации относительно фона

276 
ментов. Диапазон накопления сравнительно широк. Более чем в 10 раз в сравнении с фоном накапливаются В и 2п, от 3 до 10 раз - 5п, Ag, Ni, Mo. Полуторакратное превышение отмечено


5г, $\mathrm{V}$ и $\mathrm{Pb}$.

Многокомпонентный характер имеют геохимические ассоциации элементов в листьях и корнеплодах кормовой свеклы. Однако в отличие от трав, накопление в них химических элементов по сравнению с фоном не превышает трехкратного уровня и сама ассоциация накапливающихся элементов значительно уже, особенно для листьев.

Наибольший уровень загрязнения всем комплексом химических элементов отмечен для надземной части многолетних трав $\left(Z_{c}-38,7\right)$, что в $6-4$ раза превосходит суммарное накопление элементов в листьях и корнеплодах кормовой свеклы.

Загрязнение сельскохозяйственных почв и продукции в связи с орошением речными водами, несущими техногенные потоки рассеяния, практически не изучено. Однако небольшой массив данных, собранных авторами, показывает, что по своей значимости проблема достаточно серьезна.

Материалы, приведенные в табл. 84, показывают, что на пойме ниже промышленного города формируется полиэлементная геохимическая аномалия тяжелых металлов с суммарным пока-

Т а бл и ц а 84. Химические элементы (мг/кг) в почвах, орошаемых загрязненными речными водами

\begin{tabular}{|c|c|c|c|c|c|c|c|c|c|}
\hline \multirow{2}{*}{$\begin{array}{l}\text { Химический } \\
\text { элемент }\end{array}$} & \multicolumn{2}{|c|}{ Фоновые почвы } & \multicolumn{4}{|c|}{ Аномальные почвы } & \multicolumn{3}{|c|}{ Капуста } \\
\hline & $\begin{array}{c}\text { валовые } \\
\text { содер- } \\
\text { жания }\end{array}$ & $\begin{array}{c}\text { подвиж- } \\
\text { ные } \\
\text { формы }\end{array}$ & $\begin{array}{l}\text { валовые } \\
\text { содер- } \\
\text { жания }\end{array}$ & $K_{1}$ & $\begin{array}{c}\text { подвиж } \\
\text { ные } \\
\text { формы }\end{array}$ & $\mathrm{K}_{\mathrm{c}}$ & $\begin{array}{c}\text { на фоно- } \\
\text { вых } \\
\text { почвах }\end{array}$ & $\begin{array}{c}\text { на ано- } \\
\text { мальных } \\
\text { почвах }\end{array}$ & $\mathrm{K}_{\mathrm{c}}$ \\
\hline Серебро & 0,41 & - & 4,4 & 11 & 0,01 & 1 & 0,002 & 0,005 & 3 \\
\hline Вольфрам & - & Не опр & 10,7 & 7 & Не опр. & - & Не опр. & Не опр. & - \\
\hline Цинк & 104,5 & 4,8 & 650,0 & 6 & 112,9 & 23 & 3,3 & 8 & 2 \\
\hline Медь & 48,5 & 0,23 & 245,0 & 5 & 17,4 & 76 & 0,9 & 3 & 2 \\
\hline Свинец & 43,4 & 0,38 & 157,5 & 4 & 4,6 & 12 & 0,54 & 0,6 & 1 \\
\hline Ртуть & 0,26 & Не опр. & 0,86 & 3 & Не опр & - & Не опр & - & - \\
\hline Сурьма & 1,78 & » & 5,35 & 3 & $»$ & - & 0,95 & 1 & 1 \\
\hline Хром & 73,55 & $\gg$ & 209,5 & 3 & $»$ & - & 0,34 & 0,4 & 1 \\
\hline Олово & 8,65 & 》 & 22,1 & 2 & $\gg$ & - & 0,05 & 0,1 & 2 \\
\hline Мышьяк & 15,0 & $\gg$ & 29,6 & 2 & » & - & Не опр. & Не опр. & - \\
\hline $\mathrm{Hn}$ & 23,7 & 0,09 & 54,3 & 2 & 1,52 & 17 & 0,37 & 0,3 & 0,8 \\
\hline Моль & 1,26 & Не опр & 1,3 & 1 & Не опр. & - & 0,20 & 0,5 & 3 \\
\hline Стронций & 29,25 & Не опр & 30,0 & 1 & Не опр. & - & 3,56 & 12 & 3 \\
\hline Кобальт & 8,05 & - & 9,1 & 1 & - & - & - & 0,02 & 2 \\
\hline Марганец & 883,0 & 26,3 & 757,5 & 0,9 & 17,64 & 0,7 & 1,51 & 2 & 2 \\
\hline $\begin{array}{l}\text { Суммарный } \\
\text { показатель } \\
\text { загрязнения }\end{array}$ & - & - & - & 38 & - & 125 & - & - & 13 \\
\hline
\end{tabular}

Примечание: «-»-элемент не обнаружен, «не опр »- элемент не определялся. 
зателем загрязнения около 40 и с относительно небольшим уровнем концентрирования отдельных элементов $(2,0-6,0$ для Си, 5г, 2п, Сг, $\mathrm{S} n$ и др.). Комплекс элементов достаточно типичен для промышленных источников.

Для этого типа аномалий характерен высокий уровень содержания подвижных, усвояемых растениями форм нахождения элементов, особенно Си, $\mathrm{Cd}, \mathrm{Ni}, 2$, $\mathrm{Pb}$ (в 10 и более раз выше, чем в фоновых условиях).

Это привело к высокому уровню накопления тяжелых металлов в продукции (в данном случае, в капусте), где суммарный показатель загрязнения порядка 17, а концентрация отдельных металлов (Си, 5п, 2п, Сг) в 2,5-3,5 раза больше фонового.

Промышленные отходы в сельском хозяйстве применяются пока в небольшом масштабе. Проблема эта ставится давно и возможные масштабы воздействия здесь огромны, так как речь идет прежде всего о таких многотонных отходах как золы угольных электростанций, шламы и шлаки металлургии, органические отходы целлюлозно-бумажных комбинатов, отходы производства фосфорных удобрений. Во всех этих отходах загрязняющими веществами могут быть не только химические элементы, но и синтетические органические соединения и, прежде всего, весьма опасные полициклические ароматические углеводороды типа бензапирена и других веществ, в сущности, почти не исследованных в этих продуктах.

Кроме того, состав промышленных отходов очень изменчив, зависит от конкретных технологических условий на предприятии и условий сочетания тех или иных видов применяемого сырья. Поэтому возможность сельскохозяйственного использования того или иного отхода должна оцениваться на каждом конкретном предприятии [29].

Так, золы электростанции, планируемые как известьсодержащие мелиоранты, не содержат особенно высоких концентраций тяжелых металлов, но, например, в золах некоторых ТЭЦ наблюдалось до 20000 г/т 5п (в 70 раз выше кларкового количества) и до 600 г/т В (в 20 раз больше, чем в почвах). В золах сланцев встречаются повышенные содержания РЬ (до 125 мг/кг, в 5 раз выше, чем в фоновых почвах), иногда $\mathrm{F}$ (до 1210 г/т, в 6 раз выше фонового).

Шлаки черной металлургии, также используемые для известкования кислых почв, содержат повышенные количества Сг, V, Mn. При принятых дозах внесения обогащение этими элементами почв невелико - 5-16\% от фонового запаса, однако подвижность их и доступность для растений совершенно не изучены.

Для отходов ЦБК большое опасение вызвала ртуть, которая по ряду технологий используется в сопутствующем здесь хлорщелочном производстве и является опасным загрязняющим веществом для водных систем. В осадках сточных вод содержание 


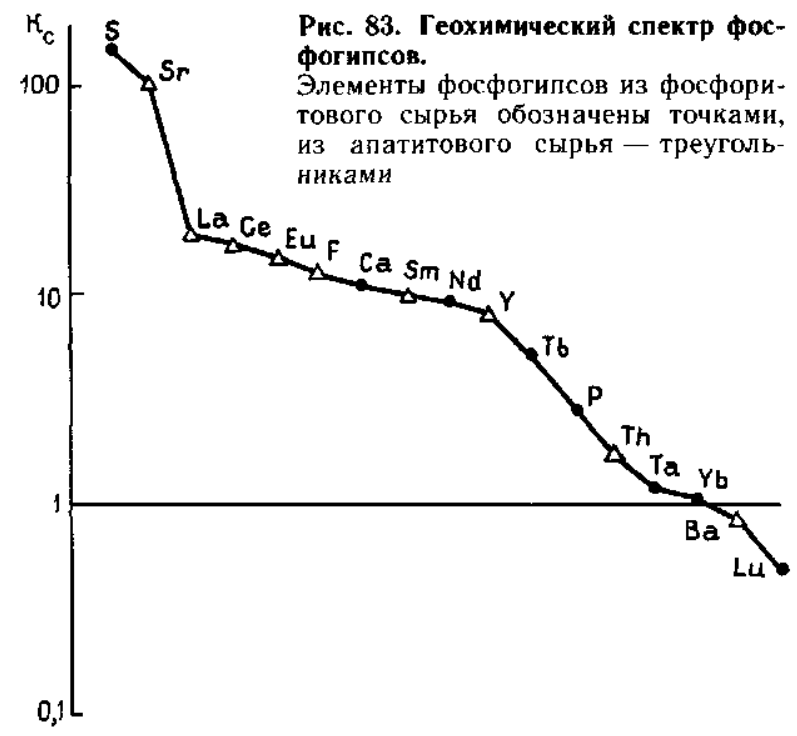

ртути на очистных сооружения варьирует от 0,1 мг/кг (в 10 раз больше фонового содержания в почвах) до 0,7 мг/кг (в 70 раз выше). Таким образом, даже в отходе уровень не превышает допустимого содержания для почвы $(2,2$ мг/кг).

Анализ распределения ртути в агроландшафтах, проведенный для условий дерновых сильноподзолистых почв, показал, что уровень содержаний в них лишь эпизодически повышается до 0,2 мг/кг (в 20 раз выше фонового, но в 10 раз ниже нормативного). В раскениях содержания ртути не более 0,2 мг/кг, что близко к фоновому уровню. Таким образом, использование отходов не создает опасных геохимических ситуаций.

Большую и хорошо известную специалистам проблему представляет фосфогипс. В настоящее время разработано множество вариантов его применения в сельском хозяйстве для улучшения кислых (в композиции с известковыми материалами и органическими удобрениями) и щелочных (солонцовых) почв. Все эти способы, однако, разрабатываются практически без учета уровня загрязнения фосфогипса элементами-примесями фосфорных руд.

Исследование состава двух разновидностей фосфогипса, характеризующих предприятия перерабатывающие апатитовое и фосфоритовое сырье, показывает (рис. 83) близость их состава. В обоих случаях фосфогипс является концентратом 5 и $\mathrm{Sr}$ (в 100 раз больше кларковых величин), а также широкой ассоциации редкоземельных элементов ( $\mathrm{La}, \mathrm{Ce}, \mathrm{Eu}, 5 \mathrm{~T}, \mathrm{Nd}), \mathrm{y}$ и $\mathrm{F}$ (в 10-20 раз выше кларковой величины).

Прогнозные расчеты показывают, что при внесении 60 т/га фосфогипса, содержание 5г может превысить верхний безопас- 




ный предел (600 мг/кг) Остальные элементы практически не могут быть оценены, так как их биогеохимия и экологическая значимость не изучена

Опыт, проведенный в условиях дерново-подзолистой зоны, в ходе которого в почву вносили фосфогипс в смеси с органическими удобрениями (рис 84) не дал возможность выявить накопление элементов-примесей в почве Однако в выбранной культуре (картофель, который обычно плохо концентрирует микроэлементы) отчетливо проявилось некоторое накопление 5г, Се, 5т и La (20-40\% прибавки по сравнению с контролем без фосфогипса) Попутно установлено интенсивное накопление $\mathrm{Br}$ Полученный результат хотя и не дает ясного свидетельства об опасности применения фосфогипса в данных условиях (слабокислые дерново-подзолистые почвы) и для данной культуры (картофель), тем не менее свидетельствует о биогеохимической активности Sr и TR При этом условия кислых дерново-подзолистых почв наименее благоприятны для миграции этих элемен тов Таким образом, полученные данные подтверждают возможность загрязнения сельскохозяйственных территорий при применении фосфогипса в качестве мелиоранта Они показывают нерешенность этой проблемы и необходимость дальнейших исследований, особенно в аридных районах со щелочными условиями 


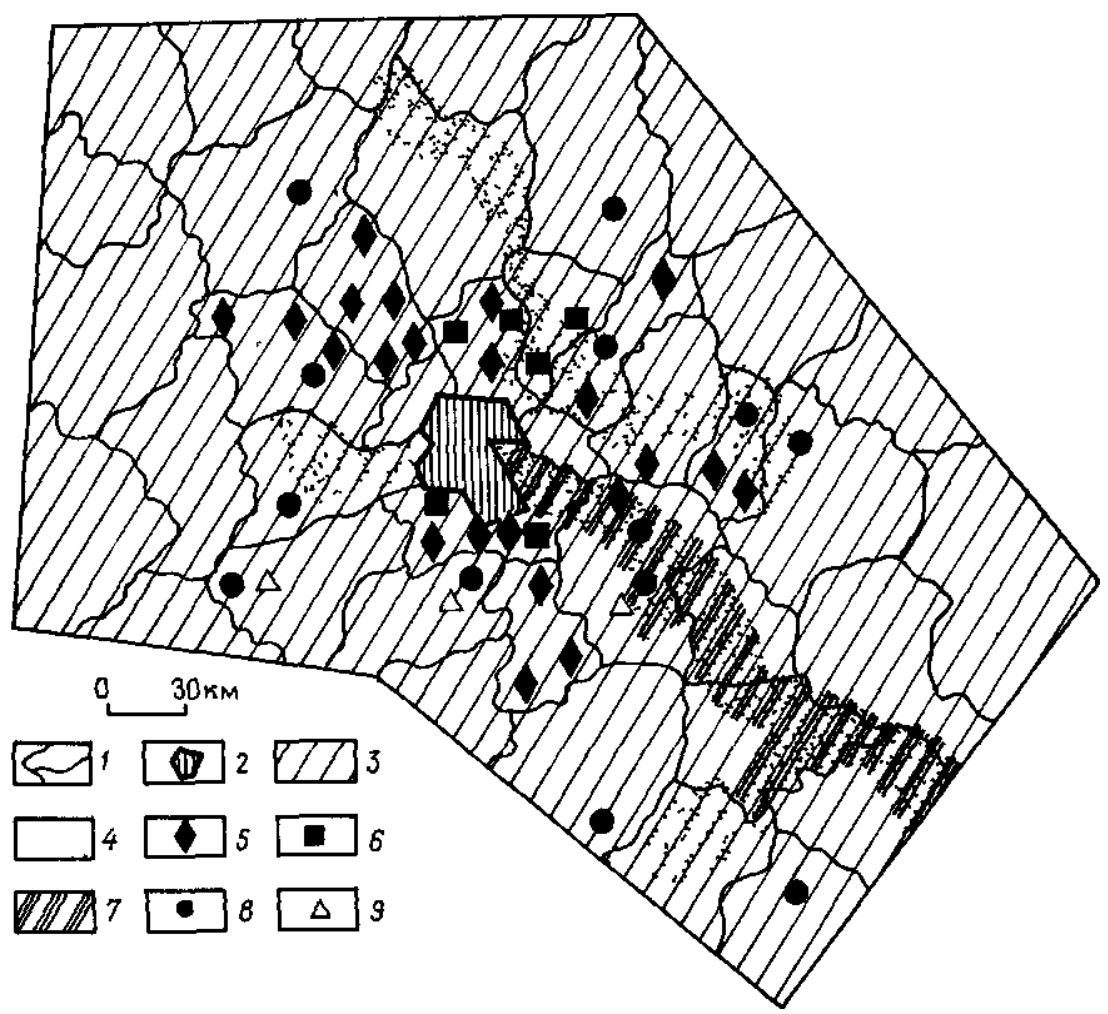

Рис. 85. Схема загрязнения сельскохозяйственных почв в зоне влияния крупного промышленного города:

1 границы административных районов, 2 - территория крупного промышлен ного города, 3 - водораздельные территории слабого регионального загрязнения ( $\mathrm{F}-\mathrm{Sr}-\mathrm{TR})$ минеральными удобрениями, $4-$ пойменные территории с повы шенным уровнем регионального загрязнения $(\mathrm{F}-\mathrm{Sr}-\mathrm{TK})$ минеральными vдобре ниями, 5 - участки интенсивного локального загрязнения тяжелыми металлами при внесении осадков сточных вод (доза 150 т/га), 6 - участкн интенсивного локального загрязнения тяжелыми металлами при внесении компостов из твердых бытовых отходов (доза 50 т/га), 7 - пойменные участки с повышенным уровнем локального загрязнения тяжелыми металлами в результате полива загрязненными речными водами, 8 - участки загрязнения осадками городских сточных вод, $9-$ участки слабого локального загрязнения (2п, 5г) отходами животноводческих комплексов

миграции, где должна резко возрасти подвижность редких земель

Оценивая экологические итоги агротехногенных геохимических воздействий следует отметить, что, несмотря на неболь шие абсолютные площади около крупных городов образуется своеобразный пояс загрязненных сельскохозяйственных почв (рис 85) 


\section{3. ТЕХНОГЕННЫЕ ГЕОХИМИЧЕСКИЕ \\ ПРЕОБРАЗОВАНИЯ СЕЛЬСКОХОЗЯЙСТВЕННЫХ ТЕРРИТОРИЙ}

Техногенные геохимические преобразования в агроландшафтах не связаны со спецификой сельскохозяйственных технологических процессов. Они, как отмечалось, обусловлены загрязнением окружающей среды в результате промышленных и транспортных воздействий. Это прежде всего влияние выбросов в атмосферу и выпадений на поверхность почв и растений.

По своим основным характеристикам (составу ассоциаций химических элементов, дальности их распространения и формам нахождения) аэрогенные аномалии урбанизированных и сельскохозяйственных территорий мало различаются. Эти вопросы детально рассмотрены в фундаментальных работах Н. Г. Зырина, С. Г. Малахова, Д. С. Орлова и других $[16,20,45]$. Отметим лишь некоторые особенности, важные для эколого-геохимической оценки техногенных воздействий на сельскохозяйственные территории.

Загрязнение почв вследствие выпадения на них выбросов промышленных предприятий очень интенсивно. Круг накапливаемых элементов здесь ничем не ограничен и в каждом случае обусловлен особенностями применяемой технологии. Как показывают многочисленные данные, среди обогащающих почвы химических элементов всегда встречаются экологически токсичные. Конкретный уровень накопления в почвах зависит от мощности источника и расстояния от него. Так, в почвах огородов в 500 м от завода по переработке вторичных цветных металлов избыточное накопление $\mathrm{Hg}$ составляет 5900\%, 2п и Си более $2000 \%$, $\mathrm{Pb}$ и 5п более $1500 \%$, в 1000 м от выброса степень накопления снижается, но остается избыточной $(\mathrm{Pb}-550 \%, \mathrm{Zn}-240 \%$, $\mathrm{Cu}-110 \%$, остальные элементы - десятки процентов). Даже в 3000 м для таких химических элементов как $\mathrm{Pb}, \mathrm{Zn}$ и Си избыточное накопление в почве около 50\%. Вблизи мощной промышленной зоны с кабельным заводом в почвах в 2-3 км от источника выбросов, избыточное накопление РЬ $300-600 \%$, $2 \Pi-200-350 \%, \mathrm{Ni}-125-325 \%, \mathrm{Cr}-$ около $100 \%$.

Загрязнение сельскохозяйственной продукции в связи с выбросами происходит не только путем поглощения химических элементов из почв, но и прямым осаждением материала выброса на поверхность растений.

Эти два варианта увеличения содержаний токсичных элементов в продукции различить довольно трудно, так как отмывка листьев (и плодов) часто не эффективна. Кроме того для зон воздействия выбросов характерна очень высокая вариация в распределении содержаний элементов и индивидуальная изменчивость по отдельным растениям. Например, в пределах площадки $10 \times 10$ м валовые содержания Си в почвах в центре ано- 
Рис. 86. Распределение меди в системе «почва-растение» в зоне воздействия медеплавильного комбината:

$\Pi \mid$ - валовое содержание меди в почве, $\Pi_{2}-$ содержание подвижных форм меди в почве, $\mathbf{P}-$ содержание меди в сельскохозяйственной продукции

малин медеплавильного завода варьировали от 250 мг/кг до 13600 мг/кг (более, чем в 50 раз). Вариация содержаний Си в сельскохозяйственных растениях в этой зоне была меньше, но все же различия между отдельными особями были десятикратными (от 44 до 451 мг/кг сухого вещества). С удалением от источника выброса неравно-


мерность распределения выпадений уменьшается. В 4 км от предприятия (на фланге аномалии) валовые содержания Си в почвах на аналогичной площадке варьировали от 300 до 380 мк/кг, a в растениях от 30 до 37 мг/кг (при фоновых содержаниях в почвах $55-65$ мг/кг, в растениях $11-20$ мг/кг).

Высокий уровень выпадения из почвы растворенных форм тяжелых металлов и повышенная растворимость металлов из аэрозолей, обеспечивает в почвах техногенных ореолов высокую степень концентрации подвижных, усвояемых растениями форм нахождения химических элементов. При этом зоны высокого и опасного загрязнения этими формами нахождения распространены довольно далеко, до 5-7 км для крупного металлургического предприятия (табл. 85). Это определяет и зону влияния на сельскохозяйственную продукцию, которая для крупных предприятий цветной металлургии прослеживается до $5-7$ км (рис. 86). Однако в большинстве случаев зоны влияния значи-

Т а бл и ц а 85 Среднее содержание подвижных форм микроэлементов в почвах в зоне влияния крупного металлургического предприятия

\begin{tabular}{|c|c|c|c|c|c|c|c|c|c|}
\hline \multirow{2}{*}{$\begin{array}{c}\text { Расстояние } \\
\text { загрязнения, } \\
\text { м }\end{array}$} & \multicolumn{3}{|c|}{ Медь } & \multicolumn{3}{|c|}{ Цинк } & \multicolumn{3}{|c|}{ Свинец } \\
\hline & Мг/КГ & $\mathrm{Kc}$ & КПДК & МГ / К Г & $\mathrm{K}$ & КПДК & МГ Г КГ & $\mathrm{K}_{\mathrm{c}}$ & КПДК \\
\hline \multirow[t]{2}{*}{$0-300$} & 770,0 & 621 & 154,0 & 124,0 & 90 & 7,75 & 31,0 & 77,5 & 5,17 \\
\hline & 958,0 & 773 & 191,6 & 210,0 & 152 & 13,12 & 76,0 & 190,0 & 12,17 \\
\hline 4000 & 354,0 & 286 & 70,8 & 55,2 & 40 & 3,45 & 37,8 & 94,5 & 6,3 \\
\hline 5000 & 86,0 & 69 & 17,2 & 6,0 & 12 & 1,0 & 12,0 & 30,0 & 2,0 \\
\hline 7000 & 2,1 & 1,7 & 0,4 & 2,3 & 1,6 & 0,14 & 0,5 & 1,2 & 0,08 \\
\hline
\end{tabular}

Примечание $K_{c}-$ коэффициент концентрации по отношению к фоновой почве, КПДК коэффициент превышения предельно допустимой концентрации 

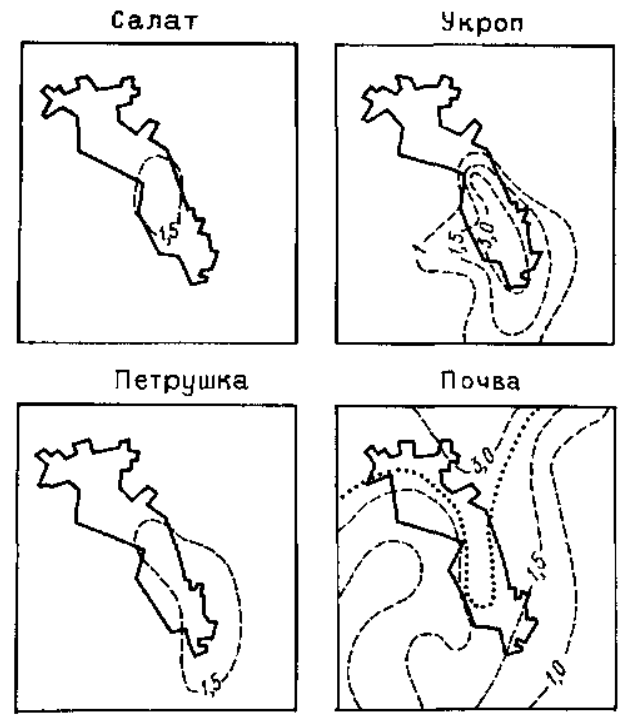

Рис. 87. Распределение фтора в зонах воздействия предприятий по пронзводству удобренкй

Рнс. 88. Содержанне хнмнческих элементов в почвах (a) и пшенице $(\sigma)$ на различном расстоянии от завода вторичных цветных металлов:

$I$ - аномальные уровни, 2 - фоновые уровни

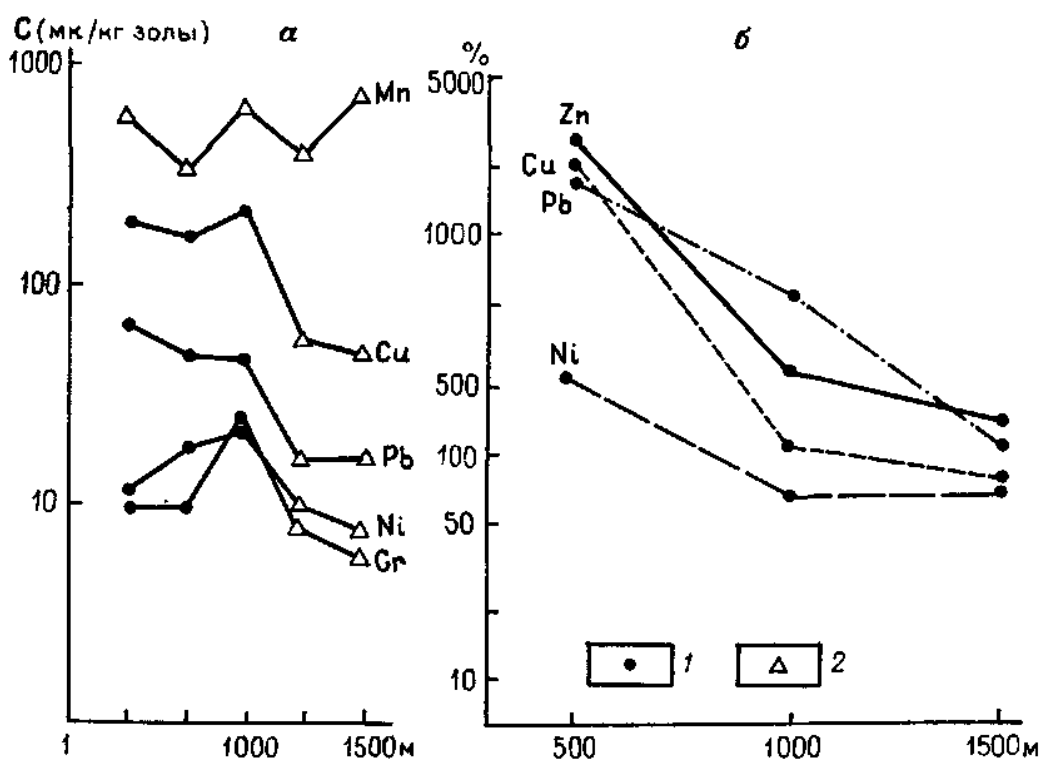

тельно меньше и не превышают 0,5-1,5 км даже для таких достаточно мощных источников выбросов как заводы по производству удобрений (рис. 87) и типичных для городов предприятий по производству вторичных цветных металлов (рис. 88). 




Рис. 89. Содержание микроэлементов в плодах груши (сухое вещество) в зоне влияния автотрассы. По данным Л. Н. Павловой

Тем не менее именно здесь расположены территории по состоянию воздушного бассейна, входящие в санитарно-защитную зону, но используемые под сельское хозяйство (особенно под частные огороды и сады), на которых возникают особенно опасные ситуации.

Влияние автотранспорта на сельскохозяйственные территории изучено детально. Обычно описываются [45] повышенные содержания свинца (в 5, редко до 10 раз) в придорожных ландшафтах (10 м, редко до 50 метров от полотна).

В придорожных зонах отмечается увеличение содержания свинца во всех культурных растениях. Так, в зерновых культурах (пшеница и ячмень) содержание свинца превышает фоновое в среднем в 5 раз. Высокие концентрации свинца отмечены также в капусте, моркови (в 4-7 раз) и репчатом луке (в 10 раз).

Описанные нами выше участки ландшафтно-геохимической концентрации свинца в горно-долинных территориях (содержание в почвах выше 500 мг/кг свинца) с биогеохимических позиций не изучены. В то же время такие участки характерны для небольших городов с развитым частным сельским хозяйством.

Аномалии, связанные с транспортными магистралями, часто комплексные по химическому составу. На это обычно не обращают внимания; в состав ассоциации (рис. 89) включают такие элементы как V, 2п, Co, $\mathrm{Ni}, \mathrm{Cr}$, т. е. типоморфные спутники выбросов дизельных двигателей.

Таким образом, воздействие выбросов транспортных потоков на сельскохозяйственные территории приводит к появлению полиэлементных геохимических и биогеохимических аномалий. 


\section{4. ВЛИЯНИЕ СЕЛЬСКОГО ХОЗЯЙСТВА НА ВОДНЫЕ СИСТЕМЫ}

В общем случае потенциальное воздействие сельскохозяйственного производства на состояние и качество природных вод связано с 1) применением различных средств химизации (удобрений, ядохимикатов, комностов, сточных вод и их осадков и т. П.), поступающих в водные объекты с поверхностным, внутрипочвенным и грунтовым стоком; 2) влиянием сточных вод и отходов животноводства, птицеводства, звероводства; 3) влиянием стока поверхностных и грунтовых вод с территорий выпасов и пастбищ; 4) влиянием возвратных (дренажных) вод орошения; 5) ускоренной эрозией сельскохозяйственных территорий.

Геохимическое изучение сельскохозяйственной деятельности как источника загрязнения водных систем начато сравнительно недавно. В настоящее время наиболее подробно рассмотрены и освещены в литературе вопросы, связанные с оценкой поступления, главным образом, биогенных элементов (P, N, K). Детально рассмотрены особенности загрязнения вод органическими веществами в результате применения пестицидов, а также бактериальное загрязнение водных объектов при поступлении сточных вод животноводческих комплексов. Хорошо изучено воздействие ускоренной эрозии сельскохозяйственных территорий, хотя геохимические аспекты этого явления освещены не достаточно подробно. Загрязнение водных систем химическими элементами (микроэлементами, тяжелыми металлами) в результате сельскохозяйственной деятельности изучено очень слабо. В то же время, имеющиеся данные показывают, что в различных средствах химизации и сельскохозяйственных отходах содержится широкий комплекс химических элементов, которые при их использовании или утилизации могут накапливаться в компонентах водных систем.

В табл. 86 приведен состав агрогенных потоков рассеяния в донных отложениях малых рек агроландшафтов. Агрогенные ассоциации характеризуются накоплением широкого круга химических элементов. Значительная группа элементов, в первую очередь, литофильных, отличается невысокими коэффициентами концентрации (1,5-3, редко до 4-5). Как правило, эти элементы обнаруживаются в виде нежелательных примесей в составе минеральных удобрений, применяемых в данном районе. Таким образом, элементы, специально не используемые в сельскохозяйственном производстве, отличаются невысоким уровнем загрязнения, но их слабоконтрастные аномалии проявляются на значительных территориях. Группа более интенсивно концентрирующихся элементов ( $\mathrm{Hg}, \mathrm{Ag}, 2$, 5e, P, Си, 5п, As и др.), как правило, связаны с целенаправленным внесением в состав минеральных удобрений, микроудобрений, ядохимикатов или с влиянием стоков животноводства и агропоселков. 
Т а б ли ц 86 Ассоциации химических элементов в донных отложениях малых рек агроландшафтов

\begin{tabular}{|c|c|c|c|}
\hline \multirow{2}{*}{$\begin{array}{c}\text { Характер } \\
\text { использования } \\
\text { территории }\end{array}$} & \multicolumn{3}{|c|}{ Коэффициенты концентрации относительно фона } \\
\hline & $30-10$ & $10-3$ & $3-1,5$ \\
\hline $\begin{array}{l}\text { Свиноводческий } \\
\text { комплекс } \\
\text { Комплекс крупно- } \\
\text { рогатого скота } \\
\text { Бассейны рек ком- } \\
\text { плексного } \\
\text { сельскохозяйствен- } \\
\text { ного использова- } \\
\text { Ния } \\
\text { Бассейны рек зем- } \\
\text { ледельческого ис- } \\
\text { пользования } \\
\text { Агрол оселки }\end{array}$ & $\mathrm{Ag}, \mathrm{Hg}$ &  &  \\
\hline
\end{tabular}

Аномалии, обусловленные сбросом сточных вод, более контрастны, но имеют локальное распространение, проявляясь в непосредственной близости от мест сброса. Для большей части элементов, связанных с неточечными источниками загрязнения, характерно довольно однородное распределение в руслах рек (коэффициенты вариации в среднем составляют $30-50 \%$ ). Неоднородность распределения возрастает вблизи мест сброса сточных вод с сельскохозяйственных объектов.

Существенные изменения может претерпевать и химический состав вод сельскохозяйственных рек (табл. 87). Наиболее сильное воздействие связано с животноводческими комплексами. В целом для рек сельскохозяйственных районов отмечено увеличение содержания не только биогенных элементов, но и некото-

Т аблица 87 Химический состав воды малых рек агроландшафтов (макрокомпоненты в мг/л; микроэлементы в мкг/л)

\begin{tabular}{|c|c|c|c|c|c|c|c|c|c|c|c|c|c|c|c|}
\hline $\begin{array}{l}\text { Характер } \\
\text { территории }\end{array}$ & $\mathrm{pH}$ & $\mathrm{HCO}_{3}^{-}$ & $\mathrm{SO}_{4}^{-}$ & $\mathrm{Cl}^{-}$ & $\mathrm{Na}^{+}$ & $\mathrm{Ca}^{2+}$ & $\mathrm{Mg}^{2+}$ & $\mathrm{K}^{+}$ & 2 & $\mathrm{NO}_{2}^{-}$ & РОГ & $P$ & $2 \pi$ & As & $5 \mathrm{e}$ \\
\hline $\begin{array}{l}\text { Свиноводче- } \\
\text { ский комплекс }\end{array}$ & 6 & 236 & 51 & 84 & 64 & 72 & 20 & 9 & 612 & 0,13 & 7,5 & 400 & 15 & 3,5 & 0,85 \\
\hline $\begin{array}{l}\text { Интенсивное } \\
\text { земледелие }\end{array}$ & 7,0 & 275 & 50 & 47 & 39 & 70 & 19 & 6 & 545 & 0,4 & 1,4 & 600 & 15 & 1,0 & 0,23 \\
\hline $\begin{array}{l}\text { Дачный посе- } \\
\text { лок }\end{array}$ & 6,2 & 168 & 149 & 49 & 44 & 76 & 16 & 13 & 531 & 0,15 & 0,5 & 400 & 11 & 1,0 & 0,10 \\
\hline $\begin{array}{l}\text { Фоновый во- } \\
\text { доток }\end{array}$ & 7,9 & 293 & 20 & 10 & 12 & 62 & 17 & 1 & 432 & 0,02 & 0,02 & 200 & 9 & 10 & 0,09 \\
\hline
\end{tabular}

Примечание Выделены компоненты, значительно превышающие фоновые уровни 
рых макро- (натрий, сульфаты, хлориды) и микроэлементов (2п, $5 \mathrm{e}, \mathrm{F}, \mathrm{As}, \mathrm{Ag})$. Выявленные слабоконтрастные аномалии довольно стабильны во времени и в пространстве. Снижение уровней содержания компонентов отмечается при переходе к водотокам более высокого порядка и связано с процессами разбавления. В реках агроландшафтов увеличены содержания, кроме названных выше ингредиентов, Ре, Са, резко возрастает поступление твердых частиц, в районах орошения заметно увеличивается минерализация вод. Особенно резко меняется состав вод в районах использования различных компостов и осадков сточных вод. Так, по данным американских исследователей М. Шелтона и Г. Лессмана, в поверхностном стоке с водосбора, удобренного осадком городских сточных вод, содержания $\mathrm{Cd}$ достигало 31 мкг/л, Ре 78100, Не 35, Рb 36, 2п 78100 мг/л. Отмечено также резкое повышение концентраций $\mathrm{Ca}, \mathrm{Mg}, \mathrm{Cl}, \mathrm{Na}, \mathrm{A} 1$, нитратного азота, Р и взвешенных веществ. Есть указания на увеличение концентраций ртути в воде и донных отложениях в результате использования ее соединений в сельском хозяйстве. Большинство авторов считает, что данный источник загрязнения вод ртутью незначителен, а основную опасность ртутные препараты представляют для птиц и человека (при использовании протравленного зерна в пищу) .

В водотоках сельскохозяйственных районов формируются агрогенные потоки рассеяния широкой группы химических элементов, в том числе и высокотоксичных. Наиболее сильное, но локальное воздействие связано с животноводческими комплексами. Контрастность аномалии в районах земледелия невелика, но они фиксируются на значительных территориях. При существующих темпах химизации сильного воздействия следует ожидать дальнейшей геохимической трансформации водных систем в агроландшафтах. Это указывает на необходимость проведения специальных исследований, направленных на изучение поступления, распределения и миграции химических элементов в водных объектах и оценки экологических последствий, связанных с их отрицательным воздействием.

\section{5. МЕТОДИЧЕСКИЕ ВОЗМОЖНОСТИ И ПРАКТИЧЕСКОЕ ЗНАЧЕНИЕ ГЕОХИМИЧЕСКИХ ИССЛЕДОВАНИЙ}

Преобразования сельскохозяйственных территорий, вызванные агротехническими, агрохимическими, агромелиоративными воздействиями, использованием отходов в качестве удобрений, орошением загрязненными речными водами, а также общим техногенным загрязнением окружающей среды и прежде всего выбросами в атмосферу приводит к образованию в агроландшафтах экологически опасных геохимических и биогеохимических аномалий. 
Технология и методика изучения этих аномалий в основном такая же как и при изучении техногенных аномалий урбанизированных территорий. В основе исследований лежат методы геохимического картирования с выявлением ассоциаций химических элементов и форм их нахождения в почвах, а также оценкой биогеохимических и биологических реакций растений на дифференциацию геохимической структуры почвенного покрова.

Изучение агроландшафтов должно предусматривать дифференцирование их в соответствии со степенью агрогенной нагрузки. Последняя определяется особенностями применения средств химизации (видами, частотой внесения и дозами удобрений), характером агротехнической обработки (периодичностью, интенсивностью) и обусловливает определенный уровень и спектр поступающих химических элементов.

Дифференциация химических свойств агроландшафтов, обнаруживаемая на уровне микрорельефа или небольших по площади зон различных содержаний элементов, определяемых неоднородностью агротехнического воздействия (доли гектара), показывает, что не во всех случаях приемлема стандартная методика агрохимического опробования, основанная на усредненных пробах для значительных по площади участков и сглаживающая ландшафтную неоднородность распределения.

В агроландшафтах практически повсеместное использование минеральных удобрений обусловливает слабое загрязнение почв водораздельных территорий фтором, стронцием, редкими и тяжелыми металлами. Более высокие уровни накопления этих элементов выявлены на пойменных участках, где необходимо соблюдение водоохранной агротехнологии и контроль за дозами удобрений.

Необходимо изучение элементов-примесей во всех удобрениях и особенно получаемых из вновь разведуемых месторождений фосфора. В частности, особое внимание следует обратить на так называемые фосмелиоранты-удобрения из небольших местных месторождений, используемых в виде фосмуки, т. е. без обработки, снижающей содержание примесей. Среди новых видов удобрений не исключено обнаружение источников с очень высокими содержаниями токсичных элементов.

Следует выявить в технологических процессах на заводах удобрений и обогатительных фабриках причины появления высоких содержаний мышьяка в цепи концентрат-удобрение. Предположительно, они могут быть связаны с используемой в технологии серной кислотой и в этом случае могут быть разработаны мероприятия по снижению содержаний мышьяка в удобрениях.

Для концентратов из фосфоритовых месторождений следует начать разработки по оценке принципиальной возможности уменьшения содержания в. них кадмия и других тяжелых металлов. 
Для всех видов удобрений необходимо провести надежную оценку интенсивности влияния элементов-примесей для различных доз внесения и разных ландшафтно-геохимических условий биологического поглощения.

С целью повышения надежности оценки уровней загрязнения сельхозпродукции необходимо создать эталонные по химическому составу растения, выращенные в стандартных условиях, исключающих антропогенное химическое воздействие.

Применение бытовых отходов в качестве удобрений практически неизбежно приводит к формированию локальных аномалий загрязнения почв тяжелыми металлами.

Контроль за этими процессами должен осуществляться не только на последнем этапе сельскохозяйственного производства - этапе получения готового продукта, фиксирующего уже сложившуюся геохимическую ситуацию в агроландшафте,-- но и на более ранних этапах, когда экологическая ситуация только формируется и ее можно регулировать. При этом с эколого-геохимнческих позиций рассматриваются все звенья технологического процесса химической мелиорации: мелиорант, как источник элементов-загрязнителей; почва, как среда питания; растение, как продукт питания.

Практически все виды нестандартных удобрений в той или иной степени загрязнены химическими элементами. При этом. в значительной части случаев концентрации их достигают токсичных уровней, но и тогда, когда уровни загрязнения не столь велики, применение мелиорантов низкого экологического качества чревато опасностью долговременных и отдаленных последствий. В связи с этим очевидна необходимость в регламентировании концентраций загрязняющих вешеств в составе всех видов удобрений. Это, однако, не предусматривается действующими или разрабатываемыми нормативами в отношении таких токсичных мелиорантов как осадки сточных вод и компосты из бытовых отходов. В определении параметров качества мелиорантов с позиций содержания в них элементов-примесей видится один из насущных вопросов экологической проблемы агроландшафтов.

Отсутствие норм на содержание в мелиорантах загрязнителей обусловливает необходимость контроля за уровнями (дозами) внесения удобрений в почвы. В настоящее время этот уровень определяется по агрохимическому эффекту, строго не регламентируется. Он широко варьирует в зависимости от естественного плодородия почвы и возделываемой культуры. Рекомендуемые дозы внесения таких мелиорантов, как осадки сточных вод и компосты из бытовых отходов, колеблются от 40 до 60 т/га для первых и от 10 до 100 т/га - для вторых. На практике они значительно выше и достигают 400-600 т/га и 200-300 т/га, соответственно. Расчетные же данные по содержаниям элементов в почвах и в мелиорантах, в частности, в осадках сточных вод 290 
дозы внесения составляют: $\mathrm{Cr}-25-30$ т/га; 2 п $-13-17$ т/га; $\mathrm{Pb}-4-5$ т/га. Эти дозы, очевидно, имеют весьма низкую удобрительную ценность и фактически повсеместно превышаются (до 10 раз и более). Учитывая отсутствие жесткой регламентации внесений и контроля, трудно ожидать, что эти дозы будут соблюдаться и впредь.

В связи с высказанными соображениями можно сделать вывод о эколого-геохимической неприемлемости использования отходов, загрязненных тяжелыми металлами, в качестве удобрений.

Для компостов из бытового мусора и загрязненных промышленных отходов имеется возможность разработки технологических способов утилизации или обезвреживания без их неконтролируемого размещения в природных ландшафтах при использовании в качестве удобрений. Значительно серьезнее проблема с осадком сточных вод - неизбежным и накапливающимся видом отхода. В перспективе с развитием локальных очистных сооружений на предприятиях, с появлением отдельной ливневой канализации осадок может стать чище.

Эффективным практическим выходом представляется контролируемое использование осадка в качестве удобрений под культуры непищевого профиля на специально выделенных территориях и в специально организованных сельскохозяйственных предприятиях. Принципиальных препятствий к созданию таких хозяйств не имеется. Их появление локализует загрязнение и предотвратит его стихийное рассеяние.

, Применение промышленных отходов в сельском хозяйстве требует индивидуального исследования состава отхода для каждого предприятия.

Необходимо провести более детальное изучение распространения элементов-примесей фосфатного сырья в отходах фосфорного производства, особенно в фосфогипсе, и проследить судьбу и влияние этих примесей при всех возможных вариантах утилизации. Особенно это важно при использовании фосфогипса в качестве мелиоранта в субаридных и аридных ландшафтах.

В поймах рек, расположенных ниже по течению промышленных городов, и орошаемых загрязненными речными водами, выявлены участки с повышенным уровнем локального загрязнения тяжелыми металлами. Для предотвращения загрязнения орошаемых угодий рекомендуется локальная очистка поливочных вод. Поля, удобренные отходами животноводческих комплексов (свиноводческих, крупного рогатого скота, птицефабрик), слабо загрязнены некоторыми элементами (2п, 5г). В этих случаях требуется проведение водоохранных мероприятий.

Сложная практическая задача возникла в связи с загрязнением сельскохозяйственных территорий выбросами промышленных производств и автотранспорта. Учет таких территорий 
сейчас не ведется и известны лишь отдельные примеры, главным образом, для заводов цветных металлов, из которых следует необходимость гигиенической оценки сельскохозяйственной продукции в зонах воздействия.

Необходимо организовать планомерные и детальные (1:100001: 25 000) геохимические съемки вокруг всех предприятий, имеющих выбросы тяжелых металлов. Площадь съемки не менее 2-3 км от источника выброса, а для особенно крупных источников - до 10 км. Особенно важно оценить санитарно-защитные зоны, широко используемые под огороды и садовые участки.

При исследованиях важно учитывать не только концентрации отдельных элементов, но и суммарное воздействие комплекса загрязняющих веществ. Методики учета суммарного загрязнения почв разработаны еще плохо. В вопросе контроля за состоянием сельскохозяйственных почв существуют и некоторые другие трудности, в частности, малое количество химических элементов, для которых разработан норматив (ПДК), особенно для подвижных соединений. Это, однако, не снижает актуальности самой постановки задачи по геохимической оценке окультуренных почв.

Гл а в а 5

\section{ГЕОХИМИЧЕСКОЕ ИЗУЧЕНИЕ ГОРНОПРОМЫШЛЕННЫХТЕРРИТОРИЙ}

Горнорудная промышленность является одним из наиболее мощных факторов антропогенного преобразования окружающей среды. Это проявляется прежде всего в изъятии и механическом повреждении значительных массивов земель. Специфика добычи и обогащения руд заключается в извлечении и переработке огромных масс горных пород. Современная технология позволяет использовать лишь небольшую часть извлекаемой массы пород (как правило, несколько процентов). Все остальное накапливается в виде отходов, рассеиваемых природными миграционными процессами и являющихся источниками загрязнения окружающей среды химическими элементами.

Процессы загрязнения окружающей среды интенсивно проявлены в связи со всеми видами горнодобывающей деятельности. Опасность загрязнения токсичными химическими элементами наиболее велика для территорий добычи рудно-минерального сырья. Отрицательные воздействия угле- и нефтедобычи, очень специфичны по своим геохимическим проявлениям; детально изложены в специальных работах.

Эколого-химические исследования горно-рудных территорий рассматриваются в двух аспектах. Во-первых, с позиции оценки 

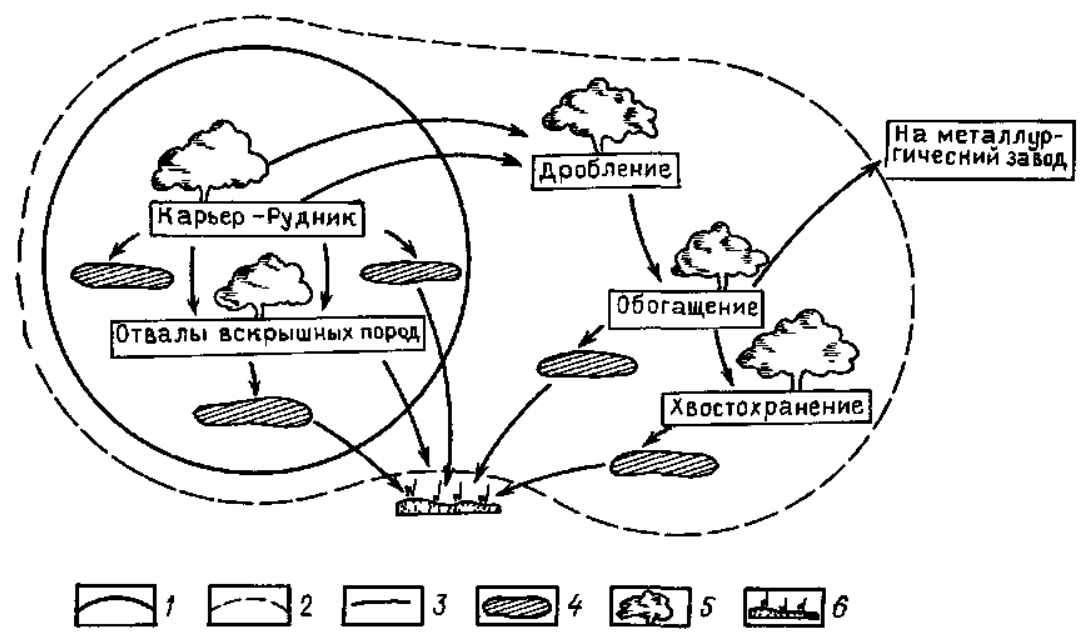

Рис. 90. Геохимические цепи воздействия горнорудной промышленности:

1 - природные геохимические аномалии во всех природных средах (зоны ограничения строительства, сельского хозяйства, водопользования), $2-$ техногенные геохимические аномалии в почвах и растениях, потоках рассеяния в водотоках и водоемах (зоны ограничения при функциональном планировании территорий), 3 - транспортировка руды и пород, 4 - твердый и жидкий сток водотоков и сброс рудничных вод в водотоки и водоемы, 5- пылегазовые выбросы в атмосферу, 6 - полив сельскохозяйственных угодий водами загрязненных рек и применение отходов в качестве удобрений (зона контроля сельскохозяйственной продукции и ограничений в использовании отходов и водопользования)

состояния окружающей среды горнопромышленных районов и, во-вторых, создания геохимических основ изучения таких территорий для прогнозирования отрицательного воздействия новых, разведуемых месторождений полезных ископаемых. Второй аспект представляется нам особенно важным. Геологоразведочные работы на месторождениях - именно тот этап, на котором удобнее и рациональнее всего получить информацию, предопределяющую экологическую обстановку на осваиваемой территории.

При проектировании предприятий, особенно при разработке функциональной структуры использования территорий, их экологическая специфика практически не учитывается. Это связано с недостаточной информированностью проектирующих освоение месторождений организаций о вероятном характере загрязнения среды химическими элементами, обусловленного геолого-геохимическими особенностями месторождения и обрамляющей его территории.

Экологические проблемы, вызванные деятельностью горнообогатительных комбинатов, обусловлены как составом перерабатываемых руд и горных пород, так и технологией их добычи и обогащения. Экологические проблемы повсеместно носят комп- 
лексный характер. Это заключается во включении в техногенные миграционные потоки всех основных цепей распространения загрязняющих веществ: воздушной (дробление, обогащение, хранение отходов) и водной (водоотведение, сток с хвостохранилищ, технологические стоки при обогащении). Для ГОКов с открытой разработкой особенно актуальны проблемы, касающиеся воздушной цепи.

Экологические проблемы, связанные с природными геохимическими аномалиями в горно-рудных районах, возникают только в случае сельскохозяйственного, селитебного и водохозяйственного использования территории.

Комплексные геохимические исследования по оценке состояния окружающей среды на ряде полиметаллических, медно-колчеданных, редкометальных и других месторождений показывают, что наиболее интенсивное загрязнение окружающей среды связано со следующими миграционными цепями (рис. 90):

1. Пылевые выбросы при открытых горных разработках, загрязняющие атмосферный воздух и образующие контрастные и значительные по площади геохимические аномалии в почвах.

2. Дефляция и размывание хвостохранилищ обогатительных фабрик, образующие интенсивные потоки рассеяния в водных системах и сравнительно локальные ореолы рассеяния в почвах.

3. Стоки водоотлива из подземных горных выработок, карьеров, образующие интенсивные и протяженные потоки рассеяния в водных системах.

4. Стоки обогатительных фабрик после очистных сооружений, загрязняющие водные системы.

5. Рассеяние рудного материала при транспортировке, загрязняющее почвы.

6. Организованные и неорганизованные выбросы в атмосферу при процессах обогащения.

7. Природные геохимические аномалии - вторичные ореолы рассеяния в почвах, потоки рассеяния в поверхностных водотоках, гидрогеохимические аномалии в подземных водах.

\section{1. РУДНЫЕ МЕСТОРОЖДЕНИЯ КАК ИСТОЧНИКИ ЗАГРЯЗНЕНИЯ}

О составе потоков загрязняющих веществ, которые начнут формироваться с началом добычи и обогащения руд разведуемого месторождения, можно судить по распределению химических элементов в рудах и первичных ореолах. Эти же данные определяют общий характер природных геохимических аномалий и ландшафтах изучаемого рудного поля.

Многолетний опыт геохимических исследований месторождений показывает, что в подавляющем большинстве случаев промышленно ценные рудные тела не имеют физических границ и выделяются по уровню содержаний химических элементов, огра- 
ничивающих блоки пород экономически и технологически эффективные для извлечения и обогащения полезных компонентов при сложившейся конъюнктуре и существующем уровне технических возможностей. Обрамляющие рудные тела горные породы содержат достаточно высокие уровни концентраций химических элементов, которыми фиксируются первичные ореолы месторождений. Пространственные размеры первичных ореолов и количество заключенных в них запасов химических элементов обычно превышают параметры самих рудных тел [5].

В состав первичных ореолов входят как главные рудные элементы, определяющие промышленный тип месторождения, так и ряд сопутствующих элементов, многие из которых являются экологически токсичными и гигиенически опасными. Обычно приводимые списки ассоциаций химических элементов в первичных ореолах с рассматриваемых нами позиций не вполне полны, так как ориентированы лишь на перечень элементов, используемых как индикаторы при поисках месторождений. Они должны быть дополнены химическими элементами, являющимися примесями в рудах. Это главным образом рассеянные элементы - In, Se, Te, Cd (который не всегда изучается в ореолах), а также некоторые элементы, составляющие макрооснову руд - Pe, 5.

В силу горно-технических особенностей первичные ореолы, как правило, при добыче составляют большую часть так называемых «пустых» пород, формирующих наиболее объемные породные отвалы (связанные с проходкой полевых выработок, стволов, или вскрышными работами). Таким образом, данные по параметрам распределения и запасам химических элементов в первичных ореолах с учетом данных по формам их нахождения и вероятной подвижности в физико-химических условиях дневной поверхности позволяют дать прогнозную оценку таких отвалов как источников загрязнения и предусмотреть необходимые меры по их безопасному размещению, экранированию и рекультивации.

Данные по химическому составу рудных интервалов приближенно-количественно соответствуют составу пылей, выбрасываемых в атмосферу в процессах механического дробления руд и, следовательно, определяют токсичность выбросов и гигиенические параметры рабочих мест в дробильных отделениях. Эти же данные качественно характеризуют возможный состав отходов обогащения, накапливаемых в хвостохранилищах (один из наиболее опасных видов отходов в горно-рудных районах).

К сожалению, опыт эколого-геохимических оценок горно-промышленных районов невелик; не по всем месторождениям имеются одинаковые по полноте материалы, что сильно сказывается на выводах.

Для одного из разведуемых колчеданно-полиметаллических месторождений обобщение данных по составу руд и отходов, 
Т а блиц а 88 Химические элементы в рудах и отходах колчеданно-полиметаллического месторождения

\begin{tabular}{l|c|c|c|c|c}
\hline \multirow{2}{*}{$\begin{array}{c}\text { Химический } \\
\text { элемент }\end{array}$} & \multicolumn{2}{|c|}{ Рудная масса } & \multicolumn{3}{c}{ Отходы } \\
\cline { 2 - 6 } & $x$, г/т & $\mathrm{K}$ & $x$, г/Т & $\mathrm{K}_{\mathbf{c}}$ & $\mathrm{P}$ \\
\hline Висмут & 40 & 4400 & 30 & 3300 & 37 \\
Теллур & 1 & 1000 & 1 & 1000 & 1,2 \\
Цинк & 66700 & 804 & 3000 & 36 & 3700 \\
Кадмий & 100 & 770 & 30 & 230 & 37 \\
Свинец & 11900 & 740 & 1500 & 94 & 1850 \\
Мышьяк & 1000 & 590 & 200 & 120 & 246 \\
Сера & 192000 & 400 & 1390 & 3 & 1712 \\
Серебро & 16 & 230 & 10 & 137 & 12 \\
Селен & 2 & 40 & 1 & 20 & 1,2 \\
Марганец & - & - & 10000 & 10 & 12360 \\
& & & & &
\end{tabular}

Примечание $\mathrm{Kc}$ - коэффициент концентрации по огношению к местному фону, $\mathrm{P}-$ за пасы элемента в отходах, образующихся за 1 год работы ГОКа, т

показало наличие очень высоких уровней концентрации широкого спектра химических элементов (табл. 88). В рудах содержание Вi, Те и, что особенно важно, таких токсичных элементов как Cd, Рb, As, 5 в сотни раз выше фонового уровня. Естественно, что при дроблении они будут переходить в атмосферный воздух. Простые расчеты показывают, что при загрязнении воздуха пылью на уровне 4-5 предельно-допустимых концентраций

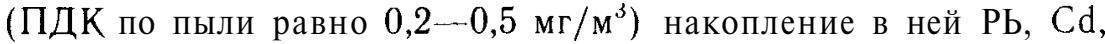
As значительно превзойдет их ПДК в воздухе. Опыт работ многих комбинатов показывает, что зоны с таким превышением ПДК по пыли обычны и закладываются в проектные расчеты, но часто без учета ее состава. Как правило, они занимают территорию в радиусе $1-3$ км.

Данные по хвостам обогащения, складирование которых предполагается в водосбросе крупного водоема питьевого и рыбохозяйственного назначения, показывают, что и для них сохраняется высокая степень концентрации ряда элементов (особенно $\mathrm{Cd}, \mathrm{Pb}, \mathrm{As}, \mathrm{Te}, \mathrm{Bi})$. При планируемых объемах добычи в хвостохранилищах ежегодно должны накапливаться большие запасы химических элементов. Таким образом, для водных систем рассматриваемого района можно предположить формирование контрастных потоков рассеяния широкого комплекса токсичных элементов.

В «породных» отвалах содержания химических элементов бывают сильно повышены. Особенно это касается отвалов разработок прошлых лет, когда выбирались руды со значительно более высокими концентрациями, чем сейчас. Например, в работе Девиса сведены данные по средним содержаниям цветных металлов в отвалах ряда полиметаллических месторождений США, Великобритании, Африки: содержания свинца в отвалах состав296 
ляют сотни и тысячи мг/кг (до 1,4\% в Уэльсе), цинка - тысячн. мг/кг (до 3\%), меди - сотни и тысячи мг/кг.

Для ряда оловорудных месторождений сульфидно-касситеритовой формации, где технологической схемой переработки предусмотрено только получение оловянного и свинцового концентратов, геохимическими работами установлено присутствие очень значительных количеств широчайшей ассоциации элементов-примєсей (особенно $\mathrm{Hg}, \mathrm{Bi}, \mathrm{Pb}, \mathrm{As}, 5 \mathrm{~b}, \mathrm{~B})$, содержания которых в сотни, тысячи и десятки тысяч раз выше фоновых. Подавляющая часть примесей не концентрируется ни в одном из продуктов обогащения, что определяет особую токсичность пылевых выбросов и отходов. Выход готового концентрата составляет всего 4\% перерабатываемой массы горных пород.

Известно, что в отвалах оловянно-полиметаллических месторождений в верхнем слое образуется зона выщелачивания (3040 см), обедненная рудными элементами и железом. Породы отвала в верхних горизонтах характеризуются также низкими pH водной вытяжки $(3,5-4,5)$. В нижних горизонтах отмечается обогащение гидроксидами F и $\mathrm{Mn}$ и иногда формируется зона скопления гипса.

В почвах, погребенных под отвалами, происходит ощутимая геохимическая трансформация. Так, в почвах, погребенных более 20 лет, происходит сильное подкисление всей толщи профиля (pH до 3,5-4,0), разрушаются почвенные коллоиды, нарушается почвенный поглощающий комплекс, увеличивается подвижность органического вещества, происходит вынос Сa и $\mathrm{Mg}$ из гумусового горизонта. Горизонты почв обогащаются рудными компонентами, глубина проникновения которых для различных химических элементов неодинакова. Все это свидетельствует о подвижности химических элементов в отвалах, которые часто практически не изолированы от водных систем и могут оказывать воздействие на территорию подсобных хозяйств ГОКа, в зоне воздействия выбросов и отходов хранилищ. Не учтены эти обстоятельства и при размещении рабочих поселков ГОКов.

Разведуемое месторождение медистых песчаников концентрирует в рудах лишь Си, Ре, 5 и Ag (вполне вероятные элементыпримеси - 5e, Te, As - не изучены). По предварительной технологии из руд будут получать медный и магнетитовый, а также карбонатный концентрат, соответствующий по техническим условиям флюсовым известнякам. Отвальные хвосты составят 85$89 \%$ исходной руды. Они будут иметь преимущественно алюмосиликатный состав и содержать около 1300 г/т сульфидной меди (в 28 раз выше фона) и значительное количество сульфидов железа. Хвосты планируется разместить на водосброce крупной водной системы рыбо-хозяйственного и питьевого пользования. При планируемых объемах добычи ежегодно в хвосты будут поступать значительные абсолютные массы меди. 
Т а б ли ц а 89 Состав исходной руды железорудных месторождений

\begin{tabular}{|c|c|c|c|c|}
\hline \multirow{3}{*}{ Элемен г } & \multicolumn{4}{|c|}{ Месторождения } \\
\hline & \multicolumn{2}{|c|}{ магнетитовых руд } & \multicolumn{2}{|c|}{ борато магнетитовых руд } \\
\hline & $x, \Gamma / \mathrm{T}$ & $K_{\text {r }}$ & $X, \Gamma / \mathrm{T}$ & $\mathrm{K}_{\mathrm{c}}$ \\
\hline Cepa & & & 20000 & 42,5 \\
\hline Ванадий & 308 & 3,4 & - & - \\
\hline Хром & 170 & 2,0 & - & - \\
\hline Марганец & 1550 & 1,5 & - & - \\
\hline Кобальт & 386 & 21 & 945 & 52,5 \\
\hline Медь & 1100 & 24 & 425 & 9 \\
\hline Цинк & 900 & 10,8 & & - \\
\hline Молибден & - & - & 105 & 95 \\
\hline Вольфрам & - & - & 200 & 154 \\
\hline
\end{tabular}

Примечание Кс - коэффициент концентрации по отношению к местному фону, в материале из хвостохранилищ борато-магнетитовых руд обнаружены высокие концентрации As и TR - Кг соответственно 59 и 5,4

Ландшафтно-геохимический анализ ситуации показывает, что с учетом малокарбонатного состава хвостов в данном случае весьма вероятно окисление в них сульфидной меди до хорошо растворимой сульфатной формы с образованием потока рассеяния. Напомним, что медь - элемент не очень токсичный в питьевых водах, но исключительно токсичный для гидробионтов.

Железорудные месторождения по относительному уровню концентрирующих в рудах элементов-примесей часто не проявляются особенно контрастными геохимическими аномалиями. Обычно наиболее значимым химическим элементом в рудах, приносящим ущерб окружающей среде, является сера, присутствие которой (до $10-20 \%$ ) при проведении агломерации концентратов приводит к выбросу сернистых соединений в атмосферу.

Тем не менее, разнообразие типов месторождений железа обусловливает пеструю картину микроэлементной ситуации в рудах. Кроме того, обычные для этих месторождений огромные объемы извлекаемых и перерабатываемых горных пород приводят даже при небольшом уровне относительного накопления элементов-примесей к появлению значительных абсолютных масс химических элементов в отходах добычи и обогащения, а также в выбросах при металлургическом переделе.

В качестве примера приведем данные по содержаниям микроэлементов для двух месторождений в древних толщах: 1) месторождение легкообогатимых богатых магнетитовых руд; 2) месторождение борато-магнетитовых руд (табл. 89).

В рудах месторождения первого типа постоянно присутствуют Си, Co, 2п, V, Cr, содержания которых значительны. Борато-магнетитовые руды содержат более широкий круг химических элементов: Pe, B, As, Сг, TR, Co, W, Си. Хвосты обогащения составляют 298 
$15-52 \%$, т. е. при переработке руд этого типа будут накапливаться значительные их объемы и, соответственно, большие количества химических элементов.

В настоящее время не разработаны стандартизованные методы прогноза поведения химических элементов первичных ореолов и руд после их извлечения и перемещении в отвалы добычи и обогащения. Большинство интересующих нас химических элементов присутствует в горных породах в сульфидных формах. В условиях дневной поверхности они начинают испытывать активное воздействие агентов химического и микробиологического выветривания. При этом миграционная подвижность продуктов выветривания обусловлена прежде всего количеством сульфидов (и, следовательно, образующейся при их окислении серной кислоты - наиболее активного агента, переводящего тяжелые металлы в подвижные формы), а также сорбционными, нейтрализующими и осадительными свойствами вмещающих оруденение горных пород. Во многих случаях содержания сульфидов в отходах (особенно, в хвостах) превышают 10-20\% при содержании металлов (Pb, Zn, Cu), в десятки и сотни раз выше фоновых. Выщелачивание химических элементов в хвостохранилищах интенсифицируется также кислотными остатками флотоагентов, поступающих вместе со сбросными водами.

Изучение на месторождениях поведения химических элементов в естественных корах выветривания позволяет дать прогноз их поведения в отвалах. В геохимической литературе эти вопросы достаточно полно освещены [41].

В разрезе зоны гипергенеза рудных месторождений четко прослеживается дифференциация ассоциаций химических элементов в зависимости от характера вертикального профиля коры выветривания, типа вмещающих пород и степени концентрации сульфидов.

Сравнение интенсивности процессов перераспределения элементов в горизонтах окислительного типа в ряду вмещающих пород «силикатные (кремнистый тип коры выветривания) -'алюмосиликатные (глинистый тип коры) - карбонатные (карбонатно-глинистый тип коры) » показывает, что для первичных ореолов и руд существуют контрастные и однонаправленные тенденции в изменении характера перераспределения типоморфных элементов.

Для пород кремнистого состава при выветривании часто наблюдается резкая дифференциация в поведении химических элементов. Многие элементы очень подвижны и энергично выносятся ( $\mathrm{Zn}, \mathrm{Co}, \mathrm{Cu}, \mathrm{Cd}, 5 \mathrm{e}-$ почти всегда; РЬ и As - часто, особенно при обилии пирита). Другие элементы (в частности, Мо, $\mathrm{Ag}, \mathrm{Ba})$ накапливаются чаще всего вместе с гидроксидами Ре.

В породах алюмосилнкатного состава, для которых характерно образование глинистых кор выветривания, подвижность мно- 
гих химических элементов уменьшается в связи с появлением сорбционного барьера. В условиях выветривания первичных ореолов (вкрапленный характер проявления минерализации) даже цинк часто становится малоподвижным. Лишь для анионогенных элементов (селен, теллур) наблюдается энергичный вынос. Однако это уменьшение подвижности наблюдается далеко не всегда, оно обусловлено временными соотношениями между процессами образования глинистых минералов и окислительным разрушением сульфидов.

Для пород карбонатно-глинистого состава тенденция уменьшения подвижности химических элементов проявлена очень контрастно. Даже в условиях выветривания сравнительно богатых руд большинство химических элементов ведет себя инертно.

Техногенное воздействие на месторождение приводит к резкому (до 10 раз) увеличению зоны гипергенеза. Такие явления наблюдались, например, В. Н. Авдониным на Красногвардейском медно-колчеданном месторождении на Урале, а также В. П. Постниковой и Л. К. Яхонтовой на сульфндно-касситеритовых месторождениях Комсомольского оловорудного района [26].

В отвалах интенсивность процессов выветривания многократно усиливается. Это связано с их высокой проницаемостью для агентов выветривания и хорошими условиями для удаления растворимых продуктов выветривания, не успевающих осадиться на геохимических барьерах. Это, собственно, и приводит к загрязнению окружающей среды.

В отвалах при их изменении новейшим выветриванием так же как и в коренных породах образуется профиль с вертикальной зональностью окислительно-восстановительного типа [26]. В работе Девиса [26] приводятся данные по формированию поверхностной зоны окисления в погребенной зоне восстановления, что и определяло распределение химических элементов в отвалах.

Таким образом, геохимическое исследование первичных ореолов и руд, их поведение в процессах выветривания дают возможность для многоаспектной интерпретации данных в природоохранных целях.

\section{2. ПРИРОДНЫЕ И ТЕХНОГЕННЫЕ АНОМАЛИИ В ГОРНОРУДНЫХ РАЙОНАХ}

\section{Выбросы в атмосферу}

Источником загрязнения атмосферного воздуха в горно-добывающей промышленности являются технологические процессы, приводящие к образованию больших масс пыли. Это буро-взрывные работы при открытых разработках, процессы дробления руд при обогащении и дефляции отвалов, отходов обогащения и добычи. Высокий уровень загрязнения воздуха возникает также на 
участках транспортировки и выгрузки на приемных пунктах или отвалах. Особенно загрязненный воздух отмечается в глубоких карьерах, где смесь газов автомобильных выбросов и минеральной пыли формирует так называемый «карьерный смог». В условиях штиля этот смог распространяется над обширными площадями прикарьерной территории. Объемы рассеиваемых в воздухе пылевых масс даже на ГОКе средней производительности составляют сотни и тысячи тонн в год, что эквивалентно выбросу крупного промышленного комбината. Так, при массовом взрыве на карьере $150-200$ т пыли поднимается на высоту $150-250 \mathrm{M}$.

В районе перечисленных источников загрязнения мощные пылевые выбросы обусловливают превышение нормативных показателей состояния воздуха по концентрации пылевых частиц в зоне от 1 до $3-5$ км.

По данным И. Н. Волковой и Н. С. Казанской, при взрывных работах на Михайловском месторождении железных руд (Курская обл.) пыль оседает в радиусе 3-6 км от карьера, а распыление руды на открытых складах наблюдалось в атмосфере в радиусе I км. Концентрация пыли в воздухе в зоне воздействия карьеров сильно варьирует во времени. В среднем она составляет $0,3-2,0 \mathrm{мг} / \mathrm{M}^{3}$ (до $\left.4-5 \mathrm{мг} / \mathrm{m}^{3}\right)$, что в 2-13 раз выше ПІДК $\left(0,15 \mathrm{Mr} / \mathrm{M}^{3}\right.$ среднесуточная) и на $2-3$ порядка выше фонового уровня $\left(0,001 \mathrm{Mr} / \mathrm{M}^{3}\right)$.

В процессах измельчения участвует вся масса руд (дробление) или руды и вмещающих пород (буро-взрывные работы). В первом приближении, состав пыли должен отвечать составу исходных пород, хотя, разумеется, избирательное измельчение тех или иных минералов может изменить соотношение между химическими элементами. Данных такого рода немного, тем не менее все они показывают очень контрастное обогащение пыли химическими элементами (табл. 90). Мы видим во всех видах выбросов сходство общей ассоциации концентрирующихся хими-

Т а блиц а 90. Ассоциации химических элементов в пылях молибден-вольфрамового ГОКа




ческих элементов (за исключением участка сульфидных концентратов, где появляется очень токсичный кадмий, отсутствующий в других пылях). В то же время степень концентрации элементов по видам пылей варьирует, а, главное, максимальные накопления характерны не для основных промышленных элементов (Mо и W), а для элементов-спутников (B1, 5b, Аз, Рb).

Площадь атмогеохимических аномалий в районе горно-промышленных комбинатов Южного Приморья, по исследованиям A. Н. Қачура, превышает 40 км². В зоне максимальных выпадений на расстоянии до 2 км от источников свинца выпадает в $10000-50000$ раз, цинка и кадмия - в $100-200$, меди и серебра - в 50-100 раз больше, чем на фоновых территориях. Содержание тяжелых металлов в поверхностных горизонтах почвы увеличено в десятки раз.

Учет состава пыли, концентрирующей широкую ассоциацию токсичных химических элементов, расширяет зоны неблагоприятного воздействия. Однако обобщающие материалы, регистрирующие фактические размеры таких зон по прямым замерам воздуха для разных типов месторождений и условий добычи и переработки руд, практически отсутствуют. Такие обобщения требуют синхронного долговременного динамического изучения концентрации широкого спектра металлов в воздухе на различных расстояниях от источника выбросов, которое пока не проводится.

В то же время данные геохимического картирования почв и снегового покрова выявляют четкие техногенные геохимические аномалии, связанные с выпадением на дневную поверхность материала выбросов. Эти аномалии фиксируют зону влияния источников выбросов, а также состав и соотношения наиболее характерных загрязняющих веществ. Как правило, в них обнаруживается весь комплекс главных рудных элементов и элементов-примесей руд.

В горно-промышленных районах аэрогенные аномалии так же как и в городах имеют четко выраженный градиент концентрации от центра к периферии. Центральные части аномалий приурочены К источнику выбросов. В их пределах уровни содержаний элементов-загрязнителей в десятки и сотни раз превышают фоновые параметры. Размеры центральных частей аномалий достигают нескольких квадратных километров (обычно не более $10 \mathrm{~km}^{2}$ ).

Морфология зон воздействия выбросов несложна и зависит от рельефа В расчлененных районах наиболее интенсивные участки аномалий целиком локализованы в пределах горно-долинных ландшафтов, в которых расположены источники выброcoB.

На рис. 91 показан характер распространения выбросов карьера молибден-вольфрамового ГОКа в горном ландшафте, установленный геохимическим картированием выпадений, уловленных снеговым покровом. Мы видим, что облако интенсивных 



Рис. 91. Интенсивность среднесуточного выпадения пыли (в кг/км $\left.{ }^{2}\right)$ и химических элементов (в r/км ${ }^{2}$ ) в зоне воздействия карьера в горном ландшафте (А - поперечный профиль через долину, Б - продольный профиль)

выпадений локализуется в долине, на склоне которой расположен карьер, и не выходит за водораздел. Оно целиком накрывает поселок, расположенный в $1-2$ км от карьера, где уровни выпадений пыли и рудообразующих металлов (в данном случае изучались только они) примерно в 50 раз выше фоновых. В продольном профиле долины зона аномальных выпадений растянута значительно дальше, и фоновые параметры достигаются лишь в 10 км от карьера Мощность выброса карьера в рассматриваемом случае очень велика (масса выпадений в районе карьера 16 т на 1 км $^{2}$ в сутки, что в 800 раз выше фоновой). В этой связи в распределении выпадений влияние обогатительной фабрики и отвалов, расположенных соответственно в 1,5 и 3,0 км от карьера, почти не сказалось. Тем не менее, все эти объекты четко фиксируются по результатам опробования почв.

Воздействие обогатительных фабрик может быть очень интенсивным. Это, в частности, демонстрируется данными по фабрике, ежегодно с 1924 г. перерабатывающей около 0,5 млн т полиметаллических руд. Фабрика расположена в горной долине на значительном удалении от добывающих предприятий Жилой поселок расположен в непосредственной близости. Геохимическое картирование почв, проведенное И. В. Токаревым и Г. А. Тимошкиным, показывает, что за годы работы здесь образовалась протяженная (более 10 км) и очень интенсивная комплексная по составу техногенная геохимическая аномалия (табл. 91). В состав аномалий входят все основные элементы перерабатываемых руд и, в частности, такие токсичные, как Pb, Cd, Co, а также Ag, 2п, Си, Bi и др. Весь выявляемый комплекс уста- 
Т а бли ц 91 Интенсивность загрязнения почв химическими элементами вблизи обогатительной фабрики

\begin{tabular}{|c|c|c|c|c|c|c|}
\hline Элемент & $\mathrm{C}_{1}$ & $\begin{array}{c}\text { Площадь } \\
\text { аномалии } \\
\text { км}^{2}\end{array}$ & $\mathrm{C}_{2}$ & $K_{c}$ & $C_{3}$ & $\mathrm{Kc}$ \\
\hline Свинец & 50 & 3,9 & 1100 & 22 & 10000 & 125 \\
\hline Серебро & 0,1 & 2,5 & 2,1 & 21 & 20 & 200 \\
\hline Цинк & 140 & 1,6 & 2250 & 24 & 10000 & 71 \\
\hline Медь & 30 & 1,5 & 290 & 10 & 2000 & 67 \\
\hline Кадмий & 1 & 1,0 & 12 & 12 & 50 & 50 \\
\hline Висмут & 1 & 0,9 & 8 & 8 & 50 & 50 \\
\hline Кобальт & 12 & 0,4 & 24 & 2 & 40 & 3 \\
\hline Молибден & 2 & 0,3 & 8 & 4 & 20 & 10 \\
\hline Олово & 5 & 0,3 & 34 & 7 & 40 & 8 \\
\hline Барий & 300 & 0,3 & 1034 & 3 & 2000 & 7 \\
\hline Вольфрам & 2 & 0,05 & 11 & 5 & 30 & 15 \\
\hline Сурьма & 10 & $\begin{array}{l}\text { Единичные } \\
\text { пробы }\end{array}$ & - & - & 30 & 5 \\
\hline Индий & 1 & $\ll$ & - & - & 5 & 5 \\
\hline Мышьяк & 50 & $\ll$ & - & - & 200 & 4 \\
\hline
\end{tabular}

Примечание С] $\mathrm{C}_{2}$ и $\mathrm{C}_{3}$ - соответственно фоновое содержание, среднее содержание в пределах аномалии и максимальное содержание на территории жнлого поселка, мг/кг, $\mathbf{K}_{c}-$ коэффициент концентрации относительно фонового содержания

навливается лишь в сравнительно локальной $(1,0-1,5$ км) зоне вблизи фабрики. Однако именно в этой зоне расположен поселок Главный элемент перерабатываемых руд - свинец - интенсивно проявлен в значительно более широкой (10 км) зоне воздействия Пространственная структура зоны определяется геоморфологией долины (рис 92) При проектировании и строительстве горно-обогатительных комбинатов особенности техногенной миграции загрязняющих веществ практически не учитываются, многие поселения, сельскохозяйственные угодья и водные объекты попадают в зоны интенсивного загрязнения окружающей среды

\section{Загрязнение поверхностных водных систем стоками}

В горнодобывающих районах резко меняются характер и интенсивность поставки химических элементов в водотоки. Это обусловливается изменением условий и соотношения механической и водной миграции, вызванных перемещением больших масс горных пород и их последующим перераспределением в отвалах под действием гравитационных процессов, разрушением хвостохранилищ под действием экзогенных факторов, сливами с рудников, обогатительных фабрик и хвостохранилищ, поверхностным стоком с территорий горных отводов Различные виды сливов - основной источник поступления техногенных веществ в водотоки 




Рис. 92. Распределение содержаний свинца, цинка и кобальта в почвах вблизи обогатительной фабрики:

1 - жилая и промышленная застройка, 2 - обогатительная фабрика, 3 - хвостохранилище, 4 - река, 5-8- почвы с различным содержанием (в $\left.\mathrm{K}_{c}\right) \mathrm{Pb}, 2$, $\mathrm{Co}$ $5-160-300$ РЬ, 350-700 2п, 21-30 Со, 6-300-600 РЬ, 700-1400 2п, $30-60$ Со, $7-600-3000$ РЬ, $1400-70002$ п, 60-300 Со, $8-3000$ и более РЬ, 300 и более Сo, 9 - почвы с фоновыми содержаниями РЬ (80), 2п (140), Со (12)

Большую роль в поставке химических элементов в водные системы играет отмечавшееся выше техногенное усиление процессов выветривания на разрабатываемых месторождениях На Красногвардейском месторождении, например, В Н Авдонин наблюдал герметично закрытую горную выработку, стенки которой были покрыты новообразованными хорошо растворимыми 
Т а бли ц 92 Химические элементы в сливных рудничных водах, мкг/л

\begin{tabular}{|c|c|c|c|c|c|c|c|c|}
\hline Месторождение & $\mathrm{Mn}$ & $\mathrm{Pe}$ & Co & N1 & Си & $\mathrm{Zn}$ & $\mathrm{Cd}$ & $\mathrm{Pb}$ \\
\hline Сульфидное, Николаев- & 15000 & 30000 & 300 & 50 & 16000 & 125000 & 500 & 200 \\
\hline $\begin{array}{l}\text { Сульфидное, Колыван- } \\
\text { ское, Западный Алтай }\end{array}$ & 6000 & 6000 & 70000 & 10000 & 6000 & 6000 & 170000 & 30 \\
\hline $\begin{array}{l}\text { Сульфидное, Змеиногор- } \\
\text { ское, Западный Алтай }\end{array}$ & 2000 & 2000 & 20 & 14 & 300 & 2200 & 200 & 40 \\
\hline $\begin{array}{l}\text { Золоторудные, ЮАР, мак- } \\
\text { симальные содержания }\end{array}$ & 4000 & 3000 & 3900 & 15900 & 5400 & 26000 & 52 & 290 \\
\hline $\begin{array}{l}\text { Средний состав вод зоны } \\
\text { гипергенеза }\end{array}$ & 547 & 49,4 & 3,31 & & 5,58 & 34 & 0,33 & 2,21 \\
\hline
\end{tabular}

минералами: мелантеритом, пизанитом, глоккеритом, самородной серой и др.

По расчетам за счет химического разубоживания за год было вынесено 170 т серы халькопирита и более 500 т серы пирита. За срок наблюдения потери меди составили $1,82 \%$, а цинка - 4\%.

Изучение баланса меди, поступившей в водотоки с одного из медно-колчеданных месторождений, показало, что за период эксплуатации (1935-1983 гг.) рудничными водами вынесено более 50 тыс. т меди, причем 2/5 этого количества поступило в окружающую среду. В настоящее время на данном руднике извлекается только медь. Все остальные компоненты (широкая группа микроэлементов), содержащиеся в рудничных водах, поступают в речную сеть. Аналогичная ситуация наблюдается на многих других месторождениях, где сопутствующие элементы часто дают уровень загрязнения, превышающий таковой для извлекаемых элементов.

Значительная часть периодически сбрасываемых стоков приходится на сливы рудничных вод и сливы с хвостохранилищ (табл. 92). Существенным источником загрязнения является поверхностный сток с породных и рудных отвалов, дорог и других объектов в пределах горных отвалов. Характернейшая особенность стоков - резкое обогащение их взвешенным твердым веществом, играющим существенную роль в техногенной миграции элементов. Содержание твердых взвесей в стоках может достигать десятков грамм на литр, т. е. на два - три порядка превышать мутность природных водотоков.

Для водотоков в зонах влияния ГОКов характерно резкое повышение содержаний $\mathrm{Na}, \mathrm{K}, \mathrm{N}$, фосфатов (влияние бытовых стоков), взвешенных веществ, Са и хлоридов (влияние промышленных стоков). Подобные изменения, характерные для многих ГОКов, отмечались в районе предприятия по добыче и обогащению вольфрам-молибденовых руд. Высокие содержания хлоридов и кальция связаны с использованием хлорной извести при очистке жидкой части хвостов от флотореагентов. Отмечены" 
также высокие содержания нефтепродуктов и различных органических веществ, применяемых в качестве агентов флотационного обогащения.

Для районов ГОКов характерны резкие пространственно-временные изменения кислотно-щелочных условий поверхностных вод, что приводит к заметной перестройке условий миграции химических элементов. Так, при опробовании реки, на которой расположен уже упоминавшийся ГОК по добыче и обогащению вольфрам-молибденовых руд, И. А. Авесаломова установила, что в естественных условиях усложнение ландшафтной структуры в пределах высокогорного рельефа практически не сказывается на изменении величин pH и содержании гидрокарбонат-иона. Все водотоки выше ГОКа характеризуются нейтральной реакцией $(\mathrm{pH}=7,2-7,5)$. Тенденция к возрастанию обоих показателей наблюдается в районе открытых разработок, в черте города (слив из штолен), в районе хвостохранилища. Это, в частности, приводит к усилению подвижности молибдена на отдельных участках речной сети, миграционная способность которого повышается в соответствии с нарастанием $\mathrm{pH}$.

Особую опасность представляют кислые рудничные воды. Так, в районах медно-цинкового сульфидного оруденения Калифорнии в результате естественного выщелачивания руд рН вод снижается до 5-7; эти воды выносят часть рудных компонентов в природные водотоки. Активная добыча руд еще более увеличивала интенсивность выщелачивания, что привело к снижению pH природных вод до 3,5-1,4. Это обуславливает контрастное возрастание содержаний многих химических элементов в водах.

В рудных потоках рассеяния, как известно, ассоциации химических элементов хорошо коррелируют с минералого-геохимическими особенностями дренируемых месторождений. Качественный состав твердофазной и воднорастворенной составляющих потоков выдерживается на значительных площадях в соответствии с металлогеническими особенностями последних. Распределение элементов, как правило, зональное.

Характер накопления и распределения химических элементов в зонах влияния ГОКов резко меняется. Эти изменения отмечаются как для растворенной, так и для твердофазной составляющих. Меняется уровень содержаний и соотношение элементов в техногенных аномалиях. Причем, даже после прекращения функционирования ГОКов уровень загрязнения может оставаться достаточно высоким.

Так, по данным Б. А. Судова, на одном из отработанных медно-колчеданных месторождений основными объектами загрязнения являются отвалы штолен и воды, вытекающие из них (штольни пройдены в 60 -70 гг.). Уровень загрязнения и в настоящее время достаточно высок (табл. 93). В эстуарии Гоннел (Великобритания), служившем приемником сточных вод 
Т а 6 л и ц а 93. Содержания некоторых химических элементов в воде водотоков в районе бывших штолен, мг/л

\begin{tabular}{l|c|c|c|c|c}
\hline \multicolumn{1}{c|}{ Место отбора проб } & Си & $\mathrm{Zn}$ & Mo & $\mathrm{Ag}$ & $\mathrm{Pb}$ \\
\hline Штольня, устье ручья & 12 & 11 & 70 & 0,20 & 3,4 \\
Ручей: & 14 & 32 & 26 & 0,13 & 1,9 \\
$\quad 000$ м ниже штольни & 8 & 7 & 50 & 0,40 & 5,5 \\
$\quad 1000$ м ниже штольни & 7 & 7,5 & 32 & 0,28 & 10 \\
Река: & 2 & 7 & 15 & 0,25 & 2,3 \\
$\quad$ ниже ручья \\
выше ручья
\end{tabular}

свинцового рудника в 1845-1885 гг., донные отложения до сих пор являются источником загрязнения водной фазы и биоты [50] .

Сравнительная характеристика содержаний химических элементов в растворе вод рудных и техногенных потоков рассеяния показывает, что последние не уступают по контрастности (табл. 94). В обоих случаях наблюдаются превышения предельно-допустимых уровней.

Одна из главных особенностей воздействия ГОКов на характер миграции элементов - резкое увеличение доли их взвешенных форм. Это связано как со значительным увеличением мутности водотоков, так и с резким возрастанием абсолютных концентраций элементов в самой взвеси, причем последний фактор играет более существенную роль. Даже при невысокой мутности

Т а бли ц а 94. Сравнительная характеристика содержаний химических элементов в рудных и техногенных водных потоках рассеяния (растворенные формы, мкг/л)

\begin{tabular}{|c|c|c|c|c|c|}
\hline Источник загрязнения & Медь & Цинк & Мышьяк & Кадмий & Свинеи \\
\hline \multicolumn{6}{|c|}{ Месторождения } \\
\hline Сульфидные, Алтай & $1-2000$ & $10-10000$ & следы & $3-150$ & $1-20$ \\
\hline $\begin{array}{l}\text { Медноколчеданные, Южный } \\
\text { Урал }\end{array}$ & $100-5000$ & $100-5000$ & $10-20$ & 12 & $20-1700$ \\
\hline Полиметаллические, Алтай & $15-80$ & $40-500$ & 一 & - & $10-25$ \\
\hline Ртутные, Закарпатье & $10-25$ & $30-100$ & $3-12$ & - & \\
\hline $\begin{array}{l}\text { Золоторудные, Восточное } \\
\text { Забайкалье }\end{array}$ & - & $8-10$ & $20--50$ & - & $5-8$ \\
\hline \multicolumn{6}{|c|}{ Районы добычи } \\
\hline $\begin{array}{l}\text { Река ниже обогатительной } \\
\text { фабрики в районе полиме- } \\
\text { таллического месторождения }\end{array}$ & 22 & - & - & 0,5 & 10 \\
\hline $\begin{array}{l}\text { Водоток, дренирующий ста- } \\
\text { рый рудник }\end{array}$ & 10600 & 21700 & - & - & - \\
\hline $\begin{array}{l}\text { Река ниже ГОКа в районе } \\
\text { полиметаллического } \\
\text { место- }\end{array}$ & - & 1200 & 250 & - & 290 \\
\hline $\begin{array}{l}\text { рождения } \\
\text { Водоток, дренирующий руд- } \\
\text { ник по добыче полиметал- } \\
\text { лических руд }\end{array}$ & $2-10,7$ & $250-1400$ & - & $2,5-16,7$ & $20-244$ \\
\hline
\end{tabular}

Примечание «一- данные отсутствуют. 
Т а блица 95. Химические элементы во взвешенной форме водного потока рассеяния в районе ГОКа по добыче и обогащению полиметаллических руд, мкг/л

\begin{tabular}{c|c|c|c|c}
\hline Место отбора проб & Си & $\mathrm{Zn}$ & $\mathrm{Cd}$ & $\mathrm{Pb}$ \\
\hline 5 км выше ГОКа & 4,2 & 12,3 & 0,1 & 3,2 \\
1 км ниже ГОКа & 9,6 & 135,4 & 1,2 & 79,1 \\
20 км ниже ГОКа & 6,1 & 96,1 & 0,3 & 16,6
\end{tabular}

воды (на уровне фона) очень высокие абсолютные концентрации рудных элементов во взвеси приводят к контрастным техногенным аномалиям в речной сети. Это важное положение необходимо учитывать при оценках степени техногенного воздействия на водные системы.

В качестве примера рассмотрим распределение взвешенных форм химических элементов в районе влияния предприятия по добыче и обогащению полиметаллических руд. Как видим, содержание элементов во взвешенной форме значительно превышает фоновые уровни; техногенные аномалии устойчивы в пространстве (табл. 95).

Высокие содержания и огромные массы взвешенных форм химических элементов приводят к формированию очень контрастных и протяженных аномалий в донных отложениях водотоков, которые в прогнозе могут определять качество воды и служить вторичнымиисточникамизагрязнения.

На рис. 93 показано распределение химических элементов в донных отложениях горной реки, протекающей в пределах ГОКа. При входе реки в зону влияния техногенеза отмечается резкое возрастание концентрации элементов (в десятки и сотни раз превышающее содержание как фоновое, так и в природных ореолах). Контрастные аномалии прослеживаются практически по всей длине изученной реки (на 40 км) и фиксируются в реке следующего порядка.

Рис. 93. Распределение химических элементов в донных отложениях реки горно-промышленного ландшафта.

$\mathrm{K}_{\mathrm{c}}$ - коэффициент концентрации относительно фона. Римскими цифрами указано расположение: I - обогатительной фабрики, II - старого действующего хвостохранилища, III - нового действующего хвостохранилища

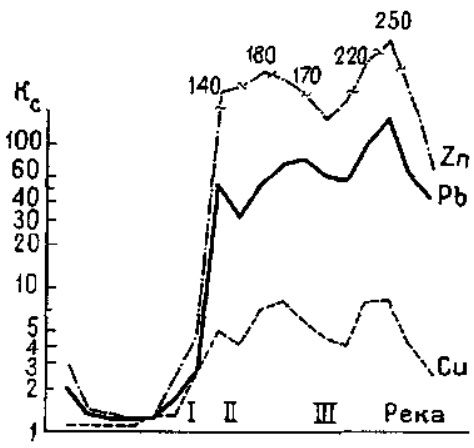


Рис. 94. Соотношение степени накопления элементов в донных отложениях в зимнюю межень (КЗ) и в летнее половодье (КЛ):

I-IV - районы реки (I - фоновые условия, II - городские районы, III район хвостохранилища, IV - район ниже хвостохранилища)

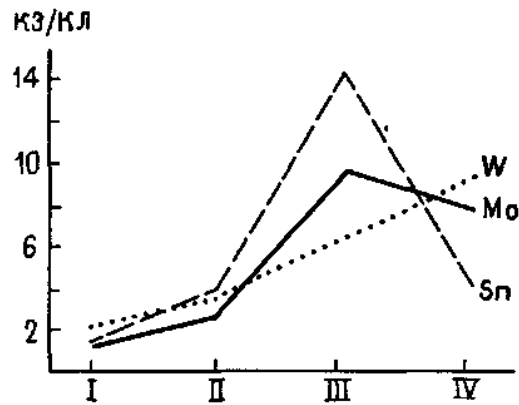

В механизме формирования техногенных потоков рассеяния в донных отложениях четко прослеживается сезонность (рис. 94). Степень накопления многих элементов в донных отложениях возрастает в зимнюю межень и снижается в период весеннего половодья. В рассматриваемом случае наибольшие расхождения наблюдаются для основных элементов сливов (Mo, W, 5п) в сфере влияния ГОК; фоновые содержания значительно меньше. Это связано с нарушением естественной годовой динамики взвешенного вещества - резкое увеличение его содержания в водах ниже сливов зимой, что не характерно для рек ледникового питания. В естественных условиях минимальные содержания взвешенного вещества наблюдаются в период зимней межени (реки находятся на грунтовом питании), максимальные - во время паводков. Более благоприятные условия для накопления в донных отложениях вблизи источников загрязнения создаются зимой, когда увеличение содержания взвешенного вещества происходит на фоне снижения расходов и скоростей течения реки.

Оценка распределения химических элементов в рудных и техногенных потоках рассеяния, формирующихся в донных отложениях, показывает, что последние по абсолютным содержаниям и протяженности не уступают, но часто даже превосходят первые (табл. 96).

В районах развития добывающих предприятий, где качественный состав техногенных источников (отвалы, хвостохранилища) в принципе адекватен рудным, соотношение между элементами в рядах концентрации меняется, а общий уровень их накопления в техногенных потоках значительно выше, чем в рудных.

Характерной особенностью горно-промышленных ландшафтов является расположение в их пределах металлургических предприятий. Как показывают исследования Г. А. Тимошкина и авторов, в зонах воздействия последних техногенные аномалии отличаются еще более комплексным составом и резко выраженной контрастностью накопления химических элементов (табл. 97) .

Таким образом, горно-добывающая промышленность оказывает существенное влияние на миграцию химических элементов, 
Т а блиц а 96. Сравнительная характеристика содержаний (мг/кг) некоторых химических элементов в донных отложениях природных и техногенных потоках рассеяния

\begin{tabular}{c|c|c|c|c|c}
\hline $\begin{array}{c}\text { Месторождения и } \\
\text { предприятия }\end{array}$ & $\mathrm{Pb}$ & $2 \Pi$ & $\mathrm{Cr}$ & $\mathrm{N} 1$ & $\mathrm{Ag}$ \\
\hline
\end{tabular}

\begin{tabular}{|c|c|c|c|c|c|}
\hline \multicolumn{6}{|c|}{ Природные потоки } \\
\hline Полиметаллические, Во- & $30-300$ & $100-2500$ & - & - & - \\
\hline $\begin{array}{l}\text { сточное Забайкалье } \\
\text { Полиметаллические, Ce- } \\
\text { верный Тянь-Шань }\end{array}$ & $200-300$ & $2000-3000$ & - & - & - \\
\hline $\begin{array}{l}\text { Железорудные, Северный } \\
\text { Тянь-Шань }\end{array}$ & - & - & $1000-3000$ & $500-2000$ &  \\
\hline $\begin{array}{l}\text { Медные и полиметалличе- } \\
\text { ские, Центральная часть } \\
\text { Чили }\end{array}$ & - & - & - & - & - \\
\hline $\begin{array}{l}\text { Сульфидные, Алтай } \\
\text { Оловорудные, Сихотэ- } \\
\text { Алинь }\end{array}$ & $\begin{array}{l}200 \\
60-300\end{array}$ & $\begin{array}{c}300 \\
1000-3000\end{array}$ & - & - & $\begin{array}{l}30 \\
30\end{array}$ \\
\hline Полиметаллические & $100-2000$ & $100-500$ & $10-100$ & $10-100$ & - \\
\hline \multicolumn{6}{|c|}{ Техногенные потоки } \\
\hline Горнодобывающие & $3000-6300$ & $3200-4700$ & - & - & $6-15$ \\
\hline $\begin{array}{l}\text { приятия в Сев Айдахо, } \\
\text { США }\end{array}$ & & & & & \\
\hline $\begin{array}{l}\text { Рудник по добыче цинка } \\
\text { и свинца, ПНР }\end{array}$ & 1200 & 2500 & 50 & 50 & - \\
\hline $\begin{array}{l}\text { Горнообогатительная } \\
\text { фабрика, ПНР } \\
\text { ГОК по добыче и обога- } \\
\text { щению полиметалличе- } \\
\text { ских руд, Кавказ }\end{array}$ & $\begin{array}{c}420 \\
\text { До } 2500\end{array}$ & $\begin{array}{c}10000 \\
\text { До } 15000\end{array}$ & 58 & 26 & \\
\hline
\end{tabular}

которое проявляется в возникновении контрастных и протяженных аномалий в водных системах. Появление последних обусловлено потерями вещества в технологической цепи и вовлечением его в миграцию. Все аномалии имеют полиэлементный характер, что хорошо согласуется с составом промышленных стоков. Наиболее резко и стабильно аномалии проявлены для твердофазной составляющей потоков рассеяния. Даже после прекращения эксплуатации месторождений, загрязненные донные осадки могут являться вторичным источником поступления веществ в водную фазу.

\section{3. ЭКОЛОГИЧЕСКАЯ И ГИГИЕНИЧЕСКАЯ ОЦЕНКИ ГЕОХИМИЧЕСКИХ АНОМАЛИЙ ГОРНОПРОМЫШЛЕННЫХ ТЕРРИТОРИЙ}

Специфика экологических и гигиенических последствий техногенного загрязнения окружающей среды горно-промышленных территорий заключается в комплексности состава загрязняющих 
Т абли ц а 97. Ассоциации химических элементов в донных отложениях рек

\begin{tabular}{|c|c|c|c|c|}
\hline \multirow{2}{*}{\multicolumn{2}{|c|}{ Источник загрязнения }} & \multicolumn{3}{|c|}{$\begin{array}{c}\text { Коэффициенты концентрации относительно } \\
\text { фонового содержания }\end{array}$} \\
\hline & & более 100 & $100-30$ & $30-10$ \\
\hline $\begin{array}{l}\text { Геологоразведочные } \\
\text { ботки }\end{array}$ & выра- & - & - & - \\
\hline \multirow{3}{*}{$\begin{array}{l}\text { Горнорудные пред- } \\
\text { приятия, } \\
\text { эксплуатируемые: }\end{array}$} & 20 лет & - & - & $\mathrm{Zn}-\mathrm{Ag}$ \\
\hline & 35 лет & - & - & $2 \pi$ \\
\hline & 150 лет & - & $\mathrm{Pb}$ & $2 \Pi$ \\
\hline \multirow{2}{*}{$\begin{array}{l}\text { Горнообогатитель- } \\
\text { ные предприятия, } \\
\text { эксплуатируемые: }\end{array}$} & 15 лет & - & - & $2 \Pi$ \\
\hline & 90 лет & - & $\mathrm{Zn}-\mathrm{Ag}-\mathrm{Pb}$ & - \\
\hline \multicolumn{2}{|c|}{ Металлургический завод } & $\begin{aligned} \mathrm{Ag} & -\mathrm{Cd}-\mathrm{Zn}- \\
& -\mathrm{Pb}\end{aligned}$ &  & $\mathrm{W}-\mathrm{Co}$ \\
\hline \multicolumn{2}{|c|}{$\begin{array}{l}\text { Пробы из шламо- и хвосто- } \\
\text { хранилищ }\end{array}$} & $\mathrm{Ag}$ & $\mathrm{Pb}-\mathrm{Cd}$ & $\mathrm{Ba}-\mathrm{Zn}-\mathrm{Cu}$ \\
\hline \multicolumn{2}{|c|}{ Полиметаллические руды } & $\underset{-\mathrm{Cb}}{\mathrm{Cd}-\mathrm{Zn}-\mathrm{Ag}-}$ & $\mathrm{Cu}-\mathrm{Bi}$ & Mo \\
\hline
\end{tabular}

веществ, среди которых определяющую роль играют токсичные химические элементы. Сравнительно небольшое значение здесь имеют органические загрязняющие вещества. Пути поступления поллютанов в живые организмы, и, главное, в организм человека в горно-промышленных районах многообразны. В районах ГОКов - это воздушный путь и продукты питания, выращиваемые на загрязненных почвах, питьевые воды с природно-повышенными концентрациями.

Реакции живых организмов в природных биогеохимических провинциях рудных районов посвящены фундаментальные работы школы Биохимической лаборатории, созданной В. И. Вернадским и возглавляемой многие годы А. П. Виноградовым и В. В. Ковальским. Эти исследования, в частности, показали, что даже при сравнительно небольших средних уровнях накопления элементов в пределах региональных геохимических полей (концентрации в породах и почвах всего в 2-4 раза выше кларковых уровней) наблюдаются серьезные экологические последствия, приводящие к различным нарушениям в растениях, а также в организме животных и человека.

Естественно, что степень концентрирования химических элементов в растениях вторичных ореолов рудных тел и месторождений может быть значительно выше, о чем, в частности, говорят многочисленные данные по биогеохимическим ореолам рассеяния. В этих случаях обычно повышается комплексность состава. На- 


\begin{tabular}{|c|c|c|c|}
\hline \multirow{2}{*}{\multicolumn{2}{|c|}{ Источник загрязнения }} & \multicolumn{2}{|c|}{$\begin{array}{c}\text { Коэффициенты концентрации относительно } \\
\text { фонового содержания }\end{array}$} \\
\hline & & $10-3$ & $3-1,5$ \\
\hline $\begin{array}{l}\text { Геологоразведочные } \\
\text { ботки }\end{array}$ & выра- & - & $\mathrm{Zn}-\mathrm{Pb}-\mathrm{Cu}$ \\
\hline \multirow{3}{*}{$\begin{array}{l}\text { Горнорудные пред- } \\
\text { приятия, } \\
\text { эксплуатируемые: }\end{array}$} & 20 лет & $\mathrm{Pb}$ & $\mathrm{Cu}-\mathrm{Nb}-\mathrm{Ga}-\mathrm{Y}$ \\
\hline & 35 лет & $\mathrm{Pb}-\mathrm{Ag}$ & $\mathrm{Ba}-\mathrm{Nb}-\mathrm{Cu}-\mathrm{Y}-\mathrm{S} r-\mathrm{Bi}$ \\
\hline & 150 лет & $\mathrm{Ag}-\mathrm{C}_{1}$ & $\mathrm{Ga}-\mathrm{Ni}-\mathrm{Co}-\mathrm{Sn}-\mathrm{B}_{1}$ \\
\hline \multirow{2}{*}{$\begin{array}{l}\text { Горнообогатитель- } \\
\text { ные предприятия, } \\
\text { эксплуатируемые: }\end{array}$} & 15 лет & - & $\mathrm{Pb}-\mathrm{Y}-\mathrm{Sc}-\mathrm{Cu}-\mathrm{Ag}-\mathrm{Co}-\mathrm{Ba}$ \\
\hline & 90 лет & $\mathrm{Ba}-\mathrm{Bi}-\mathrm{Cu}-\mathrm{Cd}$ & $\mathrm{Mn}-\mathrm{Mo}-\mathrm{Sn}-\mathrm{Co}-\mathrm{Zr}-\mathrm{Nb}$ \\
\hline \multicolumn{2}{|c|}{ Металлургический завод } & $\mathrm{Nb}-\mathrm{Sb}$ & $\mathrm{Ga}-\mathrm{Ni}-\mathrm{Mn}-\mathrm{S}_{\Gamma}$ \\
\hline \multicolumn{2}{|c|}{$\begin{array}{l}\text { Пробы из шламо- и хвосто- } \\
\text { хранилищ }\end{array}$} & $\mathrm{Bi}-\mathrm{Mo}$ & $\mathrm{Sn}-\mathrm{Co}-\mathrm{Nb}$ \\
\hline \multicolumn{2}{|c|}{ Полиметаллические руды } & $\mathrm{Sn}-\mathrm{Co}$ & $\mathrm{Y}-\mathrm{Ga}-\mathrm{Sr}$ \\
\hline
\end{tabular}

пример, авторами в пробах укоса на полиметаллических месторождениях помимо ассоциации элементов, характерной для всей провинции (Си, 2п), наблюдались концентрации токсичного $\mathrm{Cd}$ от 1,5 до 11 мг/кг (при фоне 0,4 мг/кг). Таким образом, экологическая опасность участков развития вторичных ореолов в принципе выше.

Для техногенных зон загрязнения в горно-рудных районах также известен достаточно широкий спектр отрицательных биогеохимических и биологических реакций живых организмов в связи с выбросами обогатительных фабрик, зонами влияния мест хранения отходов, использованием загрязненных вод для питьевых целей и орошения.

Прямых исследований воздействия атмосферы, загрязненной выбросами горно-обогатительных фабрик, на здоровье населения практически нет. Имеются лишь указания на рост аллергических и некоторых других заболеваний. В принципе ситуация и последствия здесь не должны отличаться от других источников загрязнения, для которых установлены значимые положительные корреляции в цепи «выброс - воздух - геохимическая аномалия выпадений и почв - человек». Материал выбросов через цепь «выпадения - почва» приводит к загрязнению растений. Так, на периферии зоны воздействия выбросов обогатительной фабрики в частных огородах и сенокосах наблюдались уровни накопле- 
Т а бли ц 98 Химические элементы в сельскохозяйственных растениях в зоне влияния фабрики по обогащению свинцовых руд, мг/кг сухой массы

\begin{tabular}{l|c|c}
\hline \multicolumn{1}{c|}{ Объект опробования } & Медь & Цинк \\
\hline Кукуруза (кормовая часть) & $4-12(1-3)$ & $106-184(3-9)$ \\
Кукуруза (початок) & $3,6(1,0)$ & $36,8(1,6)$ \\
Свекла & $21,6(2,3)$ & $212,1(7,7)$ \\
Укос трав & $9,0(1,0)$ & $110,0(2,0)$ \\
Почва & $85-152(2-5)$ & $310-1352(4-15)$ \\
\hline \multicolumn{1}{c|}{ Объект опробования } & Кадмий & Свинец \\
\hline Кукуруза (кормовая часть) & $0,44(1,0)$ & $36(4,0)$ \\
Кукуруза (початок) & $0,07(1,2)$ & $0,9(4,0)$ \\
Свекла & $0,13(3,2)$ & $6,5(7,0)$ \\
Укос трав & $0,66(11,6)$ & $39,4(5,0)$ \\
Почва & $4--6(6--10)$ & $520-560(18-26)$
\end{tabular}

Примечание В скобках указаны коэффициенты концентрации по отношению к фоновому содержанию

ния $\mathrm{Zn}, \mathrm{Pb}$ и $\mathrm{Cd}$, превышающие в сумме гигиенические нормы (табл. 98).

По материалам, собранным Девисом [26], в районах полиметаллических рудников отмечается корреляция между распределением в почвах свинца и уровнем заболеваемости атеросклерозом и кариесом. Однако прямых данных о влиянии свинца не имеется, и скорее всего этот элемент играет роль индикатора каких-то иных неблагоприятных условий.

Имеется ряд исследований, демонстрирующих отрицательное воздействие на биоту мест захоронения отходов добычи и обогащений. При этом оно сохраняется даже через десятки лет после закрытия рудников. Так, в Уэльсе и Сомерсете в $100-500$ м от старых породных отвалов вследствие ветровой и водной эрозии образовались аномалии с содержанием свинца в растениях до 275 мкг/т, что превышает допустимый уровень. При выпасе на этих участках отмечались случаи гибели домашнего скота. При этом в фекалиях коров содержание кадмия, например, достигало $6-50$ мкг/г (при норме $1-2$ мкг/г). Аналогичные случаи наблюдались в Шотландии [26] при выпасе в районе дорог, построенных из отвалов свинцового рудника. у погибших коров здесь обнаружилось высокое (2 мг/л) содержание свинца в крови. На Чиатурском месторождении Э. Б. Тюрюканова выявила обогащение марганцем растений, произрастающих на отвалах и в депрессиях с намытыми почвами. Листья кукурузы содержали 250-500 мг/кг $\mathrm{Mn}$, клевер - 80-164 мг/кг, люцерна 59 - 132 мг/кг, солома злаковых (пшеница, рожь, овес) - 22,5198 мг/кг. В среднем количество марганца в сеяных травах в 2 раза меньше, чем в укосах трав естественных лугов.

В шт. Айдахо (США), где сосредоточено 35\% фосфорных рудников, отвалы засевались люцерной и кормовыми травами на 
Т а блиц а 99. Содержания химических элементов в почве и растительности из района отвалов фосфоритовых руд, мг/кг

\begin{tabular}{l|l|r|r|r}
\hline $\begin{array}{c}\text { Характе- } \\
\text { ристика } \\
\text { отвала }\end{array}$ & \multicolumn{1}{|c|}{ Объект опробования } & $2 п$ & $\mathrm{Cd}$ & $\mathrm{Pb}$ \\
\hline Старые & Почва & 443 & 14,5 & 20,3 \\
& Люцерна & 41 & 1,1 & 2,1 \\
Кормовые травы & 70 & 1,4 & 0,6 \\
Молодые & Почва & 1112 & 33,4 & 33,7 \\
& Люцерна & 63 & 4,6 & 3,7 \\
\multirow{2}{*}{ Контроль } & Кормовые травы & 96 & 1,8 & 1,7 \\
& Почва & 54 & 1,0 & 15,4 \\
& Люцерна & 34 & 0,4 & 2,2 \\
& Кормовые травы & 30 & 0,1 & 0,6
\end{tabular}

площади 160 га, куда шел сброс стоков в разные годы [26]. Результаты геохимических исследований показали, что как в старых, так и в новых отвалах наблюдается интенсивное загрязнение почвы и растительности. Вместе с тем тенденции к снижению уровней загрязнения на старых отвалах довольно отчетливые (табл. 99).

Одно из наиболее известных эндемических заболеваний, объясняемых геохимическими особенностями окружающей среды,- болезнь Кашина - Бека (уровская). Это тяжелейшее в развитых стадиях поражение костно-суставной системы в виде деформирующего остеохондроартроза имеет очень четкую пространственную локализацию и распространено в некоторых районах Восточной Сибири, Кореи и Китая.

А. П. Виноградов выдвинул биогеохимическую гипотезу формирования очагов заболевания. В ряде последующих работ очаги распространения уровского заболевания были связаны с неблагоприятным соотношением химических элементов в природных телах и, в частности, с избытком стронция на фоне недостатка кальция и некоторых микроэлементов. Новейшие исследования А. В. Вощенко, Н. Н. Дружковой-Алексинцевой, Л. В. Зайко позволили получить данные, поставившие под сомнение материалы по кальциево-стронциевому дисбалансу в районе уровской эндемии и обосновавшие связь заболевания с фосфорно-марганцевой интоксикацией.

Комплексный анализ геологической и ландшафтно-геоморфологической специфики участков развития уровской эндемии в Восточной Сибири показал их строгую приуроченность к следующему сочетанию природных факторов: 1) ландшафтнообразующие породы коренного фундамента - толща карбонатных пород с прослоями фосфатоносных терригенных пород в сочетании с толщами эффузивных пород среднеосновного состава; 2) почвообразующие породы - комплекс склоновых отложений субавтохтонного ряда в сочетании с отложениями террас и 
пойм плоскодонных слаботранзитных рек, содержащих значительную долю местного материала; 3) геоморфологическая позиция и ландшафты - среднегорье, поймы и террасы малых рек, лугово-мерзлотные, болотно-мерзлотные ландшафты со сплошной или крупноостровной мерзлотой, преобразованные антропогенной преимущественно сельскохозяйственной деятельностью; 4) социальные условия - небольшие поселения, рацион жителей со значительной долей местных продуктов питания (картофель, мясо, молоко, хлеб) и местными источниками водоснабжения.

Геохимический анализ материалов по ландшафтообразующим горным породам фундамента позволяет четко выделить в качестве типоморфного для эндемичного района признака только повышенную фосфатоносность. Специфических источников других химических элементов не обнаружено.

Сравнительный анализ материалов большого массива данных по почвообразующим рыхлым отложениям эндемичной и неэндемичной территорий позволил выделить в качестве типоморфных накапливающих элементов P (коэффициент концентрации 43,2), $\operatorname{Mn}\left(\mathrm{K}_{\mathrm{c}} 2,2\right)$ и $\mathrm{P}(\mathrm{Kc} 1,3)$. Для обоих типов территорий проявлен дифицит ряда биологически важных микроэлементов (Си, Со, частично Zn) и 5г. Кальций в обоих случаях находится в небольшом избытке. В почвах эндемичных и неэндемичных ландшафтов распределение химических элементов, наблюдаемое в почвообразующих породах, дифференцируется еще более контрастно. Коэффициент концентрирования общего фосфора здесь 6,2, марганца - 3,2. Также отмечается избыток кальция и недостаток стронция и ряда микроэлементов. Неоднородность территории по распределению фосфора и марганца в очагах эндемии контрастно проявлена при изучении локальных структур местных ландшафтов. Например, на участках таликов даже в пределах эндемичных сел содержание этих элементов резко понижается.

Фосфор и марганец содержатся в ландшафтах эндемичных территорий в хорошо мигрирующих и легко усваивающихся живыми организмами формах нахождения. Для фосфора это доказано исследованием соотношения его валовой формы и подвижных орто- и полифосфатов. В результате в ландшафтах эндемичных территорий обнаруживаются контрастные аномалии, фосфат-иона и марганца в водах (до 15 раз выше фоновых уровней) и в растениях (в 2-4 раза) - как в природных (травы пастбищ), так и в сельхозкультурах (картофель, пшеница). Это является причиной избытка рассматриваемых элементов в рационах людей и животных.

Установление роли фосфора и марганца при формировании очагов эндемии болезни Кашина - Бека (уровской) ставит задачу эколого-геохимической переоценки эпидемиологических данных по остеохондроартрозам (может быть, и по другим костно-суставным заболеваниям) и главное - задачу оценки гео316 
T аблица 100. Содержания химических элементов в траве и кустарниках, произрастающих на почвах отвалов, мг/кг

\begin{tabular}{|c|c|c|c|c|c|c|c|c|c|}
\hline Место отбора проб & V & Co & $\mathrm{N} 1$ & Си & As & Se & Mo & $\mathrm{Pb}$ & U \\
\hline Tрава & & & & & & & & & \\
\hline на почвах отвала & 0,34 & 0,55 & 3,0 & 33 & 0,13 & 51 & 133 & 27 & 0,16 \\
\hline $\begin{array}{l}\text { на контрольном } \\
\text { участке }\end{array}$ & 0,76 & 0,33 & 5,6 & 35 & 0,04 & 2,4 & 9 & 12 & 0,07 \\
\hline $\begin{array}{l}\text { Кустарники: } \\
\text { на почвах отвала }\end{array}$ & 17 & 0,40 & 4,7 & 16 & 0,43 & 57 & 200 & 0,4 & 4,8 \\
\hline $\begin{array}{l}\text { на контрольном } \\
\text { участке }\end{array}$ & 1,06 & 0,49 & 5,1 & 0,7 & 0,10 & 48 & 8 & 2,0 & 0,04 \\
\hline
\end{tabular}

химической обстановки в районах освоения с близкими ландшафтно-геохимическими условиями.

Геохимический анализ рассматриваемого явления с более общих позиций позволяет предположить, что возможности для концентрирования фосфора и марганца в пищевой цепи могут возникнуть и в ландшафтно-геохимических условиях, отличных от изученных. Например, эндемические очаги болезни Кашина Бека в Северной Корее и KHР, вероятнее всего, не связаны с мерзлотными ландшафтами, что значительно расширяет проблему выявления и оценки экологического значения ландшафтов с фосфорно-марганцевыми геохимическими аномалиями для развития заболеваний костно-суставной системы.

По материалам Девиса [26], на полях, расположенных в пределах нескольких сотен метров от отвалов старого рудника в Западном Уэльсе, содержания металлов в почвах варьируют (средние - максимальные, в скобках - допустимые): РЬ 1759 14910 мг/кг (70 мг/кг), Си - 32-42 (29), 2п-96-641 (195), $\mathrm{Cd}-1,4-2,9(2,4)$. Основной загрязнитель здесь свинец. На полях наблюдалась гибель животных и отмечено повышенное содержание свинца в крови детей этого района $(14,7-44,1$ мг/100 мл.). Немытые листья содержали в $3-12$ раз больше свинца, чем мытые, что свидетельствует о роли пылевого фактора. Среднее содержание свинца в мытых листьях составило 75,4 мг/кг (до 128 мг/кг).

Отходы урановых горно-обогатительных предприятий содержат токсичные элементы (As, Mo, 8e, V), a также тяжелые металлы (Co, Ni, Си, РЬ), находящиеся обычно в форме сульфидов. Многие из этих элементов в результате процессов выщелачивания, происходящих на хвостохранилищах, попадают в окружающую среду, загрязняя почву, грунтовые воды, растения (табл. 100).

В некоторых работах прослеживается влияние загрязненных вод. Так, индийские ученые установили, что аномально высокие содержания РЬ в стоках (до 75 мкг/л) и в почвах, испытавших воздействие стоков, в районе обогатительной фабрики (в $13-$ 24 раза выше фона) привели к накоплению РЬ в молоке коров 
(в $15-20$ раз) и к свинцовым отравлениям животных. В районе уранового рудника в Колорадо, по данным Г. Дризена, для орошения полей применены рудничные воды. Это привело к увеличению содержаний Мо и U в травах и овощах до 110-190 мкг/г Мо (при фоне $1-8$ мкг/г) и 0,2-2 мкг/г U (при фоне $0,02-$ 0,07 мкг/г). Многолетние детальные работы в районе золотодобывающих шахт близ г. Галифакс (Канада) показали, что в результате сбросов мышьяксодержащих сточных вод увеличилась концентрация этого элемента в колодцах (до 5 мг/л или в 100 раз выше ПДК). У жителей района установлены случаи хронического мышьякового отравления [26].

Таким образом, существует значительная экологическая опасность практически для всех известных типов геохимических аномалий, формирующихся в окружающей среде горно-рудных районов.

\section{4. МЕТОДИЧЕСКИЕ ОСОБЕННОСТИ И ПРАКТИЧЕСКОЕ ЗНАЧЕНИЕ ЭКОЛОГО-ГЕОХИМИЧЕСКИХ ИССЛЕДОВАНИЙ ПРИ РАЗВЕДКЕ РУДНЫХ МЕСТОРОЖДЕНИЙ}

Геохимический анализ загрязнения окружающей среды в горнорудных районах позволяет сформулировать задачи геолого-геохимического изучения месторождений. В общем виде таких задач три.

1. Качественная и приближенно-количественная оценка месторождения как источника токсичных химических элементов в выбросах, отходах и стоках при добыче и обогащении для разработки при проектировании горно-обогатительного комбината специально природоохранных мер.

2. Установление в зоне деятельности геологоразведочной партии пространственного распространения, интенсивности и состава природных геохимических аномалий токсичных химических элементов (вторичных ореолов и потоков рассеяния, биогеохимических ореолов) с целью проектирования экологически безопасного функционального использования территорий при размещении жилых массивов, сельскохозяйственных угодий, рекреационных зон и источников водоснабжения.

3. Получение фоновых геохимических характеристик окружающей среды района месторождения и параметров ее состояния с учетом влияния производственной и хозяйственно-бытовой деятельности, сложившейся в районе проектируемого горно-обогатительного комбината, с целью проведения последующего контроля за результатами его деятельности. 


\section{Методика эколого-геохимических исследований}

Геохимические данные по окружающей среде показывают, что только комплексное изучение дает возможность всесторонней оценки ее состояния. Результаты геохимических исследований должны дать рекомендации по экологически безопасным условиям природопользования для населения, уже проживающего в изучаемом районе и для поселений геологоразведочных предприятий, создающихся на геологически перспективных территориях, а также дать материалы для обоснования природоохранных мероприятий и схем функционального использования земель для проектируемого горно-обогатительного производства.

Рассмотрим детальнее содержание задач и характер необходимых эколого-геохимических материалов, сбор которых необходим при разведке месторождений.

Оценка месторождения как потенциального источника загрязнения окружающей среды включает: 1) получение данных по первичным ореолам химических элементов в рудовмещающих горных породах, извлекаемых при вскрытии оруденения подготовительными выработками и перемещаемых в породные отвалы; 2) получение геохимических данных по составу рудной массы, поступающей на обогащение и являющейся источником загрязнения в связи с выбросами пыли при добыче, рассеивании при транспортировке руды к обогатительной фабрике и с полевыми выбросами при дроблении руды; 3) расчет баланса распределения химических элементов (как главных, так и, что особенно важно, элементов-примесей) в цепи технологической переработки руды разрабатываемой схемы обогащения, установление степени накопления токсичных химических элементов в отходах и сточных водах.

Многие из перечисленных материалов в сущности уже имеются в результатах геологоразведочных работ. Это следует, в частности, из существующих требований к итоговым материалам этих работ, предусматривающих, например, изучение первичных ореолов месторождений и комплексный анализ состава руд. Вместе с тем, при геолого-геохимических исследованиях часто ограничиваются типоморфным для данного месторождения набором элементов-индикаторов. Для эколого-геохимических целей он не всегда достаточен. Практически во всех случаях необходимо изучение таких токсичных химических элементов как $\mathrm{Hg}, \mathrm{Pb}, \mathrm{Cd}$, $5 \mathrm{e}$, Си, Аз, часто $\mathrm{Cr}$ и $\mathrm{V}$.

Для оценки токсичности породных отвалов и хвостов обогащения очень важно выяснить содержание и запасы накапливающейся в них сульфидной серы, которая при окислении в условиях дневной поверхности обязательно обусловит образование сернокислых агрессивных вод, интенсифицирующих водные потоки рассеяния тяжелых металлов. Необходимо также получить 
представление о карбонатности и емкости поглощения отвалов и хвостов, т. е. о мощности формирующихся в них геохимических барьеров для распространения потоков рассеяния. По этим данным можно простым химическим расчетом определить возможность нейтрализации или сорбции непрерывно образующихся продуктов окисления.

Для оценки опасности отходов очень полезно также изучение поведения химических элементов в процессах современного и древнего выветривания. Эти материалы позволяют прогнозировать вынос элементов.

Получаемые данные дают приближенную оценку месторождения как потенциального источника загрязнения. Эта оценка значительно уточняется при получении данных по балансу распределения всех исследуемых химических элементов в технологической цепи обогащения руд на стадии предварительной и особенно детальной разведки. Следует иметь в виду, что для элементов-примесей (чаще всего, наиболее токсичной части руды) проявляется тенденция к избирательному концентрированию в отходах (пылях, хвостах). Таким образом, реальные оценки токсичности бывают выше, чем следует из данных по среднему составу руд.

Оценка территории месторождения и, особенно рудного поля как природной эколого-геохимической аномалии, способной оказать отрицательное воздействие на живые организмы, включает: 1) построение для территории рудного поля ландшафтно-геохимических карт и детальных геохимических карт распределения в почвах наиболее распространенных и наиболее токсичных химических элементов руд и первичных ореолов (особенно на территориях, перспективных для жилищного строительства и сельскохозяйственного использования); 2) проведение выборочной оценки уровня биогеохимического концентрирования элементов в пределах выявленных аномалий в почвах; 3) построение детальных карт потоков рассеяния в донных отложениях водоемов и водотоков; 4) проведение динамической оценки распределения химических элементов в поверхностных водах на гидрогеологических створах в пределах выявленных наиболее интенсивных потоков в донных отложениях; 5) получение данных по распределению химических элементов в подземных водах, перспективных для любого типа водопользования.

В приближенных оценках многие из требуемых данных имеются в материалах геохимических поисковых работ, чаще всего в виде карт геохимических ореолов и потоков рассеяния масштаба 1:50000 и мельче. Эти материалы и определяют территорию, требующую более детальных эколого-геохимических оценок с целью безопасной организации земле- и водопользования.

Необходимость экологической интерпретации геохимических данных приводит к изменению предъявляемых к ним требований 
как по комплексу изучаемых химических элементов, так и по методам исследований и представленных данных.

При оценке состояния почв масштаб картирования должен дать характеристику территории каждого возможного вида землепользования (строительство жилых массивов, садово-огородные участки, полевые севообороты, выпасы). Опыт показывает, что масштаб съемки порядка 1:10000 достаточен для решения этих задач. Наиболее широкий комплекс элементов должен быть изучен в центрах выявленных аномалий при проведении их биогеохимического изучения. Последнее особенно важно, так как позволяет оценить качество естественной растительной продукции, дать обоснованные ограничения территорий под сельскохозяйственное использование.

При проведении эколого-геохимических оценок природных геохимических аномалий в почвах и растениях помимо расширения комплекса изучаемых химических элементов и детализации пространственной структуры их распределения большое значение имеет определение количественных параметров содержаний ингредиентов с целью их последующей нормативной оценки.

В этой связи в отличие от принятой в поисковой практике системы представления и описания геохимического материала через суммарные характеристики ассоциаций химических элементов (аддитивные, мультипликативные аномалии), поля вероятностей появления содержаний выше заданных или через показ распределения интерпретационных показателей (коэффициент зональности и т. д.), для экологических целей не менее важны данные по распределению абсолютных уровней содержаний. При этом большое значение имеют исследования форм нахождения химических элементов, которые в ближайшие годы, вероятно, будут положены в основу экологических норм. В частности, уже сейчас для ряда элементов (Pb, Си, $\mathrm{Ni}, \mathrm{P}, 2$, $\mathrm{Pe}, \mathrm{Mo}, \mathrm{B})$ для оценки состояния почв (как с позиций их загрязнения, так и с точки зрения их агрохимической ценности) необходимо определение содержаний подвижных усвояемых растениями форм нахождения.

При оценке состояния поверхностных водных систем данные поисковых геохимических съемок, как правило, довольно точно оценивают общую зону влияния месторождения и пространственное положение центров наиболее интенсивных литохимических потоков рассеяния. Основная задача эколого-геохимических работ - расширение комплекса исследуемых химических элементов. Это позволяет достаточно точно определить список химических элементов, оценка которых требуется для поверхностных и подземных вод.

Водные потоки достоверно могут быть оценены только в динамике, что требует организации створов для их гидролого-гидрогеохимического изучения. Закладка створов проводится прежде 
всего на основе данных по структуре литохимических потоков рассеяния.

Конечная цель изучения водных потоков рассеяния - оценка возможностей всех видов водопользования (питьевого, сельскохозяйственного, рекреационного). В связи с этим требования к исследованиям заключаются в необходимости получения данных по всем гостируемым ингредиентам воды (т. е. не только токсичные химические элементы, но и физические свойства, мутность, общесолевой состав). Кроме того, для поверхностных вод очень важна оценка распределения химических элементов по формам нахождения и, в частности, соотношение растворенных и взвешенных в воде форм [30].

Получение фоновых геохимических характеристик окружающей среды района месторождения, а также оценка параметров окружающей среды, связанных с уже сложившейся хозяйственной деятельностью (часто с другими горно-обогатительными комбинатами) - многоплановая задача исключительного значения. Чаще всего она может быть решена только при разведке месторождения, так как позже, с началом работы горно-обогатительного комбината, такие параметры получить или невозможно, или очень трудно.

Желательно для всех природных сред (воды, воздуха, выпадений из атмосферы на земную поверхность, почвы, растительного покрова) получить данные по распределению максимально широкого круга химических элементов в спектре типовых ландшафтногеохимических условий на территориях, не испытывающих влияния месторождения (в том числе, и природных аномалий его обрамления) или иной хозяйственной деятельности. Получение некоторых из перечисленных характеристик (геохимические данные по составу атмосферного воздуха и выпадений из атмосферы) выходит за рамки традиционных методов прикладной геохимии. Опыт и разработанная методика таких исследований уже имеются [26].

С позиций использования геохимических методов в природоохранных целях и общей периодизации освоения новой горнорудной территории рационально выделить три основных этапа.

Этап I - общее геологическое, геофизическое и геохимическое изучение территории с целью установления перспектив выявления промышленного рудного месторождения («Поисковый» этап).

Этап II - детальное геологоразведочное изучение перспективного орудения с подсчетом запасов минерального сырья для обоснования возможности и необходимости создания горнорудного предприятия («разведочный» этап).

Этап III - проектирование, проведение изысканий и строительство горно-обогатительного комплекса («строительный» этап). 
Исследования первого («поискового») этапа освоения горнорудной территории совпадают с I-IV стадиями геологоразведочных работ: 1) региональное геологическое изучение территорий; 2) геологическая съемка масштаба 1:50 000 с общими поисками; 3) детальные поиски с определением ресурсов на конкретных участках; 4) поисково-оценочные работы с оценкой выявленных проявлений. На этом этапе для территории существует сложившаяся хозяйственная структура природопользования, пока еще не связанная с освоением перспективного месторождения. В этот период, как правило, принимается решение о создании постоянно действующего геологоразведочного предприятия с поселением, размещаемым чаще всего как можно ближе к участку месторождения. Задача геохимических исследований - дать экологическую оценку природных геохимических аномалий как зон загрязнения и обосновать ограничения по использованию земель и водопользованию.

Перечень геохимических данных, собираемых в этот период в соответствии с инструкцией по геохимическим методам поисков, включает:

результаты районирования территории по условиям проведения геохимических поисков с учетом ландшафтно-геохимических и геологоморфологических критериев;

материалы литохимических поисков в масштабе 1:200000 по результатам опробования донных отложений современной гидросети;

геохимические карты остаточных вторичных ореолов рассеяния в почвах и потоках рассеяния в донных отложениях масштаба 1:50000(1:25000);

детальные геохимические карты вторичных ореолов рассеяния в почвах на участках рудопроявлений, намечаемых для поисково-оценочных работ;

данные по составу оруденения и предварительные данные по первичным ореолам на участках поисково-оценочных работ.

Собираемые геохимические материалы образуют значительный массив разнообразных данных и могут быть легко переинтерпретированы с экологических позиций.

В частности, имеющиеся результаты позволяют:

оценить общий тип геохимической провинции района месторождения;

выявить пространственную позицию зон наиболее высоких концентраций химических элементов в почвах и дать гигиеническую оценку уровням накопления тех элементов, для которых имеются нормативы содержаний в почвах;

выделить конкретные участки водоемов и водотоков с аномальными характеристиками донных отложений, которые могут фиксировать места появления загрязненных химическими элементами вод и водной биоты. 
Система анализов проб, применяемая при геохимических поисках, позволяет дать представление о распределении большой части (но не всех) важных с экологических позиций химических элементов. В получаемых анализах отсутствуют представительные сведения по $\mathrm{Cd}$, $5 \mathrm{e}, \mathrm{Hg}, \mathrm{As}$, требующих для своего определения применения специальных методов. Интенсивные аномалии этих элементов расположены внутри контуров аномалий основных элементов-индикаторов.

При принятых сейчас на практике комплексах геохимических исследований как правило не формируется массив данных по биогеохимическим особенностям территорий и микроэлементами в водных системах (общий гидрохимический состав вод при проведении геологического картирования часто все же характеризуется) .

Необходимость специальных эколого-геохимических исследований на рассматриваемом этапе зависит от полученных результатов и интенсивности хозяйственного освоения территории. В большинстве случаев задачи, характер и объемы специальных работ рационально определять по итогам исследований на стадии детальных поисков (стадия III), а осуществлять на стадии поисково-оценочных работ (стадия IV). С этой целью карты ландшафтов геохимического и геолого-геоморфологического районирования территорий должны быть дополнены картой их функционального использования. Эта карта, фиксирующая расположение и типы сельскохозяйственных угодий, поселков и частных хозяйств, предприятий, зон отдыха, заповедников и особо охраняемых природных территорий, при совмещении с картами вторичных ореолов и потоков рассеяния позволяет выделить типы, положение и объемы потенциально опасных с экологических позиций участков - «горячих точек».

Проведение специализированных эколого-геохимических работ на рассматриваемом этапе исследований необходимо в следующих случаях.

1. Для территорий интенсивного сельскохозяйственного освоения с проявлением в почвах широких по площади и контрастных по интенсивности геохимических аномалий проводится биогеохимическое изучение концентрирования химических элементов в растительном покрове выпасов и в сельскохозяйственной продукции (особенно садово-огородной) .

2. Для водных систем с интенсивными потоками рассеяния в донных отложениях, используемых для питьевого и сельскохозяйственного водоснабжения, проводится динамическое изучение концентрирования химических элементов в водах с определением основных форм их нахождения, а также изучение концентрирования химических элементов в водах, используемых для полива, и в почвах, поливаемых этими водами.

Получаемые материалы позволяют дать рекомендации по эко- 
логическим ограничениям развитой в районе хозяйственной деятельности, необходимым исследованиям для уменьшения вредных последствий уже существующего природного «загрязнения» окружающей среды и безопасному размещению геологоразведочного поселения.

Исследования «разведочного» этапа освоения горно-рудных территорий совпадают с V и VI стадиями геологоразведочных работ: 5) предварительная разведка; 6) детальная разведка.

На этом этапе необходимо получение детальной характеристики окружающей среды территории и оценки возможного влияния на нее добычи и обогащения руд. Это, в частности, вытекает и из требований к составу и результатам геологоразведочных работ на стадии детальной разведки, предусматривающих задачу рекомендаций по размещению объектов промышленного и жилишно-гражданского назначения и разработку природоохранныхмероприятий.

Проводимые исследования включают экологическую переинтерпретацию материалов геолого-геохимических работ и проведение комплекса специальных эколого-геохимических работ, являющихся в данном случае уже обязательными.

В состав исследований входят:

1. Детальное количественное изучение распределения в рудах всего комплекса токсичных элементов-спутников и элементовпримесей, а также состава макроэлементов.

2. Выделение по данным изучения первичных ореолов блоков пород, обогащенных химическими элементами, которые должны быть перемещены в отвалы. Детализация для этих блоков данных по распределению токсичных элементов, а также микроэлементов и показателей пород, влияющих на их миграцию (концентрация сульфидной серы, карбонатов, емкость поглощения).

3. Детальное количественное изучение перераспределения токсичных элементов в корах выветривания.

4. Изучение баланса химических элементов в продуктах и отходах разрабатываемой технологической схемы обогащения. Изучение общего состава отходов обогащения.

5. Составление детальных $(1: 10000-1: 5000)$ геохимических карт распределения в почвах основных токсичных элементов для территорий всех планируемых видов землепользования.

6. Проведение биогеохимического изучения выявленных аномалий в почвах (см. работы I этапа).

7. Проведение в основные гидрологические периоды динамического изучения распределения в поверхностных водотоках выявленного на месторождении комплекса химических элементов (с исследованием форм их нахождения).

8. Геохимическая съемка состава выпадений из атмосферы.

9. Оценка состояния атмосферного воздуха на комплекс ток- 
сичных металлов (в случае выявления геохимических аномалий в выпадениях).

10. Оценка уровней в планируемых источниках водоснабжения содержаний выявленных химических элементов.

- 11. Изучение фоновых параметров окружающей среды.

Материалы, полученные в ходе перечисленных исследований, дополненные гидрометеорологическими сведениями в совокупности с результатами инженерно-геологических и гидрогеологических изысканий (как на месторождении, так и в районах размещения отвалов и хвостохранилищ), служат фактическими данными для разработки природоохранных мероприятий и экологически безопасного функционального планирования территории проектируемого горно-обогатительного комбината.

\section{Природоохранные разработки и мероприятия}

При использовании геохимических данных для разработки природоохранных мероприятий необходимо иметь в виду общие требования «Основ законодательства Союза ССР и союзных республик о недрах», предусматривающие:

полное и комплексное геологическое изучение недр;

предупреждение необоснованной и самовольной застройки площадей залегания полезных ископаемых;

предотвращение вредного влияния работ.

Методологическая основа природоохранных работ в горнорудных районах сформулирована в виде трех основных положений [35]:

1. В горно-рудных районах интересы горного дела на период существования ГОКа имеют приоритет перед другими видами деятельности.

2. Горно-обогатительная деятельность имеет временный характер и должна осуществляться таким образом, чтобы оставить возможность последующего эффективного использования территорий для других народнохозяйственных целей.

3. В ходе горно-обогатительной деятельности необходимо соблюдать количественные критерии допустимых нарушений с тем, чтобы они не оказывали вредного воздействия на общую экологию района.

Естественно, что геохимические данные могут определить лишь принципиальные направления деятельности по защите от загрязнения. Конкретные проектные и технологические решения должны разрабатываться компетентными специализированными организациями.

Намечаются возможности использования геохимических материалов при разработке природоохранных мероприятий в следующих основных направлениях: 
1. Сокращение вредного воздействия твердых отходов, обогащенных химическими элементами.

2. Экологически безопасное функциональное планирование территорий и технологических мероприятий в соответствии с особенностями природной геохимической структуры и прогнозируемым характером выбросов.

3. Сокращение вредного воздействия сточных вод и охрана водных систем.

4. Рекультивация территорий после завершения горно-обогатительной деятельности.

В приведенный перечень не включены такие важнейшие в природоохранном плане результаты геологоразведочных работ как рекомендации по снижению уровня потерь полезных компонентов и увеличению комплексности использования руд, снижению разубоживания руд при добыче, рациональное использование вскрышных пород. Такие рекомендации в соответствии с существующими требованиями являются обязательным результатом разведки месторождений. Они, в сущности, главный природоохранный итог детальных исследований геологии, минералогии и состава руд месторождений. Разумеется, и при этих исследованиях применение геохимических методов очень важно. Например, изучение первичных ореолов позволяет более точно представить морфологию рудных зон и тем самым исключить выборочную отработку месторождений. Данные по первичным ореола.м позволяют наметить объемы горных масс, которые в ближней или отдаленной перспективе могут стать объектами вторичной переработки и требуют отдельного складирования.

Природоохранные мероприятия по сокращению вредного воздействия твердых отходов основываются на геохимических данных по распределению токсичных элементов-примесей в цепи обогащения и на материалах по составу и пространственному положению первичных ореолов в сочетании с проектными материалами по системе и организации горно-добычных работ.

Блоки околорудных пород вскрыши с первичными ореолами, намечаемыми под извлечение, с содержаниями токсичных элементов выше предельно-допустимых в почвах, содержанием сульфидной серы более $10 \%$ (нормативные оценки) или с контрастно высокими (в 5-10 раз и более выше фонового уровня) концентрациями химических элементов (эмпирическая оценка) требуют отдельного учета.

При утилизации отходов такие породы рационально использовать для закладки горных выработок, что уменьшает объемы и токсичность породных отвалов. Эти категории отвальных пород не должны предусматриваться в проектах как материал для улучшения прилегающих к месторождениям неудобий (засыпка оврагов и т. д.), а также как щебень для строительства дорог. Для случаев, когда характеризуемые породы все же необхо- 
димо разместить на дневной поверхности, для них следует предусмотреть формирование наиболее безопасного вида отвалов и систему изоляции от поверхностных и подземных вод. При выборе вида отвалов для пылящих и токсичных отходов непригодны гребневидные и конические формы и лучше применять системы внутреннего отвалообразования. Для изоляции отвалов можно рекомендовать создание искусственных техногенных геохимических барьеров карбонатного или карбонатно-глинистого типа.

Особую опасность, как было показано, представляют отвалы хвостов обогащения, сложенные мелкодисперсным и легко окисляющимся при выветривании материалом. Они часто вынужденно размещаются на породах, плохо изолирующих подземные водоносные горизонты от попадания загрязняющих веществ. Также часто хвостохранилища от поверхностных водотоков отделяются лишь дамбами, не препятствующими фильтрации растворенных солей. Кроме того, они испытывают воздействие талых и паводковых вод, переполняющих и размыкающих их.

Для хвостов обогащения с высокими содержаниями токсичных химических элементов, низкими содержаниями карбонатов и повышенной концентрации сульфидной серы (более 10\%) с геохимических позиций представляется особо важным созданием условий, препятствующих интенсивной миграции химических элементов при выветривании. Это может быть достигнуто смешением или переслаиванием хвостов с карбонатно-глинистым материалом (внутренний геохимический карьер) и созданием «рубашки» того же типа, изолирующей чашу хвостохранилища. Необходимо также предусматривать дренирование и водоотведение ливневых и талых вод с последующей их очисткой.

Экологически безопасное функциональное планирование территорий базируется на материалах по геохимическому картированию природных зон загрязнения (вторичных ореолов рассеивания в почвах и биогеохимических аномалий) и на данных по прогнозу токсичности выбросов, следующему из геохимического анализа состава руд и вмещающих пород.

Большая часть рекомендаций по рациональному и безопасному функциональному планированию территории разрабатывается еще до проведения разведочных работ на стадиях поисковых и поисково-оценочных работ. На основе эколого-геохимических карт в районных планировках должны быть выделены территории, занятые природными геохимическими аномалиями, непригодные для жилищного строительства и требующие ограничения в сельскохозяйственном использовании и прежде всего в выращивании садовых культур и овощей. Для участков, где экологическая опасность природных аномалий хорошо доказана, необходимо запрещение всякой сельскохозяйственной деятельности. Для прочих аномальных территорий, в зависимости от кон- 
кретных данных, агрохимическими организациями может быть разрешено выращивание злаковых (обычно слабо концентрирующих химические элементы в зерне) или технических и кормовых культур В последнем случае зоотехнические и ветеринарные службы могут предусмотреть возможный ущерб для животноводства и принять необходимые профилактические меры, а также организовать соответствующий контроль качества продукции.

Эти рекомендации наследуются и развиваются при проектировании размещения жилых массивов и подсобного хозяйства горно-обогатительного предприятия.

В результате детальных геологоразведочных работ по данным изучения геохимических особенностей извлекаемых и перерабатываемых руд и вмещающих пород, на основе аналогии с близкими месторождениями и технологиями и по расчетам рассеивания выбросов прогнозируется зона влияния ГОКа. Использование геохимических данных позволяет дать полноценную качественную характеристику зоны загрязнения и выявить ее размеры (и соответственно, размеры санитарно-зашитных зон) с учетом достижения индивидуальных и аддитивных предельно-допустимых концентраций для всех основных загрязняющих веществ. При этом следует иметь в виду, что по имеющимся многочисленным материалам, зона воздействия выбросов фиксирует не только санитарно-защитную зону по атмосферному воздуху, но и зону гигиенически опасного загрязнения почв. Учитывая, что стоимость отведения земель под горные работы варьирует в пределах 1000-6000 руб/га, и принимая положение, что загрязнение земель эквивалентно их изъятию, следует планировать более значительные затраты на технологические мероприятия по охране от выбросов. При проектировании систем пылеподавления их следует выбирать тем прецезионней, чем токсичней состав вероятных выбросов по геохимическим данным. В этих случаях эффективно применение относительно дорогостоящих пылесвязывающих веществ на карьерах, дорогах, отвалах (мазут, универсин) .

Для обогатительных фабрик и энергообеспечивающих производств очень важно соблюдение правил размещения с учетом метеорологической ситуации, особенно в горных районах, где инверсионный слой воздуха колеблется в пределах 200-300 м над днищем котловин и способствует концентрированию загрязнения. Однако обычная рекомендация вести строительство пылящих объектов выше этого слоя верна лишь для случаев, когда и объект и жилье приходится размещать в пределах одной котловины. При иных условиях проектирования могут встретиться случаи, когда загрязнение выгоднее локализовать.

Мероприятия по функциональному планированию землепользования для размещения жилья и сельского хозяйства в зоне воздействия выбросов носят в основном запретительный харак- 
тер. Материалы по состоянию воздуха в районе промплощадки показывают, что вблизи интенсивных источников выбросов не следует размещать вспомогательные производства и организации, не связанные непосредственно с обслуживанием основного производства. Это положение следует особо подчеркнуть, так как опыт показывает, что в санитарно-защитных зонах часто расположены отделы, цеха и лаборатории, сотрудники которых без всяких оснований испытывают воздействие загрязняющих веществ, близкое по уровню к воздействию интенсивных загрязняющих источников основного производства.

Природоохранные мероприятия по сокращению вредного воздействия сточных вод и охране водных систем, в сущности, всегда проводятся по гидрохимическим материалам. В этой связи обобщенные геохимические данные могут лишь дополнить общепринятые решения некоторыми позициями, на которые обычно мало обращают внимания .

В частности, при разработке водоохранных мероприятий следует проводить исследования и учитывать при определении типов водопользования уровни концентрации в водах элементовспутников рудных месторождений. Несмотря на то; что многие из этих элементов токсичны и для них разработаны предельнодопустимые нормы, наличие природных гидрогеохимических аномалий с широкой комплексностью состава учитывается редко. Это важно не только при выборе источников питьевого водоснабжения поселений, но и при оценке вод, используемых в животноводстве и поливном земледелии.

Значительным источником загрязнения вод в горно-рудных районах являются сбросы шахтного, рудничного и карьерного водоотлива. В настоящее время обычно производится сбор этих вод в прудах - накопителях и отстойниках с последующим сбросом в поверхностные водные системы. Загрязнение этих систем таково, что отрицательное экологическое влияние прослеживается далеко за пределами месторождений и охватывает крупные районы. Вероятнее всего только каскад очистных сооружений механических, физико-химических и биологических, может дать ожидаемый результат. Геохимический анализ показывает эффективность оборудования прудов - отстойников искусственными геохимическими барьерами карбонатно-сорбционного типа, участвующими в очистке воды и экранирующими сточные воды от подземных горизонтов.

Для уменьшения возможности попадания загрязненного поверхностного стока в подземные воды особое значение имеет тампонаж буровых скважин.

Рекультивация территорий после завершения горно-обогатительной деятельности является обязательным требованием, определяемым Постановлением СМ СССР от 2 июня 1976 г., согласно которому предприятия должны приводить земли в со- 
стояние пригодное для использования в сельском, рыбном или лесном хозяйстве.

Среди видов территорий, подлежащих рекультивации, упоминаются 1) горные отводы; 2) участки размещения отходов; $3)$ водохранилища $(20-25 \%$ общей площади); 4) территории, нарушенные в результате изменения инженерно-гидрогеологических условий и загрязнения [35]. Однако практические рекомендации по использованию земель нарушенных горными работами, известны только для различных типов механического нарушения. Загрязнение среды при этом почти не учитывается. Геохимические данные могут оказать значительное содействие при установлении потребности и характера рекультивации и в выборе экологически безопасных типов землепользования на рекультивируемых территориях.

Карьерные выработки (всегда), западинообразные и котловинообразные нарушения (часто) используются под водоемы рекреационного и рыбоводческого характера. Западины и котловины очень часто благоустраиваются под пашню и сенокосы. Терассированные нагорные нарушения обычно занимаются садами.

Эти виды землепользования очень чувствительны к уровням загрязнения среды. Особенно это касается рыбохозяйственных водоемов, для которых предельно-допустимые концентрации химических элементов ниже, чем для питьевых вод. Как правило, в рудных районах прогноз токсичности карьерных выработок (стенки которых часто сложены породами с первичными ореолами) и западин рельефа (концентраторы ливневого стока) неблагоприятен. В то же время отрицательные эффекты могут наступить через довольно длительное время после рекультивации. Таким образом, для выбора характера рекультивации необходимо геохимическое изучение всех нарушенных типов территории. Для карьеров прогнозы могут быть выполнены по данным изучения первичных ореолов.

При планировании рекультивации необходимо учитывать также почвы, загрязненные выбросами и не подвергшиеся механическим нарушениям. Площади таких земель значительно больше, чем площади с механическими повреждениями. Токсичность их очень велика; тем не менее, они включаются в объемы рекультивации и не учитываются в расчетах ущерба.

Перед началом горных работ рекомендуется провести снятие плодородного слоя (содержание гумуса более $1 \%$, мощность более 100 мм). Для рудных районов надо учитывать возможность накопления в нем токсичных химических элементов. Поэтому при проведении рекультивационных работ этот почвенный слой может использоваться для засыпки территорий, которые не будут использоваться в сельском хозяйстве.

При рекультивации отвалов требования к оценке их фитоток- 
сичности известны (ГОСТ 175103 -78) В случае повышенной фитотоксичности обычно рекомендуется применение изолирующего биологически активного слоя и почвы Вместе с тем, как показывают данные по вторичным ореолам погребенного оруденения [41], при реальных мощностях такого изолированного слоя с течением времени может происходить накопление химических элементов в растениях Поэтому отвалы пород, обогащенных токсичными химическими элементами, могут быть рекомендованы только для использования под естественные насаждения 


\section{СПИСОК ЛИТЕРАТУРЫ}

1 Авессаломова $И A$ Геохимические показатели при изучении ландшафтов М Нзд-во МГУ, 1987

2 Агрохимикаты в окружающей среде - М Колос, 1979

3 Аксенов $И Я$, Аксенов $B$ И Транспорт и охрана окружающей среды М Транспорт, 1986

4 Алаев Э Б Социально экономическая география - М Мысль, 1983 (поня тийно терминологический словарь)

5 Барсуков $B \pi$, Грасорян $C B$, Овчинников $Л H$ Геохимические методы поисков рудных месторождений - М Наука, 1981

6 Бецс $A A$, Грабовская Л И Тихонова $H B$ Геохимия окружающей среды - М Недра, 1976

7 Буштуева $K A$ Случанко $И$ С Методы и критерии оценки состояния здоровья населения в связи с загрязнением окружающей среды $-\mathrm{M}$ Меди цина, 1979

8 Василенко В $Н$ Назаров И $M$ Фридман III $Д$ Мониторинг загряз нения снежного покрова - Л Гидрометеоиздат, 1985

9 Вернадский $В$ И Живое вещество - М Наука, 1978

10 Вернадский $B$ И Химическое строение биосферы Земли и ее окруже ния - М Наука, 1987

11 Гигиена окружающей среды - М Медицина, 1986

12 Гидрогеологические аспекты урбанизации - М

13 Глазовская $M A$ Теория геохимии ландшафтов в приложении к изуче нию техногенных потоков рассеяния и анализу способности природных систем к самоочищению // Техногенные потоки вещества в ландшафтах и состояние экосистем - М , $1981-$ С $7-41$

14 Голубев $И P$, Глотова $\Gamma \Pi$, Дудинская $И$ Д Применение направ ленного отбора контингентов для количественной оценки влияния факторов окру жающей среды на здоровье населения // Гигиена и санитария - 1980 - № 12 C $6 \ldots 11$

15 Добровольский $B \quad B$ География микроэлементов глобальное рассеива ние - М Мысль 1983

16 Зырин $H \Gamma$, Садовникова Л $K$ Химия тяжелых металлов, мышьяка и молибдена в почвах - М Изд во МГУ, 1985

17 Нзраэль Ю А Экология и контроль состояния природной среды - Л Гидрометеоиздат, 1984

18 Исследование элементного состава атмосферных аэрозолей с помощью современных аналитических методов/В А Михайлов, С Г Пушкин, А А Наза ров и др // Труды Западно Сибирского регионального научно исследовательского гидрометеорологического института - М , 1980 - Вып 40 - С 55-78

$19 \mathrm{Kucm} A$ A Феноменология биогеохимии и бионеорганической химии Ташкент $\Phi A H, 1982$

20 Ковда $B$ A Биогеохимия почвенного покрова - М Наука, 1985

21 Кунцевич $И E$, Терещенко $O \quad B$ Причинно следственные связи между содержанием свинца в биосубстратах и некоторые показатели его бнологиче ских эффектов у детей дошкольного возраста // Гигиена и санитария - 1986 № $8-$ C $35-37$

22 Куприянов $B$ B Гидрогеологические аспекты урбанизации - Л Гидро метеонздат, 1987

23 Линник П $Н$ Набиванец Б И Формы миграции металлов в пресных поверхностных водах - Л Гидрометеоиздат, 1986

24 Лукащев $B K$, Лукащев $K \quad И$ Научные основы охраны окружающей среды - Минск Высшая школа, 1980

25 Львович $M$ В Вода и жизнь водные ресурсы, их преобразование и охрана - М Мысль, 1986 
26 Методические рекомендации по геохимическим исследованиям для оценки воздействия на окружающую среду проектируемых горнодобывающих предприя тий - М Изд ИМГРЭ, 1986

27 Методические рекомендации по геохимической оценке загрязнения по верхностных водотоков химическими элементами - М Изд ИМГРЭ, 1982

28 Методические рекомендации по геохимической оценке загрязнения терри тории городов химическими элементами - М Изд ИМГРЭ, 1982

29 Методические рекомендации по геохимической оценке источников загряз нения окружающей среды - М Изд ИМГРЭ, 1982

30 Методические рекомендации по геохимической оценке состояния поверх ностных вод - М Изд ИМГРЭ, 1985

31 Mинеев В $Г$ Агрохимия и биосфера - М Колос, 1984

32 Москалев Ю И Минеральный обмен - М Медицина, 1985

33 Муравьева $C$ И, Казина $H$ И, Прохорова $E K$ Справочник по конт ролю вредных веществ в воздухе - М Химия, 1988

34 Мур Дж, Рамамурти С Тяжелые металлы в природных водах контроль и оценка влияния - М Мир, 1987

35 Охрана окружающей среды при проектировании и эксплуатации руд ников - М Недра, 1981

36 Перельман А И Изучая геохимию - М Наука, 1987

37 Покровская $C \boldsymbol{\Phi}$ Загрязнение окружающей среды тяжелыми металлами и его влияние на сельскохозяйственное производство // Достижения сельско хозяйственной науки и практики - М, 1981 - С $19-28$

38 Рациональное использование твердых бытовых отходов/С В Дуденков, В А Зайцев, Г Л Пекелис и др - М, Изд ВИНИТИ 1984 (Охрана природы и воспроизводство природных ресурсов Итоги науки и техники)

39 Peймерс $H \Phi$, Яблоков $A B$ Словарь терминов и понятий, связанных с охраной живой природы - М Наука, 1982

40 Ртуть критерии санитарно гигиенического состояния окружающей среды - Женева, изд ВОЗ

41 Caet $E$ Вторичные геохимические ореолы при поисках рудных месторождений - M Наука, 1982

42 Свинеи гигиенические критерии состояния окружающей среды - Же нева, изд ВО3, 1980

43 Свинеи в окружающей среде - М Наука, 1988

44 Сидоренко $\Gamma H$, Можаев $E A$ Санитарное состояние окружающей среды и здоровье населения - М Медицина, 1987

45 Тяжелые металлы в окружающей среде - М Изд во МГУ, 1980

46 Химия окружаюшей среды - М Химия, 1982

47 Шандала $M \Gamma$, Звиняцковский $Я$ И Гигиеническое изучение окружающей среды современных городов в ее связи со здоровьем населения/Проблемы экологии человека - М , $1986-$ С $65-70$

48 Экология человека основные проблемы - М Наука, 1988

49 Яблоков $A B$, Остроумов $C A$ Уровни охраны живой природы - М Наука, 1985

50 Forstner $U, W$ Wttmann $O T W$ Metal pollution $\mathrm{T}$ the agnatic environ ment - Berin, Heidelberg, New York Springer Verlag, 1979 
Предисловие

Введение

Глава 1. Понятийный аппарат и научно-методические основы геохимического изучения окружающей среды

11 Окружающая среда и ее компоненты

12 Изучение загрязнения окружающей среды

Глава 2. Технология геохимических работ

21 Общая схема прикладных геохимических исследований 60

22 Методика отбора и обработки проб

23 Исследование неблагоприятных реакций населегия на загрязнение окружающей среды

24 Химико аналитические исследования

25 Обработка результатов изучения ореолов и потоков рассеяния

Глава 3. Геохимическое изучение окружающей среды городов

31 Основные источники загрязнения окружающей среды городов Общая оценка их воздействия

32 Аэрогенные ореолы рассеяния

33 Техногенные потоки рассеяния

34 Биогеохимическая и геогигиеническая оценки техногенных аномалий

35 Методические особенности и практические возможности использования геохимических методов

Глава 4. Геохимическое изучение сельскохозяйственных территорий

41 Агрогенные геохимические аномалии 256

42 Агротехногенные геохимические аномалии 268

43 Техногенные геохимические преобразования сельскохозяйственных тер риторий

44 Влияние сельского хозяйства на водные системы

45 Методические возможности и практическое значение геохимических ис следований

Глава 5. Геохимическое изучение горнопромышленных территорий 292

51 Рудные месторождения как источники загрязнения 294

52 Природные и техногенные аномалии в горнорудных районах 300

53 Экологическая и гигиеническая оценки геохимических аномалий горно промышленныхтерриторий

54 Методические особенности и практическое значение эколого геохими 